
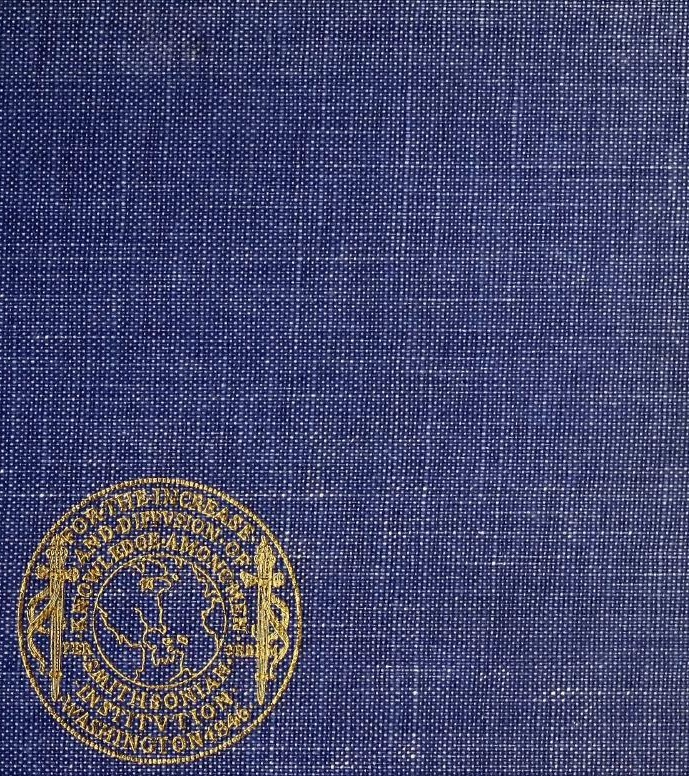
8117 



\title{
CHINESE PORCELAINS FROM THE ARDEBIL SHRINE
}

\author{
By \\ JOHN ALEXANDER POPE
}

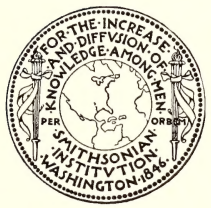

SMITHSONIAN INSTITUTION

FREER GALLERY OF ART

WASHINGTON

1956

Freer Gallery at An

Washington, 0.8 
SMITHSONIAN PUBLICATION 4231

THE LORD BALTIMORE PRESS, INC.

BALTIMORE, MD., U. S. A. 
738.51

P 79

To

ANNEMARIE 



\section{CONTENTS}

PREFACE .

PAGE

CHRONOLOGICAL DATA

\section{PART I-INTRODUCTION}

HISTORY . . . . . . . . . . . . . . . . . 3

ARdebil and the Rise of the Safavid Dynasty . . . . . . . . . 3

ShāH 'Abbās the Great and the Shrine of Sheikh Safĩ . . . . . . . . 5

The Dedication of the Porcelains . . . . . . . . . . . . . . . . 8

Three Centuries of Rumor . . . . . . . . . . . . . . . . 11

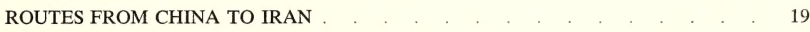

MARGINALIA ON THE STUDY OF MING PORCELAIN _ _ . . . $\quad 27$

The Evaluation of Chinese Sources . . . . . . . . . . . . 27

"IMPERIAL" Wares . . . . . . . . . . . 33

The Beginnings of Blue-And-White in China . . . . . . . . . . 38

PART II-THE ARDEBIL PORCELAINS

THE COLLECTION TODAY . . . . . . . . . . . . . . . . . . 49

THE NON-CHINESE MARKS . . . . . . . . . . . . . . . . 51

THE BLUE-AND-WHITE: THE FOURTEENTH CENTURY _ _ . . . . . 59

SHAPE . . . . . . . 60

DECORATION . . . . . . . . . . . . . . . . . . . 65

SUPPORTING EVIDENCE

Ham̄̄

Kharakhoto . . . . . . . . . . . . . . . 72

HUNG-WU . . . . . . . . . . . . . . . 77

THE BLUE-AND-WHITE: THE EARLY FIFTEENTH CENTURY _ . . . . $\quad 83$

SHAPE . . . . . . . . . 85

DECORATION 89

THE BLUE-AND-WHITE: THE MID-FIFTEENTH CENTURY: "INTERREGNUM" . 101

THE BLUE-AND-WHITE: THE LATE FIFTEENTH CENTURY _ _ . . . 107

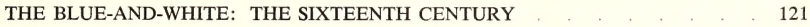

THE WHITE WARES . . . . . . . . . . . 143

THE POLYCHROME WARES . . . . . . . . . . . . . . . . 149

THE MONOCHROME WARES . . . . . . . . . . . . . . 151

THE CELADONS . . . . . . . . . . . . . . . . 153

APPENDIX: STATISTICAL NOTES ON THE COLLECTION $\quad . \quad 159$

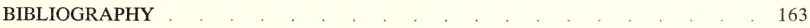

PLATES

following 172

INDEX 


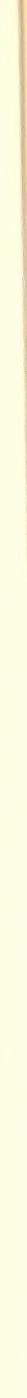




\section{THE ILLUSTRATIONS}

In addition to the 268 negatives taken by Elizabeth S. Ettinghausen, and further acknowledged in the preface, credit is due the following for photographs of porcelains in the Ardebil Collection:

\section{Archaeological Museum, Tehran:}

Pl. 40, no. 29.35; Pl. 55, no. 29.455; Pl. 69, nos. 29.472, 29.459; Pl. 79, nos. 29.515, 29.520; Pl. 80, no. 29.364 (base); Pl. 82, no. 29.140; Pl. 88, no. 29.387 (inside); Pl. 89, nos. 29.314, 29.265; Pl. 90, no. 29.150; Pl. 91, nos. 29.147, 29.148; Pl. 94, no. 29.207; Pl. 96, nos. 29.481, 29.367; Pl. 97, no. 29.445; Pl. 114 , no. $29.772 *$; Pl. 116, nos. 29.769*, 29.761; Pl. 117, nos. 29.763, 29.764*; Pl. 118, no. 29.758 ( $\left.1^{*}\right)$; Pl. 119, no. 29.747( base).

\section{RichaRd ETTINGHAUSEN:}

Pl. 40, no. 29.62; Pl. 44, no. 29.310 (base); Pl. 70, nos. 29.437, 29.353; Pl. 78, no. 29.132; Pl. 80, no. 29.364 (3 views); Pl. 81, no. 29.262; Pl. 86, no. 29.456; Pl. 87 , no. 29.377; Pl. 90, no. 29.279; Pl. 108, no. 29.444; Pl. 109, no. 29.473; Pl. 113 , no. 29.718 ; Pl. 120 , the cat; Pl. 125 , no. 29.655 ; Pl. 129 , no. 29.648 (base).

\section{RICHARD N. FRYE:}

Pl. 77, no. 29.346 .

JOHN A. POPE:

Pl. 6, marks A-I and K; Pl. 48, no. 29.333 (black and white print made from a color transparency); Pl. 54, Isfahan; Pl. 74, Isfahan (2 views); Pl. 99, nos. 29.423, 29.424; Pl. 109, no. 29.484.

Objects not in the Ardebil Collection are credited in the respective descriptions except for the following, which were photographed at the Freer Gallery of Art:

Pl. 110, duplicate of 29.678; Pl. 131, Fostāt shards; Pl. 137, Seljuk bronze, dish with $c h^{i} i$-lin, late fifteenth-century shard; P1. 138, albarello.

All sketches are by the author.

* These prints made by the Archaeological Museum were kindly lent for publication here by the Oriental Ceramic Society, London. 


\section{NUMERICAL LIST OF THE ARDEBIL PORCELAINS ILLUSTRATED IN THIS VOLUME}

\begin{tabular}{|c|c|c|c|c|c|c|c|c|c|}
\hline Object & Plate & Object & Plate & Object & Plate & Object & Plate & Object & Plate \\
\hline 29.1 & 30 & 29.132 & 78 & 29.332 & 47 & 29.413 & 51 & 29.520 & 79 \\
\hline 29.3 & 31 & 29.136 & 72 & 29.333 & 48 & 29.415 & 56 & 29.522 & 26 \\
\hline 29.6 & 31 & 29.137 & 71 & 29.334 & 48 & 29.419 & 51 & 29.523 & 26 \\
\hline 29.21 & 31 & 29.139 & 72 & 29.335 & 49 & 29.420 & 56 & 29.617 & 121 \\
\hline 29.33 & 31 & 29.140 & 82 & 29.336 & 49 & 29.423 & 99 & 29.619 & 121 \\
\hline 29.35 & 40 & 29.142 & 73 & 29.338 & 49 & 29.424 & 99 & 29.621 & 122 \\
\hline 29.37 & 45 & 29.143 & 57 & 29.340 & 49 & 29.427 & 54 & 29.624 & 124 \\
\hline 29.38 & 7 & 29.147 & 91 & 29.341 & 60 & 29.428 & 54 & 29.626 & 123 \\
\hline 29.39 & 12 & 29.148 & 91 & 29.342 & 61 & 29.430 & 54 & 29.630 & 123 \\
\hline 29.40 & 8 & 29.149 & 59 & 29.343 & 62 & 29.433 & 98 & 29.631 & 123 \\
\hline 29.41 & 8 & 29.150 & 90 & 29.344 & 64 & 29.434 & 98 & 29.646 & 125 \\
\hline 29.42 & $9-10$ & 29.154 & 102 & 29.345 & 63 & 29.435 & 98 & 29.647 & 126 \\
\hline 29.43 & $10-11$ & 29.164 & 103 & 29.346 & 77 & 29.436 & 98 & 29.648 & 129 \\
\hline 29.44 & 18 & 29.171 & 104 & 29.347 & 67 & 29.437 & 70 & 29.649 & 127 \\
\hline 29.45 & 16 & 29.172 & 100 & 29.348 & 66 & 29.439 & 55 & 29.650 & 130 \\
\hline 29.46 & 17 & 29.174 & 104 & 29.349 & 65 & 29.442 & 69 & 29.651 & 128 \\
\hline 29.47 & 15 & 29.175 & 104 & 29.353 & 70 & 29.444 & 108 & 29.652 & 129 \\
\hline 29.48 & 21 & 29.178 & 104 & 29.355 & $83-84$ & 29.445 & 97 & 29.654 & 130 \\
\hline 29.49 & $19-20$ & 29.203 & 101 & 29.362 & $83-84$ & 29.447 & 53 & 29.655 & 125 \\
\hline 29.52 & 38 & 29.205 & 93 & 29.364 & 80 & 29.448 & 53 & 29.657 & 115 \\
\hline 29.55 & 37 & 29.207 & 94 & 29.367 & 96 & 29.451 & 74 & 29.678 & 110 \\
\hline 29.58 & 38 & 29.208 & 94 & 29.369 & 85 & 29.455 & 55 & 29.679 & 112 \\
\hline 29.60 & 39 & 29.231 & 92 & 29.371 & 87 & 29.456 & 86 & 29.687 & 110 \\
\hline 29.61 & 40 & 29.233 & 92 & 29.375 & 65 & 29.458 & 55 & 29.694 & 111 \\
\hline 29.62 & 40 & 29.239 & 92 & 29.376 & 95 & 29.459 & 69 & 29.697 & 112 \\
\hline 29.63 & 41 & 29.242 & 92 & 29.377 & 87 & 29.464 & 97 & 29.702 & 113 \\
\hline 29.64 & 32 & 29.262 & 81 & 29.378 & 64 & 29.465 & 97 & 29.714 & 114 \\
\hline 29.65 & 32 & 29.264 & 100 & 29.380 & 106 & 29.466 & 97 & 29.716 & 113 \\
\hline 29.68 & 32 & 29.265 & 89 & 29.382 & 108 & 29.467 & 109 & 29.717 & 113 \\
\hline 29.75 & 33 & 29.271 & 29 & 29.386 & 108 & 29.468 & 109 & 29.718 & 113 \\
\hline 29.83 & 33 & 29.272 & 29 & 29.387 & 88 & 29.470 & 53 & 29.722 & 115 \\
\hline 29.88 & 34 & 29.274 & 29 & 29.388 & 107 & 29.471 & 53 & 29.747 & 119 \\
\hline 29.92 & 34 & 29.277 & 58 & 29.389 & 107 & 29.472 & 69 & 29.758 & 118 \\
\hline 29.98 & 34 & 29.279 & 90 & 29.390 & 107 & 29.473 & 109 & 29.759 & 118 \\
\hline 29.101 & 35 & 29.283 & 108 & 29.392 & 105 & 29.475 & 28 & 29.761 & 116 \\
\hline 29.106 & 35 & 29.284 & 108 & 29.393 & 106 & 29.476 & 28 & 29.763 & 117 \\
\hline 29.109 & 35 & 29.310 & 42,44 & 29.394 & 105 & 29.477 & 86 & 29.764 & 117 \\
\hline 29.113 & 36 & 29.311 & $43-44$ & 29.397 & 89 & 29.479 & 52 & 29.769 & 116 \\
\hline 29.117 & 36 & 29.312 & 42,44 & 29.399 & 68 & 29.480 & 27 & 29.772 & 114 \\
\hline 29.119 & 36 & 29.313 & $75-76$ & 29.401 & 95 & 29.481 & 96 & 29.773 & 115 \\
\hline 29.120 & 13 & 29.314 & 89 & 29.402 & 86 & 29.483 & 55 & 29.774 & 114 \\
\hline 29.121 & 13 & 29.319 & 23 & 29.403 & 50 & 29.484 & 109 & \multicolumn{2}{|c|}{ Unnumbered } \\
\hline 29.122 & 14 & 29.320 & 24 & 29.406 & 25 & 29.485 & 55 & cat & 120 \\
\hline 29.123 & 22 & 29.321 & 47 & 29.407 & 25 & 29.495 & 52 & & \\
\hline 29.127 & 21 & 29.326 & 47 & 29.408 & 25 & 29.496 & 56 & Isfahan: & \\
\hline 29.128 & 22 & 29.327 & 46 & 29.409 & 51 & 29.510 & 27 & Mei-p'ing & 26 \\
\hline 29.129 & 22 & 29.328 & 46 & 29.411 & 51 & 29.512 & 79 & Ewer & 54 \\
\hline 29.131 & 78 & 29.330 & 47 & 29.412 & 25 & 29.515 & 79 & Dish & 74 \\
\hline
\end{tabular}




\section{PREFACE}

"I have no intention to pre-engage the reader's approbation . . . by a studied preface; and think it sufficient to declare, that nothing will be found here, but what I have seen with my own eyes, and have examined with the utmost attention and care. I shall not enlarge on the errors [of earlier writers] lest I should be taxed with an inclination to recommend myself at their expense, and to set off this account . . . by decrying those of others. Persons of judgement and taste will know what to determine concerning us, by comparing our several performances. . . . I may likewise declare, that I have been altogether industrious to afford the public, and especially persons of taste, as much satisfaction as is consistent with my small abilities. To which I may add that I have made it an indispensable law to myself, not to deviate in any respect from the truth, merely to give an ornamental air to this work, in which there are no facts but what are related with the strictest veracity. It, however, is well known that when an author presents a book to the public, he exposes himself to the censure of such as take pleasure in depreciating whatever is above their capabilities."

Thus in part did Cornelis de Bruyn preface the monumental account of his journey to the Near East which appeared in English in 1737. ${ }^{1}$ In his own picturesque way he has said much that is in the mind of any author whose book is an account of things seen; and to his engaging generalities need be added only a few paragraphs outlining the circumstances more immediately concerned with the conception and birth of the present volume.

As for explanation, those happy souls who find absorbing interest in the history of man and his works will need none. For them it is enough to know that over three centuries ago a great collection of Chinese porcelains, part of which remains intact today, was assembled on the shores of the Caspian Sea some 4,000 miles from where it was made. That very fact raised questions that not only stimulated the broader historical curiosities of all who knew it, but which seized upon the imaginations of a whole group of scholars, collectors, and connoisseurs on three continents who had long devoted themselves to the problems of reconstructing Chinese ceramic history. The scanty notes and the handful of unsatisfactory photographs that had appeared since the turn of the century served only to make the questions more urgent, for none of them were prompted by anything but the most casual interest on the part of visitors to Iran with other ends in view. No one, it seemed, who had any interest in Chinese porcelain ever went to the Near East, and the rumors that found their way back were varied and contradictory. It was a fabulous treasure, said one, innumerable magnificent pieces remaining in a perfect state of preservation; or, contrariwise, it was

\footnotetext{
${ }^{1}$ Travels into Muscovy, Persia, and part of the East Indies . . . , 2 vols., London 1737.
} 
a handful of late Ming export wares, mediocre to poor in quality, limited in scope, and most of it badly damaged. While the latter view seemed to prevail, no one really knew; and, worst of all, the questions remained unanswered. Why was it there? How did it get there? And even more urgent, what did it consist of? What sort of Chinese porcelains reached Iran in the Safavid Dynasty? Did it all come at once, or over a long period of time? How was it documented? What could it add to the knowledge of ceramic history? The tantalizing bits of news that reached us not only failed to answer these questions but seemed to make them all the more demanding. After 50 years and more of uncertainty, it was time to find out.

And so it was that on an auspicious day in the midsummer month of $1950 \mathrm{I}$ found myself face to face at last with the legendary porcelain collection of Shāh 'Abbās. Here amid the disorganized mass of unwashed dishes lay possible answers to some of those questions. At a glance it was clear that they would be numbered in the hundreds, that there were both superb and ordinary pieces, that they represented some two and a half centuries of production in China, and that many of them were in perfect condition. But this was not enough, and it was even more apparent that the task of making a full study in the limited time at hand was enormous. Far-reaching decisions had to be made before the scope of the material could be fully grasped, for there was little chance that once the precious month had run out it would be possible to see the collection again; and it was all too evident that the work done then and there would be fundamental; it would form the basis of all future study no matter how many years might intervene between the first-hand examination of the porcelains themselves and any publication that might result. ${ }^{1 a}$

Order was of the first importance. Before all else, the collection had to be washed and sorted. Once clean, pieces of similar shapes were placed in separate groups, numbered to provide some basis for reference, and then, within each group, arranged as far as possible by period and by type of design. With the almost purely physical labor of this first step completed, the question was how to proceed from there. Time did not permit the leisurely contemplation that might have been desirable, nor did it allow the making of complete written descriptions and photographs of every piece. On the assumption that photographs could somehow be obtained later, and that verbal descriptions, to be of any service, had to be made by him who was to use them, the decision was made in their favor. Every piece was measured and described; and the record thus embodied in a thick and well-worn notebook formed the basis of all later work. From it lists of photographs were ordered, and on it are based the descriptions in this book. Final details included the sketching of certain structural features, the copying and recording of various marks, and the taking of a small selection of special photographs. Then the time was up.

1a Letter from the Near East, HJAS, 13(1950): 558-564, is my preliminary report on this survey of the collection. 
A year later an excellent set of almost 300 photographs came into being, thanks to the kind help that will be duly acknowledged below; and the intervening years have been spent in seeing and handling as much Ming porcelain as I could find, in the search for documents relating to the various phases of the history of the collection, and in conversations on all manner of related problems with scholars and connoisseurs on both sides of the Atlantic. Great as was the satisfaction of spending a month handling the Ardebil porcelains, these years of study have been by far the most rewarding part of the project, and it would have been the greatest pleasure to let them go on indefinitely. But the line had to be drawn somewhere; the book had to be written.

By no means all the questions are answered, and many vexing problems remain to be solved. As it stands, this volume deals with three aspects of the subject: (a) the place of the Ardebil Shrine in Safavid history, the dedication of the porcelains by Shāh 'Abbās the Great, the routes by which they may have reached Iran, and the later history of the sanctuary as recorded by European visitors; (b) comments on certain fundamental problems relating to the study of Ming porcelain by way of establishing the frame of mind in which I have approached the main part of the work; (c) the description and analysis of the collection as it illustrates the chronological development of the manufacture and decoration of Chinese porcelain from about 1350 to 1610 .

For that purpose the Ardebil Collection provides a body of material not rivaled elsewhere in one place. The fact that it has a documented terminal date in A.D. 1611 means that there need be no worry about weeding out post-Ming wares; and the second fact that about three-quarters of the 800 odd pieces are blue-and-white provides an opportunity to concentrate on the essential qualities of form and decoration without distraction by other factors involved in the consideration of enamel colors and monochrome glazes. It is on those basic matters that I have dwelt; and in so doing, in looking intently for a long period of time at hundreds of pieces of porcelain manufactured at various times throughout two and a half centuries, one cannot help but sense the existence of a large-scale pattern of development in which most of them are bound to find their places. But simple as this sounds, it is by no means cut and dried. Copying is one of the most deeply rooted traditions of Chinese art, and this, added to the fact that several classes and qualities of porcelains must have been manufactured at the same time and in various places, means that anachronisms and geographical confusions abound. So in spite of the great over-all evolutionary pattern into which most of the pieces seem to fall, it is dangerous to be dogmatic about any individual piece. It has been my purpose to try to communicate to the reader the larger outlines of this pattern in terms of the pieces preserved at Ardebil; and for those that elude precise classification, I have tried to suggest the most likely possibilities.

Much remains to be said; many historical, sinological, and stylistic problems call for further investigation; but, fully aware of the shortcomings and lacunae in the present text, I bring it reluctantly to an end. The rare opportunity of having been the first 
to study an unknown collection of this importance and scope imposes the responsibility of publishing, and this I now do. In making the acknowledgments that follow, I wish to record my gratitude for the generous good will and valuable counsel of many colleagues who have contributed immeasurably to whatever merit this book may have; the imperfections are my own.

It is hard to determine when and where this project really began. The study of Chinese art has been my principal preoccupation for over 20 years, and for perhaps three-quarters of that time ceramics in general and Ming porcelains in particular have been of primary interest; so in a sense my work on the Ardebil Collection began long before I had the opportunity of visiting Iran. To enumerate all those who have been helpful in that long period would be impossible; and except for the mention of the two men who first opened my eyes to the beauty and absorbing interest of Ming porcelain, R. L. Hobson and George Eumorfopoulos, my acknowledgments are confined to those friends whose help has in one way or another intimately affected this volume.

In Tehran the work was carried on with the blessing of André Godard, then director of the Service of Antiquities of the Government of Iran, and the friendly cooperation of the late Dr. Mehdi Bahrami, director of the Archaeological Museum of Tehran where the collection is housed. Thanks are also due Dr. K. M. Mostafavi for his continuing help, and Miss Barsin and all those members of the staff who gave so generously of their time and effort. Our hosts in Tehran, Mr. and Mrs. Charlemagne Edward Wells, not only gave us the freedom of their comfortable house but did everything to make our visit pleasant; and in his official capacity as public affairs officer of the United States Embassy, Mr. Wells was helpful in many ways.

Lacking training and linguistic competence in the Near Eastern field I am particularly grateful for the friendly cooperation of many scholars who have them. V. Minorsky, A. J. Arberry, and R. Levy of Cambridge University, D. S. Rice and R. M. Savory of London University, K. H. Menges of Columbia University, and G. C. Miles of the American Numismatic Society have been most helpful with epigraphic problems. Thanks are also due R. N. Frye of Harvard University, J. Aubin of the Institute Franco-Iranien in Tehran, Dr. Myron Bement Smith, chairman of the Committee for Islamic Culture and director of its Islamic Archives, for help of various kinds; and for the extended loan of her unpublished thesis which provided valuable references, I am indebted to Harriet Harrison Merry.

The finest collections of Chinese porcelain in the Western world and the keenest connoisseurship are concentrated in London; and I am deeply grateful to the private collectors and museum officials of that city for friendly cooperation of many kinds. For giving me frequent and complete access to their private collections or those of which they are custodians and for many valuable suggestions and criticisms my warm thanks are due Mrs. Alfred Clark, Mrs. Walter Sedgwick, Mrs. C. G. Seligmann, John Ayers, Sir Percival and Lady David, Professor E. D. Edwards, Sir Harry Garner, Basil 
Gray, Soame Jenyns, Arthur Lane, and W. W. Winkworth. Elsewhere in Europe, I have benefited from the kind help of Daisy Lion-Goldschmidt, André Leth, Bo Gyllensvärd, and Jean-Pierre Dubosc.

Many American colleagues have been helpful, but none more so than Arthur W. Hummel, retired chief of the Division of Orientalia in the Library of Congress, whose wisdom and knowledge have placed in the hands of American scholars the greatest Chinese library outside of China. He and his associates in the Chinese Section have been models of patience and cooperation in finding and placing at my disposal the treasures of that incomparable collection. I also wish particularly to thank my old friend and fellow student Francis Woodman Cleaves of Harvard who has been most generous in sharing his unsurpassed knowledge of Mongolian and Chinese and has supplied me with much valuable information. Dr. Li Hui-lin, now of the Morris Arboretum, has continued to be most helpful on botanical questions; Dr. Herbert Friedmann and Herbert G. Deignan of the United States National Museum have identified many of the birds; and Dr. William M. Mann, director of the National Zoological Park, pointed out the several varieties of deer used in the decoration of blueand-white. The eagle eyes of Paul H. Oehser and Ruth B. MacManus of the Editorial and Publications Division of the Smithsonian Institution have saved me from many an embarrassing slip. Further individual acknowledgments for help on special problems will be found in the pertinent notes to the text.

In the Freer Gallery of Art nearly everyone has contributed in one way or another to the production of this book. The director, Archibald G. Wenley, has been interested from the outset, has sponsored all the necessary travel, and has made welcome suggestions; Dr. Richard Ettinghausen took a number of additional photographs on his latest trip to Tehran and provided help on the Iranian phases of the work; and Harold P. Stern called attention to a number of useful Japanese references. The photographic prints were made by Burns A. Stubbs and Raymond A. Schwartz, and Bertha M. Usilton has helped with the bibliography and prepared the index. The many versions of the manuscript have been typed and kept in order successively by Jean H. Copley and Emily F. Boone who have been helpful in many ways.

No one has made a more important contribution to the final appearance and usefulness of this volume than has Elizabeth S. Ettinghausen, who took most of the photographs. Working from lists, she made 268 negatives in Tehran under conditions that were something less than ideal, and I wish to record here my full appreciation of her effort, her interest in the project, and her skill as a photographer.

From the beginning, when she wrote the original notes and kept them in order during the hectic days in the blistering heat of Tehran and Isfahan, to the end, when she read the manuscript and made many valuable suggestions as to its form and content, my wife has given constant help and support. 



\section{CHRONOLOGICAL DATA}

The dynasties, rulers, and reign names listed below are those of particular interest to this study.

SUNG $960-1279$

\section{CHINA}

YUAN 1260-1367

(Nineteen years elapsed between Khubilai's election as Khan and the extinction of the last Sung pretender. The only Yüan reign period mentioned here is Chih-cheng, 1341-1367.)

\section{MING 1368-1644}

(Normally each new emperor continued to use the old reign name until the end of the calendar year in which he came to the throne. Thus the dates of actual tenure are not identical with the dates of the reign periods. For the Ming Dynasty both sets of dates are given below.)

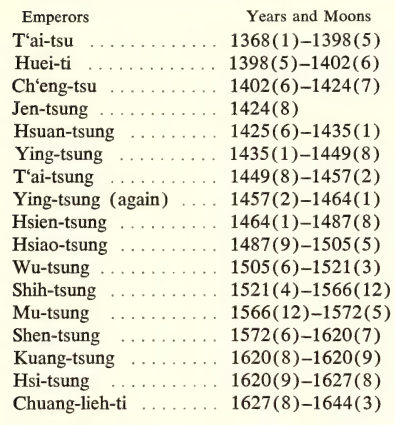

CH'ING 1644-1912

\begin{tabular}{|c|c|}
\hline Reign Names & Years \\
\hline Hung-wu . & 1368 \\
\hline Chien-wen & 1399 \\
\hline Yung-lo .. & 1403 \\
\hline Hung-hsi & \\
\hline Hsüan-te . & 1426 \\
\hline Cheng-t'ung & $1436-1449$ \\
\hline Chin & 1450 \\
\hline$T^{\prime}$ ie & 145 \\
\hline $\mathrm{Ch}^{\prime} \mathrm{e}$ & 1465 \\
\hline Hur & 1488 \\
\hline Che & 1506 \\
\hline his & 1522 \\
\hline ch'ing & $1567-1572$ \\
\hline & $1573-1620$ \\
\hline & 1620 \\
\hline & \\
\hline Ch'ung-chen & $1628-1644$ \\
\hline
\end{tabular}

Reign Names $\quad$ Years

Tao-kuang . . . . . . . . . . . . 1821-1850

Hsien-feng ............ 1851-1861

Tung-chih . . . . . . . . . . 1862-1874

Kuang-hsü . . . . . . . . . . . 1875-1908

Hsüan-t'ung . . . . . . . . . . . 1909-1911

\section{IRAN}

The principal events related in this account of the Ardebil Collection took place when Iran was controlled by the Timurids (1369-1500) and during the first half of the Safavid Dynasty which reigned from 1501-1736. The genealogy of the Safavid rulers through Shāh 'Abbās I is sketched in the first chapter. 

PART I-INTRODUCTION 



\section{HISTORY}

\section{ARDEBIL AND THE RISE OF THE SAFAVID DYNASTY}

Some 30 miles west of the Caspian Sea not far from the Russian border the town of Ardebil stands on a plateau almost 5,000 feet high where, since ancient times, it has prospered by virtue of its commanding position at the crossing of two major avenues of trade: the road from Tabriz to the Caspian and that from Astrakhan to the great cities of central Iran. Although its origin is involved in legendary events of great antiquity, its actual founding is credited by tradition to the Sasanian emperor Fīrūz in the fifth century of our era; and by Umaiyad times it was the capital of Azerbaijan Province. Through the centuries its fortunes rose and fell; it was more than once destroyed and rebuilt, and after it was laid waste by the Mongols about 1220 it rose again, more beautiful than ever, to await the event that was to bring it lasting fame and incidentally make it the home of the porcelain collection which is the subject of this book.

This was the birth of the man who was to become the ancestor of the Safavid kings of Iran, the Sheikh Ishāq Safī ed-Dīn, the Sũfī saint who claimed descent from Mūsā Kāzim, the seventh Imām, and through him from 'Alī and the Prophet himself. Although the genealogy is obscure, ${ }^{2}$ there is ample evidence that Sheikh Safi, as he is known for short, was a man of extraordinary sanctity and great personal influence in his own time. Most of his life was spent in religious pursuits; and for 25 years he sat at the feet of the Sheikh Zāhid of Gīann, whose daughter Bībī Fātima he married and whom he succeeded as head of an order of Süfis whose courage and self-sacrificing devotion to the Safavid cause were to become proverbial. On Safīs death in 1334 at the age of 85 the title of Sheikh passed to his second son, Sadr ed-Din, who headed the Order for 59 years and was himself credited with many miracles. During his long life he directed the compilation of a vast monograph, the source of all our information about his saintly father; he built the latter's tomb at Ardebil, thus in effect establishing the spiritual core of the Shrine; and at the end of his life, like his father before him, he performed the pilgrimage to Mecca. His son Khwãja 'Alī, who inherited the title in 1392, took, perhaps unwittingly at the time, the second important step toward establishing the future power of the Safavids. Having won the good will of Tīmūr by a display of his physical prowess, he persuaded the great conqueror to release a group of

${ }^{2}$ Browne, A literary history of Persia, vol. 4, pp. 31-35. Chapters 1-3 of this volume provide a useful short account of the Safavid Dynasty and its background; unless otherwise noted the details of this historical sketch and the quoted passages are taken from that source. 
Turkish prisoners captured at Dyār Bakr; and the grateful devotion of these "Turkish Süfīs" as they were known passed undiminished from generation to generation and placed a fanatically loyal following at the disposal of the Safavids for the next three centuries. But this is to anticipate; and it was only under Juneid, the grandson of Khwāja "Alī, that the family showed its first signs of temporal ambition when he ingratiated himself with Ūzūn Hasan, the celebrated leader of the "White Sheep" Dynasty (Aq-qoyūnlū) of the Turkomāns, and received the hand of his sister in marriage. This alliance led only to disaster, for it so alarmed the neighboring princes that they united against Juneid, and he was killed in battle after only nine years of Sheikhhood. Heidar his son, who became Sheikh in 1456, continued the friendship with Ūzūn Hasan and married his daughter Martha, whose Muslim name was Halima, granddaughter on the distaff side of a member of the noble Greek family of the Comneni, Kalo Ioannes, the last Christian emperor of Trebizond; and his principal contributions to the cause were first his further organization of the "Turkish Süfīs" mentioned above, particularly his decision that they should be distinguished by wearing scarlet caps, which quickly gave them the nickname Qizilbäsh (Redheads) as they were henceforth known in history, an epithet of pride among themselves but a term of violent abuse in the mouths of their enemies; and second the fact that he was the father of Ismā'il.

Orphaned at the age of one and hidden from his father's enemies during childhood, this remarkable boy emerged from seclusion at the age of 13 with seven Süfĩ followers to rally the seven loyal Turkish tribes that composed the Qizilbäsh, march through a series of military victories in the northwest, and make a triumphal entry into Tabriz, where he was crowned Shāh of Iran in his fifteenth year (1501-1502). First to bear that title since the death of the last Sasanian ruler in 652, Shāh Ismā‘îl lost no time in consolidating his territory, and in the next decade he brought under his control such widely separated places as Baghdad, Dyār Bakr, and Herāt. Behind the young Shāh's meteoric success in restoring Iran to the physical size it enjoyed in the days of its ancient greatness lay not only extraordinary personal qualities of leadership and charm, which are repeatedly stressed in contemporary accounts by his own countrymen as well as by visiting Europeans (who must have been hard put to it to reconcile them with his sometimes savage cruelty), but also a fanatical and single-minded devotion to the propagation of the Shīa doctrine. Finding at their head a gifted military leader who was at the same time directly descended from an Imām, the Shī'as were united as never before in their determination to destroy their enemies the hated Sunnis wherever they might be. The very battle cry of the Safavids proclaimed their faith, "God! God! and "Alī is the Friend of God!" and when Ismā'ill assumed the crown he resolved that "the Shi'a faith should become not merely the State religion but the only tolerated creed." To the realistic doubts of the Shí a divines who knew they were still vastly outnumbered, the Shāh replied, "I am committed to this action; God and the Immaculate Imãms are with me and I fear no one; by God's help, if the people utter one word of 
protest, I will draw the sword and leave not one of them alive." To further impress his views on his people he instituted the public cursing of the first three Caliphs of the Sunnīs, Abū Bakr, 'Umar, and 'Uthmān, with the added refinement that all who heard should respond on pain of death, "May it be more, not less!" Thus strengthening the irreconcilable animosity of Shī'a against Sunnī, Ismā'īl established the background against which the history of the newly founded Safavid Dynasty was to unfold, for Iran lay in the middle with fanatical and powerful Sunni forces on either side: the Ottoman Turks to the west and the Uzbeks of Transoxiana to the northeast. It was the former, under the leadership of Sultān Selīm the Grim, who inflicted upon Ismā‘îl his only major military defeat at the great battle of Chāldirān in August 1514, a Turkish victory which led to the occupation of Tabriz and thus played its part in the formation of the Ottoman collection of Chinese porcelains at Istanbul. ${ }^{3}$ But this was only a temporary setback; Ismā‘îl recaptured Tabriz within a matter of weeks, and Selīm, beset by domestic troubles and preoccupied with the conquest of Egypt, Syria, and Arabia, did not threaten again. When Shāh Ismā'îl died at the age of 38 (23 May 1524), he bequeathed to his successors the greatest Iranian nation since the rise of Islam, beset by formidable enemies on both sides and defended by an army which made up in fanaticism what it lacked in military genius and equipment.

\section{SHĀH 'ABBĀS THE GREAT AND THE SHRINE OF SHEIKH SAFĪ}

Thus established, the Safavids enjoyed another century of greatness, and we need dwell but briefly on the historical scene. Shāh Tahmãsp, son of Ismã'îl, continued the wars with his traditional enemies all through his 52 -year reign on a pattern set by them rather than by himself. His Ottoman adversary, Süleymān the Magnificent ("The Grand Turk"), to free his eastern flank from pressure that he might concentrate on his principal objective, the conquest of the Holy Roman Empire, incited the Uzbeks to harass the Persians in Khorasan; and the European powers at the same time encouraged the Shāh to continue the attack on his Turkish frontier in the hope of diminishing the Sultān's threat along the Danube. In this complex game Tahmāsp more than held his own; but ground was lost by his two sons Shāh Ismā‘il II, a bloodthirsty and debauched character who died of his excesses after 18 months on the throne, and Shāh Mohammad Khodā-bandeh who abdicated after 10 years of indecision in favor of his son 'Abbās.

It was October 1587 when this second son of Mohammad Khodā-bandeh, the first having been murdered by a barber and the two younger having been deprived of their eyesight and imprisoned in the Castle of Alamūt by 'Abbās himself, ascended the throne as Shāh 'Abbās to begin a 42-year reign in which he was to raise Iran "to the

\footnotetext{
${ }^{3}$ Pope, Fourteenth-century blue-and-white, p. 12.
} 
highest degree of power, prosperity and splendour ever attained by her in modern times." The international situation remained the same, and by skillful handling of his adversaries in the beginning Shāh "Abbās paved the way for ultimate victories on both fronts and was then free to turn to the philanthropic activities for which he won his lasting fame. Toward the end of the sixteenth century he moved his capital to Isfahan, which he made one of the beautiful cities of the world; he restored the Shrine of the Imām Rezā and rebuilt Mashhad, which had suffered destruction at the hands of the Uzbeks, and also improved and beautified the cities of Qazvīn, Kāshān, Astarābād, Tabriz, and Hamadān. But the benefaction that concerns us here was that bestowed on the ancestral home of the dynasty, the town of Ardebil where our brief historical sketch began with the birth of the Sheikh Safĩ more than three centuries earlier.

It was in Ardebil, as we have already seen, that Sadr ed-Din about the middle of the fourteenth century had built a tomb for his saintly father and thus brought into being the Shrine which was to increase in size through the years as the Holy Order grew in strength and influence until it became a dynasty; and Shāh 'Abbās the Great was responsible for certain major improvements and additions. Unfortunately there seems to have been little effort to draw upon contemporary texts as aids to the reconstruction of the history of the Shrine; and most of what we know today rests upon Sarre's study of the site as he found it at the beginning of this century. ${ }^{4}$ He describes the whole as "a complex of various building entities, grouped around a court, which were intended as tombs, mosque, library, porcelain collection, rooms for domestic purposes and dwelling purposes for the molläs and for pilgrims, the poor, and for fugitives"; his plan is reproduced on plate 2. Entering the main gate from the meidan, the visitor moved southeast passing through a large formal garden a hundred yards long on the longer side and entered the small forecourt through silver-mounted doors. At the left of this in ancient times lay the kitchen from which the hospitality of the Shrine was dispensed. Beyond, through a second silver door, was the great forecourt; and entering this the visitor stood facing the long wall of the prayer hall with the dome of the Holy of Holies, the tomb of the Sheikh Safi, rising at its southwestern end; to the left in the short end of the court opened the eivan that is the vestibule to the mosque. Adjoining the far side of the prayer hall and forming the eastern end of the Shrine as a whole was the Chīni-khäneh (China house) which housed the great porcelain collection.

Historically, the mosque came first and was already almost a hundred years old when Sadr ed-Dīn built the tomb of the Sheikh Safī. Shäh Ismã‘îl seems to have erected his own tomb, perhaps between 1510 and 1520; and it was Tahmāsp who brought together the individual structures and created a unified complex around the great forecourt on the basic plan that remains today. The reconstruction undertaken

${ }^{4}$ Sarre, Denkmäler persischer Baukunst, 1901 (plates) and 1910 (text). The details given here are taken from that work unless otherwise noted. 
by Shāh 'Abbās included the kitchens, the enlargement of the mosque, additional dwellings for the clergy and for fugitives, and also, presumably, the building of the Chīni-khāneh, although the possibility remains that the outer shell may be earlier and that his contribution was limited to the magnificent interior designed to receive his gift.

The domed, thick-walled structure shows a square exterior with blunted corners and a half-round buttress in the middle of each side (pl. 3). But the interior is curious in that the square under the dome has been rotated $45^{\circ}$ so that each corner points to the middle of an outer wall, and the great niches which open from the sides fill the corners of the exterior square. Most remarkable of all is the interior revetment of this great chamber, which measures some 32 feet on each side of the inner square with niches over 14 feet wide and 12 feet deep (pl. 4). Around the bottom of the walls is an 8-foot dado of colored tiles decorated with elaborate patterns including vases, flowers, and scrolling tendrils; and above this, covering the entire area up to the base of the cupola, is a paneling of wood in which have been cut hundreds of niches of various shapes to serve as receptacles for the porcelains. The entire woodwork and the vaulting of the dome are painted in blue and gold. Thus did Shāh 'Abbās prepare a setting which he considered to be in keeping with the magnificence of his gift of Chinese porcelain; thus did he enhance his own merit by dedicating his choicest possessions to the memory of his saintly ancestor, the founder of his house, the Sheikh Safĩ ed-Din.

This was not an isolated gesture but part of a large-scale philanthropic program, and it will be of interest to note briefly the circumstances in which it was carried out. In 1607 Shāh 'Abbās returned to Isfahan after four years of campaigning, and having rewarded those who helped him reestablish the frontiers of his empire by gifts of robes of honor, promotions in the hierarchy of Begs, Sultãns, and Khäns, by political appointments and grants of fiefs, he set up a series of endowments in the names of the Fourteen Innocents: the Prophet, his daughter Fātima, and the 12 Imāms. His personal fortune at that time consisted of lands and the slaves that went with them to the value of 100,000 tomāns, which brought him a net income of 7,000 tomāns a year, in addition to stores surrounding the Meidān-e-Shāh at Isfahan and a considerable number of bathhouses which he had had built. All this went into the foundation (vaqf) which was divided into 14 parts beginning with the largest share in the name of the Prophet and prorated in descending order of spiritual importance to the twelfth Imām. The income of these trusts, the management of which was reserved to the Shăh and his successors, was to be used particularly to help the indigent, the honest, the scholars, doctors of religious law, theological students, and devotees, and in general to be spent in the interest of religion and the state. At the same time that he made this disposition of his lands for purposes of the general good, Shāh 'Abbās made special bequests of his personal property also in the form of vaqfs to be used in the same way. It was thus 
that he gave to the Shrine of Mashhad his Arabic books on religious science, and to the Ardebil Shrine his Persian books of history and poetry and his porcelain dishes. He also got rid of all his jewels, his gold and silver vessels, his studs of stallions and mares of all breeds, his camels, his flocks, in a word all he possessed; and it then passed from his hands into those of the Shi'ite community and more particularly of the Tajik people who became the true beneficiaries. It was the first time in the history of Iran that a sovereign performed a deed so broadly humanitarian in scope; and Shāh "Abbās was to be repaid a hundredfold all through his reign by the eager and selfless devotion of the molläs and the people who adored him as they did a divinity. ${ }^{5}$

\section{THE DEDICATION OF THE PORCELAINS}

By great good fortune the account of the benefaction which interests us most has been preserved in the writings of a man who may well have been present at the time, Jalāl ed-Din Mohammad Munajjim Yazdī, chief astronomer (munajjim) at the court of Shāh 'Abbās. His book, Ta'rīkh-e-'Abbāsī, a year-by-year record of the history of Iran, from the death of Shāh Tahmāsp in 1576 through the twenty-fifth year of the reign of 'Abbās, survives today in several manuscript copies, among them three in the British Museum and one in the Bodleian Library, all dating from the seventeenth century. ${ }^{\circ}$ Near the end of the book Mollă Jalāl, as he calls himself, describes the events that took place in the summer of 1611 as the Shāh journeyed to Ardebil and relates the small miracles that occurred in the Shrine itself before the vaqf was established; his narrative has the flavor of an eyewitness account. In translation the passage runs: " "On the 18th of this month (28 August 1611) he ("Abbās) marched forth from the pasturelands of Sultāniyeh and encamped on the outskirts of Zinjān, where a stud of horses was brought to him. From amongst these he gave 41 mares and 100 horses to deserving people and to learned men: 400 horses were bestowed upon the qürchī and ghulämān: and a stud comprising 600 horses, mares, and stallion foals was granted to Mohammad Beg Shams ed-Dīn. On the 21st of the month he crossed Mount Bardlis, whose upward slopes told of the highest level of the dun-coloured heavens, and whose lower slopes gave hint of the treasure of Qärūn. And toward the

${ }^{5}$ Bellan, Chah 'Abbas I, pp. 170-171. This book is undocumented, and it is impossible to trace any given statement to its source; but the passage which is partly translated and partly paraphrased here probably gives a reasonably good general view of the establishment of vaqfs at this time.

${ }^{6}$ Storey, Persian literature, vol. 2, no. 384. Two of the British Museum copies, Add. 27.241 and Or. 3549, are catalogued by Rieu, I: 184, and Supp. 57; the third one, Or. 7465 (1), is not in Rieu. There must be other copies in Iran which were consulted by Bahrami and Aubin.

${ }^{7}$ Roger M. Savory, School of Oriental and African Studies, University of London, very generously took the time to make this translation from B. M. Add. 27.241 , fol. 339-342, and while he wishes it to be considered very tentative pending further study, he has been kind enough to consent to its publication here. 
end of Jumādā II ${ }^{8}$ he entered the precincts of the 'pole-star of the gnostics', Shāh Safī, and after visiting the shrine he went toward the kitchens, and when he went toward a cauldron the lid of a nearby saucepan lifted itself about nine inches and crashed down on the saucepan with such a noise that those who were in the kitchen. . . . The 'dog of the threshold of 'Alī' ('Abbās) placed his head upon the ground and returned thanks. When . . . the lid as before became separated from the saucepan, and returned of its own volition, much to the astonishment of those present. The 'dog of the threshold of 'Alī' ('Abbās) gave 12 tomāns to the cooks, and they made four mortars of silver. But it is well known that an Arab brought this saucepan from Mecca in 921/1515, and bequeathed it to the shrine, and later, because of certain statements unbecoming to Sūfīs, he turned away from the shrine and went to the home of the 'Uthmānlū. After awhile he regretted his action, and returning he slew a sacrificial sheep and put it in the cauldron. When it came to the boil, all the pieces of meat fell out, and this occurrence increased the faith of the Sūfis in the reign of Shāh Ismā'îl II. And he ('Abbās) gave orders that the door of the shrine be enlarged and be made of gold, and that the tomb of Rostam Mirzā, the son of the late Shāh Ismā'îl, should be leveled so that it should not get in the way of the door opening: he further ordered that a peripheral wall should be constructed of silver, and that the dias before the inner sanctuary should be enlarged, and that a door should be constructed in the centre leading into the inner sanctuary. And for two years no drums were beaten at the shrine except his. After the happening of this miracle, the royal decree ordained that they should restore ... . it to its former condition, and this was a source of great joy to the men and women of Ardebil. And when the prince who is the 'dog of the threshold of 'Ali' ('Abbās) set out to perform the pilgrimage to the shrine of the Shāh whose place is paradise (Safī), the lower door which is outside the inner sanctuary was closed. When the auspicious hand reached the door of the sharbat-khanneh of the 'pole-star of gnostics' (Safī), he placed his hand on the lock, and the door opened at once. And when he reached the sharbat-khäneh, which the 'dog of the threshold of 'Alī' ('Abbās) had endowed-the spiritual reward for this act he placed to the credit of his mother in heaven-a crowd which had heard the news of these spiritual activities began to arrive in large groups, and when the 'dog of the threshold of 'Alì' put his hand upon the lock, the lock parted, and this act increased the faith of the people. And a very fine china-store was created. And the articles of china, etc., which the noble and holy slave, the prince who is the 'dog of the threshold of 'Alī' ('Abbās), bestowed to the holy and illustrious shrine of the 'pole-star of the gnostics' (Safi), and for which Maulānā Mohammad Hosein Hakkāk-e-Khorāsānī (the paragon of his age) engraved the vaqfnameh, and which were transferred to the china-store, are as tabulated on the following page.

${ }^{8}$ This month fell between 11 August and 8 September. 
Langarī: large, medium, and small . . . . 270

Bādiyeh: (wine cups) ............. 45

Sahn, etc. .............. 60

Sahncheh .................. 61

Shāh kāseh: (large bowls), large, medium, small

Na'lbakī: (saucers)

170

206

Piyāleh: (small bowls)

95

Äftäbeh: (ewers) large and small .... 14

Tabak-e sorkh: (red trays) ......... 23

Qaräbeh: (double-handled pitchers), large

Sarāhi: (long-necked jars)

Tabak

Qadah: (wine bowls)

Küzeh: (earthenware jugs)
Sabū: (tall jars with single handle).... 5

Martabān .................. 32

Markāb ................... 36

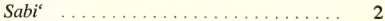

Kafcheh ................ 3

Huqqeh: large and small .......... 6

Marhamdāni ................. 1

Kävdüsh . . . . . . . . . . . . 1

Namakdān: (saltcellar) . . . . . . . . 1

Finjān: (cup) .................. 1

Piyãleh, huqqeh, etc. ........... 84

Zurūf: (vessels) of Yamanite carnelian (or agate)—pasha, etc. yashb

Kashkül: (beggar's bowls) .......... 3

Piyāleh-ye-yashb ............... 4

Yamani carnelian 'an Kashkül ....... $1^{9}$

"At this time too Turāb Khãn, the son of Sheikh Shãh Beg, was killed by Vali Sheikh Beg, because his father Sheikh Shāh Beg had been instrumental in having Sultān Hasan Khān, who had taken sanctuary in the Shrine, dragged forth and killed. . . . The 'dog of the threshold of 'Alī' ('Abbās) overlooked this crime . . . so that it might be a warning to others . . . , and the people of Nau Dỉhī in Tālish. . . . Since he killed a Sayyid of Abhar, he took sanctuary in the shrine of the 'pole-star of the gnostics' (Safī). At the royal command Farīdūn Khān marched against a group of the Küklan tribe, and killed 500 men of that tribe, and forwarded all the articles he seized for the royal consideration. And on the first day of Rajab (9 September 1611) he ('Abbās) gave 14,000 tomāns for the gold and silver of the doors and windows of the shrine and the kitchens, and the work was commenced. It was decided to make the doors and the windows of the inner sanctuary of gold, and the windows in front of the sanctuary of silver. And he stayed for 15 days in Ardebil, making careful enquiries into the condition of poor and infirm. And he decided to repair the school of the Shāh Jannat-Makānī (Safī), which had been destroyed (or had fallen into disrepair)."

Thus did Shāh 'Abbās make his gift to the Shrine. The itemized list of Jalāl ed-Din totals 1,162 pieces, ${ }^{10}$ but in spite of the detailed form of the account the nature of the Persian terminology makes it difficult to identify any of the pieces which remain today. Some of the terms are translated above, and they give only a rather general

${ }^{9}$ The original text of this list is reproduced on plate 5 .

${ }^{10}$ Bahrami, TOCS, 25 (1949-1950): 14-15, gives 1,221 including six pieces of jade and agate. This must be accounted for by the discrepancies between the figures preserved in various surviving versions of the text. There seems to be no reference to the manuscripts mentioned by later visitors to the Shrine (pp. 13-16), or to the carpets which Bahrami told me were also included in the gift (HJAS, 13: 559n.). 
idea of what may have been intended in the seventeenth century. Some of them may be examined a little further. Langari means a large tub, basin, or laver; and in view of the number of this type recorded, it seems likely that the reference is to the large dishes. The suggestion that bädiyeh means wine cups is tantalizing; does it imply that originally there were stem cups although none remain today? ${ }^{11}$ Sahn is a large tray, plate or dish, or a wide basin; but it is hard to say how they distinguished these from langarī. Shāh kāseh, large bowls, and piyāleh, small bowls, are probably identifiable among the whole range of vessels of that type. Ewers, äftäbeh, are also easy to point out, and a dozen of the original 14 survive; but again it is not easy to tell what they had in mind in listing five sabu which may mean the same. Tabak-e sorkh, red trays, seems insoluble at the moment; had there been any Ming lacquer it is unlikely that they would have included it among porcelains. Martabān is a well-known Near Eastern term for celadon, ${ }^{12}$ but it is curious that more of these remain today than were noted in the original list. Kafcheh means spoon, ladle or skimmer and is very puzzling. Huqqeh is the word usually written hookah in English where it means a water pipe or narghile, and this probably refers to the vessels of that type described here as kéndi ${ }^{13}$; but the Persian word can also be used to describe vessels of several other types and uses. Kāvdūsh (or rather $g \bar{a} v d \bar{u} s h$ ) is described as a vessel with a wide top and narrow bottom for milking, a milk container, or a churn, and the one listed must be 29.481 (pl. 96). The last four entries refer to the jade or other hardstone vessels in the collection.

Because of its very general nature, this list throws little light on what the Safavids thought of these treasures. While they seem to have had no interest in the decoration, the fact that they felt it important to dedicate these wares to the ancestral shrine and to include an inventory in the record of the dedication indicates the high regard in which porcelain was held. Although it is well known that large shipments were reaching Europe in the early years of the seventeenth century, ${ }^{13 a}$ there is still no accurate information on the quantities that went to Iran; but abundant or scarce, cheap or expensive, it was, above all, porcelain, a material that combined beauty and practicality to an unheard-of degree, and a material they could not make. For these qualities alone it commanded admiration and respect.

\section{THREE CENTURIES OF RUMOR}

For the period of almost 300 years between the dedication of the porcelains to the ancestral Shrine in 1611 and the publication of Sarre's text in 1910, the fullest sources of information at our disposal are the journals of European travelers who

${ }^{11}$ Cf. p. 63 below.

${ }^{12} \mathrm{Cf}$. Pope, Fourteenth-century blue-and-white, p. 10.

${ }^{13}$ Nos. $29.445,464,465,466,472$; plates 69,97 , and pp. 116-117, 132-133.

${ }^{13 a}$ See p. 136 below, and T. Volker, Porcelain and the Dutch East India Company, Leiden, 1954, pp. 21-24. 
visited Ardebil and recorded their observations. In these sporadic and uneven accounts we can trace the varying fortunes of the Shrine and the porcelain collection down to our own times. As will be seen from the selected quotations which follow, the tone and scope of the reports vary greatly with the personal tastes and interests of the several observers; some did not mention the Chīni-khäneh at all, while others marveled at it, but when taken all together the journals provide a full and often lively picture of the activities of a major national shrine and the part it played in Persian life particularly in the seventeenth century.

To cite the writings of all these travelers in full, even insofar as they touch on Ardebil alone, would extend this section beyond reasonable bounds, and the passages that have been chosen are limited for the most part to those that speak of the porcelain collection. On the other hand, one or two are of such general interest in throwing light on the function of the Shrine or on its condition, or on the attitude of Christian Europeans toward Muslim Persians in the early days of their contact, that they seem worthy of inclusion. For these reasons and because he was the first of a long series of hardy spirits to make the difficult journey, it is appropriate to begin with the words of Anthony Jenkinson, who traveled to Persia by way of Russia on behalf of the Right Worshipfull Societie of Merchants Adventurers, bearing credentials from Queen Elizabeth I, for the purpose of establishing commercial relations. ${ }^{14}$ Arriving in the reign of Shāh Tahmāsp some 49 years before the benefactions of Shāh 'Abbās were bestowed on the Shrine, he wrote, ". . . the 16. day of October [1562] we arrived at a citie called Ordowill [Ardebil], where we were lodged in a hospitall builded with faire stone, and erected by this Sophie's ${ }^{15}$ father named Ismael, only for the succor and lodging of strangers and other travellers, wherein all men have victuals and feeding for man and horse, for 3. dayes, and no longer. This foresayed late prince Ismael, lieth buried in a faire Meskit [= Masjid = Mosque], with a sumptuous sepulchre in the same, which he caused to be made in his lifetime." ${ }^{16}$ Here the Shrine is revealed in its function as travelers rest house, but in spite of the hospitality thus afforded to strangers we feel the bitter underlying hatred of Christian for Muslim in a short passage soon after where Jenkinson describes the Persians as "esteeming all to be infidels and Pagans which doe not believe as they doe, in their false filthie prophets Mahomet and Murtezallie." ${ }^{17}$

${ }^{14}$ It was Jenkinson who brought back the great Ardebil carpet dated 1540 in the Victoria and Albert Museum.

${ }^{15}$ To contemporary Europeans the Safavid Shāh was The Great Sophie or Sophi. Browne, op. cit., p. 21, says it derives from the fact that the Shāh was not only temporal ruler but also spiritual leader (Sheikh) of the Süfīs and hence the Great Süfī or Sophi; he doubts if it can be considered a corruption of the dynastic name Safavi. Ross, Sir Anthony Sherley, p. 92n., however, clings to the latter explanation.

${ }_{16}^{16}$ Jenkinson, Early voyages and travels to Russia and Persia, p. 139.

${ }^{17}$ Op. cit., p. 145. 
Jenkinson's countrymen, the famous Sherley brothers who reached Persia in 1598 and served Shāh 'Abbās in various capacities, seem not to have visited Ardebil; and the next to do so was the Italian Pietro della Valle, who stopped there about 1619. $\mathrm{He}$ described the Shrine but declined to enter the tomb of the Sheikh and only relates the impression he gained from his traveling companion, the remarkable Madame Maani. Soon thereafter, however, comes the most complete of the seventeenth-century accounts and the first to mention the porcelain collection. It is that written by Adam Olearius who served as secretary to the ambassadors sent by Frederick, Duke of Holstein, to the Great Duke of Moscovy and the King of Persia, and arrived in Ardebil in 1637. Describing it as "one of the most ancient and most celebrious cities of all the Kingdome, not only by reason of the residence which several Kings of Persia made there, but also particularly upon this accompt, that Shich-Sefi, Author of their Sect, liv'd and dy'd there," he goes on to discuss the climate and the products of the region. Coming to the Shrine, he begins with the approach including this interesting passage, "Leaving the Maydan you come into the Bazar . . . three covered streets all beset with shops . . . several caravanserais . . . for the convenience of foreign merchants as Turks, Tartars, Indians, etc. We saw there also two Chineses, who had brought ther, to be sold, Porcelane, and several things of Lacque." Then he describes the Prayer-Hall and the Sepulchre and continues thus, "Having taken notice of all that was to be seen in that place, we were conducted through the same Gallery, towards the right hand, into another spacious apartment, which was arched all about and Gilt; where we could not but admire the manner of its building, which being as large as a fair Church, was nevertheless sustained by the strength of the Roof, and without Pillars. This Hall is called Tzenetsera $[=$ Chīnī-serai $=$ Chinī-khäneh], and serves for a Library." At this point he gives an account of the books in Arabic, Persian, and Turkish, bound and covered with gold and silver plates, and some with colored illustrations, and continues, "In the Neeches of the Vault, there were above three or four hundred vessels of Porcelane; some, so large, as that they contain'd above 40. quarts of Liquor. ${ }^{18}$ These are only used at the entertainments, which are brought from the Sepulchre, to the King and other great Lords, who pass that way: for the holiness of that place permits not that they should make use of any Gold or Silver. Nay, it is reported of Shich-Sefi, that he, out of an excessive humility, made use only of Woodden Dishes." ${ }^{19}$ Olearius was also immensely impressed by the wealth of the Shrine which he describes thus, "The foundations of several Kings, its vast Revenues, and the Presents which are daily made thereto, do so augment the Wealth of it, that some conceive, its Treasure amounts to many Millions of Gold, and that, in case of necessity, this Mesar $[=$ Mazar $=$ Shrine, place of pilgrimage $]$ might raise and maintain a very

${ }^{18}$ The largest vessels in the surviving collection are the kuan vases like 29.520 (pl. 79). A similar piece in the Freer Gallery of Art (45.35) holds 79 quarts by actual measure.

${ }^{19}$ Olearius, The voyages and travells of the ambassadors . . . , p. 179. 
powerful Army, and that it would furnish more ready Money than the King could himself." ${ }^{20}$

Some 40 years after Olearius, the Frenchman Jean Baptiste Tavernier saw the Shrine but made no reference to the porcelain ${ }^{21}$; and thereafter we are left with a gap of more than a century until Jaubert in 1805-1806 described the tombs of Sheikh Safī, Heidar, and Ismā'īl as "placés sous dômes peu élevés et tombant en ruines." ${ }^{22}$ It was James Morier, creator of the immortal Hajji Baba of Ispahan, who, on his second journey to Iran, was next to mention the porcelains in these brief terms: "From the tombs we were led to a saloon of large dimensions, painted and ornamented in a beautiful style, and upon the floor of which were placed a great variety of Chinese bowls, vases, etc. besides several curious wrought cups of jade and agate, that did not appear to be of Mohamedan workmanship. A collection of manuscript books, the gift of Shah Abbas, were here preserved, in two large closets inserted in the wall, and which we were permitted to inspect. The books were in excellent preservation, and consisted of the best Persian works, some of which were beautifully written and highly illuminated. Most of them were stamped with the seal of Shah Abbas; and on the blank page at the beginning of each, it was inscribed, that they were left for the use of those who would read them on the spot, but that a curse would fall upon whomsoever should take them from it." Among the books he described two of special interest, "a koran, six hundred years old, made of the thick silky paper of Khatai, so large and heavy that two men could scarcely lift it; and a book in the Cuffick character, containing several chapters of the koran, as we were assured, written by the hand of Ali, seven years after the hejra." ${ }^{23}$ This is the first reference to the jade vessels mentioned in the list of Jalāl ed-Din, and the first time the porcelains were described as being on the floor, a circumstance explained less than a decade later by the next visitor to record what he saw.

James B. Fraser entered Ardebil on 9 July 1821 and found it in a poor state. "I took every opportunity to examine the town of Ardebeel," he wrote, "though it does not contain many objects capable of arresting the traveller's attention"; and he described it as built on the remains of a famous city and now not equal to a third the size of Shiraz having no more than five or six hundred families. Of the Chini-khäneh he wrote, "A large octagonal apartment, covered by the principal dome, has obtained the name of zerfkhanah or china-ware-room, because all the dishes used in the feasts which Shah Ismael gave to his daily guests, were preserved here in niches formed for the purpose in the wall. This apartment had been very richly adorned, and the niches

${ }^{20}$ Op. cit., p. 180.

${ }^{21}$ Tavernier, Les six voyages . . . , pp. 54-55.

${ }_{22}$ Jaubert, Voyage en Arménie et en Perse . . . , p. 167.

${ }^{23}$ Morier, A second journey through Persia . . . , pp. 255-256. Morier visited the Shrine on 19 October 1812. 
which occupy the walls on all sides, and in various figures, produce an effect resembling that of a magnificent fretwork. But the china-ware no longer fills them; in one of the earthquakes to which this district is liable, so many of them were thrown down and destroyed, that the whole were taken from their cells and placed upon the floor, where they now stand covered with dust. There are also in the chamber, as I understood, some valuable books, in like manner going to decay." ${ }_{24}$ Fraser also added an interesting observation on the finances of the Shrine at his time when he said it had no fixed revenues as had those at Mashhad and Qum but was dependent on the donations of pilgrims and pious Shī'as; and he assumed this was why foreigners like himself were allowed to visit every part of it. He was told there that the Qajārs "are more apt to take from than give to an establishment of any kind," an observation that helps more than a little to explain the sorry state of the monument under that dynasty.

In 1826 Lt. (later Sir) James Alexander, late H. M.'s 13th light dragoons, and then attached to the suite of Col. Macdonald Kinnier, K.L.S., Envoy Extraordinary to the Court of Tehran, passed through Ardebil. On 28 August of that year he wrote, "We proceeded to visit the tomb of Shaikh Suffee and his illustrious descendant, Shah Ismail. Their remains repose under lofty domes; four swords surmounting the apex of that of the latter. The ark over the grave of the saint is fenced off by a silver grating. The rooms are highly ornamented. In one is a large collection of china (amongst which I observed some beautiful agate cups and dishes), and a library of splendidly bound and valuable books, one of which is remarkable for its weight. All of them had been presented by Shah Abbas the Great, as offerings at the tombs of his ancestors." ${ }^{25}$ Alexander was the last traveler to see the books, for in 1828 the Russians, who were already stirring up trouble in the neighborhood and some of whom he met, sacked Ardebil and carried off the library, as is recorded by the few travelers who remain to be quoted.

Colonel Montieth wrote in 1832, "The fine library was sent to Russia when the place surrendered to Count Soukhtaline, and the tomb has been much damaged, at least in outward appearance, by earthquakes." ${ }^{26}$ And in 1845 there appeared the least flattering of all descriptions of the Shrine by W. R. Holmes who wrote, "The exterior presents three or four domes, but is neither striking nor picturesque"; but he again noticed the porcelains, and spoke of "the large domed chamber, containing the china which belonged to Shah Ismael, or, as some say, to the Sheik, consisting principally of large dishes, vases, drinking cups and flagons, spread out on the floor; the numerous recesses in the walls originally intended for their reception, being left empty. The walls and niches were beautifully gilt and painted." ${ }^{2 r}$ It is he who tells us that the

\footnotetext{
${ }^{24}$ Fraser, Travels and adventures . . . , p. 296.

${ }^{25}$ Alexander, Travels from India to England . . . , p. 189.

${ }^{26}$ JRGS, 3 (1832) : 27.

${ }^{27}$ Holmes, Sketches on the shores of the Caspian . . . , p. 38.
} 
books taken by the Russians were 160 in number, all that were found there, but that "there were others in the possession of various inhabitants of Ardebeel, which thus escaped the hands of the plunderers, and have since been restored to the library." ${ }^{28}$

Finally, the last account before that of Sarre was written in 1875 by Lt. Baron Max von Thielmann, secretary of the Imperial German Embassy at St. Petersburg, and is remarkable in at least two respects. The Baron wrote, "The celebrated library of Sheikh Sefi no longer exists; after the capture of the town it was sent to St. Petersburg by Paskiewitsch and incorporated into the Imperial Library. The mausoleum of Sheikh Sefi possesses a treasure quite unrivalled. This is a collection of old Chinese and Persian porcelain, offerings from Persian rulers, displayed over the floor of the vaulted hall, which from its unique character is perhaps of incalculable value. These offerings, amongst which are huge dishes and bowls, are so numerous that, in order to find accommodation for them in the hall, they have been piled up one above the other in small heaps. Even if the total amount of these pieces be estimated at 2,000, that figure would, perhaps, still be below the margin. Owing to want of care a great many of them have unfortunately been cracked or otherwise injured, and each individual piece lies buried beneath an inch of dust. It would have been a great gain to the world at large, and to art in particular, if Paskiewitsch had equally sent this collection to St. Petersburg." ${ }^{29}$ It seems likely that the noble author, who was the only traveler to sense the importance of what he saw, did so because he was familiar with some of the great porcelain collections which existed in Germany in his time; and apparently his enthusiasm got the better of his judgment when it came to making an estimate of the number of pieces.

A quarter of a century after Thielmann, the Shrine was visited for the first time by a man who was trained to evaluate what he saw and to study it and record his findings in terms which placed it in proper historical perspective. With Sarre, the period of rumor came to an end. His description of the separate units that made up the elaborate architectural complex is the most complete one on record and must form the basis of any future study; and his publication includes photographs of the porcelains on the floor of the Chini-khäneh as well as comments on the scope and nature of the collection. The passage runs thus, "The porcelain vessels which were originally placed In the niches now stand upon the ground, approximately 500 in number. They are blue-and-white Chinese Ming porcelains in a number of forms. Above all there appear among them large-barrelled vases almost a metre high; besides these there are plates, bowis, pitchers; the latter are also frequently in pure Persian form. Among the blueand-white porcelains are some few vessels decorated in variegated enamel colors, and further a number of jade works (cups and incense burners in the form of animal figures and flowers) and finally a splendid gold-enamelled glass lamp. The great part of these

${ }^{28}$ Op. cit., p. 40.

${ }^{20}$ Thielmann, Journey in the Caucasus . . . , vol. 2, pp. 33-34. 
vessels is well preserved." ${ }^{30}$ Some 20 years later, writing a popular article in connection with certain objects lent to the Exhibition of Persian Art held at Burlington House in 1930-1931, he again described the Ardebil Shrine and with it the Chini-khäneh; while some of it repeats what he had written before, there are differences which are worth noting, and to make the record as nearly complete as possible, this new description of the room and the porcelains is quoted in full: "The interior consists of a square-domed chamber with four niches. Below is a tile covered base, then a corbel with flat concave fluting, which leads to a most unusual wall decoration consisting of pierced woodwork forming variously shaped niches, which served to contain pieces of Chinese porcelain and follow the shapes of these vessels exactly. The general effect at first sight is that of a very artistically arranged collector's cabinet or museum, and may be compared to a European porcelain cabinet of the eighteenth century. Though they now stand on the floor, the original position of the porcelain vessels in the corresponding niches leaves no doubt about the artistic intention-the delight in the precious Chinese porcelain vessels-which must have determined the design; on the other hand, the vessels also served purely practical purposes, and were used for meals at court and on festive occasions such as the reception of foreign ambassadors. This is no doubt the largest collection to find its way out of the country in early times, apart from the collection in the Serail at Constantinople. Perhaps, as suggested by Mr. A. [sic] L. Hobson, this Chinese porcelain was sent to Ardebil as a personal present from the Chinese Emperor Wan-li (1573-1619), who is known to have sent similar presents to the Mogul Emperor of India. Most of the vessels belong to the cobalt-blue underglaze painted Ming porcelain of the sixteenth to seventeenth century." ${ }^{31}$

Three points in this passage are worthy of comment. As a glance at Plate 4 will show, the many intricate niches with which the walls are covered by no means "follow the shapes of these vessels exactly"; some of them approximate the porcelain shapes, and others may be cut in generally appropriate proportions; none are precise imitations of any of the pieces in the collection. As to Hobson's suggestion that the porcelains came to Ardebil as the gift of the Wan-li emperor, all the evidence that has come to light since that article was written, including the fact that porcelains were included in the Turkish booty removed from Tabriz as early as 1514, points to the fact that Chinese porcelains must have been known and used in Iran for generations by the time Shāh 'Abbās made his gift; and no doubt this collection was in the process of formation over a period of many years. It is difficult to credit the suggestion that it all came at one time. And finally it is curious to note that none of the early observers from Olearius to Sarre seems to have noticed the dedicatory inscription of Shāh 'Abbās which appears on most of the pieces.

${ }^{30}$ Sarre, Denkmäler, vol. 2, p. 41.

${ }^{31}$ Sarre, The Holy Shrine of Ardebil. 



\section{ROUTES FROM CHINA TO IRAN}

Not the least interesting of the questions surrounding this collection is that relating to the routes by which it reached Iran. The suggestion that it came en bloc as a present from the Emperor Shên-tsung to Shāh 'Abbās ${ }^{32}$ need not be given serious consideration; and it seems likely that it came westward from China by land and by sea, a little at a time, over a period that may well be measurable in centuries. While it is possible that now and then a piece may have come west as a present from a Chinese to an Iranian or Turkic visitor in China, most of it probably made the journey as trade goods exported from the land of its origin on a purely commercial basis. Commerce between eastern and western Asia was nothing new, and Chinese porcelain had long been known in the Near East. Many literary references testify to the esteem in which this remarkable material was held by Arab and Persian alike. ${ }^{83}$

The celebrated Persian philosopher and scientist Al-Bīruni (A.D. 973-1048) described the methods used by the Chinese in preparing the clay and glazing the wares in his Al-Jumahir fi Ma'rifat al-Jawahir as early as A.D. 1000; and in the same work he reported that these vessels were imported from Yang-chou. In the home of a friend in Ray he saw "vases, sugar-basins, wash-basins, plates, jugs and drinking-cups-nay, even ewers, cups, censers, lamp-stands and lamp-holders and other utensils, all made of Chinese porcelain and I was amazed at his good taste in all that elegance" ${ }^{34}$; and all these must have been wares of early Sung or earlier. In Damascus more than 300 years later, Ibn Battuta (A.D. 1304-1377) the Arab traveler saw on the street a small slave who "dropped and broke a Chinese porcelain dish, and the people said 'Gather up the pieces and take them to the custodian of the endowments for utensils." This he did, and he was given enough to buy a similar dish and so avoided being beaten or scolded by his master ${ }^{35}$; and later on when he reached China, Battuta gave a short account of the manufacture of pottery and referred to the Chinese as the finest of all makes. $^{36}$

Instances like these need not be multiplied; there is abundant evidence that

${ }^{32}$ Cf. p. 17.

${ }^{33}$ Cf. Kahle, Islamische Quellen zum chinesischen Porzellan, for an extensive study of these references; only a few selected examples are given here.

${ }^{34}$ Krenkow, The oldest western accounts of Chinese porcelain, pp. 464-465. This article is based on an erroneous assumption and hence is unreliable; but there seems no reason to doubt his translation of this passage from Al-Bīruni.

${ }^{35}$ Ibn Battuta, Travels in Asia and A frica, p. 70.

${ }^{36}$ Op. cit., pp. 282-283. 
porcelain was there, and the more difficult matter is the determination of the routes by which it came. In fact, so complex is this problem that it cannot be properly approached without a long preliminary program of research into the original sources, both Chinese and Persian; and as we already know, procelain, much as it may have been admired, was not always the subject of such extensive comment as scholars today might hope for. So the story will only emerge gradually as a sentence from one author and a phrase from another are painstakingly ferreted out and pieced together. For the present we must be content with a handful of hints gathered from various sources which permit us to reconstruct a rough outline of the means by which these porcelains moved between China and the West; and because we are here principally concerned with the collection from the Ardebil Shrine, most of which was blue-and-white, we may set our limits between the period of the earliest wares of the type and the terminal date of the collection, or roughly the two and a half centuries between A.D. 1350 and 1600 .

Evidence for the land routes is meagre, but two great travel diaries of the early fifteenth century provide a certain amount of light. Between 1403 and 1406 Ruy Gonzalez de Clavijo undertook an embassy from Henry III of Castile to the court of Timür whom he found in residence at Samarqand ${ }^{37}$ preparing for the conquest of China, an attempt that was forestalled only by his death less than three months after the departure of the Spanish ambassador. Clavijo's report is filled with details of absorbing interest; but we may confine our comments here to the fact that he observed the use at feasts of "large trencherlike basins, these some of gold and some of silver, while others were of vitrified earthenware, or else what is known as porcelain, and these last are much esteemed and of very high price"; and he notes also the presence of wine vessels of about 60 gallons' capacity though he fails to mention the material. If these were porcelain they were much larger than anything known from that period ${ }^{38}$ and would have been extremely heavy and cumbersome to transport. Shortly before his arrival, a caravan of some 800 camels had come in from China only to be interned by Tīmūr; and Clavijo was able to ascertain that the capital of China, which he called Cambaluc as did the Mongols, ${ }^{39}$ was six months' journey from Samarqand. As that Timurid capital in turn lay some two months east of such Persian centers as Qazvīn and Tabriz, it seems likely that porcelains traveling by the central Asian route were eight months or so on the way.

A more detailed itinerary is provided by the journal of an embassy sent by Tìmūr's son and successor Shäh Rokh to the court of Peking in the years 1419-

${ }^{37}$ Clavijo, Embassy to Tamerlane, esp. pp. 218-300.

${ }^{38}$ Cf. p. 13 , n. 18 , for the capacity of the largest type of sixteenth-century porcelain.

${ }^{39}$ By the time of Clavijo, the Ming capital had been at Nanking for 35 years and in 1403 was again moved north to the old Cambaluc now renamed Peking. There are other unexplained lapses in his journal such as his reference to the emperor of China as "Chays Khan," a name that remains to be explained. Cf. Pelliot, TP, 27 (1930):443. 
$1422^{40}$; and before launching into an account of the journey itself the author describes the arrival of ambassadors from China to Herāt bearing gifts including satin, velvet, and porcelain vases. A former embassy having been given a gray horse, the next embassy brought back a portrait of this horse by a Chinese painter, and there seems to have been abundant traffic between the Ming and Timurid rulers at this time. On its return this latter embassy was accomplished by representatives of Shāh Rokh to the emperor of China; and after a good deal of preliminary formality they set out from Herāt on $16 \mathrm{Zu}-1-\mathrm{Qa}^{\mathrm{d}} \mathrm{da} 822$ (5 December 1419). Through Balkh and Samarqand into "the lands of the Mongols," they passed Tashkent, Sairam, Ashpara, and Amalik to reach the ancient Buddhist oasis of Turfan on 8 Jumādā II 823 (21 June 1420). Proceeding via Karakhodja and Hami, they reached Su-chou on 14 Shaban (25 August) and this they describe as the first Chinese city on the route ${ }^{41}$; here in the midst of the desert they were given a banquet which impressed them immensely: goose, chicken and meats, and dried fresh fruits were served them in porcelain dishes on tables decorated with artificial flowers and greenery. And from here on the journal abounds in glowing descriptions of the wonders of China, with comments on everything from the splendor of the temples with their colossal gilt images to the beauty of the women. They traveled on through Kan-chou, across the Yellow River down to Hsi-an-fu and northeast again to Peking (still called Khanbalik), which they reached on $8 \mathrm{Zu}$-1-Hijja (15 December), a year and ten days after the departure from Herāt. This schedule tends to clarify the estimate of Clavijo; his six months from Samarqand to China was about right; it took the embassy of Shāh Rokh five months and ten days from there to Su-chou, and seven months to the Yellow River. The pace of the caravan is leisurely.

On the return journey they varied the route by traveling south of the Taklamakan Desert via Khotan and Kashgar; and both the northern and southern roads were evidently in common use as they had been in the time of Hsüan-tsang eight centuries earlier. As for the porcelains which must have accompanied the westward journeys of such missions, some may have gone along as the private baggage of individuals, but most of it probably moved on the camels of traveling merchants, for in accordance with age-old custom the huge caravans were made up of any number of smaller parties, each bent on its own business but banded together for common safety on the perilous crossing of the mountain and desert wastes of Central Asia.

Writing early in the sixteenth century 'Alī Ekber, who had traveled to China and spent some time in Peking, does not describe his journey but only remarks that from

${ }^{40} \mathrm{~A}$ bibliographic history of this work by Abderrazak Samarqandi is given by Quatremère, Mémoires historiques sur la vie du Sultan Schah-rokh, and the journal is translated by the same author in Notices et extraits des manuscrites de la bibliothèque, vol. 14, pt. 1.

${ }^{41}$ The embassy was actually within the borders of China when it reached Hami 24 days earlier. Cf. Herrmann, Atlas of China, pp. 54-55, for the complete route. 
the lands of Islam there are three land routes to China: one through Kashmir, one through Khotan, and one through "Mogholistan, the land of Chaghatay." ${ }^{42}$ His definition leaves something to be desired. A route through Kashmir might lead through Khotan as well, or, if taken farther north before making the eastern swing, it could lead to the Kucha-Turfan-Hami road north of the desert; and either one could be described as passing through what he calls "Mogholistan, the land of Chaghatay." All he tells us in effect is that in his time, as earlier, both the northern and southern routes were in use. As to the time, he reports that "from the banks of the river Jaihun (Amu Darya or Oxus) to the boundaries of Khitai is a distance of three months, every day a stage about twice the march of the army of his majesty, the Conqueror of the World." ${ }^{43}$ This is shorter than the journey of the Shāh Rokh embassy but may only reflect a difference in travel conditions or in the habits of individual caravans.

A group of documents translated more than 150 years ago throws light of another kind on the central Asian trade of these times. This is a series of 17 letters from various Muslim princes to the emperor of China enumerating the presents they offer and stating the kinds of things they hope to get in return..$^{44}$ Four of them ask for porcelain, and as they bear directly on our problem they are quoted here. The numbers are those of Amiot.

(9) "Shan-si-ting, envoy of the Kingdom of Tu-lu-fan (Turfan), dares to present himself before your Majesty to offer him in tribute two horses of the western lands and one camel. I most humbly beg your Majesty to do me the kindness of accepting them, and to have the goodness to have given to me some pieces of satin brocaded with gold, and some pieces of porcelain such as cups, plates and dishes, etc. I hope you will not disapprove the liberty I take, and that you will give your orders in conformity with my request."

(12) "Sha-chu-ting of T'ien-fang (Mecca) dares to present himself before the great emperor to offer him in tribute a hundred and fifty pounds of jade stone and ten horses of the western lands. I beg of your Majesty to have given to me some pieces of satin of different colors, some tea leaves, and some pieces of porcelain. I hope you

${ }^{42}$ Kahle, Eine islamische Quelle über China um 1500, gives a full account of 'Alī Ekber's journal, the Khitai Nameh. See note 254, p. 122 below.

${ }^{43}$ The reference is to the Ottoman Sultan, either Selīm I or his successor Süleymăn I. "Alĩ Ekber dedicated his book to the former, who died before the work was finished, whereupon the author wrote a second dedication to Süleymān.

${ }^{44}$ Amiot, Mémoires concernant les . . . chinois, vol. 14, 1789, p. 241. Father Amiot does not reveal the source of these letters, but Bretschneider, Medieval researches, vol. 2, p. 149, says "they are preserved in the Sz'yi kuan [四夷館], a book published in the fifteenth century in the linguistic office at Peking, established in 1407 for diplomatic purposes." The Ssŭ-i-kuan-k'ao, based on a Ming manuscript version of this work, was published by Lo Chen-yü in 1924. 
will have consideration for my petition and give your orders in conformity of my desire."

(16) The same man as in (9) above makes the same offering and asks for satin brocaded with gold and some vases of porcelain.

(17) "Sa-chu-ting, your slave, Envoy of the Kingdom of Sa-ma-erh-han (Samarqand) presents himself before the supreme Emperor. I have come to prostrate myself before the golden door of your august Palace, and, having struck my forehead on the ground, to offer you in tribute 50 pounds of jade stone and 500 small knives. I most humbly beg your Majesty to have the goodness to not disdain my homage and to please have given to me some pieces of satin brocaded with gold, and some pieces of porcelain, and other things. I hope your Majesty will please give orders in conformance with the petition I make to him."

Commenting on these letters Father Amiot points out that "what is called tribute is properly an exchange of some merchandise for other things more valuable. It is Chinese policy to keep those whom they call tributary in their debt, heaping them with benefits; and it is in their interest not to grant them benefits except in the form of recompense; and it is part of their greatness not to give recompense except in regulated terms."

These are but a few of the many missions that crossed Central Asia in Ming times. Referring only to Samarqand and places farther west, Bretschneider lists close to a hundred specific missions in addition to those cases where they are reported to have gone "every year" or "frequently." ${ }^{45}$ They are pretty well distributed through the length of the dynasty: Hung-wu $12+$, Yung-lo 24+, Hsüan-te 6, Cheng-t'ung 6, Ching-t'ai 2, T'ien-shun 4, Ch'eng-hua 6+, Hung-chih 6, Cheng-te 5+, Chia-ching $12+$, and Wan-li $10+$, so that porcelains of all periods must have reached the Near Eastern markets when they were new; and even a relatively small shipment each time would account for a considerable accumulation of Ming wares by the end of the Wan-li period.

But land routes provided only half the means of contact between China and the Near East; and the weight and bulk of porcelain being what they are, that commodity is much more suited for transportation in the holds of ships than on the packsaddles of camels, and so further information may be sought in the records of the maritime trade. Although it was written about the middle of the thirteenth century, a hundred years before the earliest wares in the Ardebil Collection were made, the Chu-fan-chih 諸蕃志 of Chao Ju-kua 趙讯适 must be mentioned as the classic compilation on the

${ }^{45}$ Medieval researches, vol. 2, pp. 256-309. Most numerous were embassies to or from Samarqand, Khorasan, Badakshan, Herāt, Shiraz, Mecca, and Rūm (Turkey). A most curious fact is that ambassadors from the latter country included porcelain vases among the articles brought as tribute to China in 1548 and 1554; one would like to have more details on this remarkable transaction. 
history of the subject up to its time. ${ }^{46}$ Discussing the countries that traded with China, and the history of relations in each case, he also describes the products peculiar to each and lists the Chinese things they liked to receive in exchange; in the latter category porcelain is mentioned on a number of occasions. Referring to an even earlier work, the P'ing-chou- $k^{\prime} o-t^{\prime} a n$ 萍洲可談 of Chu Yü 朱或 written in the first quarter of the twelfth century, ${ }^{47}$ the translators in their introduction give some interesting details about the make-up of fleets and the practical aspects of shipping out of Canton, among which the following is pertinent: "The greater part of the cargo consists of pottery, the small pieces packed in the larger, till there is not a crevice left." Thus even in Northern Sung times pottery seems to have been sent abroad in some quantity.

Most of the countries mentioned by Chau Ju-kua are in eastern Asia, southeast Asia, and India, but a few of the more westerly lands are included providing evidence that the Chinese of Sung times were in commercial contact by sea with Arabia, Iran, Egypt, and the African coast. Zanzibar, curiously enough, is the only one of these latter which is mentioned as receiving porcelain in trade, and the author reports that it was shipped there from Gujerat and the coastal towns of Arabia. ${ }^{48}$ On the whole, because of the early date of his text, Chau Ju-kua is only of marginal interest to our immediate problem, but the work contains a wealth of background material showing that by the time the fourteenth-century and later porcelains which are the subject of this study were being shipped westward, maritime trade between China and the Near East was already an old story.

Most of this shipping was in the hands of Arabs, and it was only in the early fifteenth century that large-scale maritime operations were launched by the Chinese. These were the great voyages sponsored by the Ming emperor Ch'eng-tsu and carried out in his own reign and that of his successor (Yung-lo and Hsüan-te; the Hung-hsi reign was of no consequence) which were the most important naval expeditions in Chinese history spreading the prestige of the Ming Dynasty to distant lands and bringing home vastly increased first-hand knowledge of the world. ${ }^{49}$ Most famous are the seven voyages commanded by the eunuch Cheng Ho in 1405-1407, 1408-1411, $1412-1415,1416-1419,1421-1422,1424-1425$, and 1430-1433; and for our present purpose it need only be noted that the third, fourth, and last of these included Ormuz among the ports of call. This island commanding the entrance to the Persian Gulf was also the port of entry to that country for all seagoing trade, and while specific

${ }^{46}$ Hirth and Rockhill, Chau Ju-kua, St. Petersburg, 1911, is the complete translation of this work; cf. also Pelliot's extensive review in TP, 13 (1912): 446-481.

${ }^{47}$ Op. cit., p. 16 , n. 1 (second note).

${ }^{48} \mathrm{Op}$. cit., p. 126. No doubt it was transshipped at those places, having come there from China.

${ }^{49}$ Duyvendak, Ma Huan re-examined, Pelliot, Les grandes voyages maritimes chinois du debut du $X V^{\text {e }}$ siècle, TP 30 (1933): 237-452, and Duyvendak, The true dates . . . TP 34 (1938-39): 341-412, are the most up-to-date and exhaustive studies of the accounts of these voyages; in these articles will be found reference to all previous studies and translations. 
references to porcelain are wanting there can be little doubt that this material was included among the cargoes traded at that port. These goods then made their way to the cities of the Iranian plateau by caravan, a journey which Clavijo, reporting on Sultānīyeh, describes as taking 60 days. $^{50}$

Less seems to be known of the trade in the latter part of the fifteenth century, and by the beginning of the sixteenth the seas were pretty well controlled by the Portuguese who continued the shipping. In 1514 they took Ormuz, thus gaining control of the maritime commerce of Iran; under their rule it became one of the fabulously rich ports of the East and remained so until 1622 when they were driven out by Shāh 'Abbās with English help..$^{\text {5oa }}$

This in brief outline describes the ways by which the Ardebil porcelains moved westward from China to Iran and the means by which they were transported. Many questions are unanswered; and as has been suggested they may remain so for a long time because of the casual way in which the cargoes and shipments are described and the matter-of-fact light in which the Chinese regarded porcelain. For general purposes, however, this is almost enough; porcelain was in Iran in early times, commercial intercourse by land and sea is well documented, and though more specific details would add color to the picture, the answer to the question "How did it get there?" is clearly in our hands.

${ }^{50}$ Clavijo, op. cit., p. 161.

soa Additional information on the sea trade may be found in $\mathrm{T}$ 'ien-tse Chang, Sino-Portuguese trade from 1514 to 1644, Leyden, 1934, and T. Volker, Porcelain and the Dutch East India Company, Leiden ( $\mathrm{sic}), 1954$, though neither is specifically concerned with the trade between China and Iran. It is a source of particular regret that Volker's book was unknown to me until after my manuscript was completed. Although he deals largely with a period after the dedication of the Ardebil porcelains he gives many valuable data, reference to which would have enriched the present text. 



\section{MARGINALIA ON THE STUDY OF MING PORCELAIN}

\section{THE EVALUATION OF CHINESE SOURCES}

It is not surprising that the nineteenth century, which witnessed the first great flowering of scientific research in so many fields, should have come to a close with the publication of the first major contribution to the study of Chinese porcelain. Nor is it surprising that Stephen W. Bushell, the author of the monumental Oriental ceramic art,$^{51}$ should, as a scientific man himself and a younger contemporary of such giants as Darwin, Huxley, and Pasteur, have been inspired to make an intensive search into all the original source materials he could lay his hands on to prepare a solid basis for his investigations. He was by no means the first to venture into the field; in $1877 \mathrm{Sir}$ Augustus Franks had published the catalogue of his extensive collection ${ }^{52}$; and in $1881 \mathrm{Du}$ Sartel had brought out his sumptuous La porcelaine de Chine, the product of his fascinated devotion to the porcelains with which he had surrounded himself, and the first de luxe volume in Europe on Chinese porcelain. Both men in turn leaned heavily upon the Ching-te-chen-t'ao-lu 景德鍢陶錄 as partially translated by Stanislas Julien ${ }^{53}$ in the first important attempt to make a Chinese source available in a European language. Bushell, however, went to a slightly earlier work, the T'ao-shuo 陶說 by Chu Yen 朱堘, the first Chinese book to deal solely with the subject of ceramics, which was published in $1774^{54}$ and which not only included the author's own

${ }^{51}$ This is the catalogue of the Walters Collection which appeared in 10 large folio volumes with 160 color plates and over 400 illustrations in black and white in 1897 . The text was published as a separate volume in 1899 , and all references are to that edition.

${ }^{52}$ Franks, Catalogue of a collection of oriental porcelain and pottery. On $\mathrm{pp} . \mathrm{ix}-\mathrm{x}$ of the second edition, the one to which I have access, he lists the earlier works he has consulted.

${ }^{53}$ Julien, S., Histoire et fabrication de la porcelaine chinoise, Paris, 1856. The T'ao-lu, as it will be referred to hereafter, was written by Lan P'u 藍浦 and contains a preface by Liu Ping 劉丙 and a postface by Cheng T'ing-kuei 船廷桂, both dated in correspondence with 1815 . The work has since been fully translated into English by Geoffrey R. Sayer, Ching-tê-chên t'ao-lu, London, 1951.

${ }^{54}$ The T'ao-shuo bears an undated preface by $\mathrm{Ch}^{\prime}$ iu Yueh-hsiu 浆曰修 and postfaces by the author's kinsman Chu Wen-tsao 朱文澡 and by the eminent bibliophile Pao T'ing-po 鮑延博 both dated in 1774. Another edition, apparently very rare, bears a preface by Hsieh Chao-huang 薛肇璜 dated in accordance with 1782. This was first seen by Pelliot in the Rumyancov Museum in Moscow (cf. TP, 22 (1923): 45-46), and in 1938 I discovered another copy in the library of the Sinological Institute in Leiden; one of my own copies was printed from the same blocks as the latter and although fragmentary, in that it unfortunately lacks that preface, is identical in every other respect. A third edition has a postface of 1787 by Huang Hsi-fan 共錫蕃; and this is included 
knowledge as a connoisseur but also drew heavily upon all the sources at his disposal, more than 100 titles from which he quoted freely if not always accurately ${ }^{55}$ Working with Chu Yen's text as he did over a period of years, Bushell achieved a considerable familiarity with the literature of his subject, and his translations into English have been standard fare in all books on Chinese ceramics since his time.

But Bushell worked under two handicaps. He lacked the critical apparatus of modern sinology, and his first-hand contact with ceramic wares dating from periods earlier than the Ch'ing Dynasty must of necessity have been somewhat limited. This is in no way to his discredit; he simply lived too early, and the fact that he accomplished what he did, that in spite of these obstacles his book should still be an essential tool at the elbow of every student more than half a century later, but adds to his stature. Except for certain types of Ming wares that had been known abroad ever since Ming times, very few pieces of pre-Ch'ing date were seen in the West until after the turn of the century. True connoisseurship began with Hobson, ${ }^{56}$ and his first-hand knowledge of a wide range of wares combined with Bushell's knowledge of many texts to form the cornerstone of what we know today. But while many have undertaken to continue where Hobson left off, and great quantities of new material have come to light from a variety of sources to add to our first-hand knowledge, the translations of Bushell are still being quoted without change or criticism. Only a single voice has been raised to call attention to this curious lapse, and that appears to have been a voice crying in the wilderness.

As long ago as 1937 Sir Percival David took an immense step forward when he published his analysis of the relative merits to be found in the principal Chinese sources on ceramics and gave us some idea of the complex bibliographic problems involved. ${ }^{57}$ Remarking that "there is still today an uncritical and almost indiscriminate acceptance of all these various texts," he launched into a most thorough and penetrating study of the source materials he encountered in his search for new light on Ju ware;

in the latest edition I have seen which ends with a postface by Wei Ching-yü 魏經㛣 dated in the twentieth year of the Republic (1931). Sir Percival David has discussed the history of the $T^{\prime} a o-s h u o$ and the $T^{\prime} a o-l u$ at some length in Artibus Asiae 12, 3 (1949): 165-182, but does not seem to have seen this last edition. Chu's given name is written $x^{\prime}$ in his book, but his biographers use the variant orthographies 炎 and 琰.

${ }^{55} \mathrm{Cf}$. Oriental ceramic art, p. 664, where Bushell says "nearly a hundred and fifty different authors are quoted." In his complete translation of the T'ao-shuo, which appeared posthumously in 1910 under the title Description of Chinese pottery and porcelain, he says, "I have collected a hundred and five of the principal of these titles" (p. ix), but he includes the T'ao-lu which appeared only in 1815 and could hardly have been seen by Chu Yen! (p. 173).

${ }^{56}$ Chinese pottery and porcelain, 2 vols., 1915, is the locus classicus; and for Ming wares especially it is The wares of the Ming dynasty, 1923.

${ }^{57}$ A commentary on $J u$ ware, TOCS, 14 (1936-1937): 18-69. He and Pelliot had already exploded the myth of Hsiang's album, TOCS, 11 (1933-1934): 22-47; TP, 32 (1936): 15-58; TP, 33 (1937): 91-94. 
and although his problem at the moment centered on one particular kind of Sung pottery, the resulting paper is required reading for anyone who seeks to investigate what the Chinese themselves have written about the ceramic practices of early times. Unfortunately there is little evidence that this required reading has been done, and books on one phase or another of our subject continue to appear all richly flavored with that "uncritical and almost indiscriminate acceptance of all these various texts" against which Sir Percival warned us 17 years ago. In respect to Ming porcelain, which is the principal concern of the present volume, this practice has been particularly widespread; again and again the T'ao-shuo and the T'ao-lu and their sources have been quoted until the repetition rings like a refrain through book after book, and as the reader progresses through the chapters on the several Ming reigns he can hardly expect any surprises but only be quite sure he already knows many of the sentences that lie in store for him. In the same years that have witnessed this awe-inspiring flood of redundancy, hundreds of new porcelains have come to light and have taken their places in the public and private collections of Europe and America; first-hand knowledge of the wares themselves has increased accordingly, and the positive contribution of these writers has been the illustration and description of a wealth of new material which has done much to facilitate comparative study and contribute to the development of standards of judgment. The repeated parroting of the same old quotations translated from the same old Chinese sources, occurring as it does in the midst of these otherwise interesting expositions of new material and fresh and often provocative ideas, sounds a curiously incongruous note. It will continue to do so unless and until the original texts are examined with a critical eye and evaluated in terms of their inherent authority and the relevance of any particular passage to the problem on which it is brought to bear.

For these reasons the discussion of the porcelains in the Ardebil Collection which begins in the next chapter will contain only a limited number of such references, and in each case the source will be subjected to as critical a scrutiny as possible. But first a few general observations may not be out of place concerning the value of those two old standbys, the $T^{\prime} a o-s h u o$ and the $T^{\prime} a o-l u$, as sources of information on the subject of our present study, the porcelains of the Ming Dynasty. In terms of chronology alone one cannot but regard them with suspicion; an opinion on a Yung-lo or Hsüan-te bowl by an eighteenth-century writer carries about as much weight as does a critical analysis by Horace Walpole of a painting by Giotto. Beyond the fact that it throws some light on the connoisseurship of the time, it is worthless. Obviously we who write today are even farther removed from our subject, but on the other hand this increased remoteness in time and space is more than compensated for by other factors. In the matter of textual sources, although we always complain we have so few, we are in a better position than the eighteenth-century authors to evaluate what we have; and, more important than that, every student of our day can hold in his hand and study at 
his leisure more Ming porcelains than Chu Yen and Lan P'u between them are likely ever to have seen. These two were gentlemen and scholars in the Chinese tradition; but like others of their ilk they had a wide variety of interests, and the fact that each wrote a book on porcelain does not necessarily mean that they specialized in that subject. No doubt they collected in a small way, and one likes to think of comfortable evenings spent over a few pots of the yellow wine of Shao-hsing when they and their friends wrote verses, painted landscapes, and passed around for admiration a newly acquired bowl, maybe a K'ang-hsi piece or perhaps on rare occasions, one dating back as far as one of the Ming reigns.

As for the men themselves, nothing at all seems to be known of Lan P' $u$ beyond the brief references in the prefaces to the $T^{\prime} a o-l u$ by Liu Ping and Cheng T'ing-kuei. The latter states that Lan's manuscript had lain forgotten in a trunk for 20 years, or since 1795 , and his laudatory remarks are no more than the customary formalities employed by a Chinese scholar when speaking of his teacher. Chu Yen, on the other hand, is immortalized in no less than five biographies: (a) Chung-kuo-jen-ming-ta$t z^{\prime} u$-tien 中國人名大鲜典, p. $255 \mathrm{a}$; (b) Kuo-ch'ao-shih-jen-cheng-lueh 國朝詩人徽略, chüan 40, p. 17v4-10; (c) Hsu-yin-jen-chuan 續印人傅, chüan 5, pp. 9r9-10r4; (d) Ch'ing-hua-chia-shih-shih 淸甾家詩史, pp. 29v7-30v9; and (e) Mo-hsiang-chü huashih 毀香居䋖識, chüan 4, pp. 2r7-2v4. All agree that he was a native of Hai-yen 海監 in Chekiang Province and that he took his Chin-shih degree in 1766, but beyond that they become confusing. (a) and (b) say that he served as an official in Fu-p'ing-chih Hsien 阜平知䅫, a place not recorded in Chung-kuo-ku-chin-ti-ming-ta-tz'u-tien 中國 古今地名大鲛典; (d) says he served in Fu-ch'eng-chih Hsien 早城知稲 which is likewise unrecorded; and (c) and (e) assign his service to Fu-ch'eng 阜城 in Chihli Province, a name which leads to further complications because it may refer to either one of two places. To abandon this unrewarding track, however, and return to more pertinent matters, none of the biographies links him in any way with Jao-chou or Ching-te Chen where both Chu Wen-tsao and Pao T'ing-po in their prefaces tell us he spent some time studying the methods of porcelain manufacture; nor do they refer to the official post in Kiangsi Province which Pao tells us gave him the opportunity to pursue that study. Further, while the biographies allude to his literary and antiquarian interests and list some of the titles of his writings, only two, (a) and (b), mention the $T^{\prime}$ ao-shuo at all. In one or another they quote from his poetry, cite his proficiency in landscape painting, and refer to his interest in seals, in inks, and in calligraphy; but never a word about ceramics. In spite of the excellent recommendations of Chu Wentsao and Pao T'ing-po who were, it must be remembered, his kinsman and his publisher respectively, these serious lacunae in his credentials on the part of five biographers can hardly be overlooked.

While Chu and Lan may well have enjoyed a considerable familiarity with the

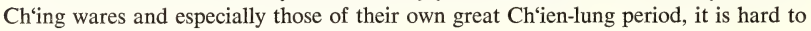


imagine that they could have seen and handled more than a few Ming wares from any one reign. Museums were unknown in eighteenth-century China; the great shipments of fine porcelain that went annually to Peking lay inaccessible behind the walls of the Forbidden City, and all they could possibly have seen were the private collections of a handful of scholars who might have accumulated a few dozens of pieces each. In these circumstances their knowledge of Ming porcelain must have been extremely limited; and indeed as we study Chu Yen's text it sounds more and more like hearsay whenever it is not straight quotation. Rarely does he give the impression of a man describing something he has seen. Writing of this kind has its place in the scheme of things and is not to be dismissed completely; it provides a valuable record of the connoisseurship of the period if only it be treated as such and not as a factual account of the nature of Ming porcelain. Moreover it throws a heavy burden of responsibility on the written sources it quotes, and for that reason it is pertinent here to examine briefly some of the latter. ${ }^{58}$

Chapters three and six of the T'ao-shuo are devoted to the wares of the Ming Dynasty, and in them Chu Yen has quoted from more than 20 separate works. If we set aside those compiled in the Ch'ing Dynasty and therefore suspect as first-hand sources on chronological grounds alone and those from which the quotations are not descriptive but merely supply collateral comment, there are eight Ming texts which undertake to discuss Ming porcelain. Two of these are local records: the Chiang-hsita-chih 江西大志, which Bushell ascribes to a certain Wang Tsung-mu of the early sixteenth century, ${ }^{59}$ and the Yü-ch'ang-ta-shih-chi 颜章大事記 by Kuo Tzu-ch'ang 郭子章, who received his Chin-shih degree in the Lung-ch'ing period (1567-1573). ${ }^{60}$ The former is given as the source of a long list of Chia-ching wares in chapter six, ${ }^{61}$ and this may be a reliable repertory of the types of wares produced at that time, although the lack of bibliographic data makes it impossible to say whether it suffered any revisions or modifications in the more than two centuries between the time it is assumed to have been compiled and the time Chu Yen used it; and if there were subse-

${ }^{58}$ An exhaustive analysis of the sources of the $T$ 'ao-shuo has long been needed, but such a study has no place in the present volume. It is an exacting and time-consuming task rendered even more difficult at the moment by the inaccessibility of the great libraries of China. In the hope of making a start, however, I have examined those sources quoted in Chu Yen's chapters on Ming wares to the extent that they are available to me. This work has been greatly facilitated by Sir Percival David's important bibliographic study (op. cit.), and without reviewing the intricate problems on which he has thrown so much light I limit myself here to certain general remarks about these books and their authors. See also Bushell's bibliographic notes in Oriental ceramic art, p. $650 \mathrm{ff}$.

${ }^{59} \mathrm{Cf}$. Description of Chinese pottery and porcelain, p. 173.

${ }^{60} \mathrm{I}$ have not seen either of these books, nor have I been able to identify Wang Tsung-mu. A biography of Kuo Tzu-ch'ang appears in CKJMTTT, p. 1043d.

${ }^{61}$ Bushell, op. cit., pp. 144-151. 
quent editions, as was the case with most local histories, there is no way of telling which one was available to Chu. The Yü-ch'ang-ta-shih-chi suffers from the same obscurity, but one quotation referring to the sixteenth year of the Wan-li reign $(1588)^{62}$ indicates that it must be later than that, and thus the author's remarks about the "Interregnum" ${ }^{63}$ were written more than a hundred years after the events he described.

Chu Yen's remaining Ming sources are all short chapters or even sentences from general works on antiques, ${ }^{64}$ works in which the subject of porcelain plays no more than a minor role. The authors, like Chu himself, were gentlemen scholars, dilettantes who dabbled in such a wide variety of subjects as archaic inscriptions, seals, inkstones, musical instruments, bronzes, jades, and paintings, and who may also have been small collectors in these fields. In every one of the books quoted, however, the mention of porcelain is little more than incidental, and there is no evidence that any one of the authors took the subject seriously or pretended to make more than the most casual observations. ${ }^{65}$ They are the superficial work of amateurs who wrote to while away the time; and in one case it is known that the author was simply amusing himself after several failures in the public examinations, a circumstance hardly calculated to inspire the confidence of his readers. ${ }^{66}$ On the whole, in spite of the fact that they were written in the Ming Dynasty, these works deserve no more credence than does that of Chu Yen who cited them.

The final evaluation of these Chinese texts on ceramics must await a more thoroughgoing analysis than has yet been undertaken, and this brief discussion serves only to provide an objective viewpoint from which they may be seen in proper perspective. They are neither fallible nor infallible in their entirety; they have served a very useful purpose in providing hints and suggestions during those early days of awakening interest in pre-Ch'ing ceramics when there was nothing else to work with. But they no longer carry the authority they were given half a century ago. Knowing something of the circumstances in which they were written and understanding the interests and limitations of their authors, we can see their weaknesses; and the time has

${ }^{62}$ Bushell, op. cit., pp. 63-64.

${ }^{63}$ Op. cit., p. 61. See below, p. 101.

${ }^{64}$ Ko-ku-yao-lun 格古要論, Shih-wu-kan-chu 事物紺珠, Ching-pi-tsang 清祌藏, Ni-ku-lu 妮古錄, Po-wu-yao-lan 博物要㗨, and $T$ 'ung-ya 通雅.

${ }^{65}$ The exception to this is the Po-wu-yao-lan, which Chu quotes most frequently and which must have in it a long section on pottery. I have never seen the original of this work which, on chronological grounds, to have been quoted by $\mathrm{Chu}$ Yen, must have been that compiled by Ku T'ai 谷泰 in the T'ien-ch'i period (1621-1627). The commonly available version is that published by Li T'iao-yüan 李雕元 in the second edition of his Han-hai 函海, which appeared only in 1801; and this is not the proper Po-wu-yao-lan but a modified version of a work called Ku-tung-chih 骨董志 with the title changed. (Cf. David, op. cit., pp. 39-40, 43-46). The fact that this latter work contains a longer passage on pottery than any of these other works is irrelevant to a study of Chu Yen's Ming sources.

${ }^{66}$ David, Commentary on $\mathbf{J} u$, p. 38. 
long since passed when anything is to be gained by trying to force the Ming porcelains we know today into the patterns outlined by these gentlemen and scholars of the Ming and Ch'ing.

\section{"IMPERIAL" WARES}

Turning from the texts to the porcelains themselves we come to another problem which merits a greater degree of objective consideration than it has received so far. This is the question of the so-called "Imperial" wares. It is known that certain porcelains were made in response to orders from Peking and destined for use in the Palace; and it has been customary among scholars and connoisseurs to think of these as "Imperial" wares and to try to single out the pieces that belong in this category from among the great masses of porcelain that have come on the market in recent decades and have made their way into public and private collections. Although there are no precise rules, certain criteria have come to be regarded as essential qualifications for admission to this select circle. Quality is given primary consideration, and to be called "Imperial" a piece must always be of the finest. Secondly, it has been assumed that such a piece should be marked with the nien-hao 年號 or reign name in six characters. And finally, when dragons appear in the decoration, it is considered that they must have five claws on each foot if the piece is to have "Imperial" status. ${ }^{67}$

In many instances these criteria are so interwoven that it is not easy to discuss them separately. Quality, which would seem at first glance to be the most obvious and simple of the three to deal with, is in some ways the most difficult because it is a relative matter based largely on experience; but so much good porcelain is available today that the prevailing standard of judgment is high. Beyond this come matters of taste, which are always highly individual and subject to disagreement; and further complications arise from the fact that an object may be the finest of its kind in a category somewhat below the top rank. Marks and dragons, on the other hand, lend themselves to more concrete discussion.

Before attacking the basic question of how far we are justified in making these assumptions about "Imperial" wares, and, as will be shown, they are no more than assumptions, it will be of interest to cite some specific examples of the occurrence of marks and dragons of various kinds. It should be noted at the outset that no acceptable fourteenth-century Ming mark has yet come to light, ${ }^{68}$ and only three

${ }^{67}$ Among some 1,500 pieces of Ming blue-and-white known to me, only about 150 are decorated with dragons of any kind.

${ }^{68}$ The Hung-wu nien-hao is seen on a number of porcelains, but I know of no case where it is genuine. A well-known series of small dishes with landscapes and figures bear this mark-e.g., Philadelphia Catalogue, 1949, no. 149 (henceforth abbreviated PMA to refer to the catalogue of the Ming blue-and-white exhibition held at the Philadelphia Museum of Art in 1949), and Oriental Ceramic Society Catalogue, 1953, nos. 211, 212 (hereafter abbreviated OCS Catalogue, 1953); but 
pieces which may be assignable to that period are decorated with 5-clawed dragons, ${ }^{69}$ and so our discussion begins with the wares made after 1400. Not one of the 200odd pieces of fiftenth-century blue-and-white in the Ardebil Collection carries a nien-hao, in spite of the fact that a number of them are of the highest quality and a few have properly marked counterparts in other collections. Certain of the white wares and colored wares, on the other hand, carry Ch'eng-hua and Hung-chih marks; and one of the finest blue-and-white pieces of all (29.403, pl. 50) is decorated with a 5-clawed dragon. Among the sixteenth-century wares are several with proper nien-hao; the great Cheng-te dish with Arabic script in the decoration (29.313, pls. 75 and 76) is the earliest, and there are marked Chia-ching and Wan-li pieces, some of them decorated with 5-clawed dragons (e.g., 29.520, pl. 79). If the generally accepted criteria for "Imperial" wares are valid, it is difficult to explain the presence of these pieces in the Ardebil Collection.

But there are equally puzzling problems among the blue-and-white wares that have left China in more recent times. A kuan in the Metropolitan Museum of Art and a pair of mei-p'ing in the William Rockhill Nelson Gallery of Art were exhibited together in Philadelphia in 1949, ${ }^{70}$ and this juxtaposition left no doubt that they belong together. In material, potting, glaze, drawing, and in the quality of the blue the three are evidently products of the same shop; and, as far as it is possible to judge, they give every indication of having been made, painted, and fired at the same time. Each is decorated with a single large and powerfully drawn dragon flying through cloud scrolls with four monster masks on the shoulder above; between two of these masks, at the top of the shoulder, each bears the mark of the Hsüan-te period written in four characters in a horizontal line. The only inconsistency as between the three is that the dragon on the kuan has three claws while those on the mei-p'ing have five; yet no one who has handled and studied these pieces has ventured to suggest that the latter are

these are all sixteenth century, as is the table screen illustrated by Reidemeister (Ming-Porzellane in schwedischen Sammlungen, $\mathrm{pl}, 1$ ). The mark appears again on a small deep bowl with almost vertical sides in the David Collection (Hobson, 1934, pl. 115), a piece which seems ill suited to the early Ming attribution it was given 20 years ago. The shape, more nearly related to that of the typical Raku ware tea bowl than anything else, is well known in Japan in both Chinese and Japanese blue-andwhite (e.g., Kushi, pls. 47-49; Fujita Sale Catalogue, 1929, no. 314; Shima Sale Catalogue, 1934, no. 138). The Japanese often refer to the ware as Gosu 吳須 (or Goshu 吳洲), a term which raises its own problems but which in general means coarsely made blue-and-white produced in the seventeenth century, and apparently having some traditional connection with the Tea Ceremony (cf., e.g., Yamanaka Shokai, Ko sometsuke . . . intro., p. 3). Whether this bowl was made in China or Japan is difficult to say; but the decoration of fighting cocks, rockery, and coxcomb in underglaze blue and red is entirely in keeping with the repertory of the late Ming and early Ch ing Transition Period, and the similar bowl illustrated on the same plate and bearing the Yung-lo mark must date from the same time. Both may well be seventeenth-century Chinese wares made for export to Japan.

${ }^{69}$ See p. 80 below.

${ }^{70}$ PMA, nos. 47, 48, 49. 
"Imperial" while the former is not. Still another example of the apparent contradiction between the 4-character mark and the 5-clawed dragon occurs on number 72 in the same catalogue; and the very beautiful foliated brush washer (number 43 in the same show) is of the highest quality in every respect, is decorated with 5-clawed dragons and carries no mark at all.

Further examples may be found in the sixteenth century. While it is not clear that "Imperial" status has been claimed for any of the Cheng-te pieces decorated with Arabic script, all seem to be marked with six characters while most of those decorated in the Chinese style are marked with four; and among the latter are several with 5clawed dragons in the decoration. ${ }^{71}$ This curious use of marks in the Cheng-te period still awaits explanation. ${ }^{72}$ Chia-ching wares with 6-character marks and 5-clawed dragons are not rare, but in most cases they are of indifferent quality ${ }^{73}$; and while the whole standard deteriorated in that reign, the pieces decorated with dragons are not even the best products of their time. ${ }^{74}$ The same is true of Wan-li; and as will be seen later, when we come to that period in the Ardebil Collection, these last two reigns saw a steady decline in the quality of those wares which adhered to the traditional repertory of decoration, what might be called "the dragon-phoenix-lotus-cloud-and-wave group," while the most skillful drawing is found on those wares in a newly developing style then appearing for the first time. So, as the dynasty draws near its end, we are faced with a curiously anomalous situation in which the very wares which seem to be made for "Imperial" use on grounds of their nien-hao and of the 5-clawed dragons in their decoration, if we are to honor the traditional belief, are actually the poorest of their time, surpassed on every side by unmarked wares without dragons.

A final example may be cited to illustrate the sort of question that must be solved before we can pretend to understand the real significance of the 5-clawed dragon in porcelain decoration. Among the Wan-li pieces in the Oriental Ceramic Society exhibition was an unusual type described as a "stove-jar," ${ }^{75}$ which is decorated with 5clawed dragons over waves; and in a reserved panel on one side is a long inscription dedicating the piece to a temple in Shansi and dating it in the forty-sixth year of Wan-li (1618). So this is a case where 5-clawed dragons appear on a piece which is not only not "Imperial," in the sense that it is not for the emperor, but is specifically designated for provincial use.

These examples of the discrepancies, inconsistencies, and contradictions encountered in trying to apply the three criteria of quality, marks, and 5-clawed dragons

${ }^{71}$ E.g., PMA, no. 101; OCS Catalogue, 1953, nos. 127 and 130 (the latter wrongly numbered 131 on pl. 11); Pope, Ming Porcelains in the Freer Gallery of Art, p. 33, fig. 29.

${ }^{72}$ Cf. note 306 on p. 149.

${ }^{73}$ E.g., PMA, nos. 109 and 111.

${ }^{74}$ OCS Catalogue, 1953, no. 160, represents the finest in Chia-ching blue-and-white.

${ }^{75}$ OCS Catalogue, 1953, no. 204. Lu-p'ing 爐䑳 is the term used in the inscription. 
to the identification of "Imperial" wares could be multiplied at length; but enough has been said to show that something is wrong or at least that all is not so simple and straight-forward as might seem to be the case in view of the light-hearted way in which the term "Imperial" is bandied about. The "Imperial" implications of the 5-clawed dragon have been common knowledge ever since the Western world began to learn about China, but it is not clear just when it began to be assumed that the decoration of porcelains was controlled in that respect. Jacquemart and Le Blant mentioned the symbolism in $1862{ }^{76}$ but did not state that it was specifically applicable to porcelain. In 1888 Hippisley wrote, "The dragon thus intimately associated with the Emperor is always depicted with five talons on each claw, and it is he alone, properly speaking, who can use such a device upon his property; the dragon borne by princes of the blood has but four talons on each claw" ${ }^{77}$; but went on to say that the distinction was not rigidly maintained. Bushell, in his description of the dragon as an element of decoration wrote, "The claws, originally three in number on each foot, were afterwards increased to four and five, the last number being restricted to the imperial dragon of the last and present dynasties, as brocaded on imperial robes and painted on porcelain made for the use of the palace." ${ }^{78}$ Hobson cited the above passage from Hippisley in his first great work, ${ }^{79}$ and since that time the idea has been adopted so universally that today one seldom hears a discussion of a piece with dragon decoration in which the point is not mentioned.

But not one of these writers, be it noted, has cited a Chinese text in support of this theory which has gradually assumed the status of an axiom in the connoisseurship of Chinese porcelain. The reason for this is obvious: no such text has yet been found. In the T'ao-shuo, for all its shortcomings, there is more detailed information on the decoration of Ming porcelain than in any other work, ${ }^{80}$ and dragons are mentioned frequently but without any reference to the number of claws they have or to the fact that they may have been reserved for the decoration of those wares destined for the use of the emperor; and the $T$ 'ao-lu is similarly silent. It seems curious, therefore, that a notion of "Imperial" wares and of a set of standards by which they may be defined can have become so firmly implanted when there is no reference to any such thing in the very texts on which the whole indoctrination of two generations of scholars is based.

Strict prescriptions governed the decoration of court robes at various levels in the official hierarchy, and the number of claws on dragons was one of many details that were subject to regulation. ${ }^{81}$ It might be expected therefore that the statutes of the

${ }^{76}$ Histoire . . . de la porcelaine . . , , p. 226.

${ }^{77}$ A catalogue of the Hippisley collection of Chinese porcelains, p. 443.

${ }^{78}$ Oriental ceramic art, p. 592.

${ }^{79}$ Chinese pottery and porcelain, vol. 2, p. 292.

${ }^{80}$ Especially in chüan 6.

${ }^{81}$ Cammann, China's dragon robes, pp. 10-19. 
Ming Dynasty which provide this information would deal similarly with porcelain, but this does not seem to be the case. A preliminary survey of the appropriate sections of the Ta-ming-hui-tien 大明曾典 reveals only the most casual references to porcelain throughout, and there is no evidence that it was held in any particular esteem at court. ${ }^{82}$ In the section on works, ${ }^{83} \mathrm{Kung}$ - $p u$ 工部, there are short chapters dealing with the manufacture of tiles and pottery vessels, but these have no bearing on the present problem. In the section on ceremonial, $L i$-pu 禮部, which occupies 64 chüan (42105), are detailed descriptions of the court rituals, and among the voluminous regulations controlling every phase of the many cermonies are frequent references to the kinds of vessels to be employed. An overwhelming majority of them are gold and silver, and scattered references to porcelain are almost incidental. One example may be cited as typical; preparations for the sacrifices to deceased ancestors include the following passage ${ }^{8 *}$ : "they respectfully arrange three wine jars, eight gold libation cups, sixteen porcelain libation cups, . . ." From the standpoint of our study, this is very disappointing, and in the whole section only one passage was noted in which there is any reference to decoration. This sets forth the regulations for choice of materials from which wine vessels may be made in the following terms ${ }^{85}$ : "Princes of the first and second ranks, for wine jars and wine cups may use gold; for the rest they may use silver. The third rank to the fifth rank, for wine jars may use silver, for wine cups may use gold. The sixth rank to the ninth rank, for wine jars and wine cups may use silver; for all the rest they may use porcelain, lacquer and wood vessels; and they are not permitted to use vermilion nor gold rims, gilding, carved jewels, nor dragon and phoenix patterns. The masses, for wine jars may use pewter and for wine cups may use silver; for the rest they may use porcelain and lacquer." Pending further study and the finding of additional texts relating to the same subject, this seems to specify those ranks which were permitted to use gold and silver in certain ways. The lowest group of princes, those from the sixth to the ninth rank, could use no gold and could use silver for wine jars and wine cups only, while all other utensils had to be of porcelain, lacquer, or wood; and they were prohibited from using, among other things, dragons and phoenixes in the decoration. There is no indication that the higher ranks were forbidden to use porcelain if they wished; but the implication seems clear that it was not a particularly desirable material, especially in view of the fact that it was classed with lacquer and wood.

It would be premature to draw any final conclusions from this one regulation, and an extensive investigation of other Ming texts must be undertaken before that can be

${ }^{82}$ The edition I have used is that compiled by Hsü P'u 徐溥 (1428-1499) and printed in the sixth year of Cheng-te (1511) in 180 chüan.

${ }^{83}$ Chüan 157.

${ }^{84}$ Chüan 81, 7v9.

${ }^{85}$ Chüan 59, 2r7. 
done. These two passages from the Ta-ming-hui-tien are cited only as examples of the kind of information that may be expected to turn up. In keeping with the Chinese documentary tradition, the statements are terse and not always easy to interpret clearly today, although there is no doubt that they were perfectly intelligible to those who wrote them and those who read them in Ming times. The reference to the dragon is a case in point; no mention of the number of claws is made, but we cannot be sure today that in Ming official terminology the word lung did not specifically mean "a dragon with five claws on each foot" and not, as it does in the vernacular today and as it did in the earlier dynasties, simply "dragons in general." What may turn up in the long run is impossible to say, but for the time being it should be remembered that what has been said and written thus far about "Imperial" porcelains is based only on dealers' sales talk and on the writings of relatively recent authors. It will be of the greatest interest when one day we learn the official view of this question in Ming times.

\section{THE BEGINNINGS OF BLUE-AND-WHITE IN CHINA}

It is not known when the Chinese first decorated white porcelain with painting in underglaze blue. They themselves speak of Sung blue-and-white, and there are Western students of the subject who seem inclined to agree, so that any discussion of the origins of that type of decoration sooner or later leads back to the Sung Dynasty. The fact remains, however, that no piece of blue-and-white has yet been linked conclusively to that period, and for want of material evidence of any kind one invariably turns from the porcelains themselves to books about porcelains, and this means that the T'ao-shuo will be cited as authority.

Toward the end of his section describing specimens of the Sung Dynasty in chapter 5, Chu Yen introduces the subheading "The Blue-painted Bowls of Jao Chou" in which he cites the Ko-ku-yao-lun of Ts'ao Chao as his source for the following: 铣州 御土堂體薄而潤色百花青較定器少次. “As for the Jao Chou imperial pottery, the body was thin and unctuous, the color white, the decoration blue; compared with Ting wares they were a little inferior." Commenting, Chu goes on to say, "This seems to have been the beginning of Jao wares," which of course were the porcelains of Ching-te Chen, situated in the Jao Chou (chou = district) of Kiangsi Province, the porcelain-

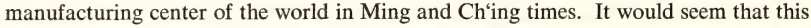
was fairly solid ground; Chu Yen writing in the eighteenth century quotes an author whose work, first published in 1387, was already a venerable authority on antiques of all kinds. But attention has already been drawn to the presence of serious shortcomings in the text of the T'ao-shuo, and the present passage is but one more indication of the urgent need for an over-all revision. In a word, Chu Yen to the contrary notwithstanding, the Ko-ku-yao-lun says no such thing. The passage, which appears under the heading ku-jao-ch'i 古偾器, “Ancient Jao Wares," in chüan 7 of the 13-chapter 
editions and in the first section of chüan 3 of the 3-chapter version, reads 御土筣 者體溥而潤最好, “As for the imperial pottery, the body was thin and unctuous, it was very fine." ${ }^{85 a}$ Blue is not mentioned at all until some lines later in the discussion of Yüan Dynasty wares. So much, then, for the principal and what has always been considered the earliest Chinese evidence for the existence of Ching-te-Chen blue-and-white in Sung times. We need not at this moment inquire into Chu Yen's motive in distorting his source; but the lack of evidence in the form of porcelain itself combined with the apparent absence of textual support tends to raise serious doubts about the existence of Sung blue-and-white.

Some 20 years ago, Dr. Nils Palmgren of Stockholm visited many of the potteryproducing areas of China and brought back great quantities of shards. Among the materials from two sites where Sung wares were made his finds included a handful of small fragments of a ware decorated in blue. Two shards from Ch'ing-ho Hsien are of gray ware with poor glaze and underglaze markings in a blackish, blurry blue turning grayish in spots. One bowl fragment bears a trace of a blue line above the foot. Two

${ }^{85 a}$ This text is the same in all the editions I have been able to consult. The bibliographic history of this work has been sketched by Sir Percival David (TOCS, 14 (1936-1937): 13-16), who notes that he has seen neither the original 3-chapter version of Ts'ao Chao nor the enlarged and revised 13-chapter version of Wang Tso 王佐, which appeared in 1459. In the Library of Congress is a rare early edition of the Ming collectanea I-men-kuang-tu 夷阴廣覑 published by the antiquarian, calligrapher, and literatus Chou Li-ching 周履靖. His own preface is dated in correspondence with 30 May 1597, and is followed by prefaces by Liu Feng 劉鳳 (undated), by Huang Hung-hsien 黃洪憲 (21 March 1598), by Chang Hsien-i 張獻翼 (undated), and finally by Ho San-wei 何三展 (2 August 1598). Chüan 13 of this work is a 3-chapter version of the Ko-ku-yao-lun bearing only the preface of Ts'ao Chao dated on the fifteenth day of the third moon of the twentieth year of Hung-wu (3 April 1387) and consisting of 61 folios or 122 pages of nine 18-character lines each. All other editions I have seen are in 13 chapters and include, at the head of each chüan, the names of Ts'ao Chao as author, Shu Min 舒敏 as editor, Wang Tso as reviser and enlarger, and Huang Cheng-wei 黄正位 as re-editor (重校); they also bear an undated preface by Cheng P'u 烸粠. All are 314 folios in length. The difficulty over the original date of this work (cf. Pelliot, TP $25(1927-1928): 124)$ arises from the fact that in one of these editions, and presumably in some others, Ts'ao Chao's preface is dated one year later, in the twenty-first year of Hung-wu.

At this time it is impossible to say whether the 3-chapter version in the I-men-kuang-tu is the same as Ts'ao Chao's original; nor can we tell how far the 13-chapter versions bearing the names of Huang Cheng-wei and Cheng P'u stray from the text of Wang Tso's revised edition. Further study of these and such other editions as may be found should make it possible to establish the validity of this important work, for unless we know precisely which statements were made in 1387 and which were added in 1459 its usefulness for purposes of specific reference is greatly weakened.

The literary section of the Ming history describes the Ko-ku-yao-lun as a 14-chapter work compiled in the Hung-wu period by Ts'ao Chao and revised in the T'ien-shun period by Wang Chün 王均. Cf. Ming Shih, chüan 98, p. 14v1 (1739 ed.). At the moment I know of no other reference to an edition in 14 chapters, nor have I been able to find Chün as one of Wang Tso's various names, though no doubt he is the man to whom reference is made. 
pieces from Chü-lu Hsien have grayish porcelain bodies somewhat finer than the above ware and are decorated in blackish blue under a semiopaque milky glaze. These pieces are said to have been dug up from levels containing Sung wares, but the degree of scientific control under which the excavations were carried out is not known. Further, there is no indication that kiln sites were involved. The presence at the Ch'ing-ho Hsien site of two fragments of fine white porcelain covered with celadon glaze of good quality suggests that the site may have been a dump heap and that wares of later periods were included. ${ }^{86}$

These fragments, in spite of their obvious interest, hardly constitute conclusive evidence of the existence of Sung blue-and-white. If, however, we give them the benefit of the doubt, they suggest that the first Chinese experiments with this ware were made in the North rather than in Kiangsi. On the other hand, while it might be expected, as Jenyns has suggested, ${ }^{87}$ that these wares would have started in that area and have been decorated in emulation of the underglaze painting on the Tz'u-chou wares, there is no indication on these insignificant shards that that was the case. Whatever it may be, this ware has little relationship to blue-and-white in its mature form, and it seems doubtful whether it played any part in the development of the Kiangsi wares under consideration here, wares which from Yüan times on were, for all practical purposes, Chinese blue-and-white.

There is one other small family of blue-and-white for which a Sung date has been suggested. It is made up of a few small dishes each of which is decorated with a single leaf at the left and a group of Chinese characters written at the right and in some cases a square simulating a seal below the latter. They are crudely made wares with brown rims, and both drawing and calligraphy are very roughly executed. A number of fragmentary examples are among the pieces excavated in the Philippines by the University of Michigan, and there is a perfect piece in the Riesco Collection. ${ }^{88}$ On the latter and on two of the Michigan fragments, the characters, although so poorly written as to be almost illegible, seem to read T'ai-p'ing-nien-chih 太平年彆, and Mr. Bluett in his publication of the Riesco dish assigns the piece to the T'ai-p'ing reign of the Liao Dynasty, which would mean that it was made in the extreme north of China between A.D. 1021 and 1031. Nothing now known about Liao pottery seems to justify the attribution of a white porcelain ware to the region extending northward from the Great Wall, and some other explanation must be sought for this curious inscription. The four other T'ai-p'ing reigns in Chinese history all fall even earlier than that in the Liao Dynasty and may equally be ruled out. Inasmuch as these and the rest

${ }^{86}$ In October 1952 Dr. Palmgren kindly permitted me to examine these fragments in Stockholm. One of them is published on the color plate facing p. 86 in the Swedish periodical Porslin, no. 1-2, Stockholm, 1952.

${ }^{87}$ Ming pottery and porcelain, p. 26.

${ }^{88}$ Bluett, The Riesco Collection, p. 11. 
of the inscriptions that appear on dishes of this group are used in a decorative way to balance the drawing of the single leaf in the composition, it seems probable that it should be taken in its literal sense rather than as a date, simply, "made in an era of great tranquility."

A recently published fragment of still another dish of this same family supports this view and establishes what seems a more acceptable date for these wares. ${ }^{80}$ The decoration consists of the same single leaf, in this case balanced by a 10 -character poem in the same stringy calligraphy; and on the base within a double circle is a 6character mark which reads Ta-ch'ing-chi-yu-nien-chih 大清己西年裂. Chi-yu is the cyclical year which corresponds with 1669 on its first occurrence in the Ch'ing Dynasty, and inasmuch as the dynastic title is given without any reign name it seems likely that this is the date intended. It is also appropriate to the qualities of this group of dishes which conform to what one might expect to find in coarse provincial or private factory wares of the early K'ang-hsi period. The discovery of this dated shard should eliminate this family once and for all from consideration as possible examples of early blue-and-white.

The status of the literary sources on Yüan blue-and-white is of no more than secondary importance because, as abundant evidence will demonstrate, this period witnessed the manufacture of what now appears to be some of the most striking blueand-white ever produced in China. On the other hand, it is worthwhile to bring together the few references that are known both for the sake of completing the record and because the very nature of the texts seems to shed some light on the attitude toward these wares in Mongol times. As will be seen, there has been a certain amount of confusion in the interpretation of these writings and it may be useful to review the available material and see what can be made of it.

The earliest account of the ceramic industry is the T'ao-chi-lïeh 陶記略 of Chiang Ch'i 蔣新, which was written as a supplementary note to the edition of the Annals of Fou-liang published in 1322 and which has been included in all subsequent editions. ${ }^{30}$ Although this work does not mention blue-and-white, a recent translation of another text on ceramics gives the impression that it does; and this erroneous notion must be disposed of with as little delay as possible. The passage in Chiang Ch'i's text reads 江湖川廣器倘青白出于鐄之熟; and this was quoted almost verbatim ${ }^{91}$ by Lan $P^{\prime} u$ in his Ching-te-chen t'ao-lu published in 1815. Including the original text and its

${ }^{89}$ Han Wei-chün, in Annual, 1953, China Society, Singapore, p. 22 (Chinese section), fig. 20.

${ }^{90}$ Fou-liang hsien-chih 浮梁將志. Cf. David, AA, 12, 3 (1949): 169. The only copy I have been able to consult is that dated in the twenty-first year of K'ang-hsi (1682), which exists on microfilm in the Library of Congress. In this edition the section on pottery administration is in chüan 4, pp. 39r3-48v4, and Chiang's note, here entitled T'ao-chi-fu陸钎附, is on pp. 48v6-51v9. The printing is weak and in a number of places the characters are almost illegible.

${ }^{91}$ Lan wrote 用 for 倘 and 於 for 于 (chïian 5, pp. 2v8-3r1), and this may reflect the text of the version he used. 
later quotation, this passage boasts no less than three published translations, each one differing in some details from the others. Taking them in chronological order we find Stanislas Julien in his translation of the $T^{\prime}$ 'ao-lu gives the following ${ }^{92}$ : "Les vases blancs et bleus dont on fait usage dans les provinces du Tche-kiang, du Hou-pe, du Sse-tch'ouen et du Kouang-tong, sortent des manufactures de King-te-tchin." The French is ambiguous, and as in English, "the white and blue vases" may mean either "the vases that are white and blue" or "the white vases and blue vases." Next in order is Bushell, who translated the passage from one of the editions of Chiang Ch'i's original memoir ${ }^{93}$ in these words: "In the provinces of Chiang (Kiangnan), Hu (Hukuang), Ch'uan (Ssuch'uan) and Kuang (Kuangtung), [they prefer] the greenish white or celadon ware which comes from the kilns of Ching-tê-chên proper." And finally Sayer renders it thus ${ }^{{ }^{94}}$ : "Kiang [-si], Hu [-nan], [Ssŭ]-ch'uan, Kuang [-tung] use 'ch'ing-pai' (blue/green and white) vessels coming from the town's kilns."

The degree of difference between these three renderings of the same Chinese sentence reveals something of the nature of the problems to be faced by the student who turns to the native sources for enlightenment. Although not related to the matter immediately in hand, the interpretation of the names of the provinces on the basis of their abbreviated forms shows considerable variation; and the proper solution depends of course upon finding the Yüan Dynasty meaning of the single characters used. ${ }^{95}$ The meaning of the term ch'ing-pai 青白, however, is crucial. Julien gives "blanc et bleu," Bushell says "greenish white" and adds "celadon ware" as his own interpolation, and Sayer translates it "blue/green and white." None of these translations is entirely satisfactory. The word ch'ing, which may be translated either "blue" or "green" depending upon the context, has always been a source of trouble when encountered in texts describing ceramic decoration. Both meanings are valid, and it seems unlikely that it will ever be possible to evolve a rule-of-thumb to cover all situations. The proper translation will always depend on the context not only in the literal sense of the word but in the broadest sense including the knowledge of the ceramics themselves. Sayer's proposed solution of "blue/green" is no solution at all. Not only does it beg the question altogether, it also succeeds in casting obscurity over those passages which are otherwise entirely clear to anyone who has even the most casual familiarity with Chinese ceramics. In this passage from Chiang Ch'i's memoir, the meaning "green"

22 Julien, Histoire et fabrication de la porcelaine chinoise, Paris, 1856, p. 85.

${ }_{93}$ Bushell, Oriental ceramic art, p. 179. He used the Tao-kuang edition (1821-1850).

${ }^{94}$ Sayer, op. cit., p. 40.

${ }_{95}$ As this problem in historical geography is of slight importance to the present subject, I shall not go into it. It may be noted, however, that in A. Herrmann, Atlas of China, p. 52, the provinces of southern China in the Yüan Dynasty, reading westward from the sea, are named Kiangche, Kiangsi, Hukwang, and, northwest of the latter, Szechwan. There is no Kuang-tung indicated, and eastern China between the Yangtze and the Yellow Rivers is all Honan. Proper interpretation of these abbreviations written in 1322 calls for further research. 
can be dismissed altogether and with it Bushell's translation. There is no evidence that Ching-te Chen was ever distinguished for the manufacture of celadon wares in Yüan times. No doubt celadons were made there; they were made in almost every pottery south of the Yellow River, but an incidental output of the commonest kind of utilitarian ceramic ware would not be likely to call for special comment.

On the other hand, the interpretations of Julien and Sayer seem equally wide of the mark. Julien's "blanc et bleu" has the advantage of being on the face of it as ambiguous as the Chinese term it attempts to translate. But the Chinese term when examined more closely is not necessarily ambiguous at all. The Chinese would not use this phrase to say "white vases and blue vases" or even the more general "white wares and blue wares" that might be expected, nor would they ever use it to express the idea of "blue and white," a concept which appears to be expressed invariably by the term ch'ing-hua 青花, meaning "blue decoration" or "blue decorated." What then of Chiang's term ch'ing-pai? The obvious answer is to take it straightforward in a manner supported by abundant precedent including the phrase ching-hua just mentioned. The translation is "blue white" or "bluish white," and Bushell, but for his choice of color, almost had the answer. Bluish white, moreover, perfectly describes the ware widely known to connoisseurs today by the twentieth-century term ying-ch'ing ${ }^{96}$ 影青, a ware produced in great quantities in Ching-te Chen and surrounding area in

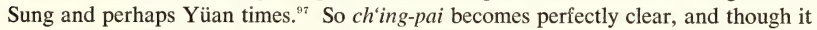
is probably unlikely that the artificial concoction ying-ch'ing will be abandoned, so deeply is it entrenched in usage, it need no longer be used only because we do not know what the Chinese called this ware in the days when they were making it. If Chiang Ch'i disappoints us by failing to mention blue-and-white, he makes amends by providing us with the answer to an old problem. ${ }^{97 a}$

The only other text early enough to be of any significance is the Ko-ku-yao-lun, which has already been discussed in connection with the lack of evidence for Sung

${ }^{96}$ The term seems to occur for the first time in the $T^{\prime} a o-y a$ 陶雅 by Chi Yüan-sou 箃園叟, which bears prefaces dated in 1906 and 1910. It is interesting to note further that the author uses it to describe the Yung-lo "bodiless" bowls. (Chüan 上, 10r6.)

${ }^{97}$ The earliest use of the term ch'ing-pai I have encountered thus far is in the Chu-fan-chih,

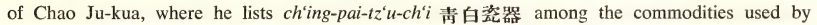
foreign merchants trading in Java. This work, probably written before the middle of the thirteenth century, was included in the Yung-lo-ta-tien 永樂大典, whence it was taken by Li T'iao-yüan for inclusion in his collection entitled Han-hai published in 1782. See Han-hai 50, 上, 12r6; Hirth and Rockhill translation, pp. 35,38 , and 78 . On p. 78 they also misinterpret the term as meaning blue-and-white.

97a Sir Percival David's note on the same subject came out while the manuscript of the present volume was in the hands of the printer. See Ying-ching, a plea for a better term, OA, new ser, I, 2 (Summer 1955): 52-53. Our Japanese colleagues have been calling this ware ching-pai for some time. 
blue-and-white. In describing the wares of the Yüan Dynasty under the same heading, “Ancient Jao Wares," the author concludes with this passage: 有青花及五色花者且俗 甚㚐, "there were blue-and-white and five-color wares but they were very vulgar." ${ }^{98}$ Here seems to be the earliest occurrence of the term ching-hua and at the same time the earliest reference to blue-and-white by a Chinese writer. The most striking thing about the passage, however, is the expression of opinion on the merit of the ware. Evidently it was frowned upon in cultivated circles, and this may have been simply because in comparison with the long-familiar monochromes it seemed garish, or perhaps because it was an innovation, always deplored by conservatives, or perhaps even because it was a foreign importation. The author dismisses the whole subject so briefly we shall never know. Thus the first literary reference to blue-and-white; there is nothing to suggest that it enjoyed imperial favor or indeed any favor at all in the second half of the fourteenth century; and under the circumstances it is not surprising that genuine nien-hao of the Hung-wu period are unknown on these wares; no doubt they were considered unworthy of the honor.

But now that fourteenth-century blue-and-white has been identified, and can be compared in retrospect with the products of the succeeding centuries, we can see what an impressive accomplishment it was, what an important step it marked in the advance of ceramic history. While the ultimate refinements still lay ahead, the materials were evidently at hand, the principal technical problems had been brought under control, and there had been established a repertory of design that was to form the basis of blue-and-white decoration from that time on. The circumstances surrounding the sudden appearance of this new technique are still far from clear, but it was gradually accorded a widespread and enthusiastic reception by the Chinese; and it seems reasonable to assume that it was introduced from the outside in Yüan times, probably from western Asia where cobalt was known and where ceramics had long been decorated by this method. It is impossible to say exactly how this introduction took place. The suggestion that the Chinese took blue-and-white wares from the Near East as their models is an obvious one, but on closer examination it is not altogether convincing. In the first place there was no reason for this ware to move eastward. Everyone knew the Chinese made better ceramic products, and no sharp-witted Asiatic trader was likely to be caught carrying coals to Newcastle; so it is not surprising that no finds of Islamic pottery on Chinese soil seem to have been recorded. Secondly, and even more important, although the repertory of design found on fourteenth-century blue-andwhite includes many elements new to Chinese ceramic decoration, it shows little if any evidence of derivation from Persian or other Near Eastern designs of the period. As

${ }^{98}$ Chüan 下, 49v9 in the 3-chapter edition as reproduced in the I-men-kuang-tu. In the 13-chapter editions, in chüan 7,25r3, the text is altered to read 青色及五色花者且俗甚 which does not change the meaning although it eliminates the explicit term ching-hua. 
will be seen in examining the details, Islamic motifs never played more than a trifling part in the Chinese scheme, whereas a number of Chinese elements made their appearance on Near Eastern blue-and-white as the centuries passed. But this is to anticipate; and we need no longer delay looking at the wares themselves. Close examination will show that, in spite of occasional minor borrowings, the blue-and-white porcelain of China was always and essentially a manifestation of the Chinese spirit. 

PART II-THE ARDEBIL PORCELAINS 



\section{THE COLLECTION TODAY}

Of the 1,162 porcelains deposited in the Shrine by Shāh 'Abbãs, as recorded in the journal of Jalāl ed-Dīn, 805 remain today. More than three-quarters of these are blue-and-white, and the 80 white wares and 58 celadons are supplemented by a handful of polychrome and single-color wares. ${ }^{99}$ All but 31 are engraved with the dedicatory inscription of Shāh 'Abbās; and the absence of the mark on those few pieces has not been explained. Three possibilities may be mentioned: (A) They were included in the original vaqf but accidentally overlooked in the marking; (B) they were placed in the Shrine after the original gift was made; or (C) they came into the collection after its removal to Tehran in 1935. Among the blue-and-white wares, those that lack this inscription have no special characteristics to distinguish them from marked pieces of related types so the omission is not important for the purpose of this study. Three of the unmarked celadons, however, may well be earlier than the rest, and these will be mentioned in the chapter on those wares.

Certain unusual features of the collection deserve attention. Because of the fact that they reached Iran in early times, these are in a sense export porcelains; but "export" is a term of derogation usually reflecting on the quality of the wares so described, and, as a glance at the illustrations will reveal, there is no need for apology in this case. Although it will be noted that certain types of wares are not represented, it is on the whole the most complete and well-rounded collection of blue-and-white from about 1350 to 1600 to be found in one place. In such a large body of material every level of quality is present, but the astonishing thing is that the general average is so high. A few pieces are crude to mediocre, the larger part of the collection is good, and at the top is a surprisingly sizable group of wares of the finest quality. This is true throughout, but perhaps most striking are the products of the fifteenth century, which are on no account to be confused with the crudely potted porcelains coarsely decorated with muddy blue under dull and pitted glazes that in those days found their way to sundry seaports from the East Indian Archipelago to the shores of the Dark Continent. It would seem that the Shāhs of Iran, themselves accustomed to every luxury and refinement, had standards of quality in what they collected not unlike those current at the court of Peking.

Examples may be chosen almost at random. Among the large dishes with unglazed bases no finer pieces are known than 29.55 (pl. 37), 29.60 (pl. 39), 29.63 (pl. 41), 29.83 (pl. 33); and 29.310-311-312 (pls. 42-44), are equaled only by two

${ }^{99}$ Typological and chronological analyses of the existing collection will be found in the Appendix, pp. 159-162. 
similar pieces in Istanbul. The bowls numbered 29.326 and 29.327 (pls. 46 and 47), and their counterparts in white, 29.717-718 (pl. 113), are of superb quality. Among the vases, too, the standard is as high as that which we know among the best wares from China; 29.413 (pl. 51), 29.415, 29.496 (pl. 56), and 29.470 (pl. 53) are typical; and the writer has seen no more perfect piece of early fifteenth-century porcelain anywhere than the mei-p'ing 29.403 (pl. 50). The same holds true for the wares of the second half of the century. Saucers like 29.149 (pl. 59) and 29.277 (pl. 58) and bowls like 29.341 (pl. 60), 29.343 (pl. 62), and 29.345 (pl. 63), to mention but a few, would be treasures in any collection in the world today. In the light of this unexpected display of quality, the significance of the term "export porcelain" deserves reexamination, for these bear little or no resemblance to wares recovered from other parts of Asia; and it seems reasonable to conclude from this that the Chinese chose their export commodities with an eye to the ultimate market. In spite of the generally accepted view that the inhabitants of the Middle Kingdom considered themselves the only civilized people on earth and regarded all those who lived elsewhere as utter barbarians, there must have been discrimination of some sort based on the knowledge that, for reasons which they perhaps could not fathom, some barbarians seemed less barbarous than others. In any case, this great Iranian collection stands quite alone among the porcelains known to have left China in Ming times. 


\section{THE NON-CHINESE MARKS}

As related in the account of Jalāl ed-Dīn, the Shāh had a certain Maulānā Mohammad Hosein Hakkāk of Khorasan engrave on each porcelain that went into the Shrine the vaqfnameh or dedicatory inscription, and this appears today on all but 31 of the surviving pieces. It occurs in two forms. The normal writing is framed in a rectangle usually five-eighths of an inch high by three-quarters of an inch wide ( $1.6 \times$ $2.0 \mathrm{~cm}$.) and varying not more than about a sixteenth of an inch in either dimension (pl. 6, A-D). The inscription reads, Bandeh-ye shäh-e wiläyat 'Abbās vaqf bar astāneh-ye shāh Safĩ namūd, and may be translated " "Abbās, Slave of the King of Saintliness made endowment (of this) to the threshold of Shāh Safī." Even in this short sentence there are three clichés. "King of Saintliness" is a customary epithet of "Alī, son-in-law of the Prophet and the first Imãm, who was second only to Mohammad in the Shī'a hierarchy; and "Slave of the King of Saintliness" is a term frequently used by devout donors in Safavid times. Here "Abbās thus refers to himself. "Threshold" stands for mosque or madraseh or, in this case, the Shrine, another common usage at the time. The second form is the abbreviated inscription where the same dedicatory formula is reduced to three letters ( $\mathrm{pl} .6, \mathrm{E})$; the sad standing for Safī, the $f e$ ف for vaqf and the ain $\varepsilon$ for 'Abbãs. This occurs on seven pieces in the collection; and these and the normal inscriptions have been rubbed with a red pigment of some kind, which in many cases remains and forms a bold contrast with the white porcelain ground. Both forms are in every case cut into the glaze just above the base or low on the side of the vessel.

In addition to these marks, which identify the porcelains with the Shrine of Sheikh Safi and with the vaqf of 1611 and thus were the latest that could have been carved, for it is hardly possible that they could have been added after the collection was in the possession of the Shrine, there are a number of other marks which seem to indicate private ownership. These are executed in two ways, either in a broad incised line or in a series of dots formed by shallow depressions made with a drill of some sort; except when otherwise noted, they are cut into the paste on the bases of the porcelains. It appears likely that the pieces bearing these names and signs had belonged to various individuals at one time or another and that they had made their way into the royal collection in earlier times or that, when they belonged to persons who were contemporary with Shāh 'Abbãs, they had been given to him so they could be added to the vaqf and their owners could thus share in the spiritual rewards to be gained from the pious donation. Many of these marks are now meaningless, but some are legible; and in a few cases it seems reasonable to attempt to identify them with known persons. The one that occurs most frequently is the single word Qarachaghāy, which is incised or 
drilled on some 94 pieces ( $\mathrm{pl} .6, \mathrm{~F}-\mathrm{G})^{100}$; and this was the name of a man who enjoyed a position of particular favor at the court of Shāh 'Abbās. Born of Armenian Christian parents, he had been stolen from his family in boyhood by the Tatars, who circumcised him and sold him to Shāh 'Abbās. This account of his origin is given by Olearius who continues, ${ }^{101}$ "The freedom and sincerity of his disposition and demeanour, had gained him the friendship of the whole Court, and his courage had so well settled him in the king's favour, that having, by this means, had several great victories over his Enemies, he had conferred on him the Command of his Army, and looked upon him with such respect, that he never called him by any other name than that of Aga, that is, Captain." Another source ${ }^{102}$ verifies this last fact and states that Qarachaghãy was chief of the royal pages ( $Q u l-l a r A g a-s \breve{l}$ ), one of the great offices of Iran, and later commander in chief (Silpasālār); in 1617 he was appointed governor of Azerbaijan and in 1619 governor of Khorasan. So great was the esteem in which he was held that on his death the Shāh gave the latter post to his son Manūchehr Khān. ${ }^{103}$

This Qarachaghāy was involved in the blackest event in the career of Shāh 'Abbās. It was no more than normal Persian procedure in his time that the Shāh on coming to the throne should have blinded and imprisoned his two younger brothers to insure his own tenure; but even by these standards this latest deed was considered shocking and the story as related by Olearius throws an interesting light on the character of Qarachaghāy and on the esteem in which he was held by his sovereign. 'Abbās's eldest son, Safi Mirza, had a jealous wife who succeeded in planting in the mind of her father-in-law the idea that her husband had premature designs on the throne. His suspicions thus aroused, 'Abbãs grew more and more fearful until he finally decided to do

${ }^{100}$ The word is properly written قرحفاى, but on the porcelains the final letter ye is written above the others; strict transliteration would be Qrchghāi, but various romanizations include Qarajaghāī, Qarchiqay, Qarachaghāī, Qarachaqhāy, etc. Pietro delle Valle wrote it Carcicā, Olearius (1669) used Kartzschukai, and Malcolm (vol. 2, p. 561) wrote Karachee Khan.

${ }^{101}$ Op. cit., pp. 261-262.

${ }^{102}$ Nașrollāh Falsafī, Zindegānī-ye Shāh 'Abbās, vol. 1, pp. 180-181.

${ }^{103}$ A copy of the Shāhnämeh of Firdawsī in Windsor Castle is dated 1058/1648 and inscribed as having been copied for the library of Khān 'Alī Shān Qarachaghāy Khān, Supervisor of the Mashhad Shrine (Robinson, Persian paintings, p. 7, no. 1). If we attempt to identify this man with the Qarachaghāy in our story, we are faced with an anachronism. Manūchehr Khān must have succeeded his father as governor of Khorasan before the death of Shāh 'Abbās in 1629; and therefore our Qarachaghāy could not have been alive in 1648. Another disturbing factor is a miniature in the Walters Gallery which depicts a group of persons among whom is one labeled Qarachaghãy. Both Ettinghausen and Robinson consider the painting about mid-seventeenth century, and the portrait of Qarachaghāy is that of a middle-aged man about fifty at most. While he could be the patron of the 1648 Shähnämeh, he could hardly have been old enough to have owned an important collection of Chinese porcelain more than 37 years earlier. Yet beyond these two documents no reference to a second Qarachaghāy has yet turned up. Could Manūchehr Khān have taken his father's name at some later date? 
away with his son; and thinking that Qarachaghāy of all people was most obliged to him, he asked him to murder Safī. But Qarachaghāy was horrified and said "he would rather lose a thousand lives than that he should ever be reproach'd to have imbru'd his hands in the blood of any of the royal progeny" ${ }^{104}$; he told the Shāh that he would repent as soon as he had done it, and so highly did the Shāh regard him that he was excused. "Abbās, however, did not give up his plan and engaged the services of "a Gentleman named Behbut-Beg whom he found not so scrupulous." Behbūd arranged to meet Safī Mirza one morning as he came from his bath riding on a mule and murdered him. As Qarachaghāy had predicted, 'Abbās at once deeply regretted his hasty action and mourned and fasted "and all his life after he wore not anything about him, that might, as to the matter of cloaths, distinguish him from the meanest of his subjects." Later at a banquet in Qazvīn he poisoned all who had urged him to do it; and he made Behbūd behead his own son so he would see how he felt and then said to him, "my son and thine are no more, and reflect, that thou art in this equal to the King thy master." Shortly thereafter Behbūd was murdered by his own servants who had accidentally scalded his hands in washing them and feared the inevitable punishment. This then may have been the Qarachaghāy who owned these pieces of blue-and-white and contributed them to the vaqf out of devotion to the master to whom he owed so much; and among these pieces were some of the finest of those that have survived.

Another readable name drilled into the paste of four of the porcelains is Behbūd (pl. 6, H), and while there is more difficulty in assigning it to the right man, there is more than a reasonable possibility that this is the same not so scrupulous gentleman who carried out the assignment given him by Shāh 'Abbās in the horrid episode just related. As has been suggested elsewhere, ${ }^{105}$ the name has also been identified with that of a personage who was a favored page and became an amir at the court of Hosein Baïqara, the great art patron of the Timurid Dynasty who ruled Khorasan from 1469 to 1506 . But although the four porcelains are of early fifteenth-century date and might well have been owned in Herăt in the latter part of the century, and although the word behbüd is found on Timurid coins, the identification is by no means certain. On coins minted at Herāt, Astārabād, and elsewhere it occurs as a counterstamp from the reign of Abū Sa'īd (1452-1469), and only under Hosein Baïqara does it appear on the original coin. The question is whether this word behbüd is a personal name in these cases or whether it should be considered semantically as a validating phrase

${ }^{104}$ Olearius, op. cit., p. 261; the following quotations are from the same passage. The incident is also related by Malcolm, op. cit., vol. 1, pp. 561-562.

${ }^{105}$ Bahrami, TOCS, 25 (1949-1950): 16; and Pope, TOCS, 26 (1950-1951): 45-46. In the latter article (note 15) I have already corrected a still earlier statement I made about Behbüd in my Letter from the Near East (p. 561), which was based on erroneous information given me in Tehran. Malcolm, loc. cit., calls this man Beh-bood Khan. 
signifying "good for circulation" or some such thing. ${ }^{106}$ If the latter interpretation is acceptable, the word could presumably have been used in the same way on the porcelains, but on the face of it this does not seem a likely solution. In the absence of any other evidence that links these wares to the court of Herāt, and in view of the historical events in which a Qarachaghāy and a Behbūd were closely associated with Shãh 'Abbãs, it seems more logical to dismiss for the time being the possibility of Timurid connections and to consider that the porcelains once belonged to these men of the Safavid Dynasty. Further support for this view is provided by the appearance on the handsome dragon bottle 29.471 of both names together; Behbūd is written above in bold dots and Qarachaghāy below in dots that are slightly smaller. ${ }^{107}$ On a large oval bottle decorated with lotus scrolls the name Qarachaghãy appears drilled on the shoulder, while the name Behbuid is drilled on the base together with a third name Abū Tãlib ${ }^{108}$ (pl. 6, I). Behbūd is also found on two bowls 29.329 and 29.339 (not illustrated but pairs to 29.330 on pl. 47 and 29.340 on pl. 49) ${ }^{109}$; all four pieces with this mark are of excellent quality.

The Abū Tãlib mark on 29.469 has already been mentioned, and it occurs again on 29.478 , which is a pair to 29.471 ( $\mathrm{pl} .53$ ). On these two unusually fine pieces are the only surviving examples of this mark noted in the collection. Identification is difficult if not impossible; Abū Tâlib was the uncle of Mohammad and the father of "Alī, and consequently his name was always popular among Muslims. The only contemporary individual of that name who appears in the records was one of the Shãh's younger brothers who, as we have seen, was deprived of his eyesight and his liberty while still a boy.

${ }^{108}$ The Behbūd who was a Timurid amīr is mentioned in A. S. Beveridge, The Bäbur-näma in English, vol. 1, p. 277; and the name appears on a small agate bowl which also bears an inscription relating to Hosein Baïqara, cf. Survey of Persian Art, vol. 6, plate 1455B. The bowl was no. 193Z in the London exhibition; and the Behbüd inscription, not mentioned in the Survey, is discussed by Wiet, L'exposition persane de 1931, p. 48. In the early sixteenth century the word appears on a coin of Ismā'îl I (1501-1524) which is counterstamped "Behbüd Mashhad," cf. Rabino di Borgomale, Album of coins, medals, and seals of the Shähs of Iran (1500-1948). Dr. George C. Miles, who has been most generous with his help on this and other epigraphic problems, assures me that the solution is still to be found; he points out that no less eminent a scholar than Barthold more than 50 years ago came to the conclusion that the word on the coins refers to the man, cf. Zapiski Vostochnago Otdeleniya imp. Russ. Arkheolog. Obschestva, St. Petersburg, vol. 14, 1901 (1902), 0106-7.

${ }^{107}$ The difference in the sizes of the dots seems to be only a matter of technique; variations in size within a single word are also noticeable and probably just reflect unevennesses in the amount of pressure applied to the drill.

${ }^{108}$ Cf. Bahrami, op. cit., plate 2, c and d, for illustrations of this vase, our no. 29.469.

${ }^{109} \mathrm{Op}$. cit., plate $1, \mathrm{c}$ and $\mathrm{d}$. On c the Behbüd mark is incised in addition to the drilled mark on the base; it is not visible in the photograph. 
Even more puzzling is a word for which the writing is not entirely clear; some-

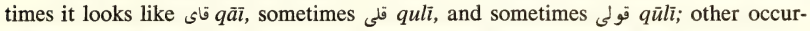
rences are marginal. Quli occurs as part of many Persian names but does not stand alone in such cases; as a word it can mean "slave," but that seems to be of little help in this case. One possibility is that it might refer to a certain Qulī Beg Afshāh, an eminent Qizilbash contemporary with Shāh 'Abbās; but this is the purest speculation.

The word نارنج närinjī (or nāranjī), incised on the bases of 29.28 and 29.83 , is also unexplained. ${ }^{110}$ It offers two possibilities. Narin

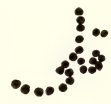

The word $Q u l i$ as drilled in the base of 29.85 . occurs today as the name of a region that lies about 100 miles due north of Kabul in Afghanistan, and it is also the name of a river, one of the upper confluents of the Syr Darya (Jaxartes) in Ferghana where there is a town of the same name. Närinjī could be a nisbah referring to a man from a place called Narin; but we are handicapped here by the fact that it has not been possible to determine precisely the antiquity of these names. In the case of the river and the town in Ferghana, it appears that the name was Khāylan or Khätlan in the tenth century and Uzgand as late as the fifteenth. In any case nārinji does not occur in the standard corpus of nisbah. On the other hand, if the reading näranji is accepted in its meaning of "orange," it could be interpreted as describing the color imparted to the base by the iron content of the clay.

Most remarkable is the short inscription written in underglaze blue beneath the rim of the largest of the fourteenth-century dishes (pl. 6, K). Many examples of Arabic writings in underglaze blue are known in the Cheng-te period, and one such piece has a Hung-chih mark ${ }^{111}$; but this antedates all other known cases by something like a century and a half, and in view of the fact that Persian was evidently the current language of international commerce in China over a long period of time it seems strange that until the appearance of this dish no other such inscriptions have been found. Unfortunately, not only do the words written here tell us nothing that throws any light on the problem, but there is almost no agreement among scholars about what they say. They were evidently written by a Chinese, or at least someone not accustomed to writing the Arabic script; hence the calligraphic stresses are wrong and they cannot be read conclusively. On this point all are agreed. A number of tentative suggestions have been advanced, and they are set forth here. For the first word, Hosein seems a likely possibility; harim was suggested by two informants and sharply rejected by two others, one of whom hinted at Mohammad. The second word has been read haqq and also be-juft; marhüm has likewise been mentioned, and others have given it up altogether. Such combinations as Hosein haqq, "Hosein is truth," and Hosein be-juft, "Hosein is peerless," extolling the virtues of the grandson of the Prophet, naturally

${ }^{110} \mathrm{Cf}$. TOCS, 26 (1950-1951): 45. I have not been able to add anything to the remarks made in that article, and they are repeated here to complete the record.

${ }^{111}$ Cf. p. 123 below. 
come to the mind of any reader of Persian as the sort of obvious pious slogan likely to be encountered; but beyond the fact that they reveal the presence of at least one devout Shi'ite on the premises of a Kiangsi porcelain factory around the middle of the fourteenth century, these readings tell us nothing.

On a white bowl with Hung-chih mark exhibited in the Chehel Sotūn in Isfahan there appears, in addition to the dedicatory inscription of Shāh 'Abbās, a mark incised in extremely fine and delicate script which reads Shāh Jahāngīr Shāh Akbar. ${ }^{112}$ Jahāngīr, Mughal emperor of India from 1605 to 1627, was in correspondence with Shāh 'Abbās all during his reign, and in spite of the fact that they had minor quarrels over the possession of the fortress of Qandahar, the two sovereigns held one another in the highest esteem and frequently exchanged presents. The tone of this happy relationship is felt in a passage in the memoirs ${ }^{113}$ where Jahãngïr describes a picture gallery he had installed in his garden as "now adorned with pictures by master hands. In the most honored positions were likenesses of Humāyūn and of my father [i.e., Akbar] opposite to my own, and that of my brother Shāh "Abbās." Porcelain is not mentioned among the gifts exchanged as they seem to have been more concerned with such things as horses, rubies, crystal goblets, and fine silk stuffs; but in almost every instance the phrase "and other fitting gifts" is added, and porcelain may well have been included. One case is worth quoting because of the light it throws on inscriptions of the kind we are concerned with here. In 1031/1621 ${ }^{114}$ Jahāngir wrote of receiving "a loving letter from that noble brother, together with a black and white plume (kalgi-i-ablaq), valued by the jewellers at Rs. 50,000. My brother also sent me a ruby weighing 12 tanks which had belonged to the jewel chamber of Mirza Ulugh Beg, the successor of Mirza Shāh-rukh . . . on this ruby were engraved in the Naskh character the words 'Ulugh Beg b. Mirza Shāh-rukh Bahadur b. Mĩr Timūr Gūrgān.' My brother Shāh 'Abbās directed that in another corner they should cut the words:

\section{Banda-i-Shāh-i-Wilāyat, 'Abbās}

'The slave of the King of Holiness, 'Abbās' in the Nasta'liq character. He had this ruby inserted in a jigha (turban ornament), and sent it to me as a souvenir"; and then he adds that he had engraved in another corner "Jahāngìr Shāh b. Akbar Shāh" and the current date. Here we find Shāh "Abbās referring to himself by the same formula he used in the vaqfnämeh on the porcelains, and Jahāngīr using a phrase similar to the one on the white Hung-chih bowl.

A Hung-chih dish with yellow glaze in the Victoria and Albert Museum carries

${ }^{112}$ Cf. Fourteenth-century blue-and-white, p. 22, n. 33, where I gave this mark as Shäh Jahān Shāh Akbar. Further study makes the new reading entirely admissible, and in terms of chronology it is the logical choice. Cf. p. 146 below.

${ }^{113}$ Tüzuk-i-Jahāngīrī or Memoirs of Jahāngīr, vol. 2, pp. 161-162.

${ }^{114}$ Op. cit., p. 195. 
a similar inscription together with a date on the twenty-eighth day of the second month of A.H. 1021, which corresponds to February 1612. As it was not possible to get a photograph of the mark in Isfahan, the latter is reproduced here on plate $6, \mathrm{~J}$, by kind permission of the museum, and it will be seen that these Mughal inscriptions were cut with a finer and more delicate line than that ordinarily used by Mohammad Hosein, the Khorasan lapidary who carved the vaqfnämeh for Shāh 'Abbās. Most of those were done in a rather thick stroke, and the glaze was often badly scratched around the inscribed words; but as a glance at the examples on plate 6 will show, some, especially those on the white wares, were executed with considerable finesse. Another piece with a Mughal inscription is the early fifteenth-century blue-and-white flask belonging to Mrs. Walter Sedgwick which bears the name 'A Alamgir referring to the emperor Aurangzeb and a date corresponding to $1659-1660 .^{115}$

Also in the Chehel Sotūn and also unphotographed is a blue-and-white bottle with a Portuguese inscription, a type of which at least two other examples are known. One is in the Victoria and Albert Museum, ${ }^{116}$ and another is in the Walters Art Gallery in Baltimore, which has kindly given permission for its reproduction here (pl. 6, L). That in the Victoria and Albert Museum has the neck cut down and is mounted with a silver cover; under the base is the 4-character mark Ta-ming-nien-tsao in a double circle. The main designs are all different, with ducks and aquatic plants on the vase just described, lions playing with brocaded balls and streamers on the Walters piece, and leaves among tight scrolls on the Ardebil example. The two latter are marked with the characters $W a n-f u-y u-t^{\prime} u n g$ on a cash symbol; and all three have the same decoration on the upper shoulder and around the base, and the same Portuguese inscription written upside down in two lines on the lower shoulder. Obviously copied by a Chinese who had no idea what they meant, the letters are crudely drawn and difficult to decipher; and they differ slightly from one inscription to another although it seems likely that they are misunderstood versions of the same text. Laid out in two lines as written, the Isfahan inscription, with the vase inverted, looks like this:

\begin{tabular}{|c|c|}
\hline $\bar{E}\{E O M A N D O V E A\} E$ & $E A I V B \cdot N$ \\
\hline 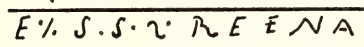 & - $A E R A O$ \\
\hline
\end{tabular}

While he finds some of it completely baffling and is extremely reluctant to do more than suggest what the rest might possibly be, Prof. C. R. Boxer of Kings College very tentatively offers the following partial transcription: "o mandou fazer na era de 1552 reina . . . ," the end of which could be understood to read "reina[ndo El Rei

${ }^{115}$ OCS Catalogue, 1953, no. 44.

${ }^{116} \mathrm{King}, \mathrm{A}$ document in Ming porcelain. 
D. João III]." This would mean, "So-and-so [presumably a name, but unreadable] had it made in the era [= year] of 1552, reign[ing King John III]"; and such a formula is not uncommon in Portuguese epigraphy.

For the rest, the non-Chinese marks on the Ardebil porcelains are single letters or groups of letters that cannot be read as words, or merely signs; and it can only be guessed that they are ownership marks. A selection of these is illustrated below, and all appear on early fifteenth-century wares. The curious mark $\psi$ is found on blueand-white, on white, and on one polychrome piece all dating from the late fifteenth and early sixteenth centuries.

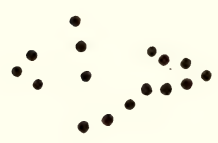

29.82

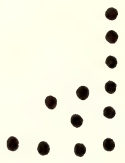

29.82

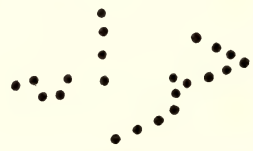

29.88

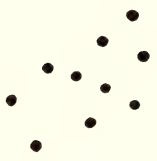

29.96

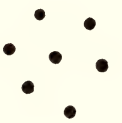

29.84

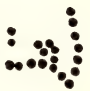

29.84

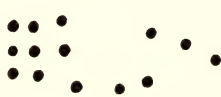

29.94

Examples of the undeciphered marks drilled in the bases of early fifteenth-century dishes. 


\section{THE BLUE-AND-WHITE: THE FOURTEENTH CENTURY}

On an auspicious day in the fourth month of the eleventh year of the Chih-cheng reign, which fell between 26 April and 25 May, 1351, a certain Chang Wen-chin 張文進 of Hsin-chou 信州 in Kiangsi Province made an offering of two flower vases and an incense burner; and the two vases survive today in the collection of the Percival David Foundation of Chinese Art, School of Oriental and African Studies, University of London. Their inscriptions supply the details of the event. Their large size ( 25 inches) has given the decorator ample space to record a cross section of his repertory, and this together with the distinctive physical characteristics they exhibit has made it possible to use them as guides to the identification of a mid-fourteenthcentury type. A number of pieces which have not fallen readily into the well-known fifteenth- and sixteenth-century categories have gradually proved themselves quite at home with the David vases until the family has now assumed a respectable size and is rather generally recognized. In addition to the isolated pieces in various collections, the principal corpus of this ware is divided between the two great collections of the Near East. The 31 pieces in the Topkapu Saray have already been published, ${ }^{117}$ and the 32 examples in the Ardebil Collection form the subject of this chapter. The description of these pieces therefore presents an opportunity to review the distinguishing characteristics of the group as a whole. This was done in preliminary fashion for the fourteenth-century wares in the Topkapu Sarayi; and further study and the close examination of additional material have tended to support the thesis advanced by the writer at that time that "these wares may, with a high degree of probability, be assigned to the fourteenth century, and the decorative repertory that distinguishes them may be regarded in a general way as the fourteenth-century blue-and-white style."

The Ardebil examples add nothing new to previous notions about the physical characteristics of the ware. All are large and heavy, boldly potted, and neatly finished. The bases are unglazed, and the paste is white with a tendency to be coarser in grain and less thoroughly prepared than in the finer early fifteenth-century wares. Probably because of lack of care in the process of wedging, small air bubbles were left in the clay, and these account for the little holes to be seen in the edges of broken fragments as well as for the slight cracks and openings which often appear on both glazed and unglazed surfaces of the finished wares. Most pieces show a reddish tinge wherever the body is left exposed; and the degree of redness varies so much that no particular condition can be cited as typical, a state of affairs further complicated by the fact

${ }^{117}$ Cf. Pope, Fourteenth-century blue-and-white. 
that the natural surface of the base was sometimes altered by the use of slips or washes before firing and of abrasives after firing.

The bases themselves usually bear spiral traces of the wheel, and the foot rims of the dishes and bowls are sturdy and neatly finished. On the large dishes there is a clearcut angle between the inner slope of the foot and the bottom although the degree of the angle varies widely; and occasionally it is replaced by a curve. Examples of the various types are illustrated on plate 139. The bowl foot rims are high, thick, and strong, and the larger ones appear to have been added after the bowls were thrown. This is not always evident in the case of undamaged pieces, but the foot of 29.319 (pls. 23 and 141) has certainly been added, while those of the type represented by 29.320 (pl. 24) seem to have been cut from the bowl body itself. Fostāt has yielded a number of fragments of bowls of related types which permit close examination of this structural detail. In every case the foot has been hollowed out of a solid piece of clay; the central depression is shallow as compared to the outside height of the foot, and the rim itself is much thicker in relation to its total diameter than is the case on later wares (pl. 131). On the vases this area shows greater diversity than among vessels of other types; broad, low, rounded rims are the rule, though they are by no means distinctive. Such foot rims occur in fact from these earliest examples of blue-and-white kuan and mei-p'ing right on up through the sixteenth century; and while it appears that the foot rims of bowls and dishes may have some value as hints to chronology one is tempted to say that, in the case of vases, the cutting of the foot rim per se is almost meaningless. Long habit will make it difficult to refrain from saying that such and such a foot rim seems right for the period, but in the over-all consideration of any vase this detail probably merits the least serious attention.

\section{SHAPE}

At present the range of known shapes is rather limited, and this collection includes nothing we have not already seen in the Topkapu Sarayl. Nineteen of the 32 pieces are large dishes 16 to 18 inches in diameter, with one piece exceeding 22 inches. All have flattened rims about evenly divided between those with plain and those with foliate edges; and on some of the latter the extreme outer margin of the lip is raised in slight relief. Next most numerous are the five mei-p'ing, then come three kuan, two bowls, two rectangular bottles, and the lower half of a double gourd. Other known fourteenth-century shapes not found here are bottles, stem cups, vases with handles (e.g., the David vases and related types), and miscellaneous oddities like the Oxford stem bowl, miniature altar sets, ${ }^{118}$ etc. The inscription on the David vases, it will be

${ }^{118}$ Cf. Ayers in OA, 3, no. 4 (1951): 135-141; OCS Catalogue, 1953, no. 18; PMA 9. 
remembered, speaks of an "incense burner," ${ }_{119}$ and this and other shapes still unknown to us may be expected to turn up some day.

So conspicuous is the blue-and-white decoration as a new factor in Chinese ceramic history in the fourteenth century that it seems to have distracted attention from the emergence at the same time of a whole new series of ceramic forms. Among these, the large dishes are not only the most numerous but the most revolutionary. In Han, T'ang, and Sung times a dish more than a foot in diameter seems to have been rare; some are known in Yüeh ware and among the san-ts'ai wares of $\mathrm{T}^{\prime}$ 'ang, but most of the latter are flat with only a slight rim and the whole dish is raised on three short legs. In no case do they approach the generous proportions of the present dishes with their broadly curving cavettoes and wide flat rims. Occasionally a small dish of Chün, Lung-ch'üan, or Ting ware shows these characteristics; but only one known piece of the latter ware has the flattened rim with foliate edge and the generous cavetto of the blue-and-white examples. In shape, proportion, and in the disposition of the decoration it is very similar ${ }^{120}$; but the foot is low and narrow, and the base is glazed over. At first glance this might seem to be a rare example of the prototype, on a small scale, of the big foliate dishes; but it has been assigned to the thirteenth century which does not exclude a Yüan Dynasty date, and it may possibly be later. A few large celadon dishes of similar form have been given Sung attributions; and while these will be discussed at greater length below in connection with the Ardebil celadons, it may be noted that there is very little documentation to justify such an early date, and most of them seem to be later. It is not impossible that some of these spacious dishes may have been made in Sung times, but the sudden increase in popularity which they obviously enjoyed in the fourteenth century must be considered a result of the wave of influence which at that time swept across to China from the Near East where related forms had long been in use.

Another new form is the large bowl with inturning rim (pl. 23) which is first seen among the mid-fourteenth-century wares ${ }^{121}$ and which lasted, as far as we now know, only little more than half a century. The shape with flaring rim which came on the scene at about the same time ( $\mathrm{pl} .24$ ), however, lived on, with minor changes in proportion, to become one of the standard Ming Dynasty types.

${ }^{119}$ Among some 650 pieces bequeathed to the Ashmolean Museum in Oxford by Francis Mallet of Bath about 1947 is a large blue-and-white tripod since published by Denis Barnham in OA, I, 1 (1948): 33-36 and by Jenyns in his Ming pottery and porcelain, plate 13B. Jenyns informs me that in a letter, now in the British Museum, Mallet once wrote Hobson suggesting that this might be the lost incense burner made to accompany the David vases. There seems to be no record of Hobson's reply. I am inclined to agree with Jenyns that the piece is from a provincial kiln and may date from the second half of the fifteenth century.

${ }^{120} \mathrm{Cf}$. Hobson, et al. Chinese ceramics in private collections, p. 41, fig. 86 . The dish is now in the British Museum; it is $10 \frac{1}{8}$ inches in diameter.

${ }^{121}$ Cf. Pope, op. cit., plates 20-22. 
The vase known as the mei-p'ing is not a new form at this time for abundant examples are known in the Tz'u-chou wares of Sung; and Ting, Ch'ing-pai, Chün, and northern celadon types are also known. ${ }^{122}$ A survey of the many published pieces shows a considerable degree of variety in the form; and although the attempt does not seem to have been made, a detailed study of the several shapes might prove useful as an aid to establishing a more precise chronology than we now have. Too many pieces are simply labeled "Sung" without any further ado; and certain ones among them when examined closely seem not to be so early. As a preliminary generality it may be observed that the characteristic Sung mei-p'ing of Tz'u-chou ware has sloping shoulders and sides that taper down to the foot in a single long curve sometimes almost approaching a straight line. In Ming times the shoulder is higher and more square while the sides take a more or less noticeable reverse curve as they come down to the foot. As an over-all result the early vases have a rather slender shape, or, if broader in proportion, they look somewhat egg-shaped, whereas the Ming examples are more squat and sturdily planted on their widened bases. ${ }^{123}$ The fourteenth-century mei-ping as seen here on plate 25 show the intermediate profile that might be expected between the two extremes. Sloping shoulders and a slight reverse curve near the foot are evident, and this group also presents a detail in the proportions of the neck that seems to be limited to this time. This member takes the form of a truncated cone with the sides tapering inward in almost straight lines from the shoulder upward to the lip. No. 29.408 is the purest type in this respect, and even on 29.406 and 29.407 , where there is a slight curve, the tendency can still be traced. ${ }^{124}$ The typical early fifteenth-century neck is symmetrical in its curve, equally wide at top and bottom. (See facing page.)

The kuan vase too is distinctively Chinese with origins in some of the san-tsai wares of the T'ang Dynasty; and while there is more variety in this broad heavy form all through its history, a detailed study of all the known types might also prove rewarding.

It is hard to say what prompted the transformation of the old pilgrim flask form into the cumbersome rectangular bottle with shoulder loops (pl. 28); but there appears to be no other possible prototype. Only one example is known in another ware,

${ }^{122}$ A curious green mei-p'ing was published as "Late T'ang" in Hobson's Eumorfopoulos Catalogue (vol. 1, no. 380), but neither the shape nor the glaze is convincing.

${ }^{123}$ Cf. Trubner, Chinese ceramics, nos. 186 and 187 . Both these mei-p'ing are labeled Sung, but while 186 is a typical Sung shape, 187 has an entirely different profile which can hardly be earlier than the fourteenth century. The style of the incised decoration confirms this impression.

${ }^{124}$ Consideration of this detail tends to support the fourteenth-century attribution of the Nelson Gallery mei-p'ing that is PMA 10, a piece about which I expressed uncertainty in my Fourteenthcentury blue-and-white (p. 32, n. 44); it also forces reconsideration of the fifteenth-century attribution of PMA 87 which, on this and other grounds, I now believe may be of fourteenth-century date. 
and that is the large piece of Tz'u-chou type now in the British Museum ${ }^{125}$; Hobson called it "Yüan?" and this seems like an acceptable attribution though one which may make it contemporary with its blue-and-white counterparts, thus leaving as much mystery as ever about its origin.

Another innovation at this time is the so-called "double-gourd" ${ }^{226}$ vase, which has not been noticed in earlier wares. Its origin too is obscure.
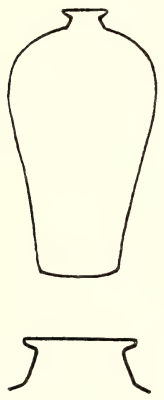

29.408
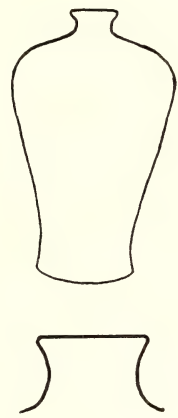

29.409
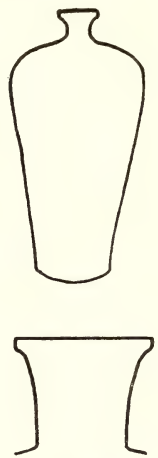

29.402

Sketches of three mei-p'ing vases illustrating the characteristic proportions of this form in the fourteenth (29.408), fifteenth (29.409), and sixteenth (29.402) centuries. Variations occur in each period, and the existence of many unclassified pieces makes it impossible to establish any comprehensive rule; but each of these three is typical. The neck is perhaps the most striking feature, and this detail is shown enlarged below each example. The outlines are drawn to uniform scale to emphasize the forms.

Although not included in the Ardebil Collection, the stem cup is a well-known form in early blue-and-white which also seems to have achieved its first great popularity at this time. Again certain examples in other wares, Tz'u-chou, Ting, and Lungch'üan among them, are known, but there is no evidence for dating any of these earlier than the fourteenth century, and some of them may be later. As in the case of the large dishes mentioned above we must look for a prototype in the Near East. The question of Islamic influences on Chinese ceramic forms has been studied at some

${ }^{125}$ Cf. Hobson, Eumorfopoulos Catalogue, vol. 3, no. C299.

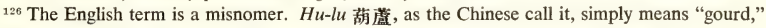
not "double gourd"; and the typical form of that fruit is imitated in this type of vessel. 
length by Basil Gray, ${ }^{127}$ and there will be occasion to refer to this work again in the chapter on the early fifteenth century; but his remarks on the stem cup introduce certain problems that should be examined in relation to these fourteenth-century wares because at the time he wrote no serious attempt had yet been made to distinguish between the fourteenth- and fifteenth-century porcelains. Summarizing those features of the Ming porcelain stem cup which he believes point to its origins in West Asian metalwork, he listed (p. 54) the following points: (a) "the knop in the stem, corresponding to the more or less pronounced ridge at the same point in the porcelain stem cup"; (b) "the bowed or splayed hollow stem sometimes closed at the foot"; (c) "the lip everted at a rather sharp angle which seems more characteristic of metal than of ceramic practise." In commenting on this, two things should be noticed: first, the stem cup he illustrates (his pl. 7e) is an early fifteenth-century type and hence does not properly belong among the earliest Chinese porcelain examples ${ }^{128}$; and second, among what is generally recognized as the earliest group, there are two quite distinct types. In one case, the bowls are of small diameter with deep sides and a sharp angle at the lower edge where the bottom turns toward the center. These have the knop on the stem and the splayed foot, which he relates to the similar features on the metal prototype. ${ }^{129}$ The other type, which seems more numerous, has quite a different profile; the bowl is shallow in proportion to its diameter, the lip is everted in a gentle curve, and the stem, which has no knop but is often fluted horizontally in a manner reminiscent of the bamboo, is hardly splayed at all but only widens very gently toward the base..$^{130}$ No doubt the former type is related to the West Asian metal form adduced by Gray, although in most instances these latter have almost vertical lips often strengthened by a thickened edge; and while some of them flare slightly they are hardly ever "everted at a rather sharp angle." ${ }^{131}$ The second type with shallow bowl, on the other hand, although similarly making its first appearance at this time, seems to lack any ancestors either Near Eastern or Chinese, and the riddle of its origin remains to be solved.

Because of the limited number of fourteenth-century wares known to us, this discussion of shapes is no more than preliminary. In the course of time, as new pieces come to light, our knowledge of the repertory may be expected to grow, and we shall

${ }^{127}$ TOCS, 18 (1940-1941): 47-60.

${ }_{128}$ A similar stem cup with a Hsüan-te mark was PMA 66.

${ }^{129}$ Cf. TOCS, 16 (1938-1939): plate 3c, right. The knop, although so small as to be almost invisible in the photograph, is nonetheless present. The stem cup next to this is similar except that it has a coffee-brown glaze on the exterior; each has a single Sanskrit character in underglaze blue on the inside. Another brown stem cup of this shape, this time with a Chinese character in blue on the inside, belongs to the Nelson Gallery, Kansas City.

${ }^{130}$ Cf. PMA 4-8; and OCS Catalogue, 1953, nos. 8, 9, 11, 12, for a variety of examples.

${ }^{131} \mathrm{Cf}$. the series of silver stem cups published in Smirnov, Argenterie Orientale, pls. 96-100. 
gradually acquire a more balanced and fully rounded understanding of the ceramic output of that period. In the meantime, the above observations may serve as a basis for further studies of the question of shapes, a subject which has not yet received the attention it deserves and which may be expected to shed additional light on some of the troubling problems of chronology.

\section{DECORATION}

The most striking thing of all about these porcelains is the blue with which they are decorated and the way it is applied. Although a normal range of variation is to be seen between individual pieces, and atmospheric conditions in the kiln have produced every effect from pale and even grayish blue to rich dark shades approaching navy and often revealing specks of blackish brown, the color is generally strong and vivid. The reasons for this are not far to seek. The cobalt, wherever it came from, was certainly of excellent quality; and while no records have come to light, it may be assumed that in those early years it came, along with the technique of using it, from the Near East. And in addition to the quality, it was exceptionally striking because of the way it was handled. As comparison with any fifteenth- or sixteenth-century blue-and-white will show, it was applied to the body more freely, with a broader brush and a bolder hand. The men who decorated these wares had more of the painter in them and were obviously men of spirit and imagination still uninhibited by the demands of mass production and not yet broken to the copybook. In this quality of freedom and spontaneity lies the greatest difference between these early blue-andwhites and all those that were to follow, a situation nowhere more strikingly demonstrated within the limits of a single collection than in these porcelains preserved in the Ardebil Shrine. One type within this fourteenth-century group deserves special mention, and this is the series of dishes on which the design is executed by leaving the patterns reserved in white against a background of dark blue. The technique does not produce the calligraphic line that is so conspicuous in the ordinary blue-on-white wares, with the notable exception of the serpentine waves on the borders, but it makes a bold and formal design wherein the imagination of the painter is given its fullest play in the separate details rather than in the over-all composition. These white-on-blue wares are among the most spectacular ever made, and why the technique was largely discarded sometime near 1400 one can only surmise ${ }^{132}$; the matter of taste must cer-

${ }^{132}$ A marked Hsüan-te bowl in the Freer Gallery of Art is so decorated but seems to be very rare (Pope, Ming porcelains in the Freer Gallery of Art, p. 16, no. 51.4); and the nearest thing to this style is found on those early fifteenth-century wares that show white dragons against grounds of blue waves (e.g., 29.403 and 29.471 on pls. 50 and 53 in the present volume). After this time, no backgrounds seem to have been painted with blue; where solid blue occurs it has evidently been applied by some other method giving a rather different effect, or else to consist of a blue glaze. 
tainly have been a factor. For the rest, one can only venture the suggestion that with the end of the Yüan Dynasty, perhaps because of curtailed production or because export control was imposed, the best quality cobalt became scarcer. Such textual evidence as remains indicates that even during those Ming reigns when it was available it was highly treasured; and obviously this trick of filling in the background used up more cobalt, so that economy not only put an end to the general use of this style but left its mark on the whole character of the design in years to come.

Intimately related to the quality of the blue and the manner of its application is the nature of the designs delineated on the surface of the porcelain. It is of particular interest because at this moment, with the perfection of this new technique, there came into being a whole new cycle of ceramic decoration, a vast and complex assortment of motifs that was to grow and develop with undiminished fertility almost to the end of the Chinese Empire. Yet it is no contradiction to say that by no means everything was new. As will be seen, at least one form was as old as Shang, and indeed the whole range of Chinese ornament was drawn upon, combined with new elements, elaborated and refined into a decorative repertory probably never surpassed in richness and variety. In the course of the Ming and Ch'ing Dynasties, it was adapted to use in lacquer, textiles, jade, ivory, metalwork, etc., with such modifications as the nature of each medium required, until it pervaded every phase of decorative art; and in the sixteenth century it was this repertory that first opened European eyes to the full splendor of the Chinese artistic genius.

The large dishes, which comprise more than half of the Ardebil group and about the same proportion of the known pieces, all have flattened rims about evenly divided between those plain and those with foliate edges, and each lot has its characteristic decoration. The circular dishes are almost always decorated in blue on a white ground ${ }^{133}$ (pls. 7-15). Borders of diamond diaper pattern predominate in this group, and classic scroll, crapemyrtle scroll, and concentric waves are also found. With a single exception ${ }^{134}$ the cavettoes are decorated with the heavy wreath of lotus blossoms with spiky leaves which is so widely used that it almost assumes the status of a hallmark of the period. It is also common on the outsides of dishes in both groups though occasionally replaced by lotus panels. The decoration of the central areas falls into two main types dominated by aquatic and terrestrial plants, respectively. The usual aquatic scene is a lotus pond, sometimes including ducks, and there are several examples of large fishes surrounded by symmetrical arrangements of eelgrass and other water plants. Land scenes customarily show one or more traditionally stylized garden rocks and a variety of plants, which may include bamboo, banana, grape,

${ }^{133}$ The only exception noticed thus far is a dish acquired in 1954 by the Victoria and Albert Museum (C10-1954); no doubt others may come to light.

${ }^{134}$ Pope, op. cit., plate 7a. 
morning-glory, and watermelon. Lotus is sometimes thrust into these combinations, and occasionally phoenixes and chi-lins appear on the scene. Whatever the nature of the composition, the round frame provided by the bottom of the dish is always crowded with details so that, except in those cases where a large bird, animal, or fish exercises a stabilizing influence, the over-all effect is rather confused. The single large dragon against a white cloud above a sea of concentric waves, although representing the water element, does not really conform to either of the type groups; but the beast itself is a splendid example of the albino group of the fourteenth-century dragons. ${ }^{135}$

The second lot of dishes, those with foliate rims, has a greater variety of decoration, most often in the white on blue style. In some instances this is modified by the introduction of a rim, a cavetto or even a center lifted bodily from the blue-on-white repertory. The typical rim carries a band of serpentine waves, and the cavetto is decorated with a peony wreath more often than with any other single motif. In general both rim and cavetto are treated as elements in an over-all concentric pattern that covers the whole dish so that it is often difficult to tell from a photograph where the cavetto ends and the bottom begins. Perhaps the most striking motif encountered here is the cloud collar point used as a frame for compositions made up of other elements. It appears to be peculiar to dishes of this group, as it has not been noticed on the ordinary blue-on-white dishes with plain rims. It may point inward from the rim or properly outward from the center (pls. 16, 17, 18, 21), and the degree of roundness of each point varies greatly. Sometimes the outlines are flattened and joined together so that the whole thing resembles nothing so much as the foliate rim of a $\mathrm{T}^{\text {'ang }}$ mirror or indeed the rim of the dish itself (pl. 18). Lotus panels, which are commonly found on all blue-and-white, are also pressed into service as frames on the inside of these white-on-blue dishes (pls. 19,21). The core of these concentric patterns varies in scale from a single blossom to an aquatic scene with egrets, which gives the whole dish an essential orientation (pl. 18).

Aside from these two groups are occasional dishes on which the white-on-blue designs are combined with areas borrowed from the normal blue-on-white repertory. The three examples in this collection all have foliate rims. This rim and the white-onblue peony wreath in the cavetto are the only elements that distinguish 29.123 (pl. 22) from a standard blue-and-white dish with an aquatic scene in the center. The other two offer more exceptional variations. The peony wreaths have been modeled in slip so that the flowers are raised in slight relief, and the curious white-on-blue borders, each showing a vine with what may be identified as chrysanthemums (appearing alone on 29.129), and gardenias and crabapple flowers have been treated in the same slight relief by means of slip.

Examination of the forms outlined above will show that there is almost no pos-

${ }^{135}$ Op. cit., p. 41. 
sibility of confusing these fourteenth-century dishes with those of any other period once the main characteristics are well in mind; and the same general principles are applicable to porcelains of other shapes although the distinctions may not always be so clear-cut. The two fourteenth-century bowls in the collection are unmistakable products of the period. Most striking is 29.319 (pl. 23), a magnificent example of the white-on-blue style on the inside, while the outer surface combines a broad band of white peonies against a blue ground with a classic scroll band and lotus-petal panels from the blue-on-white repertory. No. 29.320 (pl. 24), on the other hand, is a more usual type of which several examples are known and a good many fragments have been recovered from widely scattered sites. The decoration is made up of standard elements from the fourteenth-century repertory, and the handling of the blue is characteristic of the time.

Vases of mei-p'ing and kuan shapes dating from this period are generally decorated in horizontal bands from three to eight in number although exceptions have been noted. ${ }^{136}$ Dragons, aquatic scenes with large fish, and figure scenes, perhaps from the drama, are sometimes used, ${ }^{137}$ but for the most part the main zone of decoration is filled with a large, richly painted peony scroll (pls. 25 and 26); on 29.480 (pl. 27) this has been combined with peafowl, and where the peonies are repeated in a narrower band on the shoulder, phoenixes have been worked into the pattern (pl. 25). The great lotus scroll with spiky leaves does not seem to have been used for the principal decorative element but is often found playing a secondary role on the shoulder where it sometimes serves as a setting for legendary birds and beasts. Around the bases the lotus panels stand tall and bold framing a variety of forms including small circles, various abstract scrolls, and formalized lotus buds; and sometimes they are accompanied by curious elements which look like the tips of inverted panels placed with their points spaced over the gaps below (pls. 25 and 26). On the shoulders of some vases, the panels serve in a pendent position to frame auspicious objects (pl. 26). A mei-p'ing in the Isfahan group (pl. 26) has four large cloud collar frames on the shoulder; in the one illustrated a praying mantis carries a bee among fruiting grapevines. Another unusual variation on this piece is the appearance of symbols in the lotus panels around the base.

In addition to the kuan and mei-p'ing, vase forms include the two rectangular vessels with rounded shoulders (pl. 28). One is decorated with two peafowl among peonies on one side, a pai-ts' $e$ and a phoenix among lotuses on the other, and chrysanthemum sprays on the narrow ends; the other has two peafowl amid peonies on

${ }^{136}$ E.g., Pope, Fourteenth-century blue-and-white, plate 27; and OCS Catalogue, 1953, no. 19 (which was no. 431 in the sale of the Arnim-Muskau Collection at Lempertz Kunstauktionshaus, Köln, May 1951).

${ }^{137}$ E.g., Pope, op. cit., plates 26, 32, 39a; PMA 27; another mei-p'ing so decorated in the Victoria and Albert Museum is published, by Jenyns, Ming pottery and porcelain, plate $8 \mathrm{~B}$. 
each side beneath imposing cloud collar patterns, and lotus sprays on the ends. In addition to the two examples of this curious form in the Ardebil Collection, three others are now known, all decorated with dragons. ${ }^{138}$ The handsome double gourd vases of this period ${ }^{139}$ are represented at Ardebil by no more than a fragment, the lower half of a piece decorated with peonies ( $\mathrm{pl} .27$ ).

\section{SUPPORTING EVIDENCE}

At the present writing something like a hundred pieces of blue-and-white have been found assignable to the middle decades of the fourteenth century by virtue of their stylistic and physical relationships with the David vases dated in correspondence with 1351; and another group of smaller and lighter wares has also been generally accepted as belonging to the same century on less precise grounds. ${ }^{140}$ The striking homogeneity of the former group and the structural and decorative affinity it displays for the dated documents have won for it a high degree of acceptance among students of the subject. So far, however, little attention has been given to the external evidence which might be brought forth in support of the conclusions thus reached. Two such bits of evidence exist, and while they have not passed unnoticed, they have not been examined in the minute detail they deserve in view of their importance for the problem at hand. These are the finds of related material recovered from the two sites of Hamã and Kharakhoto, almost at the opposite ends of Asia, for which termini near the end of the fourteenth century are demonstrable, in the one case on historical grounds and in the other by the nature of the associated finds. Both will be treated at length in due course by full-scale publications of the expeditions which worked on the ground; but in the meantime, preliminary articles have appeared, and because the writer has had the opportunity of examining most of those finds which relate to the problem of fourteenth-century blue-and-white, it seems worthwhile to set forth the results of this study in as much detail as possible.

\section{Hamā}

Hamā lies on the Orontes River in Syria some 75 miles south of Aleppo on the road to Damascus. Here a series of Danish archaeological expeditions has traced human occupation from neolithic times forward to the fourteenth century. ${ }^{141}$ The last

${ }^{138}$ Cf. Pope, op. cit., plate 25; Hobson, Eumorfopoulos Catalogue, vol. 4, plate 7, no. D42; and OCS Catalogue 1953, No. 29.

${ }^{139}$ Cf. Pope, op. cit., plates 33, 34, 35.

${ }^{140}$ The latter types are well represented by nos. 1-6 and 8-14 in OCS Catalogue, 1953; and PMA 1-9. Some of these may in fact date from the early part of the century as suggested in the former publication.

${ }^{141}$ Ingholt, Rapport préliminaire sur le première campagne . . . (1934), p. 59; and Rapport préliminaire sur sept campagnes . . . (1940), p. 154. 
city to occupy the top of the ancient mound flourished from the end of the twelfth century to the middle of the fourteenth as evidenced by the coins recovered, and probably enjoyed an even longer maximum span of life from about A.D. 950 to 1400 . The latter date is conclusive in every sense of the word because in that year the city was destroyed by Tīmūr ${ }^{142}$ never to rise again on its age-old foundations, for when Hamā was rebuilt after the conqueror had passed on his way, the new city arose at the foot of the mound and has been there ever since.

Among the material excavated on that uppermost level which perished under the sword of Timmur were a few fragments of Chinese porcelain including celadon, the white wares of Te-hua, and blue-and-white. The published shard of the latter ware ${ }^{143}$ is apparently the base of a coarse bowl decorated with roughly drawn floral pattern in the center; but it is among the numerous Near Eastern copies of Chinese blue-andwhite that even more interesting evidence is to be found. One of these has already been published, ${ }^{144}$ and thanks to the kindness of Dr. Selim Abd el-Haq, Director of Antiquities of Syria, and of Dr. Vagn Poulsen of the Nationalmuseet in Copenhagen, it has been possible to publish it here in two views together with three other hitherto unpublished pieces in the latter museum (pls. 131-132). ${ }^{145}$

It is the decoration of these wares which is of particular interest. The small round saucer features a single large leaf surrounded by lesser foliage; and this central leaf, unlike anything ever seen in the decoration of Islamic pottery of the time, is clearly a copy of one of the spiky leaves which have been found to be characteristic of the Chinese repertory in the fourteenth century. Another out-and-out imitation of a fourteenth-century Chinese dish is a larger piece with the foliate rim. The form itself is not found in the Islamic repertory, and the over-all conception of the design is based on some of the fourteenth-century blue-and-white we have examined in the Ardebil Collection. The rim has foliate scrolls with blossoms not closely related to anything that has so far turned up in the fourteenth century, but the cavetto design is inspired by those found on the Chinese foliate dishes with white flowers reserved on a blue ground (pl. 22). What remains of the central area suggests that the pattern was based on melons and tendrils and on certain of the grape leaves found on such dishes as 29.121 (pl. 13). A third piece from Hamã is a fragment of what must have been an octagonal dish or bowl. This form has not yet been noticed among Chinese wares, but

${ }^{142}$ Fischel, Ibn Khaldūn and Tamerlane, p. 45. Tīmūr left Hamā on 28 December 1400 (p. 104).

${ }^{143}$ Cf. Ingholt, op. cit. (1940), plate 47, 4.

${ }^{144}$ Cf. Ingholt, op cit. (1934), plate 11; and Basil Gray, TOCS, 24 (1948-1949): plate 9b.

${ }^{145}$ In 1952 I had the opportunity of handling the pieces in Copenhagen and found them to be made of the coarse, rather soft clay that is characteristic of Near Eastern pottery. The poor-quality glaze is crackled and yellowish, imparting a somewhat muddy tone to what might otherwise be a fairly decent blue. 
the inside of the rim is decorated with scrollwork, and in the center is a lotus plant clearly composed of elements taken from aquatic scenes like those on 29.38, 29.40, and 29.41 in the Ardebil Collection (pls. 7 and 8). The large dark element in the center is a sketchy rendering of the side view of the lotus leaf as executed in the Chinese versions, and the lotus blossoms themselves are drawn as clusters of pointed petals each of which has a white base and a dark tip, a very typical representation on the early wares. This unmistakable lotus blossom appears five times on the large dish published by Ingholt and Gray and shown here in two views (pl. 131, C-D). The side view of a large leaf dominates the center of the composition with its dark mass, and below this the stems are shown tied together with a ribbon. Poulsen and Gray ${ }^{146}$ have found this dish similar in design to the type represented by numerous examples in the Ardebil Collection assigned to the early fifteenth century and illustrated on plates 30 and 31 . These also feature lotus and other plants tied in a bouquet, but beyond this one detail the similarity weakens. The arrangement of the design from Haman is stiff and formal, closely crowding the whole center of the dish; the graceful drawing of the individual stems and flowers found on the Chinese pieces is altogether lacking. While it might be tempting to attribute this shortcoming to the fact that it is a misunderstood copy, the first thing to do is to establish just what was being copied; and the whole spirit in which the center of this Near Eastern dish is painted is that of the middle fourteenth century when, quite regardless of the subject matter, the decorator seemed possessed to crowd as much detail as possible into the available space. ${ }^{14 z}$ The impression conveyed by this part of the composition is further strengthened by the treatment of the cavetto where the Syrian painter has made a good copy of the heavy lotus wreath with spiky leaves, one of the key elements in the fourteenth-century Chinese repertory. The big leaves are as striking as the blossoms in the over-all effect, while in the later Chinese version of the cavetto scrolls in bouquet-pattern dishes the leaves are always subordinated to the flowers in size and importance. As a final detail it might be noted that the Hamā dish has seven blossoms in its wreath, one more than appears in the standard Chinese wreath of the fourteenth century (pls. 7-15); in the cavettoes of the early fifteenth-century bouquet-pattern dishes there seem always to be thirteen (pls. 30-31). The rim of the Hamã dish is the poorest copy of all, and it can only be guessed that the unhappy Syrian painter, perhaps faced with a pattern he did not understand and lacking both the Chinese brush and the calligraphic skill to use it, did a makeshift border design as best he could. The outside of the dish bears a simple linear decoration that is no more than very remotely related to anything Chinese. It may be that the painter had in mind the outline of the lotus panel form, but if he did, it made only a very superficial impression on his thinking.

${ }^{146}$ Poulsen, Burlington Magazine, May 1948, p. 150; and Gray, op. cit., p. 28.

${ }^{147}$ The prototype of the design on this Hamā dish is clearly the lotus bouquets shown on the Kharakhoto bowl fragments (pl. 133, nos. 13-14) which is the forerunner of the more sophisticated bouquet of the early fifteenth century. 
These fragmentary pieces of Near Eastern pottery, found on a site with a known terminus in 1400 and bearing between them several striking elements of design that are purely Chinese in origin, are of interest on two counts. They not only confirm the date at which this repertory was current in China, but also provide evidence that these great blue-and-white dishes reached the shores of the Mediterranean at this early date.

\section{Kharakhoto}

Some 3,700 miles east of Hamā and about 500 miles to the north, in the Chinese border province of Ningsia, lie the ruins of Kharakhoto. This ancient walled city has been visited by several archaeological expeditions, ${ }^{148}$ and in spite of the rich treasures it has yielded it still holds hidden in the desert sands its most absorbing mystery: exactly when and how it met its end. For it must have been an imposing city situated on the delta of the remote Etsin-gol with its massive 30 -foot clay walls surrounding an area about 380 by 460 yards; and it is surprising that no account of its fate has yet been found in recorded history. A number of clues seem to point to the fact that it was abandoned at the end of the Yüan Dynasty, a view that a small but stubborn group of sceptics disagrees with for reasons which we shall discuss presently; but it will be of interest to bring together here all the evidence that has been put forward thus far and to examine it as a whole.

Turning to the available textual sources, we find it mentioned by the Venetian traveler Marco Polo, who passed that way on his journey to the court of the Great Khan; he called it Etzina and mentioned only the fact that it was 12 days march north of Kan-chou and another 40 days march thence north to Karakorum, both of which accounts are substantially correct. ${ }^{149}$ Unfortunately, he left no account or description of the city iself. Apparently the latest contemporary record of the name is that in the

${ }^{148}$ Col. P. K. Kozlov discovered the ruins in 1908-1909, and his preliminary report, The Mongolia-Sze-chuan expedition of the Imperial Russian Geographical Society, appeared in the Geographical Journal, vol. 34, no. 4 (October 1909): 384-408. His book Mongolia, Amdo and the dead city of Kharakhoto was published in Petrograd, 1923, followed by a German translation in 1925. A new Russian edition appeared in 1947. In May 1914 Sir Aurel Stein made an extensive survey of the site and surrounding territory which is described in Innermost Asia, Oxford 1928, vol. 1, pp. 428-506; vol. 3, plates 49-66. A field party of the Sino-Swedish Expedition under the leadership of Dr. Sven Hedin worked there in 1934-1935, and preliminary notes have been published by the late Dr. Folke Bergman in History of the Expedition in Asia, pt. 4, Stockholm, 1945, pp. 148-151. The untimely death of Dr. Bergman cut short the work of this able young archaeologist while he was in the midst of preparing the large publication covering his findings on this expedition; after some years of delay, it is now being carried to completion by his colleagues.

${ }^{149}$ Yule, The book of Ser Marco Polo, vol. 1, pp. 223-224; Moule and Pelliot, Marco Polo ... , vol. 1, pp. 160-161. 
Sino-Mongolian inscription of 1362 in memory of Prince Hindu, ${ }^{150}$ where both versions of the bilingual text state that one of his sons held the office of tsung-kuan of the I-chi-nai circuit 亦集乃路摠管. ${ }^{151}$ I-chi-nai is the Chinese transcription of the Mongolian name Isina which Marco Polo romanized as Etzina; and it occurs in the geographical section of the Yüan history. ${ }^{152}$ That book was completed in 1370, and the passage which describes I-chi-nai makes no reference to the destruction or abandonment of the city. On the other hand that part of the geographical section of the Ming history which deals with the same area fails to mention the place. ${ }^{153}$ While this omission constitutes negative evidence, it cannot be ignored; evidently something happened to cause the disappearance of the name I-chi-nai from the Ming records.

Most abundant, of course, is the evidence provided by the finds of the Kozlov, Stein, and Hedin expeditions; and in the huge mass of material recovered from the site nothing has yet been found which can with certainty be assigned to the Ming Dynasty. It is at this point that the sceptics raise their voices, and this statement will not be allowed to pass unchallenged, for there are in fact two places in the published reports where Ming attributions have been suggested. They are worthy of close scrutiny. In Kozlov's first English report he lists among the finds "paper money (assignats of the Min dynasty)" ${ }^{154}$; and the presence of Ming money certainly suggests that the place was alive and functioning in Ming times. But this was a premature statement on the part of Kozlov and understandable in view of the superficial similarity between the paper currency of Yüan and Ming. The notes in question were even then being more carefully studied; and in the same year in which the above-mentioned report appeared in English, a Russian scholar published an article on Yüan Dynasty currency based on the eight paper notes recovered by Kozlov. ${ }^{155}$ He described them as having been printed in 1287 , adding that the issue was valid in circulation until the end of the dynasty in 1367 although after 1309 it was devalued as much as sixty percent. Similar data were published by A. Ivanov in 1910 in a study of paper money

${ }^{150}$ Cf. Cleaves, HJAS, 12 (1949): 1-133.

${ }^{151} \mathrm{Op}$. cit., p. 35.

${ }^{152}$ Yüan Shih, ch. 60, p. 25v1 (1739 ed.) or p. 6278d (K'ai-ming ed.). See also Hsin Yüan Shih, ch. 48, p. $6721 \mathrm{~b}$ (K'ai-ming ed.). Another occurrence of the name in the same history mentions it as the place to which the great minister, commander-in-chief of troops, princes and provinces, Prince T'o-t'o 脱脱, was exiled in disgrace in the first month of 1355 . Cf. Hambis, Le Chapitre CVIII du Yuan Che, 70. Professor Cleaves tells me that the Yüan Shih abounds in references to I-chi-nai; see also his latest article An early Mongolian loan contract from Qara Qoto in HJAS, 18 (1955): 1-49; especially note 13 on page 19.

${ }^{153}$ Ming Shih, ch. 42, pp. 11r6-23v3 (1739 ed.) or pp. $7178 b-7180 d$ (K'ai-ming ed.). In both Yüan and Ming times all the northwest was included under Shensi.

${ }^{154}$ Cf. Geographical Journal, loc. cit., p. 387. Min is the Russian transcription of Ming.

${ }^{155}$ Kotvich, Obraztsy assignatsii Iuanskoi dinastii v Kitae. 
in China up to the fifteenth century ${ }^{156}$; and he included illustrations of three Yüan Dynasty notes, one dated in the Chung-t'ung reign (1260-1264) and two in the Chihyüan reign (1264-1295). Yüan paper money was also included in Bergman's finds, ${ }^{157}$ but so far no Ming money has appeared.

The other published reference to the Ming Dynasty in connection with the Kharakhoto finds occurs in Hobson's descriptions of some of the porcelain fragments brought back by Stein. ${ }^{158}$ Writing with his usual caution and within the framework of what was known about blue-and-white a quarter of a century ago, his attributions were extremely guarded. In the case of the bowl base decorated inside with ducks in a lotus pond (K.E.II.01), he ventured to say "(Sung?)"; but that was the only instance in which he suggested a date in connection with the descriptions of the individual pieces. In his more general comments on the finds he used the phrase "mostly of Ming types," and again he wrote "some of the blue and white, which one would expect to be as late as the sixteenth century." ${ }^{159}$

Apparently these two references form the basis of all the scepticism about the terminal date of Kharakhoto; and it is clear today that both are erroneous. Kozlov was evidently unable to read Chinese and so misinterpreted the date on his paper money; and Hobson, ignoring the evidence implicit in Stein's dated documents, none of which was later than $1366,{ }^{160}$ and working with the still elementary knowledge of blue-and-white that was then current, did not see that the six fragments he described all represent typical fourteenth-century wares.

The strongest support for this view is provided by the much larger body of material recovered from the site in 1931 by the late Folke Bergman. Among the several hundred shards brought back were about 120 pieces of blue-and-white, and the writer has had the opportunity of examining this material in detail during two visits to Stockholm, once in the summer of 1938 and again in October 1952. There is nothing about any piece in the group to suggest a date later than the fourteenth century. Through

${ }^{156}$ Ivanov, Bumaznoe obraztsenie v kitae do $X V B$. For help in finding and translating these Russian references I owe thanks to the kindness of Melvin Kessler and Rudolf Loewenthal.

${ }^{157}$ Bergman, op. cit., p. 149n. Cf. also his article Some Chinese paper currency from the Yuan and Ming Dynasties which appeared posthumously in Contributions to ethnography, linguistics and history of religion (Publication 38 of the Sino-Swedish Expedition), Stockholm, 1954. This paper, which just came to my attention as the present volume was in proof, discusses the Yüan Dynasty notes found at Kharakhoto by both Bergman and Kozlov, and compares them with Ming notes from other sources.

${ }^{158}$ Stein, Innermost Asia, vol. 1, pp. 462 (A.K. 018), 464 (K.K. 045, 047), 501 (K.E. II.01), 503 (K.E. XV.02); vol. 2, p. 1014; vol. 3, plates 51 and 57.

${ }^{159} \mathrm{Op}$. cit., vol. 2, p. 1014.

${ }^{160} \mathrm{Op}$. cit., vol. 1, p. 441 . It is, of course, possible that Hobson, working with the porcelains, was unaware of the work of other scholars who were studying the documents even though the findings of both were ultimately published in the same book. 
the kindness of Dr. Gösta Montell, editor of the Reports of the Sino-Swedish Expeditions, who obtained the permission of Dr. Sven Hedin, it has been possible to reproduce a selected group of fragments (pls. 133, 134). They are numbered from 1 to 60 and are described here with reference to certain published examples of the types of complete pieces they evidently represent. ${ }^{161}$

1 and 2 . The partially restored bowls of two stem cups decorated outside with blue 3-clawed dragons and inside with 4-clawed dragons and lotus panels in slip surrounding a blue flaming jewel in the center. (Cf., PMA 4, 5, 6, 7, and OCS Catalogue, 1953, nos. 9, 11, and 12.)

3,4 , and 5 . Small fragments with similar crosshatched blue dragons very sketchily drawn.

6. Fragment of the base of a dish with a well-drawn, small 3-clawed dragon in the center; a piece of this type has yet to be seen.

7 and 8 . Two views of piece of a large jar decorated with a dragon with small white scales like that on Ardebil 29.47 (pl. 15); the inside of the shard shows sloppy glazing.

$9,10,11$, and 12. Four shards from a large vase decorated with a blue dragon with large scales like those on the David vases and on Sir Harry Garner's rectangular bottle (Cf. Pope, Fourteenth-century blue-and-white, pl. 36, and OCS Catalogue, 1953, no. 29).

13. The inside of a bowl decorated with chrysanthemum scrolls surrounding a central design of a lotus bouquet tied with a fillet. This is the design copied by the Near Eastern potter on the dish from Hamā, and the difference between it and the early fifteenth-century lotus bouquets as shown on plates 30 and 31 are so obvious as to make comment unnecessary. The chrysanthemum scroll is repeated on the outside of the fragment.

14. Bottom of a bowl with aquatic decoration; a lotus leaf, and two blossoms are shown. Outside are lotus panels.

$15,16,17$, and 18. Three fragments, one shown in two views, with ducks from typical aquatic designs. Compare the duck on 15 with one on 29.38 (pl. 7). Those on 16 and 18 each hold a leafy stem in their beaks; 17 shows the unglazed base of 16 with its unusually thin high foot tapering down to a sharp narrow rim.

19. Rim of a bottle-shaped vase or possibly a ewer. (Cf., PMA 22 for a possible prototype.)

20 and 21. Base of a bowl with aquatic design in the center; 21 shows a simple low foot rim with a smaller raised ring inside made of rather poorly prepared clay.

22 and 23. Two views of a large fragment from one of the big mei-ping of the period. The cloud collar frame surrounds foliage and probably a flying bird of which some wing tips and part of the body remain (cf. Pope, op. cit., pl. 39b), and below this are the band of classic scroll and the large peony design typical of many of these vases as shown on 29.408 (pl. 25). The inside of the shard shows one of the usual joints between the sections of these tall wares, and the roughly finished surface of the wet clay is characteristic of this group.

24,25 , and 26. Three shards from another vessel of the same type; the type of design seen to the left of the cloud collar on 24 is illustrated on one of the mei-ping in the Topkapu Sarayı (cf. Pope, op. cit., pl. 29).

${ }^{101}$ Reference is also made to the preliminary descriptions of Dr. Sommerström of the Ethnografiska Museet in Stockholm who is preparing the material for publication. My thanks are due him for his kindness in supplying me with a copy of his notes. 
27 and 28. Two views of the bottom of a vase with traces of lotus panels around the base and blurry classic scroll around the foot. As is sometimes the case on these smaller lighter wares, glaze is applied inside the foot, but the area is carelessly prepared and the whole job very roughly done with coarse gravelly matter adhering to the foot rim. The inside view shows the customary rough finish of unglazed areas.

29 and 30 . Base of a smaller vase of similar shape with better drawing and stronger blue. The structure of the foot is clearly shown in 30 ; and again this area is roughly glazed.

$31,32,33,34,35,36$, and 37 . Six fragments of various vessels illustrating some typical forms of the lotus panel and its filling; 37 is the unglazed inner surface of 32 , a polygonal vase, perhaps with eight sides. Sommerström has described it as seven-sided which would be most unusual, but as the type of design has not yet been identified with that on any whole piece, it is not impossible that a completely new type is represented here.

38. Base fragment of a small jar with flat base and decoration of pendent blade forms around the lower sides; a few small covered jars of this type are known (cf. OCS Catalogue, 1953, nos. 3, 4 , and 6; although the form is known in Sung celadon, I am not convinced that the covers of 4 and 6 really belong).

39 and 40 . Two views of the base of a bowl with double vajra design in strong blue in the center surrounded by the remains of a peony scroll painted in paler blue washes. The outside view shows a splendid example of one of the typical bowl feet of the fourteenth century; the cleanly cut, rather thick foot is flat on the bottom and slopes down at an angle to the shallow base with conical center inside.

41 and 42 . Two views of the base of a smaller and more crudely made bowl with floral decoration inside.

43. Piece of the inside of a small bowl showing part of a duck (or goose) flying amid foliage; outside are lotus panels.

44. Fragment from the foliate rim of a large, thinly potted bowl showing lotus scrolls painted in outline and wash.

45. Rim fragment of a large dish showing lotus blossom and scrolling foliage on the inside.

46. Small fragment of the rim of a vessel that is hexagonal at the shoulder but has a round mouth; a band of crude thunder pattern surrounds the rim above traces of floral designs.

47. Small fragment from the leg of a stand to a miniature vase. (Cf. PMA 9.)

48. Scroll-shaped fragment probably from one of the buttresslike members which supports the spout of a ewer by linking it to the neck. A ewer with pierced support of this type has not yet come to light.

49. Fragment of a bowl decorated inside with a willow tree like that on the mei-p'ing in the Victoria and Albert Museum (cf. Jenyns, Ming pottery and porcelain, pl. 8B). Outside are lotus panels.

50. Small fragment of a vessel of undetermined shape with a hitherto unrecorded design; inside unglazed.

51. Piece from the foliate rim of a small bowl decorated with a border of the cash diaper pattern above foliage painted in thin washes. 
52. Fragment of a bowl rim decorated with peony leaves in outline and wash.

53. Rim fragment from a bowl decorated inside with a border of crapemyrtle and blackberry lily as seen on 29.320 (pl. 24).

54 and 55. Two shards decorated with lotus scrolls.

56. Fragment showing an unidentified 5-petaled flower amid scrolling foliage.

$57,58,59$, and 60 . Four fragments showing various drawings of the chrysanthemum. The combination with the upper parts of pendent blades on 59 suggests the type of vessel represented by 38 above. (Cf. OCS Catalogue, 1953, no. 4.)

In summary, the facts about Kharakhoto are these: the site yielded documents dating no later than 1366, Yüan Dynasty currency, and abundant fragments of fourteenth-century blue-and-white; the two latest occurrences of the name are in an inscription dated 1362 and in the Yüan history which was completed in 1370. Conversely, nothing attributable to the Ming Dynasty has been noticed among the finds from the site, and the name does not appear in the account of that area in the Ming history. If the city continued to be inhabited in Ming times, it is curious that no evidence of that fact has come to light. So little has been done with the history of that region in the fourteenth century that much source material remains untapped, and it is quite possible that one day the story may emerge. Until that time the secret of Kharakhoto remains inviolate.

\section{HUNG-WU}

This chapter on the fourteenth century cannot be brought to a close without some mention of the great upheaval that took place when the Chinese finally turned on the invading Mongol, drove him from the land, and resumed control with the founding of their last great native dynasty, the Ming. This crucial moment in history presents one of the most perplexing of all the unsolved questions in the development of Chinese ceramics: how, if possible, to distinguish Yüan from Ming porcelains. Chu Yüan-chang, the militant Buddhist monk, placed himself on the Dragon Throne on the $23 \mathrm{~d}$ of January 1368 and called his reign Hung-wu. Thus almost the last third of the century was Ming; and it would be of the greatest interest if a change in style at that precise moment could be demonstrated, a change that would permit us to say with conviction that such and such wares are Yüan while another group is clearly Ming. Unfortunately for those who concern themselves with the minutiae of the history of the things man makes, matters are seldom so conveniently arranged. The evolution of style is gradual and continuous, and in retrospect it may be seen to have conformed with other developments, economic, social, or political, that have left their mark on the human scene; but it is rarely if ever that a change of regime is accompanied 
by a sudden break in man's personal habits with reference to himself, his family, or the things he makes and uses as part of his daily life. So there is no reason to expect that the forms and designs of blue-and-white porcelains made, used, and exported by the Chinese showed any more difference between 1360 and 1370 than they did between 1370 and 1380 or in any other single decade thereabouts.

For the purpose of our immediate subject, there is a 75-year hiatus in reliably documented pieces between the David vases, made in the last Yüan reign, and those of the beginning of the Hsüan-te reign when date marks began to come into common use; and it will be remembered that Chinese writers have left us no contemporary information. Such remarks as have been culled on the wares of early Ming come from the random notes of later authors which suffer from brevity, vagueness, and imperfect transmission by subsequent editors. In the investigation of this long period of threequarters of a century we are left, therefore, to fall back upon the wares themselves. Those of the mid-fourteenth century now stand fairly well defined; and a solid tradition of connoisseurship, both Chinese and Western, lends confidence to the recognition of an early fifteenth-century group which some prefer to define more precisely as Yung-lo. The questions to be faced concern the filling of that void: How long did the midfourteenth-century style last? When did the early fifteenth-century style which culminated in Hsüan-te begin? The answers to both obviously depend on our ability to point out a body of wares in which elements of the two styles, so widely different in their essentials, are found together. This is of course no easy matter, for the repeated and minute examination of any group of porcelains makes it ever more evident that many of the small differences to be observed in drawing and structural details as between one piece and another need not be attributed to anything more than a normal diversity in the habits and skills of two men working side by side. Chronological factors may or may not be involved, and the problem of determining the relative import of the temporal and the human elements in accounting for such differences is often extremely difficult.

A number of pieces that have proved hard to classify may possibly be assignable to the Hung-wu period on these grounds; and without insisting on such an attribution, this is the place to examine their qualifications. One small family is represented in the Ardebil Collection by five small dishes (29.271-275) of which four are illustrated on plate 29. Eleven more, some of them decorated in underglaze red, were shown in the Philadelphia Exhibition. ${ }^{162}$ All have the physical characteristics of the mid-fourteenthcentury group just examined; the paste has the gaps and flaws we have found to be typical, the spiral wheelmarks are often evident on the base, and the unglazed surface shows an orangy red looking in some cases as though it had been smeared on. In general, they are heavy and strongly potted. It is in the decoration that they reveal

${ }^{162}$ PMA 14, 15, 16, 17, 19, 20, 21, 22, 23, 24, and 25. 
qualities common to both earlier and later styles. The tendency to crowd the surface with the design is still evident, but at the same time a new taste for more orderly arrangement begins to make itself felt. This is particularly evident in the cavetto of the large dish with foliate rim and in those of the cup stands and small dishes where the ornament is broken down into separate floral sprays. ${ }^{163}$ The central designs of the two large dishes combine the crowded feeling of the fourteenth century with the sense of order conveyed by the unified orientation of the single peony spray ${ }^{164}$; and the centers of the small dishes also betray conflicting inspirations in the fact that some of them are decorated with concentric bands surrounding a small medallion, as were the earlier white-on-blue wares, while others are covered with a single large spray (29.274). Two further details in this group should be noted. On the large foliated dish, the wave border reflects what must surely be a last feeble attempt to draw the vigorous serpentine waves of the midcentury repertory before they passed into the stylized fifteenth-century formula; and where they occur, the lotus panels cling to the earlier tradition both in the over-all proportion of the frame itself and in the nature of the elements they contain..$^{165}$

The suggestion that these wares, or some of them, may be assignable to the Hungwu reign by virtue of the characteristics just mentioned is not basically upset by the existence of two small dishes related to the type shown on plate 29, which are marked with the Hsüan-te nien-hao. ${ }^{166}$ Both of these pieces, although containing the physical qualities of the early group, are decorated more nearly in the fifteenth-century style; and the question of how long any given style characteristic may have been perpetuated is probably the most insoluble of any that have to be faced in attempting to unravel the complex history of this art. It is the ever-present possibility of an anachronism that makes it so difficult to place with confidence any single piece which shows unusual features excluding it from an established type group. It is the same thing, on the other hand, that offers insurance that the study of Chinese porcelain is unlikely to become a dull and routine exercise. In offering the dozen or so pieces just discussed as one type that may turn out to fill this obscure gap in the chronology, these facts have not been forgotten. The proposal is made in the most tentative spirit with the hope that it may lead to further thought on this vexing question.

Several pieces of other types suggest themselves for inclusion in this period. A bowl in the Topkapu Saray1 is potted with the rim turned slightly inward, recalling,

${ }^{163}$ PMA 20, 23, 24, and 25.

${ }^{164}$ PMA 19 and 20.

${ }^{165}$ PMA 14, 15, 16, 19, 21, 22, and 23.

${ }^{168}$ One of these, a badly warped waster in the private collection of Sir Percival and Lady David, is marked on the upper part of the outside just below the flattened rim; the other, which I saw some years ago but have since lost track of, is marked in tiny characters on the edge of the rim itself. 
although not exactly reproducing, the form of some of the fourteenth-century pieces ${ }^{167}$; the base is unglazed and slightly concave with no rim. Around the outside is a long, slim, 3-clawed dragon with small white scales and a thin, pointed snout, one of the two well-known fourteenth-century types. ${ }^{168}$ The fact that this dragon shows none of the characteristics assumed by that beast in typical early fifteenth-century representations points to an early date; yet in spite of the implications of the inturning rim, the potting of the bowl is refined to a degree beyond anything found in the mid-fourteenth-century group. The same is true of a small dish in the collection of Mrs. Alfred Clark in that it combines the qualities found in both periods. Especially noteworthy are the dragons drawn in slip on the inner surface of the dish and in blue outside; they are in the midfourteenth-century style in every way except for the fact that they have five claws, an indication that they are likely to have been drawn after the Ming Dynasty came into power. ${ }^{169}$ The same dragons appear again on two large mei-p'ing one of which is in the Burrell Collection in the Glasgow Art Gallery, ${ }^{170}$ and in this instance the hint provided by the decoration is supported by the shapes of the vessels which do not conform with anything yet seen in the mid-fourteenth-century or earlier groups. The high rounded shoulders, the profile of the neck, and the strong reverse curve of the sides all combine to suggest a later date. ${ }^{171}$ Aside from this Burrell example the earliest mei-p'ing to show this exaggerated pinching of the waist is the handsome early fifteenth-century mei-p'ing in the Ardebil Collection (29.403, pl. 50), and there may not be more than a decade or so between the two.

The extremely tentative nature of the proposals offered in this section cannot be emphasized too strongly. In the long run they may or may not turn out to have some

${ }^{167}$ Zimmermann, Altchinesische Porzellane im Alten Serai, plate 35. Cf. no. 29.319 on plate 23 of the present volume, and Pope, Fourteenth-century blue-and-white, plates 20-23. A single bowl with inturning rim is known to be painted in the early fifteenth-century style (see 29.328 on p. 86 below and plate 46 ).

${ }^{168}$ Cf. Pope, op. cit., p. 41 and plates 13, 25, and 39a; and also Ardebil 29.47 on plate 15, which, however, has a stubbier snout.

${ }^{169}$ Cf. FECB, vol. 6, no. 2 (June 1954): p. 11.

${ }^{170} \mathrm{Cf}$. Jean Gordon Lee in ACASA, 6 (1952): 33-40. In the second paragraph of her article Miss Lee describes this piece as having "all the attributes of a 14th century product," and in the description of Cut III (p. 39), which is a drawing of one of the cloud forms, she says "1st half of 14th century." My reasons for assigning it to the closing decades of the century are given here. The pair to this Burrell mei-p'ing once belonged to the celebrated Chinese collecter Wu Lai-hsi, although it was not included in his sale at Sotheby's (26 May 1937); its present whereabouts is unknown. Photographs of this piece in the Percival David Foundation show that the two Chinese characters are not blurred as on the one in Glasgow. They are ch'un "spring" and shou "longevity" written in their seal forms.

${ }^{171} \mathrm{Cf}$. p. 62 above. Even in those instances where the neck is curved on fourteenth-century pieces, it is never wider at the top as it is on the Glasgow piece. 
merit; but for the time being they are put forward as possibilities. The problems involved in assigning a group of wares to the last third of the fourteenth century are such that the answers must lie in the wares themselves; and on all these pieces it is the combination of elements recognized to be characteristic of two distinct periods separated by a long hiatus that suggests an intermediate attribution to Hung-wu. 



\section{THE BLUE-AND-WHITE: THE EARLY FIFTEENTH CENTURY}

Although no perceptible line was drawn across the path of stylistic evolution as the year 1399 drew to a close, we can see in retrospect that the dawn of 1400 marked the beginning of what was perhaps the most important century in the history of the ceramic art. De gustibus . . . , and there are those who prefer other periods; Han,

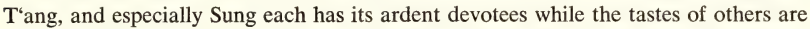
more nearly satisfied by the inimitable virtuosity of the eighteenth-century enamels. Each dynasty, each reign had its own special qualities, each made its particular contribution to the total development; and to compare one stage with another serves no purpose. But seen in its full perspective no one century so deeply influenced the course of ceramic history the world over as that in which the technical and artistic aspects of blue-and-white were simultaneously brought to perfection. Porcelain itself was already an old story in China. For some centuries it had been covered with high-fired felspathic glazes of perfect transparency, and in the century just ended decoration in underglaze blue and underglaze red had moved beyond the stage of experiment. It would seem as if, with these technical accomplishments well in hand, the Chinese potter, like an apprentice at the close of his training, his newly mastered tools all sharp and shining in his kit, were ready to give free rein to his imagination. What lay ahead was in the realm of genius, and in the fashioning and decoration of porcelain the Chinese potter of the fifteenth century yielded to none. To paraphrase one of the most learned and at the same time most sensitive scholars in the field, one who unfortunately did not remain among us to share in the identification of the wares discussed in the previous chapter, it could be said that in the second half of the fourteenth century the lotus budded, in the first half of the fifteenth century the flower opened in all its freshness, and in the closing half of the century the leaves began to tremble in the breeze. ${ }^{172}$

For the wares produced from 1350 on display all the vigor of an art just old enough to have found its strength, and the power of the drawing and the spontaneous and restless crowding of every surface are evidence of the enthusiasm and boundless energy of youth still uncurbed by the restraints of sophistication and maturity. As we have seen, there is no signpost to mark the moment when that lusty spirit began to feel the demands imposed by refinement, but no doubt this was a gradual process in the latter decades of the century, in the Hung-wu reign. The few pieces pointed out as possible products of that period are enough to suggest that definite forces were at work; and in the wares which form the subject of this chapter that gradual trend toward order and elegance has almost run its course. Without insisting upon the precise dates

${ }^{172}$ Brankston, Early Ming wares of Chingtechen, p. 3. 
imposed by the accessions and deaths of rulers, for some of these pieces may have been made in the closing years of the fourteenth century and others may date from after 1435, most of them are undoubtedly Yung-lo and Hsüan-te.

Sixty-three representative examples selected from the 183 blue-and-white pieces of this period in the Ardebil Collection are illustrated on plates 30-55. For the most part they are familiar types recognizable as the wares usually assigned to the first 35 years of the fifteenth century, although a number of the designs and some of the forms have not been noticed hitherto. None of the pieces bears a nien-hao, but the abundance of parallels between members of this group and a large number of pieces with accepted marks in other collections makes identification easy; and the over-all family resemblance within the group as a whole is striking. It is this latter fact that makes it possible to identify certain pieces which may have new and unfamiliar characteristics and to feel a fair degree of assurance in assigning them to this period.

Certain essential qualities give this group its unity and distinguish it from the wares of the fourteenth century as well as, though perhaps to a less marked degree, from those which were to follow. The attempt to describe porcelains in words is inevitably frustrating, as there is no substitute for handling and comparing the actual pieces, and to essay precise descriptions of the minute details involved would hardly serve any purpose. For this reason the following paragraphs are not intended to be definitive but only to convey the most general impressions. Perhaps the key word which may be used to characterize these wares is "refinement"; it is evident in every aspect of the blue-and-white of the early fifteenth century. The paste is finer in grain and of a purer whiteness, indicating a more complete mastery of the techniques of preparation, and as a result the little cracks and imperfections found in the fourteenth century are largely gone. The potting is more skillful, the forms more elegant, and such details as bases and foot rims are finished with more loving care; the orangy-red ferruginous coating which was so unpredictable in the fourteenth century is now more carefully controlled.

The blue of the decoration is strong and rich, and in the heaviest concentrations the tone is extremely deep but always modulated and lively. One of the characteristic features is the occurrence here and there of spots where the supersaturation of cobalt was such that the glaze could not contain it and a black or rusty-brown patch appeared on the surface. These may have been the result of insufficient grinding of the pigment so that small lumps remained, and the technique of preparation must have been perfected over the years for the spots seem largely to have disappeared in Ch'eng-hua times. Or possibly a change in material had something to do with it as Chinese tradition holds that the imported su-ni-po 蘇泥勃 blue was no longer available after Hsüante, and in Ch'eng-hua a local cobalt was used. ${ }^{173}$

${ }^{173}$ Cf. T'ao Shuo, ch. 3, p. 4r3-5 (Bushell, trans. p. 59). Although, as Sir Percival David has pointed out (TOCS, 11, p. 36), Chu Yen does not quote the Tsun-sheng-pa-chien, a passage of 
In the drawing of the decoration this new period provides the most striking evidence of the trend toward refinement in taste. The disorder and crowding of the fourteenth-century compositions gave way to a more orderly and spacious conception of the decorative scheme; less blue was used, and the white of the porcelain played a more important part in the visual effect. The various forms are drawn in bold, sure strokes, in most instances without preliminary outline; and this characteristic style of the time is found in nearly all the floral decorations which largely dominated the repertory. On the other hand, the technique of outline and wash was not altogether unknown, ${ }^{174}$ though it seems not to have come into general use until the second half of the century.

\section{SHAPE}

Increasing inventiveness on the part of the potters, larger output in response to a growing demand, higher rate of survival because the wares were more highly esteemed and consequently better cared for-all these help to account for the wider variety of shapes we know in the early fifteenth century. On the other hand, while many new types must have been produced, it must not be forgotten that our knowledge of fourteenth-century wares is still limited, and we cannot dogmatically say any particular shape was not used then and now appears for the first time. Such observations as can be based on pieces now known to us, however, suggest that certain characteristics of shape are typical of the period even though they be found in vessels of already familiar types, and a good many more appear to be new. Among the latter are the smaller, more refined and delicate wares made for the scholar's study and perhaps purely for the delectation of small circles of dilettanti and for ornamental purposes. Although many of these do not seem to have been sent abroad in early times, ${ }^{175}$ the Ardebil Collection includes a number of extremely fine early fifteenth-century pieces which make it difficult to determine just where the line was drawn between those types which might be exported and those which were jealously guarded at home.

As in the case of the fourteenth-century wares, the large dishes with unglazed bases are by far the most numerous. Flattened rims, both round and foliate, are present as before, and among the latter a new style seems to have appeared in which the cavettoes were molded to match the foliations (pls. 37-38, 41); but special interest attaches to the many dishes with plain rims (e.g., pls. 30, 31, 39, 42, 43) which have yet to be seen among the fourteenth-century wares. Why this simple and obvious form

strikingly similar import occurs in that work, ch. 14, p. 51r5-7 (cf. Brankston, op. cit., p. 40). But even this, the earliest record we have of such a statement, was published only in 1591, more than a century after the events it describes; and the origin of the tradition is not yet known.

${ }^{174}$ Notice, e.g., the leaves on the melon vine on 29.61 (pl. 40 ).

${ }^{175}$ Cf. OCS Catalogue, 1953, p. 4 (the pages are unnumbered). Sir Harry Garner's explanation that "they were evidently regarded as too precious to be sent out of China" may well be right. 
should not have been in use earlier remains to be explained; or if it was, one wonders why, out of almost 50 known dishes, not one of this type should have turned up. Among the bowls a striking new form with deep sides, plain rim, and small foot is often called the "lotus bowl" because of its resemblance in form to the seed pod of that flower, lien-tzŭ 婵子 (pls. 46-47). Another innovation in blue-and-white is the shallow conical bowl (pls. 47-48) which had appeared earlier in Ch'ing-pai, Lung-ch'üan, and Ting wares. The bowl with inturning rim (pl. 46) is mentioned not as a new form but as the only example of this relatively rare shape to have come to light with decoration in the early fifteenth-century style. Like the dragon bowl in the Topkapu Sarayl, this is a survival of a short-lived mid-fourteenth-century shape, and whereas the Istanbul piece retains certain of the decorative characteristics of its period and may still belong to the latter part of the century, ${ }^{176}$ this piece exhibits the fully developed style of the period to which it is here assigned.

The vases show even greater inventiveness than do the bowls and dishes. The familiar form of the mei-p'ing, while remaining entirely recognizable, undergoes some striking modifications. In general these are slightly broader in proportion to their height, the shoulders are less sloping, and there is a reverse curve of varying degrees as the sides drop down to the foot. The neck, too, has now lost its conical form and is most often curved symmetrically so that it is equally wide at top and bottom (pls. 50-51). ${ }^{137}$ In this group is the finest mei-p'ing to have survived from this period (29.403), a vase of imposing proportions and faultlessly executed decoration which is in flawless condition. The exaggerated slimness of the waist while found on a number of coarser examples of uncertain date is otherwise unknown in pieces of this quality. The large bottle-shaped vases ( $\mathrm{pl} .53$ ) are now seen for the first time, and both round and flattened examples are known. ${ }^{178}$

A number of the new forms introduced in the early fifteenth century were based on Islamic prototypes. Although only a few of these are found in the Ardebil Collection, it may be of interest to take a brief look at the family as a whole and examine the origins of the several shapes. ${ }^{179}$ The small flask with flattened sides and two handles joining the shoulders to the short straight neck, the form called "moon flask," yüeh p'ing, by the Chinese follows an Islamic glass vessel as old as the tenth century ${ }^{180}$; and

${ }^{176}$ Cf. pp. $79-80$ above.

${ }^{177}$ Cf. p. 63 above.

${ }^{178}$ See TOCS, 25 (1949-1950): plate 2c; also PMA 36; OCS Catalogue, 1953, plate 5a, which is decorated with a dragon; and Ottema, Chineesche ceramiek, p. 106, fig. 121.

${ }^{179}$ Cf. Gray, TOCS, 18 (1940-1941): 47-60. I propose to note only those Chinese shapes which, appearing for the first time in the early fifteenth century, show clear evidence of influence from the Islamic world.

${ }^{180}$ Cf. Lamm, Mittelalterliche Gläser und Steinschnittarbeiten aus dem Nahen Osten, vol. 2, plate 2, no. 25 ; plate 7 , no. 3 ; plate 158 , no. 3 . A fine Chinese example is shown in Garner, Oriental blue and white, plate $30 \mathrm{~A}$. 
one of the outstanding examples of the prototype is that in the Toledo (Ohio) Museum of Art which has been dated about the year 1300 (pl. 135, A). The form not only was adopted by the Chinese but was modified to produce another which is in effect a marriage between the flask and the "double gourd" (29.458, pl. 55). The neck has been extended and expanded in the middle, and the handles are raised in a more graceful arch and somewhat flattened in horizontal section. ${ }^{181}$ Even with these changes, however, the ancestry of the type remains clear.

It has long been customary to speak of Ming ewers as "Persian" in form; but the matter is not so simple as all that, and the history of the type involves a number of complex problems. Ewers as such, that is, vessels with spouts designed for pouring, go back to the huo types of the Bronze Age, and so the idea has a respectable ancestry of its own on Chinese soil. Ceramic ewers, moreover, were common in T'ang and Sung times. The shapes that appeared for the first time in Ming porcelain were new, and one of the things to be determined is how far these were influenced by contacts with the Near East and how far they were normal developments of existing Chinese forms. No doubt both factors were involved. One type, that with heavy body, abrupt shoulder, and tall cylindrical neck (e.g., 29.439, pl. 55) is obviously based on a well-known Islamic ewer which was made in both metal and pottery from the twelfth to the fourteenth century. ${ }^{182}$ But this is the less well known type; the one most commonly considered to be of "Persian" form has a pear-shaped body, flaring lip, and long curving spout $(29.427-30, \mathrm{pl} .54)$, and for this no Islamic prototype has yet been found. ${ }^{183}$ It seems rather to be an adaptation of the Chinese yü-hu-ch'un-p'ing, which was known in Ting, Lung-ch'üan, and Tz'u-chou wares among others and which is the shape of what may be some of the earliest blue-and-white. Sometime around 1400 the spout and handle were added, and the shape gradually evolved in the next century and a half to the high-footed slender ewer of the Wan-li reign (29.423-424, pl. 99). It was this form in turn that moved westward across Asia as part of the wave of Chinoiserie which influenced the potters of Iran in the sixteenth and seventeenth centuries, the very wave of which the Ardebil Collection itself is the outstanding residue. So in the long run this Chinese form became "Persian," and when it was picked up by the Iranian metal-

${ }^{181} \mathrm{Cf}$. PMA 32 and 69, which illustrate the varying proportions of the neck and the handles. ${ }^{182}$ Cf. Pope, A.U., Survey of Persian art, vol. 6, plates 1282A, 1322-1328; and vol. 5, plate 637B.

${ }^{183}$ This view, first expressed to me by Basil Gray, is revolutionary and still not generally accepted; but none of those who disagree has been able to produce a convincing prototype. The nearest suggestion I have yet seen is a metal ewer of the fourteenth century in the Benaki Museum, Athens, of which D. S. Rice has very kindly given me a photograph (pl. 136, A). Fine though this may be as an example of the metalworker's technical skill, and in spite of the superficial similarity suggested by the fact that it has a spout, a handle, and a raised teardrop panel on the side, it is essentially an ugly piece clumsily conceived in over-all design and can hardly have played much of a part in inspiring the very elegant porcelain ewers under discussion. 
workers of the seventeenth and eighteenth centuries (pl. 136, B) its fate was sealed; ever since it has been the vessel from which is poured the thick coffee of the Near East, ever since the traveler has returned with his brass or silver ewer set on a tray with small cups as his souvenir of the lands of Islam. These latter-day horrors in every tourist bazaar on the cruise routes and every oriental antiquary's shop in the capitals of Europe have by sheer force of numbers confused the issue and obscured the true origin of the form. The documentation of these exchanges is not altogether clear, for Iranian modifications of the Chinese form went back to China from time to time, and one day the whole story may be filled out in greater detail. For the moment, however, it seems likely that the so-called "Persian" ewer of the seventeenth century is directly descended from a Chinese type some two centuries earlier.

Tankards have been the subject of some discussion but are now generally accepted as early fifteenth century in date. A number of the known examples are marked Hsüan-te, and with minor variations all are the same type. The form goes back to about the eighth century in the Near East. ${ }^{184}$ Persian potters used it widely as early as the tenth century. That they provided it with a foot and indulged in some variation of the proportions does not alter the fact that it is essentially the same vessel. ${ }^{185}$ The Turkish jugs of the sixteenth century by which Hobson 25 years ago sought to date this then almost unknown Chinese form ${ }^{186}$ are undoubtedly, like so many other Turkish wares of that time, products of the great wave of Chinese influence then being felt in the ceramic centers of the Near East.

Another form based on an Islamic metal vase is a subject of controversy among students of Chinese porcelain. This is the small vase with cylindrical neck and base separated by a body in the shape of a faceted cube. A number of these carry the mark of the Hsüan-te period and some are unmarked, but doubt has been expressed as to the validity of this presumptive date. ${ }^{187}$ Whatever the solution to this perplexing question the prototype is clearly an Islamic metal form dating from the twelfth century (pl. 137, A).

The pen box has its origin in the same medium ${ }^{188}$ as has the deep basin with sides sloping inward toward the top and wide-flaring rim, and the latter was also known in

${ }^{184}$ Lamm, op. cit., illustrates two examples from the Caucasus in glass (his pl. 2, no. 15, pl. 8, no. 10), and a striking carved crystal jug from Egypt (his pl. 80, no. 6), which he calls eleventhtwelfth century.

${ }^{185}$ Typical variants are illustrated on plates 576B, 592C, 599A of A. U. Pope's, Survey of Persian art, vol. 5.

${ }^{186} \mathrm{Cf}$. Hobson et al., Chinese ceramics in private collections, p. 170 and fig. 304.

${ }^{187} \mathrm{Cf}$. OA, 3, no. 1 (1950): 22-23. In that article I suggested a Cheng-te date for these vases; but while the structural similarities between these and certain of the heavy Cheng-te pieces are undeniably striking, I am no longer altogether happy about that attribution. Some of them may be Hsüan-te, but for the moment I prefer to leave the question open.

${ }^{188}$ Cf. Gray, op. cit., plate 5. 
Syrian glass as early as the late thirteenth century (pl. 135, B). The most famous metal example is the Baptistère de St. Louis, one of the great treasures of the Islamic Department of the Louvre. ${ }^{189}$ A small, squat bowl with contracted mouth also has abundant prototypes in the Islamic world in metalwork, glass, and even ceramics. ${ }^{190}$ Rarest of all these Islamic types in that only a single example seems to have been noticed thus far is the pharmaceutical jar of distinctive form best known by its Spanish name "albarello" (pl. 138, A). Prototypes are known in pottery all over the Near East beginning as early as the eleventh century; and it appears to have gone west with the Moors to Spain, where it continued until the sixteenth century, by which time it was also known in Italy. ${ }^{101}$

\section{DECORATION}

Although many of the elements in the full-blown decorative scheme of the midfourteenth century continue to be found on the wares of the early fifteenth century, the way in which they are used is so different as to change the whole character of the style. The decorators adopted new ways of drawing the individual elements, and even more striking is the inventiveness they displayed in combining them. As a result, when these chronological traits are recognized, there is little likelihood of confusion between the two. Such difficulties as still exist, and they are by no means completely eliminated, arise from the fact that in all periods blue-and-white was made in various places, places of which we know little or nothing; and while the principal body of fourteenth-century wares and the principal body of early fifteenth-century wares, probably made at or near Ching-te Chen, each has its own special characteristics, there are always strays that do not fit comfortably in either group. As will be seen later, there are a number of such pieces in the Ardebil Collection.

Since it is impossible to divide the wares into groups that retain their individualities from all points of view, they are arranged arbitrarily on the basis of form; and it is appropriate to begin with the large dishes, which are numerically the most important. The rims of these are decorated in a great variety of ways though the most common borders are waves, classic scroll, thunder pattern, and sundry floral combinations. Altogether gone is the diamond diaper pattern that played such an important role in the middle decades of the fourteenth century. Of the border designs just mentioned

${ }^{189}$ Cf. Rice, Le baptistère de Saint Louis, Paris, 1953. A Chinese example is in Garner, op. cit., plate 22B, and there is an unpublished one on the Topkapu Sarayı (1472).

${ }^{190}$ Cf. Pope, A.U., Survey of Persian art, vol. 6, plate 1337; Lamm, op. cit., plate 13, no. 3; and Wallis, Persian ceramic art, plate 24. All these pieces are assigned to the thirteenth century. Cf. the Chinese example in OCS Catalogue, 1953, no. 51 (no. 7 on pl. 6).

${ }^{191}$ Many examples are published. Cf., e.g., A. U. Pope, Survey of Persian art, vol. 5, plates 625B, 751A, 777B; Wallis, op. cit., plates 9, 11, 12; Rivière, La céramique dans l'art musulman, plates $9,20,96$. 
the thunder pattern gained the most in popularity, and this was especially so in respect to its use on blue-and-white. The design itself was common on the bronzes and pottery of the Shang Dynasty and thus one of the oldest decorative motifs in China. The classic scroll was in use on the fourteenth-century wares, and the wave was common. But somewhere along the line, probably in the still obscure second half of that century, this latter element had been subjected to such a major change in style as to make it almost unrecognizable. No longer are the borders alive with the vigorously calligraphic serpentine waves seen on the dishes we have just examined; the new formula consists of a more static series of forms distributed in various ways around the rims. Nos. 29.1 (pl. 30), 29.33 (pl. 31), 29.55 (pl. 37), 29.61 (pl. 40), and 29.63 (pl. 41) show some of the innovations. Even more diversity is exhibited in the use of floral scrolls on the borders. The crapemyrtle and blackberry lily combination which was so common in the fourteenth century survives only in greatly modified form, so changed in fact that the identification is suggested only for want of a more precise description of the type of border found on 29.58 (pl. 38). The 6-petaled blossom is still there and crapemyrtle leaves as well, but these are supplemented by the addition of conventional lotus leaves. New motifs include a scroll with ling-chih fungus seen on 29.75 (pl. 33), one with tiny serrated leaves as on 29.92 (pl. 34), and miniature lotus scrolls, highly conventionalized, like those on 29.83 (pl. 33), 29.113, and 29.117 (pl. 36 ). In addition to using the continuous scroll, the decorator now began to vary his borders by means of separate plant forms spaced at intervals around the rim. Evidence of the variety offered by this new method may be found on 29.60 (pl. 39) and 29.65 (pl. 32) on which the pomegranate, camellia, and chrysanthemum are recognizable.

The use of the cavetto as a ground for floral patterns also reflects the new attitude toward decoration, and the heavy wreath of lotus or peony found on the fourteenthcentury dishes now gives way to a series of delicate and more varied motifs. In most instances several different blossoms are used on a single vine, and the leaves, always more difficult of identification, may or may not be appropriate. Even in those cases where only one type of bloom occurs, the whole spirit of the decoration is lighter and more elegant. Lotus scrolls appear on 29.119 (pl. 36) and 29.65 (pl. 32), the former drawn with exceptional skill and inventiveness in the rendering of both the blossoms and the leaves. On 29.68 and 29.75 (pls. 32, 33) is the plain peony scroll. These four examples suggest that there was no feeling about the relationship between the flowers in the cavetto and those in the center of the dish; 29.119 has the lotus in both places, and 29.68 has all peonies; the other two mix lotus with peonies, and peonies with chrysanthemums, respectively. Cavettoes with several kinds of flowers are more common, and these are frequently placed in pairs as on 29.1 (pl. 30) and other dishes in that group where pairs of lotus, chrysanthemums, camellias, and peonies may be seen among the 13 flowers represented. The odd number indicates that the system of pairing is not fully carried out on the inside, although it will be noticed that on this 
group they have placed 14 flowers on the outside of the cavetto in seven pairs. In spite of these indications of a tendency toward systematic use of flowers, the arrangement on most types of pieces seems to be variable; some of the blossoms are repeated and others are used but once. Several of these are illustrated, and perhaps the most outstanding piece from the standpoint of quality is 29.60 (pl. 39) where the sizes of the flowers are varied and the freedom of the arrangement and facility of the drawing are comparable to those qualities found on 29.119 (pl. 36).

As in the case of the borders, the most striking innovation in the cavettoes of the early fifteenth-century wares is the use of separate floral sprays or bunches of flowers instead of the continuous scroll. That this device may have come in fairly early we know from such pieces as numbers 20, 23, 24, and 25 in the Philadelphia exhibition and the four small dishes 29.271-275 (pl. 29) in the Ardebil Collection. In its mature form the most common pattern shows 12 flower sprays consisting of two sets of six each repeated in order so that each flower is diametrically opposite another of the same kind. A typical example is 29.101 (pl. 35), and a minor variant is 29.117 (pl. 36), on which each separate spray is encircled by its leafy stem. On 29.58 (pl. 38 ) the alternate sprays are all fungus and between them are seen chrysanthemum, lotus, hibiscus, camellia, peony, and rose (?), while the outside carries these six and six more varieties with no fungus at all. Still other arrangements include a variable combination of 12 sprays as seen on 29.83 (pl. 33), a mixture of flower and fruit sprays as seen on the smooth cavetto of 29.64 ( $\mathrm{pl} .32$ ), and a uniform pattern of identical sprays as on 29.63 (pl. 41) where because of the huge size of the dish there is room for it to be repeated no less than 16 times. It will have been noticed that with one exception in the present group (29.64) the use of separate flower sprays in the cavetto is limited to those dishes with foliate rims, and the sprays may be centered either on the points of the foliation or between them.

The two concentric decorative zones formed by the rim and the cavetto are almost standard on all dishes of this period, but in some instances when the rim is plain the whole area serves as the ground for a single design. In the Ardebil Collection three examples of this treatment were found on the large landscape dishes, which are remarkable not only in this respect but also for their quality and size: $29.310-312$ (pls. 42-44). No two are alike, nor does the design on the outside ever exactly duplicate that on the inside; altogether, including the center designs, more than 30 varieties of plants have been identified with a fair degree of certainty. They are listed in detail on the descriptions facing the several illustrations.

Before leaving our discussion of this area some mention should be made of its outer surface. As has been noted, the design here may or may not be the same as that on the inside. The group typified by 29.1 has a similar floral scroll both inside and out varying only in the number of blossoms shown whereas a dish like 29.37 (pl. 45) has a floral scroll inside and dragons among clouds on the outside. The latter 
design then complements the center of the dish rather than the cavetto. Floral scrolls and separate sprays of fruits, flowers, and fungus seem to be used almost at random, but so far as has been observed none of these dishes in the typical early fifteenthcentury style is decorated outside with the bold lotus-petal panels which sometimes adorned those of the fourteenth century. As will be seen on the bowls this element did not disappear, but it was so greatly changed in detail that it can hardly be confused with its prototype.

The pattern in the central area of each dish is the largest and most striking, and it is altogether appropriate that some sort of classification should be based upon it. Thus it is common to hear of "bouquet plates," "grape plates," "melon plates," "dragon plates," and so on. Some of these various types may be noted in more detail to indicate the range of variety employed. The "bouquet plates" are represented in the Ardebil Collection by a group of no less than 34 pieces of varying sizes and with varying borders. Five of these are illustrated on plates 30 and 31. Perhaps better than any one group they illustrate an important point to be observed in the study of Ming blue-and-white. Students, collectors, and connoisseurs are plagued by the problem of distinguishing the wares of the early fifteenth century from copies made in later years, especially in the Yung-cheng and Ch'ien-lung reigns of the Ch'ing Dynasty, and many of these copies are excellent beyond any question. ${ }^{192}$ The several criteria considered in making a comparison usually include the clay, the structure of the piece, especially the foot, the glaze, the quality of the blue and the drawing. While none of these should be neglected, there seems to be a tendency to attach undue importance to minor differences in the drawing; and the five pieces were selected to illustrate this point. The bouquet design is the same in every case. A lotus blossom occupies the center of the composition; at the upper left is a second lotus blossom beside a sagittaria; at the upper right are two more blossoms, one somewhat smaller than the other; below the smaller of these is a seed pod; and at the lower right is a fifth blossom. Three large lotus leaves are disposed through the group together with aquatic grasses and three smaller plants that have escaped identification. All are tied together at the bottom by a bowed filet of some sort, and eight stems protrude below, five curving to the right and three to the left. While the arrangement never varies, the drawing of the individual elements and the spacing between separate plants changes noticeably from one example to another. To single out but a few specific points, the sagittarias on 29.3 and 29.6 are full and plump and closely crowded between the adjoining plants, while that on 29.21 has long spindly points and ample space between itself and its neighbors. The wavy stalk to the right of the sagittaria has very small leaves on 29.6 and much larger ones on 29.3; and on 29.21 they are small again but the stalk itself

${ }^{192}$ Cf. TOCS, 26 (1950-1951): 46-47, plate 13, where an early fifteenth-century ewer is compared with a copy made in the eighteenth century. 
is extended until it almost touches the bordering circle. The rendering of the lotus blossoms and leaves varies from dish to dish; and even in these black-and-white reproductions the varying intensity of the blue is suggested. Without pursuing these details further it becomes clear that differences in drawing technique need not alone be taken to indicate differences in period. The decoration of these dishes is the work of several men or even of the same man on several days. If evidence be needed that the porcelains were decorated by many men working from master patterns, surely this one little group provides it; and human coordination being what it is, we should be astonished not that they are so different but that they are so much alike. Any group of dishes in which the central decoration was obviously copied from a single master pattern, any group which we today might call a "set" is likely to show a similar diversity of detail from one to another.

A glance at the illustrations will show how wide a variety of designs was employed. Most numerous are those dishes decorated with flowers, a motif which permitted almost infinite variation although the commonest types have two to six principal blossoms either growing in lifelike fashion on a single stem as on 29.65 (pl. 32) or arranged in a formal and intricate scrollwork as on 29.113 (pl. 36). Supplementing the large main flowers are smaller blossoms, sometimes buds, and always leaves.

As on the borders and in the cavettoes, the floral designs in the centers may be composed of flowers of one variety or several. Peonies are used alone on 29.64 and 29.65 (pl. 32), while 29.83, 29.98, and 29.119 (pls. 33, 34, 36) have only lotus blossoms, and on 29.75 (pl. 33) is a single spray with three chrysanthemums. The rest of the floral dishes are decorated with mixed flowers, which may include any of the above-mentioned three and also camellia, carnation, hibiscus, and others which are often so stylized as to make certain identification impossible. It is only natural that this group, which is the largest in numbers, should also display considerable differences in quality ranging from such superb pieces as 29.119 (pl. 36), 29.65 (pl. 32), and 29.83 (pl. 33), which are unsurpassed of their kind, to dishes like 29.117 (pl. 36), which is quite ordinary.

An unusual dish related to this floral group is 29.35 (pl. 40), which is decorated with three large sprays, one of pine, one of prunus, and one of bamboo. This motif, known to the Chinese as "the three friends of winter" or "the three cold-weather friends," sui-han-san-yu 葴寒三友, is widely used in decoration and not uncommon on blue-and-white although customarily the three plants are represented growing around a fanciful rock in a garden setting. ${ }^{193}$ It is seen on smaller lighter dishes from the

${ }^{193}$ Although we know the combination as early as the mid-fourteenth century, it seems to be relatively recent. Under san-yu, the encyciopedia $T z^{\prime} u$-yuan says, "In recent times painters took the pine, the bamboo and the prunus and painted them together as the three winter friends; also there are paintings with the prunus, the bamboo and the rock. Su Tung-p'o who was a literary man and could also paint said, 'When the prunus is cold, it flowers; when the bamboo is lean, it grows old; 
Hsüan-te and Ch'eng-hua periods, and later versions exist in the late Ch'ing reigns. ${ }^{194}$ This type in which the three large branches alone occupy the center of a rather large heavy dish seems to be rare. ${ }^{195}$

Among the dishes decorated with fruits, those with grapes are the best known, and no less than 11 examples remain in the Ardebil Collection. The pattern varies somewhat in composition but is always based on three bunches of grapes attached, though sometimes rather nebulously, to a vine with leaves and tendrils (pls. 37-39). The leaves on 29.60 (pl. 39) differ from those of the others, and it may have been the decorator's intention to represent a particular variety of grape. The orientation of this latter design is curious too, for at first sight it seems as though a landscape foreground were intended; but to set the dish right for this interpretation means that the grapes assume a horizontal position, which is absurd. This must then be a bit of rocky moss-grown wall over which the vine is growing. ${ }^{196}$ Other fruits are melons (29.61, pl. 40), peaches $(29.62$, pl. 40$)$, and litchi $(29.63, \mathrm{pl} .41){ }^{197}$ all powerfully drawn and dominating the decoration of the entire dish. In this respect the whole fruit group provides a striking example of the change in spirit that had taken place since the middle of the fourteenth century. For the early painters too had used fruits, notably the grape and the melon (e.g., 29.120, 29.121, pl. 13), but the grape bunches were small, and both they and the melons were almost insignificant among the varied elements of an overcrowded composition. Now in the early fifteenth cenury each came into its own as a decorative theme and as a test of the painter's skill as well. The difference is that between a patch of jungle, however skillfully rendered, and a carefully arranged still life.

Not only the most striking but also the most unusual of the early fifteenth-century dishes in the Ardebil Collection are those decorated with a single landscape scene in

when the rock is deformed, it is elegant; that is why they are the three profitable friends.'" This latter term san-i-chih-yu 三益之友 in turn goes back to Confucius whose statement Waley (Analects, p. 205) translates, "Master K'ung said, 'There are three sorts of friend that are profitable, and three sorts that are harmful. Friendship with the upright, with the true-to-death and with those who have heard much is profitable. Friendship with the obsequious, friendship with those who are good at accommodating their principles, friendship with those who are clever at talk is harmful.' "'

${ }^{194}$ Cf. Kushi, Shina minsho, plate 7, and OCS 1953-1954 exhibition, no. 67 (not illustrated), for Hsüan-te examples; Ch'eng-hua examples are more numerous (e.g., Pope, Ming porcelains in the Freer Gallery of Art, p. 23, and PMA, 74); and a poor Tao-kuang example is published in OCS 1953-1954, no. 313, plate 17; the writer owns a Kuang-hsü dish on which the drawing is, if possible, even less inspired.

${ }^{195}$ The only other one now known to me is in the collection of Lord Cunliffe (cf. OCS 19531954 exhibition, no. 34 , pl. 5).

${ }^{196}$ The same design appears incised on a celadon dish in the Topkapu Sarayı. Cf. Zimmermann, op. cit., plate 10 , where the piece is shown $90^{\circ}$ out of proper orientation. See p. 156 below.

${ }^{197}$ Cf. op. cit., plate 12. 
the center. Only three such pieces are known elsewhere, ${ }^{108}$ and the fact that so few appear to have come to light or to have made their way into any of the Western collections must mean that they were very rare even when they were made; and this is not surprising for they represent a remarkable achievement from the technical standpoint alone. In spite of their great size they display perfection of potting in every detail. The unglazed bases are 19 inches across inside the foot rims, very slightly convex with no sign of having sagged or warped in the kiln, and velvety smooth to the touch; the rims too are symmetrical and even. Among existing porcelains of the period, this group is rivaled in size only by the litchi dish just mentioned $(29.63$, pl. 41$)$ and a dish decorated with parakeets on peach branches in a Japanese collection. ${ }^{199}$

The decoration of these three is similar but not identical. Each shows a landscape scene with a point of land protruding from the left into a body of water, while two smaller points appear at the right, one in the foreground and one in the background; the left-hand point in each case has on it a stylized garden rock. Although the composition on 29.310 (pl. 42) is not so clearly defined in the foreground, the general plan is the same. Next to the rock in each case is a large plant and this central group dominates each scene. On 29.310 are two tall stalks of coxcomb, and to the lower left of this is a narcissus with three blossoms. Above the narcissus and immediately to the left and right of the coxcomb are three nightshades. The two small plants in the foreground are dandelions, and in the lower right of the composition is a second narcissus; rising from the distant point in the upper right is the knotweed.

Behind the rock on 29.311 (pl. 43) grows a crabapple, a fern is at the lower left, and above this a Pennisetum japonicum, which appears to have no common name. The small plant to the right of the rock is a plantain, while the four flowers growing just across the water from this may be lilies. On the point in the right background a tall nightshade overhangs two aster plants.

The flora of 29.312 (pl. 42) is more sparse with the central area dominated by a large pine under which are azaleas. In the foreground is a primrose, on the point in the right background is palm, and the plant at the left may be a variety of lily.

These scenes are landscapes in the best Chinese tradition, embodying the two elements essential to the form: mountains, represented as they were in every Chinese garden by a fantastic rock, and water. And while composed with great imagination and decorative sense, they are rendered with a remarkable degree of scientific accu-

${ }^{198}$ Two are in the Topkapu Sarayı Müzesi in Istanbul, and one of these was lent to the International Exhibition of Chinese Art held in London in 1935-1936 where it was no. 1489 in the catalogue. Cf. also Jenyns, Ming pottery and porcelain, plate $23 \mathrm{~b}$. A dish with the same design as that on 29.310 was published in the fourth exhibition catalogue of the Nezu Museum, Tokyo, 1943, pp. 26-27.

${ }^{199}$ Cf. Kokka, 711, plate 7. This dish has the Hsüan-te mark written in a line outside the rim; it is 297 inches in diameter. 
racy, as is evident from the number of plants that can be given their appropriate names. Though he may have been copying a painted model, the man who executed these was not a scholar-painter, and the problems he faced in applying the solution of cobalt oxide to the unbaked porcelain body were very different from those involved in painting with Chinese ink on paper or silk. As the device of suggesting distance by the use of delicately graded washes was denied him by his limited mastery of the medium, for that technique was not developed until the sixteenth century and reached perfection only in

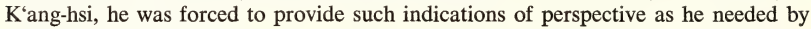
mechanical means; hence the arrangement of points jutting out from alternate sides of the picture at three different levels. Even so, the effect was but crudely achieved. His desire for botanical accuracy conflicted with the requirements of perspective, so that although the skeleton of the scene is properly laid out by the three land areas in retreating order, the plants themselves vitiate the result. In one case the knotweed on the distant point is as large as the coxcomb in the central group; and in another the asters on the background spit are almost half as high as the crabapple tree by the rock. But this is quibbling; the end in view was not a photographic reproduction of nature but an impression of a garden scene, and in this our painter has succeeded admirably. This rare group of dishes shows us the early fifteenth-century decorator at his most ambitious; the achievement in both conception and execution marks the arrival of a new era in porcelain decoration.

Flower and fruit patterns and an occasional landscape occupy the centers of most of the dishes of this period, and other motifs appear to have been used less frequently. The only examples in the Ardebil Collection are two dishes decorated with dragons, one of which, 29.37, is illustrated (pl. 45). Here a 3-clawed dragon is reserved in white against blue waves. The monster is delineated in every detail by fine lines incised in the clay, and only the eyes are indicated in blue. Aside from this central area the decoration is in the normal blue-and-white style with floral scrolls in the cavetto and four dragons among clouds on the outside. The dragon pattern executed in this way on a blue ground relates this dish to a small family including a mei-ping and a bottle-shaped vase in this same collection (pls. 50 and 53) and a few isolated pieces elsewhere ${ }^{200}$; and this handful of examples may represent almost the only survivals of the fourteenth-century taste for white decoration set off by a blue background. ${ }^{201}$ So far no dragons in the standard blue-on-white technique have turned up on these large dishes, although a number of vases and some of the smaller, lighter wares in other collections are so decorated. ${ }^{202}$ Except for these, the only large early fifteenth-century dishes with other than floral or landscape decoration to have been

${ }^{200}$ Cf. Pope, Letter from the Near East, HJAS, 13, nos. 3 and 4 (Dec. 1950): plate 6; and a similar bottle in the David Collection (Hobson, Catalogue, pl. 120).

${ }^{201}$ See note 132, p. 65 above.

${ }^{202}$ E.g., Freer, 51.13, Pope, Ming porcelains, p. 19. 
noticed so far are the four in Istanbul decorated with bulbuls and the great dish in Japan with parakeets. ${ }^{203}$

The floral repertory and the rare dragon and bird motifs described in connection with the dishes are for the most part carried out on vessels of other types with only such changes as may now and then be dictated by the requirements of a particular shape and the surfaces it presents. In the bowls, for example, the rims are decorated with the same patterns, and the sides, corresponding to the cavettoes of dishes, take on the role of major decorative areas. The central patterns are reduced to relatively small circles framing single sprays of fruit or flowers inside the bottoms. A standard example of the translation of similar motifs from one form to the other is 29.321 (pl. 47) decorated with thunder pattern at the rim, a broad band of lotus scrolls occupying most of the body, lotus-petal panels below, and a band of classic scroll around the foot. ${ }^{204}$

The use of the lotus panels is of special interest because this element which was widely employed in the fourteenth-century blue-and-white disappeared from the large dishes of the early fifteenth century, although it remained on vessels of other shapes. On this bowl it is executed in a heavy line which frames a single vertical element in the center; and the frame as a whole is tall and narrow in form. This is but one of many guises assumed by the motif in this period, and while it remained fairly constant on the wares of the middle fourteenth century it now began to develop in a variety of ways that can only be explained by the greatly increased inventiveness of the period. A look at the illustrations in this section and at the wares in other collections will give ample evidence of what took place. ${ }^{205} \mathrm{~A}$ most unusual development and one that seems to have been limited to the early part of the century, as the bowls are always called Yung-lo, though no marked pieces have yet been seen, is that on the lien-tž̆ bowls where single, solid, petal-like members rise from the base almost to the rim as seen on 29.326 ( $\mathrm{pl} .47$ ). In fact these have not generally been recognized as varieties of the same element, but there seems no reason to believe they have any different origin. Of this widely known group the Ardebil Collection boasts one hitherto unnoticed variant in 29.327 (pl. 46) where each petal is framed by a single narrow line. Other unusual features of this same bowl are the thunder pattern around the foot and the compression and elongation of the classic scroll around the rim, while the inside is painted with fruit sprays instead of the customary flowers on a scrolling vine.

The bowl with inturning rim $(29.328, \mathrm{pl} .46)$ which has been mentioned above

${ }^{203}$ Cf. TOCS, 26 (1950-1951): plate 11; and Kokka, 711.

${ }^{204}$ Several bowls of this type are marked with the Hsüan-te nien-hao; e.g., PMA 45.

${ }^{205}$ The most striking comparison is afforded by the renderings seen on the large kuan in the Metropolitan Museum and the two mei-p'ing in the Nelson Gallery (PMA 47, 48, 49) all of which are Hsüan-te pieces. This group alone makes it unnecessary to seek any chronological significance in the varying degrees to which the motif was elaborated in this period. 
as a rare form in the fifteenth century is clearly a product of the period in every detail of its decoration. The wave border, the main zone of lotus scrolls, and the simple lotus petal panels that surround the base are all characteristic of the new style as is the small peach spray inside a double circle in the bottom.

Among the shallow conical bowls (29.330, 332, 333, 334; pls. 47 and 48) there is considerable variety in the decoration including the three friends (29.330), alternating sprays of flowers and fruits (29.332), a single dragon (29.333), and a peony scroll pattern (29.334). The latter two call for special comment. The dragon which is exceptionally elongated to cover the entire outer circumference has white scales and a pointed snout, and these characteristics together with the fairly long curving claws and the narrow band of white ventral scales are reminiscent of fourteenth-century representations of the beast. Comparison with typical Hsüan-te dragons ${ }^{206}$ suggests a relatively early date for the bowl, perhaps close to the year 1400 . The peony bowl (29.334) is unusual in having the outside pattern repeated within in underglaze slip painting of great delicacy ${ }^{207}$; the whole bowl, moreover, is not white but a very pale shade of gray. Another group of bowls is made up of those with deep sides and straight rims, a late fourteenth-century form that continued in use, and these reveal the customary variety in decoration (pl. 49).

Among the vases, the outstandingly beautiful mei-ping (pl. 50) has already been mentioned with respect to its unusual shape and has been cited as a member of that small family decorated with white dragons reserved on grounds of blue waves. It need only be added here that the decoration is superbly executed in keeping with the extraordinary quality of the vase from the standpoint of potting. The other mei-p'ing in this group are standard early fifteenth-century shapes which exhibit the usual variety of decoration (pl. 51) as do the broad kuan jars (pl. 52). The shoulder of 29.495 bears a design like that on the neck of a kuan of remarkable quality dated a century later in the Chia-ching period ${ }^{208}$ although neither the blue nor the drawing on the Ardebil piece shows any affinity with the style of the latter period. Another early fifteenth-century kuan with this design is known. ${ }^{209}$ On 29.479 attention should be called to the scroll around the base which is unusually thick and bold. Unlike that on the mei-p'ing 29.415 (pl. 56), it is not simply drawn in outline and filled with pale wash, but rather seems to have been sketched in and then heavily accented with broad strokes of dark blue which cover most of the outlines and give a strongly modulated effect.

${ }^{200}$ E.g., PMA 47-49 and Pope, Ming porcelains in the Freer Gallery of Art, no. 51.13, p. 19. ${ }^{207}$ PMA 57, which is marked Hsüan-te, suggests a date for this piece.

${ }^{208}$ No. 160 in the OCS Catalogue of 1953. A similar piece is known in this country; and the design is also seen on PMA 117 in the more typical dark Chia-ching blue.

${ }^{209} \mathrm{Cf}$. Honey, The ceramic art of China, plate $86 \mathrm{~b}$. That piece is there labeled "Middle of 15 th century," but it seems to be in the early style. 
Similar scrolls are seen on the shoulders of the bottle-shaped vase 29.448 (pl. 53) and the ewer 29.430 (pl. 54) which in all other respects conform to the early fifteenth-century standard and call for no further comment. This ewer, as well as those with the heavy bodies and cylindrical necks (pls. 54 and 55), illustrates further the wealth of variety achieved by the decorators of the period in combining the standard motifs.

The large bottle with white dragon on a ground of blue waves $(29.471, \mathrm{pl} .53)$ is a beautiful example of this small but well-known family; and that with blue dragon on a white ground $(29.470)^{220}$ is unusual in having a background of scrolling lotus plants, whereas most of the dragons in this period are associated with either clouds or waves, the watery elements which form their natural habitat. Only in the Cheng-te period does the combination of dragons and lotus seem to become more customary. Another large bottle from which the neck has been broken (29.483, pl. 55) illustrates this type in its flattened form and is decorated with peony, chrysanthemum, and lotus. ${ }^{211}$

A well-known type is represented by the small flask with loop handles (29.458, pl. 55) of the type known as pien-hu. Several of these in various collections carry the mark of the Hsüan-te reign; and as no special characteristics appear to distinguish one from another no doubt this and other unmarked examples may be assigned to the same period.

Finally, mention must be made of two pieces in the Ardebil Collection which seem to have no parallels in the whole field of Chinese porcelain as it is known today. No. 29.485 (pl. 55) is an object which can only be described as a funnel. Although the shape is unfamiliar and the details of the decoration are unusual, the drawing and the blue point to an early fifteenth-century date, and indeed the formalized lotus petals which comprise the main decoration are reminiscent of those on the lien-tzŭ bowls (pls. 46 and 47) in spite of the two white dots and the chevronlike break near the top of each. The small perforations inside through which any liquid must pass in flowing from the bowl down into the tube have a strongly Near Eastern flavor; and the device was widely used as a strainer or screen in Islamic vessels of both pottery and metal. As it has not been observed in Chinese vessels, one is tempted to think that this may be an example of that much discussed and never identified rarity, a Chinese porcelain made to order for the Near Eastern trade. Equally out of the ordinary, and perhaps in the same category, is the other object, 29.455 (pl. 55), which is simply a sphere of solid porcelain with a circular hole penetrating one side (or the top? or bottom?). Among the guesses that have been made as to its use are hatstand,

${ }^{210}$ A similar bottle in the Princessehof Museum in Leeuwarden is said to have come from the Sangir Islands. Cf. Ottema, Chineesche ceramiek, p. 106, fig. 121.

${ }^{211}$ No. 29.469 is a complete bottle of this type but was inadvertently not included among the photographs; see TOCS, 25 (1949-1950), pl. 2c. 
counterweight for a mosque lamp, or part of a water pipe, but none of these can really be demonstrated, and for the time being we are completely in the dark. The decoration, admirably adapted to the spherical shape, is also somewhat puzzling. As may be seen in the illustration, the technique of outline and wash has been used for the cloud scrolls, the flowers, and some of the leaves. Some of the smaller leaves, on the other hand, are drawn with simple brush strokes and no outline. These latter are especially noticeable in the chrysanthemum scroll where they are closely similar to the fourteenth-century style, as seen for example in the chrysanthemum panel on the lower part of 29.319 (pl. 23) and on some of the Kharakhoto fragments (pl. 133, 13). The 6-petaled flowers in the centers of the circles also recall the blackberry-lily blossoms in the crapemyrtle borders of some of the fourteenth-century dishes and bowls. Yet the piece as a whole does not suggest such an early date, and the cloud scrolls in the interstices between the circles and the painting of the large leaves at the sides seem to be more in keeping with the style of the early fifteenth century. So for the time being it is tentatively placed with this group. 


\section{THE BLUE-AND-WHITE: THE MID-FIFTEENTH CENTURY: "INTERREGNUM"}

The three decades between the death of the Emperor Hsüan-tsung, which terminated the Hsüan-te period in the first moon of 1435, and the accession in the first moon of 1464 of the Emperor Hsien-tsung who named his reign Ch'eng-hua in the following year, have always been troublesome to students of Chinese ceramic history. Hobson, followed by later writers, has dwelt on the troubled political events of those years; and they need not be recited again. Such scanty knowledge as we have of the ceramic scene comes to us through the brush of $\mathrm{Chu}$ Yen, and the wares marked with acceptable nien-hao of the three reigns can probably be counted on the fingers of one hand. For these reasons it has become customary among devotees to refer to this obscure period as the "Ceramic Interregnum," and one of the favorite pastimes is to speculate on the nature of "Interregnum" wares and to suggest possible candidates for this attribution among otherwise unidentified fifteenth-century porcelains.

Some have given serious credence to the secondhand statements of Chu Yen ${ }^{212}$; but the fact that does not seem to have been noticed is that, whether his statements are accurate or not, what he says is of little consequence. It is certainly a matter of interest to know that the directorship of the Imperial factories was abolished at a certain time or that the production of these factories was curtailed at another, but this tells us nothing about what was done in the absence of these directors or what kinds of wares were made when the output was limited. In a word, whether we believe Chu Yen or not, we still know nothing whatever about the subject that intrigues us most, the nature of "Interregnum" wares. Until contemporary texts come to light or until we see acceptably marked porcelains in sufficient numbers to serve as the basis for some standard of judgment, or preferably both, we are not likely to find out. In this period of happy ignorance, however, we remain free to theorize, to exercise our wits, and to indulge our fancies as we may see fit, remembering always that we are doing just that. It is in this spirit that the following remarks are ventured.

Reverting for a moment to the historical scene, it should be pointed out that political unrest has not normally been detrimental to the progress of the arts in China. The Sung Dynasty is the classic example. Harassed from the very beginning by aggressive neighbors to the north, they suffered repeated invasions on a gradually increasing scale until after a century and a half of precarious tenure they were driven out of North China altogether; and most of this time they were torn by internal dissension between two political factions, one advocating all-out war on the invaders, the other

${ }^{212}$ Cf. Bushell, T'ao Shuo, p. 61. 
urging the payment of tribute and peace at any price. Nor did the southward flight of the court and the physical comforts of their beautiful new capital at Hangchou bring them security. The Chin Tatars continued to threaten, and the rulers of Southern Sung paid dearly for their uneasy peace by calling them "uncle" and sending costly annual gifts until, in the opening years of the thirteenth century, the relentless Mongol cast his shadow over the northwest in the first steps of a movement that was to engulf Tatar and Chinese alike in the conquest of continental eastern Asia. But all this time the painters went on painting and the potters went on potting to make Sung one of the high points in Chinese artistic history. The mere capture of an emperor and a few decades of political chaos are hardly enough to explain the present hiatus in our knowledge of the history of Ming porcelain during the middle third of the fifteenth century.

Facing the curious absence from our collections of marked porcelains of these reigns, we must assume that, because of the political situation or for other reasons unknown to us, the three nien-hao in question, Cheng-t'ung, Ching-t'ai, and T'ienshun, were very sparingly used. It is unlikely that any considerable body of wares should simply have disappeared; and it is equally improbable in view of the impetus gained by the ceramic industry in the first 35 years of the century that all pottery making should have come to a stop. Is it not logical to suppose that such wares as continued to be made, whether under circumstances of interrupted or reduced production, should have continued in the then well-established and familiar style of the Hsüan-te period? More than this, and in spite of the fact that our tradition-bound Chinese colleagues refuse to admit it, is it not likely that the potters even continued, from force of habit and lacking instructions to the contrary, to write the Hsüan-te nien-hao on some of their wares? Both of these possibilities might tend to explain in part the survival today of so many "Hsüan-te wares," marked and unmarked. There is no reason to expect or even to look for a sudden change in style in the succeeding decade or so.

Gradually, of course, a change did occur, and today we can distinguish certain differences in both style and execution between those wares we recognize as products of the first third of the century and those made in the last third; and the stages of that change must be sought in the "Interregnum." The smoother, glassier glaze, the more delicately potted bowls with deeper, thinner feet and more finely finished rims, the perfection of the outline and wash technique in the application of the blue designs, the finer preparation of the cobalt that resulted in the elimination of black and brownish spots from the blue, all these qualities which seem suddenly to emerge in Ch'enghua must have been in the course of development in the intervening years. Indeed it may be in vain that we hope to find an "Interregnum style" as such. Like the middle years of the seventeenth century, these were years of transition, though the change in style is neither so clearly evident nor so fully documented; and as in the later period 
we see the spirit of Wan-li giving way to that of $\mathrm{K}^{\prime}$ ang-hsi, we may expect to find the wares of the "Interregnum" answering to the description "Hsüan-te extended cum Ch'eng-hua anticipated." From what we have seen of Chinese texts we can expect very little help in finding out what the wares looked like even if we should turn up more sources on the ceramic activity of the three reigns. Further marked pieces may come into our hands, but in view of the wide distribution of kilns and our ignorance of the source of any given piece, ${ }^{213}$ a handful of assorted wares can never be a corpus on which to base an opinion. The "Ceramic Interregnum" will continue to provide a test of connoisseurship, for it is not likely to give up its secrets soon. Whether this state of affairs involves a major loss to the history of the ceramic art is another matter.

Although they are always ready to discuss the possibility that this or that piece may be a product of the "Interregnum," none of the recent writers on the subject has ventured to publish a photograph of any of his favorite nominees. ${ }^{214}$ Perhaps this cautious attitude is entirely justified, but it makes the situation increasingly difficult because with all the interest it arouses it still provides no point of departure for further studies; and as several pieces in the Ardebil Collection seem to show the appropriate characteristics they will be mentioned here, with all due diffidence, as possible "Interregnum" wares. The two most likely candidates are a kuan (29.496) and a mei-p'ing (29.415) illustrated on plate 56. Each is not only the only one of its kind in the collection, but the only one thus far noticed in Ming blue-and-white, and both are of the finest quality decorated with beautifully painted designs executed in a most unusual manner. Essentially it is the outline and wash technique, but in this instance the petals and leaves of the great peonies which dominate the decorative scheme are closely covered with fine wirelike lines drawn over or under the pale wash. The style seems to have been anticipated on some of the blue-and-white of the fourteenth century ${ }^{215}$ only to vanish again from the repertory of the early fifteenth. It reappears, however, on the large stoneware vase in the Topkapu Sarayı which bears an Annamese date corresponding to 1450 and on some of the related pieces like 29.143 (pl. 57) ${ }^{216}$; and whether this distinctive style was preserved in the south through the intervening years we have no way of knowing at this time,

The whole question of Annamese wares requires further study. For 20 years after its publication the dated Sarayı vase was the only clue to suggest that blue-and-

${ }^{213}$ While it is assumed, and perhaps rightly, that the finest wares came from Ching-te Chen, there must have been a wide variety of styles and qualities made in the many factories of that town; and we still have no means of identifying those less fine porcelains or of distinguishing them from similar wares made elsewhere.

${ }^{214}$ E.g., Garner, Oriental blue and white, pp. 24-25, and Jenyns, Ming pottery and porcelain, pp. 77-79.

${ }^{215}$ Cf., e.g., 29.510 and 29.522 on plates 26 and 27.

${ }^{216}$ Cf. TOCS, 11 (1933-1934): plate 4; also ACASA, 5 (1951): 32, plate 6c, d. 


\section{CHINESE PORCELAINS FROM THE ARDEBIL SHRINE}

white may have been made in that area, and at least one attempt has been made to discredit that document altogether. ${ }^{217}$ Of late, however, enough material has come to light to make this a distinct and recognizable ceramic family; no actual excavations have yet been reported, ${ }^{218}$ but several collections made in southeast Asia have included wares of the same type and these are generally considered to have originated in Annam. ${ }^{219}$ Many periods and many types are represented among these wares, and much work remains to be done in establishing the chronology. For the moment the Saray1 vase remains the only datable document; such classification as has been undertaken has consisted in finding those pieces which seem to be comparable in material, quality, and style and which may therefore be considered a mid-fifteenth-century group. Further progress will involve working backward and forward from that point relying to a large extent on analogy with the better-known Chinese types, a process which entails many risks because nothing is known of the relations between the potters of Kiangsi and those who made these Annamese wares in similar style. For the time being, however, there is nothing else to do, and this method will at least provide a means of starting if it be recognized that the result is always subject to later revision based on new evidence.

This digression on the problem of the Annamese wares not only serves to account for the assignment of this one Ardebil example to the "Interregnum," but also to contribute to a certain extent to the like attribution of the kuan and the mei-p'ing (29.496 and 29.415). They are wares of outstanding quality in every respect; they display an unusual degree of emphasis on the outline and wash style of drawing; and in addition to these two characteristics they have a striking and otherwise unexplained similarity of style to the mid-fifteenth-century Annamese group. It is on these grounds that they are tentatively suggested as representing at least one type of "Interregnum" ware.

As has already been pointed out, it is hardly likely that ceramic activity came to a halt in this period, and even if production of certain kinds of wares was reduced to some extent, a good many porcelains must still have been made. Some of these no doubt exist among the pieces now generally assigned to the period covered by the

${ }^{217}$ Reitlinger and Button, Early Ming blue and white.

${ }^{218}$ Dr. Olov Janse informs me that he heard of the existence of Ming kiln sites in the delta east of Hanoi but was unable to investigate them; and more recently there have been rumors of excavations yielding blue-and-white in that area by French archaeologists. (Cf. Okuda, S., Annamese ceramics, pp. 13-14.) Their publications are awaited with interest.

${ }^{219}$ The largest is that in the Musée du Cinquantenaire in Brussels, which I was able to visit briefly in 1954. Some 2,900 pieces illustrate the whole ceramic history of Annam; and there are two particularly interesting groups of blue-and-white, mostly in fifteenth-century style, recovered respectively from Phu-Tinh-Gia in Thanh-hoa and Lam Dien, Ha-dong in Tonkin, although these were cachettes rather than kiln sites. Cf. Aga-Oglu, Five examples of Annamese pottery; Orsoy de Flines, Gids voor de keramische Verzameling; and Okuda, op. cit. 
Yung-lo and Hsüan-te reigns, and there may be others among those now considered Ch'eng-hua. Everything considered, however, the earlier group seems to provide the more logical hunting ground. One rather distinctive family usually included in the early fifteenth-century class seems to invite further scrutiny to that end. It is represented in the Ardebil Collection by nine pieces; and with even less assurance than that which prompted the tentative attribution of the mei-p'ing and the kuan just described, they are, although already called early fifteenth century in the previous chapter, mentioned again as possibly deserving reconsideration. These are the conical bowl 29.332 (pl. 47), the four deep-sided bowls of which 29.338 and 29.340 are illustrated on plate 49, and the four mei-p'ing represented by 29.413 (pl. 51)..$^{220}$ It is most difficult to define the qualities in these pieces which give rise to the suspicion that they may be post-Hsüan-te; again they are of the highest quality in every respect, and the decoration is beautifully drawn and disposed on the various surfaces in a subdued outline and wash style in which the blue is more smooth and even than that usually associated with early fifteenth-century wares. The bases of the four deep-sided bowls are roughly covered with a bluish glaze which leaves certain areas thinly covered or quite bare to reveal a very fine paste of faintly yellowish tone. On the mei-p'ing the plantain or fern leaves around the base are executed with a regularity and finesse that anticipate the almost mechanical appearance they assume on certain pieces which have been assigned to $\mathrm{Ch}^{\text {'eng-hua. }}{ }^{221}$ Beyond these main things that strike the eye, all the pieces are finely potted, and the mei-ping are remarkably light in weight for their size. Admittedly this is very little to go on, and nothing more than the most tentative suggestion is ventured; but it is not beyond the realm of possibility that this family may one day turn out to be later than Hsüan-te or "Interregnum" wares.

${ }^{220}$ Other possible members of this family are PMA 78, 84, 85, 89.

${ }^{221}$ Cf. TOCS, 26 (1950-1951): 40, plate 10e, and Ming porcelains in the Freer Gallery of Art, p. 26; PMA 125, which was there called "16th century," is evidently closely related to the Freer mei-p'ing, and PMA 124 may also belong to the same group. 



\section{THE BLUE-AND-WHITE: THE LATE FIFTEENTH CENTURY}

That only a very few pieces in the Ardebil Collection may be assigned to the last third of the century is not surprising for the same situation exists in all known collections of Chinese ceramics. The reason for this is not understood, but the output of these three decades was evidently smaller than in any other equal period in the fifteenth and sixteenth centuries. Indeed a survey of the blue-and-white made in the Ch'eng-hua and Hung-chih reigns and marked with the nien-hao reveals that only some 30-odd pieces are known from the former while those from the latter number less than a dozen. Inasmuch as the attribution of unmarked pieces is materially assisted by the availability of a body of marked wares which serve as standards, the proper documentation of these two reigns presents certain problems. This is all the more regrettable because, to judge from those wares we know, it was a period of particular interest. The Chinese themselves ranked the wares of Ch'eng-hua second only to those of Hsüan-te, mostly it seems because tradition held that in the latter reign the potteries were deprived of the imported cobalt which had produced the rich dark blues they so greatly admired. From the vantage point of our own time with some four centuries of perspective to temper our view we may feel this is merely a question of taste for some connoisseurs today prefer the unparalleled delicacy of the Ch'eng-hua wares in spite of the sometimes paler shades of blue with which they are decorated, though it would be hard to say if the esteem in which they are now held is not in some degree enhanced by their rarity. Be that as it may, for sheer perfection in every detail, the best blue-and-white wares of Ch'eng-hua stand in a class by themselves. And even the small handful of fine examples in the Ardebil Collection, for all that they may be called "export wares," amply support this view.

Before turning to the pieces themselves a word about the general style of the period may be in order. The refinement which was noted as the principal characteristic of the early fifteenth century, in comparing those wares with their predecessors, was carried forward to its highest point in the two decades of the Ch'eng-hua reign, nor was there any serious falling off as the century drew to a close. Never was the hand of the Ming potter more controlled or that of the Ming painter more sure. At their best these are the most sensitively potted wares the dynasty produced, and in all the 276 years of Ming rule no porcelains were decorated with greater delicacy and finesse than these. If the earlier wares are admired for the superior strength of their potting and the vigor of their decoration, these later wares bespeak no less admiration for their supreme purity and elegance. It was a point in the history of the potter's art whence there was nowhere to go but down, and the decline in quality that marks the 
wares of the sixteenth century was inevitable. One is reminded of that other turning point in the history of Chinese art some 2,500 years earlier when bronze casting reached such a zenith of perfection near the end of the Shang Dynasty that there was nothing left but gradual deterioration.

Obviously not all the wares were fine, and the considerable range in quality between the best types and those of humbler origin is well illustrated in the Ardebil Collection. The bowls and dishes with counterparts among the marked pieces in other collections are thinly potted and the foot rims tend to be deeper and narrower with the inside almost vertical and the outside tapering down to a very thin and smoothly finished edge. The clay itself is rarely dead white but more likely to be of a cream or ivory tone just off white, a shade that is often most noticeable on the bases and especially near the foot rims. The decoration is executed with great delicacy in a blue that tends to be paler and less dense than that of the earlier period. Even on those occasions where it is thick and dark in tone, it is less heavy and fails to produce the effect of speckling or the occasional dark spots of oxidation which mark the blues of the first half of the century. It seems as if the cobalt were more finely ground and more evenly distributed through the solution, so that no lumps or particles remained to be picked up and left on the surface of the porcelain by the decorator's brush. And the style itself tends to support this view, for now instead of painting in big bold strokes with a heavily charged brush as did his predecessors, the decorator more often than not outlined his subject with fine lines and filled in the patterns with graded washes, a technique ill suited to a less-refined pigment. Not that outline and wash were unknown in the first half of the century or that bold drawing with heavy strokes was completely abandoned in the second, but each tends to be more characteristic of one period.

In addition to these fine wares, the Ardebil Collection includes certain pieces not so readily recognizable but which, upon close examination seem to be contemporary though not of the same quality (pls. 67-74). The potting is less fine, the glaze is often poorer, and the decoration is hasty and sometimes crowded and mechanically composed. Some have more claim than others to inclusion in this group, and in the descriptions of the individual pieces below the merits of each are discussed in detail.

Among the pieces of fine quality, illustrations are shown of two small dishes, one of which is decorated inside and out with lions at play with brocaded balls (29.277, pl. 58) and one with a landscape scene showing a prunus tree in bloom beside a fantastic rock and flanked by a fungus plant and a bamboo with a crescent moon above (29.149, pl. 59). The motif of the sporting lions is well known and apparently not limited to any particular period within the Ming Dynasty. Here, although freely and strongly painted, it is nonetheless carried out in the outline and wash technique. The dish itself meets all the standards of potting, glaze, and finish one has come to expect of the finest $\mathrm{Ch}^{\natural}$ eng-hua wares. No less perfect is the landscape 
dish, and the outline drawing filled with washes of delicate lavender blue is carried out with a freedom not often found in fifteenth-century work early or late. ${ }^{222}$ Outside the dish are four flowering branches, two of prunus, and two unidentified.

The bowls provide good examples of the range of quality in this group and at the same time illustrate the broad scope of the decorative repertory. Considering the limited quantity of late fifteenth-century wares at our disposal, it is impossible to attempt a definition of that repertory; but if this small selection is any indication of the true state of affairs, the variety must have been considerable. The bowls introduce a question of terminology that requires further consideration than it has so far received. Apparently originating with Brankston, the term "Palace Bowls" has gained wide currency to describe a number of bowls of the finest quality both in potting and decoration. All those so described are close to 6 inches in diameter, and all are marked with the Ch'eng-hua nien-hao in six characters. ${ }^{223}$ It is not clear where Brankston got the term, and he did not define the type he described by it; these observations on size and on the use of the 6-character mark derive simply from examination of the bowls to which the term has been applied. So far as has been noticed no such term appears to have been used in any Ming text so it seems likely that, as in the case of the socalled "Imperial" wares discussed in an earlier chapter, this is not an authentic designation contemporary with the porcelains it describes but simply a modern term coined by the Peking dealers of Brankston's time who considered these bowls fine enough to have been used in the Palace. As a descriptive term it serves a useful purpose, for every connoisseur immediately knows what is meant by "Palace Bowl"; but it would be a mistake to assume that it carries any precise implications relating to the use of porcelain in the Palace in Ming times.

It may be argued that the question is not pertinent because none of the Ardebil bowls is marked. On the other hand, even though this is the case and even though all these are larger than the typical "Palace Bowl," several of them are equally fine in quality; and 29.344 (pl. 64) has a lotus scroll design closely resembling that on Mr. Norton's bowl, which was no. 108 in the OCS exhibition of 1953-1954. Equally fine is 29.341 (pl. 60), which is decorated with scholars and attendants in a landscape that includes pines, a banana growing behind a rock, and a palace in the clouds. Inside is a circular medallion framing a formal composition of the three friends around a highly stylized garden rock. Two similar bowls are known, one in the Freer Gallery of Art (52.4) and one in the Percival David Foundation of Chinese Art (B631). The latter two are identical in size and design, though the blue on the David bowl is stronger and darker than that on the Freer. Both are thirteen-sixteenths of an inch

${ }^{222}$ A tall bottle-shaped vase in the Topkapu Sarayı is similarly decorated. Cf. TOCS, 26 (1950-1951): 37-40, plate 9.

${ }^{223}$ Cf. Brankston, Early Ming wares, p. 46, plate 26; and nos. $98-108$ in the OCS Catalogue of 1953-1954. 
larger than the Ardebil bowl, and as may be seen by comparing the photographs, ${ }^{224}$ the figures on the latter are slightly stouter, wear a different type of headgear, and are more crowded together in the composition. So slight are these differences and so minor the variations in detail that any choice between them would be a matter only of personal taste; in quality there is nothing to distinguish one from another. This scene has its roots in the past, and though no identical compositions come to mind, the motif of figures in a landscape with the corner of a palace seen behind clouds is known on more than one Hsüan-te bowl. ${ }^{225}$ But in physical quality as well as by analogy with the so-called "Palace Bowls" these three pieces are evidently Ch'eng-hua.

In the same class is another bowl with what has generally come to be considered a typical Ch'eng-hua pattern. No. 29.343 (pl. 62) has four dragons on the outside above a trefoil band; inside is the design of crossed vajras, which suggests Buddhist associations. It is the curious style of the dragons, however, that calls for special comment. Only the two front legs are drawn, and the rest of the body trails off in a succession of ornate scrolls. At the shoulders are small wings; the proboscidiform snout extends upward, and from the tip of the protruding tongue springs the stem of a lotus with leaves and a blossom. This beast is found on a small number of porcelains all but one of which are unmarked and drawn, like this one, in the outline and wash technique typical of the latter half of the fifteenth century. ${ }^{226}$ None of the others

${ }^{224}$ Pope, Ming porcelains in the Freer Gallery of Art, p. 27. The David bowl has not been published.

${ }^{225} \mathrm{Op}$. cit., p. 20 . The Hsüan-te versions usually show ladies on a terrace bounded by a balustrade; but the spirit is much the same, and no doubt all represent Taoist paradises in which ladies and gentlemen alike are engaged in the comfortable pursuits associated with immortality. Another variant, known only on one large unmarked bowl probably of the Ch'eng-hua period, shows, among other scenes, a group of gentlemen admiring a painting (OCS Catalogue, 1953, no. 114, pl. 10).

${ }^{226} \mathrm{Cf}$. Jenyns, op. cit., plates 64A, 68B. The one marked example is a covered vase of kuan shape in the Fitzwilliam Museum in Cambridge which carries the 6-character nien-hao of the Hsüan-te period (cf. Sotheby and Co. auction catalogue of 26 May 1937, no. 37). There the dragons are drawn without outline in the heavy dark-blue strokes characteristic of the time. While we know too little to state dogmatically that any given design was not used before or after a certain date, we may fairly say that we know the period of its widest popularity; and it is entirely possible that this curious dragon may have been used before Ch'eng-hua. The Fitzwilliam vase may be an example of this, but on the other hand it is not on all grounds entirely free from suspicion. The cover is almost certainly late; and when compared with the dragons on this bowl, those on the vase are far inferior. Stiffly drawn in profile with paws for claws and no understanding of the relationship between the two legs, they have disproportionately large lotus blossoms emerging from their throats behind the tongues. The scrolling bodies are greatly over-extended and somewhat awkwardly drawn. Furthermore, close examination of the base reveals a very curious thing. It is not covered by a single smooth layer of glaze, but in the center is a roughly circular area slightly larger than the double ring enclosing the mark where the glaze is noticeably thicker, more greenish blue and more uneven than it is elsewhere. Is it possible that the piece was made at some undetermined later date, 
adorns a piece of such high quality as this bowl; the potting, the glaze, and the foot rim are all extremely fine, and these together with the beautifully executed painting mark this as the best piece to have come to light bearing this typical late fifteenthcentury design. The significance of the Buddhist symbol inside the bowl is not clear as nothing is yet known of the use of porcelains in the service of that religion. ${ }^{227}$ The whole problem is further complicated by another bowl (29.348, pl. 66) decorated outside with five symbols and inside with two rows of Tibetan script surrounding a central medallion consisting of a flaming wheel. Mrs. Antoinette K. Gordon, of the American Museum of Natural History, who has been kind enough to examine the photograph, reports that the upper row of script consists of the syllables va-la-gla-maja-na repeated over and over, and that Vala is an epithet of Indra. Indra was one of the deities of Hinduism, lord of the atmosphere and the sky, the bringer of rain; one of his symbols is the vajra and another is the flaming wheel. In later times he figured extensively in Buddhist lore as well. The inner line of script is unfortunately not decipherable in the photograph but seems to be the same. What these Hindu symbols are doing on this late fifteenth-century Chinese bowl is a question requiring further study, but though the piece is somewhat thicker and heavier than usual, there can be little doubt that it dates from Ch'eng-hua or Hung-chih times.

Most unusual and most striking of all is 29.345 (pl. 63) decorated both inside and out with birds perched on flowering crabapples. It is a piece of the finest quality in every respect except for the mark which consists of two interlocking lozenges carelessly drawn in underglaze blue on the base. The decoration reminds us at once of that on the great dishes in Istanbul which show two bulbuls on a branch of flowering crabapple and which suggest a date somewhere toward the end of the first half of the fifteenth century. ${ }^{228}$ The present bowl, however, is clearly Ch'eng-hua in potting and glaze and in the very fine handling of the deep foot which tapers down to a narrow rim. The drawing also is in keeping with the period, and this is particularly evident in the

decorated with these dragons of late fifteenth-century type, though not in the proper style, and left unmarked? Then, still later, may the glaze not have been ground off a circular area in the center of the base, the Hsüan-te mark written on and covered with new glaze, and the whole piece refired? Actual experiment might determine whether such a procedure was possible, and the above theory is offered simply as a tentative explanation of a most puzzling piece. The most elaborately conceived dragons of this type to have been noticed so far are those on a large dish in the Princessehof Museum in Leeuwarden, which may be dated somewhere near the year 1500. (ACASA, 5 (1951): 32-36, pl. 7, e and f.) They are drawn in outline and filled in with wash.

${ }^{227}$ Brankston felt that "most of the Hsüan-te wares were intended for ritual use" and referred to stem cups "placed on altars and filled with clear water" and to globular cups "also filled with water and carried probably during prayers." In Ch"eng-hua times he tells us that "ritual vessels are in the minority." (Op. cit., pp. 25, 36.) Unfortunately, he gives no authority for any of these interesting statements.

${ }^{228}$ Cf. TOCS, 26 (1950-1951): plate 11. 


\section{CHINESE PORCELAINS FROM THE ARDEBIL SHRINE}

trunks of the trees which are rendered in fine outline with delicate washes as compared with the bolder more sketchy drawing of the branch on the Istanbul dishes. The meaning of the mark is not clear, but the same device written in pale blue in the same careless style, though it lacks the misdirected extra stroke, appears on the base of a bowl fragment acquired by the writer in Peking (pl. 137, D). Enough of the fragment remains to show a starlike flower in a circle inside and part of a row of Sanskrit characters above an overlapping petal band on the outside. As has been shown elsewhere the latter design has demonstrable associations with the Ch'eng-hua period, ${ }^{229}$ and nothing about the fragment contradicts that view. This in turn tends to support a Ch'eng-hua attribution for this bowl decorated with birds.

Aquatic scenes are not so well known on wares of this period, but several included in the present group may be assigned, if not to the Ch'eng-hua reign, at least to some time in the last third of the century. ${ }^{230}$ No. 29.378 (pl. 64) is in the shape of the so-called "Palace bowls" though, like the others just described, it is over 2 inches larger than the size which seems to have been accepted as standard. The potting and the treatment of the foot conform, and the decoration shows fish swimming among knotweed and lotus plants. In the case of 29.375 (pl. 65) the same quality is evident, but the shape is slightly different in that the rim is not everted. Here the scene is of ducks swimming among lotus plants while the inside decoration of a fungus scroll at the rim and a peach spray in the center contrasts curiously with the aquatic spirit of the outer surface. An altogether new design appears on 29.349 (pl. 65) which is plain inside and covered outside with a solid sea of incised waves against which four fishes are painted in underglaze blue.

A large bowl decorated with camellia scrolls (29.342, pl. 61) raises problems to which the answers are not readily available. Although the foot is heavier and has a broader rim than those on the bowls just described, the fine potting of the whole piece and the manner in which the design is composed and executed make an attribu-

${ }^{229}$ Cf. TOCS, 26 (1950-1951), pp. 38-40.

${ }^{230}$ A small jar decorated with aquatic plants is reproduced in color on the cover of the Japanese periodical Chawan, vol. 20, no. 5 (August 1950). It is described as having a Ch'eng-hua mark on the base, and judged from the illustration the quality is excellent. Kushi, op. cit., plate 45, published a basin decorated in the same style with ducks in a freely drawn aquatic landscape. Although he calls it Hsüan-te (p. 50; cf. also Bijutsu Kenkyu, no. 143, vol. 6 (1947), pl. 6), the piece is not marked with a nien-hao. Mr. J. Mayuyama has kindly sent me a photograph showing the base of the vessel which is marked with a double circle in underglaze blue and no characters. Although this mark is often seen on $\mathrm{K}^{\prime}$ ang-hsi wares, it must be very rare in Ming times. The shape, too, is uncommon in Ming porcelain where most pieces of the general type are either shallower dishes or deeper bowls so far as is now known. No. 29.353 (pl. 70) in the Ardebil Collection is the only documented exception to have been noticed. In spite of the shape and the curious mark, however, this basin published by Kushi shows every sign of belonging to the late fifteenth century insofar as it is possible to judge from the design as seen in a photograph. 
tion to this period seem quite justified. Particular interest attaches to it not because of any of its basic qualities but because of the curious spot of black enamel on the base. Its presence there is unexplained and, so far as is known, without precedent. The size and position of the enamel suggest at once that it was placed there to cover up a mark. Hoping to find at least a trace of an underglaze blue line, and with the permission of Dr. Bahrami, the writer attempted to remove a bit of the enamel with the blade of a pocket knife. Not only was the effort unsuccessful, but it failed to leave so much as a scratch on the hard black surface. So the question remains unanswered, and we are left to speculate. If the patch does not cover a mark, it is hard to imagine why it was put there at all. If it does cover a mark, why was this done? Perhaps to hide a faulty writing, or perhaps to obliterate an imperial nien-hao before the piece was sent abroad? These and other answers may be acceptable. Even more intriguing, however, is the problem of where it was covered and when. The question of location is not too difficult; the potters of Persia do not seem to have used a heavy black enamel of this kind; it could hardly have been done en route, and it must therefore have been done in China, a conclusion already adumbrated by the range of possible answers to the first question. Finally, when? The presence of the engraved mark of Shāh 'Abbās reminds us that it must have been done before 1611 when the bowl was placed in the Shrine, or, in Chinese terms, before the thirty-ninth year of the Wan-li reign. Colored enamels had been in use as far back as the fifteenth century, and by the time of Chia-ching and Wan-li they were commonplace; but they were mostly green and yellow, less often aubergine and turquoise, but never black. The development of a thick black enamel was, we have come to believe, one of the technical achievements of the K'ang-hsi potters, and their results were so striking that they came to dominate a whole group of porcelains, the so-called famille noire. Even this is not a real black enamel; it is a thick transparent green laid over a black wash that gives the desired effect. A real black enamel of such thickness as to be sensible to the touch does not appear to have been used by Chinese potters at all, although ample use was made of thick black high-fired felspathic glaze by the potters of Fukien and of Honan in Sung times. Where the black spot on this bowl fits into the scheme of things is a question that cannot now be answered.

Two bowls of shallower proportions bring us to a group of wares somewhat less fine in quality but which seem to have some claims to inclusion in this period. The shape is not like anything noted so far, the potting is somewhat heavy, and the glaze is imperfect in places. No. 29.347 (pl. 67) has fish and water plants outside, and inside is a fish leaping above waves toward the sun with flame scrolls on either side. The drawing in outline and delicate blue washes is excellent. On 29.399 (pl. 68) the outside is decorated with children playing in a garden, while the inside again displays an aquatic motif. The design here, though somewhat less skillfully drawn, is executed in the same way. At first sight the writer was inclined to assign these two bowls to the 


\section{CHINESE PORCELAINS FROM THE ARDEBIL SHRINE}

sixteenth century, and that possibility is still not altogether excluded; but further study and the examination of additional material suggest that they may well be earlier. They do not seem at home with any of the well-known Cheng-te or Chia-ching wares, and if they are sixteenth century they must be very early, and so they are here tentatively assigned to a period close to the year 1500 or the Hung-chih period.

The same holds true for an unusual bottle-shaped vase decorated with floral scrolls painted in fine outline and filled in with wash, 29.451 (pl. 74). The floral scrolls are topped by a band of clumsily drawn and badly misunderstood classic scroll, and the neck is ornamented with a network of beaded strings. The deterioration of the classic scroll toward the end of the fifteenth century is a recognized phenomenon in porcelain decoration that can be seen on any Hung-chih dish that carries the motif, and the pattern was even more badly distorted in the sixteenth. The beaded string pattern, on the other hand, seems to have come into being in the Ch'eng-hua reign or thereabout ${ }^{281}$ and is not infrequently found on some of the coarser wares which are tentatively assigned to the period. It is known to have continued in use, though always sparingly, until at least the middle of the sixteenth century, when it is found on some of those wares with Portugese inscriptions which seem to bear Western dates in the 1550 's. ${ }^{232}$ Below the lip is a row of pointed leaves. In view of these factors in the decoration, it seems quite possible that the vase may well have been made in the closing years of the fifteenth century or at least in the Hung-chih reign. Even more interesting than the decoration is the fact that, if this dating proves to be right, this is the earliest blue-and-white piece in the Ardebil Collection to bear a date mark of any kind for in a double circle on the base are the four characters Ta-ming-nien-tsao. This, of course, is not a proper nien-hao, as it fails to provide the name of a reign but merely designates the dynasty which in the case of the Ardebil Collection is superfluous. This mark written with tsao is well known on coarse pieces most of which have been assigned to the sixteenth century. Jenyns, however, states that $t$ sao was used "on Imperial pieces of the Hsüan Te period." ${ }^{233}$ Be this as it may, the mark on this vase (and on the broken base of a similar one in the same collection, so there was once a pair of them) does nothing to alter the fact that it may be a Hung-chih piece.

Related to this vase and also serving as a transition between it and the coarser wares to follow is 29.442 (pl. 69), a ewer with squat body and tall thick neck. Although by no means fine it is well made and the glaze is good. The closely crowded decoration is typical of a style that seems to have come into being in the second half of the fifteenth century and which is in fact related to the style of the Ch'eng-hua

${ }^{231}$ Cf. TOCS, 26 (1950-1951), p. 37, plate 9.

${ }^{232}$ See p. 57 and plate $6, \mathrm{~L}$.

${ }^{233}$ Ming pottery and porcelain, p. 68 . In a letter of 14 April 1954 he writes that his source for this statement is a letter from Wu Lai-hsi to Edgar E. Bluett which the latter had shown him. He does not claim to have seen such a piece so marked, nor have I. 
pieces we have just examined, differing principally in that it is more coarsely done. As may be seen on the body of this ewer, the flowers and some of the leaves are drawn in outline and filled in with wash, other leaves are done in line only; but all the lines are thicker and heavier than those on the fine Ch'eng-hua pieces. In addition to this, the surface is more densely covered and the leaves are smaller. One or more of these traits may be observed on a whole group of porcelains including those remaining to be discussed in this section. A number of these wares have been assigned indiscriminately to the sixteenth century, but this may be to a large extent because they are rather coarse and sometimes even unattractive and for this reason have not been so carefully studied. Such documentation as we have tends to suggest that the style began to develop in the latter half of the fifteenth century, reached its period of most general use in Hung-chih, and continued on into Cheng-te and, as new evidence now shows, even survived in the early years of Chia-ching. The key piece in this style is the large vase in the David Foundation dated in the ninth year of Hung-chih (A.D. 1496) ${ }^{234}$ One or two other characteristics shared by the members of this group may be mentioned. The glaze is usually glossy; and in addition to the overcrowding of the rather shriveledlooking leaves the cloud collar design is commonly used, though now in a somewhat less graceful shape than the one it enjoyed in the fourteenth century, as a frame for a very dense design of scrolls, flowers, and sometimes birds. This may be seen on the neck of the David vase and again on the shoulder of the ewer under discussion. Birds among cloud scrolls in similar frames are found on the shoulder of a hitherto unpublished vase of kuan shape in the Victoria and Albert Museum (pl. 136, C); and on another piece in the same museum published by Jenyns, the cloud collar points frame a very coarsely drawn pattern of abstract scrolls. ${ }^{235}$ In each of these cases as on our ewer and on the bulbous top of the famous bottle in Istanbul, ${ }^{236}$ the spaces between the cloud collar points are filled with strands of beaded strings or jeweled pendants of one sort or another. Before leaving the ewer, attention should also be called to the band of stiff leaves below the lip, an old design that takes on a new character with the outline and wash technique. It is closely related to that on another ewer which was no. 26 in the Philadelphia exhibition where it was dated "Late 14th-Early 15th century" but which upon closer examination seems to belong in the late fifteenth-century group. A more carefully drawn and slightly modified version of the same leaf pattern is used in a pendent position on a mei-p'ing in the Freer Gallery of Art and a kuan in the Philadelphia exhibition both of which probably date from the Ch'eng-hua period. ${ }^{237}$ Probably in the same group is 29.437 ( $\mathrm{pl} .70$ ), another ewer with similar design on a slightly different body shape. Instead of the bulbous body contracted above the foot,

${ }^{234}$ Hobson, Catalogue, 1934, plate 131.

${ }^{235}$ Ming pottery and porcelain, plate 69B.

${ }^{236}$ TOCS, 26 (1950-1951): plate 9.

${ }^{237}$ Pope, Ming porcelains in the Freer Gallery of Art, p. 26, no. 53.3. 
this one tapers evenly from shoulder to base; and the form is like that of two others in Istanbul. ${ }^{238}$

Even coarser though embodying all these characteristics are four flasks, of which 29.459 is illustrated on plate 69 . The shape is a modification of that found in the double-gourd flasks of the early part of the century (pl. 55). Not only are the proportions somewhat different, but the form of the upper bulb has been changed to provide a sharp angle at the base where it is joined by the handles. The body itself has a deep cuplike depression in the center of each flat surface, and at the same level two hemispherical lugs protrude from the sides. The hollow base has the shape of a lobed oval which is glazed only in the small recessed central area. Although the indications are very slight,the body was evidently made by a vertical joining of two molded sections. The decoration speaks for itself. Below a border of thunder pattern near the top is a row of overlapping petal band found on a number of pieces of approximately $\mathrm{Ch}^{\text {'eng- }}$ hua date. ${ }^{239}$ On the lower neck are the pointed leaves, and the outer rim of the body shows phoenixes among lotus scrolls of the type familiar on the coarse wares of the period. Five cloud collar points each closely packed with scroll patterns and what in this case looks like fungus surround the central depression which is ornamented with a conch shell with the animal's head emerging at the base against a ground of concentric waves. On the other flasks of this group $(29.460,461$, and 462$)$ there are variations in the decoration; floral scrolls without the phoenixes surround the outside, and dragons with foliate tails replace the cloud collar design. The reappearance of this latter motif on this coarse flask tends to support the belief that it may be Ch'eng-hua. A vase of similar quality and bearing these same curious beasts has been published by Jenyns who agrees with a probable attribution to that reign. ${ }^{240}$ Two unpublished flasks of this same ware and with related designs are known: one in a private collection in London, and the other no. 1335-1876 in the Victoria and Albert Museum (pl. $136, \mathrm{D})$. All are coarse wares and may be provincial in origin, for it can only be assumed that they were not made in the same center that produced the extraordinarily fine wares of the period; but the quality of the glaze, the elements of the decoration, and the style in which they are executed all combine to link them rather closely to the wares of Ch'eng-hua so they may well be assigned to the last quarter of the fifteenth century.

Another member of this same family introduces a whole new set of factors by virtue of its curious shape. No. 29.472 (pl. 69) has a squat body, a short stem with flaring top which is partly covered leaving only a small hole in the center, and on one

${ }^{238}$ TOCS, 26 (1950-1951): 49 and plate 15, b and c. Those ewers are there dated early sixteenth century, but are not for that reason excluded from this group.

${ }^{239}$ TOCS, 26 (1950-1951): 37-40. Published pieces bearing this pattern are illustrated on plates $9,10 \mathrm{~d}$, and $10 \mathrm{e}$ of that article and also in Hobson et al., Chinese ceramics in private collections, fig. 38, and PMA 125.

${ }^{240}$ Ming pottery and porcelain, plate 68B. 
side an extended mammiform spout. In the Near East where most of these are found they are called "pipes"; and Jenyns has called his example a "Narghili Bottle," ${ }^{241}$ both terms suggesting that they were used for smoking tobacco in the Near Eastern fashion of cooling the smoke by causing it to pass through water. The present vessel, however, can hardly be later than 1500 , and Jenyns calls his Ch'eng-hua, which it may well be; but in view of the fact that tobacco was not known in Asia until sometime in the latter part of the sixteenth century, some other explanation must be sought. Happily there is plenty of evidence for the antiquity of the form which is in reality a specialized drinking vessel. Over 30 years ago, I. H. N. Evans published a short study of the type on the basis of examples found in Southeast Asia ${ }^{242}$ and pointed out that while it was already ancient in Java and Malaya, it probably had an even earlier origin in India. His illustrations include an earthenware piece with fluted body, a dragon in relief around the shoulder and covered with a green lead glaze, which could possibly be T'ang. Through the courtesy of Dr. Leonard Cox of Melbourne a similar piece is illustrated here on plate 137. Evans goes on to say that though made in China such pieces were apparently made only for export to peoples who used them. In a later paper, Mr. Han Wai-toon treats the same subject, ${ }^{243}$ and, relating the story of the Chinese pilgrim $\mathrm{Fa}$ Hsien who threw his drinking vessel overboard during a storm en route from Singhala to Javadvipa, ${ }^{244}$ refers to it as a kerndi, which is the Malay term, and derives it from the Indian kundika . It is clear from Fa-hsien, he says, that the kundi (kĕndi) was imported from ancient India to the Archipelago; and he tells us that the form was imitated by the Chinese only beginning in Ming times. Whether the green one mentioned above was made in China or made locally in the T'ang style is hard to say. The use of the term kĕndi $>$ kundi $>$ kundikä raises further problems, for Coomaraswamy and Kershaw have described as kundika a drinking vessel of quite another type. ${ }^{245}$ The latter was filled through a funnel-shaped spout on the side and the contents poured into the mouth from the narrow spout on top whereas the present vessel is obviously designed to be used in the opposite way. Coomaraswamy does not seem to have been aware of this latter type at all, and the question of terminology remains unsolved for the moment. ${ }^{245 a}$

${ }^{241}$ Ming pottery and porcelain, plate 68A. See also a piece with Hsüan-te mark which is described in the same terms in Hobson and Hetherington, The art of the Chinese potter, plate 109, and is probably sixteenth century.

${ }^{242}$ On the persistence of an old type of water-vessel, JMBRAS, I, no. 87 (April 1923): 248250.

${ }^{243} A$ research on Kendi, JSSS, 7, pt. 1 (no. 13), 1951.

${ }^{244} \mathrm{Cf}$. Beal, S., Buddhist records of the western world, vol. 1, p. 1xxx.

${ }^{245}$ A Chinese Buddhist water vessel and its Indian prototype, AA, 3, no. 2-3 (1928-1929):

$122-141$.

${ }^{245 a}$ Gorgelet is another name for the type. See T. Volker, Porcelain and the Dutch East India Company, p. 19, note 5. Unfortunately this valuable book was not available to me until the present volume was in proof. 


\section{CHINESE PORCELAINS FROM THE ARDEBIL SHRINE}

Be that as it may, the form itself seems to be known more widely outside of China than in. E. W. van Orsoy de Flines illustrates several of various dates in the Jakarta Museum ${ }^{246}$ and an example in Sawankalok ware illustrated by Okuda Seiichi ${ }^{247}$ must be no later than the fifteenth century. There are four late sixteenth-century pieces in the Ardebil Collection (pl. 97) and two in the Topkapu Saray1 in Istanbul. Whether or not they were subsequently converted to the use of tobacco by their Near Eastern owners, it seems certain that their original purpose was for drinking water. Returning to this early example in the Ardebil Collection, it is clear that the decoration is very close to that on the pieces just described. The leaves at the neck, the cloud collar points on the shoulder, and the tight-leaved lotus scroll on the body are all hastily and somewhat crudely done under a very glossy glaze, the coarse style of the late fifteenth century.

Our discussion of these wares has included inevitably a certain number of doubtful pieces, pieces which as our knowledge increases may turn out to be products of the sixteenth century, for here as always the accident of a particular number in the sequence of the Christian calendar did not coincide with an abrupt change of style. In all the pieces thus far shown, however, there seems to be enough affinity with the recognized Ch'eng-hua and Hung-chih wares to suggest that there is good reason to place them here for the time being. The same is true of one of the last six pieces to be described in this chapter; the others are more doubtful. No. 29.137 (pl. 71) is decorated in the cavetto with phoenixes among lotus scrolls executed in the same manner as the similar motif on the flask $(29.459$, pl. 69), while the center of the dish is occupied by one of the most remarkable scenes ever noticed on a Ming porcelain. In a landscape setting under an arching pine branch two spotted deer are gamboling in midair; each has a ring around its neck with two dangling links. That on the left has a single grotesque horn and carries a flower spray in its mouth, while that on the right, with two pronged horns, has a fungus in its mouth. Above it are two butterflies. The whole scene is drawn with the utmost skill and pervaded with a sense of humor, lightheartedness, and charm worthy of such an artist as Walt Disney. Symbolic connotations are implicit in many of the decorative schemes on porcelain, but they are unusually concentrated in this case. The deer, $l u$ 鹿, is a rebus for $l u$ 称 meaning prosperity; the pine and the fungus are symbols of longevity, and the butterfly, tieh 蝶, is a rebus for tieh 素 meaning 70 years of age; and so the whole composition expresses the wish for wealth and long years.

Apparently assignable to the same group is a vessel of a shape not hitherto noticed

${ }^{246}$ Gids voor de keramische Verzameling, plates $44,45,57,80,93$. The one on plate 44 is late fifteenth century, and that on plate 93 is Annamese, probably mid-fifteenth century. Another late fifteenth-century kĕndi is in the Topkapu Sarayı.

${ }^{247}$ Sōkoroku zukan, p. 27, plate 49. 
in Ming porcelain, 29.353 (pl. 70). ${ }^{248}$ It may best be described as a basin with flattened rim and almost straight sides; a slightly raised ring interrupts the side profile which turns in at the bottom at an angle to meet the fairly high and somewhat undercut foot. The base is roughly glazed and has no mark. Inside the center is a decoration of two elongated winged dragons without feet flying among clouds and flames; the sides are covered with a tightly drawn floral scroll, and a debased classical scroll lies on the rim. On the outside a petal band is separated by the raised ring from another closely drawn floral scroll, and separate cloud scrolls decorate the underside of the rim. Everything about this decorative scheme points to a late fifteenth- or early sixteenthcentury date; but the shape of the basin is most unusual. Thus far it has been seen only

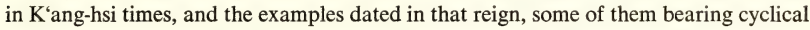
characters to an exact year, are decorated in the style of the period which is quite unlike this. A large dish closely decorated in rich deep blue (29.136, pl. 72) has something of the same style in the cavetto, but the center panel of peacocks, rock, and peonies is very boldly painted in heavy strokes with little use of outline; and the same bold style appears on 29.139 (pl. 72) both inside and out.

Two more dishes decorated in the same bold style in strong deep blue call for special mention. One is 29.142 ( $\mathrm{pl} .73$ ), which has a degenerate classic scroll around the rim and four large and four small clumps of plants with a horizon line indicated all

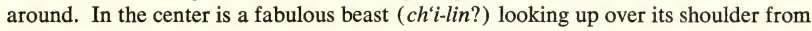
a recumbent position; above is a crescent moon, to the right is a large group of plantain leaves, and scattered elsewhere are flame scrolls and crudely drawn auspicious objects. The dish has a brown rim, and the base is deeply recessed inside an unusually broad and rounded rim. The design of the recumbent animal is evidently old. It occurs on a ting yao dish in the British Museum which has already been cited for other reasons, ${ }^{249}$ and in that case the beast has no mane but rather a single horn. Constellations are seen near the crescent moon in the sky, and below is a raging sea. In spite of this coincidence there can be no question of dating this blue-andwhite dish by reference to its ting prototype. The composition occurs in equally sketchy style on a small saucer dish given to the writer by Langdon Warner who acquired several of them in Annam (pl. 137, C). This latter piece also has the brown rim, but the body as seen at the foot rim is typical grayish-buff Annamese stoneware glazed under the base, while the Ardebil dish is unglazed underneath revealing a fine white porcelain. Prof. James Marshall Plumer reports having seen this design on porcelains in Fukien, and in the absence of indications to the contrary this may tend

${ }^{248}$ Its nearest relative in terms of shape is the type usually marked Hsüan-te inside the bottom (e.g., TOCS, 1928-1930, pl. 10; and Hobson, David catalogue, pl. 137); some examples have covers. The base and lower sides are constructed much like those of our basin; but the sides of the earlier pieces are more curved, the rims are not flat, and the vessels are about half the size.

${ }^{249}$ Hobson et al., Chinese ceramics in private collections, fig. 86 . See p. 61 above. 
to suggest a southern origin for this piece. ${ }^{250}$ A dish in the Isfahan group (pl. 74) is decorated with the same bold, free painting in rich blue. Lacking only the border scroll, the cavetto carries a design similar to the one just described. In the center two ducks fly among lotuses, and the fantastic tail feathers and tips of the wing plumage are drawn in fine calligraphic strokes of unusual power. The base differs considerably from that of the preceding dish in that it has a thin coating of pitted glaze within the rather deep foot which tapers on the outside and is almost vertical on the inside.

These last two dishes are perhaps the most striking members of this little family painted with great assurance in broad strokes of solid color and showing little interest in refinement of detail. The group as a whole has thus far eluded precise attribution and has usually been assigned simply to the fifteenth century ${ }^{251}$ Lacking more accurate information, one hesitates to suggest placing them within a narrower range; but the possibility must not be excluded that they may belong in the last few decades before the year 1500 . There seems to be no place for them among the well-known sixteenthcentury types.

${ }^{250}$ Related designs appear on some of the coarse blue-and-white excavated in the Philippines. Cf. Janse, HJAS, 8 (1944-1945): plates 5 and 7.

${ }^{251}$ Published pieces include a kuan vase and a tripod shown on plate 13 of Jenyn's Ming pottery and porcelain; a kuei-shaped vessel which was no. 109 in the Detroit exhibition entitled The arts of the Ming Dynasty. Another is the mei-p'ing which was no. 123 in the OCS exhibition of 1953-1954, but not illustrated in the catalogue. 


\section{THE BLUE-AND-WHITE: THE SIXTEENTH CENTURY}

Once again the arbitrary point of reference to which we turn from force of habit, the immovable and invisible marker that separates one Christian century from the next, did not exist in the consciousness of the Chinese for whom the year we call 1500 was merely the thirteenth in the reign of the Ming Emperor Hsiao-tsung; and we have no means of pointing out any of the porcelains made at that moment or for another six years until a new emperor came to the throne and named his reign Cheng-te. Our discussion of the blue-and-white in the Ardebil Collection draws to a close with the century then beginning. Cheng-te, Chia-ching, and Wan-li are the reigns to be considered, for no wares from the short Lung-ch'ing period have been identified and when Shāh 'Abbãs made his vaqf the Wan-li reign still had almost a decade to run. So what we loosely call the sixteenth century for purposes of general orientation in world history includes the years of those reigns, for at this time our knowledge is not such as to permit the drawing of distinctions between the porcelains of 1600 and those of 1611.

Because the collection includes a number of pieces dated in these three reigns, the form of this chapter need not follow the pattern used in those preceding where the group was arbitrarily divided according to types and discussed as a whole with respect to shape and decoration. Here the dated examples from the three reigns serve as natural starting points for the discussion of related wares, and questions of shape and decoration are treated as they arise. The Cheng-te wares stand in the middle of a transitional period between what might be called the typical styles of the fifteenth and sixteenth centuries. Vestiges of the earlier refinement are still evident, and many beautiful pieces were produced in this short reign before the full effect of mass production began to be felt in Chia-ching. Much of the traditional repertory continued in use with outline and wash drawing now almost universal, and among the new shapes were small jars of various shapes, a deep cuplike bowl, and a large vase with baluster body and tall neck with loose ring handles. ${ }^{202}$

The most striking development was the sudden appearance of a group of wares which include Persian and Arabic inscriptions as part of the underglaze blue decoration, an innovation that was employed not only on the usual vessels but also on a series of shapes that seem to be new at this time. Among these are boxes, brush rests, hatstands, table screens, and candlesticks; the last in particular is a miniature reproduc-

${ }^{252}$ None of these is represented in the Ardebil Collection; cf. Garner, Oriental blue and white, plates 46-48; and PMA 103. 
tion of a form widely used in the Near East. ${ }^{253}$ The widespread influence of Islam in China in the Cheng-te period is well documented, ${ }^{254}$ and it has been assumed that these wares were made for the Chinese Muslims. This may have been the general practice, for most of the examples known today seem to have come from China, but it should be noted that as of the present writing we know of no regulation forbidding their export.

The two pieces so decorated in the Ardebil Collection are of ordinary Chinese shapes. One is the largest and finest dish of the type seen thus far and at the same time the earliest piece in the collection to be marked with the proper nien-hao (29.313, pls. 75 and 76)..$^{255}$ The rim is decorated with 32 small roundels; in the center, a scroll pattern surrounds a quatrefoil frame in which is a rectangular panel filled with a bold Arabic inscription which may be translated "Thanks for his goodness." On the under side of the rim is an unusual design made up of what look like bunches of three cherrystones on stems alternately springing from opposite sides of the field. Below this is the main decoration of foliate patterns scrolling around eight circles of Arabic phrases which combine to read, "Said the Prophet on whom be peace, 'Man's praise to him who gives should be increased; ingratitude for favor causes it to disappear'." Both are written in the thulth script. A horizontal cartouche set above and between two of these circles encloses the 6-character Cheng-te mark. It should be noted that these texts are not Qu'ranic in origin. In some cases they are, but on the limited number of pieces known to us the texts range from Qu'ranic quotations through all sorts of aphorisms and clichés from various literary and popular sources down to simple descriptions of the objects on which they appear, as for example a brush rest which carries the phrase "The pen is mightier than the sword" and another on which the inscription merely says "pen rest" in Persian. ${ }^{256}$

${ }^{253}$ Garner, op. cit., plates $43-45$. In his note 2 on p. 29 he remarks that he finds the resemblance of the porcelain candlesticks to their Near Eastern prototypes very small. There are, of course, several types of Islamic candlesticks, but while no exact copy has been seen, the general form of the handful of known examples in Cheng-te porcelain seems to reflect clearly the influence of those illustrated in A. U. Pope, Survey, vol. 6, plates 1332, 1333, 1364, 1371; and Barrett, Islamic metalwork in the British Museum, pp. 24 and 35.

${ }^{254}$ Cf. P. Pelliot, Le Hō̄a et le Sayyid Husain de l'histoire des Ming, TP, 38 (1948): 81-292, for an extensive account of Muslim activity in this reign. Additional material may be found in B. Laufer, Chinese Muhammedan bronzes, Ars Islamica 1 (1934): 133-146, and in P. Kahle's translation of the Khitai Nameh of the Sayyid 'Ali Ekber. The last is still unpublished, but the translator has been kind enough to give me a copy of his preliminary manuscript. C. L. Pickens, Jr., Annotated bibliography of literature on Islam in China, Hankow, 1950, lists the standard publications on the subject as a whole.

${ }^{255}$ A white saucer is correctly marked Ch'eng-hua, and several white and colored pieces are marked Hung-chih; see pp. 146, 149, and plates $115-116$ below. 29.313 is the earliest properly marked blue-and-white.

${ }^{256} \mathrm{Cf}$. Garner, Oriental blue and white, plate 44A. 
A detail of particular interest in the physical structure of this dish is the deep and sharply undercut foot. All the large dishes of earlier periods have relatively low feet which slope inward to the base at varying angles; but in the present instance the opposite is true, and the angle between the base and the inside of the foot is so acute that the dish can be lifted quite safely by the fingertips at that point. The profile drawings of typical foot rims selected from dishes in the Ardebil Collection show the gradual change in fashion with respect to this detail (pls. 139-142). The development from low simple feet in the fourteenth and fifteenth centuries to high and more or less sharply undercut feet in the sixteenth is evident so far as the large dishes are concerned. But to set up this general principle as an infallible rule would be absurd for not every large sixteenth-century dish has an undercut foot; on the other hand, however, no undercut feet have thus far been observed on large dishes of earlier date. As in the case of other details, this evolution of foot structure may be used as an aid to attribution if treated with due caution and respect, and if it be remembered that it applies to large dishes alone; the situation seems to be somewhat different in regard to vessels of other shapes. So far as the Ardebil Collection is concerned it is particularly appropriate to have this sixteenth-century characteristic so strikingly documented by this magnificent Cheng-te dish.

The second Muslim piece is quite different in character (29.346, pl. 77). This is a small bowl decorated inside with a border of Arabic script and a central circle enclosing eight lines of text; outside are four circles framing similar texts, and these are separated by cloud scrolls while a band of lotus panels surrounds the bowl below. Underneath, within a double circle, is a 6-character Hsüan-te mark. As will be seen in comparison with the clear strong calligraphy on the large dish, the writing on this bowl in a debased naskhi script is inferior in every way, the strokes are uncertain, the lines uneven and the roundels overcrowded; and the text itself has been characterized as "a misunderstood series of disconnected phrases and half phrases of a eulogistic and Qu'ranic nature written by a person with a very imperfect knowledge of Arabic." ${ }^{257}$ The bowl itself is obviously not a product of the early fifteenth century. The form, the foot, the style of decoration, and indeed the writing of the Hsüan-te mark itself all point to a time after 1500 .

Muslim blue-and-white marked with other than the Cheng-te nien-hao are known but seem to be rather rare. One is a dish in the collection of Sir David Home which is marked Hung-chih. ${ }^{257 a}$ The body is buff rather than white; the blue is good in color but somewhat pale; and the potting is heavy and lacking in finesse. It is a coarse piece made in some outlying region, perhaps near one of the coastal towns of southeast

${ }^{257}$ For this comment I am indebted to D. S. Rice, of the University of London.

${ }^{257 a}$ The owner has been kind enough to supply me with two photographs of this dish which are reproduced on plate 138. It was OCS Catalogue, 1953, no. 190 (not illustrated). 
China; and if we are to accept the broad definition of Swatow wares proposed by Mrs. Aga-Oglu, it might perhaps be classified in that group. ${ }^{258}$ The indifferently written Arabic script appears on some of the enameled Swatow pieces in much the same patterns as those used on this blue-and-white, and the only surprising thing would be to see a Swatow piece with a nien-hao; but the fact that one has not been seen before need not mean that they do not exist, nor is there any reason such a piece could not have been made in the Hung-chih period. Islam in China was by no means limited to the Cheng-te reign, and Persian was the lingua franca of commerce in the southeastern seaports over several centuries. So in spite of the differences between these two pieces marked Hsuan-te and Hung-chih and the better known Muslim wares with Cheng-te marks, they may all be datable within about the first two decades of the sixteenth century.

Two more dishes illustrated here may possibly belong to the early part of the century, although they are admittedly difficult to place. The decoration of 29.131 (pl. 78) consists of a large floral scroll, which may be intended to show camellias, in the cavetto; and in the center within a ring of degenerate classic scroll is a fantastic rock surrounded by tree peonies. Outside are scrolling peonies and a second classic scroll in the same manner. The pattern is closely crowded all over the surface and boldly but very skillfully painted in outline filled with graded wash. The base is unglazed, slightly convex and has a high and deeply undercut foot closely resembling that on the large Cheng-te dish just described. In some ways this dish seems related to certain pieces tentatively assigned to the latter part of the previous century, ${ }^{259}$ and they may all have been made within a decade or two of each other; but the painting here, though somewhat stiff, is done with great precision, and the similarity of the foot to that of the Cheng-te dish strongly suggests that the two are contemporary. Another member of this family is in Istanbul, a dish of similar size and style decorated with a fish leaping among aquatic plants. ${ }^{260}$ Even more difficult to place is 29.132 (pl. 78); the size and shape of the vessel and the treatment of the foot rim relate it to the great Cheng-te dish 29.313 , but the drawing of the interior decoration is related in style to that in the cavetto of 29.137 ( $\mathrm{pl} .71$ ), which has some claim to a late fifteenth-century attribution. The bold floral scroll on the outside of this dish, although more widely spaced, also tends to link it with 29.131; and for the time being it seems best to place it in the same group, within a decade or so of the year 1500 .

${ }^{258} \mathrm{Cf}$. The so-called "Swatow" wares: types and problems of provenance, FECB, vol. 7, no. 2 (June 1955): pp. 1-34. See also Tom Harrisson's very apt remarks on pp. 35-37 of the same volume urging continued use of the term "Swatow" to cover all these wares until we know a good deal more than we do now.

${ }^{259}$ Nos. $29.136,29.137,29.139$, plates $71-72$.

${ }^{260}$ Cf. TOCS, 26 (1950-1951): plate 14. 
With the exception of the above-mentioned pieces, the sixteenth-century blueand-white wares in the Ardebil Collection belong to the Chia-ching and Wan-li reigns. Of a total of some 350 pieces, 28 have proper nien-hao, 2 are marked Ta-ming-nientsao, 13 have commendation marks, and 10 carry spurious nien-hao of the fifteenth century. Most of the wares of this long period between 1522 and 1611, the terminal date of the collection, are well-known types and need not be described in detail. The 60 -odd selected for illustration suggest the general range, and the attempt has been made to include those with unfamiliar designs and in some cases with hitherto unrecorded shapes. With few exceptions the quality of these wares is mediocre, and in some instances it is downright poor. The rarity of fine pieces like 29.355 (pl. 83), 29.369 (pl. 85), and 29.477 (pl. 86) and a few others among the large body of Chiaching and Wan-li wares in the Ardebil Collection reflects the general state of the porcelain production in those reigns. Quality had by this time given way to quantity as the primary desideratum, and in times when orders for the Palace alone amounted to more than a hundred thousand pieces in a single year it can well be understood that potter and decorator alike had little time to work with the care that was essential to the making of some of the superb wares of the fifteenth century. For once, it seems, the Chinese forsook their traditional pride of craftsmanship, and some day we may know more about the reasons for this lapse; but from the evidence provided by the porcelains themselves we can only conclude that they were working under extreme pressure from masters whose tastes had in some mysterious way been perverted from ideals of refinement to those of abundance. The fact that China was seriously preoccupied in defensive warfare with the Mongols during the Chia-ching reign and with the Japanese until the death of Hideyoshi in 1598 is in itself hardly a sufficient explanation.

While certain well-known types have come to be recognized as Chia-ching and others are clearly Wan-li, there is a considerable body of unmarked sixteenth-century wares which remains unclassified. Many of the types of decoration appear to have been used equally in both reigns; nor does the intervening 6-year reign of Lung-ch'ing seem to have left its mark at all beyond the handful of pieces, some of unusual shapes, which are known because they bear the mark. There are none of these in the group under discussion, and for all practical purposes a designation of "late sixteenth century" will here mean Chia-ching or Wan-li. A case in point is provided by a group of five large vessels of kuan shape decorated with 5-clawed dragons. The one illustrated $(29.520, \mathrm{pl} .79)$ has the Wan-li mark written in six characters in a horizontal line on the neck, but the other four are marked Chia-ching, in three cases in a glazed circle in the center of the unglazed base. Others of this family with the Chia-ching mark on the neck are known. ${ }^{201}$ To pick this Wan-li vessel out of the group without recourse

${ }^{261}$ Cf., e.g., Pope, Ming porcelains in the Freer Gallery of Art, p. 37, no. 45.36; Hobson, Chinese pottery and porcelain, vol. 2, plate 72 . 
to the mark would be next to impossible, and this instance illustrates the futility of trying to make precise attributions within the large mass of unmarked blue-and-white produced in this period.

Altogether the collection includes some 35 large vessels of this shape with various motifs in the decoration. Landscape scenes with figures, shou characters, medallions, floral patterns, lions, and lotus scrolls are the principal categories into which they may be divided, and one of the lotus-scroll group with Chia-ching mark on the base is illustrated on plate 79 (29.515). Standing alone is the coarse kuan, on the same plate, with four loop handles on the shoulder which is decorated with very crudely painted dragons equipped with spindly 4-clawed chickenlike feet. The whole tone of the piece is rather gray and the glaze is covered with a brownish crackle. While the roughly cut base lacks the gravelly adhesions usually associated with the type, the vase clearly belongs to the family of which several members have been found in the Philippines and two of which were published by Mrs. Kamer Aga-Oglu. ${ }^{262}$ Fifteen more vessels of the type are in the collection of the Topkapu Saray1 Müzes1 in Istanbul, and there are at least four in the Princessehof Museum in Leeuwarden ${ }^{263}$; and all of them may well stem from the same source, some unknown kiln on the southeast coast of China which produced crude porcelains for the export trade. Such variations as may be observed in the drawing, the blue, the glaze, the base, and other details from one piece to another may be ascribed to the primitive conditions and inferior methods and materials available to the proprietor of this unknown provincial kiln.

Three of the ten pieces with Chia-ching marks are illustrated on plates 80-82. No. 29.364 is a good example of the decorative style involving the use of trees with trunks and branches distorted into the forms of auspicious characters. In the center a pine takes on the aspect of the character shou "longevity," which is the quality symbolized by the tree itself; and on the outside are two more pines in the same guise while a bamboo depicts a $f u$ "happiness" and a prunus represents the character $h s i$ "joy." ${ }^{264}$ A dish with grapes, squirrels, and birds in the border, plain white cavetto, and a deer and a crane in a landscape in the center, is similarly marked (29.262, pl. 81). Outside are five roundels with flying cranes, reserved in white on a blue ground, and an equal number of flower scrolls under the rim. Both of these pieces are of moderately good quality for Chia-ching wares. Much more crudely done in a blurry, muddy blue is 29.140 ( $\mathrm{pl} .82$ ), and the mark is very poorly written indeed. This and the fact that the last character is tsao instead of the more usual chih combine

${ }^{262}$ Ming export blue and white jars in the University of Michigan. AQ, 11 (1948): 201-217.

${ }^{263}$ Cf. Pope, Fourteenth-century blue-and-white, p. 21, and ACASA, 5 (1951): plate 5.

${ }^{284}$ The bamboo and the prunus are difficult to read, and I am indebted to A. G. Wenley for these suggested interpretations of the $T s^{\prime} a o-s h u$ forms. He has also called my attention to the fact that the compound hsi-shou refers especially to the seventy-seventh birthday, and a bowl thus decorated would be an appropriate gift on such an occasion. 
to suggest that it is the work of some minor private kiln engaged in making cheap wares for popular consumption. The question of the use of tsao as the verb in nienhao is not well understood, nor is there much evidence on which to base any conclusions. Beyond the fact that it seems to occur most commonly on poor-quality wares in the sixteenth century, almost nothing is known, and little is to be gained by speculation at this time. ${ }^{265}$

A set of nine bowls of the same size and shape, all with Wan-li marks and all with the same decoration, are of better than average quality for the period and provide another interesting illustration of the differences that may be found between what are, for all practical purposes, identical members of a set (29.354-362). In the presence of the bowls themselves the most striking thing is perhaps the change in tone of the blue from one to another, a condition that can be observed in the photographs of the two examples selected for plates 83-84. The design of banana and bamboo in a bleak landscape is unusual and, though always the same scene, is never twice identical within the set. There can be little doubt that this represents the work of several hands copying a single pattern; but the variation in the marks may signify nothing more than differences in the amount and quality of ink with which the brush was charged. Three more marked Wan-li pieces are above the general level of quality, a bowl with lotus scrolls under a border of diamond diaper pattern framing swastikas $(29.369$, pl. 85) and two tall heavy mei-p'ing decorated with landscape scenes with figures and marked in evenly spaced characters around the upper shoulders $(29.402$, 405 ). One of these is shown on plate 86; and it should be noted that although alike in every other respect this one is 5 inches taller than its fellow.

The shape of these mei-p'ing should be mentioned as they represent the last stage of the development of the form in the Ming Dynasty. ${ }^{268}$ The long almost straight lines of the profile are somewhat reminiscent of the fourteenth century, but there the resemblance stops. The shoulder is high, not sloping; the neck rises to almost twice the height it had on the earlier wares; and the widely flaring form of the latter, topped by a vertical lip, is entirely new $(29.402, \mathrm{pl} .86$, and p. 63$)$. Only a few dated sixteenth-century mei-p'ing are known, but it seems quite likely that more than one shape was in use, and it may not be possible to establish a typical shape for the period even though most of the marked pieces conform to the type illustrated here. ${ }^{267}$

${ }^{265}$ Cf. p. 114 above.

${ }^{266}$ See p. 63 above.

${ }^{267}$ A covered mei-ping in the Palace Museum is made in the same shape (cf. Ku-kung 故宮 16 , p. 13); but the cover makes it impossible to see the neck. It is about $15 \frac{1}{2}$ inches high, and the decoration is so similar to that on our piece that it would be very difficult to distinguish them chronologically were it not for the Chia-ching mark on the one in Peking. A plain white one in the British Museum (1945-10-16-15) has incised designs and the Chia-ching mark incised around the shoulder; it is $16 \frac{1}{2}$ inches high, with the form of the body and proportions of the neck appropriate to the period. A very crude mei-p'ing with both Chia-ching and Hsüan-te marks poorly written in a 
Among the unmarked wares a large double-gourd vase is very striking with bold all-over pattern of auspicious shou characters written in several different forms including that of a twisted peach tree seen in the upper roundel (pl. 86). On the lower section the pine in a group of the three friends is contorted into another character. The quality of this piece is good if not outstanding, but the total effect is somewhat marred by a coarse and gravelly base. A similar piece formerly in the Bloxam Collection ${ }^{268}$ was attributed by Hobson to the Wan-li period; but lacking more definite evidence there seems no reason why it could not equally well be Chia-ching. The same is true of most of the pieces that follow whether they have marks of commendation, spurious fifteenth-century nien-hao, or no marks at all. On the same plate are three views of a curious spherical object on a high flaring foot. In form it resembles the type of thing that has been called a hatstand, ${ }^{269}$ but this has on top of it the remains of some sort of rim within which are nine perforations, one of which is now filled up with glaze. Around the main surface is a landscape scene with gentlemen and attendants in a garden, a crane, and a pavilion in the clouds, all drawn in a coarse style. On the base is the mark Hsüan-te-nien-tsao in underglaze blue $(29.456, \mathrm{pl} .86)$. Five identical bowls (29.370-374), of which one is shown on plate 87 , are decorated with borders of flying horses and cloud scrolls above broad zones of fruiting peach trees with birds on the branches and butterflies flitting in between; these are marked $F u$ $k u e i-c h i a-c h ' i$ in a square, and this commendatory phrase is usually associated with the Chia-ching reign. On the same plate is a smaller bowl of somewhat finer quality (29.377) decorated with a similar motif, though in this case the trees are pomegranates. Inside is a diaper border of a type found on many Chia-ching wares and on the base is an apocryphal Hsüan-te mark in six characters. A shallow bowl in similar style has prunus sprays, dragonflies, and a crescent moon on the outside, while within is a heavy segmented blue border framing eight cranes amid cloud scrolls (pl. 88). Somewhat more formally treated is 29.397 with plain rim on plate 89 , which has three encircling lines crudely incised in the paste as the only decoration inside while the outside shows three ogival medallions each framing two lotus blossoms on a honeycomb diaper ground and separated by pairs of cloud scrolls. Here again the mark is Fu-kuei-chia-ch'i, but otherwise the bowl has nothing in common with 29.371. While the latter is quite ordinary in every respect, this smaller bowl is not only very well

line just below the shoulder is published in TOCS (1928-1930) on plate 3; the mark is admittedly freakish, but the piece cannot be earlier than the sixteenth century and serves to suggest the date for a number of coarse mei-p'ing with pinched-in waists which have sometimes been considered early (cf., e.g., Detroit catalogue, The arts of the Ming Dynasty, no. 93; Kushi, op. cit., pp. 55-56; TOCS, 21: pl. 3b). A transition between the most usual forms of the fifteenth century and the elongated types with Chia-ching and Wan-li marks is appropriately represented in the British Museum by a piece decorated with dragons in green enamel and bearing the Hung-chih mark incised on the shoulder (cf. Jenyns, Ming, pl. 76B).

${ }^{268} \mathrm{Cf}$. Chinese ceramics in private collections, p. 111 (fig. 195).

${ }^{269}$ Garner, Oriental blue and white, plate 44B. 
potted but is decorated with a blue almost as rich and brilliant as that of the K'ang-hsi period, and the quality of the drawing anticipates the blue-and-white style of that great Manchu reign.

Several more coarse pieces of this period have unusual characteristics which make them worth describing. On 29.265 (pl. 89) is a central decoration of the three friends growing in an elaborate jar which stands on a terrace with a tiled floor; the posts of the balustrade are surmounted by lions. The pine growing in the center of the group is twisted into the character shou. No. 29.314 on the same plate is a dish decorated with a crowded composition showing a chi-lin at sea. At the top of the scene, above a layer of clouds, is a mountain landscape with pines; and on the rim are seahorses flying among mountains and clouds over waves. On the base is the 6character Hsüan-te mark in underglaze blue. Another dish of uncommonly coarse ware is 29.279 (pl. 90); the flattened foliate rim is decorated with a sketchily drawn stylized design, and the plain white cavetto is radially fluted surrounding a central roundel framing a roughly drawn bush with three large flowers standing on an arching horizon. On the underside the dish is very crudely cut with deep, uneven radial incisions to match the internal fluting; and, strangest of all, the roughly glazed base is marked in underglaze blue with a poorly drawn swastika placed off center in a double circle. ${ }^{2 \theta 9 a}$ On the same plate is a dish with flying birds and prunus sprays surrounding a central peach tree growing from a pot into the form of a shou character; the mark in this case is a spurious 6-character Hsüan-te nien-hao, and the two pieces cannot be far apart in date.

Among the dishes is one with a 6-character Chia-ching mark on the base and a most curious design inside (29.148, pl. 91). At the right of the composition are five deer on a grassy bank by the edge of a body of water; in the water at the left is a tortoise, and above it is a waterfall pouring down from above and splashing onto the surface at the horizon. This waterfall in turn originates in a second and smaller landscape, which is drawn upside down with trees growing downward from the upper lefthand corner of the circle. Another waterfall is depicted on no. 29.147 , where it also springs from an inverted landscape of rocks, bamboo, and pine at the top of the scene. It divides the whole composition vertically; and two animals, an elephant and a pai$t s^{\prime} e$, are shown at the right and left of the pool into which the cascade plunges. A variant of this scene is shown on a dish published by Kushi. ${ }^{270}$ Such decoration seems rare and its significance is not clear at this writing.

Deer in a landscape are among the commoner motifs found in this group, and several types are illustrated. Nos. 29.231 and 29.233 (pl. 92) are two from a set of six which bear the same design. In this scene there are four of the animals beneath overhanging trees and rocks. Two of them carry fungus plants in their mouths and

${ }^{269 a}$ See also p. 162 below.

${ }^{270}$ Shina minsho tōji zukan, plate 93. 
recall in very debased form the design on the beautiful dish assigned to the late fifteenth century in the previous section. ${ }^{271}$ In the rims of this set are fungus scrolls and long thin dragons with bifurcated tails and manes of perfectly straight hair streaming backward. The juxtaposition of two members of this set shows again the minor differences in detail that creep in when a single composition is repeated again and again. No. 29.239 shows a scene with two deer related to those under discussion. The animals are here rendered more faithfully, and the trees, too, reflect the presence of a more skillful hand; at the left a tiny waterfall again pours from an inverted landscape into a lake. Of particular interest is the well-drawn bat which flies above the deer on the left. This creature plays an important role in the decorative repertory of the Ch'ing Dynasty where it is well known to have been used as a rebus, $f u$ "bat," standing for $f u$ "happiness." The question of the origin of this rebus has been a subject of discussion; and efforts to interpret some of the highly stylized designs on Han Dynasty bronze mirrors in this way seem to have little ground for support. In this case, however, there can be no doubt about the nature of the animal intended, and the rebus $f u$ (bat $=$ happiness) is reinforced by the rebus $l u$ (deer $=$ prosperity), thus multiplying the felicitous import of the scene. Occurring as it does on this dish in the Ardebil Collection, it is the only undoubted Ming example on porcelain to have come to this writer's attention. The border of this dish consists of a long continuous landscape scene which also plays an important part in the decoration of this period. It occurs again in modified form on 29.242 (pl. 92) where the central design is quite different from those just described. Here a crowded garden scene includes the corner of a pavilion at the left, a large tree at the right and, in between, a rock, various plants, and a golden pheasant, two mandarin ducks in the water, a flying goose, two birds which may be doves on a branch, and a butterfly. All sorts of changes are rung on this theme as on all others in the huge output of blue-and-white of this period.

Of all the landscape scenes used at this time to decorate porcelain, one of the most stylish is that found on 29.205 (pl. 93), where an 8-story pagoda rising in the foreground is complemented by the vertical movement of the tall peaks spaced at intervals through the landscape. The one at the left is topped by a willow, while pines crown the summit on the right and the row of hills above the clouds in the background. In the center are two flat-topped rocks surmounted by thatched pavilions, and in the right foreground a man sits in a boat with furled sail contemplating the beauty of this fairy landscape. Here in a circle some 11 inches in diameter the painter has captured with extraordinary economy of means one of those limitless magic landscapes so dear to the heart of the Taoist sage. The scene is drawn with beautiful clarity in a blue that is pure and strong to a degree rarely found in wares of this class, and these qualities are maintained to the full in the rhythmic floral scroll of the border and the cranes and formal devices on the back of the dish. The central landscape will

${ }^{271}$ P. 118 and plate 71. 
be recognized as the type-scene depicted in red and green enamels on some of the large dishes of so-called "Swatow" type, though the latter are so much less refined in every respect that all similarity ends with the spirit of the composition itself. In fact the pair of dishes under discussion are outstanding in quality among all the known wares of the type, as will be seen by comparison with 29.207 and 29.208 (pl. 94), two much more ordinary examples selected from a set of seven. The latter demonstrate the nature of the variations introduced within this landscape type and also show another common border of the period with white cranes among lotus.

Approaching the ultimate refinement in the sixteenth-century landscape style on porcelain is the decoration of the two bowls on plate 95. Related to those we have just seen, they are here given full play over the entire outer surface uninhibited by decorative borders of any kind. The style is much less formal than that of landscapes painted on porcelain in earlier times, and the little scenes have some of the quality of ink painting in their freedom and spontaneity with a use of graded washes in the representation of rocks and mountains that shows an increasing mastery over the difficult medium. No. 29.401 is painted with a great deal of spirit on a delicately potted bowl of elegant proportions, whereas the landscape on 29.376 lacks some of the sophistication of the former, is a little stiffer, and perhaps is more appropriate to the larger, more sturdily potted bowl. These unmarked bowls with glazed bases are related in spirit to two well-known pieces of even better quality which are marked $T^{\prime} a i$ $k o$-chia ch $^{\prime} i$ 臺䦥佳器 ${ }^{272}$ and which are perhaps the finest examples of porcelain painting to have survived from this period. Here again it is necessary to look ahead for par-

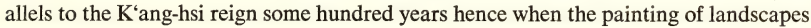
in underglaze blue reached its final perfection. These bowls stand on the penultimate rung of this ladder of development and, to indulge in a purely subjective judgment, mark in their way one of the high spots in the whole history of blue-and-white.

One of the most remarkable pieces in the collection is shown on plate 96. A thickly potted vessel in a shape not seen before, it resembles nothing so much as a champagne bucket. The broad surface of the lip is unglazed, and this biscuit area extends three-quarters of an inch down the inside surface of the vessel; below this very precise horizontal line the inner surface is completely glazed. This unglazed rim may mean that the vessel once had a cover. The upper part is decorated with a landscape scene showing, on each side, two deer within a fenced enclosure, and below is a carp leaping among waves. It is possible to identify these deer as the species first noted and sent to Europe in 1866 by the French naturalist Abbé Armand David, who found a

${ }^{272}$ Cf. Hobson, Catalogue of . . . the David Collection, pl. 133, and OCS Catalogue, 1953, no. 193, plate 13. The two translations offered for this phrase are "elegant vessel for the terrace pavilion" and "elegant vessel for the president (of the Six Boards)." Without context both are acceptable, but when it was written, one and not the other must have been specifically intended; perhaps one day we shall know which. 
herd in the Imperial Park at Hai-tzu some miles south of Peking. ${ }^{273}$ Once plentiful throughout China, they were even then near extinction, and the handful of survivors is said to have been killed by the troops during the Boxer uprising of 1900-1901. Those specimens known in European and American zoos today are descended from the pair sent to Europe by Père David; and the species (Elaphurus davidianus) is distinguished by its large feet, large muzzle, thick tail, and unusually heavy horns, all clearly showing in this representation. The fence in the drawing may mean that even in Ming times these deer were kept in enclosed parks. The carp on the lower section is handled in much the same way as are those on the Chia-ching covered jars decorated in red, yellow, and green enamels, of which a number of examples are known. On the same plate are two views of a bowl (29.367) with a crudely drawn and crowded scene of a most unusual subject. Among large flowers are three white hares, one of which lies on its back in an attitude of terror with its front paws raised as if to defend itself against a hawk which is just in the act of striking. For all its crudity this dramatic little scene shows considerable realism in the rendering of the hawk's braking wings and the talons extended forward about to seize the unhappy victim. Further interest attaches to this bowl because of the 6-character Ch'eng-hua mark on its base, a mark well known on eighteenth-century wares but not so familiar on those of the sixteenth century. While there can be little question about the date of this piece, one gets the impression that the potter had it in mind to copy a real Ch'eng-hua bowl from the careful way he made the narrow foot rim and finished the smooth base. His shortcomings are revealed in addition, of course, to the style of the drawing, in the quality of the glaze which has chipped considerably on the rim indicating an unsatisfactory bond with the porcelain body, and in the preparation of the clay which resulted in a sizable fire crack on the base.

The four drinking vessels of kéndi type ${ }^{274}$ shown on plate 97 illustrate some of the variations found in the sixteenth-century versions of this form. Nos. 29.445 and 29.466 have the familiar rounded body and bulbous mammiform spout, and both are decorated with landscape scenes one of which introduces two waterfowl which may possibly be intended to represent teal, although identification is by no means certain. ${ }^{275}$ The other two are much more fanciful with bodies in the forms of an elephant and a frog, respectively, and in each case the mouth of the animal serves as the drinking spout of the vessel. Parts of the elephant have been broken and restored with plaster, and it may

${ }^{273}$ David, Armand, Abbé David's diary, pp. 5-6, 133.

${ }^{274}$ Cf. pp. $116-118$ above, and plate 69.

${ }^{275}$ The latter deserves special notice because the drawing of the birds and the foliage looks very much like the treatment of similar subject matter on a small bowl in the Victoria and Albert Museum published by Garner (op. cit., pl. 65A, left) as perhaps belonging to the Transition period in the mid-seventeenth century. This suggests that the Transition style began well before the end of Wan-li or some years earlier than has been generally recognized. (See also OCS Catalogue, 1953, no. 227 , which is wrongly numbered 219 on pl. 14; Garner, op. cit., p. 38; and Jenyns, Later Chinese porcelain, p. 17.) 
be that the Shāh 'Abbās mark which is now missing was engraved on one of these areas. A similar elephant seems to have reached Europe at an early date, for it is represented in a still-life painting by Adrian van Utrecht. ${ }^{276}$ A frog like 29.465 was published as early as 1881 by du Sartel, ${ }^{277}$ and another is in the Topkapu Sarayl in Istanbul, which collection also includes one in the form of a white ox caparisoned, like our elephant, with a blanket decorated with a hare on a diapered blue ground. The two vessels in the form of phoenixes published by Sir Percival David ${ }^{278}$ extend the repertory of animal and bird forms to four, and it may be that even more were used.

Four ewers of related shapes are shown together on plate 98 to facilitate a comparative study of the group. The most striking exception to the customary type form is the bulging onion top surmounted by a vertical rim which distinguishes 29.434 from its fellows; at present no precedent is known for this modification of the ewer. Three of them have the usual tear-shaped medallions on the sides; and one of these is modeled in openwork biscuit depicting a peacock and a peahen by a rock among peonies, a type of decoration sometimes seen on sixteenth-century ewers.

This group of four seems at first glance to hold together very satisfactorily; all have marks of the Hsüan-te period written in the style usually associated with the late sixteenth century. Yet repeated study of the photographs over a long period of time has given rise to certain questions which are raised here in the interest of suggesting a possible line of further inquiry. It is the shape of 29.435 that first strikes the attention; here is a ewer more sturdy and compact in form than the others, and the foot, although flaring slightly, is relatively low. Taken as a bottle without spout and handle, the vessel is not unlike its fifteenth-century prototype in over-all proportion. Could it not possibly be somewhat earlier than the rest, dating, perhaps, from nearer the year 1500 ? With this thought in mind, it will be noticed that the painting of the decoration does not altogether preclude such an attribution. In the spiral scroll of the medallion the leaves are tightly drawn in outline filled with wash as they are on the bottle tentatively assigned to the Hung-chih period (29.451, pl. 74), on two bowls which may be Ch'enghua or Hung-chih (pls. 64 and 66), and in the cavetto of the dish with two deer which has been included in the same group (pl. 71). Be it noted again, however, that this matter of drawing is slim evidence indeed particularly from 1500 onward when a great variety of styles was in use; and these pieces are cited only as examples of this particular manner in the late-fifteenth-early-sixteenth-century period. That it continued on is abundantly clear from many of the pieces in this collection, including the very ewers on this plate. So no conclusion is drawn; but slim as it is, this is the kind of evidence

${ }^{276}$ No. 984 in the Musée des Beaux Arts, Brussels. This painting depicts no less than seven well-drawn pieces of Chinese blue-and-white, the largest number seen thus far in one of these seventeenth-century Dutch paintings.

${ }^{277}$ Porcelaine de Chine, p. 23, fig. 10.

${ }^{278}$ Cf. TOCS, 11 (1933-1934): plate 8. A duck-shaped vessel is in the Princessehof Museum (ACASA, 5, 1951, pl. 8a) but is of a different type with a small funnel-like opening on one side. 
that must be studied, and until such a ewer comes to light with better documentation than this, the first impression, that all four of these pieces are contemporary, must prevail.

Most widely published of those few pieces in the Ardebil Collection which have been reproduced heretofore is the so-called "fountain ewer" shown at the left on plate 99. It first appeared in one of Sarre's general views of the porcelain collection as he found it in the Shrine; the same photograph was used again by Münsterberg and also by Hannover, ${ }^{279}$ and the curiously un-Chinese subject of the decoration had already excited the interest of scholars a generation earlier. Apparently the first to notice it in the West was Sir Augustus Franks. ${ }^{280}$ As seen on the Ardebil example the fountain consists of a broad deep basin ornamented around the outside with a row of erect serrated leaves and supported by an elaborate understructure which is partially obscured by the body of a recumbent chi-lin. It is not clear in the drawing whether this is intended as a sculptural representation of a chi-lin which serves as part of the base of the fountain or whether it represents a live chi-lin lying down to cool itself in the shadow of the basin. In any case, the beast rests on a low platform of two levels which is supported in turn on low scrolling feet such as are used for example on bulb bowls of Chün ware. From the lower edge of the basin protrude two spouts each terminating in a monster head which spews forth a stream of water onto the ground below. In the center of the basin, and surrounded by the bubbling water therein, rises the superstructure, in this case based on a kuan-shaped vase decorated with white lotus scrolls on a blue ground. From this vase emerges an elaborately ornamented column which rises to support a bulbous member equipped with two more monster heads from which streams of water pour into the basin below. Finally, as the central column or pipe continues upward, two bird-headed spouts on long gracefully curving necks send further streams of water into the basin; and the short finial is a curious form that defies the written word. Examination of the pieces which bear this decoration reveals many differences in the structural details of the several fountains depicted and at the same time makes it very plain that, in spite of the differences, all are based on a common prototype of non-Chinese origin.

What was this prototype? Although several suggestions have been made, no entirely satisfactory solution has been found. ${ }^{281}$ Yet there can hardly be any doubt that the fountain which served as a model for the Chinese artists originated in Europe. It seems unlikely that an actual fountain made its way

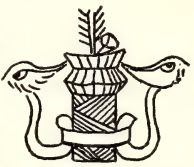

Detail. Finial of the fountain that decorates the ewer 29.423 (pl. 99).

${ }^{279}$ O. Münsterberg, Chinesische Kunstgeschichte, vol. 2, fig. 415; E. Hannover, Keramisk Haandbog, vol. 2, fig. 133.

${ }^{280}$ Catalogue of a collection of oriental porcelain and pottery, London, 1878, p. 22, no. 150.

${ }^{281}$ The latest scholar to treat this question and the only one to go into it at any length is Sir Percival David whose recent article, The magic fountain in Chinese ceramic art (BMFEA, no. 24, 
to China, and the question is whether they saw a drawing or worked from a verbal description. The numerous discrepancies in detail from one fountain to another tend to suggest the latter; but on the other hand a number of the details are so very precise, so completely un-Chinese, and so remarkably like the corresponding details of certain Italian fountains of the Renaissance that it would seem as though sketches of some kind must have been available to them. ${ }^{282}$ In any event, even when a satisfactory prototype is discovered, be it a single fountain or a composite, the case on these ewers will still remain open until we discover the means by which it reached China. ${ }^{283}$

1952, pp. 1-9) cites previous references to the type and goes on to venture a new solution by seeking to relate the design to the Magic Fountain constructed in 1254 by the Parisian goldsmith, Guillaume Boucher (or Buchier) who was then in the service of Mangu Khān at his capital in Karakorum. This miraculous fountain, which dispensed various intoxicating beverages to the assembled guests of the Mongol ruler and was automatically replenished at the trumpet call of a mechanical angel when the reservoirs ran low, is known to us from the eyewitness description of William of Rubruck, a Franciscan monk who journeyed to Karakorum as the envoy of Louis IX (St. Louis) of France (cf. W. W. Rockhill, The journey of William of Rubruck to the eastern parts of the world, p. 208; and Leonardo Olschki, Guillaume Boucher, a French artist at the court of the Khans which provides an interesting study of the symbolism and significance of the fountain). Ingenious and seductive as Sir Percival's proposal is, there is one difficulty that I find insuperable. Rubruck describes the fountain as "a great silver tree" and later on adds that "there are branches of silver on the tree, and leaves and fruit," but no one of the dozen or so fountains depicted on these ewers bears any resemblance to a tree or has any branches or leaves or fruit that might be taken to suggest that the Chinese artist had a tree in mind when he made the drawing. Granted that some three centuries and 1,500 miles intervened between Boucher and his fountain on the one hand and the Chinese and their ewers on the other, any description of this marvel that might have crossed that twofold interval must certainly, however else distorted, have transmitted the fact that it was, above all else, in the shape of a tree; and it is difficult to believe that the Chinese painters for whom trees were traditionally a favorite subject would have overlooked this essential fact about the appearance of the fountain if that was what they intended to portray.

${ }^{282}$ Among the books examined in connection with this problem are Giovanni Maggi, Fontane diverse, Rome, 1618; George Andreas Böckler, Architectura curiosa nova, Nürnberg, 1664; Arduino Colasanti, Le fontane d'Italia, Rome, 1926; and Bertha Harris Wiles, The fountains of Florentine sculptors and their followers from Donatello to Bernini, Cambridge (Massachusetts), 1933. Although this is not the place to attempt it, I believe it would be possible, by making a close study of these and other works, to assemble enough details from Italian fountains to reconstruct a satisfactory approximation of the fountain type depicted on these ewers.

${ }^{283}$ Not the least of the problems involved is that of the chronology. One of the fountain ewers in the Topkapu Sarayı bears the mark of the Chia-ching period (no. 1462), which means that, unless these marks were copied in the Wan-li reign, the design was drawn not later than 1566. It is tempting to think that perhaps such a fountain was depicted in one of the Christian paintings or engravings brought to China as part of the missionary effort of the Jesuits; but although Francis Xavier reached Japan in 1549, and at least one Jesuit, Padre Belchoir Nunes Barreto, was in Macao as early as November 1555 (cf. Boxer, Fidalgos in the Far East, p. 3); there seems to be no record of 
Aside from the fountain design, the decoration of the ewer follows the normal repertory of the late sixteenth century; a row of stiff leaves surrounds the neck above a stylized floral scroll, and the spout is covered with a formal flame pattern. Floral scrolls surround the high foot, and among these are two dragons with thin bodies and big manes of perfectly straight hair like those seen on the rims of a group of six dishes above. ${ }^{284}$ Although high on the outside, the foot is not actually hollow underneath but forms part of the inside of the vessel as may be seen in the view of the base on plate 99 and in the sectional drawing (pl. 142). This construction is known on other ewers of this type. On the glazed base is the 6-character mark of the Hsüan-te reign written in underglaze blue. The mark, the dragons, and the rest of the purely Chinese elements in the decoration all combine to suggest that this ewer was made in Wan-li; and these factors together with those relating to the time when the fountain design may have reached China suggest a strong possibility that the one known Chia-ching mark on a fountain ewer may be an interpolation. ${ }^{285}$

The other ewer shown on plate 99 is the same high-footed late sixteenth-century type with purely Chinese decoration. A lotus spray occupies the upper part of the shoulder, and the main area shows a prancing $c h^{\prime} i$-lin in a landscape; underneath the high hollow foot is the mark of a white hare on a roughly triangular blue ground ( $p$. 162). From the standpoints of potting, clay, glaze, and blue, the two pieces show every evidence of being contemporary.

A separate class of wares among the sixteenth-century blue-and-white is that which the Dutch call kraakporselein for the reason that it first appeared in Holland as part of the booty of a Portuguese carrack, the Santa Catarina, captured by the Dutch in the Straits of Malacca in 1603. This cargo was sold at auction on the dock in Amsterdam on 15 August 1604, and the wares immediately achieved such popularity that by 1614 Pontanus in his history of Amsterdam was able to write that Chinese porcelain in his city was almost commonplace. ${ }^{285 a}$ Whatever else may have been sent abroad from China in Ming times, and evidently other types did make their way across the seas, this is the true "export porcelain." When seen today in company with all the other wares now known, this kraakporselein has a distinctive character of its own; and although, as in other phases of this subject, there are borderline cases which resist precise classification, the large body of wares is relatively easy to single out.

Christian activity on the Chinese mainland between the latter years of the Yüan Dynasty and the arrival of Matteo Ricci in 1582. The dilemma is clear; either the prototype of the fountain reached China before Ricci or the Chia-ching mark on the Sarayı ewer is apocryphal. In either case the answer is awaited with interest.

${ }^{284}$ Nos. $29.228-233$, plate 92 .

${ }^{285}$ See note 283 .

${ }^{285 a}$ T. Volker, op. cit., pp. 21-23, gives fuller and probably more accurate information on the early arrival of porcelain in Europe than was known to me at the time the above was written. 
The clay, though generally fine and smooth in quality, contains occasional imperfections and tends to have small pits and pebbles embedded in it here and there. Even the largest dishes are remarkably thin in potting and seem very brittle; many are cracked and chipped, and indeed it is surprising that so many have survived at all. The smaller pieces, dishes of say 14 inches or less, have glazed bases for the most part, but the larger pieces are not so treated. In both cases, the bottoms are often, though not invariably, convex, show radial chatter marks produced by the tool with which they were finished and sometimes have traces of a gravelly substance adhering to the foot rims. The feet tend to be thin, strongly made, and either vertical or undercut. In terms of general shape the most noticeable difference between these kraakporseleins and other sixteenth-century wares is to be found in the dishes; now for the first time there appears a foliate edge on a dish without a flattened rim (e.g., 29.203, pl. 101), and in those instances where the rim is flattened the outer horizontal area is wider and separated from the cavetto by a gentle curve rather than a sharp angle so that both areas may be decorated as a unit. The blue varies exceedingly from deep rich purplish shades through paler silvery tones to a thin dry-looking black. Marks, though perhaps not unknown, are rare. These are the physical characteristics of the group, and although some of them are relatively easy to distinguish at a glance, it is the decoration which really sets these wares apart. ${ }^{286}$

Although traditional motifs continue in use in the sense that flowers, trees, rocks, birds, beasts, insects, and formal stylizations are still to be found, the arrangement of the over-all patterns, the compositions of various groups, and indeed the methods of drawing some of the individual elements take on an entirely different aspect. Most striking perhaps is the division of the border designs on the dishes into radial segments varying in number according to the size of the piece, but usually running from 8 to 12 . The dishes illustrated on plates 100-104 show typical variations in the handling of this detail. No. 29.172 is divided into 12 segments in which a fungus spray and a flower spray alternate as the bottom elements of each, while at the top the sequence diamond, butterfly, cash, and bee is repeated three times; on 29.264 the segments are flattened on the outer edges so the dish is decagonal, and there are seven flower sprays, two groups of aquatic plants, and one panel showing two magpies on the wing in a cloudy sky with bushes below. Still further variations of this style are shown on 29.203 (pl. 101), while the next six dishes (pls. 102-104) show the more common treatment of the area where each segment contains a thickened frame of blue wash and is separated from the next by white bands in which are drawn beaded pendants, sometimes with diapered areas above and below. Within these frames the compositions may vary from scenes that are all alike to those that are all different in almost any combination. The

${ }^{286}$ It should be noted, however, that the Dutch themselves have not been precise in their definition of kraakporselein, and it is not impossible that they might apply the term to certain of the sixteenth-century types already described. 
four dishes on plate 104 for example were selected almost at random from a group of 53 in which, while it could be said that they are all alike, it is probable that no two are identical. Thirty-eight have foliate rims, the rest plain rims; and six different size groups are represented with diameters ranging from $10 \frac{1}{4}$ to 18 inches. This is the result, no doubt, of mass production, not in our sense of the word where every step is rigidly guided by a blueprint, but where a master design is given as the model and each painter has free rein to fill in the allotted areas with any one or more of a set series of motifs as his fancy dictates. This being the case and with the surface of the dish broken up into so many small areas to be filled, there is room enough for diversity; and to sort these wares into groups on the basis of duplicates is almost out of the question.

The designs in the centers of the dishes show the same variety of treatment observed in the borders. They may be placed within simple double circles or polygons, as in the cases of 29.172 and 29.264 (pl. 100), or they may be framed in elaborate arrangements of overlapping or contiguous diapered panels (pls. 102-104). One of the favorite subjects was the landscape with deer which is already familiar from wares of other types; and in some cases the deer may be identified although many are so roughly and freely drawn as to elicit from zoologists no more precise information than that they are evidently members of the family Cervidae. Those on 29.481 have already been mentioned as Père David's deer, and those on 29.148 (pl. 91) though more sketchily drawn may be the same species. Another identifiable type is that on 29.264 (pl. 100), the Chinese water deer (Hydropotes inermis), a small species with no horns on either sex but in which the male develops canine tusks as shown on the left animal in this scene. The two birds in the upper part of the picture, like those in one of the border segments, are magpies (Pica pica). In one other case an identification can be attempted though it remains most uncertain; it is just possible that the spotted deer on the bowl (29.389) on plate 107 may be intended to represent young sika, a species common to both China and Japan and characterized by spotted coats.

On some occasions the central landscape scene may include only birds as on 29.174 (pl. 104) where two quail (Coturnix coturnix) are shown in the foreground while several flights appear in the distant sky. In other instances the birds are used to form a more abstract design as on 29.172 (pl. 100), where cranes among clouds surround a central medallion framing the hexagram which is composed of the two trigrams $c h^{\prime} i e n$ and $k^{\prime} u n$ symbolizing heaven above and earth below. More formal arrangements include flowers in a vase as on 29.175 (pl. 104); and a less usual variation is found in the set of small dishes of which two are 29.283-4 (pl. 108). In this group the segmentation of the border is carried out in underglaze slip, and the central areas in blue-and-white are decorated with various floral patterns and auspicious objects.

Much the same repertory is found on the bowls. No. 29.394 (pl. 105) has the 
segmentation indicated by the use of 10 vertical floral sprays, although the actual framing of each unit has been omitted. It is interesting to note that a pair to this bowl exists in a Copenhagen silver mount dated $1608{ }^{287}$ No. 29.392 on the same plate is one of the rare marked pieces in this group with the character $f u$ in a square seal form under the glazed base. An unusually large pair of bowls are 29.379-80 of which one is illustrated on plate 106; and in this case the decoration is in the most commonly found kraakporselein style with six ogival medallions, like those on the borders of the dishes, framing landscape and figure subjects and separated by fungus and lotus scrolls surmounted by auspicious objects. On the inside are ducks and aquatic plants surrounding central landscape scenes. The inside of 29.393 (pl. 106) is again decorated in slip, a technique occasionally but not frequently found on these wares; a row of six cloud collar points lies above a band of lotus panels which in turn surrounds a recumbent horse with flame scroll done in underglaze blue. No. 29.388 (pl. 107) is a small bowl decorated with eight white deer against foliage backgrounds. These little animals are extremely stylized with their long slender legs, and not only is the type well known on export wares of this period including a large number of small jars found at various places all through southeast Asia, ${ }^{288}$ but vessels with the same decoration are also known in Dutch paintings of the seventeenth century. ${ }^{289}$

No. 29.382 (pl. 108) is one of a group of cup-shaped vessels with characteristic segmented decoration on the outside. Ogival medallions separated by beaded ornaments frame landscapes, figure scenes, flowers, and auspicious objects; and on the insides are floral sprays, books, gourds, fans, etc., similarly framed surrounding in each case a central design of a bird seated on a rock. With these cups is a series of covers with the same variety of decoration; and it was impossible to say which cover went with which cup as they seemed entirely interchangeable. The covers have unglazed flanges just inside the rims which rest on the unglazed lips of the cups; and the former are provided with small circular rims on top which serve as "feet" when the covers are inverted beside the cups as is the case with covered lacquer cups and bowls in China and Japan today. Two of these "feet" are marked inside with the hare mark, and one has the character $f u$ in a square. On the same plate is a small ewer (29.444) which may possibly belong to the same group although it is one of those cases where we cannot be sure the term kraakporselein is applicable. The segmentation is carried out in the division of the whole vessel into eight vertical panels, one of which shows a sage seated under a spreading pine branch, in another a sage walks in a mountain land-

${ }^{287}$ E. Hannover, Keramisk haandbog, vol. 2, p. 75, fig. 127; and Jenyns, Ming pottery and porcelain, plate $96 \mathrm{~B}$, which is a better photograph of the same bowl.

${ }^{288} \mathrm{Cf}$. ACASA, 5 (1951): plate 8 b.

${ }^{289}$ E.g., a still life by Jan Soreau (fl. 1615-1638) in the Walters Gallery, Baltimore (no. 37.1902), shows a bowl much like the one under discussion. Cf. Journal of the Walters Art Gallery, vol. 17 (1954): 34 . 
scape, and the rest are decorated with floral sprays. Under the base is the mark $f u$ shou-k'ang-ning in a double square..$^{290}$

A tall bottle-shaped vase and a ewer on plate 109 may also be members of the same family with the principle of segmentation emphasized by the hexagonal forms of the vessels themselves. The bottle (29.468) is decorated with a number of the motifs already seen on the typical kraakporselein and has the mark of the hare under its base. The ewer (29.467) is an exceptionally well made piece but so thin and delicate that it did not fully survive the firing and sags badly to one side when seen from the front. It may be that the unusually tall and slender foot, which accounts for more than onequarter of the height of the vessel, was not sturdy enough to bear the burden imposed upon it for the fault occurred where it joins the body. On the same plate is a small ewer (29.473) with high foot and the handle in the form of a rat with floral scrolls on its back. The rest of the decoration includes two phoenixes forming a medallion on each side, floral sprays, birds on fruiting branches above, and auspicious objects below. The piece must originally have had a cover, and the whole shape is most unusual, even perhaps somewhat un-Chinese, in conception. Under the base is the mark Ta-mingnien-tsao in underglaze blue. The final piece of blue-and-white to be illustrated is 29.484 , a curious deep cup with flaring rim and low spreading foot, the only piece in the collection which can in any way lay claim to the designation "stem cup." Like the ewer with the rat handle it is not kraakporselein but is nevertheless a product of the second half of the sixteenth century; inside the rim is a border of diaper pattern consisting of small rectangles worked into white diamond-shaped lozenges on a blue ground, usually considered a typical Chia-ching decoration. The sides are plain, and in the bottom is a cloud scroll in the form of a swastika. Outside, the border is a diamond diaper pattern of another type, while six even rows of white blossoms on a ground of blue wash cover the main part of the body above a band of lotus panels. Blue dots surround the swollen ring around the top of the foot over a row of pendent leaf forms. Both the decoration and the shape of this piece are most unusual, and the latter in particular seems quite un-Chinese in spirit; may this not possibly be an early example of European influence on the art of the Chinese potter?

The blue-and-white of the sixteenth century as seen in these examples selected from the Ardebil Collection shows, when viewed as part of the over-all development that took place in the manufacture of these wares, the steps which led from the relatively small but extremely refined output of the Ch'eng-hua period to the much larger and, in its own way, highly perfected output of the first two reigns of the Ch'ing

${ }^{290}$ A ewer of similar shape in the British Museum (TOCS, 18, pl. 6e) is decorated with floral sprays only and has an apocryphal Hsüan-te mark. Fu-shou-k'ang-ning, "good fortune, old age, health, and repose" is a sixteenth-century mark entirely in keeping with the structure and decoration of this ewer; and the Ardebil piece so marked tends to verify the presumed date of the British Museum ewer. 
Dynasty: the Shun-chih reign which, for all that most of the pieces were unmarked, produced some of the beautifully designed and decorated "Transition" wares, and the

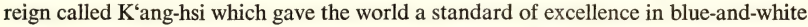
against which all wares have ever since been measured. The evolution took place, as a matter of fact, over a period of almost two centuries from the third quarter of the fifteenth to the third quarter of the seventeenth; and the reigns of Cheng-te, Chia-ching, and Wan-li were those in which the principal phases of the change may be observed, phases which included a gradual deterioration of the old style from exquisite taste and peerless technique into a routine though still skillful rendering of the traditional forms in the customary way, followed by new canons of taste and the consequent introduction of new elements of decoration executed in a noticeably bolder manner (Cheng-te and early Chia-ching), again followed by an apparently insatiable appetite for variety of decorative combinations as the demands of the court and the newborn export trade called for vast quantities of porcelain quickly, boldly, and often coarsely decorated (later Chia-ching and some of Wan-li), and finally the first glimmerings of a newly developing sense of refinement in both taste and technical ability that sometime in Wan-li heralded the coming of the great masterpieces of the Ch'ing Dynasty. Oversimplified though this may seem and difficult as would be the task of accounting for every piece of sixteenth-century blue-and-white in these terms, the hundreds of known pieces from this period when seen as a whole support the general features of an outline stated in these terms.

To return, in summary, to the beginning, the outline may be restated and further condensed to provide a synoptic view of the whole development of pre-Ch'ing blueand-white as it is known today. In the middle of the fourteenth century stands a group of wares whose antecedents are still unknown. Powerfully constructed and boldly decorated in broad areas of rich brilliant blues, they reveal a taste for closely knit vigorous designs in which is a curious combination of almost complete disorder with a sense of geometrical planning. Whether a chronological relationship exists between the two is not clear, but there is a hint that this may be the case in the wares of the next well-defined period which includes the Yung-lo and Hsüan-te reigns of the early fifteenth century. Some time about the turn of the century, soon before or after the year 1400 , the technique of the potter underwent a change which yielded wares of much greater refinement; many pieces were thinner and more delicate than their predecessors, but even the thick heavy dishes, bowls, and vases which continued in demand were more elegantly conceived and more precisely finished. And the decoration changed in keeping with the evident change in taste. Now the designs were drawn with thinner strokes and more sparingly disposed over the surfaces so that the white porcelain ground was more in evidence, and if they may be charged with a falling off in vigor, which in any case was slight, the decorators more than made up for this shortcoming with an increased skill and delicacy of drawing which matched the newfound 
refinement of the porcelains themselves. The word refinement has perhaps been used too much, but it cannot be overemphasized that therein lies the key to the age; and complementing the remarkable development of this quality in the manual skill of both potter and painter was an equal advance in the conception of the design as a decorative covering for the porcelain. All trace of disorder vanished, and orderly disposition of the elements of the design over the surface of the pot is the characteristic most striking to the eye and most permanent in its effect on the future history of the art. For in the many varieties of blue-and-white that were to follow, whether fine or coarse, overdecorated or under, vigorous or weak, the designs always reveal the fundamental sense of order that stems from the taste of this time. Whatever may have happened in the three decades of the "Interregnum," the wares of Ch'eng-hua show no evidence of decline but rather an intensification of the feeling for nicety of finish and refinement of painting that made them the most sensitive and delicate of all Ming blue-and-white. As has been said before, this was a point beyond which these qualities could hardly be expected to advance, and the reaction was inevitable. Conventional though nonetheless accomplished copying of the familiar motifs in the usual style carried into the sixteenth century when, as we have seen, the introduction of new elements in the design, the haste and often coarseness of execution under pressure of the relentless demand for quantity, led to a low point in taste as in technique. But as the century drew to a close attention was focused on the improvement of certain types of drawing which were again to reach the heights of sophistication. Curiously enough, it was not among the standard Wan-li wares with their traditional repertory of dragon, phoenix, lotus, prunus, pine, bamboo, and all the rest that this new movement took root; the heavy and uninspired drawing on these wares produced for domestic consumption grew duller and duller until it seems to have expired of sheer inertia. Side by side with this moribund art, however, was the new style begun perhaps in part to meet the requirements of the maritime trade; dull in itself to begin with, it contained in its sketchy fine line and wash drawing the seeds of the future splendor of blue-and-white, and even before the end of Wan-li there was ample evidence that something new and wonderful lay ahead. At that very moment Shāh 'Abbās completed his collection and placed it in the Shrine, and so we must look elsewhere to see what happened; all the signs were there, but so far as Ardebil by the Caspian was concerned the brilliant future to which they pointed, the wares of Shunchih and $\mathrm{K}^{\prime}$ ang-hsi, lay over the horizon. 


\section{THE WHITE WARES}

Second to the blue-and-white in numbers and most nearly related to them in interest are the white porcelains some of which are decorated with patterns incised in the paste or drawn in slip under the glaze and some of which are entirely plain. Among the latter are four dishes which are unusual in that they show traces of having been decorated with gilt designs over the glaze. In all cases, however, standards of connoisseurship for this group are the same as those to be used in considering the material and structural aspects of the blue-and-white; and in the white wares remaining at Ardebil the paste, the forms, and the details of the potting conform with those we have already found to be characteristic of the several Ming reigns; and incised decoration, when it occurs, also follows the patterns drawn in blue. For that reason it has not seemed necessary to illustrate more than a few typical examples which will serve to point out the obvious similarities between the two groups.

No one has yet ventured to point out a plain white version of any of the large midfourteenth-century wares now generally recognized in blue-and-white, nor do the remains of the Ardebil Collection offer anything that might possibly fill that gap. As has been shown, the physical characteristics of the period are such that a white piece of contemporary date should not be difficult to recognize; and if the fourteenth-century decorator had ever tried out his repertory in incised lines, the task should be even easier. On the other hand, the fact that the application of that repertory was carried out in such a purely painterly style in blue makes it seem likely that it may never have occurred to the decorator to try anything other than the brush. This does not mean, of course, that incised and slip designs were not known for both had flourished mightily in the Sung Dynasty white wares, the Ting, and the Ch'ing-pai; and both are found on the lesser wares of the fourteenth century such as stem cups and small bowls. So far, however, they have not been seen on the great dishes, bowls, and vases of the last Yüan reign, and the white wares we are about to consider begin in the early fifteenth century.

Large dishes again dominate the scene numerically, and the three standard types are represented: those with plain rims, those with flattened rims, and those with foliate rims with the cavettoes molded to match. In all cases the paste, the foot rims, and the potting parallel those details as we know them on the blue-and-white. The glaze is almost uniformly colorless, though in some cases a slightly bluish cast is evident, but no doubt this seems more striking in the absence of blue decoration, and there seems to be no reason to regard it as anything more than an accident in firing resulting from minor variations in the quality of the ingredients.

Under the thick and often uneven glaze the incised decorations, as well as those in 
slip, are difficult to make out, and when reproduced in photographs all but the clearest are impossible to see. No. 29.687 (pl. 110) bears the lotus bouquet as seen in blueand-white in such great numbers in this same collection ${ }^{201}$; and no. 29.678 on the same plate is one of two dishes decorated with large 5-clawed dragons drawn in the typical early fifteenth-century style. ${ }^{292}$ Both are plain-rimmed dishes of the kind most often found with these decorations in blue-and-white where the dragons are reserved in white on a ground of blue waves. ${ }^{293}$

No. 29.694 (pl. 111) is the best remaining example of those dishes which show traces of overglaze decoration in gold; and while a fair amount of the gilding has survived, the over-all impression is rather confused, and it is difficult to reconstruct the entire pattern. On the flaring rim is a broad and well-drawn scroll pattern not unlike the classic scroll on 29.68 (pl. 32) but with more fully developed leaf forms. The cavetto is rather jumbled, but traces of fungus sprays may tentatively be singled out; and the center pattern seems lost beyond recall. ${ }^{294}$ Outside the cavetto a chrysanthemum scroll with 11 blossoms is the best preserved of all. Among all the early fifteenthcentury porcelains now known, these seem to be the only ones with gilded decoration, ${ }^{295}$ and inasmuch as the technique is one that involves a second firing, the question naturally arises as to whether this is contemporary or a later addition. The whole problem is so new that it is too soon to draw any conclusion, but those parts of the design that remain clear enough to be seen do not contradict anything we now know about early fifteenth-century decoration; and pending more information and more examples there seems no reason not to accept them. Another dish of similar form has incised fungus scrolls on the rim, floral scrolls in the cavetto and floral sprays and scrolls in the center, all rather difficult to see clearly $(29.697, \mathrm{pl} .112)$; and 29.679 on the same plate has a flattened foliate rim and molded cavetto in the style well known from the blue-and-white group (e.g., 29.58, pl. 38), but there seems to be no decoration at all.

The white bowls again reflect well-known blue-and-white types. The lien-tž̆ shape of 29.717 (pl. 113) is a superb example with the lotus design delicately executed on the outside in incised lines beneath a narrow band of classic scroll. The

${ }^{291}$ Cf. plates 30-31.

${ }^{292}$ The dish illustrated is not in the Ardebil Collection, but a piece with identical decoration in the writer's possession photographed at the Freer Gallery of Art by infrared light in order to bring out the hidden design more clearly. Facilities for this type of photography, which is indispensable to the thorough study of this group of wares, were unfortunately not available in Tehran.

${ }^{293}$ No blue dragons on large white dishes of this period have yet been seen; cf. p. 96 above.

${ }^{294}$ Either ultraviolet or infrared light might make it possible to reconstruct these designs more fully. The condition of the cavetto makes one wonder if this dish may not have been gilded more than once.

${ }^{295}$ A large white Chia-ching bowl on the New York market is decorated with gold phoenixes among clouds, and the use of gilding in the sixteenth century is well attested by abundant wares of the kinrande group. 
double tier of slender petals is less common though not unknown ${ }^{206}$; and the slightly dotted effect of the outlines seen in the photograph is accidental. The glaze has run thick in the incised areas, bubbles have formed there, and some of them have burst in the firing; accumulated dirt in the resulting pits accounts for the appearance of the occasional dots along the lines. The pair to this bowl is decorated with a plain gold band about three-eights of an inch wide applied around the outside of the rim. Although this immediately calls to mind the famous porcelains in Istanbul ornamented with gold and jewels, ${ }^{297}$ the rather crude workmanship of the band on this white bowl and the fact that the metal surface is entirely undecorated make any connection between the two seem unlikely; and there is still no certainty about where that fine jeweling was done. Had it been the habit of the Persians to embellish their Chinese porcelains in that way, one would have expected to find some examples in the Ardebil Collection, but none remain, and there is no indication in the original list that any such wares were included in the vaqf. It has been customary to think in terms of Iran or India or Turkey as the source of this style, but there is no real reason why it could not have been done in China itself. Although no such porcelains seem to be known from that source, the same work was used in decorating the set of gold objects reported to have come from the tomb of a fifteenth-century emperor ${ }^{208}$; and a painting in the Palace Museum in Peking illustrates a bowl and a ewer studded with jewels. ${ }^{299}$ It is not clear whether porcelain or metal vessels are intended in this representation, but in either case there is evidence enough that decoration in this manner appealed to at least one segment of the Chinese taste.

No. 29.716 (pl. 113) has the deep sides and plain rim of the well-known type represented by 29.340 (pl. 49), and the incised design of a single chrysanthemum spray inside and four fruit sprays above a row of naturalistic lotus petals duplicates the pattern seen in blue-and-white. The same shape on a larger scale is seen in the case of 29.774 (pl. 114) which parallels 29.335 (pl. 49), a bowl of only slightly smaller size. ${ }^{300}$ The incised floral decoration and the general quality of the white bowl are inferior to those in the blue-and-white, but there seems no reason to distinguish between them so far as date is concerned. In the case of 29.702 (pl. 113) the form is noncommittal, and with no decoration of any kind to serve as a guide the matter of dating is more difficult, but it may well be a fifteenth-century piece.

The white group also includes two ewers of the usual early fifteenth-century type

${ }^{296}$ Cf. PMA 55; and Brankston, Early Ming wares, plate 13b. Both are marked Hsüan-te.

${ }^{297}$ Cf. Zimmermann, Altchinesische Porzellane im Alten Serai, plate 70; and Pope, Fourteenthcentury blue-and-white, p. 22.

${ }^{298} \mathrm{Cf}$. Sotheby and Co., Sale catalogue of the Eumorfopoulos Collection, May 28-31, 1940, lots 509-515.

${ }^{289} \mathrm{Cf}$. Ku-kung-shu-kua-chi 故宮書畫集, no. 34, p. 3. The painting is published as Sung but does not look that early; it may be seventeenth century.

${ }^{800}$ PMA 33 is almost exactly the same size ( $13 \frac{1}{2}$ inches) but finer in quality. 
and one of the less usual seng-mao- $h u^{301}$ type, but all are in poor condition. No. 29.722 (pl. 115) is one of five vases of mei-p'ing shape with incised fruit sprays and floral scrolls; all are very thinly potted and have unglazed bases with low flat rims. They parallel in every respect their counterparts among the blue-and-white mei-p'ing of the early fifteenth century (e.g., pl. 51), and there is no reason to date them otherwise..$^{302}$

The earliest properly dated porcelain in the Ardebil Collection is the dish 29.657 (pl. 115) with the 6-character nien-hao of Ch'eng-hua in underglaze blue on the base. Lacking decoration of any kind it is potted with all the delicacy and finesse of the period; the deep foot tapers to a narrow, finely finished rim, and the smoothly glazed base is slightly convex. As if in keeping with the extraordinary quality of this dish, the lapidary has incised the dedicatory inscription of Shāh 'Abbās with unusual precision and clarity, and the curious unidentified owner's mark can be seen incised on the base near the nien-hao. This piece introduces a group of 16 dishes of about the same size, all finely potted and with glazed bases; nine are unmarked, and in addition to this Ch'eng-hua piece, five are marked Hung-chih and one has the Cheng-te nien-hao. The seven marked pieces all share the exceptionally well-cut Shāh 'Abbās mark, and the group as a whole is of particular interest because of the great similarity of the dishes over a period of at least two and perhaps three or more decades; each one, when looked at alone, seems entirely right for the period of its mark, yet were it unmarked it would be most difficult to know which nien-hao to choose for it; and even with properly identified pieces of all three reigns right at hand, it is no easy matter to allot the nine unmarked pieces to their proper groups.

No. 29.714 (pl. 114) is one of three identical undecorated bowls which carry the Hung-chih nien-hao; and but for this mark it would be impossible to say whether they were Ch'eng-hua or Hung-chih or indeed even Cheng-te in date. In size, shape, and quality they are comparable to those mentioned in connection with the question of the so-called "Palace Bowls." ${ }^{303}$ The example of these plain white wares with their identifying nien-hao lends support to the cautious attitude that was adopted in respect to the blue-and-white grouped in the late fifteenth century; tempting as it might be to say such and such an unmarked piece is surely Ch'eng-hua, the lesson of these white dishes and bowls should remind us that our connoisseurship simply does not go that far. A marked Hung-chih bowl in Isfahan, similar to this 29.714, has incised on the side of the foot in extremely fine script the words Shāh Jahängīr Shāh Akbar. ${ }^{304}$ This mark, in addition to the dedicatory phrase of Shāh 'Abbās, suggests that the latter received the bowl as a gift from the Mughal Emperor Jahāngīr.

${ }^{301}$ Brankston, op. cit., plate 2.

${ }^{302}$ In his article in TOCS, 25 (1949-1950):13-19, the late Dr. Bahrami was in error when he described one of these mei-p'ing (his pl. 2a) as having a Hung-chih mark. None of this group is Marked, and all are early fifteenth century.

${ }^{303}$ Cf. pp. 109-112 above, and plates 62-64.

${ }^{304}$ See pp. 56-57 above. 
These notes on the white wares may be brought to a close with the mention of three more pieces. A large bowl incised with flying horses among clouds (29.772, pl. 114 ) bears the characters $f u$-kuei-chia-ch' $i$ in underglaze blue on the base, and this together with the deep undercutting of the foot rim indicates a middle or late sixteenthcentury date perhaps in the Chia-ching reign, a period entirely appropriate to the style of the decoration and the mediocre quality of the bowl; and a fragmentary bowl of smaller size, decorated with incised floral designs inside and out, is of interest as the only white piece marked with the nien-hao of Wan-li (29.704, not illustrated). No. 29.773 (pl. 115) is a small vase of kuan shape with unglazed base and no decoration. Although there is very little to go by, the shape of the piece and the indifferent quality again suggest an attribution to the sixteenth century. 



\section{THE POLYCHROME WARES}

Among the wares decorated with overglaze enamels the earliest dish is probably 29.768, which bears the Ch'eng-hua mark in six characters written in underglaze blue on the base. Well potted and with gently flaring rim, it is plain inside and decorated outside with fishes and aquatic plants in dark blue under a solid turquoise glaze. This unusual piece is almost exactly duplicated by 29.769 (pl. 116), which differs only in that it is one quarter of an inch larger and carries the 4-character mark of Cheng-te.

No. 29.761 on the same plate is one of a damaged pair of dishes with Hung-chih marks decorated on the inside with two lions and a circular design (the usual brocaded ball?) amid streamers, and outside with birds on fruiting and flowering branches, flying birds, and dragonflies. The enamels are red, yellow, and green, and the drawing is in the usual blackish-brown line. Very similar in style and quality is 29.763 (pl. 117), which is unmarked; the decoration shows bamboos, a stylized rock, a peach tree, and butterflies on the inside with the same motif adjusted to the narrow space and twice repeated outside. Without the evidence supplied by 29.761 it might be tempting to consider this dish Ch'eng-hua on the grounds of its quality, and it may possibly date from that period, but it seems likely that, whatever its proper reign name may have been, not more than a few years can separate it from the Hung-chih piece. The lesson has already been learned from the white wares above. Two bowls with flaring rims are also marked Hung-chih in six characters $(29.756,29.765$, not illustrated $),{ }^{305}$ and although somewhat damaged are of good quality and decorated outside with two $p^{\text {pa-ts }} \boldsymbol{s}^{\prime}$ in a landscape in turquoise, red, yellow, and green enamels; inside is a flower spray in red, yellow, and green.

The 6-character Cheng-te mark ${ }^{308}$ appears on 29.764 (pl. 117), and beside it is carved the unidentified owner's mark; inside the bowl is a ch'i-lin with flames and auspicious objects, and outside are a $\operatorname{ch}^{\prime} \mathrm{i}-\mathrm{lin}$, an elephant, a pai-ts' $e$, and a lion, each caparisoned and carrying on its back a red disk on which is written the character $f u$ "happiness" in gold. The foot is finely made, deep, tapering, undercut, and smoothly finished at the rim.

Two dishes decorated with one red fish inside and four red fishes outside $(29.753$ and 755, not illustrated) are probably of the same period, not far from the year 1500; the bases are well made and glazed but carry no marks.

${ }^{305} \mathrm{Cf}$. TOCS, 25 : plate $3 \mathrm{c}$.

${ }^{306}$ Cheng-te marks as a class present a number of problems which have been outlined by Sir Harry Garner [TOCS, 27 (1951-1953): 66-67]. The 6-character mark on this bowl and the 4character mark on the dish described above $(29.769$, pl. 116) are both very well written, perhaps even by the same hand, both are on pieces of excellent quality, and both employ the less usual form of the character nien 年. Calligraphically this form of nien is archaistic but entirely acceptable. One possible explanation is that it may simply reflect the personal style of one man who was writing nien-hao in Cheng-te times. 
Nos. 29.757 and 29.759 (the latter illustrated on pl. 118) are rather crudely decorated in overglaze enamels of red, yellow, and green, one showing a landscape with figures (a legendary scene?), and the other showing lions among scrolling flowers; but in spite of their indifferent quality, they are of special interest because of their marks. Crudely incised in the paste under the glaze on both dishes is the 6-character mark of the Chia-ching period, and over this, in a different orientation, is written Hsüan-te-nien-tsao within a double circle in iron red over the glaze ${ }^{307}$ It seems obvious that someone wanted to enhance the prestige of these sixteenth-century dishes by superimposing the nien-hao of one of the great early fifteenth-century reigns; but the motive for this is by no means clear, and a number of interesting questions are raised. Why, when the Chia-ching mark was incised in six characters ending with the verb $c h i h$, did the next man use the less formal 4-character nien-hao with the verb tsao? Were the Hsüan-te marks added at the same time the enamel decoration was applied or later? If later, how much later, and if at the same time, were both done as soon as the dishes were made? Or if both were added later, was this done during the Chia-ching reign or in that of Lung-ch'ing, or in Wan-li? In view of the incised Chia-ching marks and the terminal date of the Ardebil Collection, any tampering with the original dishes must have taken place within 89 years, and the definite limitation of time tends to make the questions even more intriguing, but the answers may prove elusive for some time to come.

Also from the sixteenth century is a large bowl crudely decorated in red and green enamels and gold (29.770, not illustrated); this inferior porcelain is marked in underglaze blue with the characters $f u-k u e i$-chia-ch $i$ in a rectangle on the base, a mark of commendation usually associated with the Chia-ching reign.

No. 29.758 (pl. 118) is decorated in a most unusual way in that it shows, on the outside, four fishes in underglaze red drawn in white spaces reserved in a sea of underglaze blue waves; and the curly white areas representing the foaming crests of the waves are all filled in with iron red over the glaze. A band of the latter red also surrounds the lower part of the bowl. Inside is a central medallion with a similar underglaze red fish surrounded by blue waves trimmed with iron red as on the outside. The inner sides of the bowl are decorated with aquatic plants in colored enamels. Under the base is a poorly written 6-character Hsüan-te mark in the style usually associated with late sixteenth-century copies; and this date, perhaps Wan-li, is confirmed by the deep, slightly undercut foot.

A bowl with flaring rim and marked with the 6-character Ch'eng-hua nien-hao (29.766, not illustrated) is decorated with a landscape and figures in the typical Wan-li 5-color style. From the same period are three bowls with flaring rims and a dish, all in the same colors and properly marked with the Wan-li nien-hao in six characters. The bowls are additionally decorated with four red enamel fishes inside each.

${ }^{307} \mathrm{Cf}$. TOCS, 25: plate 3a. 


\section{THE MONOCHROME WARES}

Sixteen monochrome yellow wares represent the usual types of bowls and dishes from the reigns of Hung-chih, Cheng-te, Chia-ching, and Wan-li. All but one are marked, and this is a dish with foliate rim and the sides molded in the shape of lotus panels; on the poorly glazed gravelly base is a fruit spray mark in underglaze blue. The piece resembles the poorest kraakporselein in quality and is no doubt late sixteenth century. The Chia-ching marks on two dishes are very poorly written and may possibly be Wan-li copies (29.731-732).

No attempt was made to assign dates to a bowl and a dish with coffee-brown glazes and no marks (29.743-744, not illustrated).

Among the five blue pieces is an unmarked bowl for which any one of several periods might answer. A bottle with a 5-clawed dragon incised in the paste under the blue glaze (29.746, not illustrated) is marked Hsüan-te in six characters and may be assigned to the second half of the sixteenth century; and the same date applies to two damaged blue ewers with buff-colored biscuit designs on the sides $(29.745,771$, not illustrated). Most remarkable of the blue wares is 29.747 (pl. 119), a large dish with foliate rim; the glaze is thick dark blue with a slightly mat surface, and in the center is a great 3-clawed dragon in white slip pursuing a flaming pearl. The scales and all details of the beast's anatomy are incised in the slip with fine lines; and the three long thin curving claws on each foot, the narrow snout, and the slender body are all in the fourteenth-century manner ${ }^{308}$ Further confirming this attribution is the base of the dish where the unglazed surface reveals the type of paste appropriate to the period, and the inner edge of the strongly made foot curves gently down to the flat central area. Unusual as it is, this dish does not stand alone. A mei-p'ing from what may have been the same set is in the Grandidier Collection in Paris (pl. 138, B), and saucer dishes decorated with related dragons are known. ${ }^{309}$

Perhaps the most surprising piece in the whole collection, though certainly not the most beautiful, is that shown on plate 120. Made of brownish-gray stoneware, it is modeled in the form of a recumbent cat; on its back rises a cylindrical tube with a

${ }^{308}$ Cf. the dragon on 29.47 (pl. 15) above.

${ }^{309}$ Cf. Jenyns, op. cit., plate $45 \mathrm{~b}$. Similar small saucers are in the David Foundation and in the Victoria and Albert Museum. The latter museum also has the spouted dish decorated in the same technique with a flying goose on the inside and floral sprays outside that was sold from Mrs. Alfred Clark's collection (Sotheby and Co., 24 March 1953, no. 68); the same dish was no. 1486 in the Chinese Exhibition at Burlington House, 1935-1936, where it was called "16th century." A bottleshaped vase with a dragon like those on our plate and on the Grandidier mei-p ing is shown on folio 42 of the British Museum Khwaju Kirmani Ms. It is reproduced in TOCS (1934-1935): plate 7. 


\section{2}

squared flange at the top and bottom; inside the hollow head is a small spout for pouring which can be seen through the empty eyes and again where it emerges from the half-open mouth supported between the upper teeth and the curled-up tip of the tongue. A thick streaky glaze of watermelon green covers all but the base, and there it has just run over the edges. On the right shoulder is the vaqfnameh of Shāh 'Abbās. Evidently this is a pouring vessel of some sort and may in a general way be related to the kĕndi form; but animals used as the bodies of kèndi are stiff and formal, whereas this one is shown in a relaxed and lifelike feline pose that is strikingly realistic. Nothing similar seems to have been noticed, and lack of comparative material makes the dating of such an apparently unique piece extremely difficult; in this case the Shāh 'Abbās mark happily provides a terminus post quem non, but how long before 1611 it may have been made is anybody's guess. 


\section{THE CELADONS}

Coming as they do from a different group of kilns some 150 miles southeast of the northern Kiangsi area which produced most of the white porcelains, both plain and decorated, the celadons present a separate set of problems; but at the same time it will be seen that certain relationships exist between the two kinds of wares. An important factor to be noticed is that the celadons are the survivors of an ancient ceramic tradition in Chekiang, one that goes back to the Yüeh wares of the Han Dynasty and continues without interruption through $\mathrm{T}^{\prime}$ ang and Sung in the production of fine gray porcelaneous stonewares covered with high-fired felspathic glazes tinted various shades of green by the inclusion of ferrous oxides in the mixture. At what stage in history the body material became vitreous is not clear, but it seems to have been so by Sung times if not earlier, and from then on it is entirely proper to call it porcelain, as did the Chinese, regardless of the presence or absence of such western criteria as translucency and pure whiteness. Thus by the time the blue-and-white wares came on the scene ultimately to supersede the celadons in popularity both domestically and as articles of international trade, these handsome and venerable gray-green wares already enjoyed a seniority of some 13 centuries or more. In the past half century, as the full scope of Chinese ceramic history has gradually unrolled before our eyes, the Sung celadons have proved so appealing to our taste because of the purity of their forms and the subtlety of their glazes that the word "celadon" has tended to become almost synonymous with Sung; and there has been an inclination on the part of many not too deeply versed in the complexities of the subject to assign all celadons, except of course those made of white porcelain and bearing Ming and Ch'ing dates, to that period. It was this indiscriminate and wholesale assignment of all gray-bodied wares with celadon glazes to that then newly discovered golden age of Chinese ceramics that trapped Zimmermann into the erroneous attribution of the great celadons in the Topkapu Saray for which he used what he must have considered the cautious designation "Sung or Yüan." ${ }_{110}$

Although a number of large, heavy, gray-bodied celadons are known bearing dates in the fourteenth, fifteenth, sixteenth, and seventeenth centuries, they have not yet been brought to bear on the problems they might help to solve, and a full-scale reappraisal of these wares should be undertaken. This is no easy matter, for it will require a careful comparative study of all the dated pieces that can be found; and the rest of the known wares, including the 1,300 or more in Istanbul must then be reexamined in the light of this study and of such other evidence as may be available. At the present time the ground has not yet been prepared for such a task, and it would in any

${ }^{310} \mathrm{Cf}$. Zimmermann, op. cit., plates 3-21. 
case be far beyond the scope of the present volume; but inasmuch as the 50-odd celadons in the Ardebil Collection may be considered members of the same family as those in the Topkapu Sarayı, the examination of these may be of interest as suggesting certain future lines of investigation and hinting at possible solutions to some of the problems.

As has already been noted, more than 20 of the pieces without dedicatory inscriptions are found among the celadons, and as these are not part of the original gift to the shrine they need not occupy us for long. It is interesting, however, to find that this unmarked group includes the only pieces that may possibly have any claims to Sung origins. One is a small bowl with glossy olive-green glaze and a small foot showing brownish-gray clay partially tinged with iron red, the ware known as northern celadon. ${ }^{311}$ Two small dishes with flaring rims and fine glaze of kinuta type may also be Sung; one has a fluted cavetto, the other has two fishes in relief on the inside and a fluted exterior ${ }^{312}$ Although all three are of decent quality, there is nothing remarkable about them to make them worthy of inclusion in our illustrations.

More than half the celadons are large dishes, and the sudden popularity of this new form in Yüan times has already been alluded to in connection with the fourteenthcentury blue-and-white ${ }^{313}$; but it is impossible to say at this time just what lay behind that development or to outline the steps by which it took place. In any case documented pieces of Sung date are rare. Two large dishes in the David Collection are marked Ta-Sung-nien-tsao 大年造 and Yüan-yu-nien-tsao 元称年造, respectively, under the glaze on their bases; the former, in incised characters, refers to the whole dynasty, and the latter, in relief characters, is the nien-hao of the Sung reign that covered the years 1086-1094. ${ }^{314}$ Both are unlike any other known Sung wares in shape, size, and decoration, while in physical properties they have certain points in common with some of the large celadons in the Near East. And the latter, as we shall see, have demonstrable affinities with the blue-and-white wares of the fourteenth and early fifteenth centuries.

The great dishes which bear the mark of Shāh 'Abbās have large, low, strongly

${ }^{311}$ No. 29.597 ; h. $1 \frac{3}{4}$ inches $\left(4.5 \mathrm{~cm}\right.$.) ; d. $4 \frac{3}{8}$ inches $(11 \mathrm{~cm}$.). Certain recent writers have begun to classify all northern celadon as Ju ware, a practice which I consider misleading and unjustified. Ju was a particular ware made in small quantity over a short period of time and held in the highest esteem by connoisseurs; northern celadon, for all that some fine pieces are known, is a common utilitarian ware of which there is a great abundance. The fact that some of it may have been made at Ju-chou is irrelevant; most Chinese pottery centers produced several kinds of wares, and it has not heretofore been customary for that reason to confuse the issue by calling them all the same thing.

${ }^{312}$ Nos. $29.598-599$; h. $1 \frac{3}{4}$ inches $(4.5 \mathrm{~cm}$.$) ; d. 5 \frac{1}{4}$ inches $(13.5 \mathrm{~cm}$.).

${ }^{313}$ Cf. p. 61 above.

${ }^{814}$ Cf. Hobson, David Catalogue, plates 47 and 48 . The diameters are 14.8 inches and 18.9 inches, respectively. On p. xvii of the text he notes that the latter does not convince everybody. 
made foot rings with rounded rims completely glazed over, and on the glazed base is a ring of exposed biscuit which has in most cases burned red in the firing ${ }^{315}$; this feature appears on the two dated pieces just described. ${ }^{316}$

The decoration was carried out for the most part by means of designs incised or carved in the soft clay, and the several ways in which the cutting tools could be used produced a variety of results. By holding his point vertically the decorator could draw a narrow line, and by leaning it more or less to one side or the other he achieved varying widths as the design required. While this was always a more cumbersome technique than painting, a considerable degree of modulation was available to the skillful hand as can be observed in the designs on 29.617 and 29.619 (pl. 121). On the former he has confined himself to a single bold and freely drawn lotus dominating the whole center of the dish, and on the latter separate zones of decoration are conceived to cover the rim, the cavetto, and the center, respectively, just as was done in the blueand-white. The most delicate and sensitive example of this drawing is that on 29.621 (pl. 122) where a single tree peony decorates the center of the dish. From the broad soft strokes at the points of the leaves to the fine sharp lines of the veins a wide range of possibilities in this technique has been utilized in a very simple sketch. Aside from this and a running scroll on the rim, there is no decoration. Not only in the drawing, however, is this piece remarkable; from the standpoint of quality it is unsurpassed. The fine-grained very light gray, indeed almost white, clay has been flawlessly potted, and where it shows in the unglazed ring on the base it is almost untinged by iron red; this ring itself is remarkable for its prefect delineation when compared with the messy uneven rings on other wares of the type. Aside from this band of pale gray biscuit the dish is covered in a rich even sea-green glaze with an unimpaired glossy surface. In every way it is a triumph of the potter's art. On 29.630 and 29.631 (pl. 123) the flowing waves and floral patterns of the two cavettoes surround central areas tightly covered with interlocking lozenges based on diamond patterns and squares, respectively. These latter, which thanks to the relief caused by the deeply cut lines make the center of the dish resemble a waffle, may be related in spirit to some of the diamond and interlocking cash-shaped diaper patterns of the fourteenth-century blue-andwhite. The "waffle" pattern again covers the center of 29.626 (pl. 123), but here the cavetto is executed in a different technique by which the background is all cut away leaving the floral scrolls to stand out in relief.

${ }^{315}$ They are sometimes known as the "red ring base" type.

${ }^{316}$ Among the celadons which lack the dedicatory inscription are seven dishes 13-14 inches in diameter which are treated in the opposite way: the foot rims are unglazed and the bases solidly covered. Although the feet on these latter are smaller in proportion to the size of the dishes, cut more deeply on the inside, and thicker and more sloping on the outside (pl. 124), the two groups are otherwise much the same in character, quality, type of decoration, and general proportions. It is not clear if the difference in the bases implies a distinction in date or place of origin or either. At the moment I am inclined to think it need not. 
Although none of these celadon dishes from Ardebil provides a direct parallel with the blue-and-white wares insofar as the decoration alone is concerned, there are two members of the same family in the Topkapu Sarayı which are so strikingly similar to blue-and-white dishes from Ardebil that they cannot be overlooked in this discussion. The grape design with curiously pointed leaves on one of the Istanbul dishes ${ }^{317}$ is duplicated almost exactly on 29.60 (pl. 39); and the large litchi dish ${ }^{318}$ has its counterpart in 29.63 (pl. 41) even to the separate flower sprays in the 16 molded sections of the cavetto which correspond to the foliations on the rim. These two are altogether remarkable, and even in the absence of such detailed duplication it will be seen that a number of other dishes in the Sarayı Collection are decorated in a spirit closely akin to that which inspired the painters of the blue-and-white. ${ }^{318}$

Aside from the large dishes, certain other celadons provide interesting comparative material. The bowl 29.646 (pl. 125) has a single floral spray incised in the bottom and is otherwise undecorated; and the glazed foot rim and red ring base relate it to the large dishes. It is heavily potted, and although the foot is somewhat different in profile the over-all proportions are those of 29.320 (pl. 24), which has been pointed out as a new shape heralding the advent of the typical Ming bowl. The tripod (29.655, pl. 125) is cylindrical in form and rests on three short legs, one of which has been broken off, showing that it was only lightly luted to the body. Around the surface are peony scrolls in relief; the stems were left in relief by cutting away the clay on either side, and the leaves and blossoms look as though they had been molded in separate pieces of clay and then applied to the surface at the appropriate points. The curious structure of the double bottom is shown on plate 142; in both this case and that of the baluster vase 29.648 (pl. 129) there is no opening in the inner bottom, and the function of the lower bottom with its central perforation is not clear.

No. 29.647 (pl. 126) is unfortunately fragmentary; but the curious shallow bowl contracted just below the lip strongly suggests the upper part of the blue-and-white stem bowl at Oxford, ${ }^{320}$ and the small smoothly cut remnant of a base may well have been the top of such a flaring stem. The style of the boldly incised lotus panels and the abstract leaves and round dots within them are also worthy of close examination. Two more bowls are of interest for their own intrinsic qualities rather more than as examples of a particular trend in style. No. 29.649 (pl. 127) is beautifully incised with lotus scrolls on the outside and a pattern of interlacing waves on the inside; and in the center another technique has been employed where a single floral spray in low relief

${ }^{317}$ Cf. Zimmermann, op. cit., plate 10 , where the dish is incorrectly oriented; the grapes should be pendent.

${ }^{318}$ Op. cit., plate 12 .

${ }^{319} \mathrm{Op}$. cit., plates $11,13,14,15$. The central area of the latter is reminiscent of such fourteenth-century designs as that on our 29.40 , plate 8 , although the dish itself anticipates a later form. Cf. the shape of PMA 20 and the discussion of the late fourteenth-century types on pp. 78-79 above.

${ }^{320}$ Cf. OCS Catalogue, 1953, no. 18, Garner, Oriental blue and white, plate 9. 
appears to have been impressed in the clay with an intaglio stamp. The other bowl, 29.651 (pl. 128), is plain and owes its beauty to the unusual shape, fluted sides, and foliate rim; in the center a lotiform medallion stands in sharp relief and also appears to have been stamped in a mold, perhaps, in this case, as a separate piece of clay pressed into the bottom of the bowl. The foot is very small in proportion to the over-all diameter, the unglazed rim is iron red, and there is a recessed circular hole in the center. This latter might possibly penetrate the base of the bowl proper and only be covered by the clay of the lotus medallion applied to the inside.

A small baluster vase with horizontally fluted neck of flaring trumpet shape is so well proportioned that it could be mistaken in the photograph for one of its larger counterparts. Simple incised lotus scrolls adorn the body above a row of slender petals carved in low relief $(29.648, \mathrm{pl} .129)$. The piece has a double base, and the bottom surfaces of both levels are glazed as may be seen through the central perforation in the lower one; and glaze even covers the inner edge of this hole. Much of the base is covered with gritty adhesions and deposits of reddish clay; the foot rim is unglazed and fired to an iron red. A bottle-shaped vase of the type called yü-hu-ch'un-p'ing is, surprisingly enough, somewhat taller than the preceding piece $(29.652, \mathrm{pl} .129)$. The decoration is difficult to make out in the photograph; but on close examination is seen to consist of a row of stiff leaves above a band of diamond diaper pattern on the neck, and a row of trefoils pendent on the shoulder over the main body design of floral scrolls. Around the lower part is a row of lotus panels. ${ }^{321}$

Two kuan vases are illustrated to complete our descriptions of individual vessels among the Ardebil celadons. Both 29.650 and 29.654 (pl. 130) are squat in shape, broader than high, and both have short straight necks sloping slightly inward and sides curving strongly inward toward bases which are smaller than the tops. In both cases the bottom has been made by inserting a saucer to cover up the opening. The form of 29.650 is emphasized by deep narrow vertical fluting from the neck to the base making a vase of exceptional simplicity and beauty ${ }^{322}$; and the decoration of 29.654 consists of floral scrolls left in bold relief when the background was carved away; a band of stiff leaves is indicated around the base.

It would be premature to base a final judgment of all celadons in this large heavy class on the few observations set down here; but pending a more thorough investigation of the whole subject, certain points may be restated as having possible value for future study. These wares are evidently products of Chekiang Province, and the clays and glazes are closely related to those used in that area over many centuries; but aside

${ }^{321}$ For a blue-and-white vessel of this shape decorated with elements of the same repertory (i.e., stiff leaves, pendent trefoils, and lotus panels), cf. PMA 22.

${ }^{322}$ Zimmermann, op. cit., plate 7 , is the covered counterpart of this piece. He describes it as $30 \mathrm{~cm}$. high; if this measurement includes the cover, the two pieces must be very nearly identical in size. 
from those basic physical properties and aside from the technique of decorating by incising and carving the clay which is known on such Sung wares as Ch'ing-pai, Ting, Tz'u-chou, and Yüeh, these wares have little in common with any ceramics made in the Sung Dynasty. In their most striking outward aspects, size and shape, they are new arrivals on the Chinese ceramic scene. At the same time, it is in these very respects that they are most closely related to that most important of all ceramic innovations, white porcelain decorated in blue. Further, as has been shown, there are close parallels between some of the decorative motifs used on the two kinds of wares. Which came first we cannot now say with assurance, but any priority that one may have enjoyed over the other must have been slight at best; and for all practical purposes there seems to be no reason why the fwo may not be contemporary. It is the blue-and-white which provides us with such points of reference as are available in respect to chronology; and while many questions remain to be answered, there can hardly be any doubt that the types most closely akin to these celadons are fourteenth- and early fifteenthcentury in date. In the long run, therefore, when the whole field of celadon wares is subjected to a more critical analysis we may find ourselves forced to abandon any thought of Sung attributions for the large dishes and the family they represent; the cautious designation "Sung or Yüan" may also be set aside; and these wares may find their proper niche in late Yüan and early Ming. 


\section{APPENDIX: STATISTICAL NOTES ON THE COLLECTION}

The total number of Chinese porcelains remaining in the collection is 805 . In 1949 the group was divided and 39 pieces were placed on exhibition in the Chehel Sotūn in Isfahan, and the circumstances of this study were such that these were not numbered. Of the 774 pieces numbered in Tehran, eight were celadon dishes later found to be Persian imitations of Chinese types. The 766 properly numbered Chinese wares plus the 39 unnumbered pieces in Isfahan give the total of 805 , and this group is treated as a whole throughout. Minor differences between the figures given below and those published in the preliminary note in HJAS, 13(1950): 559-562 are the result of further checking of the field notes and the revision of certain attributions as the study progressed. With the exception of those figures which arbitrarily assign marginal and uncertain types to definite periods and hence are always subject to revision, the count is believed to be as accurate as it is possible to make it without reviewing the porcelains themselves.

The types of wares are as follows:

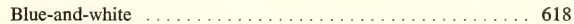

White .......................... 80

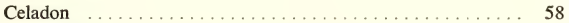

Polychrome .......................... 23

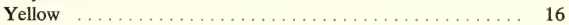

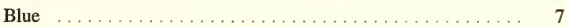

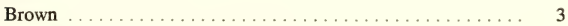

805

THE BLUE-AND-WHITE: TYPES AND PERIODS

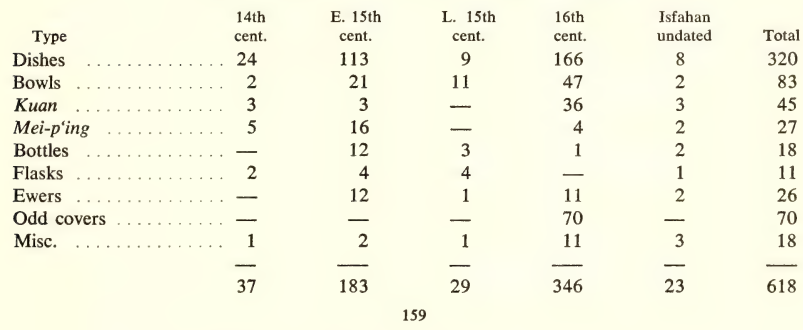


OTHER WARES BY TYPES ONLY

\begin{tabular}{|c|c|c|c|c|c|c|}
\hline Type & White & Celadon & Polychrome & Yellow & Blue & Brown \\
\hline Dishes & 46 & 33 & 10 & 6 & 2 & 1 \\
\hline Bowls & 23 & 17 & 13 & 10 & 1 & 2 \\
\hline Kuan .. & 1 & 3 & - & - & - & - \\
\hline Mei-p'ing & 6 & - & - & - & - & - \\
\hline Bottles . & - & 1 & - & - & 1 & - \\
\hline Ewers ... & 4 & - & - & - & 2 & - \\
\hline Odd covers & - & - & - & - & 1 & - \\
\hline \multirow[t]{3}{*}{ Misc. . . . } & - & 4 & - & - & - & - \\
\hline & - & - & - & - & - & - \\
\hline & 80 & 58 & 23 & 16 & 7 & 3 \\
\hline
\end{tabular}

THE NON-CHINESE MARKS INCISED OR DRILLED IN THE PASTE OR GLAZE

The vaqfnameh of Shāh 'Abbās appears on 774 pieces.

The abbreviated vaqfnameh appears 7 times among the above.

Qarachaghãy appears on a total of 94 pieces.

Blue-and-white ......................... 92

14 th century $\ldots \ldots \ldots \ldots \ldots \ldots \ldots \ldots \ldots \ldots \ldots \ldots \ldots$

Early 15 th century $\ldots \ldots \ldots \ldots \ldots \ldots \ldots \ldots$

Late 15 th century $\ldots \ldots \ldots \ldots \ldots \ldots \ldots \ldots \ldots \ldots \ldots \ldots$

White wares with traces of gold decoration $\ldots \ldots \ldots \ldots \ldots 2$

Behbūd appears on 4 pieces.

Abū Tãlib appears on 2 pieces.

Narinji appears on 2 pieces.

Qülī (or variants) appears on 12 pieces.

Owners mark $\psi$ appears on 14 pieces.

Blue-and-white

White wares.

Polychrome wares

3
10

$1\}$

Hung-chih, or Cheng-te.

THE CHINESE MARKS IN UNDERGLAZE BLUE

Genuine nien-hao appear on 71 pieces.

Blue-and-white

14th and 15th centuries

none

16 th century $\ldots \ldots \ldots \ldots \ldots \ldots \ldots\left\{\begin{array}{lr}\text { Cheng-te } & 1 \\ \text { Chia-ching } & 10 \\ \text { Wan-li } & 20\end{array}\right.$

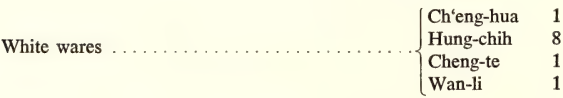


Genuine nien-hao-(continued).

\begin{tabular}{|c|c|}
\hline Polychrome wares ... & $\begin{array}{l}\text { Ch'eng-hua } \\
\text { Hung-chih } \\
\text { Cheng-te } \\
\text { Chia-ching } \\
\text { Wan-li }\end{array}$ \\
\hline Monochrome wares (yellow) & $\left\{\begin{array}{l}\text { Hung-chih } \\
\text { Cheng-te } \\
\text { Chia-ching } \\
\text { Wan-li }\end{array}\right.$ \\
\hline
\end{tabular}

Apocryphal nien-hao appear on 17 16th-century pieces.

Blue-and-white $\{$ Hsüan-te 10

\{Ch'eng-hua

Polychrome wares Hsüan-te 3 \{Ch'eng-hua

Monochrome wares (blue)

Hsüan-te

Marks other than nien-hao appear on 20 pieces, all 16th century.

Blue-and-white

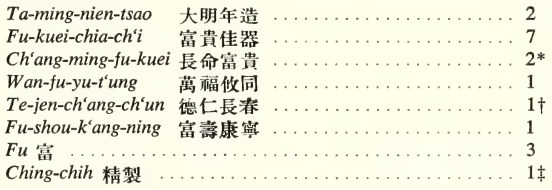

White wares

Fu-kuei-chia-chi $i$ 富貴佳器 $\ldots \ldots \ldots \ldots \ldots \ldots \ldots \ldots$

Polychrome wares

Fu-kuei-chia-chi $i$ 富贵佳器 $\ldots \ldots \ldots \ldots \ldots \ldots \ldots \ldots$

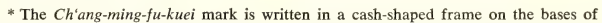
two bowls of late sixteenth-century date. Each is decorated inside with a diaper border, prunus sprays, and a central circle with an eagle perched on a rock; outside are floral scrolls and medallions. (29.365-6, D. $7 \frac{1}{2}$ in., $19 \mathrm{~cm}$., not illustrated.)

$\dagger$ The Te-jen-ch'ang-ch'un mark is written in seal characters framed by a square around which are the four characters Wan-li-nien-tsao also in their seal forms. This appears on the base of a small dish decorated inside with two fishes and outside with fish among waterweeds. (29.315, D. $6 \frac{3}{4}$ in., $17 \mathrm{~cm}$, not illustrated.)

This mark appears in the form shown here on a small ewer decorated with birds and fruiting branches on the cylindrical neck, and fish and waterweeds on the body. The first character is probably ching, the second chih. $\left(29.443\right.$, H. $4 \frac{3}{4}$ in., $12 \mathrm{~cm}$., not illustrated.) 
Marks not involving characters appear on 7 blue-and-white pieces as follows:
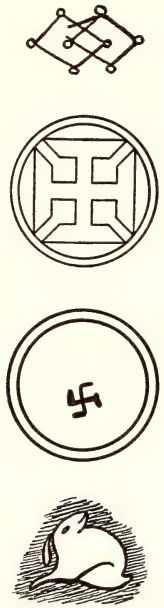

Interlocking lozenges on the bowl 29.345 shown on plate 63.

Cross in a double circle on the fragmentary base of a bottle like 29.451 shown on plate 74 . (29.454.)

Crude swastika in a double circle on the dish 29.279 shown on plate 90 .

Hare on the ewer 29.424 shown on plate 99 ; on two of the covers like 29.284 shown on plate 108 ; on the bottle 29.468 shown on plate 109 . 


\section{BIBLIOGRAPHY}

In referring to periodicals the following abbreviations are used:
AA Artibus Asiae, Ascona.
ACASA Archives of the Chinese Art Society of America, New York.
AI Ars Islamica, Ann Arbor.
AO Acta Orientalia, Leiden.
AQ Art Quarterly, Detroit.
BMFEA Bulletin of the Museum of Far Eastern Antiquities, Stockholm.
FECB Far Eastern Ceramic Bulletin, Ann Arbor.
HJAS Harvard Journal of Asiatic Studies, Cambridge.
JA Journal Asiatique, Paris.
JMBRAS Journal of the Malayan Branch of the Royal Asiatic Society, Singapore.
JNCBRAS Journal of the North China Branch of the Royal Asiatic Society, Shanghai.
JRGS Journal of the Royal Geographical Society, London.
JSSS Journal of the South Seas Society, Singapore.
OA Oriental Art, London.
TOCS Transactions of the Oriental Ceramic Society, London.
TP T'oung Pao, Leiden.
ZDMG Zeitschrift der Deutschen Morgenländischen Gesellschaft, Leipzig.

Aga-Oglu, Kamer. Five examples of Annamese pottery. Bull. Univ. Michigan Museum of Art, no. 5 (May 1954): 6-11.

Ming export blue and white jars in the University of Michigan collection. AQ, 11 (1948): 201-217.

AleXANDER, SIR JAMES EdWARD. Travels from India to England . . . in the years 1825-26. London, 1827.

Amiot, Joseph Marie. Mémoires concernant l'histoire, les sciences, les arts, les moeurs, les usages, \&c. des Chinois, 15 vols. Paris, 1776-1791.

Ayers, JoHn. Early Chinese blue-and-white in the Museum of Eastern Art, Oxford. OA, 3 (1951):135-141.

BAHR, A. W. Old Chinese porcelain and works of art in China. London, New York, Cassell \& Co., 1911.

Bahrami, Mehdi. Chinese porcelains from Ardabil in the Teheran Museum. TOCS, 25 (1949-1950):13-19.

Barnham, Denis. A XV century tripod incense burner. OA, I (1948) :33-36.

BeAl, SAmuel. Si-yu-ki. Buddhist records of the western world, 2 vols. London, Trübner \& Co., 1884. 
Bellan, Lucien-Louis. Chah 'Abbas I, sa vie, son histoire. Paris, Paul Geuthner, 1932. (Les grandes figures de l'orient, t. 3.)

Bergman, Folke. Travels and archaeological field-work in Mongolia and Sinkiang — a diary of the years 1927-1934, Stockholm, 1945. (The Sino-Swedish Expedition, Publication 26, History of the Expedition in Asia 1927-1935, part IV.)

Beveridge, A. S. The Bäbur-näma in English, 2 vols. London, Luzac \& Co., 1922. Bluett, EdgaR E. The Riesco collection of old Chinese pottery and porcelain. London, Antique Collector, 1951.

BöCKLeR, George Andreas. Architectura curiosa nova. Nürnberg, 1664.

Boston Museum of Fine Arts. The Charles B. Hoyt collection; memorial exhibition. Boston, The Museum, 1952.

BoXer, Charles. Fidalgos in the Far East, 1550-1770; fact and fancy in the history of Macao. The Hague, Martinus Nijhoff, 1948.

Brankston, A. D. Early Ming wares of Chingtechen. Peiping, Henri Vetch, 1938. BRETSCHNEIDER, E. Mediaeval researches from eastern Asiatic sources, 2 vols. London, Kegan Paul, Trench, Trübner \& Co., 1910.

Browne, Edward G. A literary history of Persia. Vol. 4: Modern times (15001924). Cambridge, The University Press, 1928.

Bruyn, Cornelis De. Travels into Muscovy, Persia and part of the East Indies . . . , 2 vols. London, 1737.

Bushell, Stephen W. Oriental ceramic art; collection of $W . T$. Walters. Text edition to accompany the complete work. New York, D. Appleton \& Co., 1899.

the T'ao Shuo. . . . Oxford, The Clarendon Press, 1910.

Cammann, Schuyler. China's dragon robes. New York, Ronald Press Co., 1952.

Ching-hua-chia-shih-shih 清畫家詩史, by Li Chün-chih 李溶之, $10 t s^{\prime} e, 1930$.

Ch'ing-pi-tsang 清舮藏, by Chang Ying-wen 張應交, 2 chüan, last preface 1595.

Ching-te-chen t'ao-lu 景德鐄陶錄, by Lan $\mathrm{P}^{\prime} \mathrm{u}$ 藍浦, 10 chüan, 1815.

Chu-fan-chih 諸蕃志, by Chao Ju-kua 趙汝适, 2 chüan, Southern Sung. Edition in Han-hai, 1782.

Clavijo, Ruy Gonzalez De. Embassy to Tamerlane, 1403-1406. Tr. by G. Le Strange. London, Routledge, 1928.

Cleaves, Francis Woodman. The Sino-Mongolian inscription of 1362 in memory of Prince Hindu. HJAS, 12, 1-2 (June 1949) :1-133.

Colasanti, Arduino. Le fontane d'Italia. Rome, 1926.

Coomaraswamy, Ananda K., and Kershaw, Francis S. A Chinese Buddhist water vessel and its Indian prototype. AA, 3, No. 2-3 (1928-1929): 122-141.

David, Armand. Abbé David's diary. Tr. and ed. by Helen M. Fox. Cambridge, Harvard University Press, 1949. 
David, Sir Percival. Chinese porcelain in Constantinople. TOCS, 11 (1933-1934): 15-20.

Hsiang and his album. TOCS, 11 (1933-1934): 22-47.

. A commentary on Ju ware. TOCS, 14 (1936-1937): 18-69.

. The T"ao Shuo and "the illustrations of pottery manufacture"; a critical study and a review reviewed. AA, 12 (1949):165-182.

. The magic fountain in Chinese ceramic art. BMFEA, 24 (1952):1-9.

Du Sartel, Octave. La porcelaine de Chine. Paris, Morel, 1881.

DuYvendaK, JAN Julius LodewiJK. Ma Huan re-examined. Amsterdam, NoordHollandsche Uitgeversmaatschappij, 1933.

Evans, I. H. N. On the persistence of an old type of water-vessel. JMBRAS, 1 (1923): 248-250.

Falsafī, NAȘRollāH. Zindegãnī-ye Shāh 'Abbās. (Life of Shāh 'Abbās.) Tehran, 1332 (1953-1954). (University of Tehran Publ. no. 171.)

Fischel, WALTER J. Ibn Khaldūn and Tamerlane, their historic meeting in Damascus, 1401 A.D. Berkeley, University of California Press, 1952.

Fou-liang hsien-chih 浮梁䅫志. Edition of the 21st year of the K'ang-hsi period (1682).

FRANKS, A. W. Catalogue of a collection of oriental porcelain and pottery lent for exhibition by A. W. Franks . . . , 2d ed. London, printed by George E. Eyre and William Spottiswoode, 1878.

Fraser, JAmes B. Travels and adventures in the Persian provinces on the southern banks of the Caspian Sea. London, 1826.

FuJita, BARoN. Fujita danshaku kazō hin nyūsatsu mokuroku 藤田男澛家藏品入札 目錄 (Auction catalogue of items in the Baron Fujita Collection.) Osaka, 1929.

Garner, Sir HARry. Oriental blue and white. London, Faber \& Faber, 1954.

GRAY, BASIL. The influence of Near Eastern metalwork on Chinese ceramics. TOCS, 18 (1940-1941): 47-60.

. Blue and white vessels in Persian miniatures of the 14 th and 15 th centuries re-examined. TOCS, 24 (1948-1949): 23-30.

Hambis, Louis. Le chapitre CVIII du Yuan Che. Leiden, E. J. Brill, 1954. (T'oung pao. Monograph III.)

Han-hai 㖤海 comp. by Li T'iao-yüan 李雕元, 142 items (1782); Supplement 績, 11 items (1801); 159 items (1882).

HAN WAI-Toon. A research on Kendi. JSSS, 7, pt. 1 (no. 13), 1951. (Conventional romanization of the author's name is Han Wei-chün.)

HAN WeI-CHÜN 韓槐準. Jou-fo-ho liu-yu fa-chien yu-kuan-shih chih wo-kuo ts'an-tz'u 柔佛河流域發見有款識之我國殘瓷. Dated Chinese pottery shards found in the valley of the Johore River. China Society of Singapore Annual, 1953, pp. 20-22. 
Hannover, Emil. Keramisk haandbog andet binds 1st Halvdel; Kina, Korea, Japan. København, Henrik Koppels Forlag, 1923.

Herrmann, A. Historical and commercial atlas of China. Cambridge, Harvard University Press, 1935.

HIPPISLEY, AlFRED EDWARD. A catalogue of the Hippisley collection of Chinese porcelains, with a sketch of ceramic art in China. U. S. National Museum Ann. Rept., 1888: 387-491. Washington, 1890.

Hirth, F., and RockhiLl, W. W., tr. Chau Ju-kua; his work on the Chinese and Arab trade in the twelfth and thirteenth centuries, entitled Chu-fan-chï. St. Petersburg, Printing Office of the Imperial Academy of Sciences, 1911.

Hobson, R. L. Chinese pottery and porcelain, 2 vols. London, 1915.

. The wares of the Ming dynasty. New York, C. Scribner's Sons, 1923.

. The George Eumorfopoulos collection . . . pottery and porcelain, 6 vols. London, E. Benn, 1925-1928.

- A catalogue of Chinese pottery and porcelain in the collection of Sir Percival David. London, Stourton Press, 1934.

Hobson, R. L., and Hetherington, A. L. The art of the Chinese potter from the Han dynasty to the end of the Ming. . . . New York, Alfred A. Knopf, 1923.

Hobson, R. L., RackHam, Bernard, and King, William. Chinese ceramics in private collections. . . . London, Halton \& T. Smith, 1931.

Holmes, William Richard. Sketches on the shores of the Caspian descriptive and pictorial. London, Richard Bently, 1845.

HONEy, William Bowyer. The ceramic art of China and other countries of the Far East. . . . London, Faber \& Faber and the Hyperion Press, 1945.

I-men-kuang-tu 夷阿廣堛 comp. by Chou Li-ching 周履靖, 106 chüan, last preface 1598.

Ibn Battuta. Travels in Asia and Africa, 1325-1354. Tr. by H. A. R. Gibb. London, Routledge, 1928.

InGHolt, HaRAlD. Rapport préliminaire sur la première campagne des fouilles de Hama. København, Levin \& Munksgaard, 1934.

. Rapport préliminaire sur sept campagnes de fouilles à Hama en Syrie (1932-1938). København, Enjar Munksgaard, 1940.

Ivanov, A. Bumaznoe Obraztsenie v kitae do XV B. Materialy po Ëtnografi Rossii, 2 (1914): 159-173.

Jacquemart, Albert, and Le Blant, Edmond. Histoire artistique, industrielle et commerciale de la porcelaine. Paris, J. Techener, 1862.

JAHĀNGīr. The Tüzuk-i-Jahāngīrī, or, Memoirs of Jahängīr, 2 vols. Tr. by Alexander Rogers. Edited by Henry Beveridge. London, Royal Asiatic Society, 19091914. 
Janse, Olov R. T. Notes on Chinese influences in the Philippines in pre-Spanish times. HJAS, 8 (1944-1945): 34-62.

JAUBert, Pierre AmÉdÉE. Voyage en Arménie et en Perse, fait dans les années 1805 et 1806. Paris, 1821.

Jenkinson, Anthony. Early voyages and travels to Russia and Persia, 2 vols. London, Hakluyt Society, 1886.

Jenyns, SoAme. Later Chinese porcelain, the Ch'ing Dynasty (1644-1912). London, Faber \& Faber, 1951.

. Ming pottery and porcelain. London, Faber \& Faber, 1953.

Julien, Stanislas. Histoire et fabrication de la porcelaine chinoise. Paris, 1856.

Kahle, Paul. Eine islamische Quelle über China um 1500. (Das Khitāynāme des 'Ali Ekber.) AO, 12 (1934): 91-110. $1-45$.

King, William. A document in Ming porcelain. The Year Book of Oriental Art and Culture. London, 1924-1925, 31-32.

Ko-ku-yao-lun 格古要論 by Ts'ao Chao 曹昭, 3 chüan, 1387; rev. and enl. by Wang Tso 王佐, 13 chüan, 1459, and other editions.

during the Yüan Dynasty in China. Russnoe geograficheskago obschestva, 45

Kотvich, V. Obraztsy assignatsîi Iuanskoi dinastîi v Kitae. Samples of "Assignats" (1909): 474-477.

Kozlov, P. K. The Mongolia-Sze-Chuan expedition of the Imperial Russian Geographical Society. Geographical Journal, 34 (Oct. 1909): 384-408.

Mongolei, Amdo und die tote Stadt Charachoto. Berlin, 1925.

. Mongolia i Amdo i mertvyi gorod Khara-Khoto, 2d ed. Moscow, 1947.

KRENKow, F. The oldest western accounts of Chinese porcelain. Islamic Culture, the Hyderabad Quarterly Review, 7, 3 (July 1933): 464-471.

Ku-kung 故宮, Palace Museum Monthly, 43 vols. Peiping, The Palace Museum, 1929-1933.

Ku-kung-shu-hua-chi 故宮書書集, 45 vols. Peiping, The Palace Museum, 1929-1937. Kuo-ch'ao-shih-jen-cheng-lueh 國朝詩人徽略 by Chang Wei-p'ing 張維屏, 64 chüan, 1842.

KUSHI TAKUSHIN 久志卓瞴. Shina minsho tōji zukan 支那明初陶磁圆鑑. Illustrated catalogue of early Ming Chinese porcelain. Tōkyō, Hō-un sha, 1943.

LAMm, CARL Johan. Mittelalterliche Gläser und Steinschnittarbeiten aus dem Nahen Osten, 2 vols. Berlin, D. Reimer, 1930.

LAUfer, BerTHOLd. Chinese Muhammedan bronzes . . . with a study of the Arabic inscriptions by Martin Sprengling. AI, 1 (1934): 132-147.

Lee, Jean Gordon. Ming blue-and-white. Philadelphia Mus. Bull., 44, no. 223 (Autumn 1949). (Abbreviated PMA.) 
Lee, Jean Gordon. Some Pre-Ming "blue-and-white"; a stylistic analysis with suggested chronology. ACASA, 6 (1952): 33-40.

Maggi, Giovanni. Fontane diverse. Roma, 1618.

Malcolm, Sir John. History of Persia from the most early period to the present time, 2 vols. London, 1815.

MERRY, HARRIET HARRISON. Chinese Islam, a study in religious acculturation. M.A. thesis, University of Michigan (unpublished).

Mo-hsiang-chü hua-shih 壆香居畫識, by Feng Chin-po 馮金伯, 10 chüan (n.d., about 1800).

Monteith, Colonel. Journal of a tour through Azerbijan and the shores of the Caspian. JRGS, 3 (1832): 1-56.

Morier, James. A second journey through Persia, Armenia, and Asia Minor to Constantinople between the years 1810 and 1816. . . . London, 1818.

Moul.e, A. C., and Pelliot, P. Marco Polo the description of the world, 2 vols. (incomplete). London, Routledge, 1938.

MuHAI DōJIN 無背道人. Sentoku seika tōka sōkin no zu oban 宣德毒華桃果雙禽圆 大盤. A bowl decorated with the design of peaches and animals. Kokka, 711 (June 1951): 232, plate 7.

MüNSTERberg, OsKar. Chinesische Kunstgeschichte, 2 vols. Esslingen a. N., P. Neff, 1924.

Ni-ku-lu 妮古镍, by Ch'en Chi-ju 陳繼儒, 4 chüan, author d. 1639.

OKUDA SEIrCHI 奥田誠一. Sōkoroku zukan 来胡錄風察. Illustrated catalogue of Sawankalok. Tōkyō, Zayūhō Kankō Kai, 1944.

\section{ceramics. Tōkyō, Kokusai shōji, 1954.}

Olearius, ADAm. The voyages and travells of the ambassadors sent by Frederick Duke of Holstein, to the Great Duke of Muscovy, and the King of Persia begun in the year MDCXXXIII and finish'd in MDCXXXIX containing a compleat history of Muscovy, Tartary, Persia and other adjacent countries. . . . London, 1669.

OlschKi, LeONARDo. Guillaume Boucher, a French artist at the court of the Khans. Baltimore, The Johns Hopkins Press, 1946.

Oriental Ceramic Society. Catalogue of an exhibition of Chinese blue and white porcelain, 14th to 19th centuries. London, The Oriental Ceramic Society, 1953. (Abbreviated OCS Catalogue, 1953.)

ORSOY DE Flines, E. W. vAN. Gids voor de keramische Verzameling (Uitheemse keramiek). Batavia, Koninklijk Bataviaasch Genootschap van Kunsten en Wetenschappen, 1949.

OTTEMA, NANNE. Chineesche ceramiek, handboek geschreven naar aanleiding van de verzamelingen in het Museum Het Princessehof te Leeuwarden. . . . Amsterdam, J. H. de Bussy, 1946. 
Palmgren, Nils. I Sung-keramikens spar. Porslin, 1-2. Stockholm, 1951-1952, pp. 61-71. (English summary: On the track of Sung ceramics, on p. 97.)

Pelliot, Paul. Le prétendu album de porcelaines de Hiang Yuan-pien. TP, 32 (1936) : 15-58. [Cf. Review of a review signed John C. Ferguson. JNCBRAS, 67 (1936) : 200-204.]

- Le Dr. Ferguson et l'album dit de Hiang Yuan-pien. TP, 33 (1937):

91-94.

81-292.

Pickens, Claude L., JR. Annotated bibliography of literature on Islam in China. Hankow, Hupeh, China, Society of Friends of the Moslems in China, 1950.

Po-wu-yao-lan 博物要霓, by Ku T'ai 谷替, 16 chüan, before 1627.

Pontanus, J. I. Historische Beschrübinghe der seer wijt beroemde Coop-stadt Amsterdam. Amsterdam, 1614.

Pope, Arthur Upham, Editor. A survey of Persian art from prehistoric times to the present, 6 vols. London and New York, Oxford University Press, 1938-1939.

Pope, JoHn A. Letter from the Near East. HJAS, 13 (1950): 558-564.

. Ming blue-and-white at Philadelphia. OA, 3 (1950): 21-27.

. Some blue-and-white in Istanbul. TOCS, 26 (1950-1951): 37-49.

. The Princessehof Museum in Leeuwarden. ACASA, 5 (1951): 23-37.

Fourteenth-century blue-and-white: a group of Chinese porcelains in the Topkapu Sarayt Müzest, Istanbul. Washington, 1952. (Freer Gallery of Art Occasional Papers, vol. 2, no. 1.)

. Ming porcelains in the Freer Gallery of Art. Washington, D. C., Smithsonian Institution, 1953.

9-14.

Poulsen, Vagn. Letters-Ming blue-and-white. Burlington Magazine, 90 (May 1948): 150.

QuAtremère, M. Mémoires historiques sur la vie du Sultan Schah-rokh. JA, 3ème série, vol. 1 (Sept. 1836): 193-233.

Rabino di Borgomale, H. L. Album of coins, medals, and seals of the Shähs of Iran (1500-1948). Oxford, The University Press, 1951.

Reidemeister, Leopold. Ming-Porzellane in schwedischen Sammlungen. Berlin and Leipzig, W. de Gruyter \& Co., 1935.

Reitlinger, G., and Button, M. Early Ming blue and white. Burlington Magazine, 90 (January 1948): 10-16; (March 1948): 67-75.

Rice, D. S. Le baptistère de Saint Louis. Paris, Éditions du Chêne, 1953.

Rieu, Charles. Catalogue of the Persian manuscripts in the British Museum, 3 vols. London, British Museum, 1879-1883. 
Rieu, Charles. Supplement to the Catalogue of the Persian manuscripts in the British Museum. London, British Museum, 1896.

Rivière, Henri. La céramique dans l'art musulman . . . , 2 vols. Paris, E. Lévy, 1913.

Robinson, B. W. Persian paintings. London, H. M. Stationery Office, 1952.

RockHILL, W. W. The journey of William of Rubruck to the eastern parts of the world, 1253-55, as narrated by himself. . . . Tr. from the Latin and edited . . . by William Woodville Rockhill. London, Printed for the Hakluyt Society, 1900.

Ross, Sir Edward Denison. Sir Anthony Sherley and his Persian adventure. London, George Routledge \& Sons, 1933.

SARre, Friedrich. Denkmäler persischer Baukunst . . . , 2 folio vols. Berlin, Ernst Wasmuth, 1901-1910. . The holy shrine of Ardebil. Apollo, 13 (March 1931): 143-148.

SAYER, Geoffrey R. Ching-tê-chên t'ao-lu. London, Routledge \& Kegan Paul, 1951. SHERLEY, Sir ANTHONY. His relations of his travels into Persia. London, 1613.

Shih-wu-kan-chu 事物紺珠, by Huang I-cheng 黄一正, 46 chüan, author's preface 1591.

SHima 島. Mokuroku 毛久ろく. Catalogue of the Shima collection of Chinese and Japanese art to be sold at the Osaka bijutsu kurabu, Nov. 27-29, 1934. Osaka, Taniguchi, 1934.

Smirnov, Y. I. Vostochnoye serebro. Oriental silver. (French summary headed Argenterie orientale.) St. Petersburg, 1909.

Sotheby \& Co., London. Catalogue of valuable Chinese porcelain . . . the property of a well-known collector, formerly resident in Peking . . . sold at auction, 26th of May, 1937.

Ssŭ-i-kuan-k'ao 四夷馆考, 2 chüan, [Tientsin], Tung-fang-hsüeh-hui 東方學會, 1924.

Stein, Sir Mark Aurel. Innermost Asia . . . , 4 vols. Oxford, The Clarendon Press, 1928.

Storey, C. A. Persian literature; a bio-bibliographical survey. London, Luzac \& Co., 1927-1953.

Ta-ming-hui-tien 大明會典. Compiled by Hsü P'u 徐溥 in 180 chüan. Edition of the 6th year of the Cheng-te period (1511).

T'ao-chi-lïeh 陶記略, by Chiang Ch'i蔣新. A memoir included in the Fou-liang hsienchih, printed for the first time in 1322.

T'ao-shuo 陶說, by Chu Yen 朱琰, 6 chüan, 1774 and later editions.

T'ao-ya 陶雅, by Chi Yüan-sou 叔園叟 (pseudonym of Ch'en Kung-liu 陳公瀏), 2 chüan, author's prefaces 1906 and 1910. 
TAVernier, JeAn Baptiste. Les six voyages de Jean-Baptiste Tavernier, Chevalier Baron d'Aubonne, qu'il a fait en Turkie, en Perse, et aux Indes, nouvelle ed., 3 vols. Paris, 1681-1881.

Thielmann, Max von. Journey in the Caucasus, Persia and Turkey in Asia, 2 vols. London, 1875.

Trubner, Henry. Chinese ceramics from the prehistoric period through Ch'ien-lung. Los Angeles, The Los Angeles County Museum, 1952.

Tsun-sheng-pa-chien 導生八侥, by Kao Lien 高濂, 19 chüan, 1591.

T'ung-ya 通雅, by Fang I-chih 方以智, $52+3$ chüan, 1666. (Author took his Chinshih degree in the Ch'ung-chen period 1628-1644.)

Tüzuk-i-Jahängīrĩ (see Jahāngīr).

VAlle, Pietro Della. Extracts from the travels of Pietro della Valle in Persia. (In Pinkerton, John, A general collection of . . . voyages and travels. London, 1808.)

The travels of Sig. Pietro della Valle, a noble Roman, into East India and Arabia Deserta. London, 1665.

Wallis, Henry. Persian ceramic art in the collection of Mr. F. DuCane Godman . . . the thirteenth century lustred vases. . . . London, Taylor \& Francis, 1891.

Wiet, Gaston. L'exposition persane de 1931. Le Caire, Imprimerie de l'Institut Français d'Archaeologie Orientale, 1933.

WILES, BERTHA HARRIS. The fountains of Florentine sculptors and their followers from Donatello to Bernini. Cambridge, 1933.

YAMANAKA SHOKAI 山中商會, Ko sometsuke sara hyakusen 古染付血百刎. Osaka, 1933. (Introduction by Okuda Seiichi.)

Yin-jen-chuan 印人傅, by Chou Liang-kung 周亮工, 3 chüan; supplement 縔 by Wang Ch'i-shu 汪啓淑, 8 chüan (1789).

Yule, Sir Henry. The book of Ser Marco Polo, the Venetian, concerning the kingdoms and marvels of the East, 3d ed. rev., 2 vols. London, J. Murray, 1921.

Zambaur, E. DE. Manuel de généologie et de chronologie pour l'histoire de l'Islam, 2 vols. Hanovre, Heinz Lafaire, 1927.

Zimmermann, Ernst. Altchinesische Porzellane im Alten Serai. Berlin und Leipzig, de Gruyter, 1930.

\section{NOTE}

Too late for inclusion in the bibliography and for reference in the text is the latest corpus of material for the study of Chinese porcelains of the periods represented in the Ardebil Collection. It is volume 11 of Sekai-toji-zenshu (Catalogue of world's ceramics), published by the Zauho Press and the Kawade Shobo, Tokyo, 1955. Treating Yüan and Ming porcelains, this volume includes 20 color plates, 119 black-and-white plates, 304 text figures, and 15 articles on various phases of the subject. 



\section{PLATES}

It has not been feasible to illustrate the several pieces shown on any one plate to scale. The measurements given in the descriptions are to the nearest eighth inch and the nearest half centimeter; where these two figures do not coincide, the actual size of the piece may fall between the two. In practice few porcelains are exactly circular, nor are the rims exactly level. 


\section{PLATE 1}

Map of Asia showing the principal places mentioned in connection with the history of the Ardebil Collection. 


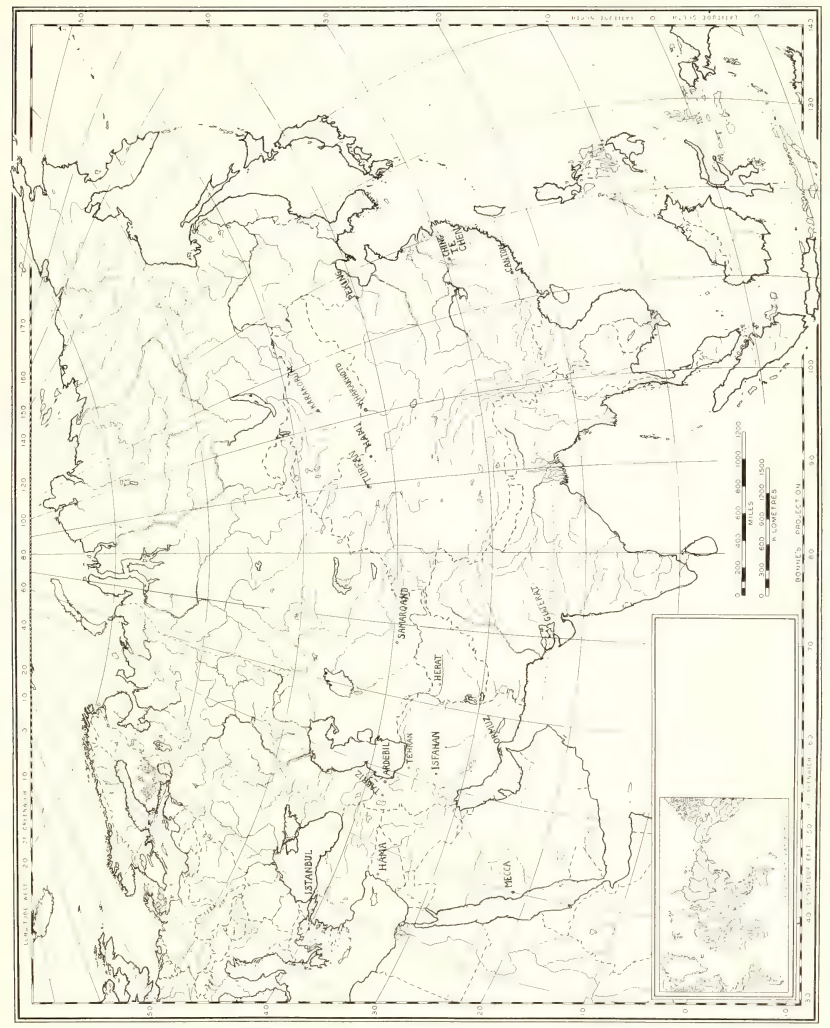




\section{PLATE 2}

Plan of the Shrine of Sheikh Safi at Ardebil. The entrance at the bottom leads from the meidan into the long garden court; beyond is the small forecourt (e.), and the area to the left (east) of this originally housed the kitchens which, three times a day, provided rice for the inhabitants of the Shrine: the molläs, the various officials, the poor, and those who sought sanctuary in the sacred precincts. According to Olearius, as many as a thousand people were fed at a meal, and at the ceremonial feasts of Shāh 'Abbās the Chinese porcelains were used for serving. Entering the great forecourt (f.) the visitor saw the mosque (k.) at his left and the prayer hall (h.) directly before him, and at the right end of the latter stood the tomb of the Sheikh (i.). Beyond the prayer hall, at the extreme upper left of the plan, is the Chini-khäneh.

From Sarre, Denkmäler persischer Baukunst, vol. 1, fig. 31, p. 35. 


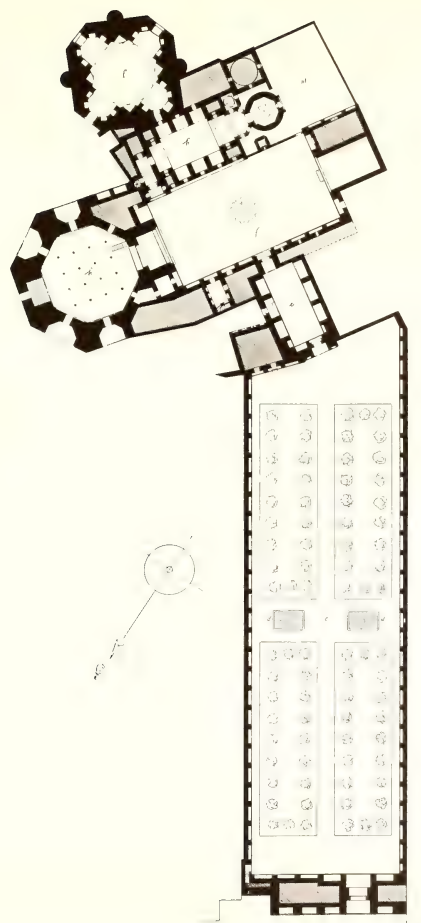


PLATE 3

The Chinni-khäneh seen from the northeast.

Photograph by Myron Bement Smith.

Courtesy of the Islamic Archives.

See page 7 . 


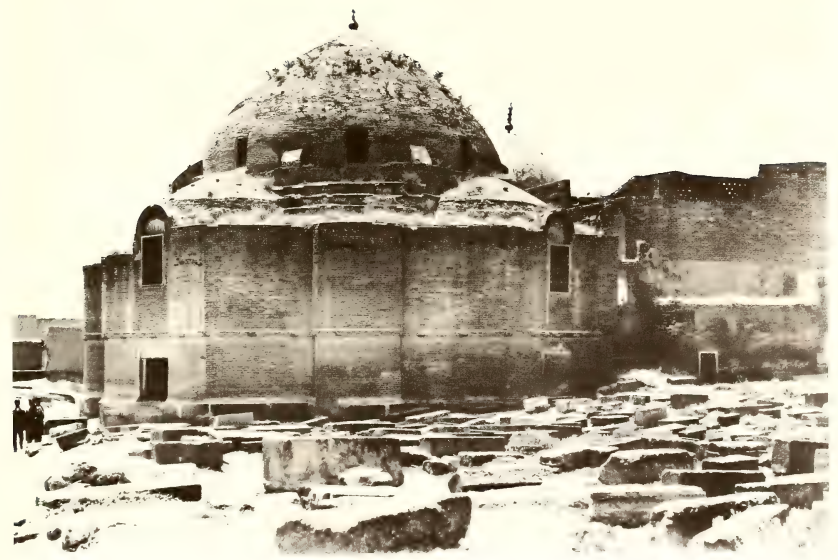


PLATE 4

Interior of the Chïni-khäneh showing the southeast corner.

Photograph by Myron Bement Smith.

Courtesy of the Islamic Archives.

See pages 7, 17 . 

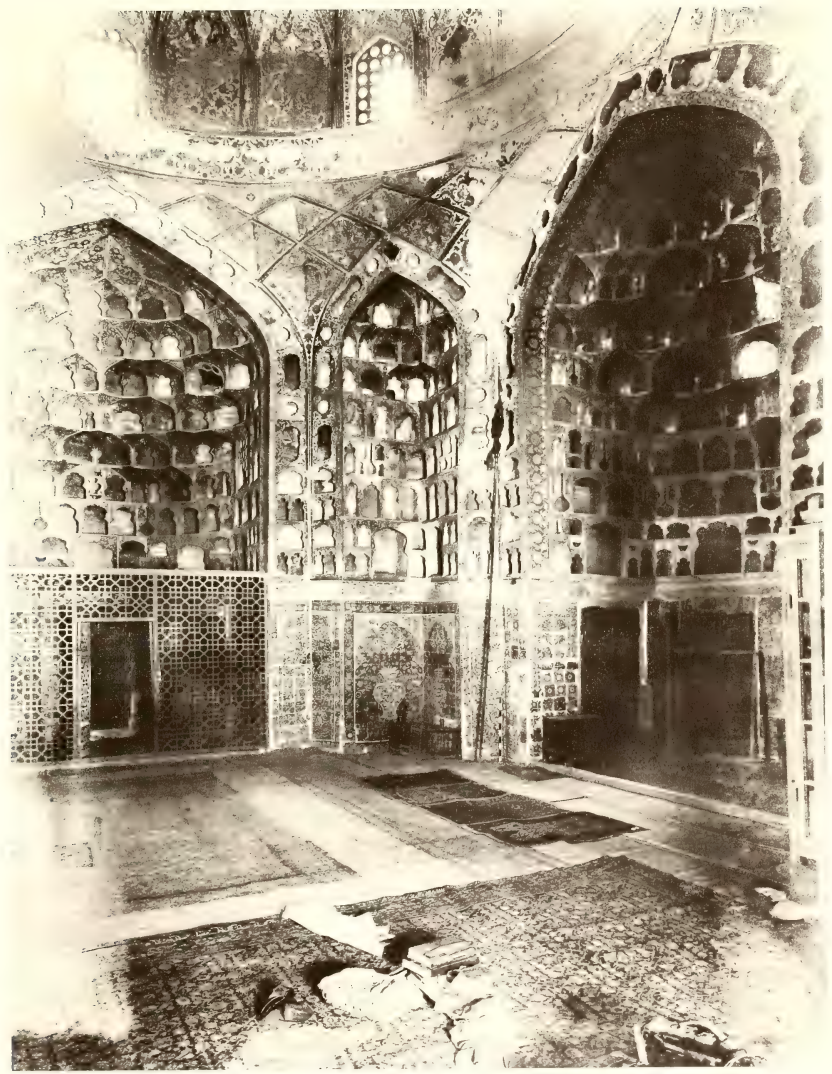
See pages 7,17 .

PLATE 5

Folios 341r and 341v of the Ta'rikh-e-'Abbāsì (B.M. Add. 27.241). The passage marked is the list of porcelains dedicated to the Shrine by Shāh 'Abbās in the month Jumādā II 1020 (11 August-8 September, 1611).

See page 10 . 

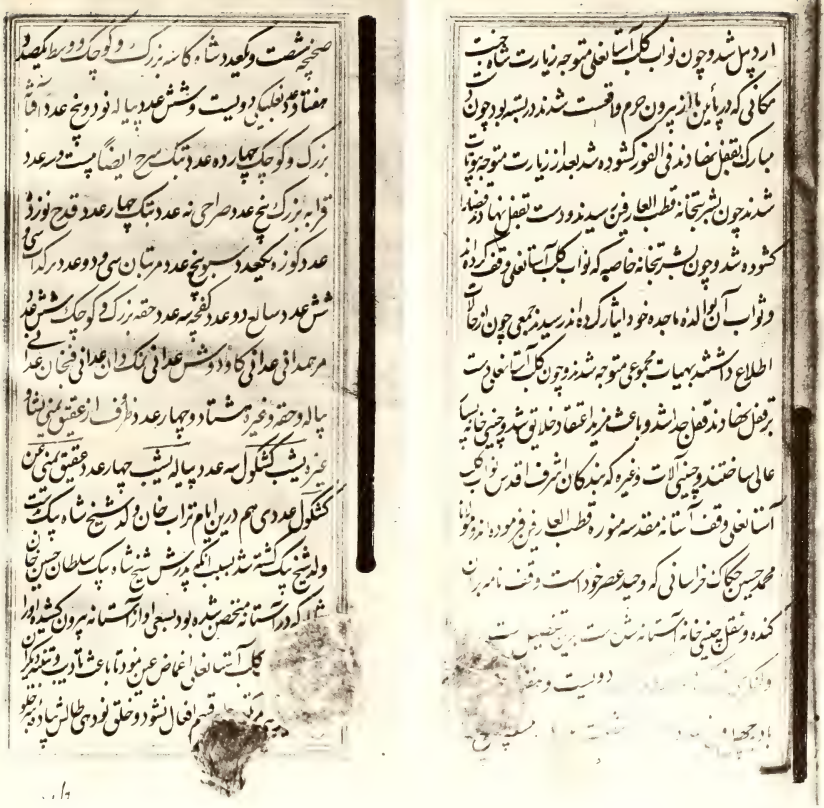


\section{PLATE 6}

The non-Chinese marks

A-D. Examples of the vaqfnāmeh of Shāh 'Abbās incised in the glaze and rubbed with red pigment on three blue-and-white wares and one plain white piece.

E. Abbreviated vaqfnāmeh of Shāh 'Abbās.

F-G. Examples of the mark of Qarachaghāy incised in a line and drilled in dots on the unglazed bases of dishes.

H. Marks of Behbüd and Qarachaghāy drilled in the glaze on 29.471.

I. Mark of Abū Tālib drilled in the unglazed base of 29.469 .

J. Mark of Jahāngīr. (Courtesy of the Victoria and Albert Museum.)

K. Undeciphered mark in underglaze blue on 29.49 .

L. Bottle with Portuguese inscription in underglaze blue. (Courtesy of the Walters Art Gallery.)

See pages $51-58$. 


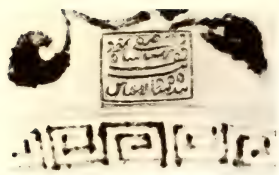

A

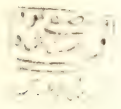

D

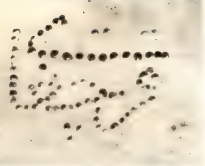

G

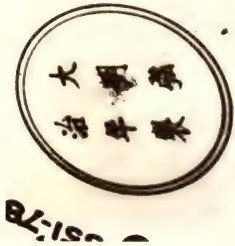

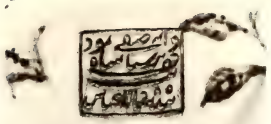

B

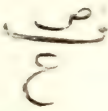

E
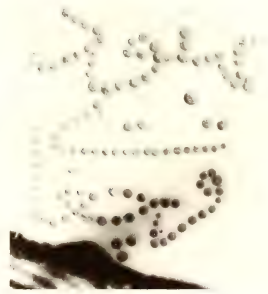

H
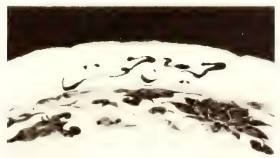

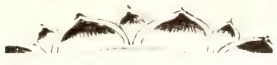
K

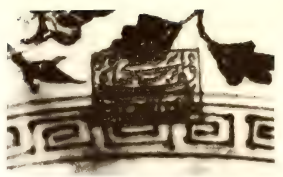

C

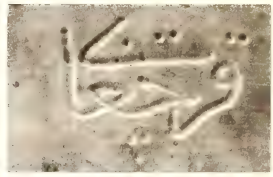

F

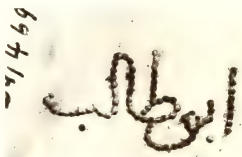

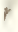

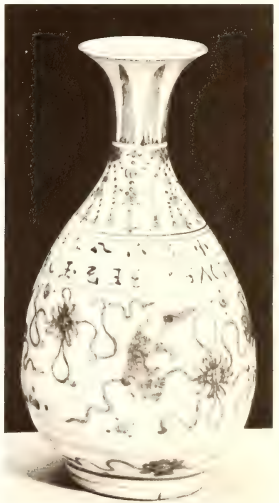




\section{PLATE 7}

Dish with flattened rim on which are segments of concentric wave patterns; a lotus wreath with spiky leaves decorates the cavetto; in the center is a lotus pond with two ducks. On the outside is a band of lotus panels framing abstract leaf forms.

The blue on this piece is exceptionally strong.

29.38 H. $2 \frac{3}{4}$ in. $(7 \mathrm{~cm}$.$) . D. 16$ in. $(41 \mathrm{~cm}$.).

Fourteenth century.

See pages 66,71 . 

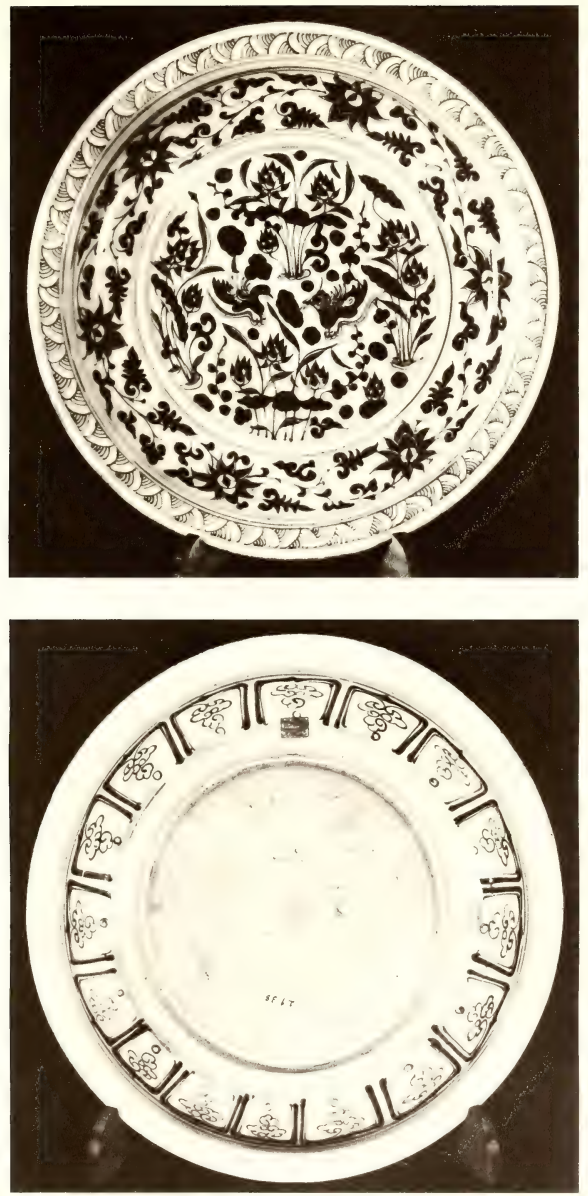
PLATE 8

Dishes with flattened rims decorated with diamond patterns; in the cavettoes are lotus wreaths with spiky leaves; the centers show ponds with symmetrically disposed aquatic plants although the two scenes are not identical in detail. On the outsides are rows of lotus panels.

$29.40-41$ H. $2 \frac{3}{4}$ in. (7 cm.). D. 16 in. $(40.5 \mathrm{~cm}$.).

Fourteenth century.

See pages 66,71 . 


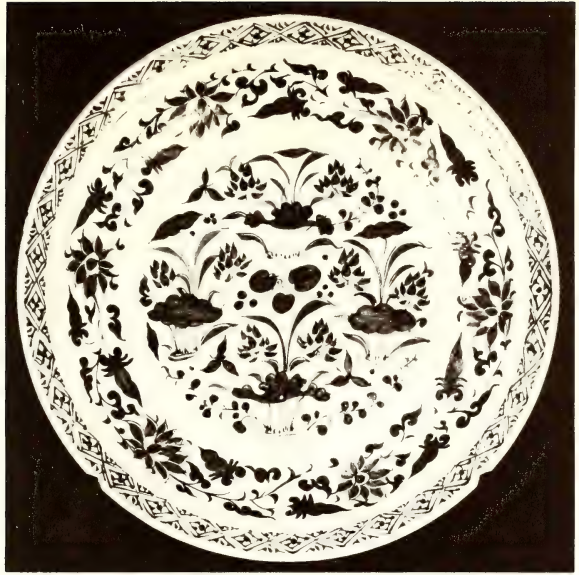

29.40

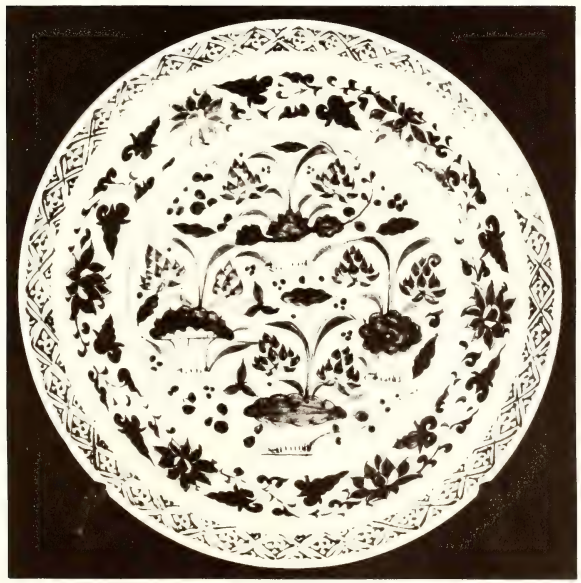




\section{PLATE 9}

Dish with flattened rim decorated with diamond pattern, and a lotus wreath with spiky leaves in the cavetto; central design of a large fish of the sea-perch family swimming among aquatic plants, which include duckweed, eelgrass, waterchestnuts, water ferns, and feathery grasses. On the outside is a lotus scroll with spiky leaves (pl. 10).

On the body of the fish is the character ch'un, "spring," written by scratching away the pigment before the piece was glazed and fired.

29.42 H. $2 \frac{5}{8}$ in. $(6.5 \mathrm{~cm}$. $)$. D. 16 in. $(41 \mathrm{~cm}$. $)$.

Fourteenth century.

See pages 66,71 . 


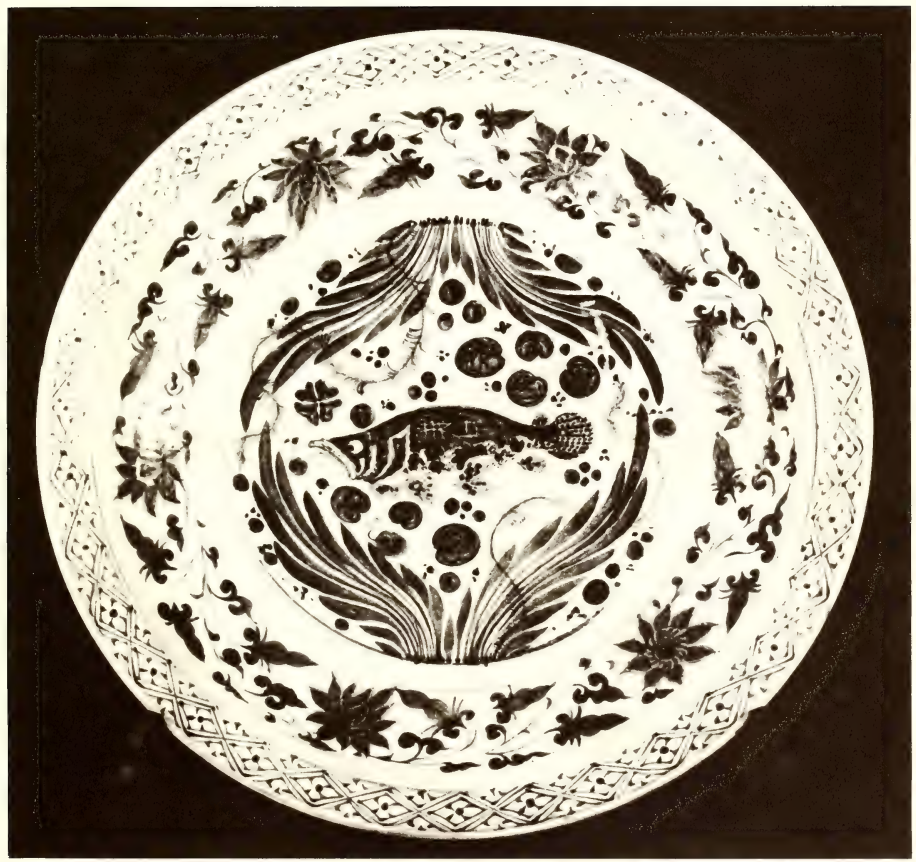


PLATE 10

Base of dish on preceding plate (29.42).

Base of dish on following plate (29.43).

See pages 66,71 . 


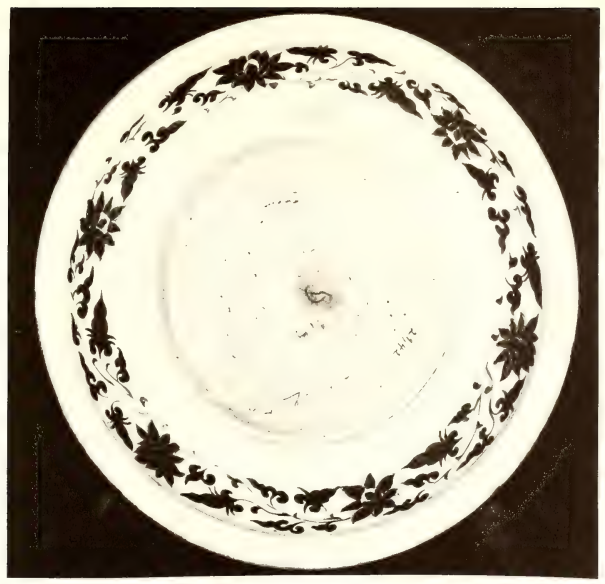

29.42

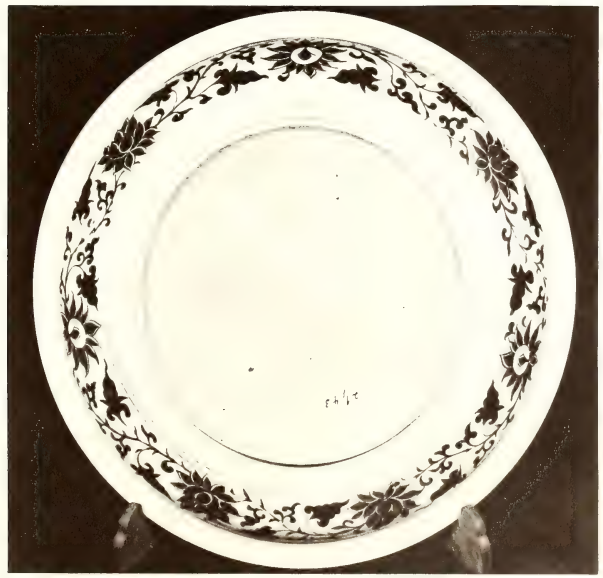




\section{PLATE 11}

Dish with flattened rim decorated with the classic scroll; a lotus wreath with spiky leaves in the cavetto surrounds the central scene in which is a large carp among aquatic plants including duckweed, eelgrass, waterchestnuts, and water ferns. On the outside is a lotus scroll with spiky leaves (pl. 10).

29.43 H. $3 \frac{1}{4}$ in. $(8 \mathrm{~cm}$.$) . D. 18$ in. $(45.5 \mathrm{~cm}$.).

Fourteenth century.

See pages 66,71 . 


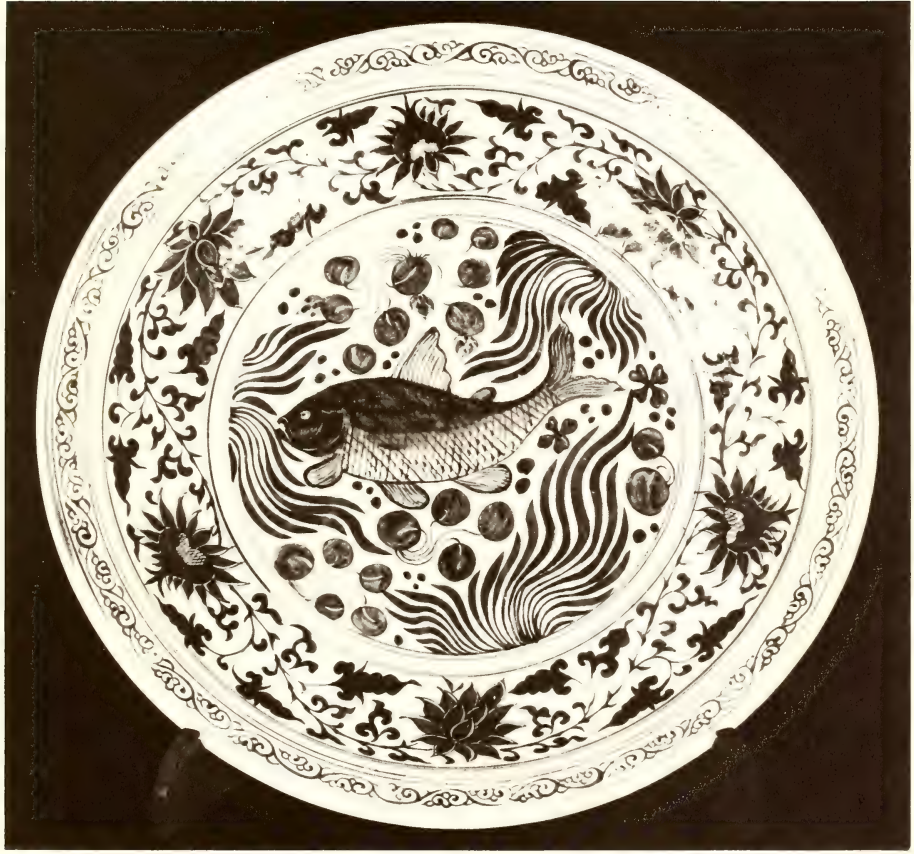




\section{PLATE 12}

Dish with flattened rim. The classic scroll on the rim and the cavetto with lotus wreath and spiky leaves surround a central pattern of banana, rocks, melons, bamboos, and a lotus spray. On the outside is a band of lotus panels framing abstract leaf forms.

29.39 H. $2 \frac{3}{4}$ in. $(7 \mathrm{~cm}$.). D. 16 in. $(40.5 \mathrm{~cm}$.).

Fourteenth century.

See pages 66,71 . 

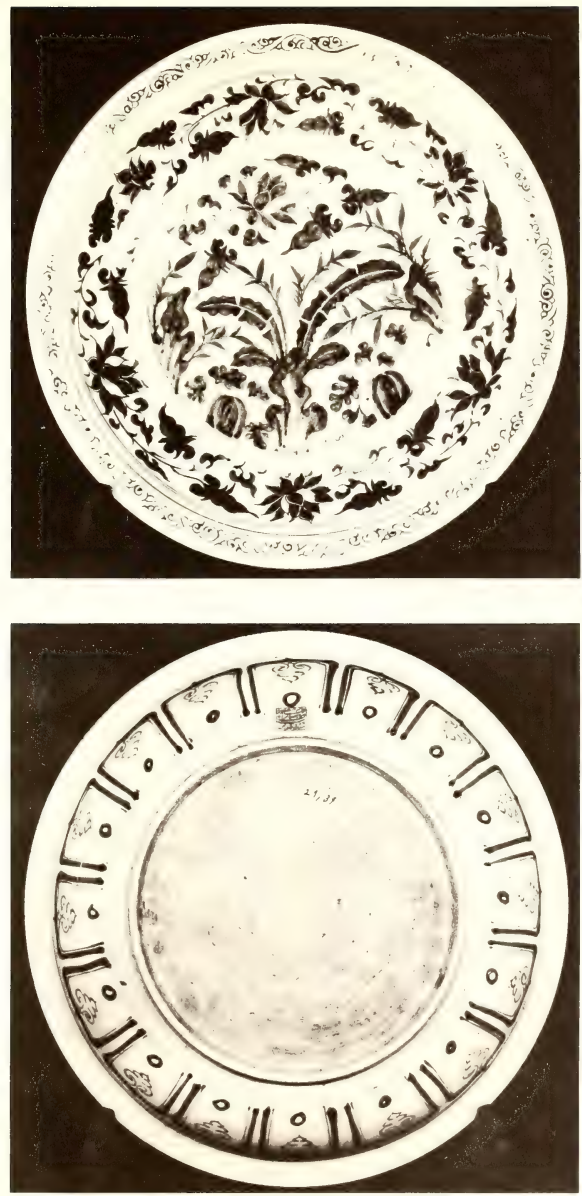


\section{PLATE 13}

Dishes with flattened rims decorated with diamond patterns; lotus wreaths with spiky leaves in the cavettoes surround central designs composed of bamboos, bananas, grapes, morning-glories, rocks, and watermelons. Outside both are lotus scrolls with spiky leaves.

These two illustrate the freedom and variety with which two essentially similar designs may be executed. The morning-glories are missing from 29.121 .

$29.120-121$ ( 2 pieces) H. 3 in. $(7.5 \mathrm{~cm}$.). D. 18 in. $(45.5 \mathrm{~cm}$.).

Fourteenth century.

See pages $66,70,94$. 

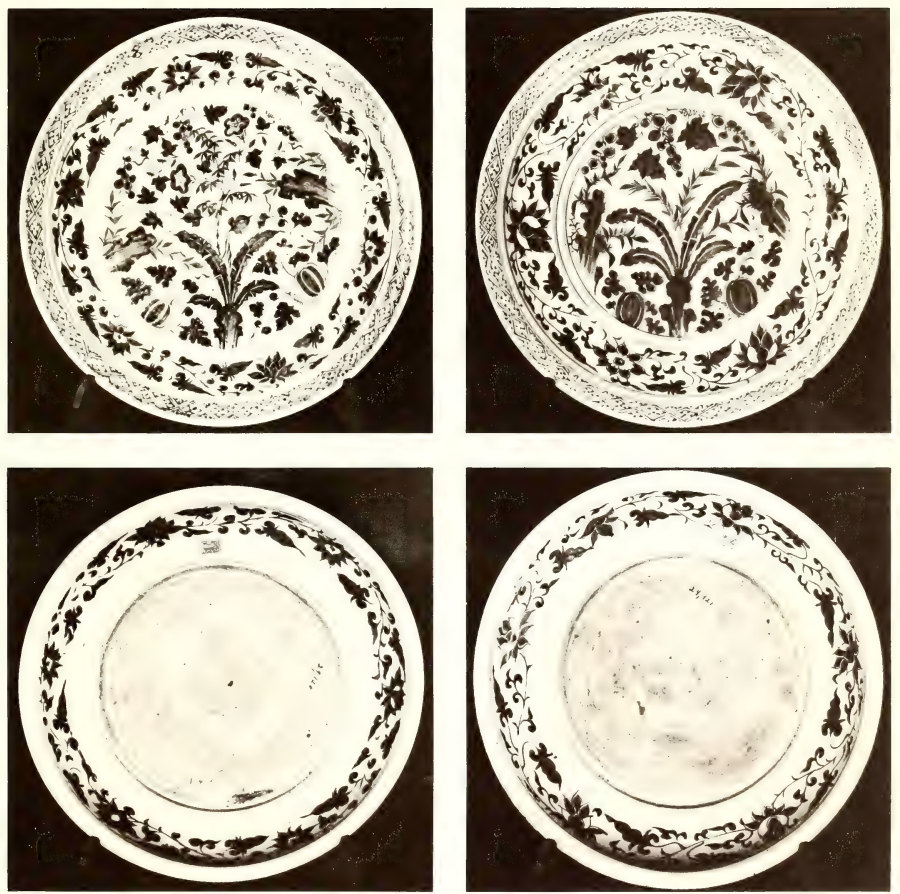


\section{PLATE 14}

Dish with flattened rim decorated with crapemyrtle and blackberry lily; lotus wreath with spiky leaves in cavetto; in the center a phoenix flies downward over banana and bamboo plants between sprays of lotus and chrysanthemum. Outside is a lotus wreath with spiky leaves.

This has the reddest base of all the fourteenth-century group, but the color is only faintly glossy and does not seem wiped on. There are traces of radial chatter near the center.

29.122 H. $2 \frac{3}{4}$ in. $(7 \mathrm{~cm}$.). D. 16 in. $(41 \mathrm{~cm}$. $)$.

Fourteenth century.

See pages 66,71 . 

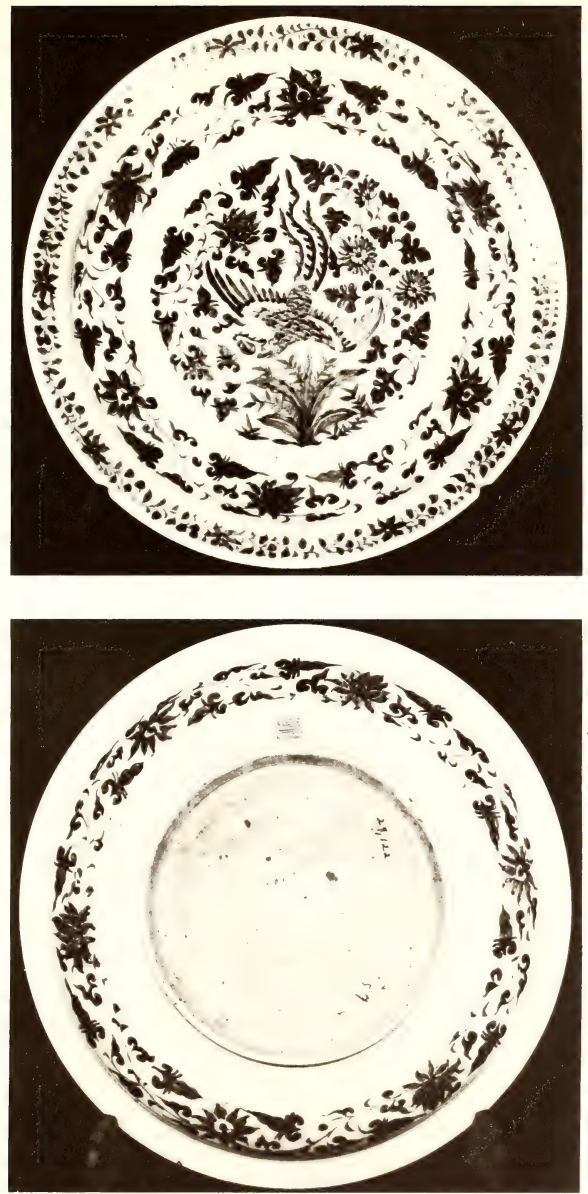


\section{PLATE 15}

Dish with flattened rim; border of diamond-shaped diaper pattern; lotus wreath with spiky leaves in cavetto; in the center a 3-clawed dragon with small white scales flies against a background of white cloud over a sea of concentric waves. Outside is a lotus wreath with spiky leaves.

This dish is very much warped.

29.47 H. $3 \frac{1}{4}$ in. $(8 \mathrm{~cm}$.). D. 18 in. $(46 \mathrm{~cm}$. $)$.

Fourteenth century.

See pages 66,71 . 


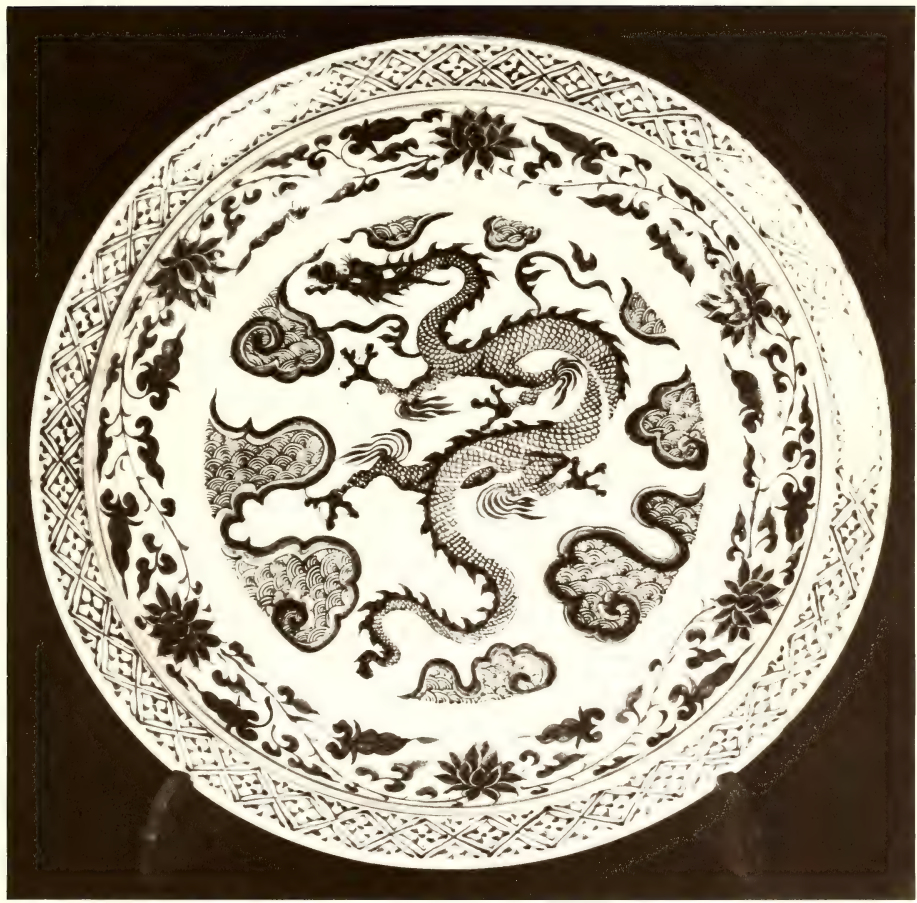




\section{PLATE 16}

Dish with flattened foliate rim and the main decoration reserved in white against a blue ground; border of serpentine waves breaking to the right; lotus wreath in cavetto; four cloud collar points extend inward on a ground of serpentine waves, each point framing a lotus composition; a central circle frames a melon and grape scene. Outside is a lotus wreath with spiky leaves.

29.45 H. $2 \frac{3}{4}$ in. $\left(7 \mathrm{~cm}\right.$.). D. $16 \frac{1}{4}$ in. $(41.5 \mathrm{~cm}$.).

Fourteenth century.

See page 67. 

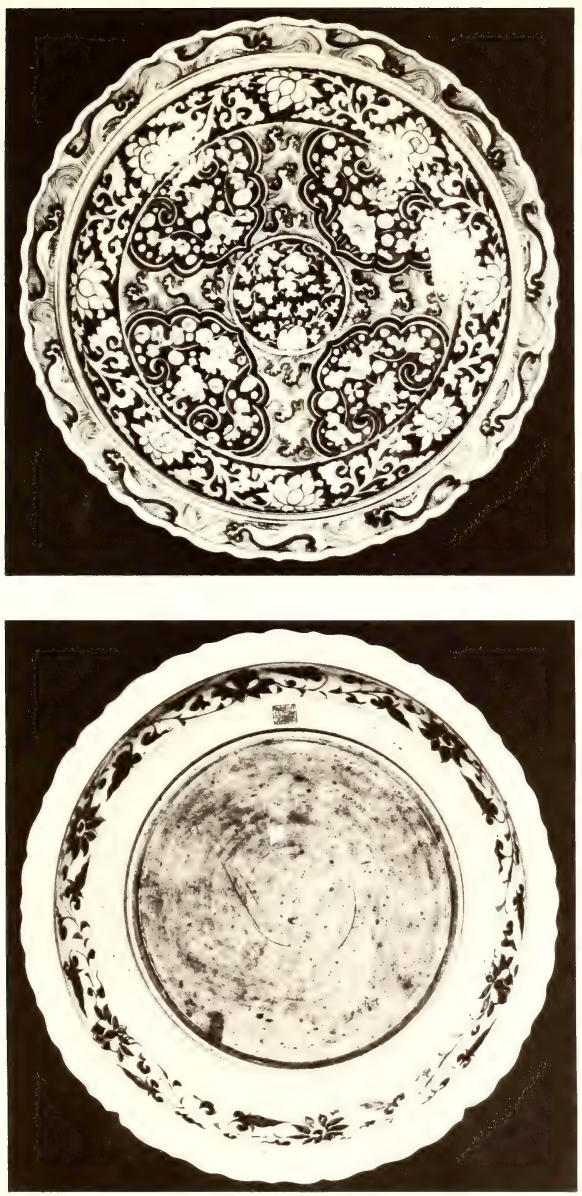


\section{PLATE 17}

Dish with flattened foliate rim and main decoration reserved in white against a blue ground; border of serpentine waves breaking to the left; peony wreath in cavetto; eight large and eight small cloud collar points framing floral sprays, the outer row including two peonies, chrysanthemum, camellia, morning-glory, lotus, and two unidentified blossoms; in center, two phoenixes amid cloud scrolls in foliate medallion. Outside is a lotus wreath with spiky leaves.

29.46 H. 3 in. ( $7.5 \mathrm{~cm}$.). D. 18 in. $(46 \mathrm{~cm}$.).

Fourteenth century.

See page 67. 


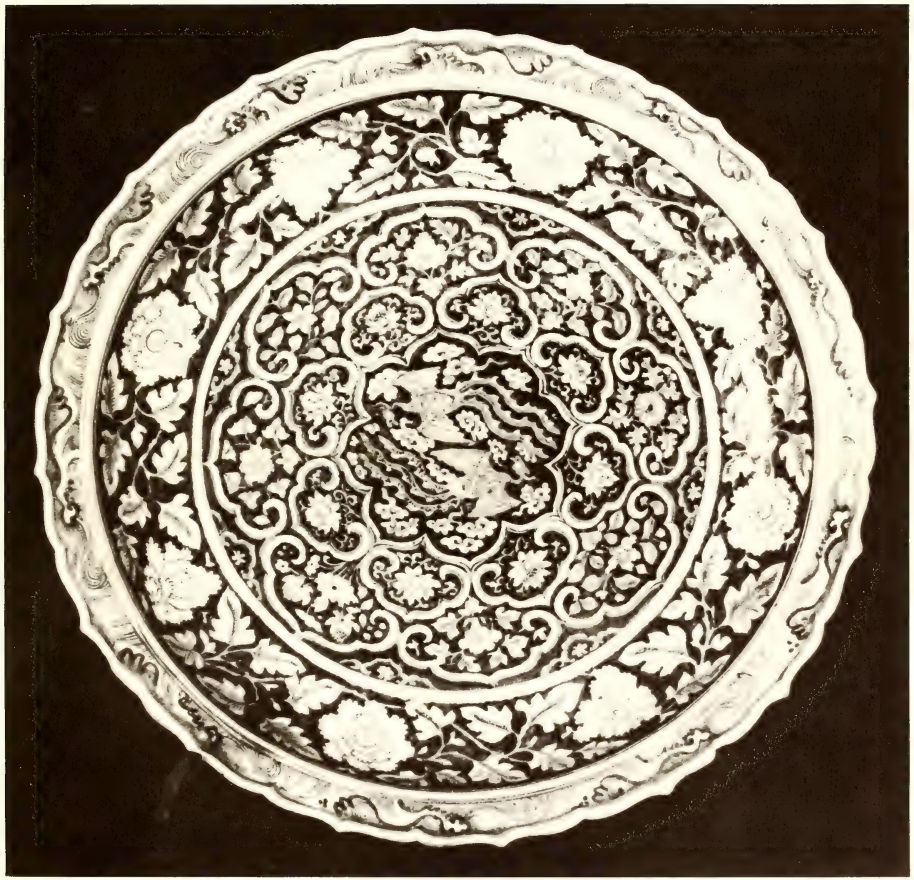




\section{PLATE 18}

Dish with flattened foliate rim and main decorative zones reserved in white against a blue ground; border of serpentine waves breaking to the left; lotus wreath in cavetto; a second band of serpentine waves oriented in the opposite direction to be seen from the rim of the dish and breaking to the right; two cloud collar bands, the outer one framing an area of cloud scrolls, the inner framing the central design of two egrets among lotus plants. Outside is a lotus wreath with spiky leaves.

29.44 H. 3 in. ( $7.5 \mathrm{~cm}$.). D. $15 \frac{3}{4}$ in. $(40 \mathrm{~cm}$.).

Fourteenth century.

See page 67. 

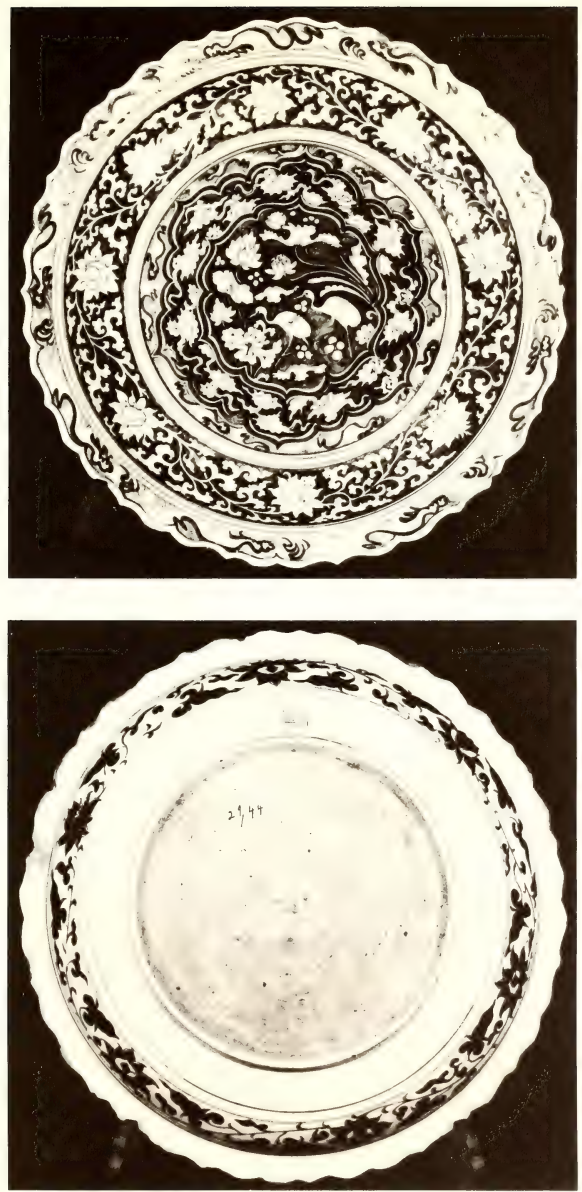


\section{PLATE 19}

Dish with flattened foliate rim and the main decoration reserved in blue against a white ground; border of serpentine waves breaking to the left; peony wreath in cavetto; a second band of serpentine waves, this time breaking to the right; four phoenixes flying among chrysanthemum scrolls; eight auspicious objects framed in stylized lotus panels; a lotus spray with spiky leaves in an 8-pointed cloud collar frame.

29.49 H. $3 \frac{1}{2}$ in. ( $9 \mathrm{~cm}$.). D. $22 \frac{1}{2}$ in. $(57.5 \mathrm{~cm}$.).

Fourteenth century.

See page 67. 


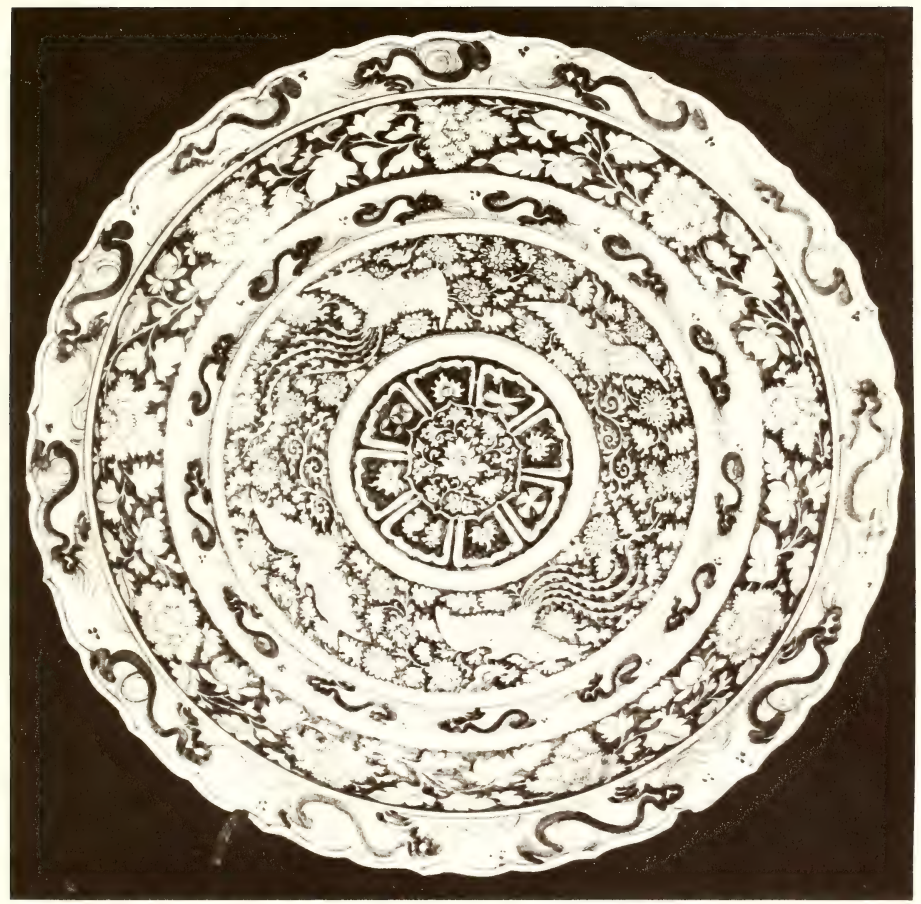


PLATE 20

Base of dish on preceding plate (29.49); a lotus wreath with spiky leaves lies above a band of lotus petals surrounding the foot rim; under the rim is a Persian inscription in underglaze blue.

See pages 55,67 . 


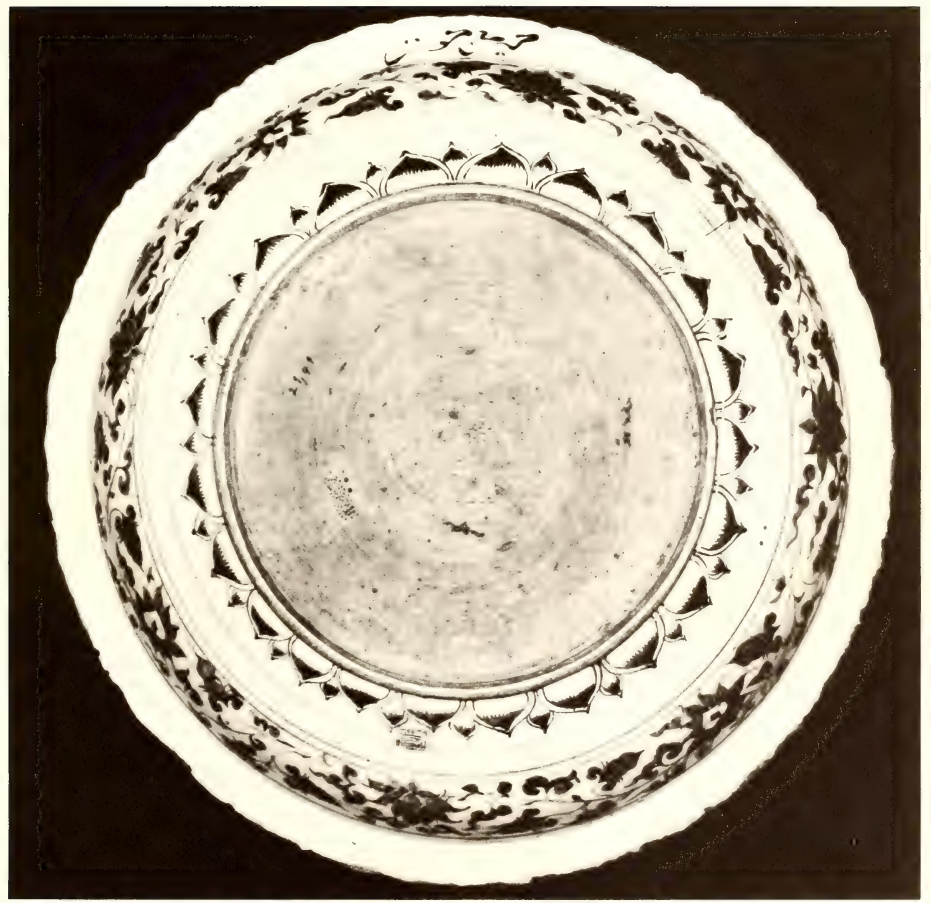




\section{PLATE 21}

Dish with flattened foliate rim and decoration in white against a blue ground; border of serpentine waves breaking to the right; chrysanthemum scrolls in cavetto; band of camellia scroll surrounding a circle of fourteen lotus-petal panels alternately framing floral sprays (including two chrysanthemums, peony, lotus, camellia, and poppy) and auspicious objects; in the center are two phoenixes among cloud scrolls. Outside is a lotus wreath with spiky leaves.

The white areas on one side of this dish are spattered with blue as though cobalt had been spilled on it by accident before glazing.

29.127 H. 34 in. $(8 \mathrm{~cm}$.). D. 18 in. $(46 \mathrm{~cm}$.).

Dish with flattened foliate rim and main decoration in white against a blue ground; border of serpentine waves based on the outer edge of the rim and breaking to the right; peony scrolls in cavetto; 6-pointed cloud collar medallion with a border of serpentine waves breaking to the right; between the points are small formal scrolls and inside each point a phoenix flies among cloud scrolls; in the center six lotus-petal panels frame floral sprays surrounding a miniature cloud collar medallion. Outside is a lotus wreath with spiky leaves.

29.48 H. 31 in. $(8 \mathrm{~cm}$.). D. 18 in. $(45.5 \mathrm{~cm}$.).

Fourteenth century.

See page 67. 


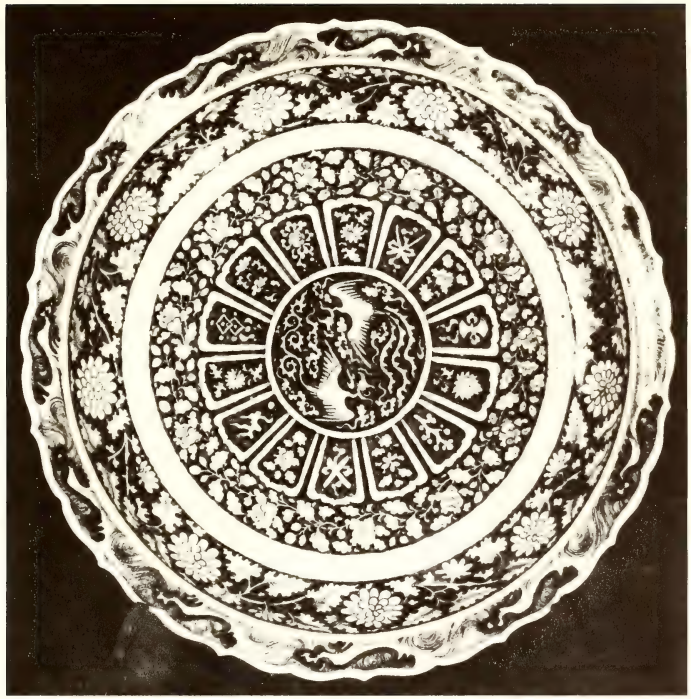

29.127

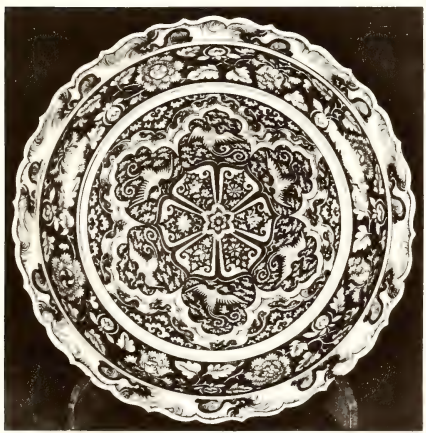

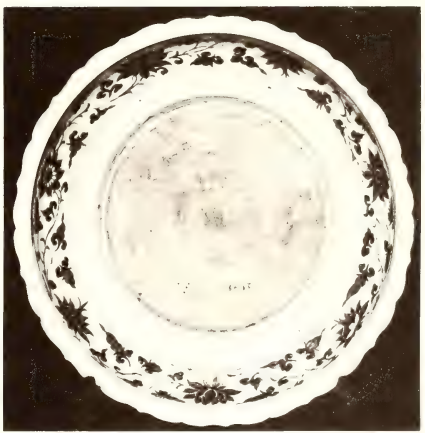

29.48 


\section{PLATE 22}

Dish with flattened foliate rim of which the white outer edge is raised in relief; the border is decorated with white floral scrolls in relief on a blue ground showing three kinds of flowers (chrysanthemum, gardenia, and crabapple) arranged in five segments, three long and two short; the cavetto has a peony scroll in white slip relief against a ground of fine blue lines; in the center a phoenix flies upward among rocks, banana, bamboo, morning-glory, grapes, and melons. Outside is a lotus wreath with spiky leaves.

29.128 H. 3 in. $(7.5$ cm. $)$. D. $18 \frac{3}{4}$ in. $(47.5 \mathrm{~cm}$.).

Dish with flattened foliate rim decorated with crapemyrtle scroll and blackberry-lily blossoms; peony wreath in white on blue in cavetto; in the center is a lotus pond with four plants. Outside is a lotus wreath with spiky leaves.

29.123 H. 3 in. $\left(7.5 \mathrm{~cm}\right.$.). D. $18 \frac{1}{2}$ in. $(47 \mathrm{~cm}$.).

Dish with flattened foliate rim of which the white outer edge is raised in relief; the border has a single white chrysanthemum scroll in relief against a blue ground; in the cavetto is a peony scroll in white slip relief, enhanced with blue outline on the petals, against a ground of fine blue lines; in the center is a lotus pond with four plants. Outside is a lotus wreath with spiky leaves.

29.129 H. 3 in. $\left(7.5 \mathrm{~cm}\right.$.). D. $17 \frac{3}{4}$ in. $(45 \mathrm{~cm}$.).

Fourteenth century.

See pages 67,70 . 


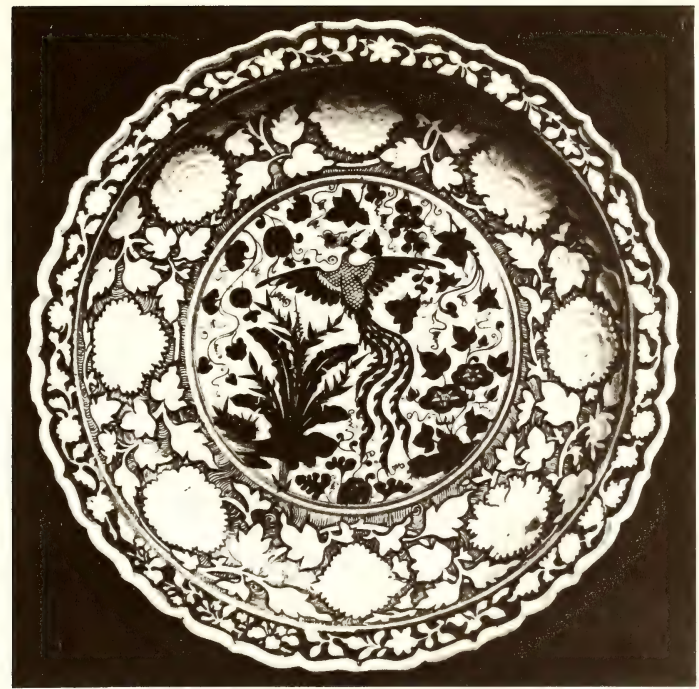

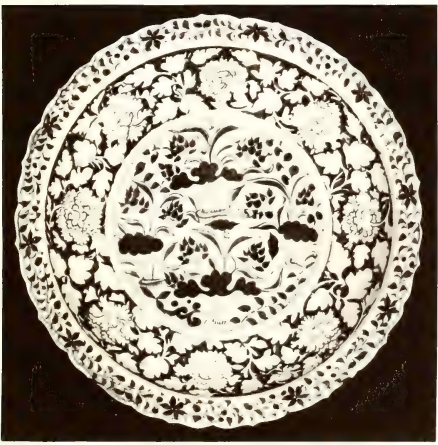

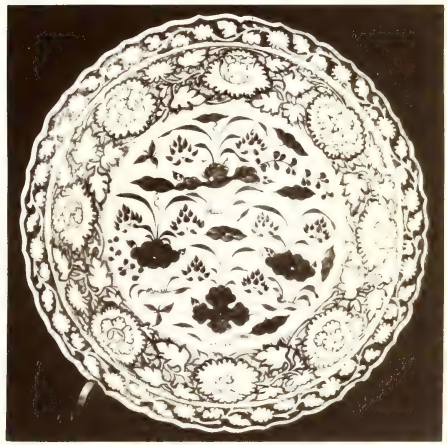

29.129 


\section{PLATE 23}

Bowl with contracted rim slightly beveled on the outside; inside decoration and one band outside reserved in white against a blue ground; a border of 17 lotus panels inside the rim provides frames for as many separate floral sprays, among which lotus, chrysanthemum, and peony are recognizable; below this is a scrolling band showing three peonies, three chrysanthemums, a lotus, and a clematis (?); the next band has a peacock and a peahen among peony scrolls; in the center, on a ground of concentric waves is a 4-pointed cloud collar design somewhat resembling a Buddhist double vajra. Outside is a border of nondescript waves above a wide band of peony wreath; a band of classic scroll lies above a row of lotus panels framing alternate chrysanthemum and blackberry-lily blossoms amid foliage.

The foot rim is $11 / 16$ in. $\left(1.8 \mathrm{~cm}\right.$.) thick, $1 \frac{5}{8}$ in. $\left(4 \mathrm{~cm}\right.$.) deep, and $5 \frac{1}{8} \mathrm{in}$. $(13 \mathrm{~cm}$.) across at its bottom point. It seems to have been made separately and luted to the bowl. (Pl. 141.)

29.319 H. $7 \frac{1}{4}$ in. $(18.5 \mathrm{~cm}$. $)$. D. $14 \frac{1}{2}$ in. $(37 \mathrm{~cm}$.) at rim.

Fourteenth century.

See pages $60,61,68,100$. 

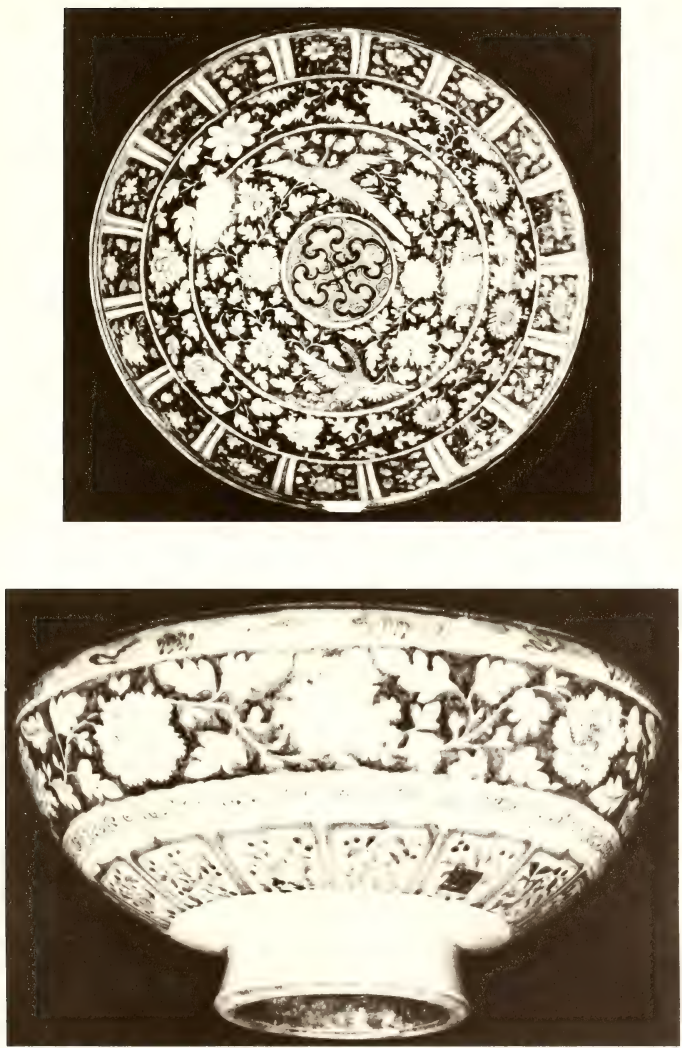


\section{PLATE 24}

Bowl with flaring rim; inside is a border of crapemyrtle scroll with blackberry-lily blossoms above a broad band of plain white; in the center are bamboo, grapes, and morning-glories. Outside is a broad band of lotus wreath with spiky leaves above a row of lotus panels framing stylized leaf forms.

The foot is glazed down to the outer angle of the bevel (pl. 141), and the unglazed base underneath shows a very fine smooth paste.

29.320 H. 5 in. $\left(12.5 \mathrm{~cm}\right.$.). D. $11 \frac{3}{4}$ in. $(30 \mathrm{~cm}$. $)$.

Fourteenth century.

See pages $60,61,68,156$. 

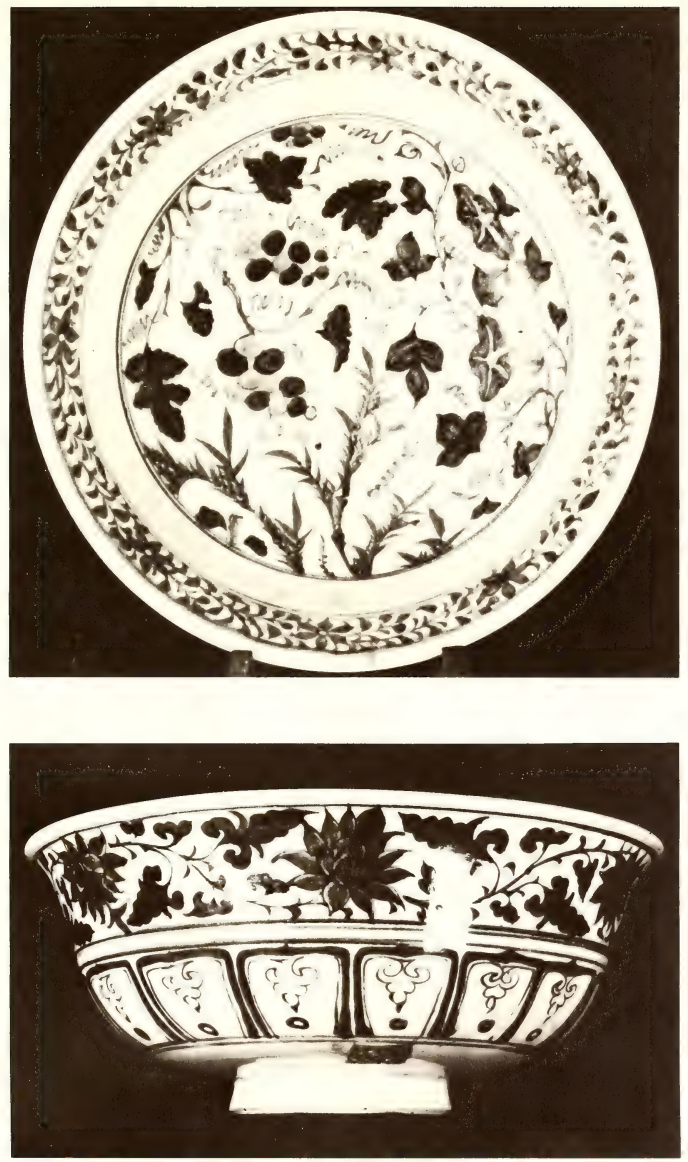


\section{PLATE 25}

Four vases of mei-p'ing shape illustrating some of the common decorative motifs of the period; classic scroll and various diaper patterns fill the narrow bands; on the shoulders are plain peony scrolls, peony scrolls with phoenix, lotus scrolls with pai-ts'e, and cloud collar points framing phoenixes amid foliage and flowers; large peony scrolls appear on the central zone of all this group though other forms are known; the lotus panels below are typical as are the motifs they frame. The unglazed bases have low, broad, roughly cut rims.

The mark of Qarachaghāy is seen on the shoulders of all but 29.412 , which lacks it; except for these three mei-p'ing all other pieces bearing his mark are fifteenth-century wares.

29.406 H. $15 \frac{1}{2}$ in. $\left(39.5 \mathrm{~cm}\right.$.). D. $8 \frac{3}{4}$ in. $(22.5 \mathrm{~cm}$.).

29.407 H. $16 \frac{1}{2}$ in. $\left(42 \mathrm{~cm}\right.$.). D. $8 \frac{3}{4}$ in. $(22.5 \mathrm{~cm}$.).

29.408 H. 17 in. (43 cm.). D. $9 \frac{1}{2}$ in. $(24 \mathrm{~cm}$.).

29.412 H. $16 \frac{1}{2}$ in. $(42 \mathrm{~cm}$.). D. 9 in. $(25 \mathrm{~cm}$. $)$.

Fourteenth century.

See pages $62,63,68$. 


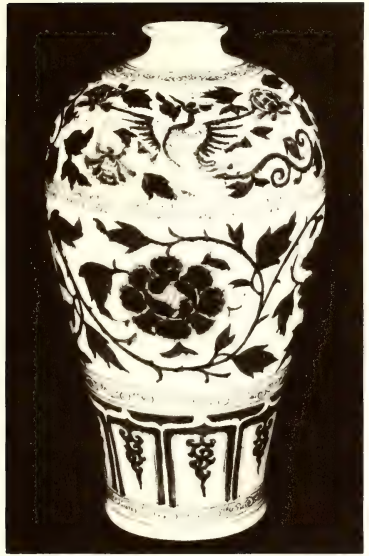

29.406

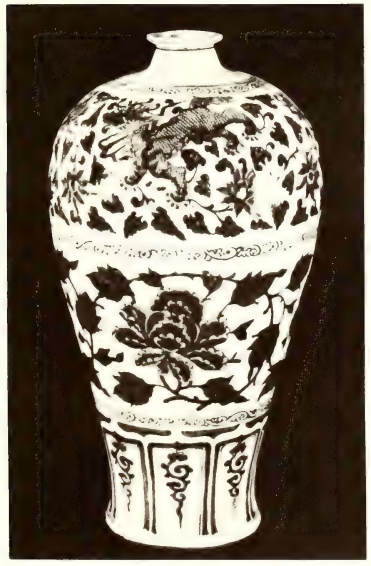

29.408

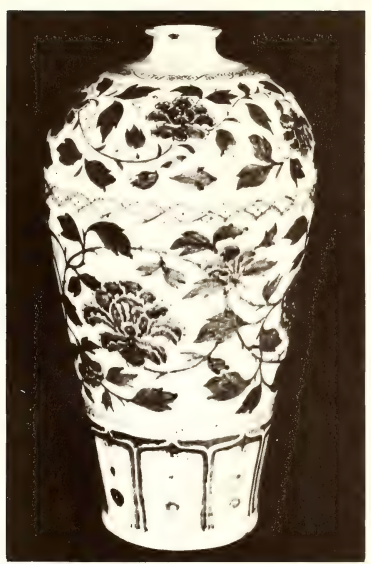

29.407

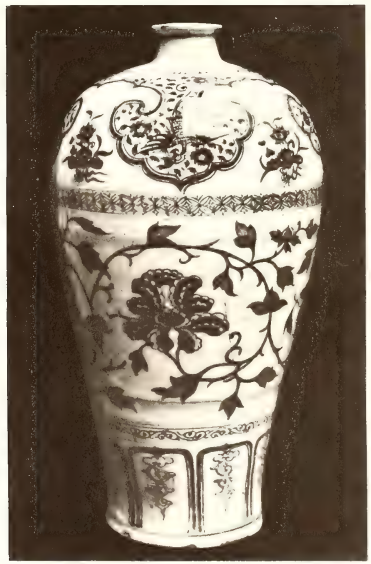

29.412 


\section{PLATE 26}

Vase of kuan shape with diaper band on lip; serpentine waves break to the right around the neck, and on the shoulder are two pai-ts'e with large blue scales standing among bamboo, banana, grapes, melons, and morning-glories; the handles are restored; main zone of large peony scroll; band of diamond diaper pattern above lotus panels framing stylized leaves, lotus buds, and circles.

29.523 H. 197 in. $(50.5 \mathrm{~cm}$.). D. 16 in. $(40.5 \mathrm{~cm}$.).

Vase of mei-p'ing shape showing a praying mantis carrying a bee among scrolling grapevines within the cloud collar frame. The incorrectly restored neck has been blacked out in the photograph.

Unnumbered (Isfahan). H. $15 \frac{3}{4}$ in. $(40 \mathrm{~cm}$.) as restored.

Vase of kuan shape with classic scroll on lip and breaking waves on neck; on the upper shoulder 16 pendent lotus panels frame auspicious objects and flower sprays; below this two lions, each with a brocaded ball, and two ch'i-lins cavort among lotus scrolls with spiky leaves; main zone of large peony scroll above a narrow band of chrysanthemums on a scrolling vine; lotus panels frame stylized leaves and lotus buds below. Lacks the Shāh 'Abbās mark.

29.522 H. $16 \frac{1}{8}$ in. $(41 \mathrm{~cm}$.$) . D. 14 \frac{3}{4}$ in. $(37.5 \mathrm{~cm}$.).

The proportions of the two kuan illustrated on this plate differ considerably one from the other, and the painting of the design on 29.522 might be considered more sophisticated in some details; it may perhaps date from the closing years of the century and be some decades later than 29.523 .

Fourteenth century.

See pages $62,63,68$. 


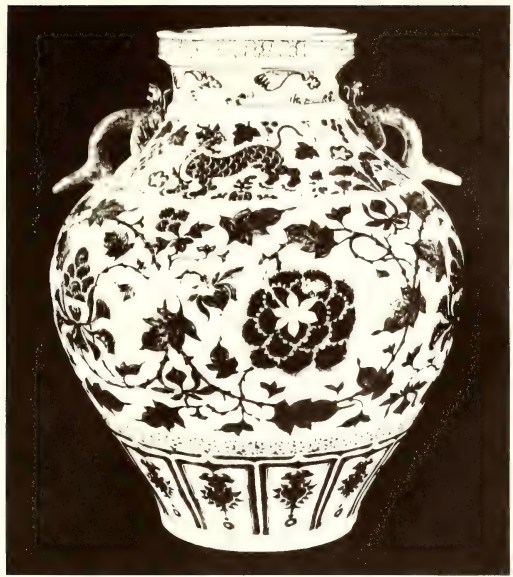

29.523
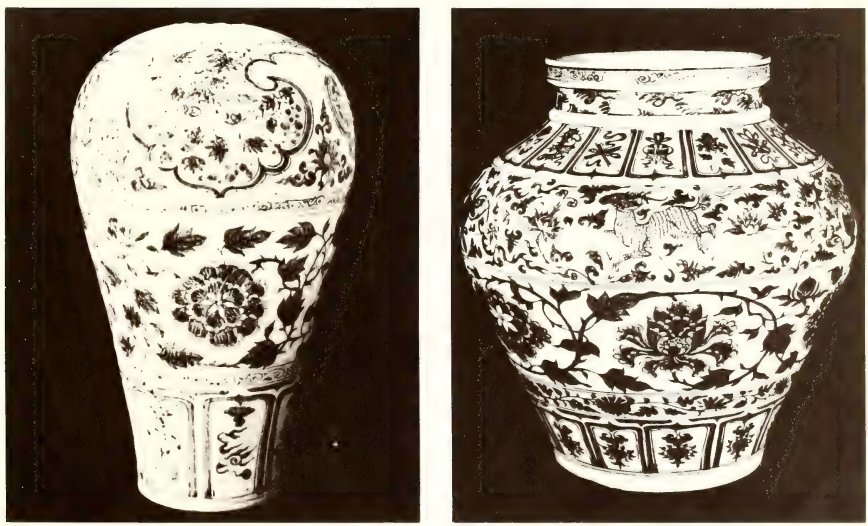
PLATE 27

Vase of kuan shape with serpentine waves around the neck; the main design shows a peacock and a peahen amid poppy scrolls; at the base stand lotus panels framing stylized leaf forms and circles. Lacks the mark of Shāh 'Abbās.

29.480 H. $10 \frac{3}{4}$ in. $(27.5 \mathrm{~cm}$.). D. 13 in. $(33 \mathrm{~cm}$.).

Bottom half of an octagonal "double gourd" vase; the main zone of peony scroll is bounded above and below by rows of lotus panels framing stylized leaf forms, lotus buds, and circles.

The low broad foot is so cut that the central recess is circular in form. (Cf. Pope, FourteenthCentury Blue-and-White, pls. 33, 34.)

29.510 H. $13 \frac{3}{8}$ in. $(34 \mathrm{~cm}$.$) . D. 12 \frac{1}{2}$ in. $(32 \mathrm{~cm}$.).

Fourteenth century.

See pages $62,63,68,69$. 


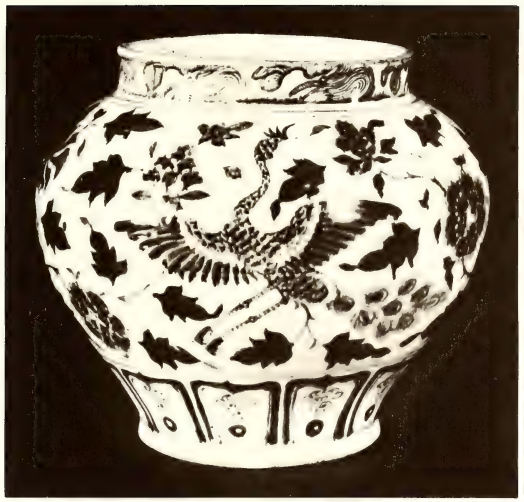

29.480

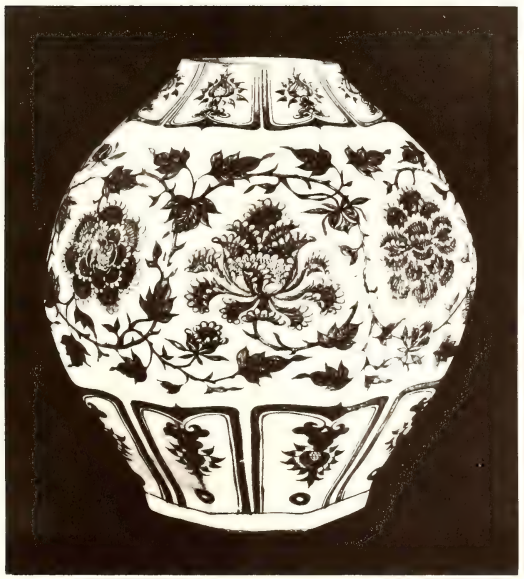




\section{PLATE 28}

Two vases of flat rectangular shape with necks and four loop handles on the curving shoulders; 29.475 has on one side a peacock and a peahen amid peonies growing from behind a garden rock, on the other a phoenix flies down over a pai-ts'e among lotus scrolls; chrysanthemum sprays decorate the ends; two of the four handles are restored; on 29.476 complex cloud collars frame blossoms and foliage against a plain white ground; below are peacocks and peahens among peonies, and on each end is a lotus spray. The neck and all four handles are restored to conform with those on 29.475 but traces of scrolling tails in relief and underglaze blue below the restoration suggest that the originals were in the form of dragons. (Cf. OCS, Catalogue, 1953, no. 29; and Garner, Oriental blue and white, pl. 24.)

The bases of both are roughly finished and splashed with glaze.

29.475 H. $14 \frac{3}{8}$ in. (36.5 cm.). W. $10 \frac{3}{8}$ in. $(26.5 \mathrm{~cm}$.). T. 4 in. $(10 \mathrm{~cm}$.).

29.476 H. 15 in. $\left(38 \mathrm{~cm}\right.$.). W. 11 in. $\left(28 \mathrm{~cm}\right.$.). T. $3 \frac{1}{2}$ in. $(9 \mathrm{~cm}$. $)$.

Fourteenth century.

See pages $62,63,68$. 

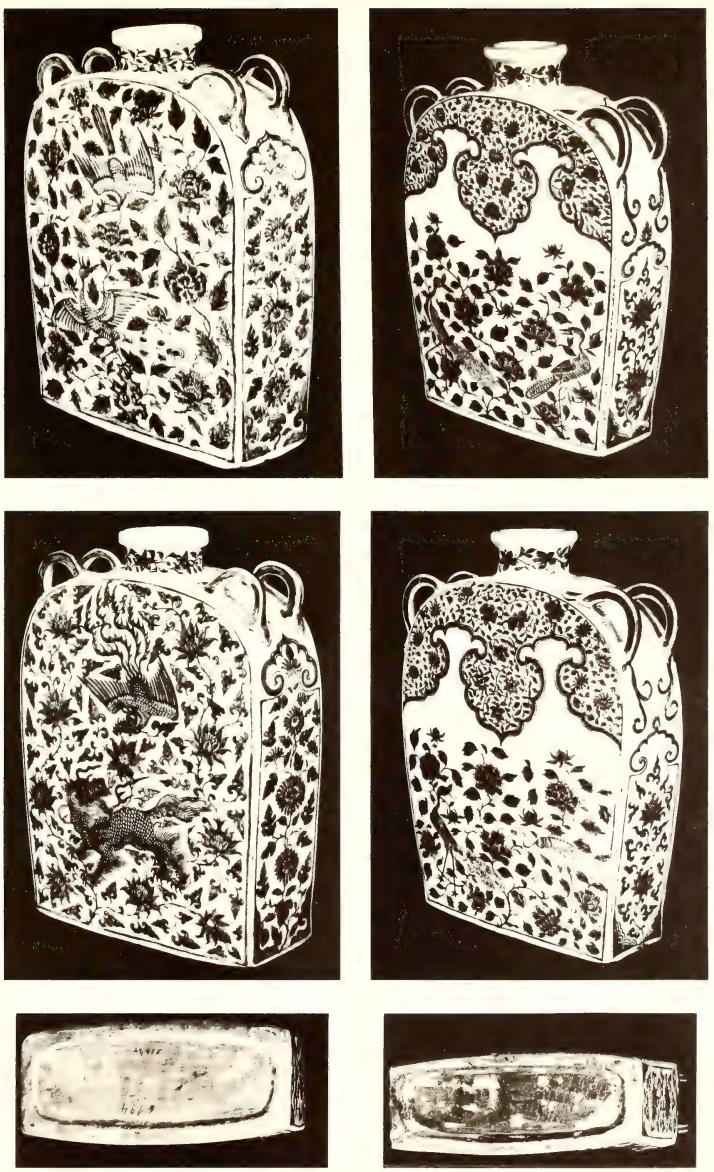


\section{PLATE 29}

Dishes with flattened foliate rims; borders decorated with various designs such as floral and fungus sprays and scroll patterns; flower sprays in molded sections of cavetto; in the centers illustrated are a fungus scroll around a lotus petal medallion, a chrysanthemum scroll around a stylized blossom, and a grape spray; outsides decorated with similar variety; unglazed bases reveal fine paste and the foot rims are neatly trimmed.

Similar dishes with raised rings in the centers are called cup stands (cf. PMA, 24, 25); the type is also known in underglaze red.

$29.271-275$ (5 pieces) H. 1 in. $\left(2.5 \mathrm{~cm}\right.$.). D. $7 \frac{5}{8}$ in. $(19.5 \mathrm{~cm}$.).

Late fourteenth or early fifteenth century.

See pages $78,79,81$. 


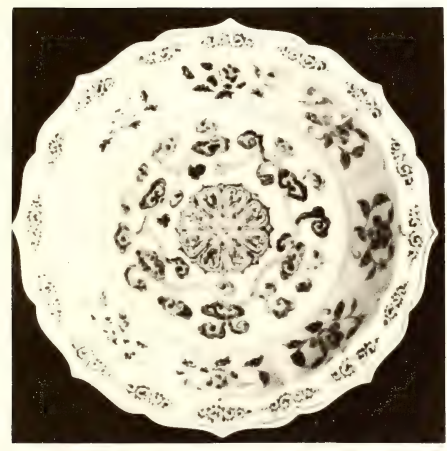

29.271

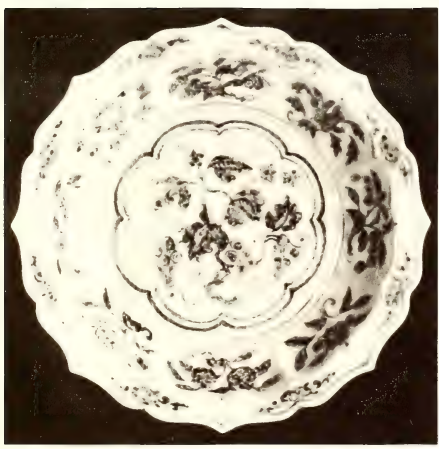

29.274

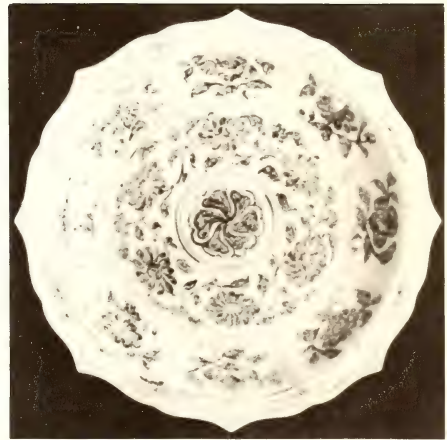

29.272

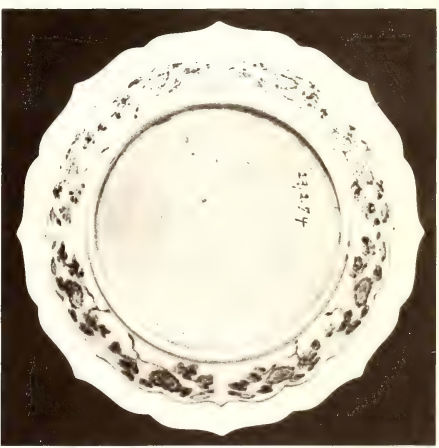

29.274 


\section{PLATE 30}

Dish with plain rim; inside is a border of stylized waves above a cavetto decoration of scrolling vine with 13 blossoms; in the center is a bouquet tied with a fillet. Outside are bands of classic scroll, scrolling vine and thunder pattern.

There are 17 of these dishes; 29.8-9 lack the Shāh 'Abbãs mark; 12 are marked Qarachaghāy; 2 are marked Quli, several bear undeciphered owners' marks, and 29.3 has what looks like Uighur script in ink on the base. The piece illustrated has a Chinese inscription on the base in ink. Even on the original it is very faint and some of the characters are illegible, but the iron red of the base seems to lie on top of the ink, which may mean it was written before the piece was fired. It consists of 43 characters in five unequal lines as follows:

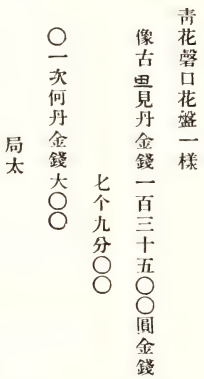

It has not been possible to make a sensible translation of this inscription so far. Two things, however, are worthy of note. The first two characters, ching-hua, are perfectly clear and may, if the inscription was actually written when the piece was made, be the earliest occurrence of this standard term for "blue-and-white" noticed thus far. And second, there seems to be reference to 135 monetary units of some sort. Whether this refers to the price of the dish cannot now be determined, but it seems like a possibility that deserves consideration.

\begin{tabular}{|c|c|c|}
\hline 29.1-7 (7 pieces) & H. $2 \frac{3}{4}$ in. $(7 \mathrm{~cm})$. & D. 16 in. $(41 \mathrm{~cm}$.$) .$ \\
\hline 29.8-11 (4 pieces) & " & D. $13 \frac{1}{2}$ in. $(34 \mathrm{~cm}$.$) .$ \\
\hline $29.12-15$ (4 pieces) & “ & D. $12 \frac{1}{4}$ in. $(31 \mathrm{~cm}$.$) .$ \\
\hline $29.16-17$ ( 2 pieces) & " & D. 11 in. $(27.5 \mathrm{~cm})$. \\
\hline
\end{tabular}

Early fifteenth century.

See pages $71,85,90,92$. 

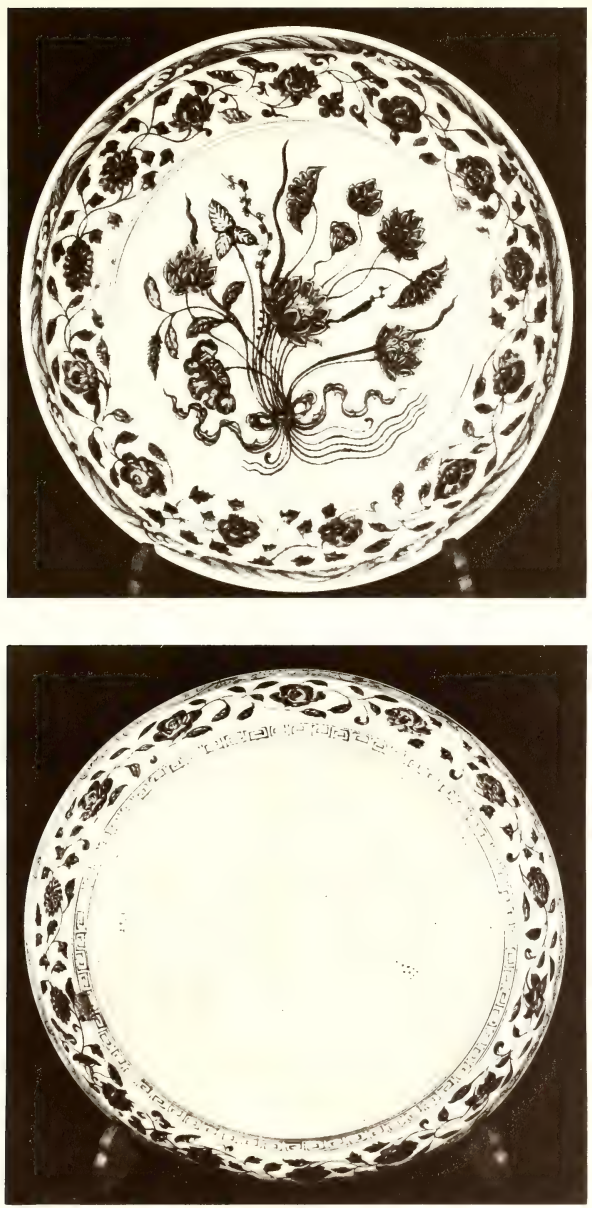
PLATE 31

Four dishes with bouquet patterns to illustrate the variations in the drawing of the central motif, in the intensity of the blue, and, on 29.21 and 29.33 , in the treatment of the rim and its decoration.

The two on the left are from the group described facing plate 30 . Eleven of the type represented by 29.21 and both 29.33 and 29.34 have the mark of Qarachaghäy; one of the former is marked Quli and one Nārinjī.

29.18-27 (10 pieces)

29.28-31 (4 pieces)

29.32 ( 1 piece)

29.33-34 ( 2 pieces)

H. 21 in. $(6 \mathrm{~cm}$. $)$.

D. $13 \frac{1}{2}$ in. ( $34 \mathrm{~cm}$.).

" " D. $12 \frac{1}{2}$ in. $(31.5 \mathrm{~cm}$. $)$.
"
D. $11 \frac{1}{4}$ in. $(28.5 \mathrm{~cm}$.$) .$

H. 3 in. $(7.5 \mathrm{~cm}$.). D. 17 in. $(43 \mathrm{~cm}$. $)$.

Early fifteenth century.

See pages $71,85,90,92$. 


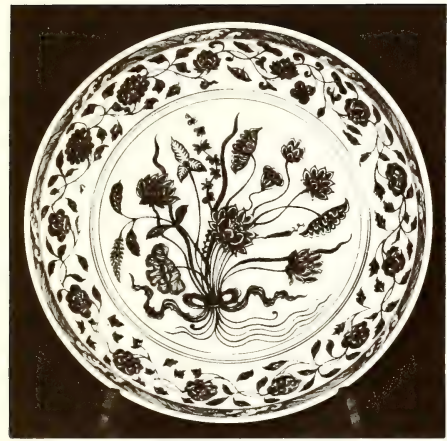

29.3

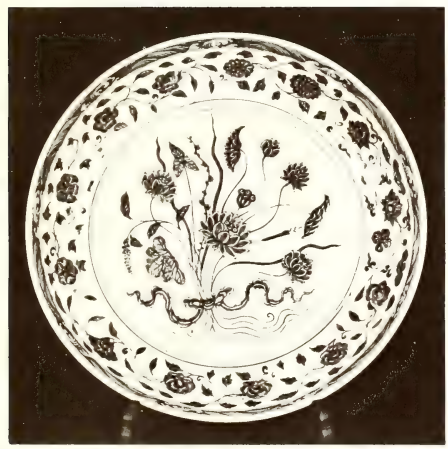

29.6

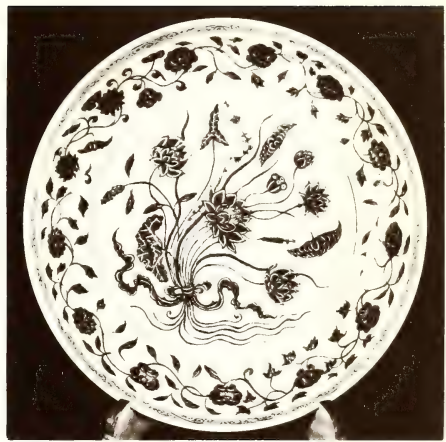

29.21

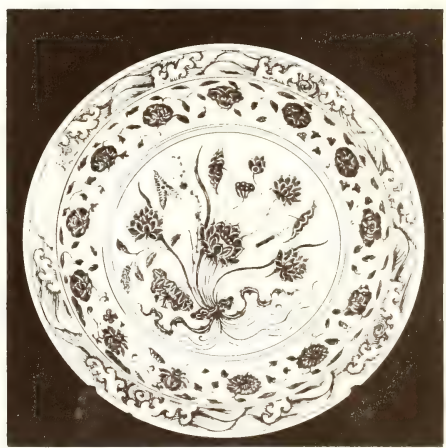

29.33 


\section{PLATE 32}

Dish with flattened rim decorated with eight flower and fruit sprays among which chrysanthemum, pomegranate, and camellia are identifiable; in the cavetto is a scrolling vine with eight lotus blossoms; the center frames a single large branch with two full-blown peonies, another just opening, and one bud; outside is a scroll with lotus buds.

29.65-66 (2 pieces) H. $3 \frac{1}{4}$ in. $\left(8 \mathrm{~cm}\right.$.). D. $17 \frac{1}{\mathrm{in}}$. $(43.5 \mathrm{~cm}$.).

Dish with plain rim, leafy scroll border, and nine flower and fruit sprays in the cavetto; the central design and outside are as above except for the spindly stem.

29.64 ( 1 piece) H. 3 in. ( $7.5 \mathrm{~cm}$.). D. $17 \frac{1}{2}$ in. $(44.5 \mathrm{~cm}$.).

Dish with flattened rim decorated with classic scroll; peony scroll with seven blossoms in cavetto; central peony design as above but with different leaves; floral scrolls outside.

29.67-71 (5 pieces) H. $2 \frac{3}{4}$ in. $\left(7 \mathrm{~cm}\right.$.). D. $14 \frac{3}{4}$ in. $(37.5 \mathrm{~cm}$.).

All eight dishes have the mark of Qarachaghãy.

Early fifteenth century.

See pages $90,91,93,144$. 


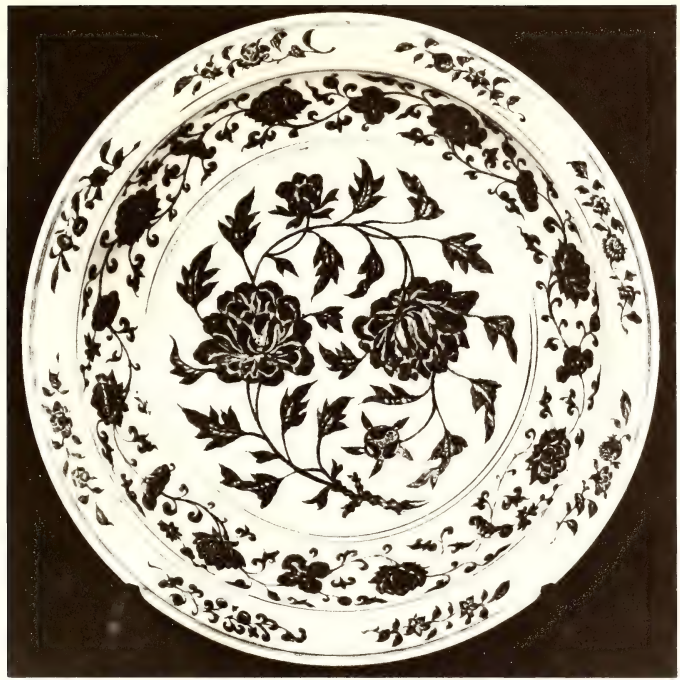

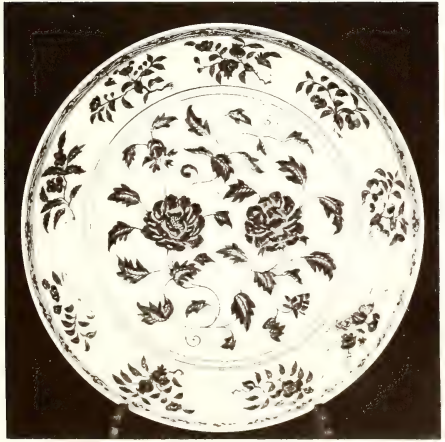

29.64

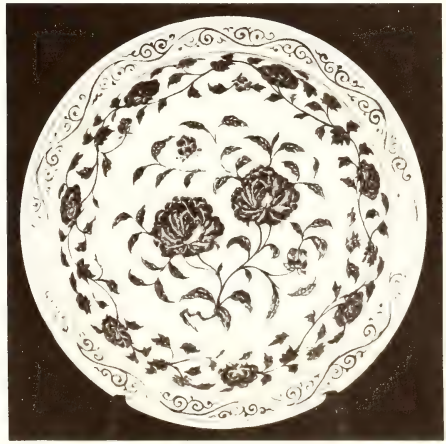

29.68 


\section{PLATE 33}

Dish with plain flattened rim decorated with fungus scrolls; in the cavetto are eight peony blossoms on a scrolling vine; in the center, within an 8-pointed foliate frame drawn with double line, are three large chrysanthemum flowers on a vine spray arranged in a circle and bearing one smaller blossom and a number of buds. Outside are six separate floral sprays including rose, lotus, peony, and chrysanthemum.

Eight of these pieces bear the mark of Qarachaghāy.

29.72-77 (6 pieces) H. $2 \frac{3}{4}$ in. $(7 \mathrm{~cm}$.$) . D. 15$ in. $(38 \mathrm{~cm}$.$) .$

[One of this group is $14 \frac{3}{4} \mathrm{in}$. in diameter.]

29.78 (1 piece) H. $2 \frac{3}{4}$ in. $(7 \mathrm{~cm}$.$) . D. 16$ in. $(40.5 \mathrm{~cm}$.$) .$

29.79-81 ( 3 pieces) H. 3 in. $(7.5 \mathrm{~cm}$.). D. 17 in. $(43.5 \mathrm{~cm}$. $)$.

Dish with flattened foliate rim on which is a single scrolling vine with 24 small lotus blossoms separated by as many leaves; in the 12 molded sections of the cavetto are 12 single flower sprays including peony, lotus, camellia, convolvulus, crabapple, pomegranate, and chrysanthemum; in the center in a hexafoil frame in double line is a spray of three lotus blossoms with leaves. Outside are six fungus sprays alternating with six lotus sprays.

Both pieces bear the mark of Qarachaghāy; one is also marked Quli and the other bears an undeciphered mark.

29.82-83 (2 pieces) H. $2 \frac{3}{4}$ in. $(7 \mathrm{~cm}$.$) . D. 14 \frac{3}{4}$ in. $(37.5 \mathrm{~cm}$.).

H. 3 in. $(7.5 \mathrm{~cm}$.$) . D. 16$ in. $(40.5 \mathrm{~cm}$. $)$.

Early fifteenth century.

See pages $49,90,91,93$. 


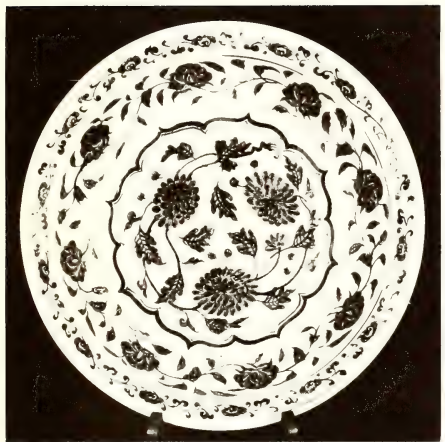

29.75

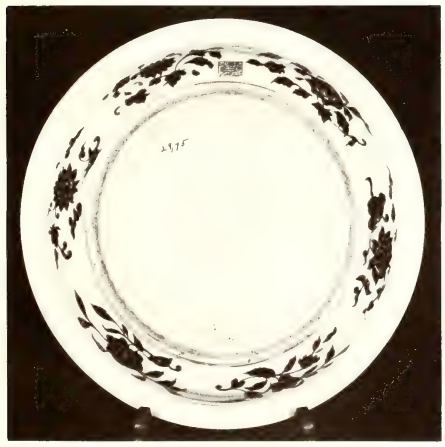

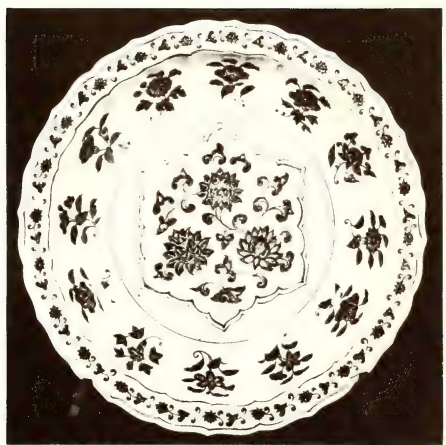

29.83

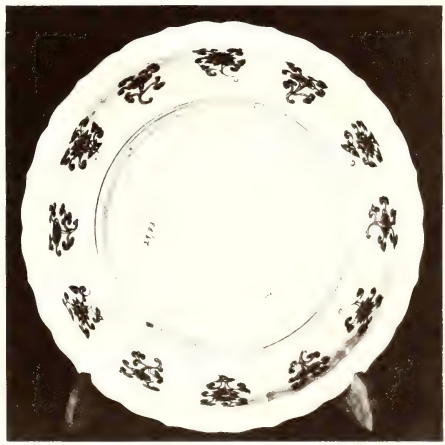

29.83 


\section{PLATE 34}

Dish with flattened rim decorated with a fine scrolling vine bearing peony leaves; in the cavetto is a scrolling vine with 11 blossoms including chrysanthemum, lotus, and camellia; in the center are four main flowers (hibiscus, peony, and two camellias) and three lesser ones; outside are floral scrolls.

29.91-94 (4 pieces) H. 3 in. $(7.5 \mathrm{~cm}$.$) . D. 161$ in. $(41 \mathrm{~cm}$.$) .$

Dish with flattened rim decorated with waves; other details as above.

29.84-90 (7 pieces) H. 3 in. $\left(7.5 \mathrm{~cm}\right.$.). D. $15 \frac{3}{4}$ in. $(40 \mathrm{~cm}$.).

Dish with plain rim and wave border; floral scroll in cavetto has 12 blossoms arranged in pairs including lotus, peonies, camellias, and chrysanthemums; in the center are five lotus blossoms and a leaf amid scrolls; outside is a fungus scroll border, floral scroll cavetto, and a scalloped band at the base with trefoils perched on alternate tips.

29.95-99 (5 pieces) H. 3 in. $\left(7.5 \mathrm{~cm}\right.$.). D. $15 \frac{1}{4}$ in. $(39 \mathrm{~cm}$.).

Twelve of these 16 dishes are marked Qarachaghāy; three have undeciphered marks.

Early fifteenth century.

See pages 90,93 . 


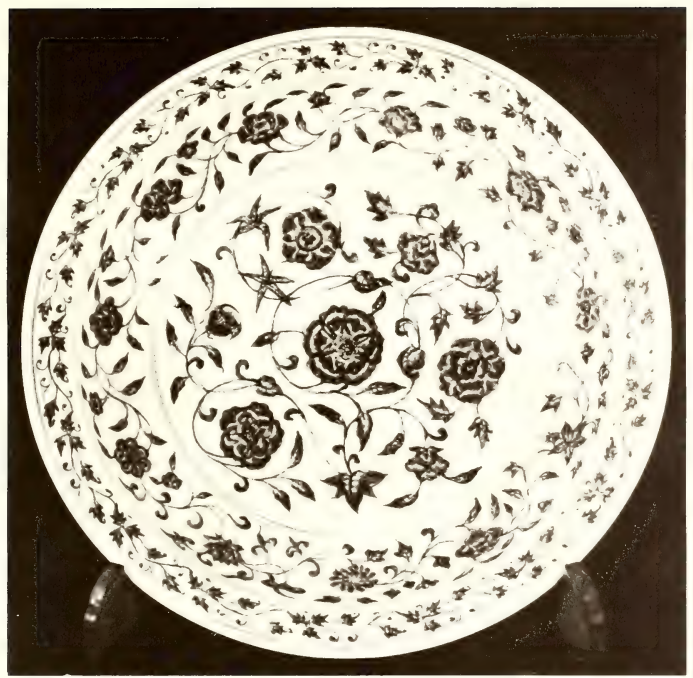

29.92

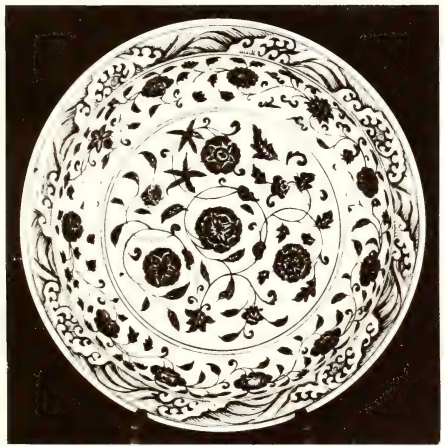

29.88

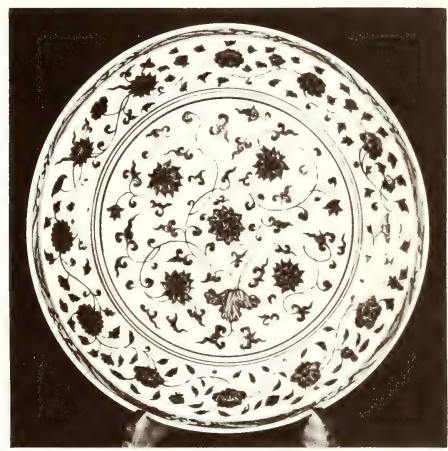


PLATE 35

Three dishes with flattened foliate rims decorated with scrolling vines and fungus; in the molded sections of the cavettoes are 12 separate floral sprays consisting of a series of six repeated; morning-glory, chrysanthemum, peony, and lotus have been identified; in the center are five main blossoms and four lesser ones formally disposed on an elaborate, scrolling vine; lotus, peony, and perhaps camellia may be identified; outside are 12 floral sprays.

These three pieces from the same set and bearing identical designs are illustrated to show the variations that may be found in the style and quality of the drawing and in the density of the blue as between dishes which are, for all practical purposes, and no doubt by intent, all alike.

Nine of this group have the mark of Qarachaghāy.

29.101-111 (11 pieces) H. $2 \frac{3}{4}$ in. $(7 \mathrm{~cm}$.$) . D. 15$ in. $(38 \mathrm{~cm}$.$) .$

Early fifteenth century.

See page 91 . 

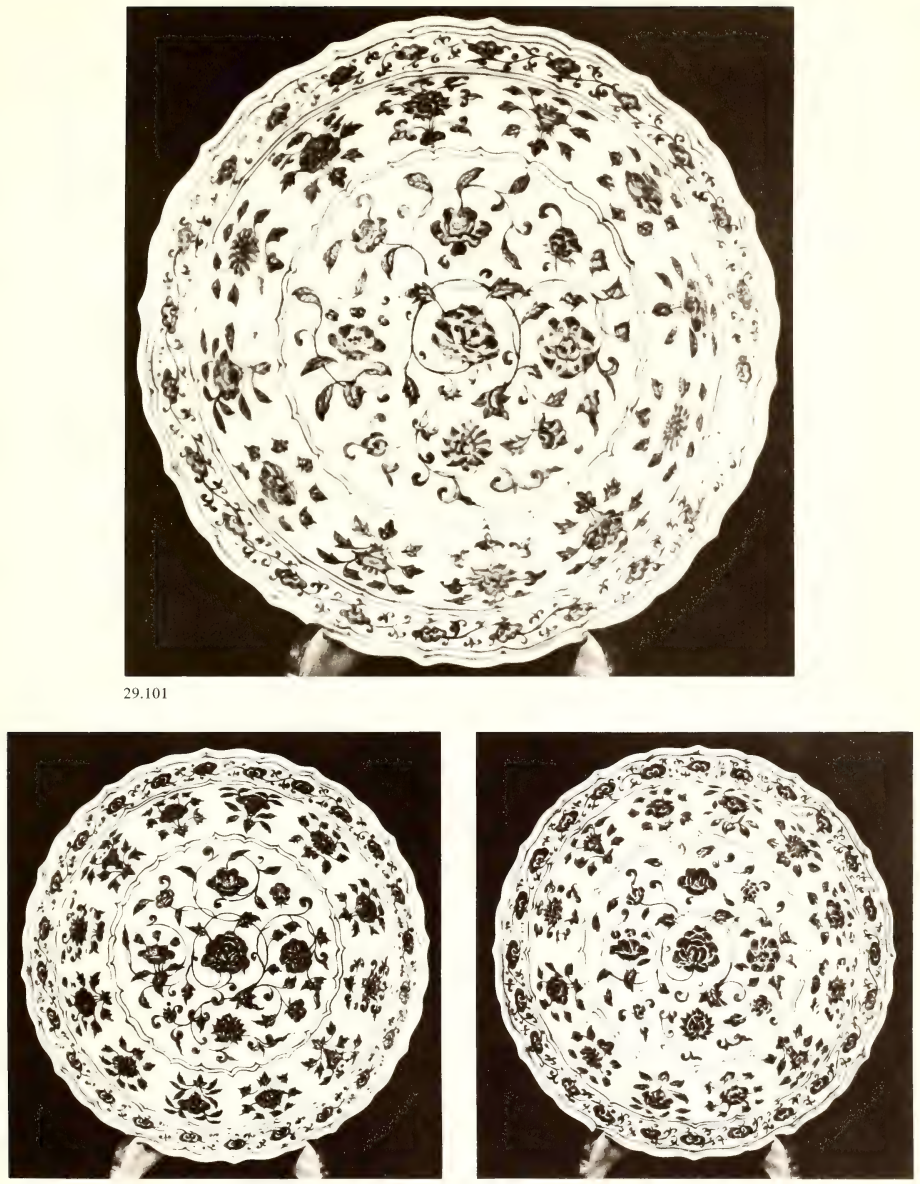


\section{PLATE 36}

Dish with flattened rim decorated with a scrolling vine and 24 small curiously stylized flowers, probably lotus; in the cavetto is a scrolling vine with 12 blossoms, among which seem to be lotus, peony, camellia, morning-glory, chrysanthemum, and others, although the stylization makes it impossible to be certain; the six large flowers in the center are equally difficult, though lotus and chrysanthemum are clearly seen; outside are floral scrolls.

29.112-114 (3 pieces) H. $3 \frac{1}{4}$ in. $(8 \mathrm{~cm}$.). D. 17 in. $(43.5 \mathrm{~cm}$.).

Dish with flattened foliate rim; except for the differences imposed by the foliate form and molded cavetto, the decoration is like that described above.

$29.115-117,125,126$ (5 pieces) H. $2 \frac{1}{4}$ in. $\left(6 \mathrm{~cm}\right.$.). D. $13 \frac{1}{2}$ in. $(34 \mathrm{~cm}$.).

Dish with plain rim and classic scroll border; in the cavetto are eight lotus blossoms on a scrolling vine, and in the center six lotus formally placed amid symmetrically arranged scrolls; outside are a border of thunder pattern, a band of floral scrolls, and classic scroll around the foot.

The drawing on this small dish is exceptionally fine, and the effect is further enhanced by the contrast between the formal stylization of the lotus in the center and the more naturalistic treatment of those in the cavetto which are accompanied by real lotus leaves, sagittaria, small water plants, and the conventional pointed leaves all on the same vine.

$29.118-119$ (2 pieces) H. $2 \frac{1}{4}$ in. $(5.5 \mathrm{~cm}$.). D. 11 in. $(28 \mathrm{~cm}$. $)$.

Of the ten dishes in these three groups, nine bear the mark of Qarachaghāy.

Early fifteenth century.

See pages $90,91,93$. 


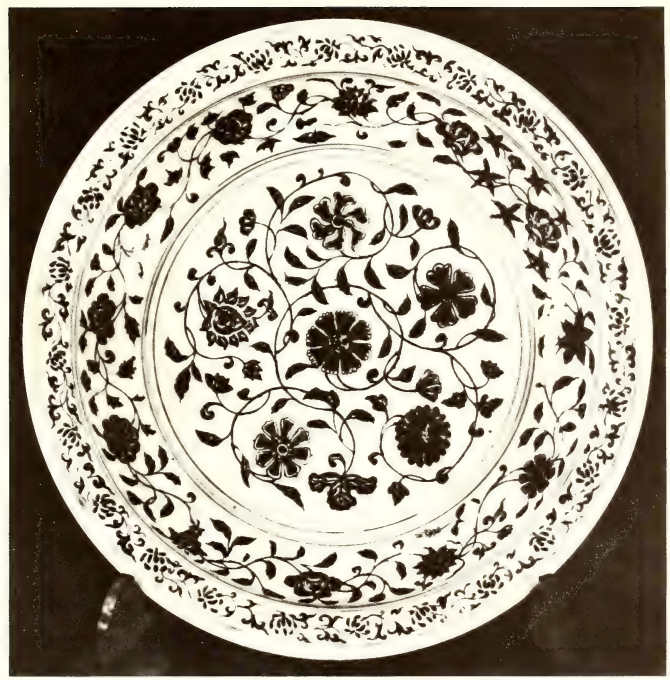

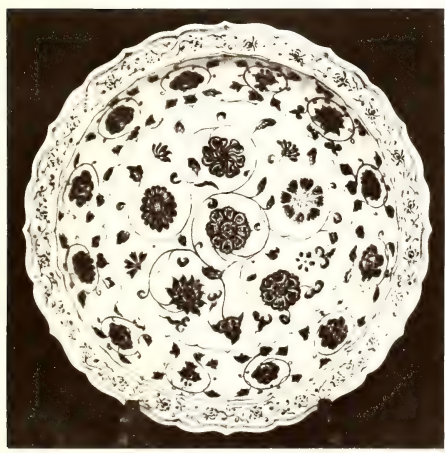

29.117

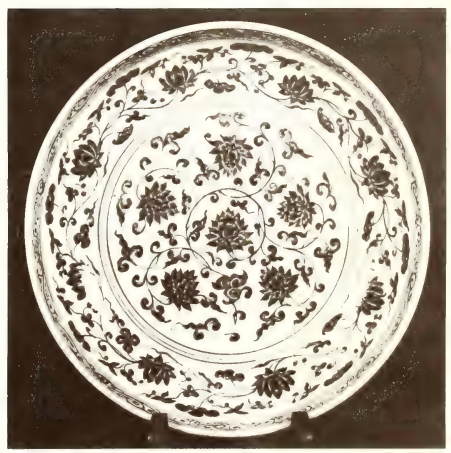

29.119 


\section{PLATE 37}

Dish with flattened foliate rim decorated with waves; in the 12 molded sections of the cavetto are six fungus sprays alternating with six flower sprays including camellia, peony, chrysanthemum, lotus, and hibiscus; in the center are three bunches of grapes with leaves and tendrils on a vine; outside are 12 separate floral sprays.

An undeciphered Persian word is drilled on the base.

29.55 H. $3 \frac{1}{4}$ in. $(8 \mathrm{~cm}$. $)$. D. 17 in $(43 \mathrm{~cm}$.).

Early fifteenth century.

See pages $49,85,90,94$. 

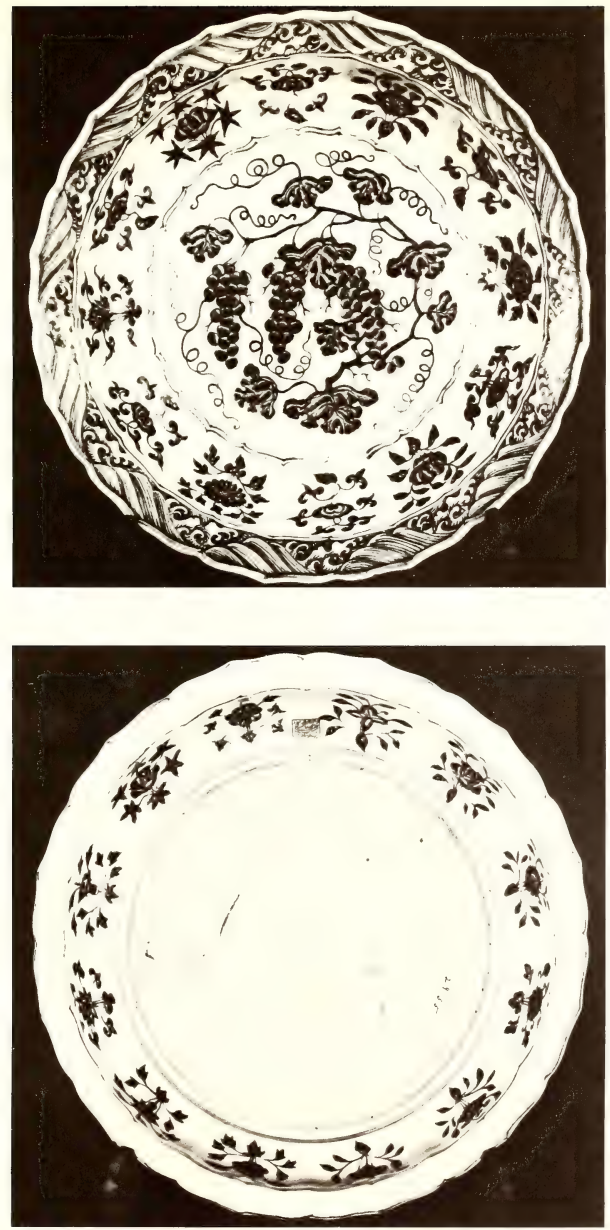


\section{PLATE 38}

Two dishes with grape patterns illustrating differences in treatment of the rims and the border and cavetto patterns as well as in the details of the grapes themselves.

All eight dishes bear the mark of Qarachaghāy.

$29.50-54$ ( 5 pieces) H. 3 in. $\left(7.5 \mathrm{~cm}\right.$.). D. $14 \frac{3}{4}$ in. $(37.5 \mathrm{~cm}$.).

29.56-58 (3 pieces) H. 31 in. $(8 \mathrm{~cm}$.). D. 17 in. $(43.5 \mathrm{~cm}$.).

[One of the latter is $17 \frac{3}{4}$ in. in diameter and somewhat lighter in weight than the other two.]

Early fifteenth century.

See pages $85,90,91,94,144$. 


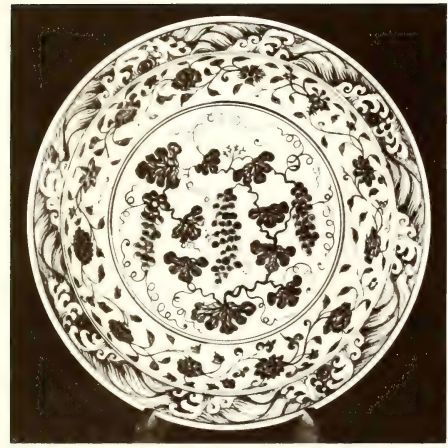

29.52

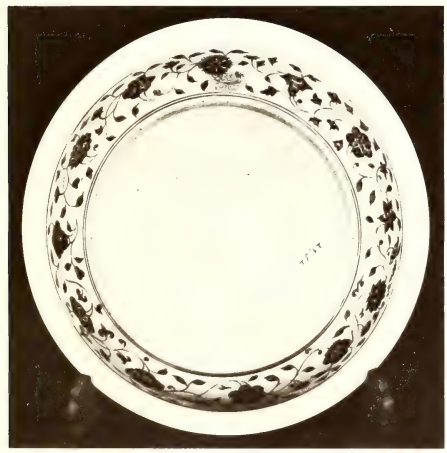

29.52

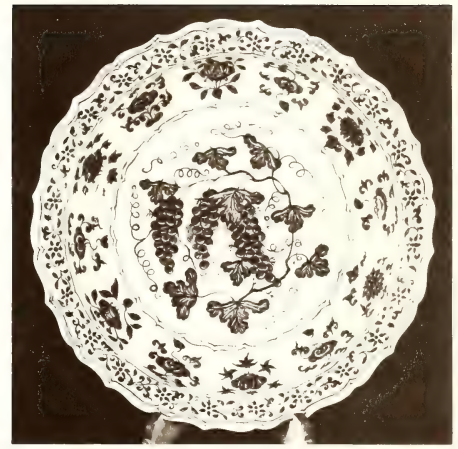

29.58

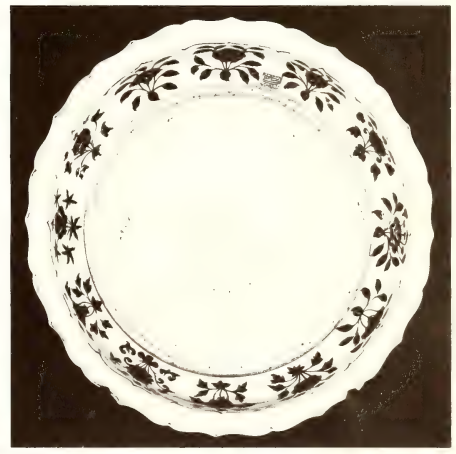

29.58 


\section{PLATE 39}

Dish with plain rim decorated inside with a border of 23 individual flower sprays; a scrolling vine with some 20 blossoms in the cavetto; in the center are three bunches of grapes on a vine with tendrils and pointed leaves and an indication of a moss-grown wall; outside is a scrolling vine with 12 lotus blossoms.

29.60 has the mark of Qarachaghāy.

29.59-60 (2 pieces) H. $3 \frac{1}{4}$ in. $\left(8 \mathrm{~cm}\right.$.). D. $16 \frac{1}{4}$ in. $(41 \mathrm{~cm}$.$) .$

Early fifteenth century.

See pages $49,85,90,91,94,156$. 

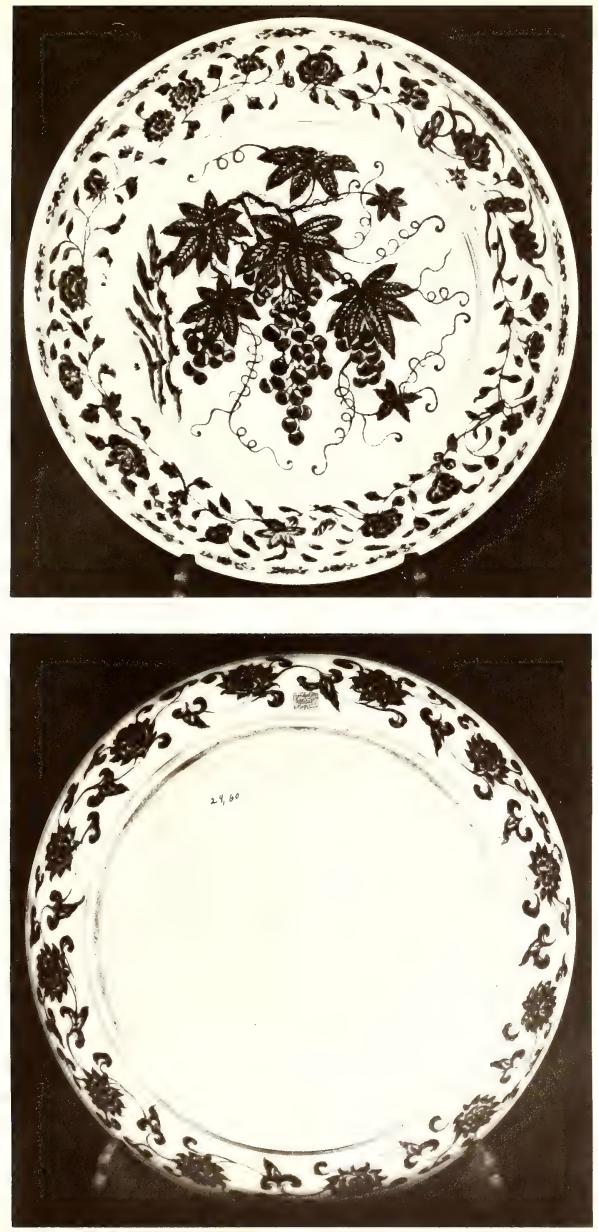


\section{PLATE 40}

Dish with flattened rim decorated inside with a border of waves; in the cavetto is a scrolling vine with seven flowers; the central design shows a melon vine growing from the ground with three fruits, leaves, and tendrils; outside are six fruit sprays.

29.61 H. $2 \frac{3}{4}$ in. $\left(7 \mathrm{~cm}\right.$.). D. $14 \frac{1}{2}$ in. $(37 \mathrm{~cm}$.).

Dish with plain rim and thunder-pattern border; in the cavetto is a scrolling vine with 12 blossoms; in the center the pine, prunus, and bamboo, the three friends, are represented by a branch of each; outside are a leafy scroll border, a scrolling vine with blossoms, and a band of thunder pattern at the base.

29.35 H. 23 in. $\left(6 \mathrm{~cm}\right.$.). D. $12 \frac{1}{4}$ in. $(31 \mathrm{~cm}$.).

Dish with flattened rim (chipped) decorated with fungus scroll; scrolling vine with eight flowers (chrysanthemums?) in cavetto; in the center a peach branch with two fruits and blossoms. Outside are six flower sprays.

29.62 H. $2 \frac{3}{4}$ in. (7 cm.). D. $14 \frac{1}{2}$ in. ( $37 \mathrm{~cm}$.).

The melon and peach dishes are marked Qarachaghāy, and the latter also Quti.

Early fifteenth century.

See pages $90,93,94$. 


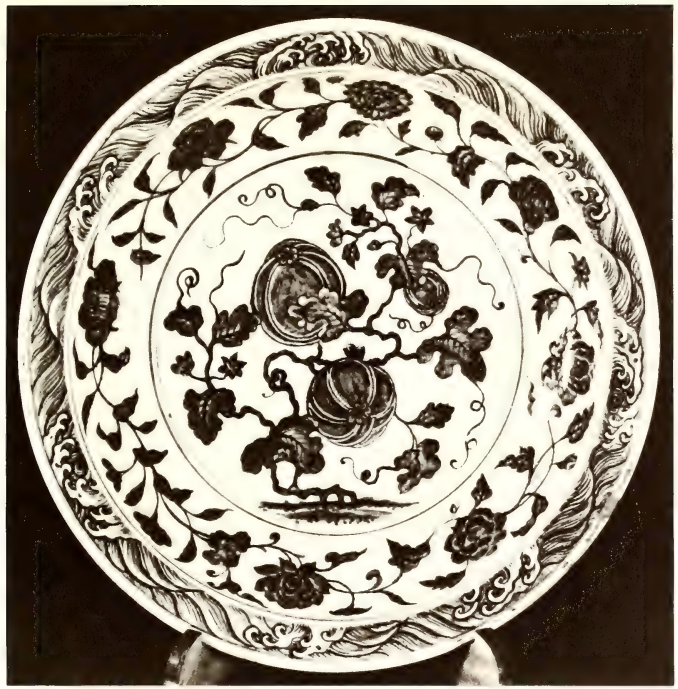

29.61
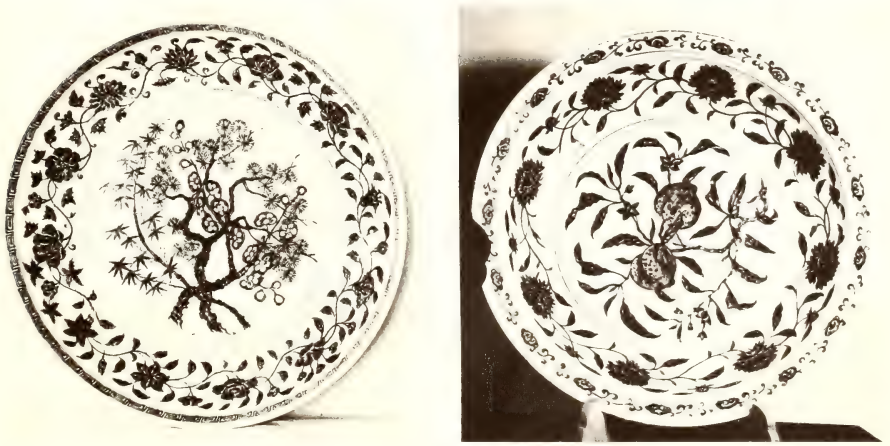


\section{PLATE 41}

Large dish with flattened foliate rim decorated with stylized waves; in the 16 molded sections of the cavetto are that number of identical sprays of roses; the central design is a large branch with leaves and three bunches of litchi nuts. Outside are a fungus scroll border and 16 separate fungus sprays.

The word Quli is drilled in the base.

29.63 H. 4 in. (10 cm.). D. $24 \frac{1}{2}$ in. $(62.5 \mathrm{~cm}$.).

Early fifteenth century.

See pages 49, 85, 90, 91, 94, 95, 156. 


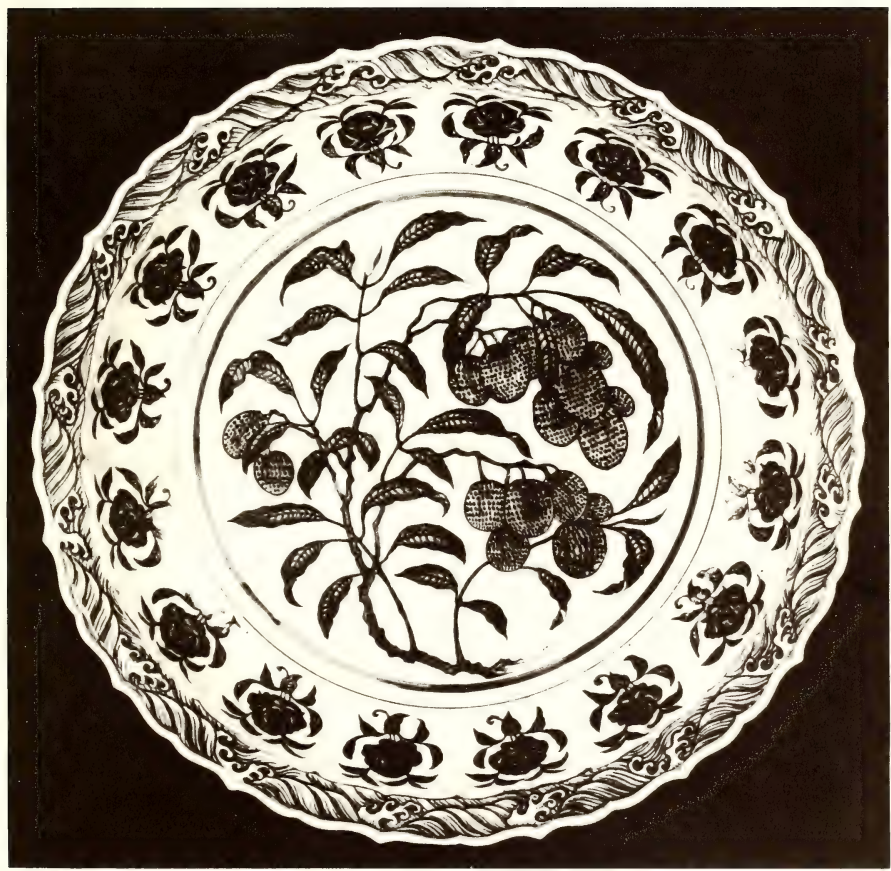




\section{PLATE 42}

Large dish with plain rim; in the cavetto are eight flower and fruit sprays, reading clockwise: camellia, cherry(?), day lily, pomegranate, narcissus, pomegranate, chrysanthemum, and peach; in the center is a landscape scene with coxcomb, knotweed, nightshade, narcissus, and dandelion. (Outside on pl. 44.)

29.310 H. $3 \frac{1}{2}$ in. $(9 \mathrm{~cm}$.). D. 25 in. $(63.5 \mathrm{~cm}$.).

Large dish with plain rim; cavetto decorated with six flower sprays-chrysanthemum, lotus (and other aquatic plants), peony, gardenia, pomegranate, and camellia; the central landscape includes lily (?), pine, azalea, primrose, and palm. (Outside on pl. 44.)

29.312 H. $3 \frac{1}{2}$ in. $(9 \mathrm{~cm}$. $)$. D. 25 in. $(63.5 \mathrm{~cm}$.).

Number 29.310 bears the mark of Qarachaghāy.

Early fifteenth century.

See pages $49,85,91,95$. 


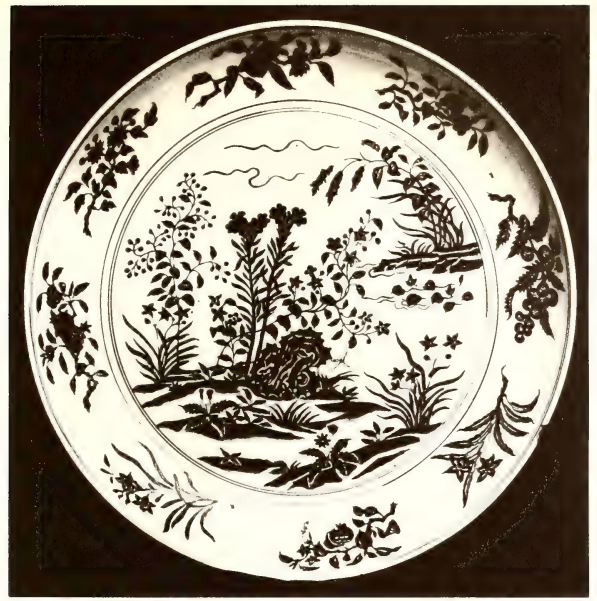

29.310

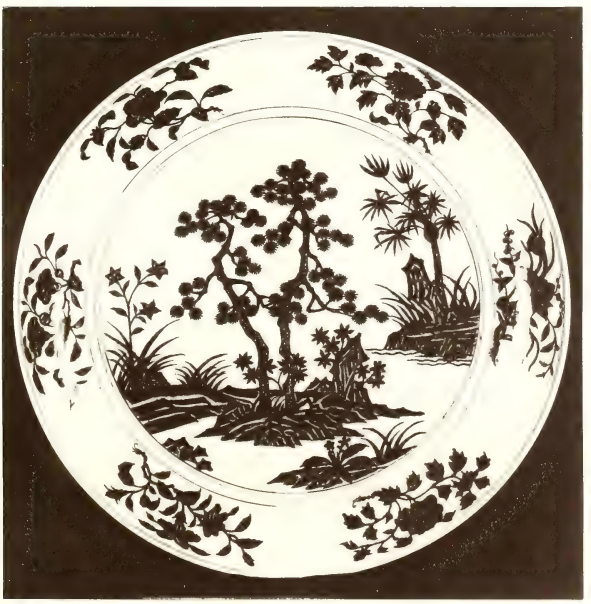




\section{PLATE 43}

Large dish with plain rim; the cavetto is decorated with eight separate groups of plants each growing from its own patch of ground, among them are Pennisetum japonicum, Calystegia hederacea, and dandelion; aster and Commelina communis; knotweed and narcissus; aster and lily(?); sedge and ??; carnation; fern and sedge; rose(?); in the central landscape are Pennisetum japonicum, crabapple, nightshade, aster, hily(?), plantain, and fern. (Outside on pl. 44.)

29.311 H. $3 \frac{1}{4}$ in. $(8 \mathrm{~cm}$. $)$. D. 25 in. $(63.5 \mathrm{~cm}$. $)$.

Early fifteenth century.

See pages $49,85,91,95$. 


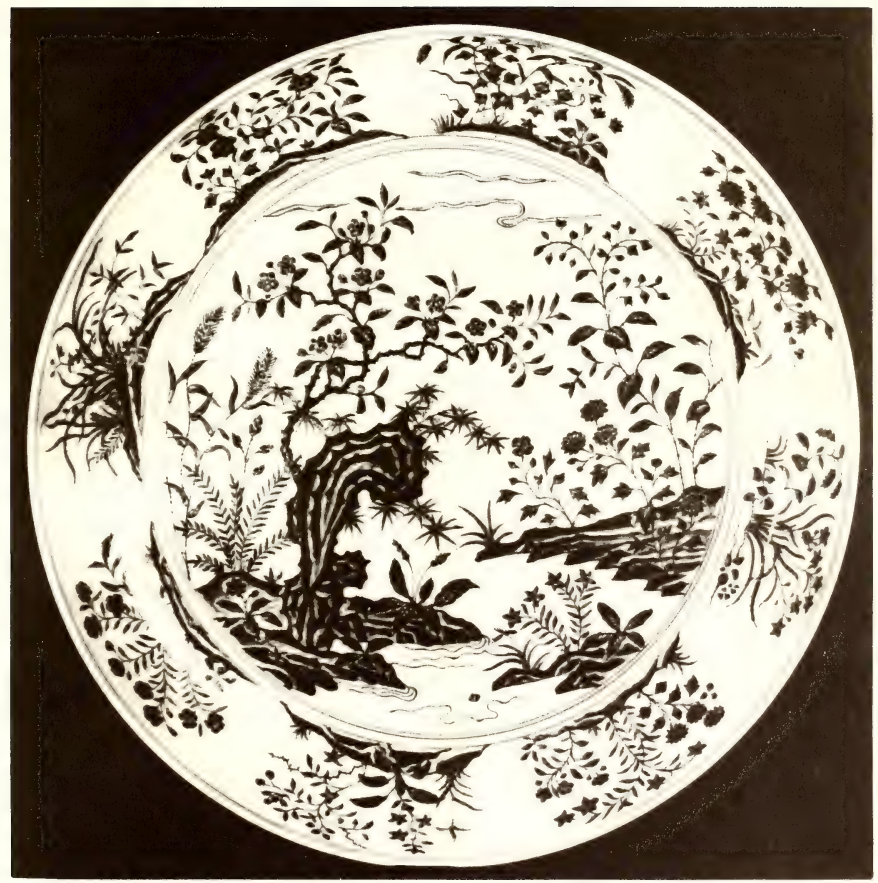




\section{PLATE 44}

Backs of the three dishes shown on plates $42-43$.

On 29.310 are the three friends: pine, prunus, and bamboo; the pine is drawn with unusually long, feathery needles.

On 29.311 are eight clumps of growing plants as in the cavetto, but here a series of four groups is repeated: fern and aster, Commelina communis and narcissus, Pennisetum japonicum and plantain, and a lily(?) and dandelion.

On 23.312 are six flower sprays: crabapple, day lily(?), unidentified, tiger lily, Calystegia hederacea, and camellia.

See pages 49,91 . 


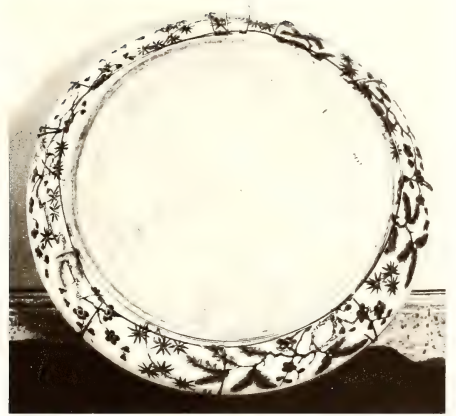

29.310
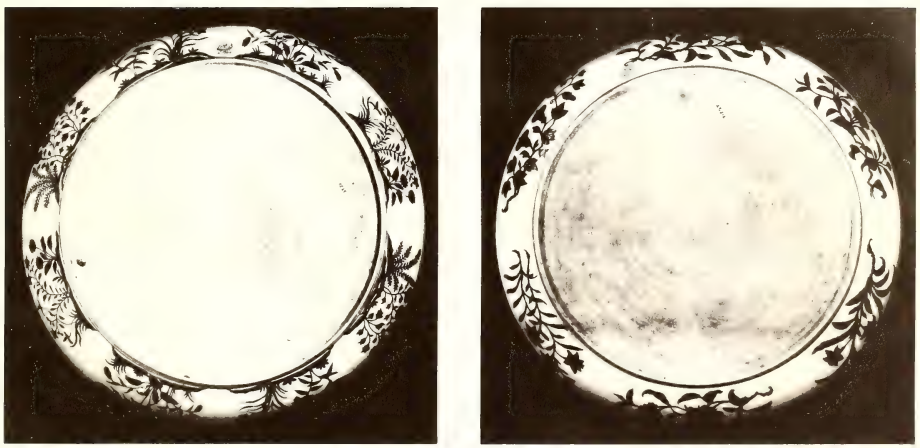


\section{PLATE 45}

Dish with plain rim; inside is a border of thunder pattern above a cavetto with scrolling vines and 12 blossoms; in the center the whole area is covered with a turbulent sea over which flies a 3clawed dragon reserved in white and delineated in every detail by lines incised in the paste; the eyes are spotted with blue. Outside, between a thunder pattern at the rim and a band of classic scroll above the foot, four 3-clawed dragons fly to the left amid cloud scrolls.

29.36-37 (2 pieces) H. 3 in. $\left(7.5 \mathrm{~cm}\right.$.). D. $15 \frac{1}{4}, 15 \frac{1}{2}$ in. $(38.5-40 \mathrm{~cm}$.). A third one in Isfahan is $13 \frac{5}{8} \mathrm{in} .(34.5 \mathrm{~cm}$.) in diameter.

Early fifteenth century.

See pages 91,96 . 

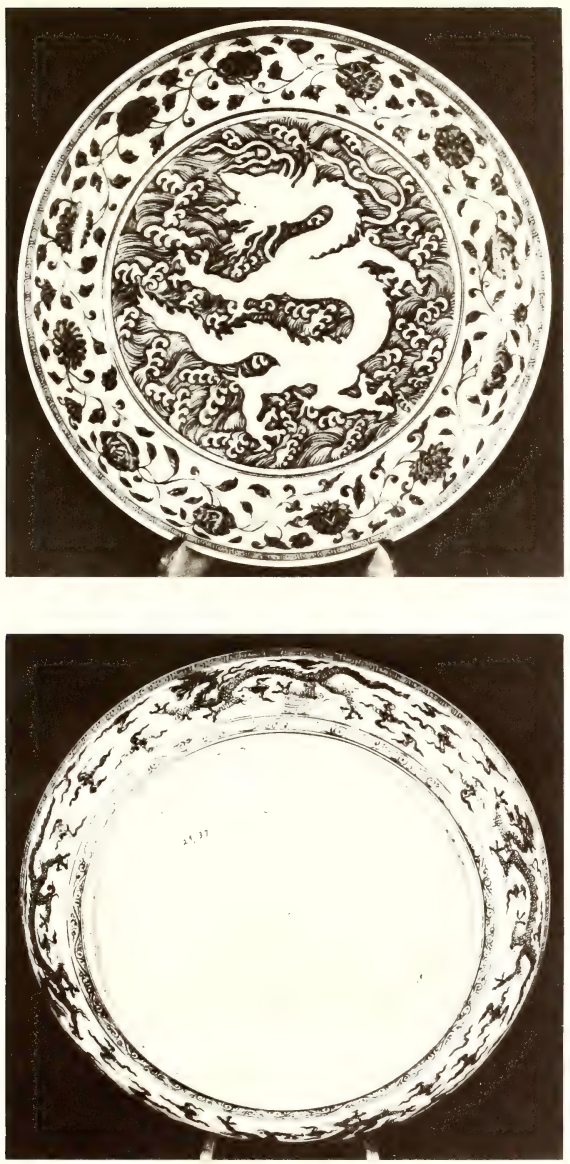
PLATE 46

Bowl with incurving rim. The inside is plain except for a spray of peaches in a double circle in the center. Outside is a wave border bounded by a single line from which depends a row of small trefoils; and the main decoration consists of lotus blossoms on a scrolling vine with buds and conventional leaves; at the base is a band of stylized lotus petals.

29.328 H. 5 in. $\left(12.5 \mathrm{~cm}\right.$.). D. $8 \frac{7}{8}$ in. $(22.5 \mathrm{~cm}$. $)$.

Bowl of lien-tzŭ shape. Inside is a border of thunder pattern above four fruit sprays surrounding a small fruit spray in the center. An attenuated version of the classic scroll forms the narrow outside border above a main decoration of lotus petals painted in pale blue with outline; a small band of thunder pattern borders the foot.

29.327 H. 4 in. $\left(10 \mathrm{~cm}\right.$.). D. $8 \frac{1}{4}$ in. $(21 \mathrm{~cm}$. $)$.

Early fifteenth century.

See pages $50,86,97,99$. 


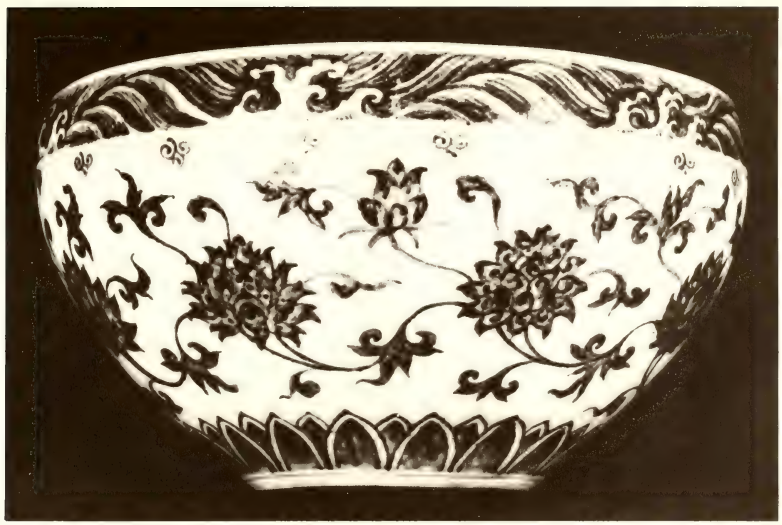

29.328

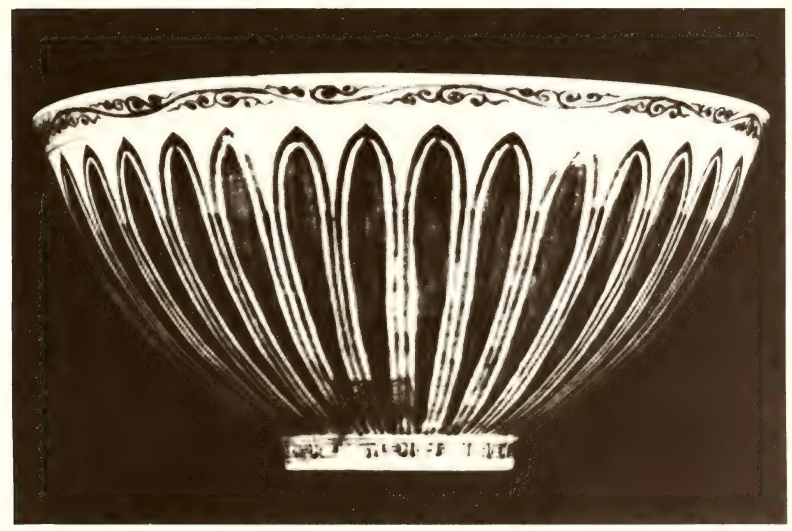




\section{PLATE 47}

Bowl with flaring rim. A border of thunder pattern lies above a main decorative zone of floral scrolls outside with a row of stylized lotus petal panels below; a band of classic scroll surrounds the foot. Inside is a narrow border of floral scroll, a main band of lotus and other flowers amid scrolling vines, and in the center a single lotus blossom with scrolling leafy vine.

29.321 H. $3 \frac{1}{2}$ in. $\left(9 \mathrm{~cm}\right.$.). D. $7 \frac{3}{4}$ in. $(19.5 \mathrm{~cm}$.).

Bowl of lien-tzŭ shape. Outside, a border of thunder pattern and plain dark blue petals. Inside, a wave border and a floral scroll with six blossoms surround a central spray of cherries.

29.324-326 (3 pieces) H. 4 in. $\left(10 \mathrm{~cm}\right.$.). D. $8 \frac{1}{4}$ in. $(21 \mathrm{~cm}$.$) .$

Conical bowl with plain rim. Decorated outside with the three friends: pine, prunus, and bamboo; the inside is plain white.

29.329-330 (2 pieces) H. $3 \frac{1}{2}$ in. $(9 \mathrm{~cm}$.$) . D. 8 \frac{5}{8}$ in. $(22 \mathrm{~cm}$.$) .$

Conical bowl with very slightly flaring plain rim. Decorated outside with three flower sprays alternating with three fruit sprays above a row of stylized lotus-petal panels; inside is a single line at the rim and a flower in a double circle in the center.

29.332 H. $3 \frac{1}{4}$ in. $(8 \mathrm{~cm}$.). D. 8 in. $(20.5 \mathrm{~cm}$.).

Early fifteenth century. (29.332 possibly "Interregnum.")

See pages $50,54,86,97,98,99,105$. 


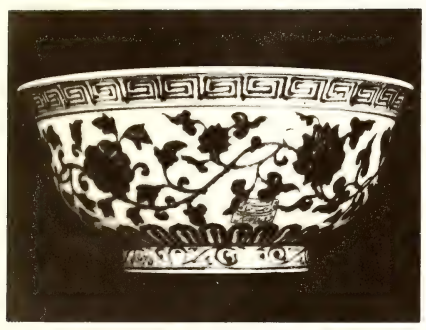

29.321

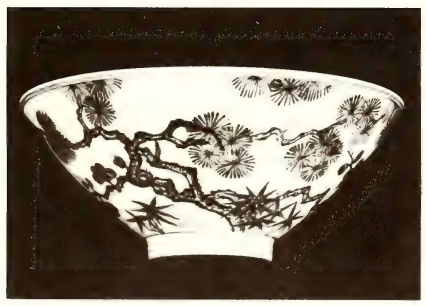

29.330

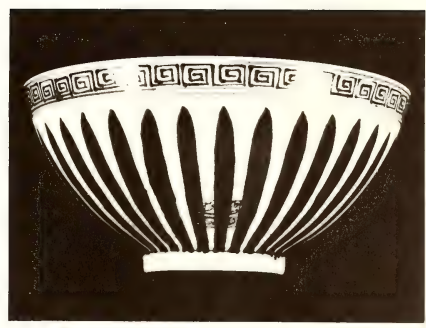

29.326

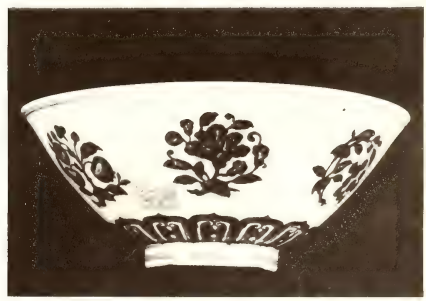

29.332 


\section{PLATE 48}

Conical bowl with very slightly flaring rim. Decorated outside with floral scrolls above a row of stylized lotus petals; inside are a blue double line around the rim and floral scrolls executed in very delicate slip painting under the glaze, a stylized blue blossom in a double circle occupies the center.

29.334 H. $2 \frac{3}{4}$ in. (7 cm.). D. 8 in $(20.5 \mathrm{~cm}$.).

Conical bowl with very slightly flaring rim. Decorated outside with a single 3-clawed dragon flying to the left amid clouds in pursuit of a flaming pearl; inside, the rim is decorated with a band of classic scroll and a single flower in a circle occupies the center.

29.333 H. $2 \frac{3}{4}$ in. $(7 \mathrm{~cm}$.). D. 8 in. $(20.5 \mathrm{~cm}$.).

Early fifteenth century.

See pages 86,98 . 


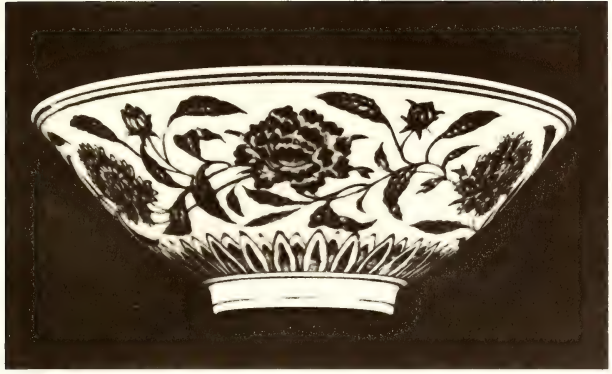

29.334
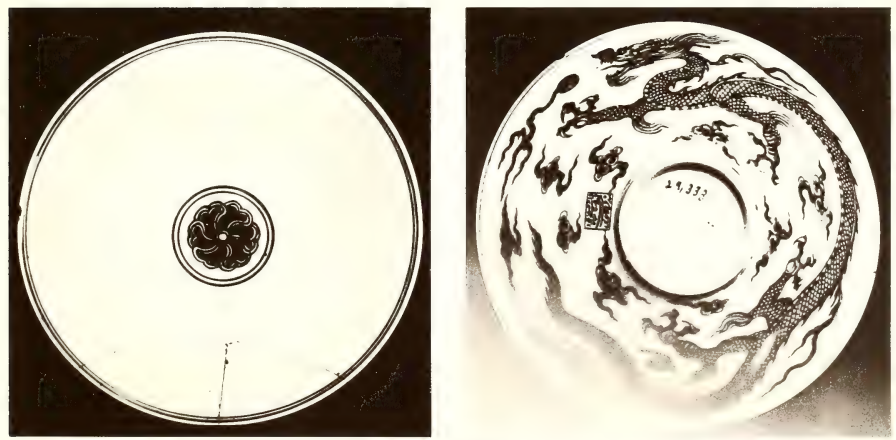

29.334

29.333 


\section{PLATE 49}

Four bowls with steep sides decorated with the usual flower and fruit patterns and conventional designs.

Two of these, 29.338 and 29.340 , represent a group of four characterized by unusually thick and squarely cut foot rims; a bluish-white glaze is unevenly smeared over the flat bases, and the paste takes on a yellowish tone where the glaze is thin. It is just possible that these may be somewhat later. On 29.339 is the incised mark of Behbūd, and 29.340 bears the abbreviated Shāh 'Abbās mark.

29.335 H. $4 \frac{3}{4}$ in. $\left(12 \mathrm{~cm}\right.$.). D. $11 \frac{1}{2}$ in. $(29 \mathrm{~cm}$. $)$.

29.336 H. $4 \frac{1}{4}$ in. $(10.5 \mathrm{~cm}$.). D. 8 in. $(20.5 \mathrm{~cm}$.).

$29.337-338$ (2 pieces) H. $3 \frac{1}{2}-3 \frac{3}{4}$ in. $\left(9-9.5 \mathrm{~cm}\right.$.). D. $7 \frac{1}{8}-7 \frac{1}{2}$ in. $(18-19 \mathrm{~cm}$.).

29.339-340 (2 pieces) H. $3 \frac{1}{2}-3 \frac{3}{4}$ in. $\left(9-9.5 \mathrm{~cm}\right.$.). D. $6 \frac{7}{8}-7 \frac{1}{2}$ in. $(17.5-19 \mathrm{~cm}$.).

Early fifteenth century and perhaps "Interregnum."

See pages $54,98,105,145$. 


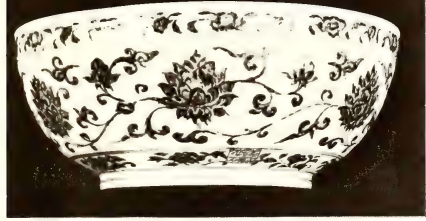

29.335

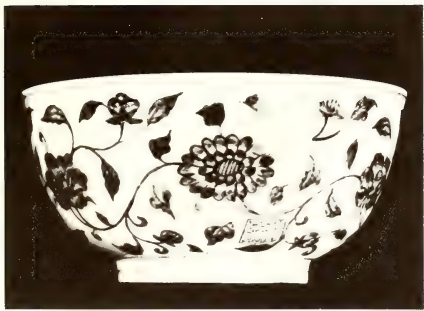

29.338

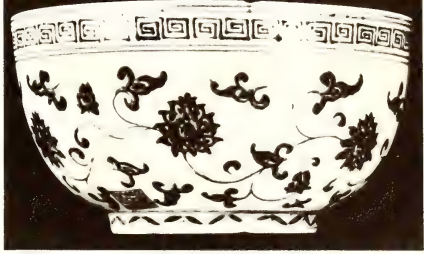

29.336

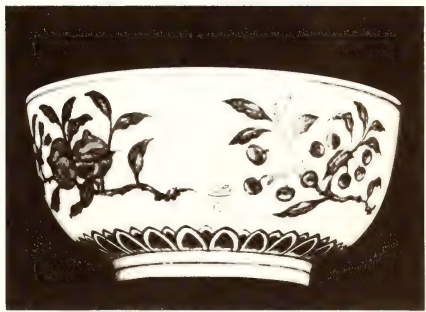

29.340 
PLATE 50

Vase of mei-p'ing shape. On the shoulder 16 pendent, stylized lotus-petal panels frame eight auspicious objects alternating with eight flames, and the main design shows a white 5-clawed dragon flying to the left in pursuit of a flaming jewel over a sea of tossing waves. All details of the dragon are indicated by fine lines incised in the paste, and the eyes are spots of blue. At the base what appear to be the tips of pendent lotus panels are seen between the tops of a row of upright panels framing stylized leaves and single lotus sprays.

The base is unglazed, and the very fine pure-white paste is perfectly flat with no sign of a rim. This vase has an unusually pinched-in waist and is light in weight for its size, suggesting that it is very thinly potted. Both the proportions and the decoration seem to be rare if not unique among surviving early fifteenth-century mei-p'ing, while the quality is unsurpassed.

29.403 H. $16 \frac{3}{8}$ in. $\left(41.5 \mathrm{~cm}\right.$.). D. $9 \frac{7}{8}$ in. $(25 \mathrm{~cm}$.).

Early fifteenth century.

See pages $34,50,80,86,96,98$. 


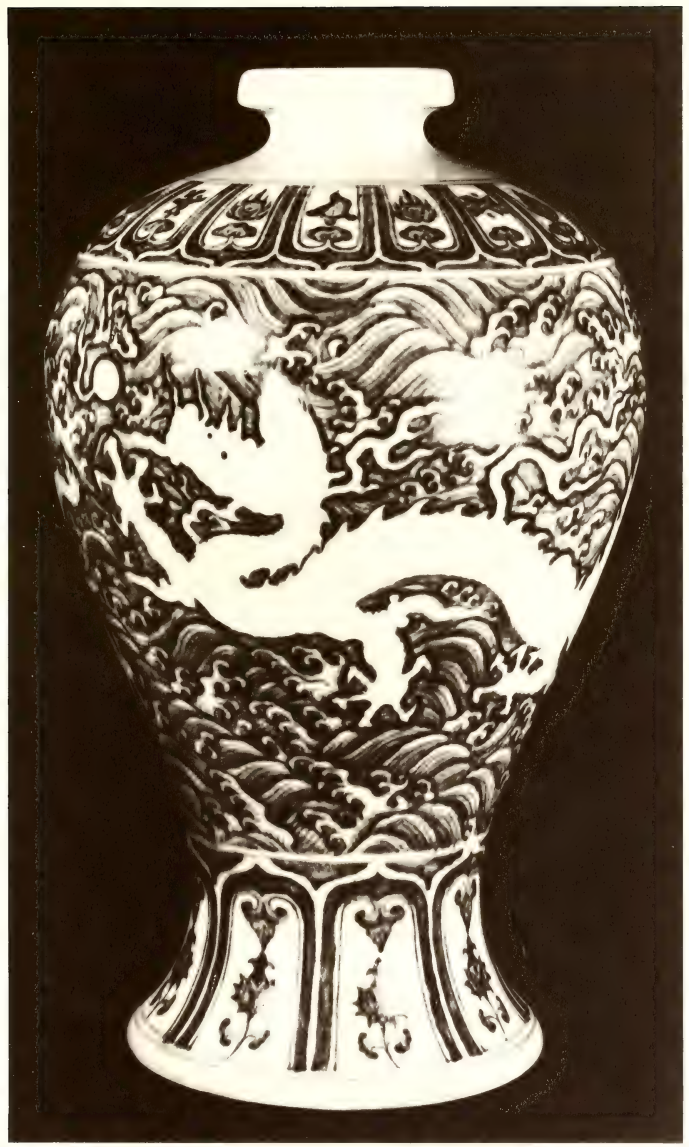




\section{PLATE 51}

Four vases of mei-p'ing shape decorated with lotus scrolls, fruit sprays, lotus sprays, lotus panels, ferns or plantain leaves, and various formal scrolls. The three pieces showing lotus scrolls as the main design illustrate the diversity of ways in which that motif may be drawn.

The six pieces represented by 29.419 are all light in weight and of the best quality; 29.421 and 29.422 have undeciphered Persian script in ink on their bases.

$29.416-419,421-422$ (6 pieces) H. $9 \frac{3}{4}$ in. $\left(25 \mathrm{~cm}\right.$.). D. $6 \frac{1}{8}$ in. $(15.5 \mathrm{~cm}$.).

Number 29.413 represents four vases with identical decoration but of different sizes; 29.414 has considerable crackle, and 29.482 is badly cracked and stained. This group may possibly be slightly later than the rest.

29.413 H. $9 \frac{5}{8}$ in. $\left(24.5 \mathrm{~cm}\right.$.). D. $5 \frac{3}{4}$ in. $(14.5 \mathrm{~cm}$.).

29.414 H. $9 \frac{3}{4}$ in. $\left(25 \mathrm{~cm}\right.$.). D. $6 \frac{1}{4}$ in. $(16 \mathrm{~cm}$.).

$29.404,482$ (2 pieces) H. $16 \frac{3}{8}$ in. $\left(41.5 \mathrm{~cm}\right.$.). D. $9 \frac{3}{4}$ in. $(25 \mathrm{~cm}$.).

29.411 H. $13 \frac{3}{4}$ in. $(35 \mathrm{~cm}$.$) . D. 8 \frac{1}{4}$ in. $(21 \mathrm{~cm}$. $)$.

29.409 H. $16 \frac{1}{8}$ in. $\left(41 \mathrm{~cm}\right.$.). D. $9 \frac{3}{4}$ in. $(25 \mathrm{~cm}$.$) .$

Early fifteenth century and perhaps "Interregnum."

See pages $50,86,98,105,146$. 


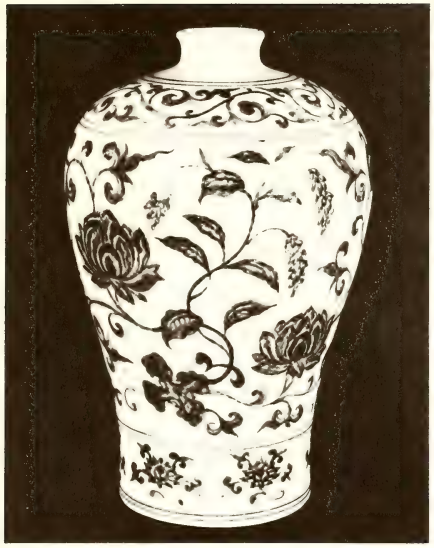

29.419

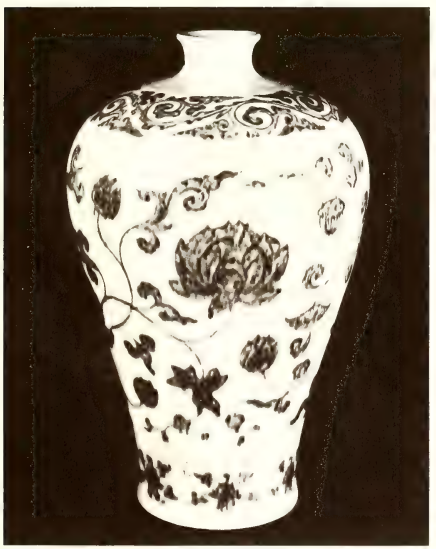

29.411

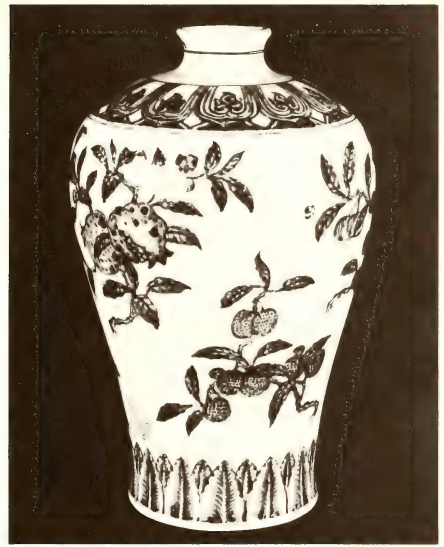

29.413

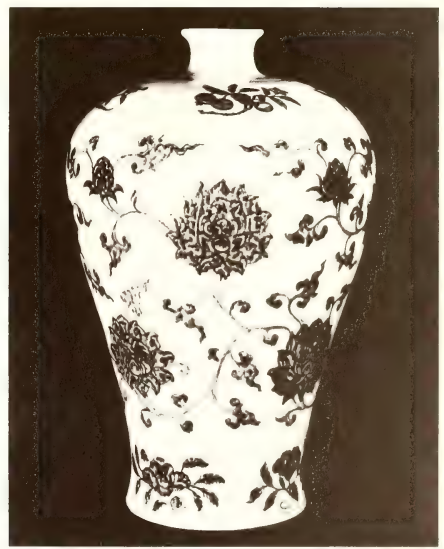

29.409 


\section{PLATE 52}

Vase of kuan shape with undecorated neck; on the shoulder is a meander recalling the cloud collar form which frames formal floral devices in alternately pendent and erect positions; the main design is a large lotus scroll with proper as well as stylized leaves, and six floral sprays surround the foot. The unglazed base has a fine paste fired iron red.

There is a small repair on one side of the neck.

29.495 H. $8 \frac{1}{4}$ in. $\left(21 \mathrm{~cm}\right.$.). D. $10 \frac{1}{2}$ in. $(26.5 \mathrm{~cm}$. $)$.

Vase of kuan shape with undecorated neck; on the shoulder a sixfold cloud collar serves to frame six flower sprays within its points which, in turn, fall between the six large fruit sprays which make up the main decoration; a thick, elaborate scroll band surrounds the base. The bottom is unglazed with low rounded rim, and the fine paste is iron red on the surface.

29.479 H. $10 \frac{1}{4}$ in. $\left(26 \mathrm{~cm}\right.$.). D. $12 \frac{1}{2}$ in. $(32 \mathrm{~cm}$.).

Early fifteenth century.

See page 98 . 


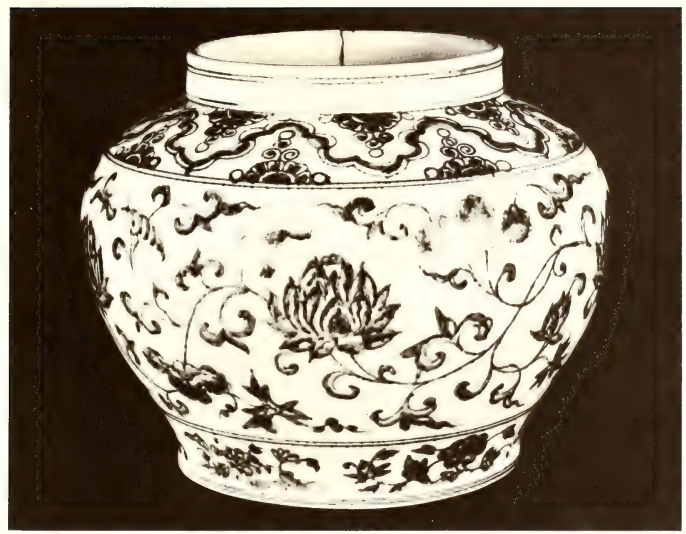

29.495

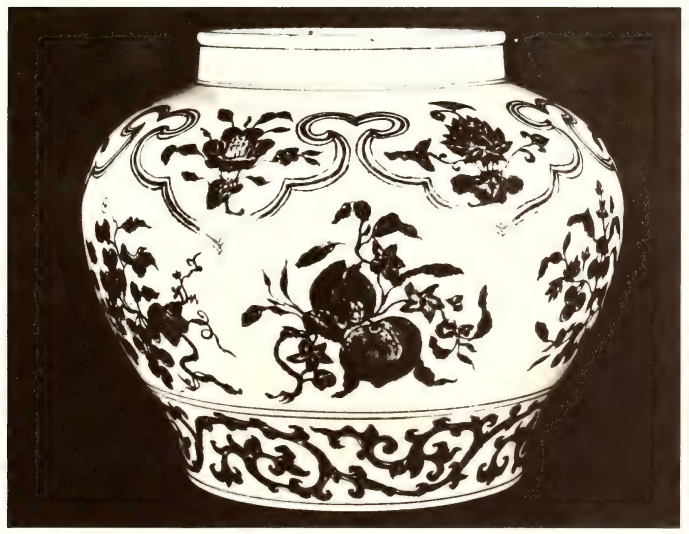




\section{PLATE 53}

Bottles of the $y \ddot{u}-h u-c h^{i} u n-p^{t} i n g$ shape with various styles of floral decoration and conventional motifs. The bases are glazed underneath.

Number 29.448 bears the abbreviated mark of Shāh 'Abbās. Still another bottle (29.446) has a similar design but is larger in size (H. $11 \frac{1}{2}$ in., D. $7 \frac{1}{4}$ in.), and the broken neck rim has been repaired with a brass mounting set with turquoise.

$29.447,449$ (2 pieces) H. $12 \frac{1}{2}$ in. $\left(31.5 \mathrm{~cm}\right.$.). D. $7 \frac{1}{4}$ in. $(18.5 \mathrm{~cm}$.).

$29.448,450$ (2 pieces) H. $10 \frac{5}{8}$ in. $\left(27 \mathrm{~cm}\right.$.). D. $6 \frac{1}{2}$ in. $(16.5 \mathrm{~cm}$.).

Large bottle with bulbous body; floral scroll at neck and main decoration of a single large 3-clawed dragon moving to the right, but with the head turned back over the shoulder, amid lotus scrolls.

29.470 H. 17 in. (43 cm.). D. $13 \frac{1}{2}$ in. $(34.5 \mathrm{~cm}$. $)$.

Large bottles with bulbous bodies; thick scroll borders at the necks and both main decorations showing white 3-clawed dragons moving to the right, with heads turned backward, over seas of tossing blue waves; details of the dragons are incised in the paste and the eyes are spotted with blue. The bases are unglazed.

29.478 shows extremely fine paste and bears the Abū Tālib mark drilled in the base. On 29.471 the marks of Behbüd and Qarachaghāy may be seen drilled on the face of the dragon; and there is undeciphered Arabic writing in ink on the base.

29.471 H. $16 \frac{1}{2}$ in. $\left(42 \mathrm{~cm}\right.$.). D. $13 \frac{3}{4}$ in. $(35 \mathrm{~cm}$.).

$29.478 \mathrm{H} .17$ in. (43 cm.). D. $13 \frac{1}{2}$ in. $(34.5 \mathrm{~cm}$.).

Early fifteenth century.

See pages $50,54,86,96,99$. 


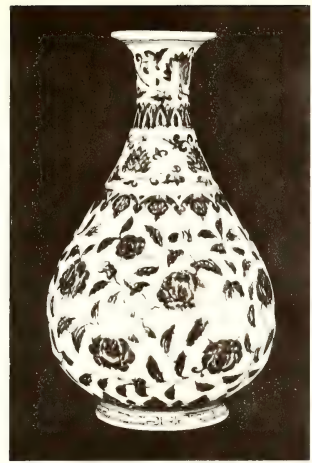

29.447

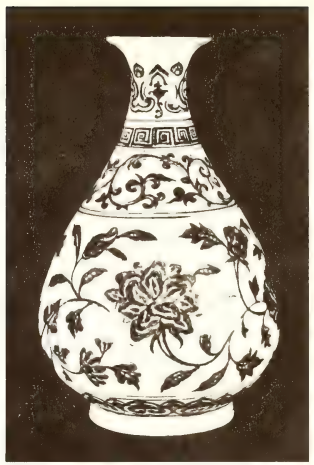

29.448

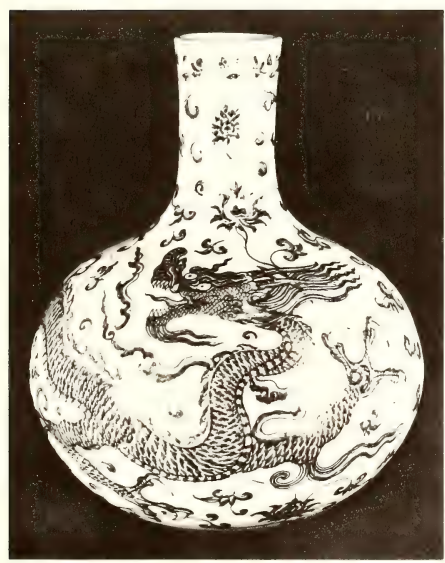

29.470

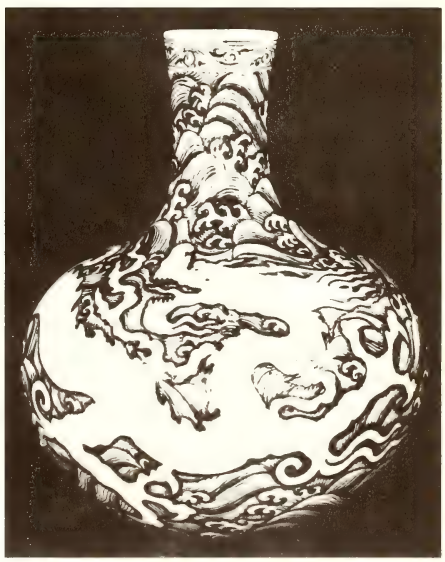

29.471 


\section{PLATE 54}

Ewers $($ chih-hu) decorated with rows of stiff leaves around the necks above bands of lotus scrolls; each body shows a spray of two peaches and blossoms on a leafy branch in a 4-pointed foliate medallion flanked by a chrysanthemum spray on the right and a peony spray on the left; bands of stylized lotus-petal panels ring the bases above classic scrolls on the foot rims. Fungus sprays are on the handles and scrolls on the spouts; the bases are glazed underneath.

The handle of one ewer (29.426) is broken, and the tip of the spout has been cut down on the other (29.427) as may be seen in the illustration.

$29.426-427$ (2 pieces) H. $10 \frac{5}{8}$ in. $\left(27 \mathrm{~cm}\right.$.). D. $6 \frac{1}{4}$ in. $(16 \mathrm{~cm}$.).

Ewers (chih-hu) decorated with rows of upright leaves around the neck; various floral scrolls decorate the bodies and spouts while bands of thunder pattern appear at the tips of the spouts and around the feet. The bases are glazed underneath.

$29.428,432$ (2 pieces) H. $11 \frac{3}{4}$ in. $(30 \mathrm{~cm}$.). W. 9 in. $(23 \mathrm{~cm}$.). D. 7 in. $18 \mathrm{~cm}$.).

Ewers (chih-hu) decorated mainly with floral scrolls; an unusually heavy and formalized scroll appears on the neck just below where the handle joins, and a band of pendent trefoils lies under this; on each side a large cloud collar point ornamented with the classic scroll serves as frame for a single lotus spray with blossom, bud, and leaves. The feet carry patterns consisting of oblique striated lines which may possibly be interpreted as modified forms of conventional waves. The bases are glazed.

The handle and spout of 29.430 have been broken and partially restored with plaster.

$29.429-430$ (2 pieces) H. $11 \frac{1}{4}$ in. $\left(28.5 \mathrm{~cm}\right.$.). D. $6 \frac{1}{2}$ in. $(16.5 \mathrm{~cm}$.).

Ewer $($ chih- $h u)$ of different form decorated with floral scrolls on the cylindrical neck; a double raised flange lies on the shoulder, the upper part circular, the lower part stellate in form, and surrounding this is a border of stylized lotus-petal panels; a band of crapemyrtle with blackberry-lily blossoms tops the main body of the vessel which is vertically molded in eight sections, each framing a flower or fungus spray; a classic scroll band surrounds the foot. The base is glazed.

Unnumbered (Isfahan) H. $13 \frac{3}{8}$ in. (34 cm.).

Early fifteenth century.

See pages 87, 99 . 


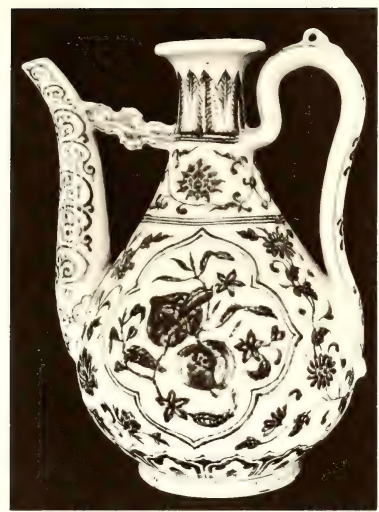

29.427

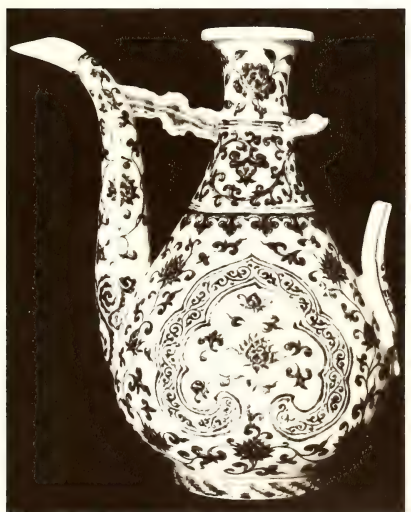

29.430

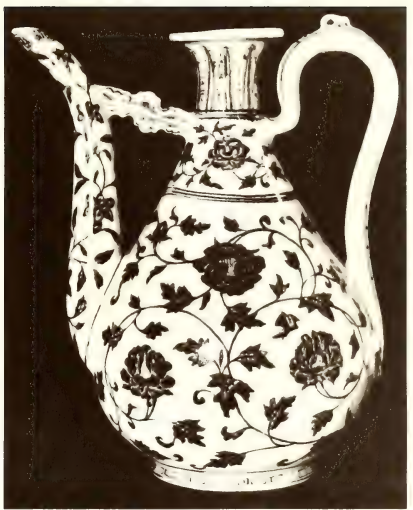

29.428

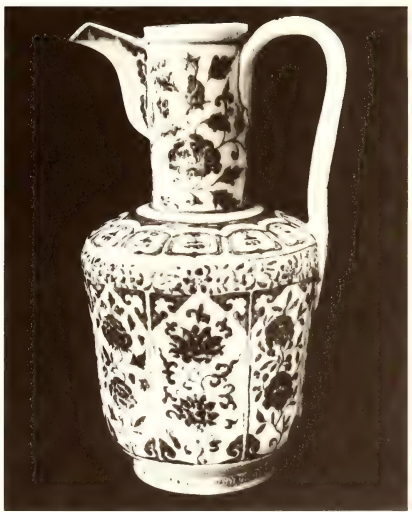

Isfahan 


\section{PLATE 55}

Ewers (chih-hu) with cylindrical necks; at the tops are bands of thunder pattern, wide zones of scrolls of pinks, and rows of curiously formless scrolls; above the shoulder on raised flanges are rows of stylized lotus-petal panels fanning outward above the main areas of mixed floral scrolls, including chrysanthemum, waterchestnut, peony, camellia, and hibiscus; classic scroll adorns the feet, and sprays of fungus and flowers appear on the handles. The bases are glazed.

$29.439,441$ (2 pieces) H. $12 \frac{1}{4}$ in. $(31 \mathrm{~cm}$.). D. 7 in. $(18 \mathrm{~cm}$.).

Flasks (pien hu) of gourd shape with loop handles; the upper bulbs are decorated with a band of floral scrolls; below on one side is a rosette surrounded by a band of foliate scroll, and on the other side the rosette has a Yin-Yang symbol in the center and is framed by a chevron band. The bases are glazed.

A number of flasks of this type carry the mark of the Hsüan-te period written in a horizontal line below the lip. No doubt this and other unmarked pieces are also datable to that reign.

$29.458,463$ (2 pieces) H. $10 \frac{1}{4}$ in. $\left(26 \mathrm{~cm}\right.$.). W. $6 \frac{1}{8}$ in. $\left(15.5 \mathrm{~cm}\right.$.). T. $4 \frac{1}{2}$ in. $(11.5 \mathrm{~cm}$.).

Body of a large bulbous bottle of oval section from which the neck has been broken; the body is covered with floral scrolls; and the base is glazed inside the low broad foot rim.

29.483 H. 121 in. ( $31 \mathrm{~cm}$.). W. 14 in. $\left(35.5 \mathrm{~cm}\right.$.), T. $9 \frac{1}{2}$ in. $(24 \mathrm{~cm}$.).

Spherical object decorated with six circles of equal size; each circle has a ring of leafy scroll with blossoms surrounding a central motif of 6-petaled white flower in a stellate frame within a circle. The eight triangular areas between the large circles are filled with cloud scrolls. One of the circles is eliminated by an opening $111 / 16$ in. $(4.3 \mathrm{~cm}$.) in diameter which penetrates the sphere to a depth of $3 \frac{3}{4} \mathrm{in}$. $(9.5 \mathrm{~cm}$.); at a depth of $7 / 16$ in. $(7 \mathrm{~mm}$.) below the surface of the sphere the cavity widens out to a diameter somewhat larger than that of the opening.

29.455 D. 5 in. $(12.5 \mathrm{~cm}$. $)$.

A funnel-shaped object with foliate rim. Inside is a band of floral scroll above a row of formalized lotus petals; in the bottom are six circular perforations leading down into the pipe below. Outside, a series of stylized lotus panels tops the foliate rim; below this is a band of cash-shaped diaper pattern, and formalized lotus petals cover the lower part.

A fine quality piece of unknown use and of a type not noted hitherto. Painted in a strong dark blue, it exhibits all the customary characteristics of the early-fifteenth-century wares. The pipe leading out of the bottom is unglazed and has been broken off, and so it is impossible to determine its original length. As may be seen in the illustration the Shāh 'Abbãs mark was cut in two by the break.

29.485 H. $3 \frac{1}{2}$ in. $(9 \mathrm{~cm}$.$) . D. 5$ in. $(13 \mathrm{~cm}$.).

Early fifteenth century.

See pages $87,99,116$. 


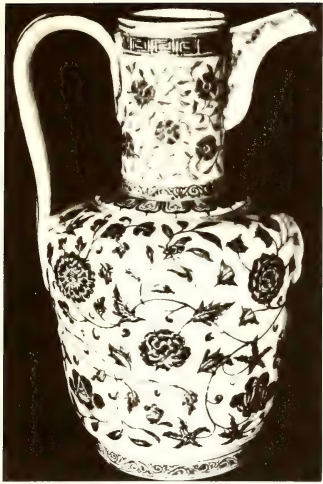

29.439

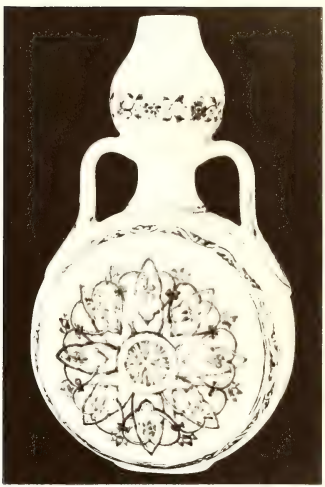

29.458

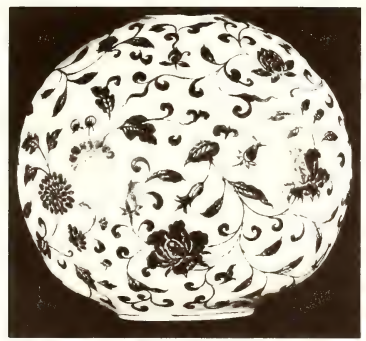

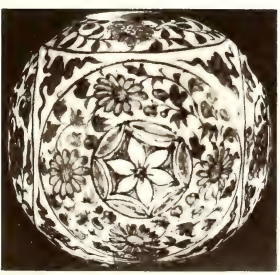

29.455
29.483

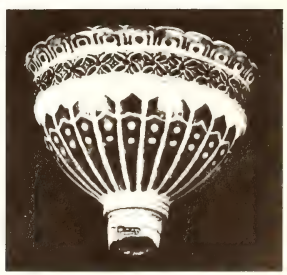

29.485 


\section{PLATE 56}

Vase of kuan shape with a band of classic scroll on the neck; four fruit sprays (cherry, grape, litchi, and persimmon) decorate the shoulder above the main zone of peony scroll; around the base a row of panels, with their tops set off by a band of shading, frames lotus blossoms mounted on trefoils.

29.496 H. $8 \frac{1}{8}$ in. $(20.5 \mathrm{~cm}$. $)$. D. $10 \frac{\mathrm{s}}{\mathrm{B}}$ in. $(27 \mathrm{~cm}$. $)$.

A mei-p'ing vase with four cloud collar points framing lotus blossoms on the shoulder; large peony scroll on the body; and a very elaborate foliate scroll around the base.

29.415 H. $11 \frac{5}{8}$ in. $(29.5 \mathrm{~cm}$. $)$. D. 7 in. $(18 \mathrm{~cm}$. $)$.

These two pieces, both of exceptional quality, are decorated in the same style with outline and pale wash enhanced by many fine lines, a technique not commonly found on early-fifteenth-century wares but seen on the "Annamese" blue-and-white of presumably midcentury date (cf. pl. 57).

Perhaps "Interregnum."

Vase of mei-ping shape rather coarsely decorated with thunder pattern, lotus scrolls, large peony sprays, and fern or plantain leaves. Clearly a provincial or private factory piece and difficult to date.

29.420 H. $10 \frac{5}{8}$ in. $\left(27 \mathrm{~cm}\right.$.). D. $7 \frac{1}{4}$ in. $(18.5 \mathrm{~cm}$. $)$.

Fifteenth century.

See pages $50,98,103$. 


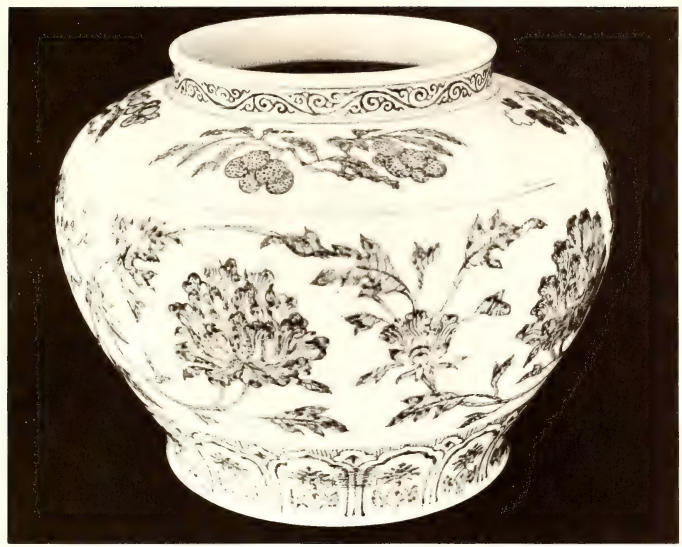

29.496
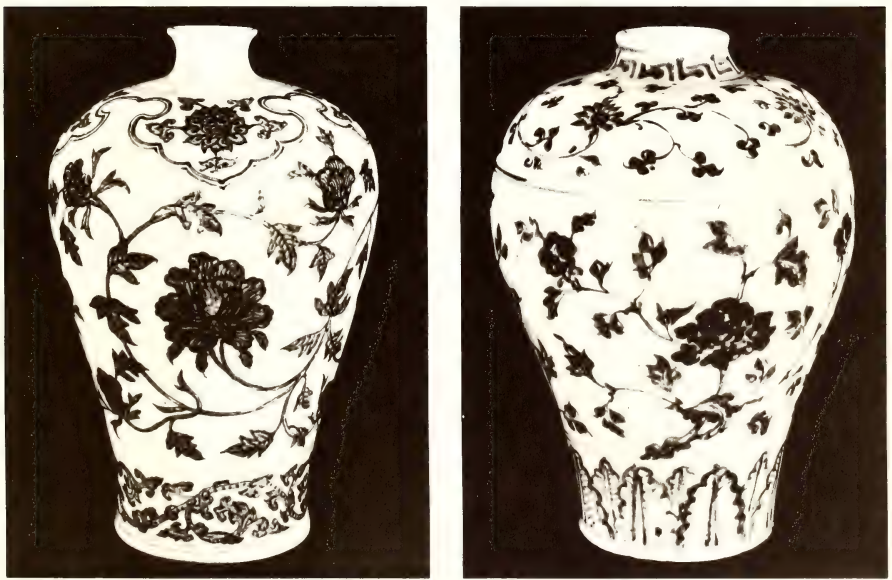


\section{PLATE 57}

Dish with flattened rim on which the edge is raised and unglazed; a narrow scroll band decorates the rim and the cavetto has large lotus scrolls; a border of scalloped petals surrounds the central design which is a single large peony surrounded by leaves. Outside is a row of stylized lotus panels. The unglazed base is washed with a chocolate-brown dressing inside the rounded foot rim. (Pl. 141.)

29.143 H. $3 \frac{1}{4}$ in. $\left(9.5 \mathrm{~cm}\right.$.). D. $17 \frac{1}{2}$ in. $(44 \mathrm{~cm}$.).

Annamese ware, mid-fifteenth century.

See page 103 . 

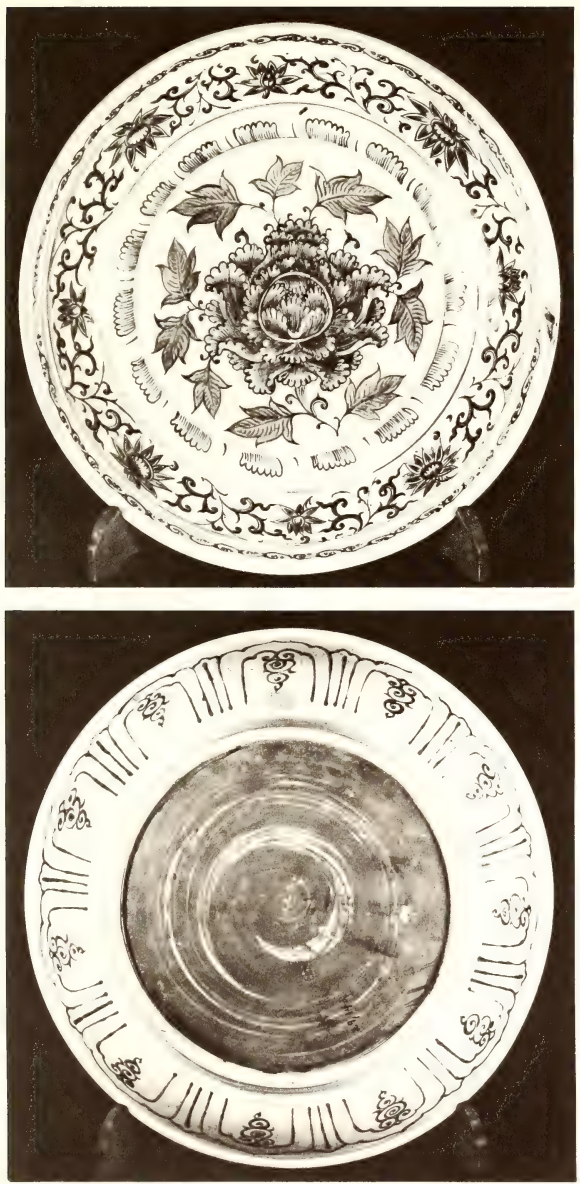


\section{PLATE 58}

Dish with plain rim; in the center are two lions playing with a brocaded ball amid swirling ribbons; outside are four lions, all running to the left, two brocaded balls, and swirling ribbons. The base is glazed and shows faint tinges of yellow.

This is one of two dishes with identical decoration but of slightly different sizes.

29.277 H. $1 \frac{1}{2}$ in. $(3.7 \mathrm{~cm}$. $)$. D. 7 in. $(18 \mathrm{~cm}$. $)$.

29.278 H. $1 \frac{5}{8}$ in. $(4.1 \mathrm{~cm}$.$) . D 7 \frac{3}{4}$ in. $(19.7 \mathrm{~cm}$.).

Late fifteenth century.

See pages 50, 108 . 

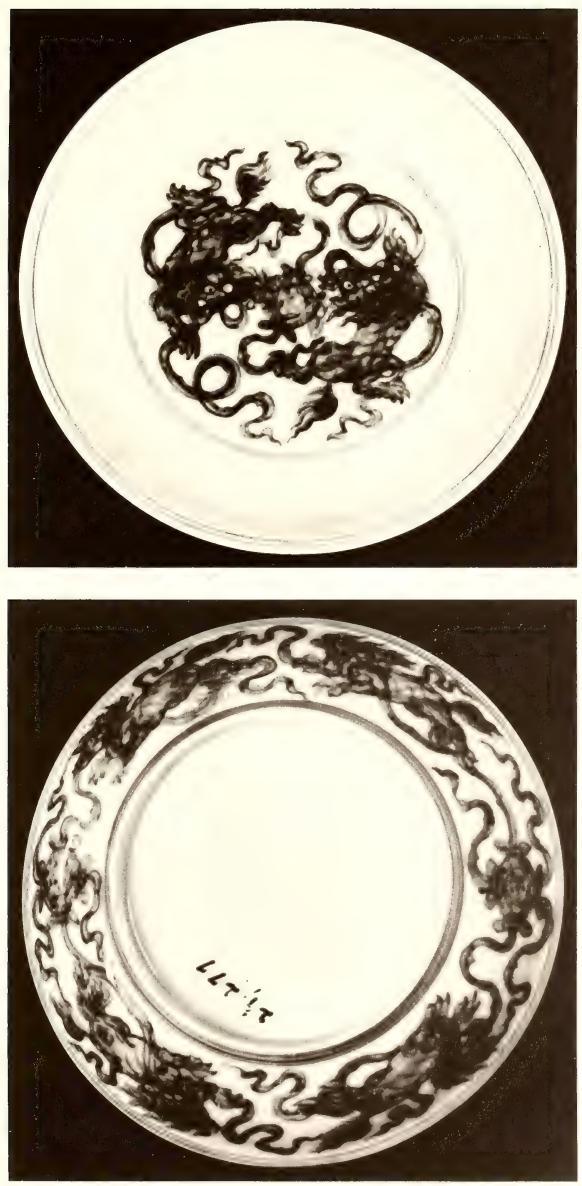


\section{PLATE 59}

Dish with plain rim; in the center is a landscape scene showing a prunus tree growing beside a fantastic rock with a crescent moon above; on the left is a fungus and on the right a bamboo. Outside are four branches: two prunus and two unidentified. The base is glazed and shows a faintly yellowish tinge.

29.149 H. $1 \frac{3}{4}$ in. $(4.5 \mathrm{~cm}$. $)$. D. $8 \frac{1}{2}$ in. $(21.5 \mathrm{~cm}$. $)$.

Late fifteenth century.

See pages 50,108 . 

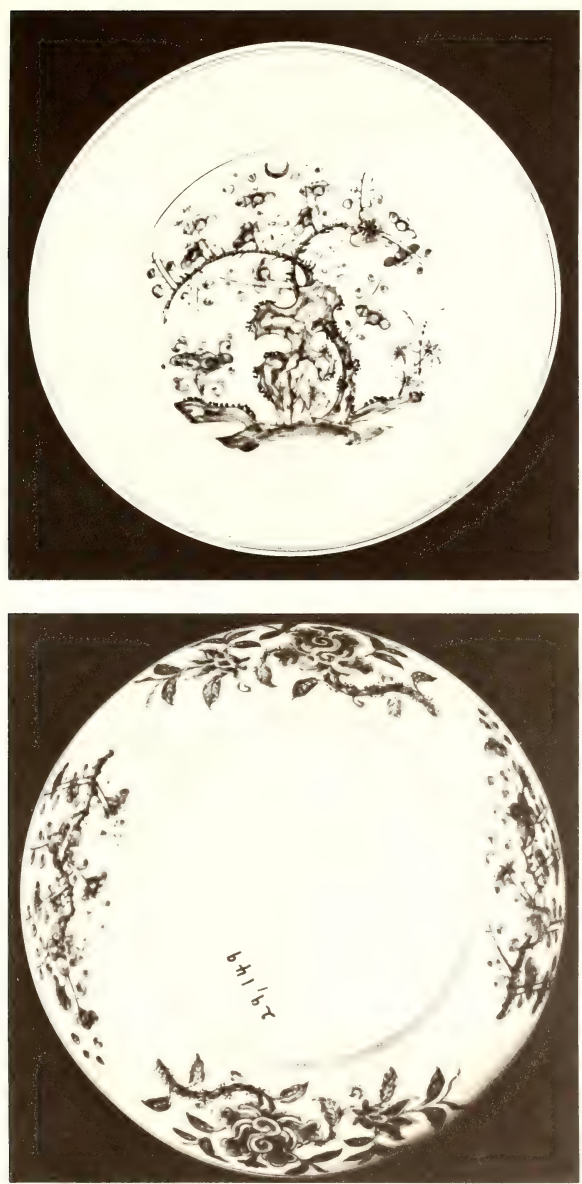
PLATE 60

Bowl with slightly flaring rim; decorated inside with the three friends: pine, prunus, and bamboo, formally painted in a circle. Outside is a garden scene with three scholars and two attendants and a palace among the clouds. The convex base is glazed and shows a faint yellowish tinge.

In the library of the Percival David Foundation of Chinese Art is an album of drawings illustrating selected porcelains from the collection of Lo Chen-yü; among them is shown a similar bowl bearing the 6-character mark of the Ch'eng-hua period.

29.341 H. $3 \frac{1}{4}$ in. $\left(8 \mathrm{~cm}\right.$.). D. $7 \frac{3}{8}$ in. $(18.5 \mathrm{~cm}$.).

Late fifteenth century.

See pages 50, 109 . 

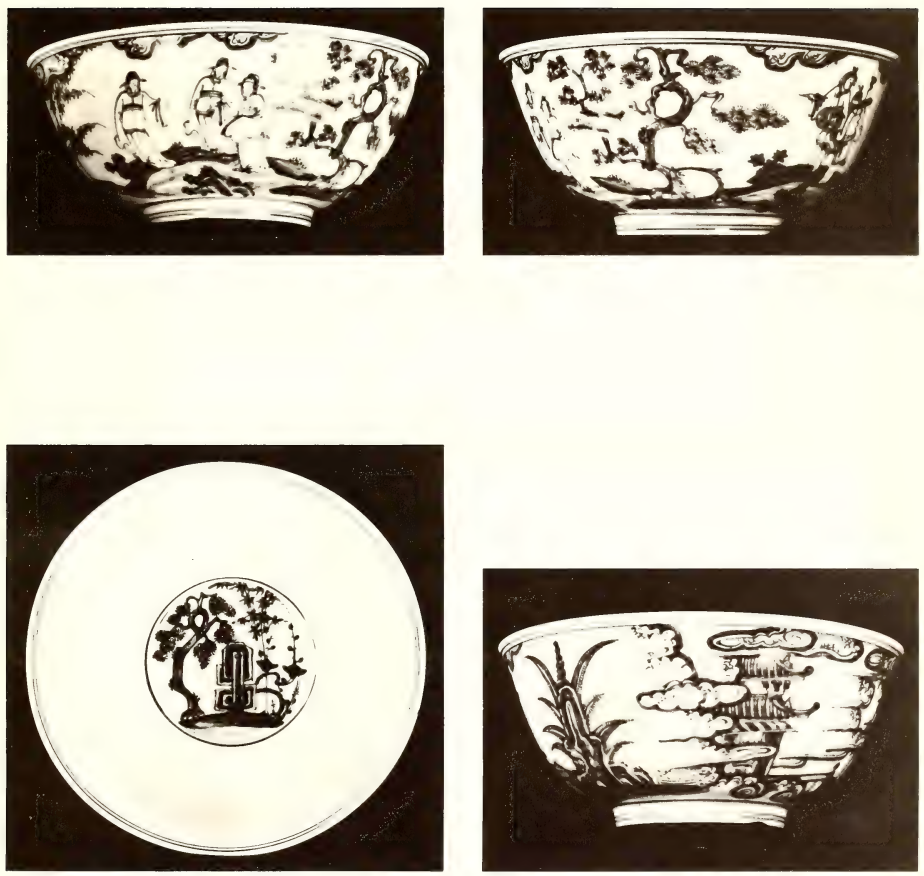

29.341 (four views) 


\section{PLATE 61}

Bowl with plain rim and steep sides decorated inside with a single floral spray; outside is a band of trefoils at the rim above a main zone of camellia scrolls; below is a row of stylized lotus-petal panels. The base is glazed over, and in the center is a patch of thick black enamel roughly 2 inches in diameter on top of the glaze.

29.342 H. 5 in. (12.5 cm.). D. $10 \frac{1}{2}$ in. $(26 \mathrm{~cm}$.).

Late fifteenth century.

See pages 112,113 . 

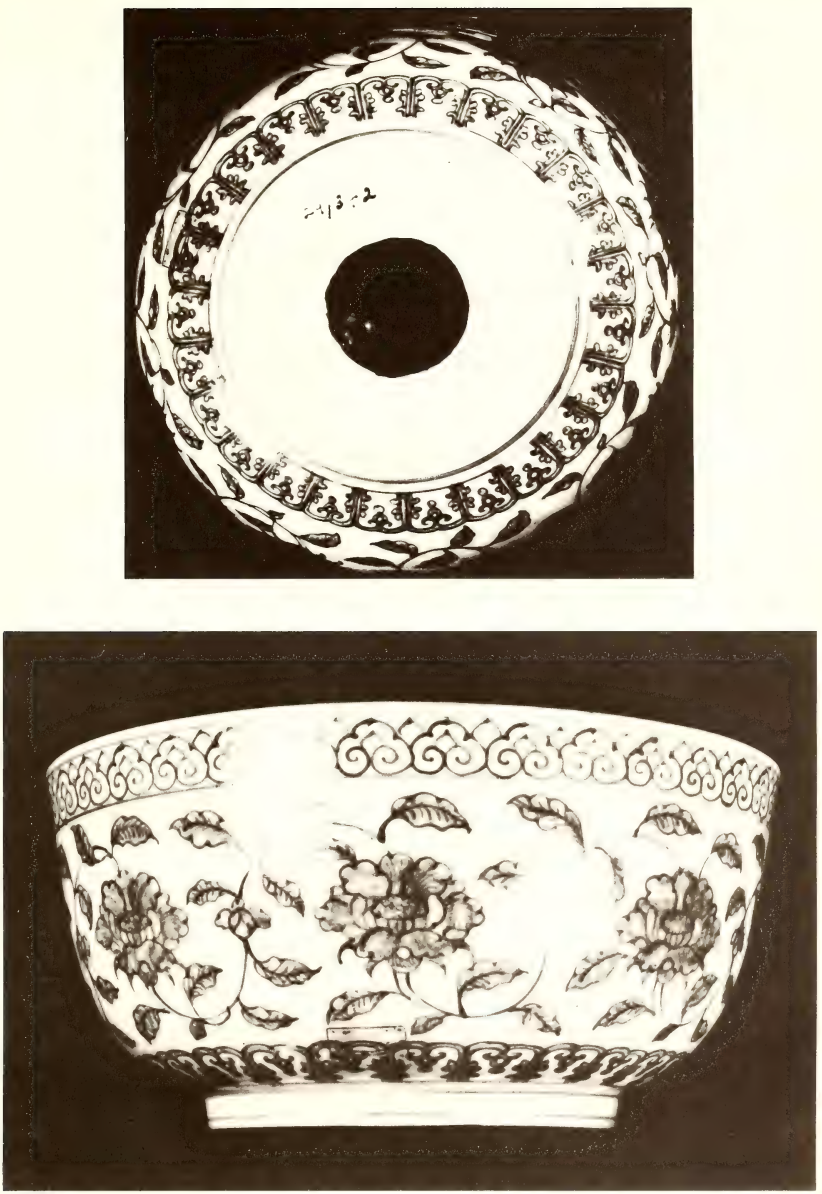


\section{PLATE 62}

Bowl with slightly flaring rim; inside is a design of crossed vajras in the center; and outside are dragons with foliate tails each with a lotus spray springing from the tip of its tongue; below is a trefoil band. The slightly convex base is glazed and shows areas of yellowish tinge.

29.343 H. $3 \frac{3}{4}$ in. $(9.5 \mathrm{~cm}$.). D. 8 in. $(20 \mathrm{~cm}$.).

Late fifteenth century.

See pages 50,110 . 

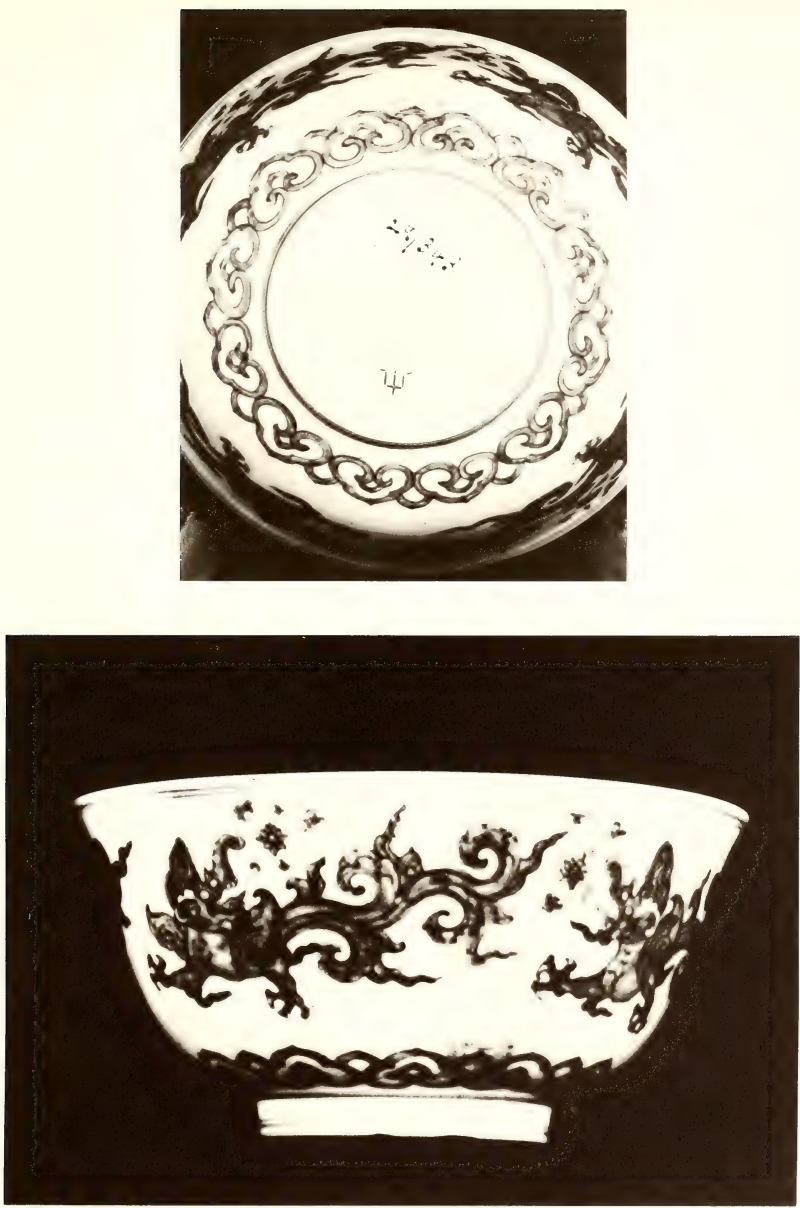


\section{PLATE 63}

Bowl with slightly flaring rim; decorated inside with two birds on a crabapple bush in a landscape. Outside are three similar groups in slightly larger size. The glazed base is marked with two interlocking lozenges carelessly drawn in underglaze blue.

29.345 H. $3 \frac{3}{4}$ in. $(9.5 \mathrm{~cm}$. $)$. D. 9 in. $(22.5 \mathrm{~cm}$. $)$.

Late fifteenth century.

See pages $50,111,162$. 

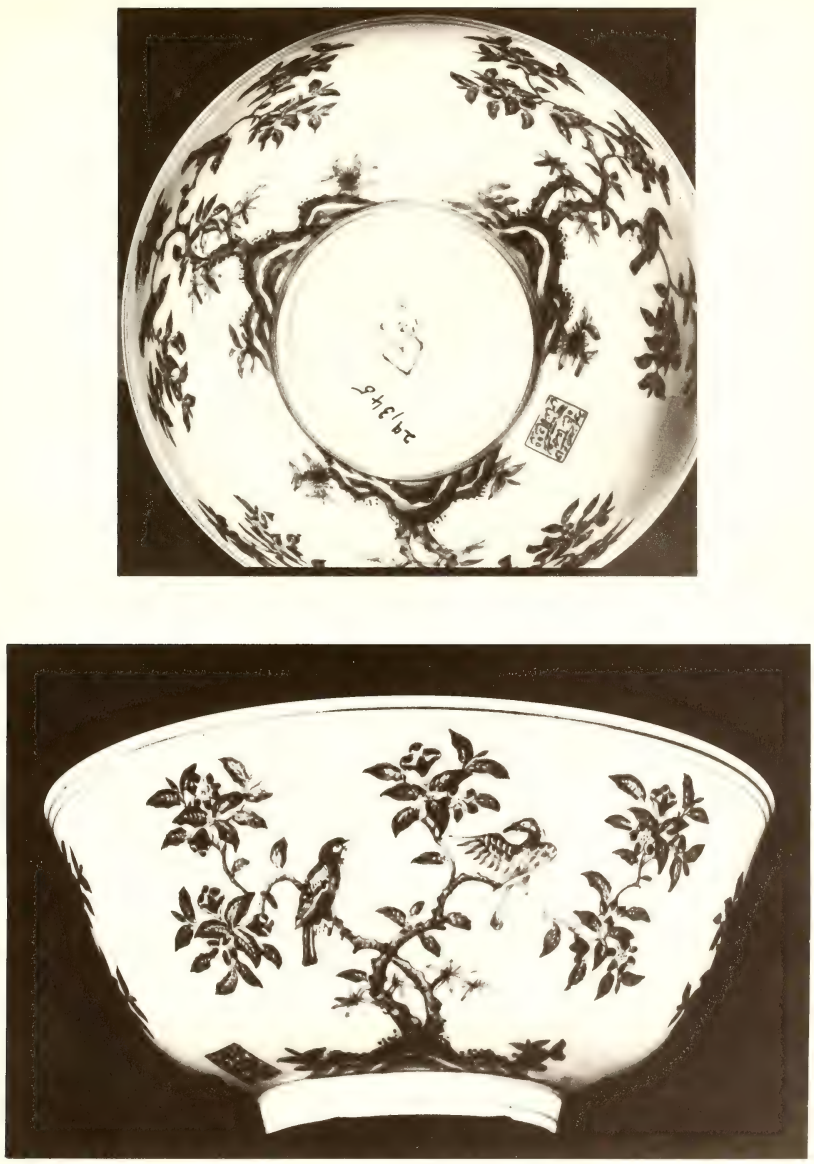


\section{PLATE 64}

Bowl with slightly flaring rim; decorated inside with a diaper border near the rim and a floral spray in a circle in the center. Outside are lotus scrolls above a row of stylized lotus-petal panels. The slightly convex base is glazed.

29.344 H. $3 \frac{t}{2}$ in. $(9 \mathrm{~cm}$. $)$. D. 8 in. $(20.5 \mathrm{~cm}$. $)$.

Bowl with slightly flaring rim; on the inside a group of waterweeds decorates the center; and outside are fish among lotus and knotweeds. The base is glazed and bears the incised owner's mark seen on plate 62 .

29.378 H. $3 \frac{3}{4}$ in. $\left(9.5 \mathrm{~cm}\right.$.). D. $8 \frac{5}{8}$ in. $(22 \mathrm{~cm}$.).

Late fifteenth century.

See pages 109, 112, 133 . 

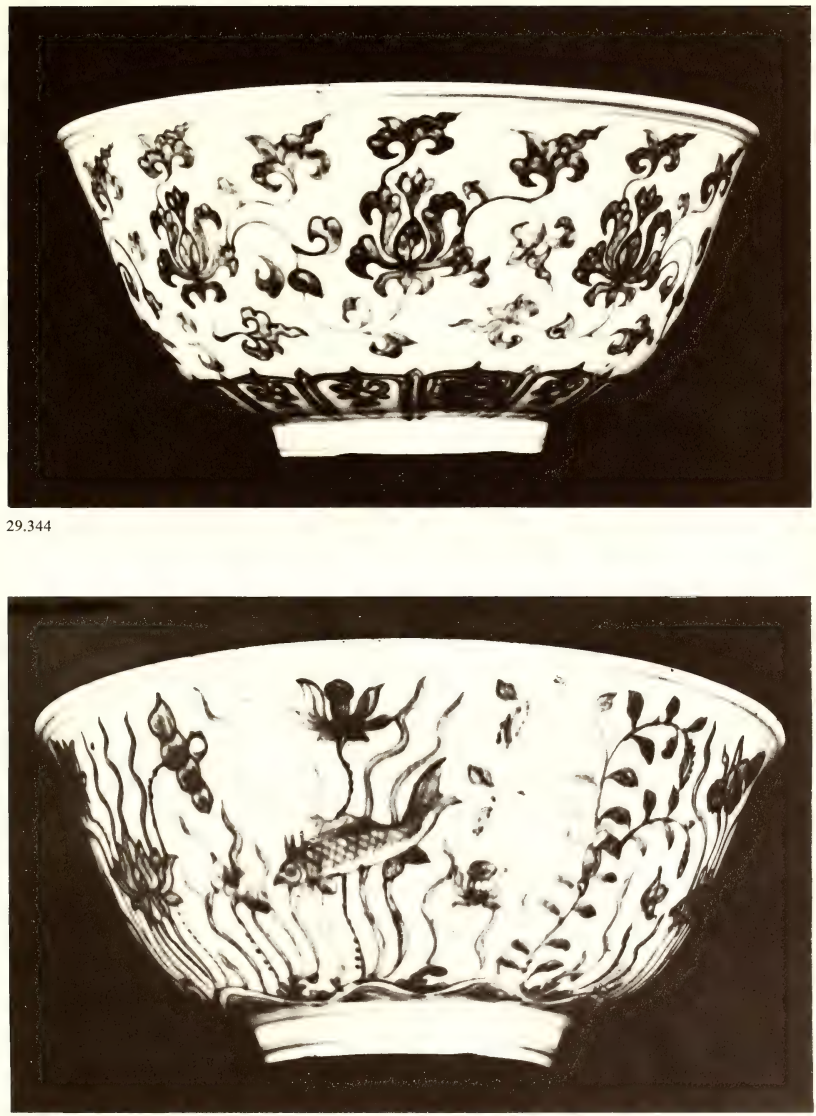


\section{PLATE 65}

Bowl with slightly flaring rim; the inside is plain, and outside are four fishes on a sea of incised waves. The base is glazed.

29.349 H. 3 in. $\left(7.5 \mathrm{~cm}\right.$.). D. $6 \frac{3}{4}$ in. $(17 \mathrm{~cm}$.).

Bowl with plain rim; inside are a fungus scroll and a peach spray in the center; outside are ducks among lotus above a trefoil band. The base is glazed.

29.375 H. $4 \frac{3}{8}$ in. $\left(11 \mathrm{~cm}\right.$.). D. $8 \frac{5}{8}$ in. $(22 \mathrm{~cm}$. $)$.

Late fifteenth century.

See page 112 . 


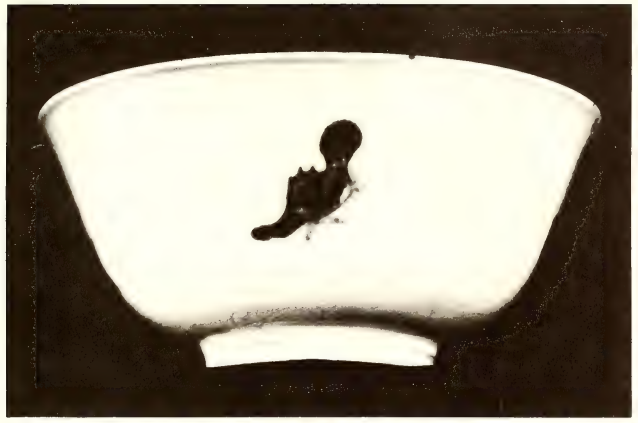

29.349

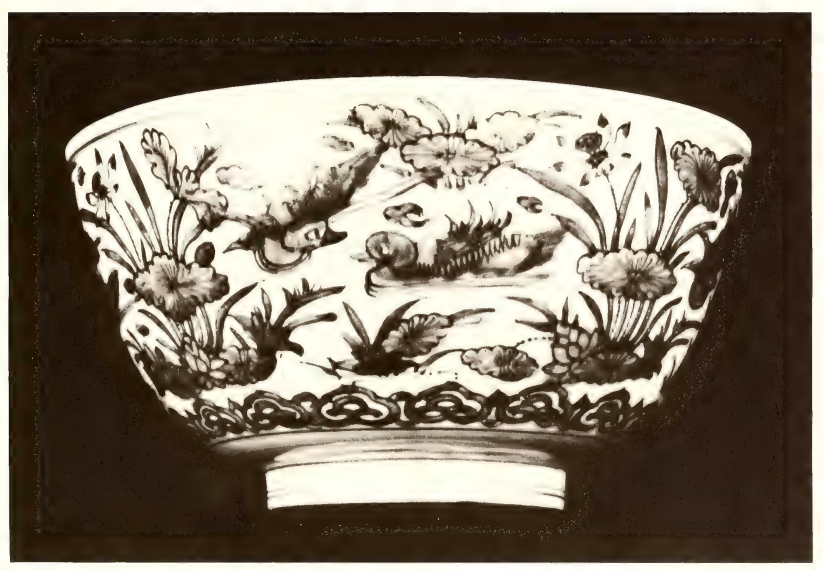




\section{PLATE 66}

Bowl with flaring rim; decorated inside with two rows of Tibetan script and in the center a flaming wheel; outside are five groups of symbols (looking something like lotus flowers backed by palm fans) amid cloud scrolls. The base is glazed.

29.348 H. $3 \frac{3}{3}$ in. $\left(9.5 \mathrm{~cm}\right.$.). D. $8 \frac{3}{4}$ in. $(22 \mathrm{~cm}$.).

Late fifteenth century.

See pages 111,133 . 

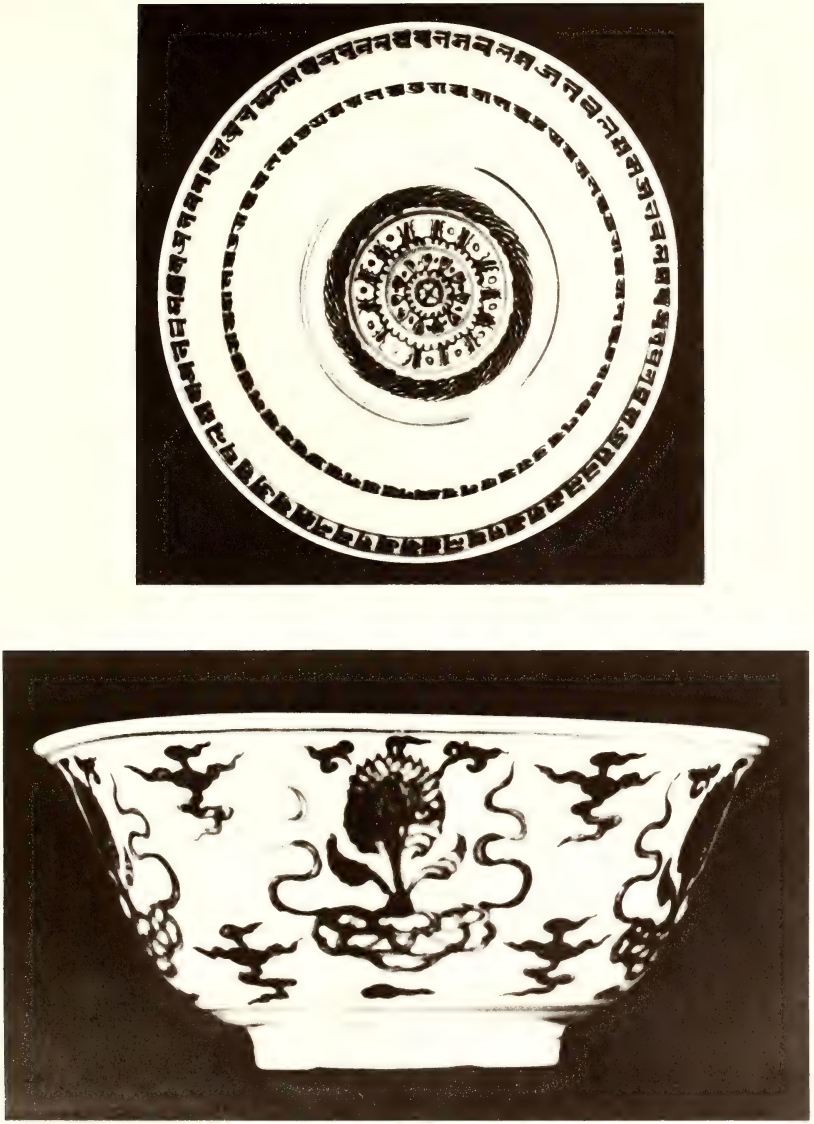


\section{PLATE 67}

Bowl with plain rim; inside is a fish leaping above waves; outside are four fishes and four plants. The base is glazed.

29.347 H. $2 \frac{1}{2}$ in. $\left(6.5 \mathrm{~cm}\right.$.). D. $7 \frac{3}{8}$ in. $(18.5 \mathrm{~cm}$. $)$.

Late fifteenth century.

See page 113 . 

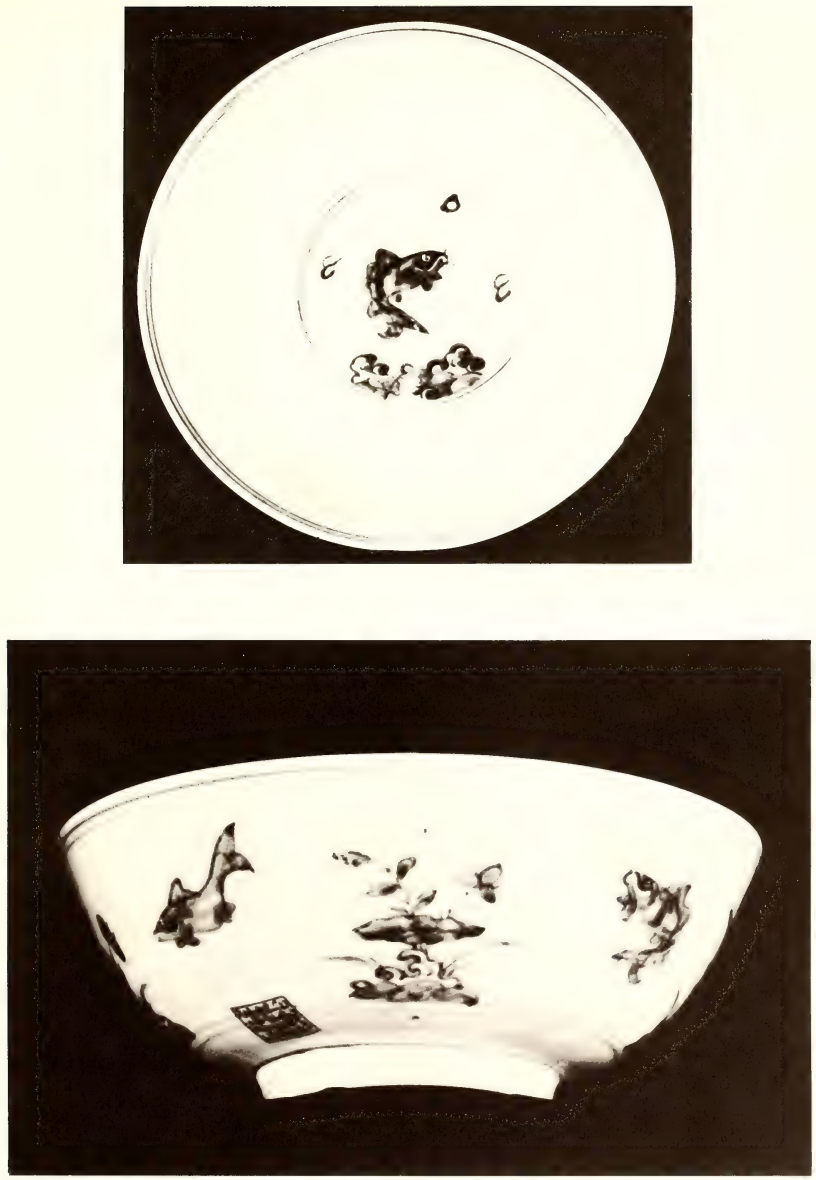


\section{PLATE 68}

Bowl with plain rim; inside are four fishes among waves and aquatic flora, and in the center a single fish leaps above the waves toward the sun, which is seen between clouds. Outside are children playing in a garden. The glazed base is convex.

29.399 H. 2 in. $\left(5 \mathrm{~cm}\right.$.). D. $6 \frac{1}{2}$ in. $(16.5 \mathrm{~cm}$.).

Late fifteenth century.

See page 113 . 

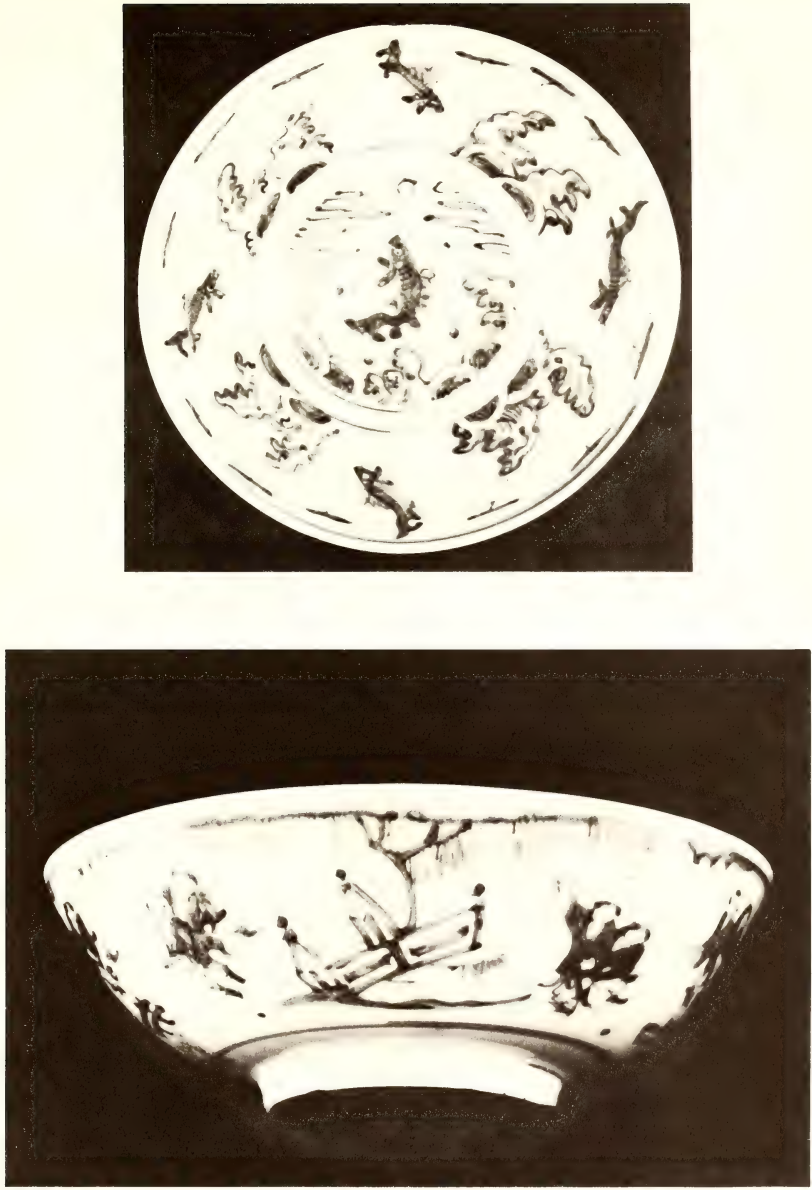


\section{PLATE 69}

Drinking vessel of kèndi shape with flaring neck and tapering spout; the domed top surrounding the small hole has a petal design, and on the neck are stiff leaves and pendent trefoils; around the shoulder, cloud collar points frame white lotus blossoms amid scrolls; the main body and the spout are covered with lotus scrolls, and around the bottom is a row of trefoils. The base is unglazed and has a low foot.

The piece lacks the mark of Shāh 'Abbās.

29.472 H. $6 \frac{1}{4}$ in. $\left(16 \mathrm{~cm}\right.$.). D. of body $5 \frac{7}{8}$ in. $(15 \mathrm{~cm}$. $)$.

A flask (pien hu) of unusual shape; on the neck are a band of thunder pattern, a row of overlapping petals and a row of stylized lotus-petal panels, both the latter in pendent position; at the narrowing within the loops of the handles is a row of plantain leaves or ferns; the circumference of the body is decorated on each side with four phoenixes among lotus scrolls; inside this is a device of five radiating cloud collar points each framing a blossom amid scrolls and separated one from another by foliate designs; in the center, in the depression, is a conch with its occupant on a ground of concentric waves; around the flaring base is a band of small pendent trefoils. Two hemispherical lugs protrude from the sides, and the broad flat foot is glazed only in the small central depression.

29.459 H. $13 \frac{3}{8}$ in. ( $34 \mathrm{~cm}$.). W. $9 \frac{1}{2}$ in. $\left(24 \mathrm{~cm}\right.$.). T. $4 \frac{1}{2}$ in. $(11.5 \mathrm{~cm}$.$) .$

Ewer (chih-hu) with squat body and tall thick neck; stiff leaves, fungus scrolls and pendent lotus panels decorate the neck; the shoulder has cloud collar points framing fungus scrolls and separated by beaded pendants; the main body is covered with lotus scrolls above a band of lotus panels while a row of inverted trefoils surrounds the foot; flame scrolls appear on the spout. The base is double with a hole in the center of the outer layer, and the latter is unglazed with a low rim.

29.442 H. $11 \frac{5}{8}$ in. $\left(29.5 \mathrm{~cm}\right.$.). D. of body $7 \frac{1}{4}$ in. $(18.5 \mathrm{~cm}$.).

Late fifteenth century.

See pages 116,118 . 


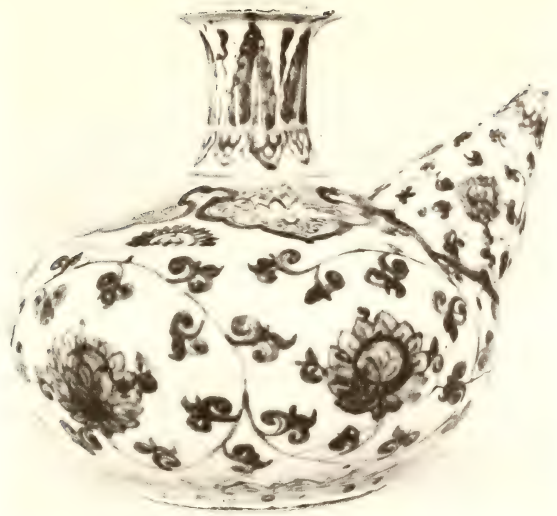

29.472

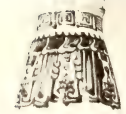

$\therefore$ br defor

$45 x$ is $x$

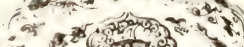

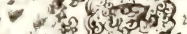

(4)

40 E

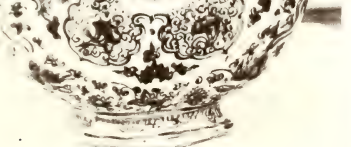

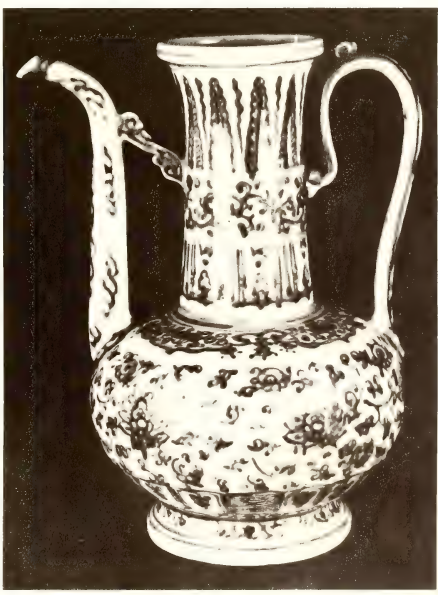

29.442 


\section{PLATE 70}

Ewer with restored handle; the shape differs from that of 29.442 , but the decoration is similar. The unglazed base has a low wide foot.

29.437 H. $12 \frac{1}{2}$ in $(32 \mathrm{~cm}$. $)$. D. $7 \frac{3}{4}$ in. $(19.5 \mathrm{~cm}$. $)$.

Basin with flattened rim and straight sides with slight horizontal flange; debased classic scroll on rim; inside are dense floral scrolls and in the bottom two winged dragons with long forked flames or tongues protruding from their mouths fly among cloud scrolls; outside are separate cloud scrolls under the rim, a petal band above the flange, and a dense floral scroll below. The base is roughly glazed.

29.353 H. $3 \frac{1}{4}$ in. $\left(8 \mathrm{~cm}\right.$.). D. $11 \frac{3}{4}$ in. $(30 \mathrm{~cm}$.).

Late fifteenth century.

See pages $115,119$. 


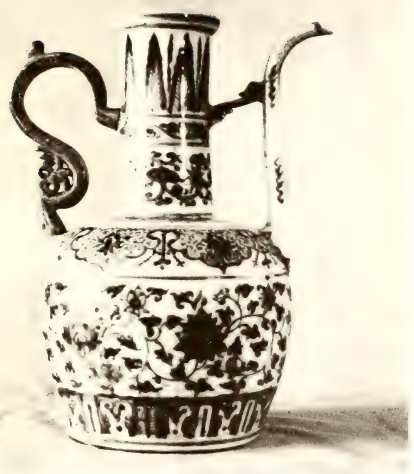

29.437

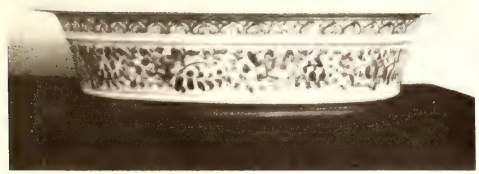

29.353

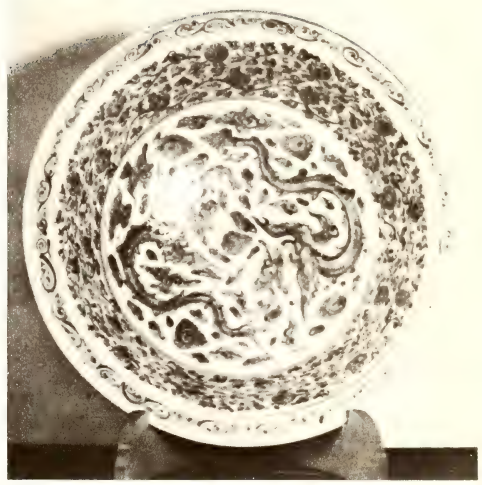

29.353

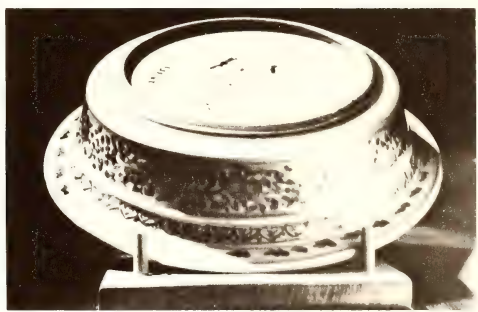

29.353 


\section{PLATE 71}

Dish with plain rim; in the cavetto are four phoenixes flying amid lotus scrolls with four blossoms; in the center is a landscape scene with two spotted deer gamboling under the arching branch of an overhanging pine; both deer have collars with two dangling links in front; the one on the left, with a single horn looking somewhat like a fungus, carries a rose spray in its mouth, while that on the right has two straight horns with prongs and carries a fungus spray in its mouth; above the latter are two butterflies. The outside is decorated with cloud scrolls among which fly eight animals (two horses, two does, a lion, a dragon, a chi-lin, and a sea monster); below this is a band of classic scroll.

Drilled in the base is the mark of Qarachaghāy.

29.137 H. $2 \frac{1}{2}$ in. $(6.5 \mathrm{~cm}$.). D. 13 in. $(33 \mathrm{~cm}$.).

Late fifteenth century.

See pages $118,124,133$. 

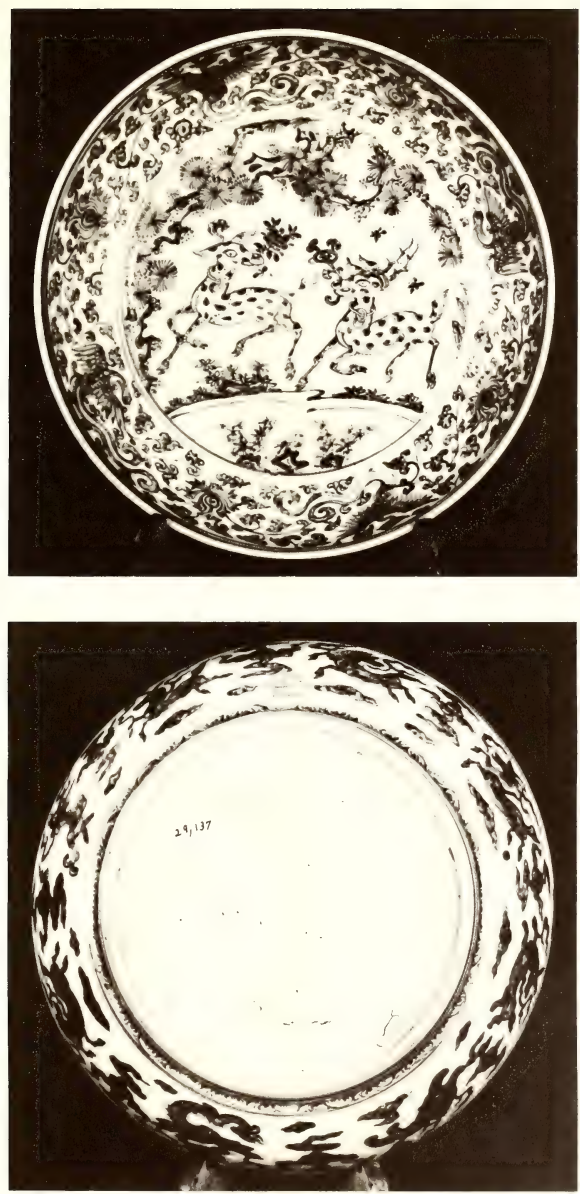


\section{PLATE 72}

Dish with flattened foliate rim decorated with dense foliate scrolls and blossoms; in the cavetto amid lotus scrolls are eight lotus blossoms each serving as a pedestal for one of the Eight Lucky Buddhist Symbols; within this is a narrow wave band, and the central area shows a peacock and a peahen with a rock and a tree peony. Outside are cloud scrolls under the rim, a broad band of lotus scrolls with nine blossoms and a border of overlapping foliate forms.

29.136 H. $3 \frac{1}{4}$ in. $(8 \mathrm{~cm}$. $)$. D. 18 in. $(46 \mathrm{~cm}$.).

Dish with plain rim; in the cavetto is a scroll with what may be intended for fungus and crossed at intervals by eight feathery sprays; a narrow band of classic scroll surrounds the central design of three large tree peonies. The outside is decorated with seven lotus blossoms separated by truncated sections of a scrolling vine.

29.139 H. 2 in. $\left(5 \mathrm{~cm}\right.$.). D. $15 \frac{3}{4}$ in. $(40 \mathrm{~cm}$. $)$.

Late fifteenth century.

See page 119 . 

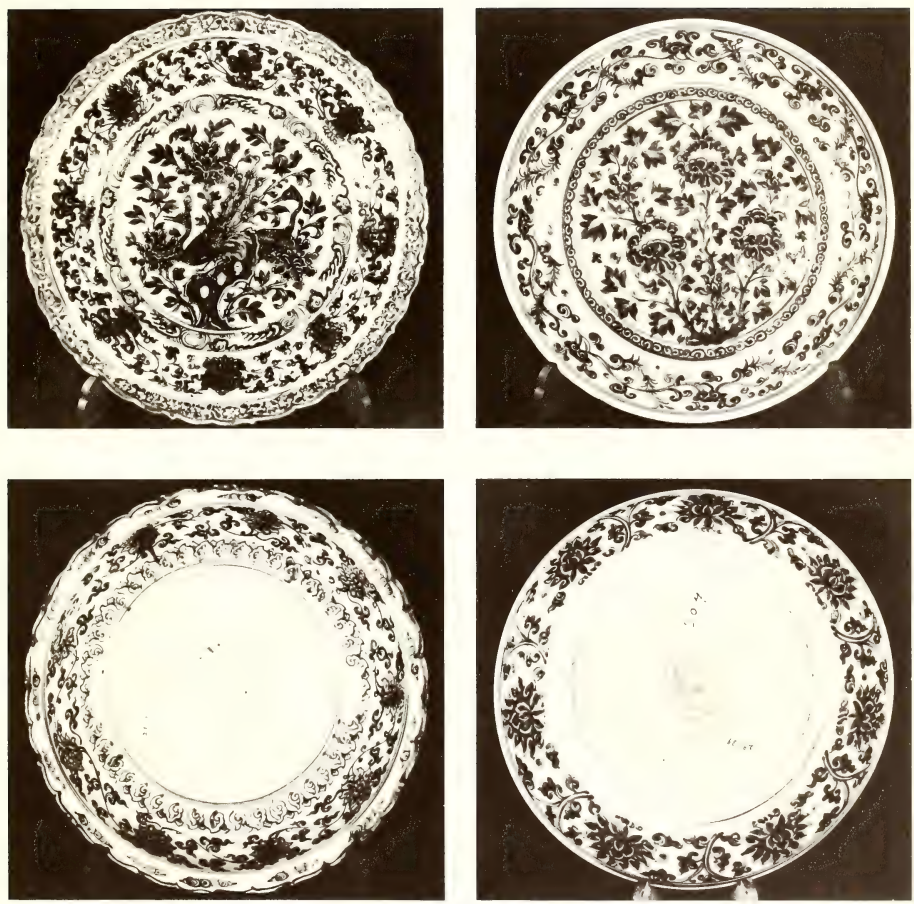


\section{PLATE 73}

Dish with flattened rim; inside is a border of classic scroll; the cavetto is decorated with four growing plants with a horizon line and four smaller plants between; in the middle is a curious composition centered around a recumbent ch $^{i}$-lin with head raised to look back over its shoulder; on the right is a banana plant, above is a crescent moon; and elsewhere are flames, a threefold scroll, and four objects that look like crudely drawn auspicious objects. Outside are cloud scrolls under the rim and lotus scrolls on the cavetto. The unglazed base is deeply recessed within a broad rounded foot (pl. 141).

29.142 H. $2 \frac{1}{2}$ in. $\left(6.5 \mathrm{~cm}\right.$.). D. $12 \frac{1}{2}$ in. $(32 \mathrm{~cm}$.).

Late fifteenth century.

See page 119 . 

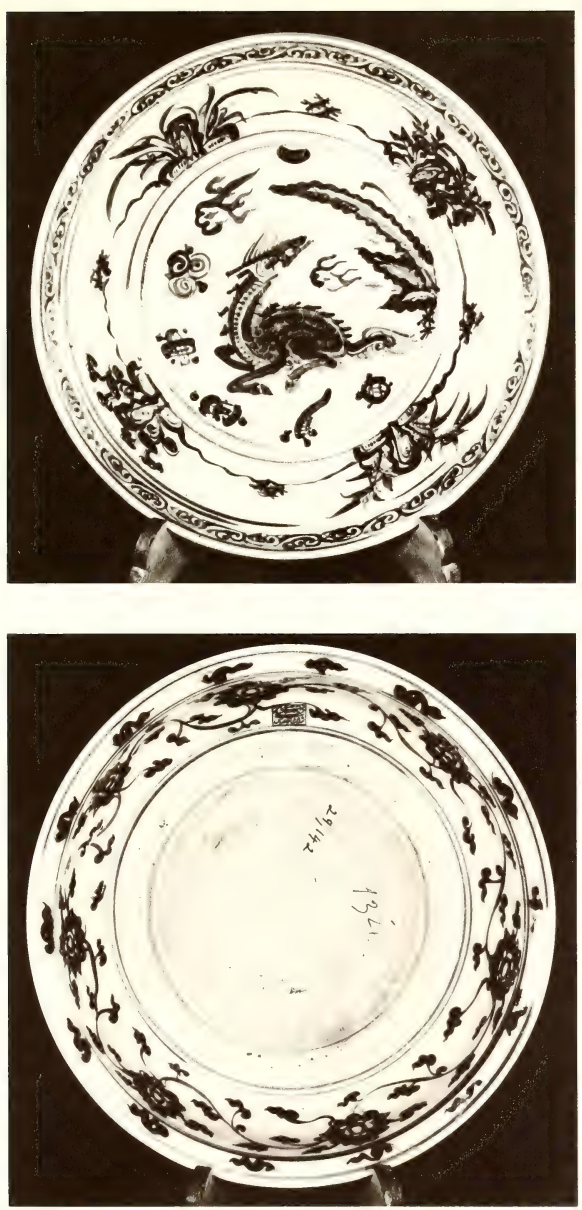


\section{PLATE 74}

Dish with plain rim; in the cavetto are four large plants with small triple clusters of pine needles between them on a wavy horizon line; in the center fly two ducks among lotus scrolls with two blossoms; outside is a lotus scroll with six blossoms. The base is roughly glazed.

Unnumbered (Isfahan) D. $12 \frac{1}{2}$ in. $(31.8 \mathrm{~cm}$.).

Bottle-shaped vase (p'ing); below the lip is a band of stiff leaves, and the neck is decorated with a network of beaded strings; a band of classic scroll on the shoulder surmounts the main design of lotus scrolls. The base is glazed and gravelly and carries the mark Ta-ming-nien-tsao in a double circle in underglaze blue.

29.451 H. 91 in. $\left(23.5 \mathrm{~cm}\right.$. ). D. $4 \frac{5}{8}$ in. $(12 \mathrm{~cm}$.).

Late fifteenth century.

See pages $114,120,133$. 


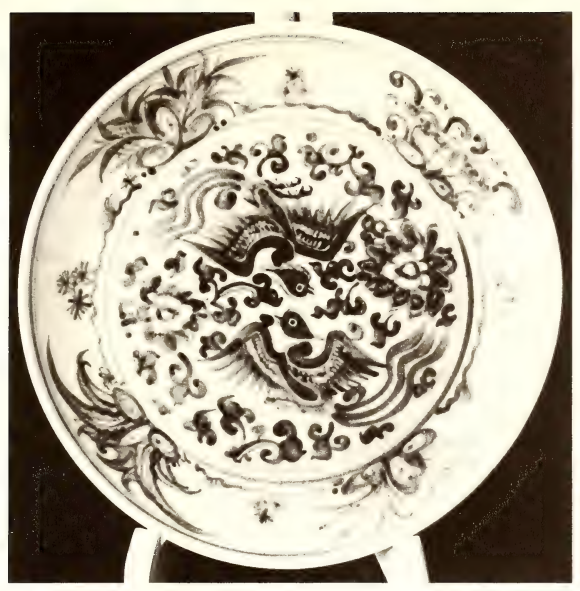

Isfahan
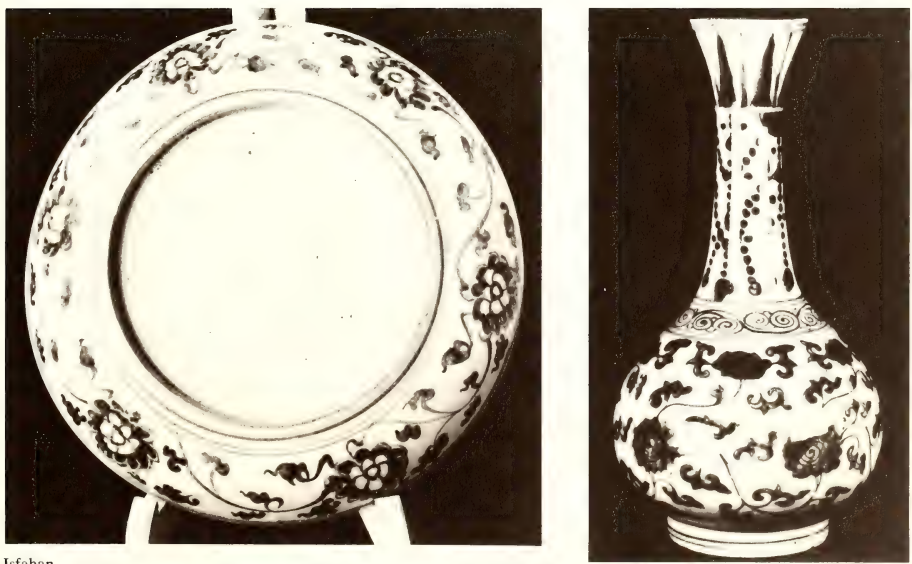

Isfahan 


\section{PLATE 75}

Large dish with flattened rim. On this are 32 small leafy roundels, and the cavetto is a broad zone of plain white; in the center a ring of foliate scrolls surrounds a 4-pointed medallion in which is a square framing an Arabic inscription which may be translated, "Thanks for his goodness." 29.313 H. $4 \frac{1}{2}$ in. (11.5 cm.). D. 23 in. $(58.5 \mathrm{~cm}$.).

Cheng-te period.

See pages 34,122 . 


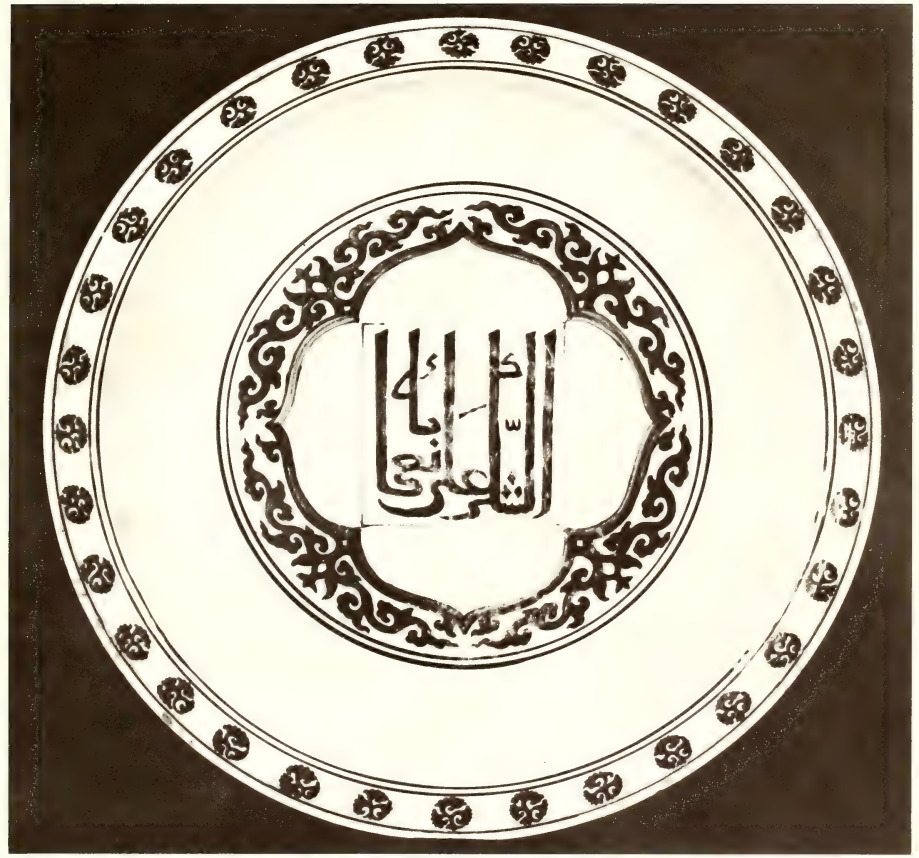




\section{PLATE 76}

Back of dish on previous plate. Under the rim is a border of stylized fruit motif; the cavetto is covered with foliate scrolls surrounding eight circles filled with Arabic script; taken all together they may be translated, "Said the Prophet on whom be peace, 'Man's praise to him who gives should be increased; ingratitude for favor causes it to disappear' "; on one side just below the rim a horizontal cartouche frames the 6-character Cheng-te mark. The foot is massive and deeply undercut (pl. 142).

See pages 34, 122 . 

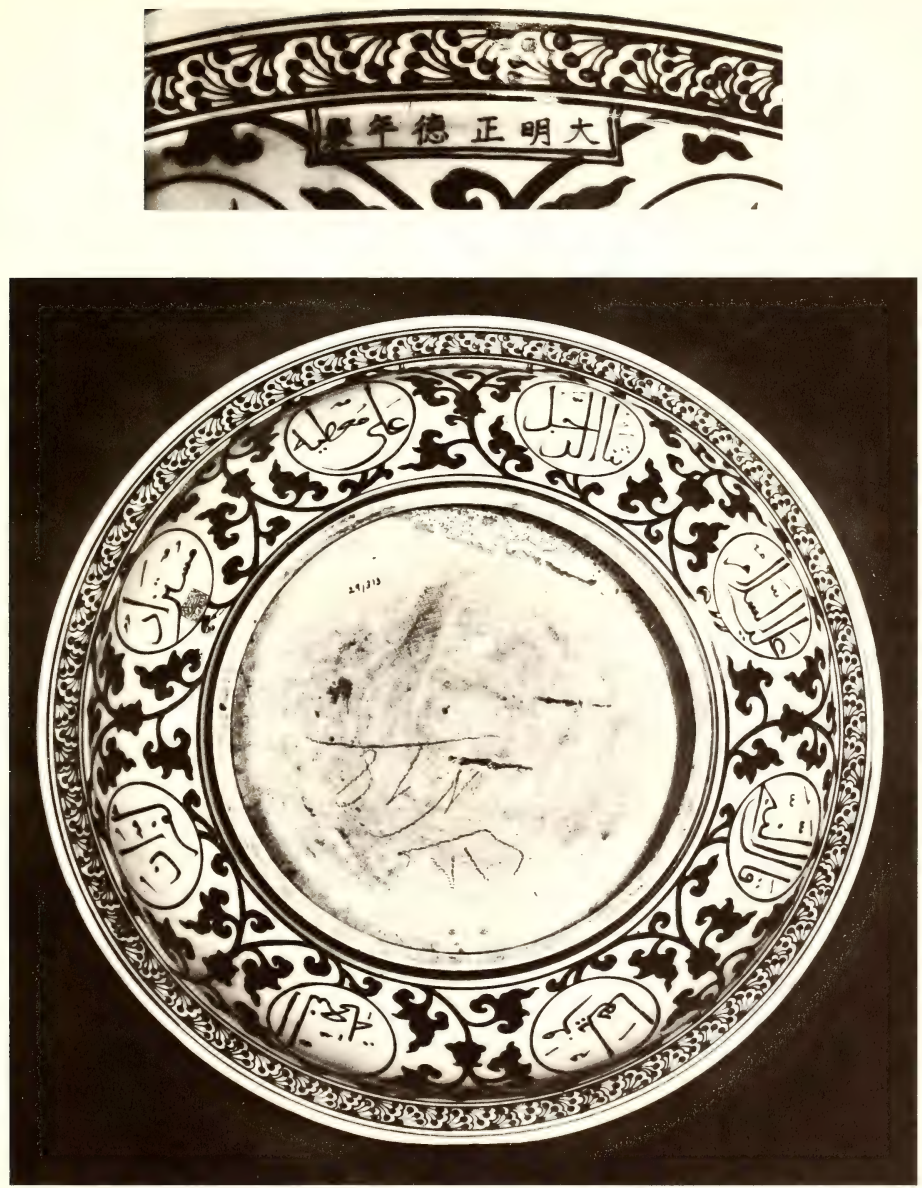


\section{PLATE 77}

Bowl with flaring rim. Inside is a narrow band of Arabic script while a circle with eight lines of similar script occupies the center. Outside are four circles each framing an Arabic text, and between these are cloud scrolls; below is a row of lotus panels. On the glazed base is the 6character mark of the Hsüan-te period.

29.346 H. 3 in. $\left(7.5 \mathrm{~cm}\right.$.). D. $7 \frac{1}{4}$ in. $(18.5 \mathrm{~cm}$.).

Early sixteenth century.

See page 123 . 

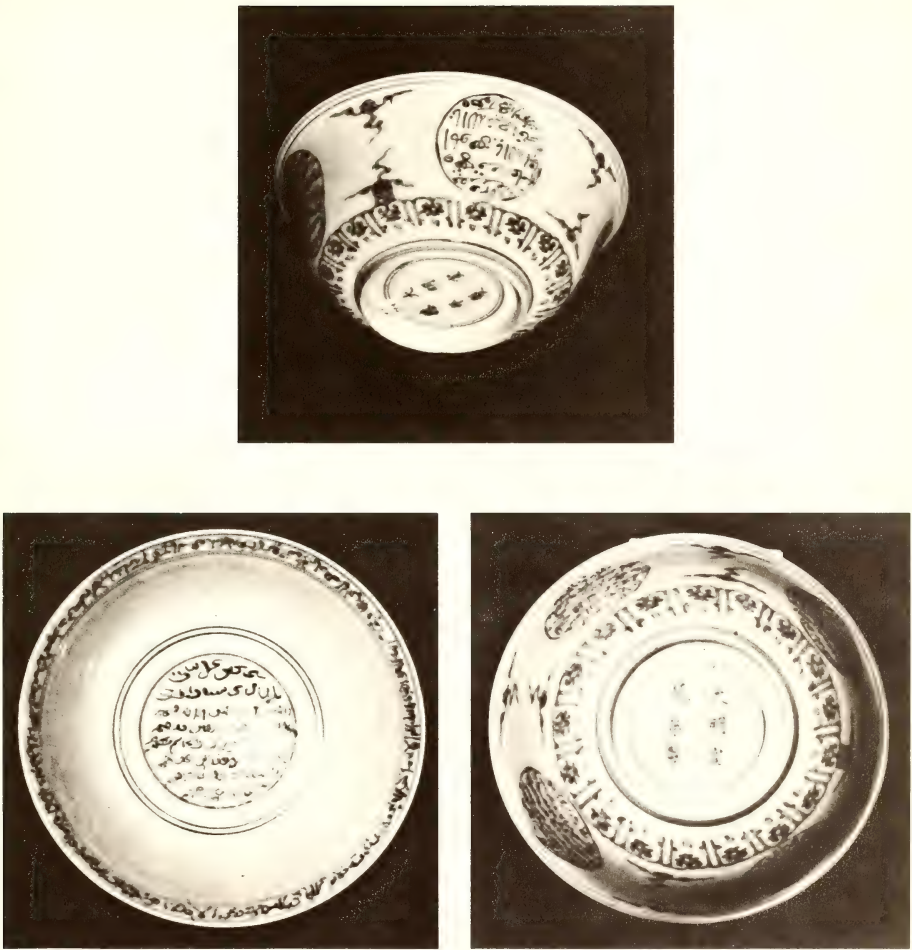

29.346 (three views) 


\section{PLATE 78}

Dish with plain rim. The cavetto is decorated with a large floral scroll; inside a narrow band of classic scroll is the central landscape scene showing a rock and tree peonies. Outside is a broad zone of scrolling peonies above a band of classic scroll. The unglazed base is slightly convex and the paste has a brownish iron-red surface with no glaze. The foot rim is large and deeply undercut (pl. 142).

29.131 H. 4 in. $(10 \mathrm{~cm}$.). D. 20 in. $(51 \mathrm{~cm}$.).

Similar dish with related decoration; a peacock stands beside the rock amid peony scrolls in the center.

29.132 H. $3 \frac{1}{2}$ in. ( 9 cm.). D. 20 in. (51 cm.).

About 1500 .

See page 124 . 

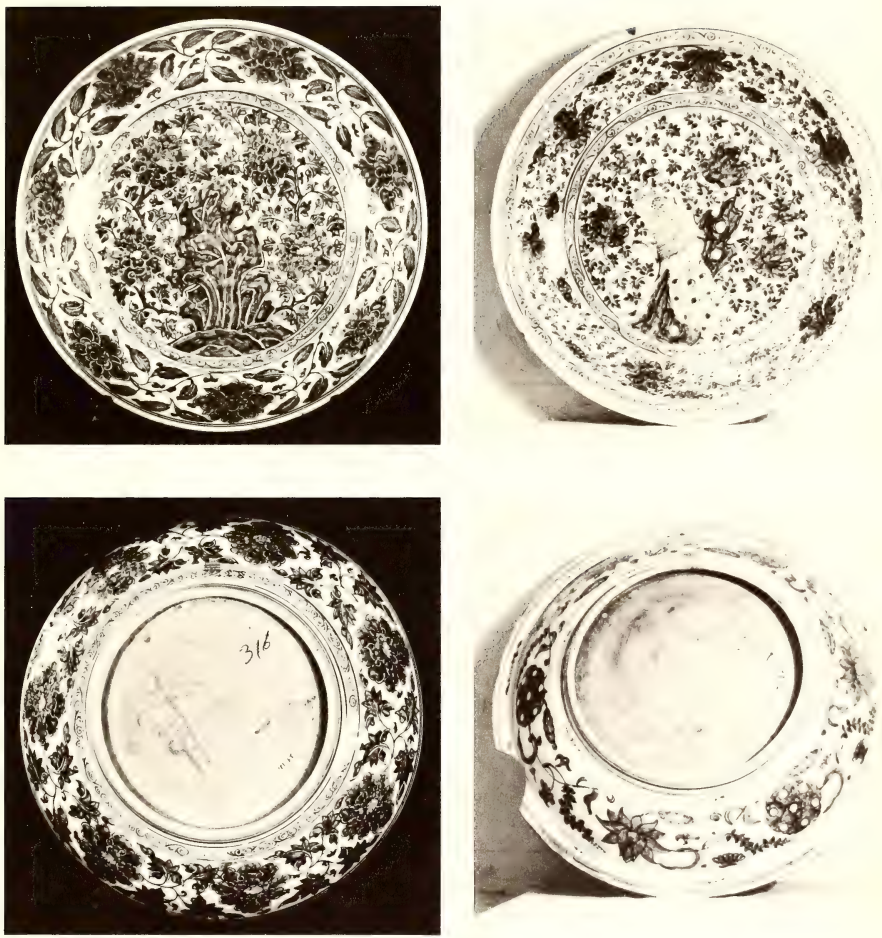

29.131 


\section{PLATE 79}

Vase of kuan shape with four small loop handles on the shoulder. Floral scrolls decorate the neck and shoulder; the main zone has two dragons with bifurcated tails and spindly 4-clawed chickenlike feet amid what are presumably clouds and waves; a floral pattern surrounds the base. The crudely finished base is splashed with glaze.

29.512 H. 14 in. (35.5 cm.). D. 11 in. $(28 \mathrm{~cm}$.).

Sixteenth century.

Large vase of kuan shape. Around the shoulder are pendent jeweled strings, and the whole body is covered with scrolling lotuses above a row of stylized lotus petals. The 6-character mark of Chia-ching appears in a glazed circle in the center of the unglazed base.

29.515 H. about $19 \frac{3}{4}$ in. $(50 \mathrm{~cm}$.).

Chia-ching period.

Similar vase. On the shoulder is a band of floral scrolls, and the main design consists of a single large 5-clawed dragon amid cloud scrolls flying above rocks and waves; below is a band of formal foliate scrolls. The 6-character Wan-li mark appears in a horizontal line on the neck.

This is one of a group of five kuan similarly decorated; the other four, 29.514, 29.516, 29.518 and 29.519 , all carry the 6-character Chia-ching mark.

$29.520 \mathrm{H}$. about 21 in. $(53 \mathrm{~cm}$. $)$.

Wan-li period.

See pages $34,125,126$. 


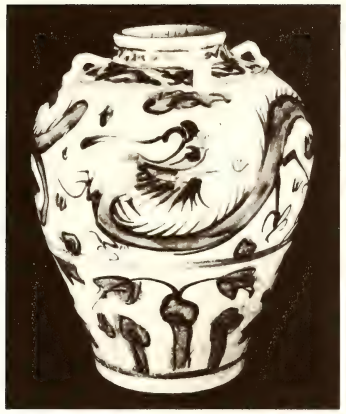

29.512
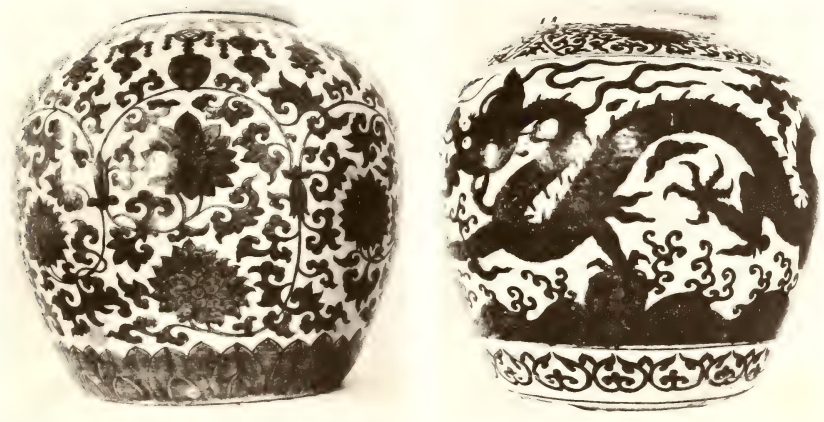


\section{PLATE 80}

Bowl with flaring rim. Inside is a pine tree twisted into the form of the character shou; outside are two pines, a prunus, and a bamboo similarly twisted into the forms of Chinese characters. On the base is the 6-character Chia-ching mark poorly written. The foot rim is broken.

29.364 H. $2 \frac{3}{4}$ in. $\left(7 \mathrm{~cm}\right.$.). D. $6 \frac{1}{4}$ in. $(16 \mathrm{~cm}$.).

Chia-ching period.

See page 126. 

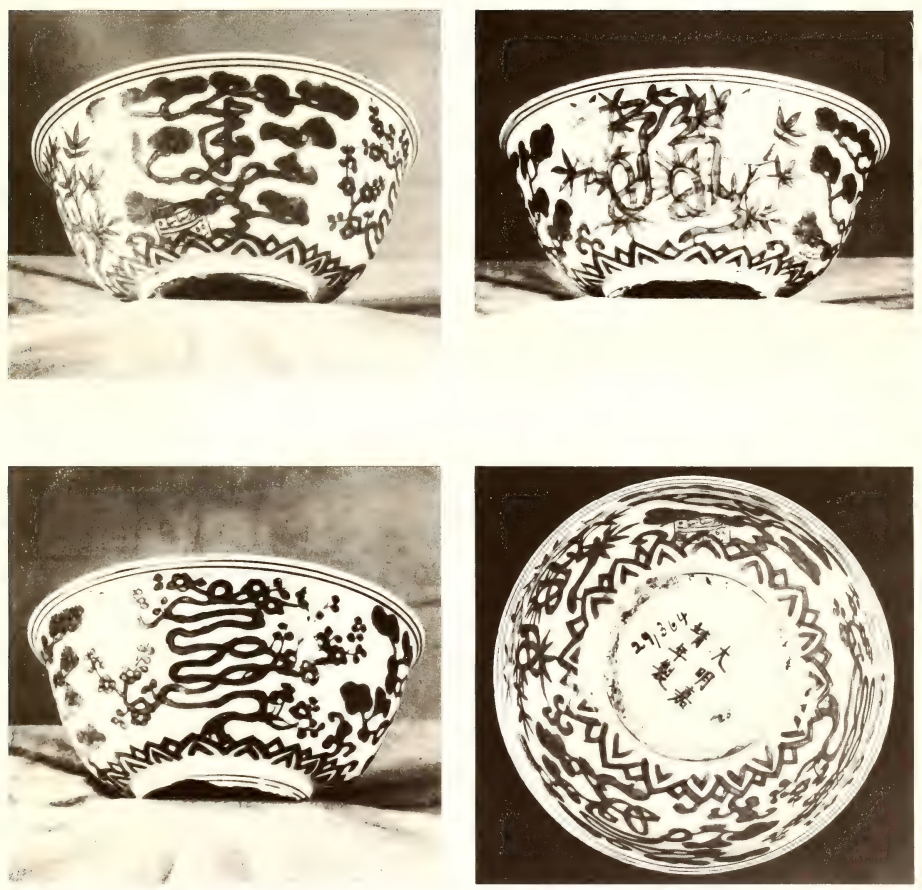

29.364 (four views) 


\section{PLATE 81}

Dish with flattened rim; border of squirrels and birds among grapevines; plain cavetto and central design of a deer and a crane in a landscape; outside are floral scrolls under the rim, and on the cavetto five roundels each showing a stylized flying crane among clouds reserved in white on a blue ground. Six-character Chia-ching mark in underglaze blue.

29.262 H. $2 \frac{1}{2}$ in. $\left(6.5 \mathrm{~cm}\right.$.). D. $11 \frac{3}{4}$ in. $(30 \mathrm{~cm}$.).

Chia-ching period.

See page 126 . 

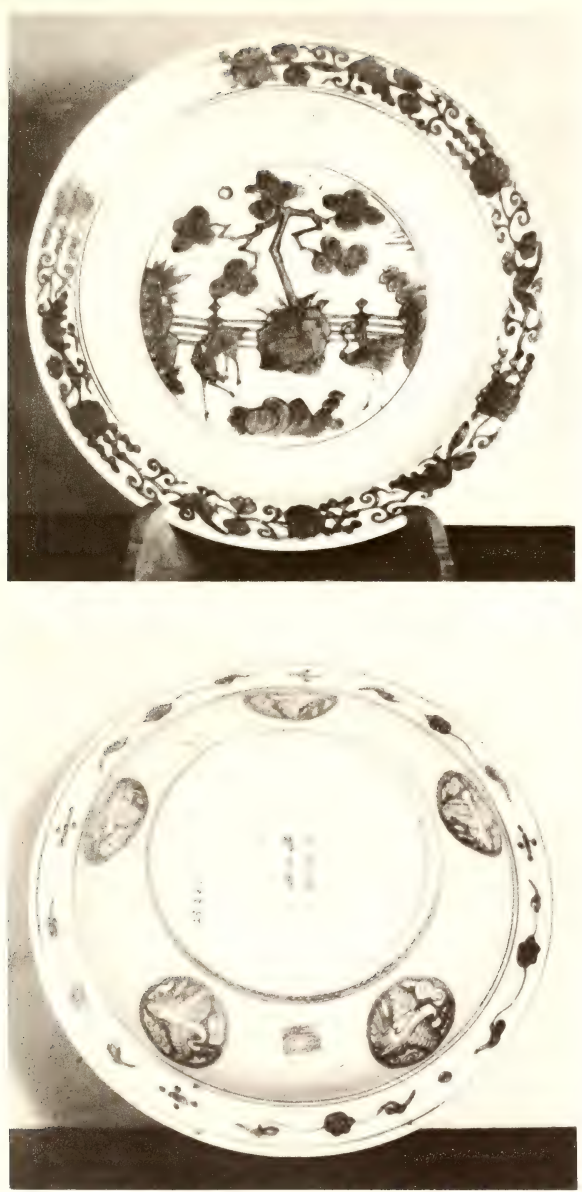


\section{PLATE 82}

Dish with flattened foliate rim. Inside is a fungus scroll border surrounding a plain cavetto and two lions with streamers and a brocaded ball in the center. The fungus scroll is repeated outside the rim and the cavetto is decorated with seven circles each framing a flying horse with flames. The undercut foot carries a simple scroll pattern. Under the convex base is the very crudely written mark Ta-ming-chia-ching-nien-tsao.

29.140 H. $2 \frac{1}{2}$ in. $\left(6.5 \mathrm{~cm}\right.$.). D. $12 \frac{1}{4}$ in. $(31 \mathrm{~cm}$.).

Chia-ching period.

See page 126 . 

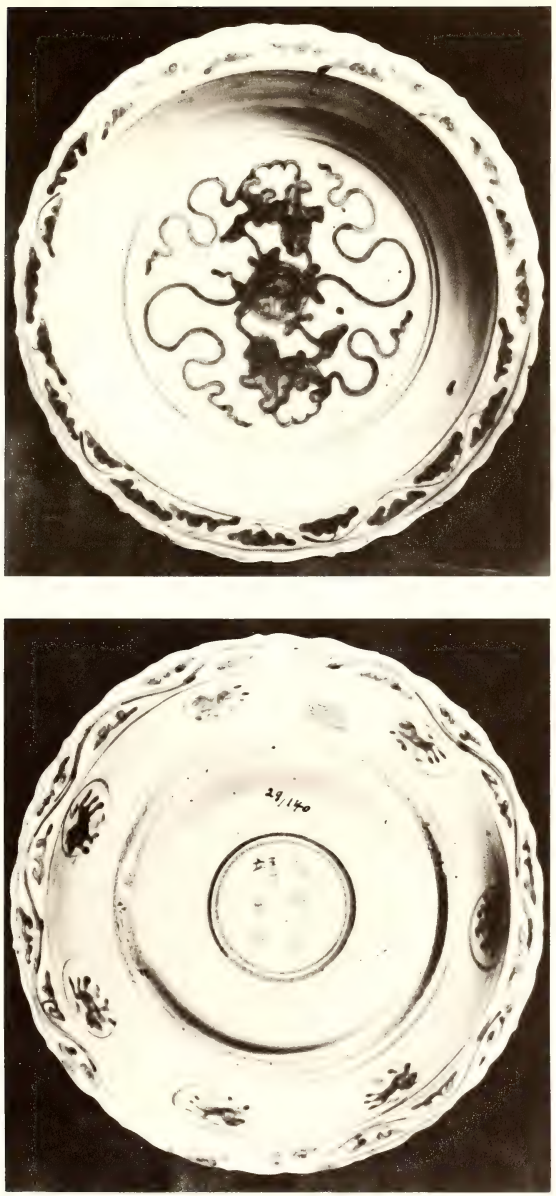
PLATE 83

Bowls with plain rims; inside are fungus scroll borders, four floral sprays around the sides, and single fruit sprays in the centers. On the outside are landscape scenes with bamboos and banana trees above borders of stylized lotus panels. The bases are glazed and carry the 6-character marks of the Wan-li period.

Two bowls from this group of nine are shown to illustrate the variations that may occur when the same design is drawn by different hands.

29.354-362 (9 pieces) H. $4 \frac{3}{4}$ in. $\left(12 \mathrm{~cm}\right.$.). D. $9 \frac{1}{2}$ in. $(20 \mathrm{~cm}$.).

Wan-li period.

See pages $125,127$. 


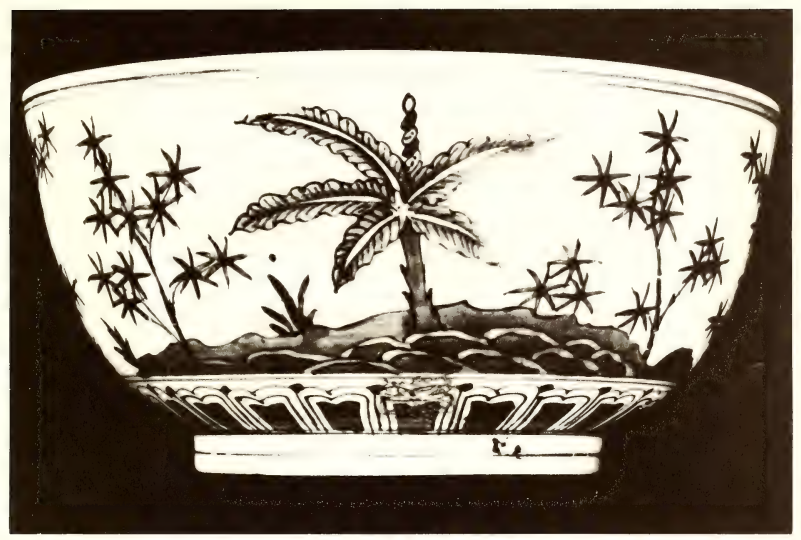

29.355

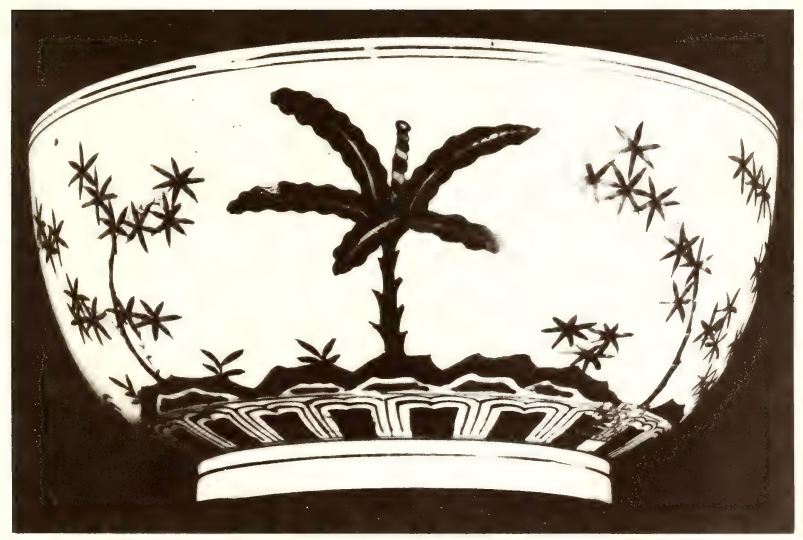




\section{PLATE 84}

Bases of the two bowls on the previous plate. The two marks may have been written by different hands or by the same hand using a more heavily charged brush in one case than in the other.

See page 127. 


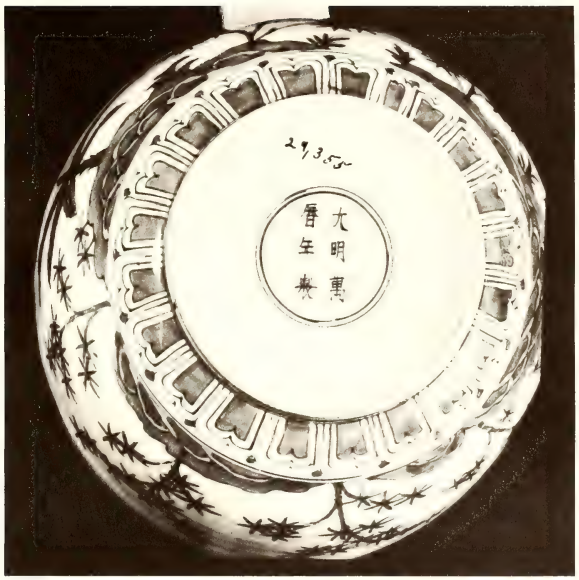

29.355

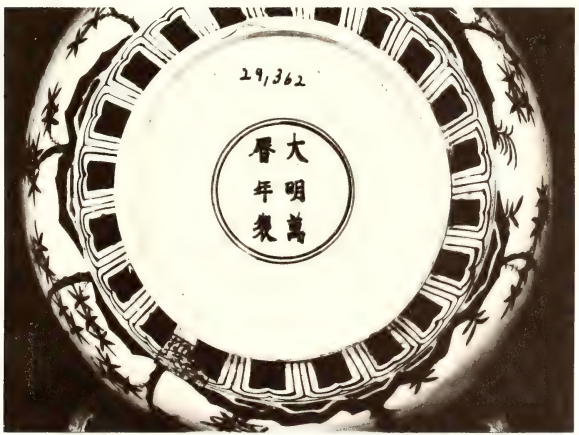

29.362 


\section{PLATE 85}

Bowl with flaring rim. Decorated inside with lotus scrolls and in the center a crossed device and four cloud collar forms. Outside are a diaper border with swastikas, a band of lotus scrolls and a row of lotus panels below. The base is glazed and carries the 6-character mark of the Wan-li period.

29.369 H. $2 \frac{5}{8}$ in. $(6.5 \mathrm{~cm}$.$) . D. 7$ in. $(17.5 \mathrm{~cm}$. $)$.

Wan-li period.

See pages 125, 127. 

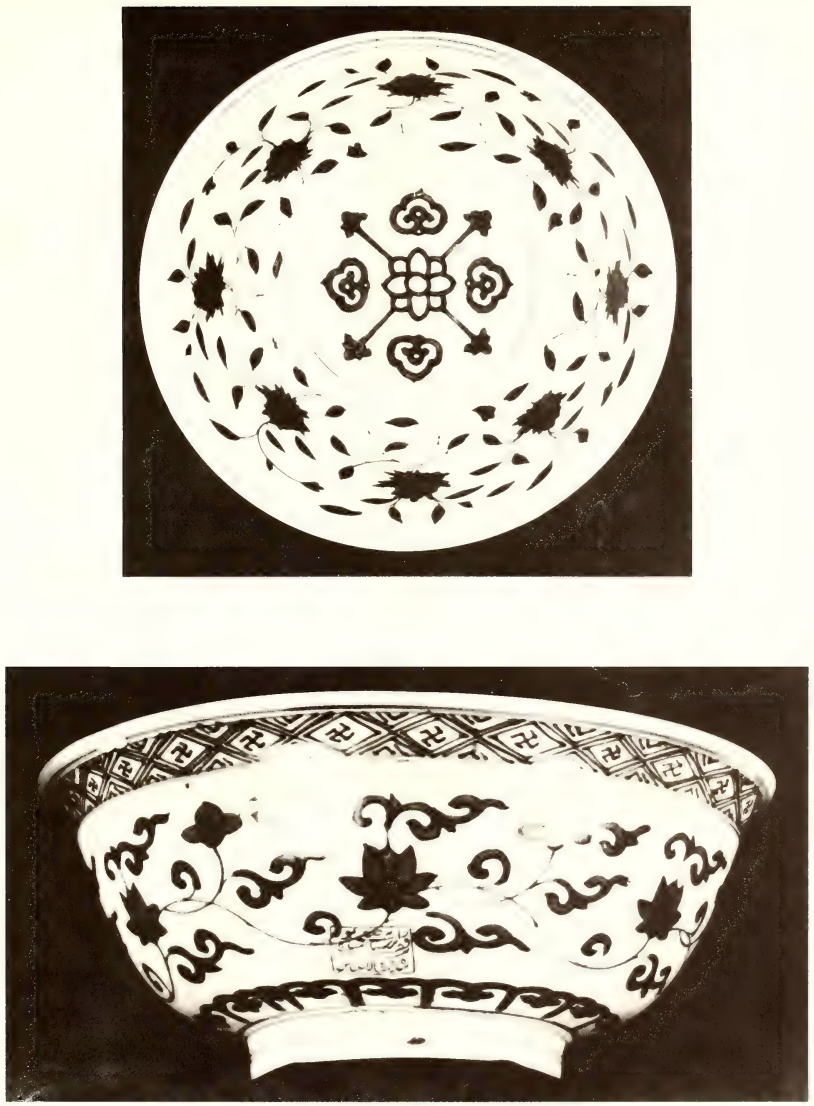


\section{PLATE 86}

Vase of mei-p'ing form. On the shoulder six cloud collar points frame floral sprays and are separated by auspicious objects; the main design is a landscape with figures; below this is a band of formal blossoms, and a row of extremely stylized inverted lotus panels surrounds the bottom. The unglazed base is rough with low rounded rim. The 6-character mark of the Wan-li period surrounds the upper shoulder.

29.402 H. $25 \frac{1}{4}$ in. $\left(64 \mathrm{~cm}\right.$.). D. $12 \frac{1}{8}$ in. $(31 \mathrm{~cm}$. $)$.

29.405 H. 20 in. $\left(51 \mathrm{~cm}\right.$.). D. $9 \frac{3}{4}$ in. $(25 \mathrm{~cm}$.).

Wan-li period.

Vase of gourd shape $(h u-l u)$; over-all decoration of shou characters in circles and in diamondshaped lozenges. Four circular medallions on the upper section frame flowering trees with their trunks contorted into shou form; and in the medallions on the lower section the same has been done with the pine trunk in a group of the three friends. A band of stylized lotus panels surrounds the bottom. The unglazed base is concave in shape, and the coarse clay has gravel adhering.

The body of this vessel is joined horizontally in three places.

29.477 H. 22 in. $\left(56 \mathrm{~cm}\right.$.). D. $10 \frac{3}{4}$ in. $(27.5 \mathrm{~cm}$. $)$.

Late sixteenth century.

Spherical object on a high spreading foot. On the top are nine perforations, one of which is filled with glaze, surrounded by the remains of a standing rim of some kind. The main decoration shows a landscape scene with figures, a crane, and a palace among clouds; inverted lotus panels surround the base. The mark Hsüan-te-nien-tsao is crudely written in underglaze blue under the base.

29.456 H. $5 \frac{3}{8}$ in. $\left(13.5 \mathrm{~cm}\right.$.). D. $5 \frac{1}{8}$ in. $(13 \mathrm{~cm}$. $)$.

Late sixteenth century.

See pages $125,127,128$. 


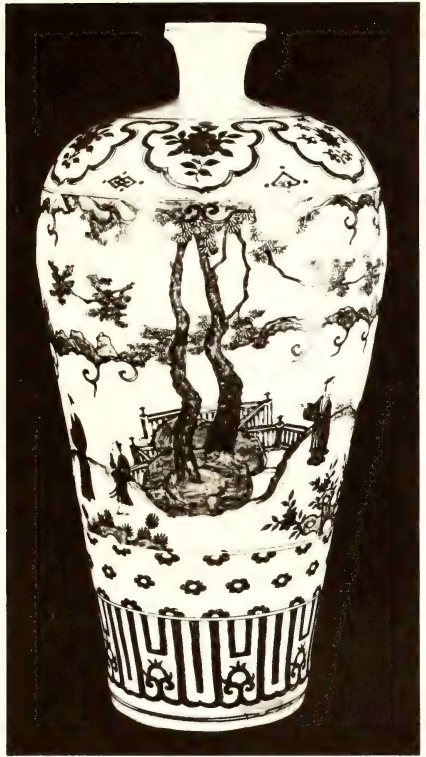

29.402
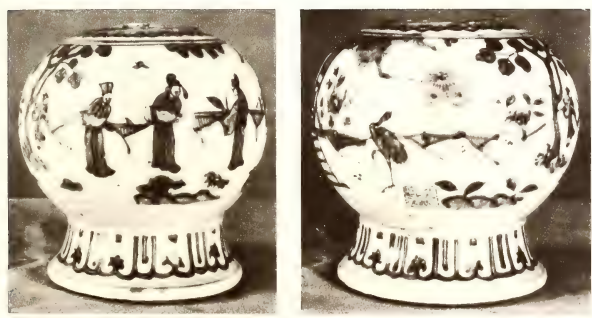

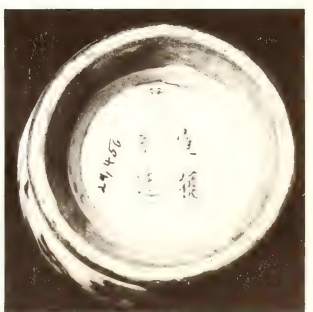




\section{PLATE 87}

Bowl with plain rim. Decorated outside with a border of flying horses and cloud scrolls, birds on fruiting trees and a band of classic scroll at the foot. The base is glazed and carries the mark $f u$-kuei-chia-ch'i in a square.

This is one of a group of five bowls of the same size and having the same mark. One has a flaring rim and all have typical Chia-ching and Wan-li decoration (29.370-374).

29.371 H. $6 \frac{1}{2}$ in. $\left(16.5 \mathrm{~cm}\right.$.). D. $13 \frac{3}{4}$ in. $(35 \mathrm{~cm}$.).

Bowl with fiaring rim. Inside is a diamond diaper border, and in the center a circle with a floral spray and insects. Outside are birds on pomegranate trees above a stylized scroll. The 6character Hsüan-te mark appears on the base in underglaze blue.

29.377 H. $4 \frac{3}{8}$ in. $\left(11 \mathrm{~cm}\right.$.). D. $9 \frac{5}{8}$ in. $(24.5 \mathrm{~cm}$.).

Late sixteenth century.

See page 128 . 


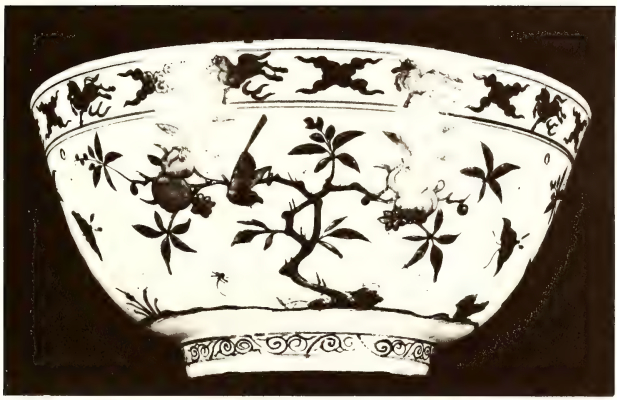

29.371
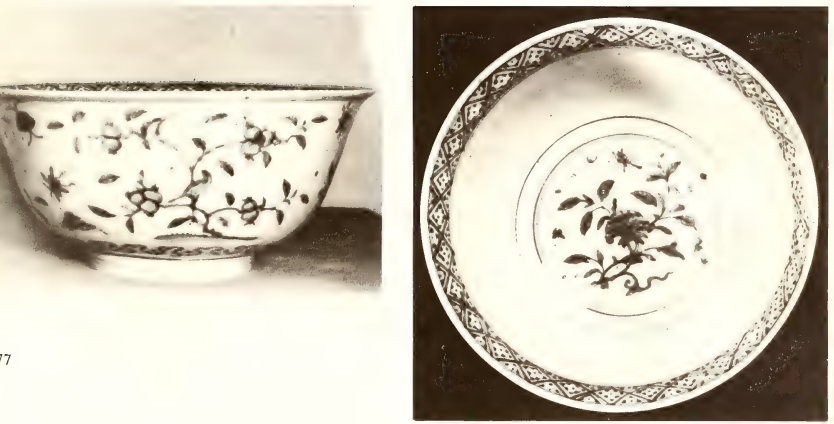


\section{PLATE 88}

Bowl with flaring rim. Inside is a border of blue rectangles surrounding four cranes amid clouds; outside are prunus branches, dragonflies, and a crescent moon. The base is glazed. 29.387 H. $2 \frac{3}{6}$ in. $\left(8.5 \mathrm{~cm}\right.$.). D. $9 \frac{7}{8}$ in. $(25 \mathrm{~cm}$.).

Late sixteenth century.

See page 128 . 

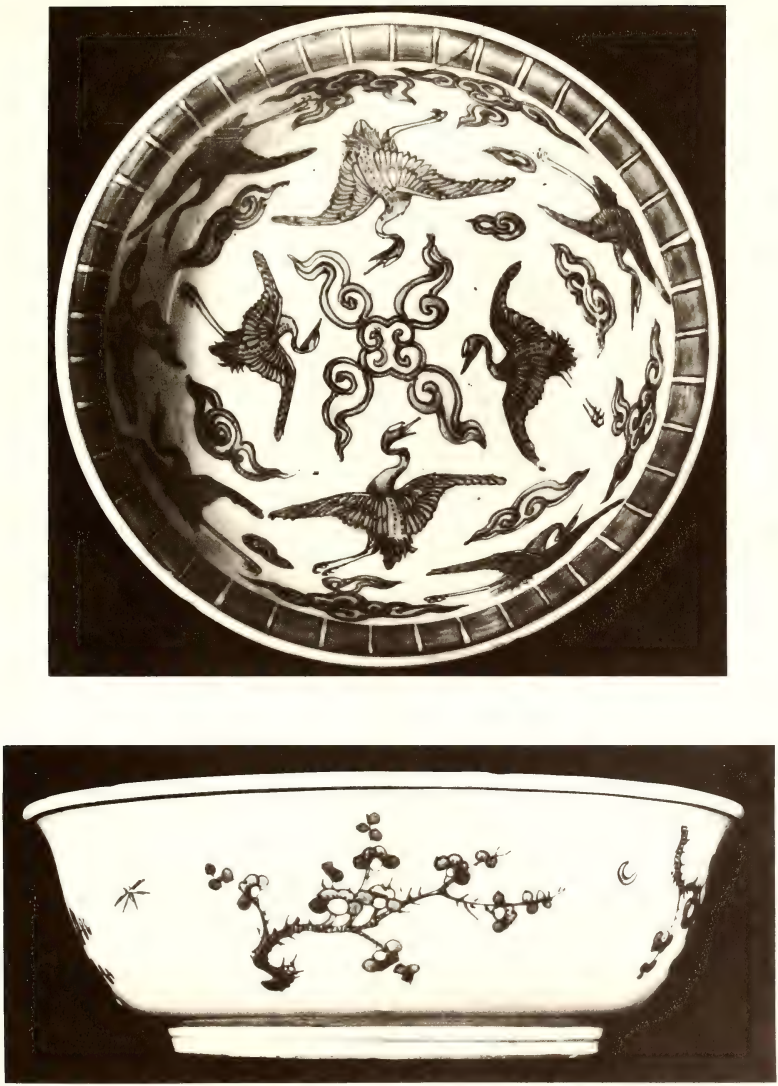


\section{PLATE 89}

Bowl with plain rim. Decorated inside with three encircling lines crudely incised in the glaze; outside are cloud scrolls and three medallions framing lotus blossoms on diaper grounds. The base is glazed and carries the mark $f u-k u e i-c h i a-c^{\prime} i$; the foot rim is deep, thin, and undercut.

29.397 H. $3 \frac{1}{4}$ in. $\left(8.5 \mathrm{~cm}\right.$.). D. $6 \frac{1}{4}$ in. $(16 \mathrm{~cm}$.).

Dish with plain rim. Inside is a border of waves with six rocks and seahorses and 12 cloud scrolls;

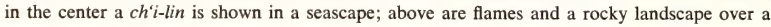
layer of clouds; outside are flowers and cloud scrolls. The glazed base has sand adhering and bears the 6-character mark of the Hsüan-te period.

29.314 H. 3 in. (7.5 cm.). D. $13 \frac{1}{2}$ in. $(34.5 \mathrm{~cm}$.).

Dish with flattened foliate rim. Inside is a border with two groups of rocks and flowering branches and two tufts of grasses; the plain white cavetto encircles a central scene of unusual formality; in the foreground is a terrace paved with elaborately decorated tiles and bounded by a balustrade with statues of lions crouching on the two posts; in front of these stands a large richly ornamented jar in which grow the three friends: the pine, the prunus, and the bamboo. The trunk of the pine is twisted into the form of the character shou, "longevity." Outside are floral sprays and birds on branches.

This dish is one of a group of five with various related designs executed in a similar style.

29.265 H. about 2 in. $(5 \mathrm{~cm}$.). D. about 11 in. $(28 \mathrm{~cm}$.).

Late sixteenth century.

See pages 128,129 . 


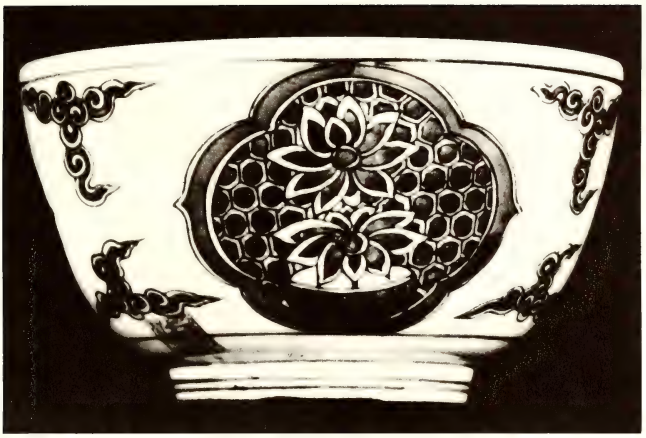

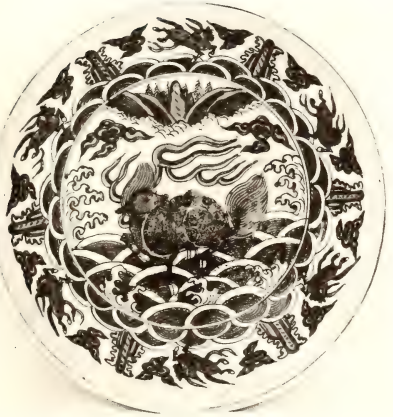

29.314

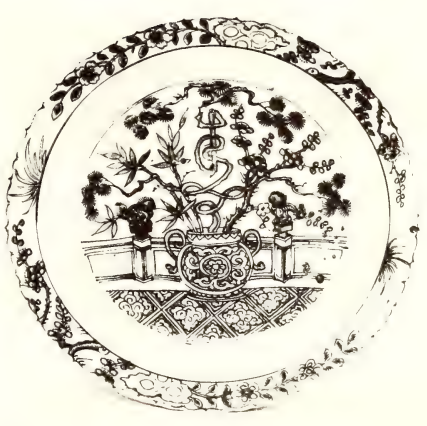

29.265 


\section{PLATE 90}

Dish with flattened foliate rim. Inside is a stylized border above a white cavetto with carved radial fluting which surrounds a roughly drawn bush with three flowers on an arching horizon. Outside are coarse scrolls under the rim and the sides are coarsely and deeply incised. On the roughly glazed base is a crude swastika in underglaze blue placed off center in a double circle. The Shāh 'Abbās mark is in abbreviated form.

29.279 H. $1 \frac{1}{2}$ in. $(4 \mathrm{~cm}$.). D. 81 in. $(21 \mathrm{~cm}$.).

Dish with slightly flaring rim. Inside are three birds on the wing and three prunus sprays around a formal central design of a peach tree in the form of a shou character growing in a pot; outside are three more prunus sprays, two butterflies, and a round dot; a simple scroll band adorns the foot. On the base is a 6-character Hsüan-te mark poorly written.

29.150 H. 2 in. $\left(5 \mathrm{~cm}\right.$.). D. $9 \frac{3}{4}$ in. $(25 \mathrm{~cm}$. $)$.

Late sixteenth century.

See page 129. 


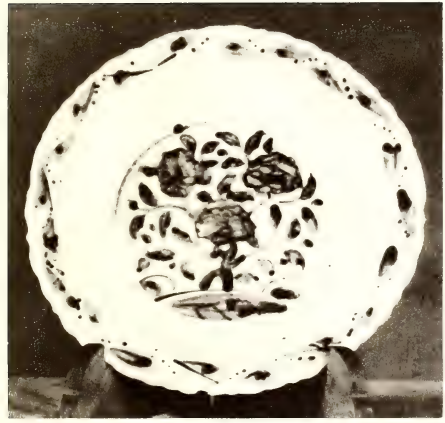

29.279

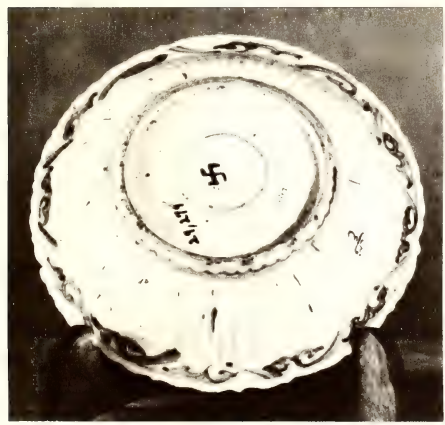

29.279

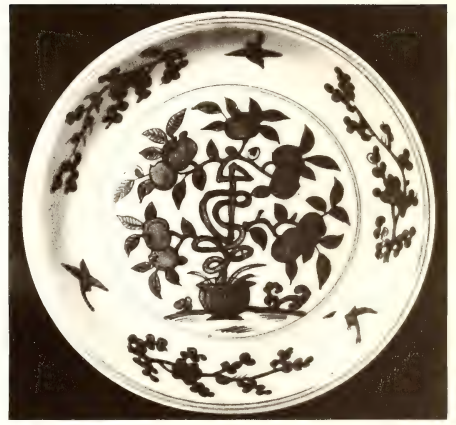

29.150

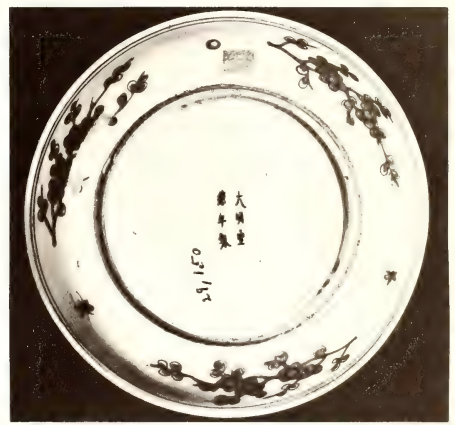

29.150 


\section{PLATE 91}

Dish with plain rim. The cavetto is plain, and in the center is a landscape with five deer (possibly Père David's deer) and a tortoise in the water at the left. Outside are birds on branches and a scroll band around the foot. The 6-character Chia-ching mark appears on the glazed base.

29.148 H. $3 \frac{1}{4}$ in. $\left(8 \mathrm{~cm}\right.$.). D. $13 \frac{1}{\mathrm{in}}$. $(35 \mathrm{~cm}$.).

Chia-ching period.

Dish with plain rim. Four flowering branches and four insects decorate the cavetto; and in the center is a landscape scene divided by a vertical waterfall; drinking from the river below are a pai-ts'e on the left and an elephant on the right; above are branches of pine and bamboo. Outside are four squirrel and melon groups above a scroll band. The base is glazed.

29.147 H. $3 \frac{1}{4}$ in. ( 8 cm.). D. 14 in. $(35.5 \mathrm{~cm}$.).

Late sixteenth century.

See pages 129,138 . 

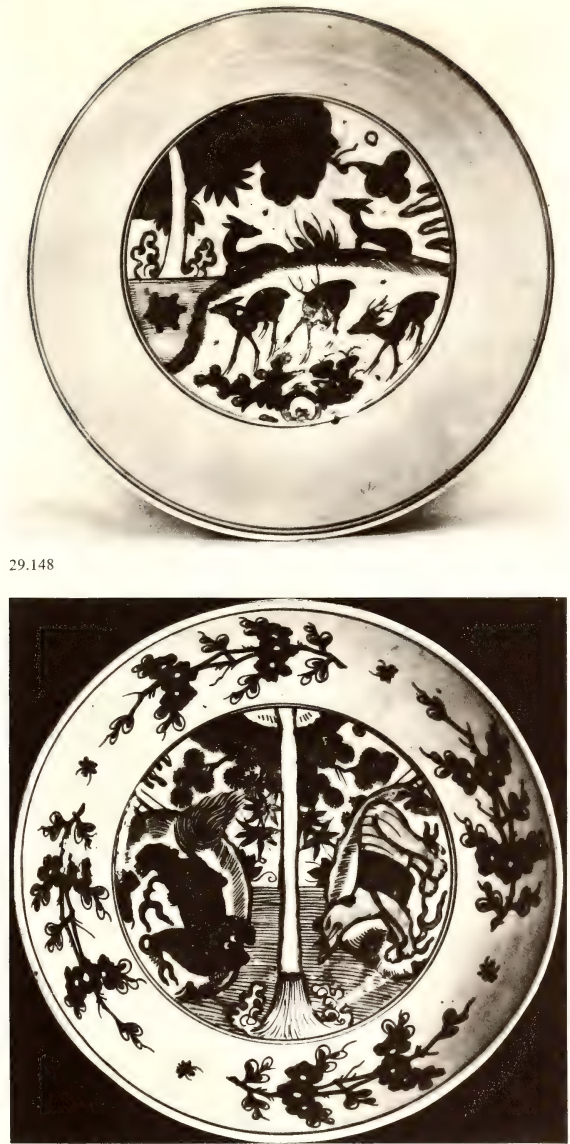


\section{PLATE 92}

Dishes with plain rims. Inside each is a border of four dragons amid fungus scrolls, and a plain white area surrounds the central scene of a landscape with deer. Outside is a border of prunus above various plant forms. The glazed bases are convex and show varying amounts of radial chatter; the foot rims are sharply cut.

$29.228-233$ (6 pieces) H. $2 \frac{1}{4}$ in. $(5.5 \mathrm{~cm}$.). D. 12 in. $(30.5 \mathrm{~cm}$.).

Dish with plain rim. Inside is a border of landscape; a broad band of white encircles the central landscape scene in which are two deer and a flying bat; outside are fruit and flower sprays. The base is glazed.

$29.238-239$ (2 pieces) H. $3 \frac{3}{4}$ in. $(8.5 \mathrm{~cm}$.$) . D. 14$ in. $(35.5 \mathrm{~cm}$.$) .$

Dish with flattened foliate rim. On the rim is a border of river landscape scenes; the cavetto is plain white, and the central scene shows a garden with rocks, trees, flowering plants, a golden pheasant, mandarin ducks, a flying goose and doves(?), and pavilions. Outside are flower sprays and birds on branches. The base is unglazed and the foot rim undercut.

$29.240-242$ (3 pieces) H. $3 \frac{1}{2}$ in. $(9 \mathrm{~cm}$.). D. 17 in. $(43.5 \mathrm{~cm}$.).

Late sixteenth century.

See pages 129,130 . 


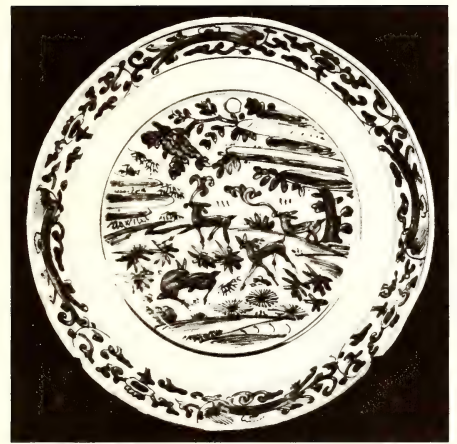

29.231

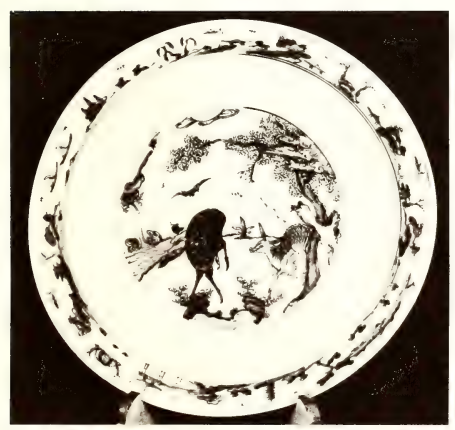

29.239

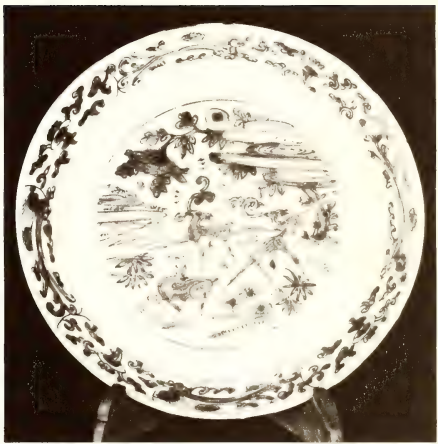

29.233

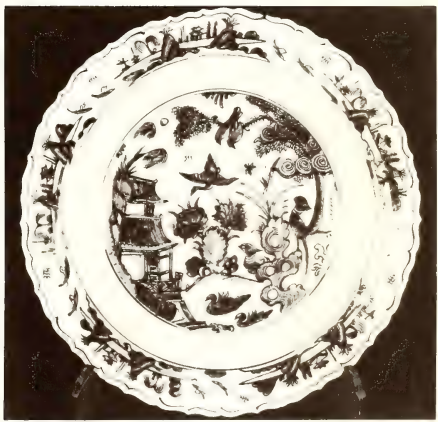

29.242 


\section{PLATE 93}

Dish with plain rim. Inside the rim is a narrow border of scrolling flowers and foliage; a broad white cavetto encircles the central landscape scene. Outside are ornamental cloud scrolls and flying cranes. The unglazed base shows wheel marks and radial chatter, and the strong foot is undercut. (Pl. 142.)

There are two of these dishes, both drawn with beautiful clarity unusual in wares of this class; the blue is strong and clear anticipating the quality which characterizes the blue of K'ang-hsi. The landscape compositions are reminiscent of those executed in red and green enamels on the coarse Swatow wares, but both the potting and the clay itself are far superior on these blue-and-white dishes.

29.205-206 (2 pieces) H. 4 in. (10 cm.). D. $17 \frac{3}{4}$ in. $(45 \mathrm{~cm}$.$) .$

Late sixteenth century.

See page 130 . 

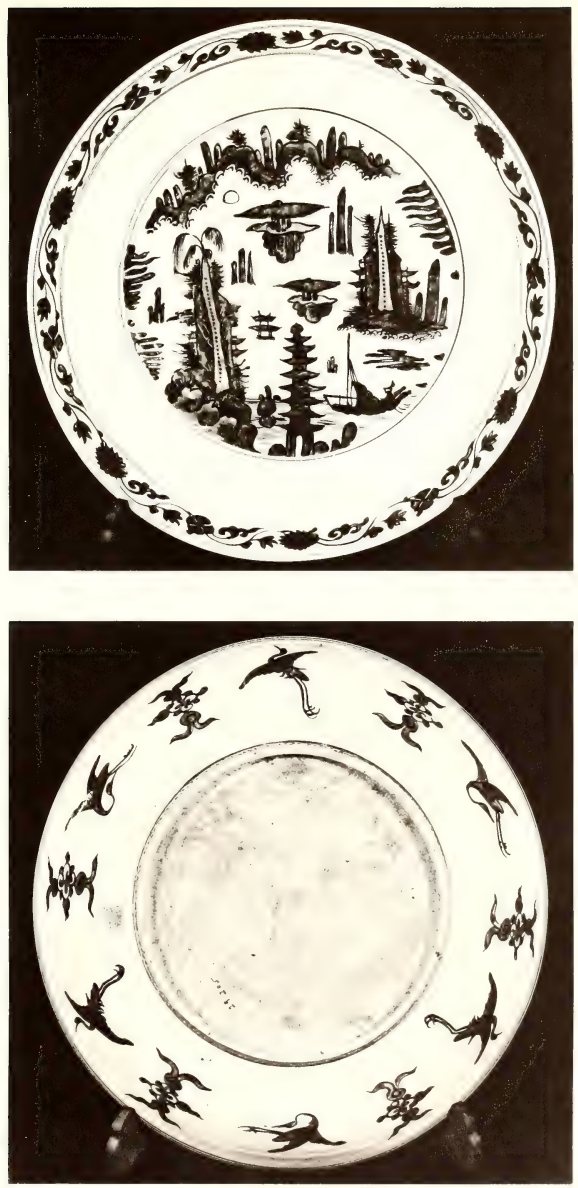


\section{PLATE 94}

Dishes with plain rims. Inside are borders of white herons amid lotus plants; broad plain white bands encircle central landscape scenes. Outside are either peach sprays or grape sprays and insects; scroll bands surround the feet. The unglazed bases show wheel marks and radial chatter, and in some cases gravelly adhesions; the foot rims are undercut.

29.207-213 (7 pieces) H. 4 in. (10 cm.). D. $17 \frac{3}{4}$ in. $(45 \mathrm{~cm}$.).

Late sixteenth century.

See page 131. 


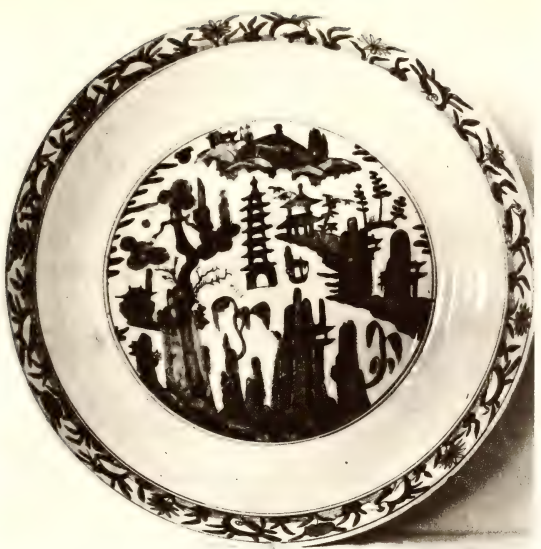

29.207

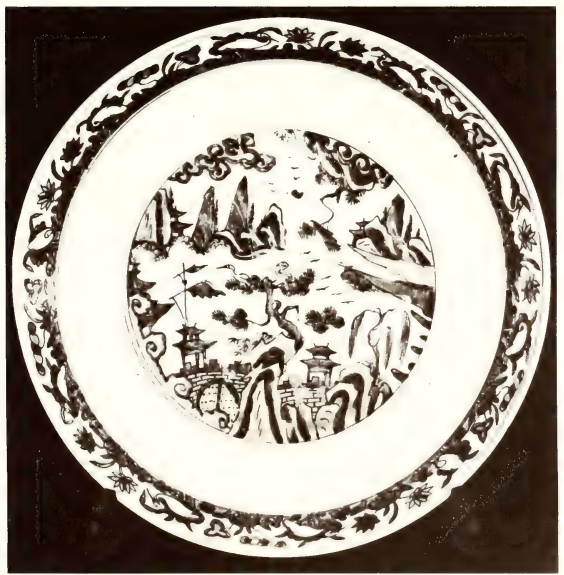




\section{PLATE 95}

Deep bowl with flaring rim. Inside is a border of lotus and cranes with a landscape in the center; a landscape scene covers the outside. The base is glazed and the foot rim is deep, thin, and undercut.

29.401 H. 4 in. $\left(10 \mathrm{~cm}\right.$.). D. $5 \frac{7}{8}$ in. $(15 \mathrm{~cm}$. $)$.

Bowl with plain rim. Decorated with landscape scenes inside and out. The base is glazed.

29.376 H. $4 \frac{3}{8}$ in. $(11 \mathrm{~cm}$. $)$. D. $8 \frac{5}{8}$ in. $(22 \mathrm{~cm}$. $)$.

Late sixteenth century.

See page 131 . 


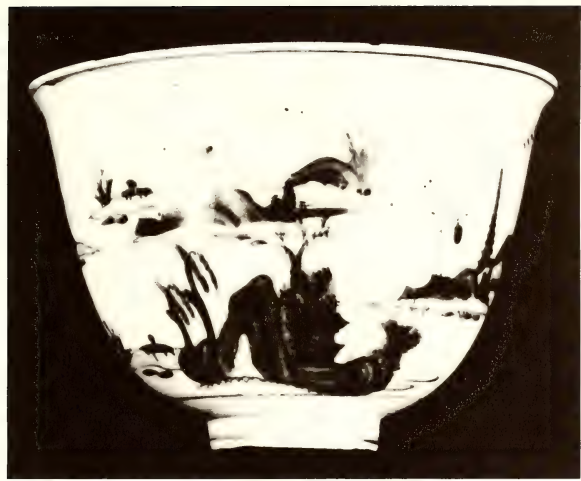

29.401

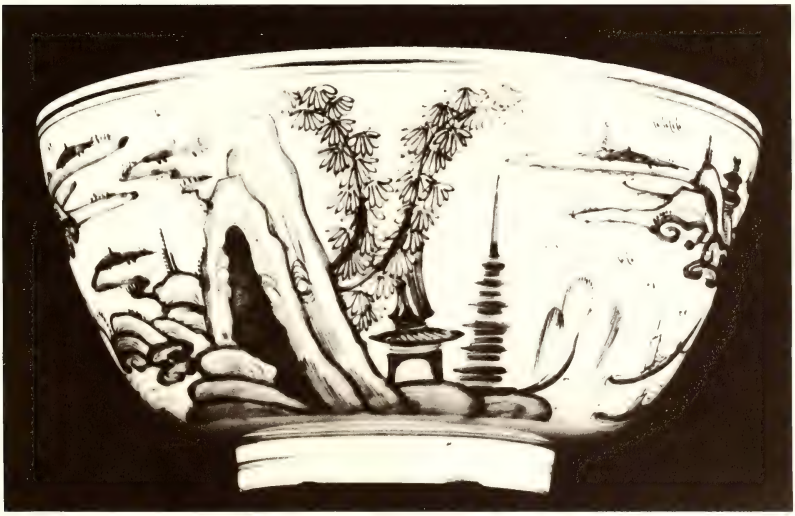




\section{PLATE 96}

Vessel in the shape of a bucket with two vertical loop handles issuing from monster mouths. The upper section shows a landscape scene with Père David's deer in a fenced park, and below a horizontal ring in very slight relief are fish leaping among waves. The flat top rim is unglazed as is the upper three-quarters of an inch on the inside; below this very even line the interior is glazed. The base is somewhat coarsely made and is glazed within the slightly rounded foot rim. 29.481 H. 11 in. $(28 \mathrm{~cm}$.). D. 11 in. $(28 \mathrm{~cm}$.).

Bowl with flaring rim. Inside is a scene with a hawk perched on a rock. On the outside is a landscape scene with three hares, one of which is being attacked by a hawk. Under the base is a 6-character Ch'eng-hua mark.

$29.367-368$ ( 2 pieces) H. $3 \frac{3}{4}$ in. $\left(9.5 \mathrm{~cm}\right.$.). D. $8 \frac{3}{4}$ in. $(22 \mathrm{~cm}$.$) .$

Late sixteenth century.

See pages 11,131 . 

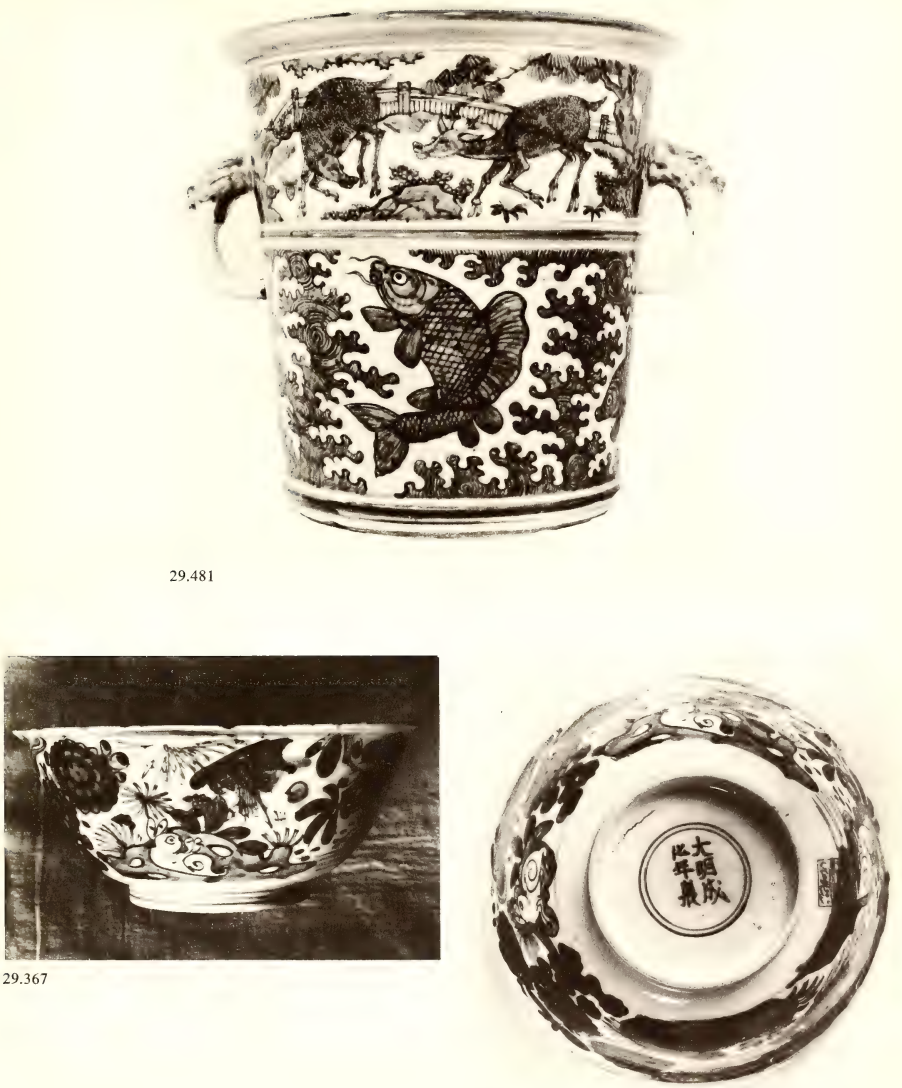


\section{PLATE 97}

Four drinking vessels of kĕndi shape characterized by tall flaring necks and spouts of various shapes. Two are in the usual form with low foot rims and glazed bases; those shaped like a frog and an elephant have flat unglazed bases. The waterfowl on 29.466 may possibly be teal; and all the decorative motifs are typical of the period.

Number 29.464 lacks the Shāh 'Abbās mark; the neck and off side have been broken and restored, and the vaqfnämeh may have been on the latter. The lip of 29.465 is also broken and restored.

29.466 H. 6 in. $(15 \mathrm{~cm}$.).

29.445 H. 7 in. $(18 \mathrm{~cm}$.).

29.465 H. $6 \frac{3}{4}$ in. $(17 \mathrm{~cm}$.).

29.464 H. $6 \frac{3}{4}$ in. $(17 \mathrm{~cm}$.).

Late sixteenth century.

See pages 118,132 . 


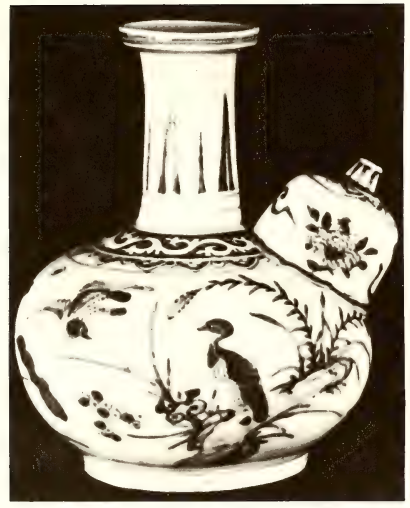

29.466

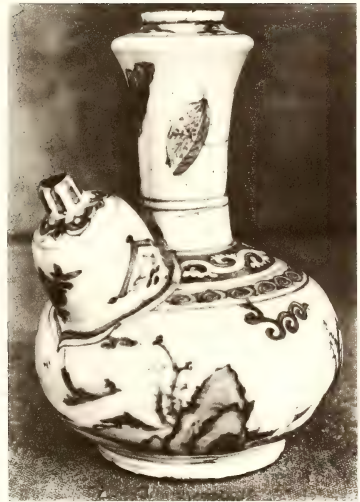

29.445
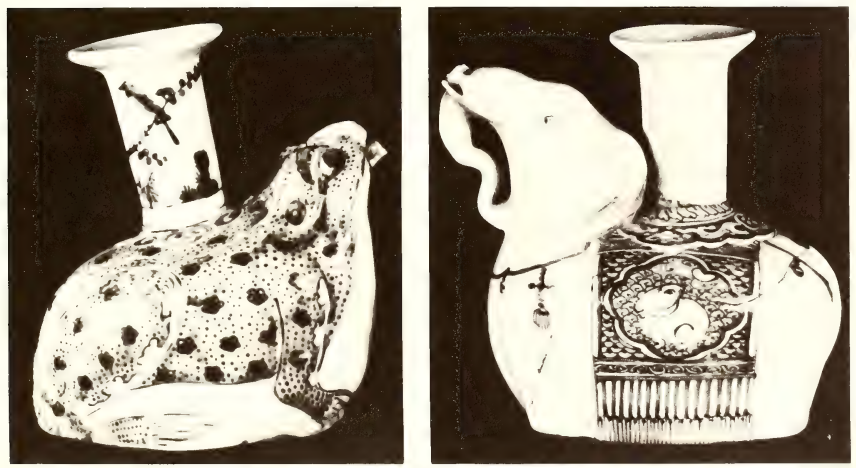


\section{PLATE 98}

Four ewers variously decorated with floral designs and phoenixes. The teardrop medallions on the sides of 29.433 are of unglazed biscuit molded in openwork relief over the proper body of the ewer; they show two peafowl by a rock among peonies. This piece has the 6-character Hsüante mark in blue under the base. The other three have 4-character Hsüan-te marks, and on 29.434 and 29.436 the verb is $t$ sao. The bulbous mouth topped by a low rim on 29.434 is unusual. Two pieces have been broken, and the handle of one is restored.

$29.433-436 \mathrm{H}$. all $8 \frac{1}{2}-9$ in. $(22.5-23 \mathrm{~cm}$.).

Late sixteenth century.

See page 133 . 


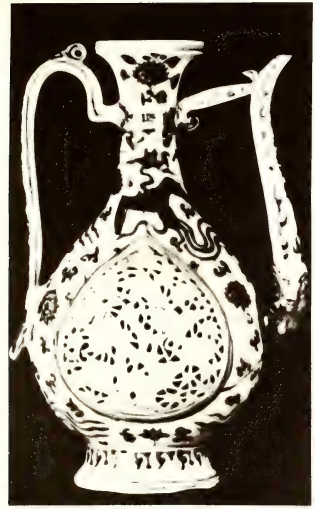

29.433

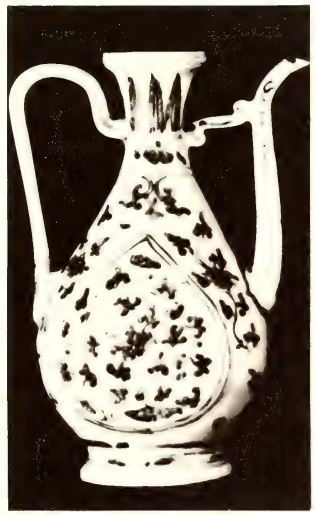

29.435

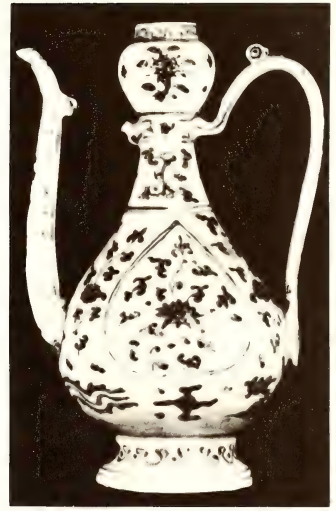

29.434

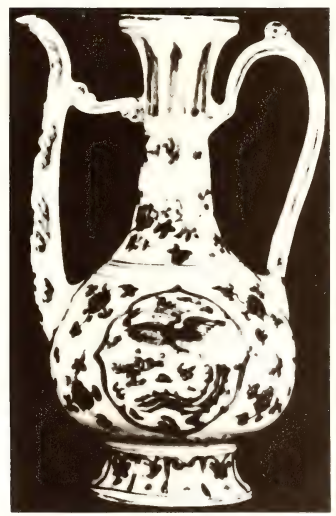

29.436 


\section{PLATE 99}

Ewer (chih-hu) with stiff leaves rising above a narrow floral band on the neck, and lions amid floral scrolls on the base. The entire body is covered on each side with the well-known curious design of a recumbent $c^{i} i$-lin at the foot of an elaborate monumental fountain. The high foot is covered over at the bottom leaving a low rim (pl. 142). The 6-character Hsüan-te mark appears on the glazed base.

29.423 H. $12 \frac{5}{8}$ in. $\left(32 \mathrm{~cm}\right.$.). D. $6 \frac{1}{4}$ in. $(16 \mathrm{~cm}$.).

Ewer (chih-hu) with thunder pattern, stiff leaves, and floral designs with insects on lip and neck and a prancing chi-lin in a landscape as the main design. Floral sprays decorate the foot which is hollow underneath and glazed. Under the base of the vessel itself is the mark of a white hare on a blue ground.

29.424 H. $13 \frac{3}{8}$ in. $\left(34 \mathrm{~cm}\right.$.). D. $6 \frac{1}{4}$ in. $(16 \mathrm{~cm}$.).

Late sixteenth century.

See pages $87.134,136$. 

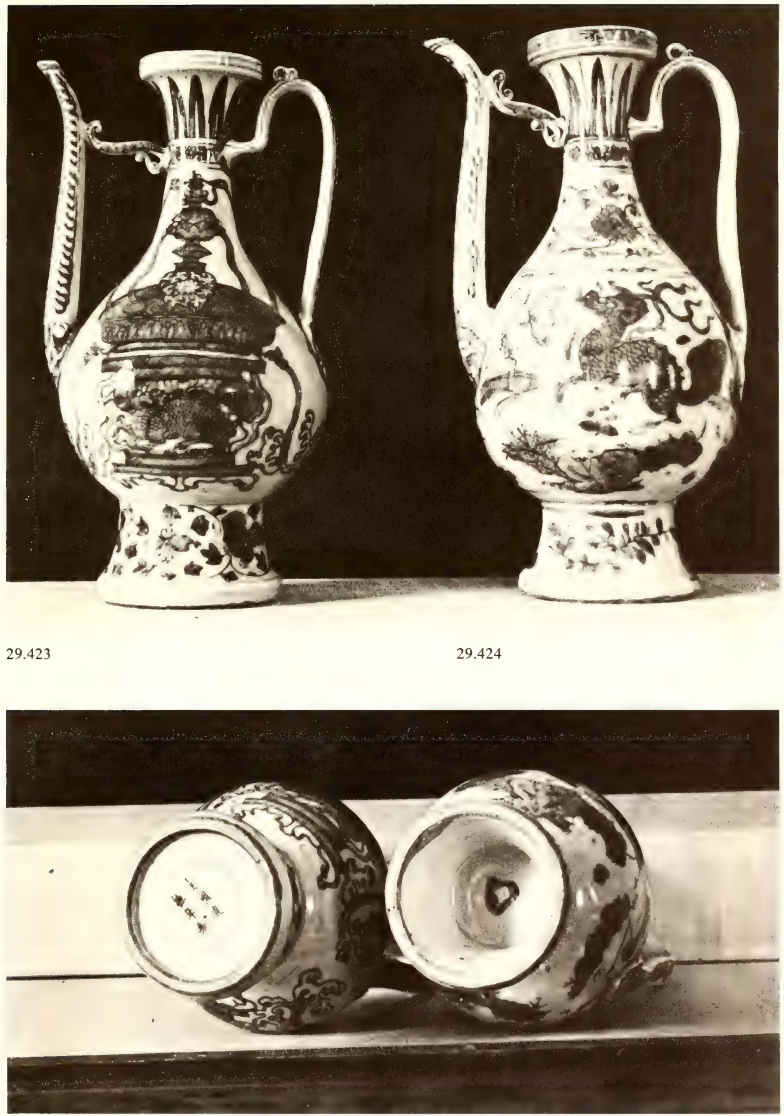


\section{PLATE 100}

Dish with flattened foliate rim. Twelve segments divide the rim and cavetto into lotus panel frames, and these contain six fungus sprays with auspicious objects and six flower sprays with insects in alternating order. In the center six cranes fly amid cloud scrolls around a circle in which is a hexagram. Outside are two birds on branches beneath auspicious objects. The glazed base is slightly convex with traces of sand adhering.

Number 29.172 lacks the mark of Shāh 'Abbās.

29.172-173 (2 pieces) H. $3 \frac{1}{2}$ in. $\left(9 \mathrm{~cm}\right.$.). D. $17 \frac{1}{2}$ in. $(44.5 \mathrm{~cm}$.).

Dish with flattened decagonal rim. Inside are 10 panels including both rim and cavetto which frame lotus plants and rose sprays, and in one case two magpies. The central area frames a landscape scene with two deer and two magpies. Outside are plants and flower sprays.

29.264 H. $2 \frac{1}{4}$ in. $\left(5.5 \mathrm{~cm}\right.$.). D. $12 \frac{1}{4}$ in. $(31 \mathrm{~cm}$.).

Late sixteenth century.

See pages 137,138 . 


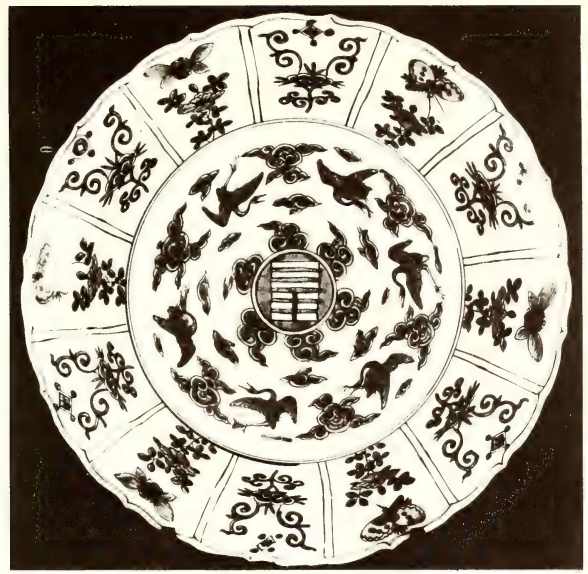

29.172

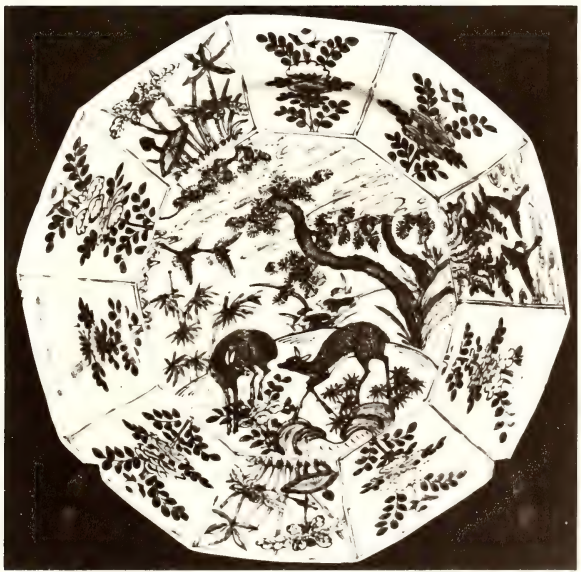




\section{PLATE 101}

Dish with plain foliate rim. Inside the cavetto are 12 panels framing six compositions of plants and flowering shrubs each repeated twice; these include peony, azalea, lotus, two varieties of rose, and crabapple. Four of the scenes include rocks and birds. In the center is a landscape with five deer. Outside are 12 panels in which peony and rose sprays alternate with birds on branches; a scroll band surrounds the foot. The glazed base is convex with signs of radial chatter; and the foot rim is high and thin with traces of adhering sand (pl. 142).

29.203-204 (2 pieces) H. $3 \frac{3}{4}$ in. $\left(8 \mathrm{~cm}\right.$.). D. $13 \frac{3}{4}$ in. $(35 \mathrm{~cm}$.).

Late sixteenth century.

See page 137 . 

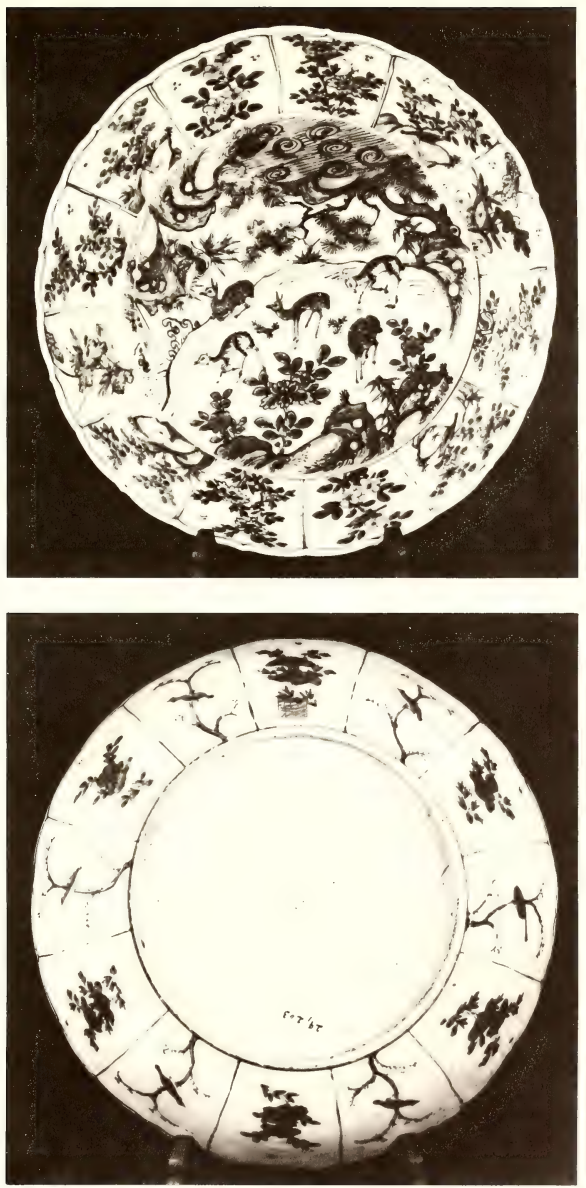


\section{PLATE 102}

Dish with plain foliate rim. The cavetto is divided into nine panels framing various decorative motifs (floral sprays, insects, etc.), and these are separated by beaded pendants; in the center on a ground of various diaper patterns is a 9-pointed star framing a landscape scene with deer. Outside are two branching shrubs with a bird on each, and two flying insects. The base is unglazed and the foot rim is strong and deeply undercut (pl. 142).

29.153-156 (4 pieces) H. $3 \frac{1}{2}-4$ in. $\left(9-10 \mathrm{~cm}\right.$.). D. $18-18 \frac{3}{4}$ in. $(46-48 \mathrm{~cm}$.).

Late sixteenth century.

See pages 137, 138 . 

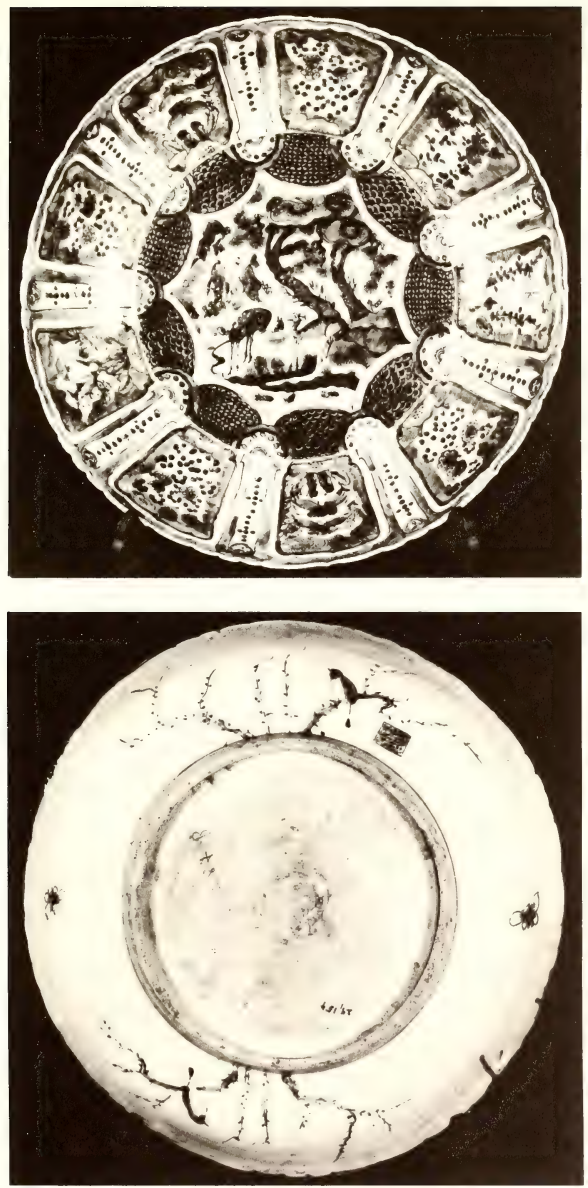
PLATE 103

Dish with plain foliate rim. The cavetto is divided into 11 panels framing floral motifs and separated by beaded pendants; in the center on a ground of various diaper patterns is a 5-pointed medallion framing a landscape scene with deer. The outside decorations show either deer in pine forests or birds on branches. The unglazed bases show radial chatter and wheel marks, and the strong foot rims are deeply undercut.

29.164-167 (4 pieces) H. 4 in. $(10 \mathrm{~cm}$.$) . D. 21$ in. $(53 \mathrm{~cm}$.$) .$

Late sixteenth century.

See pages 137,138 . 

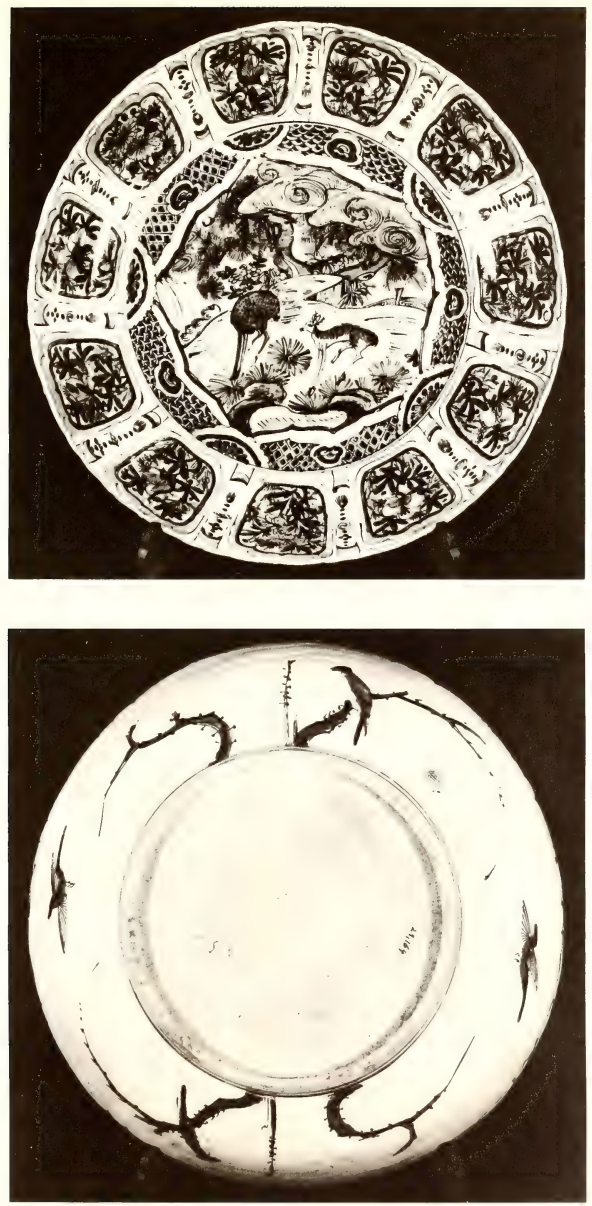


\section{PLATE 104}

Four dishes selected from a group of 53. In patterns and general structure they closely resemble the two types illustrated on plates 100 and 101; but the decoration shows great variety, and probably no two are identical in every respect. The diameters range from $10 \frac{1}{4}$ to 18 inches; the blue varies from a strong rich purplish tone through pale silvery gray to almost black, and one has had enamel colors added over the glaze.

29.171 D. 18 in. $(46 \mathrm{~cm}$.).

29.178 D. 14 in. $(35 \mathrm{~cm}$.).

29.174-175 D. $10 \frac{1}{4}$ in. ( $26 \mathrm{~cm}$.).

Late sixteenth century.

See pages 137, 138. 

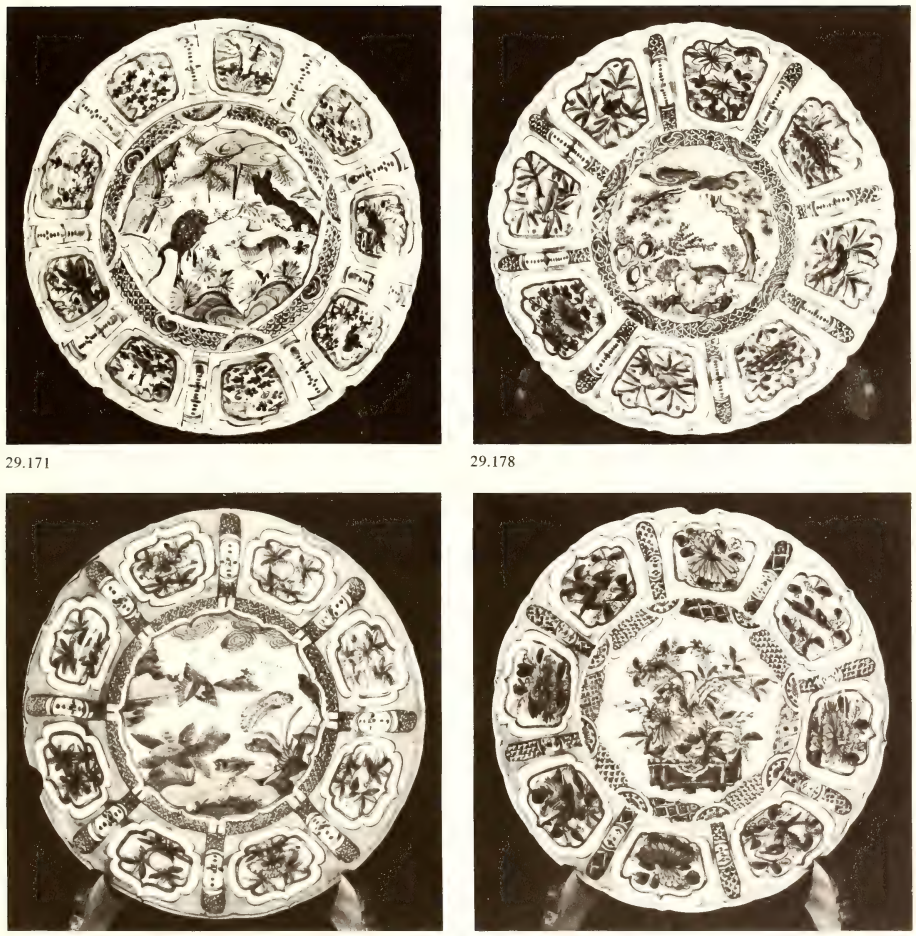


\section{PLATE 105}

Bowl with flaring foliate rim. Inside are a cloud scroll border and a bird on a flowering branch in the center; the outside is divided into eight vertical panels with alternating flower or fruit sprays in medallions on diaper ground. Scrolls surround the foot. The base is glazed and has a thin undercut foot rim. The character $f u$ is in a square underneath.

29.392 H. $3 \frac{1}{2}$ in. $\left(9 \mathrm{~cm}\right.$.). D. $3 \frac{3}{8}$ in. $(8.5 \mathrm{~cm}$.).

Bowl with foliate rim. The border inside shows a landscape with flaming wheels on a scalloped band; a landscape occupies the center. Outside is a band of horses flying over waves, and the main decoration is ten floral sprays. A band of overlapping scalloped petals surrounds the base. The glazed base shows radial chatter marks, and the foot rim is thin, deep, and undercut.

29.394 H. 4 in. $\left(10 \mathrm{~cm}\right.$.). D. $8 \frac{1}{4}$ in. $(21 \mathrm{~cm}$.).

Late sixteenth century.

See page 138 . 


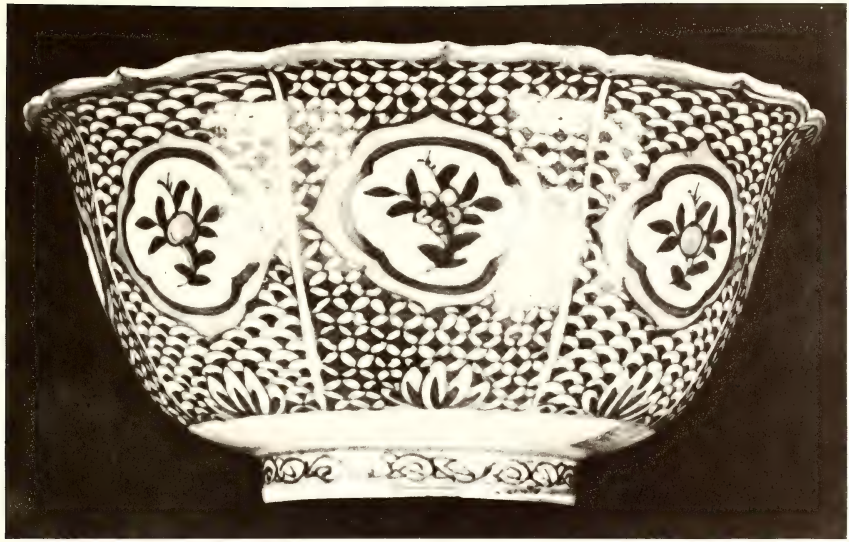

29.392

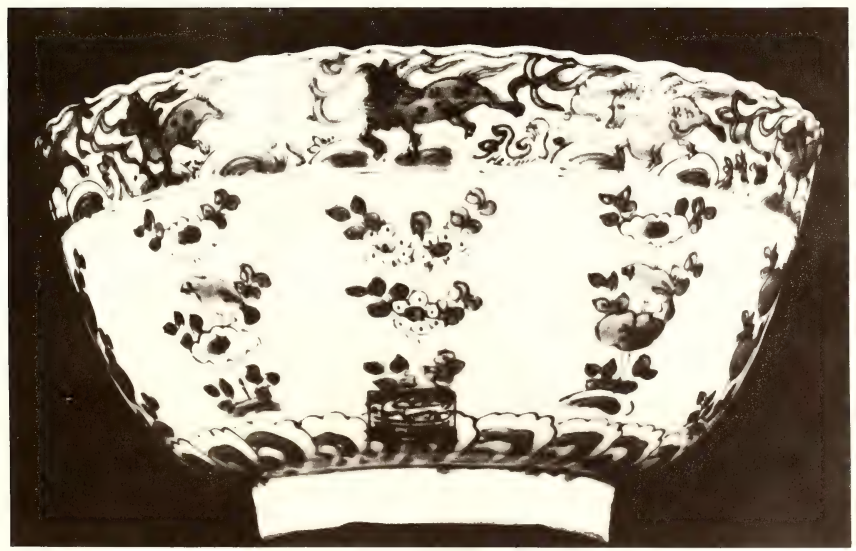




\section{PLATE 106}

Bowl with plain rim. Inside, ducks and aquatic plants surround a central landscape panel; outside are six medallions framing landscapes and figures, and these are separated by fungus and flower sprays surmounted by auspicious objects. Stylized lotus panels are below, and a band of debased scrollwork surrounds the foot. The base is roughly glazed.

29.379-380 (2 pieces) H. $6 \frac{3}{4}$ in. $(17 \mathrm{~cm}$.). D. 14 in. $(34.5 \mathrm{~cm}$.).

Bowl with flaring foliate rim. Inside are six cloud collar ornaments above a row of lotus panels in underglaze slip surrounding a central circle in which is a recumbent horse and a flame scroll. Outside are six panels extending halfway down from the rim; these are separated by beaded pendants, and each frames a flying horse over waves. Below a broad band of plain white is a row of overlapping petal-like panels. The glazed base shows radial chatter marks, and the foot rim is high, thin, and undercut.

29.393 H. $2 \frac{5}{8}$ in. (6.5 cm.). D. $5 \frac{3}{4}$ in. $(14.5 \mathrm{~cm}$.).

Late sixteenth century.

See page 139 . 


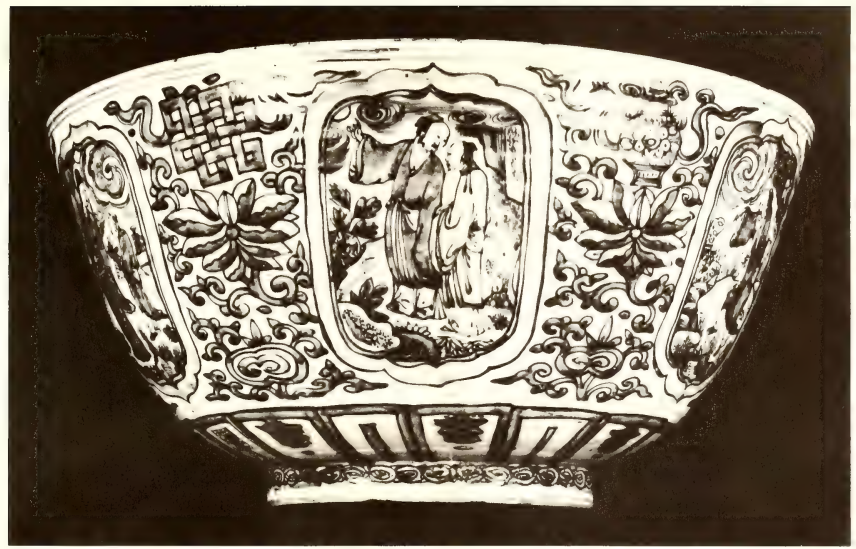

29.380
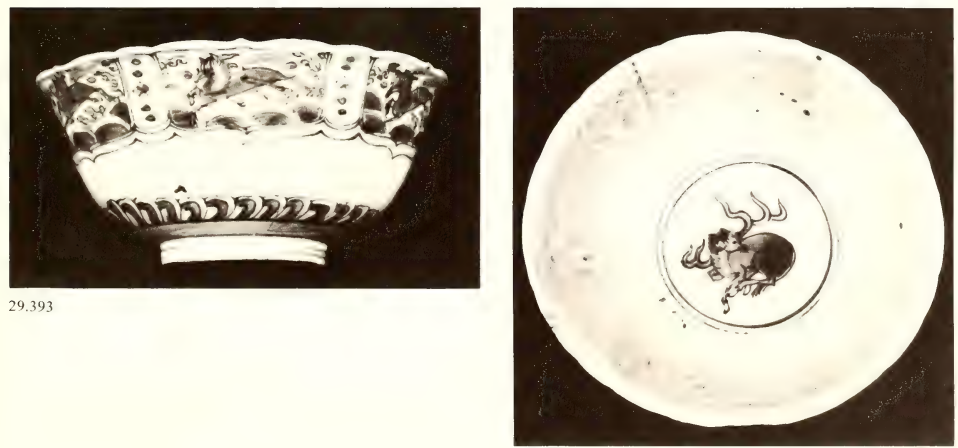


\section{PLATE 107}

Two bowls and a dish variously decorated with designs involving white and spotted deer, the latter perhaps representing Sika. In the center of 29.390 the animal is shown in a setting of the three friends: pine, prunus, and bamboo. All the bases are glazed, and the feet are deep, thin, and undercut.

29.388 H. $2 \frac{3}{4}$ in. $\left(7 \mathrm{~cm}\right.$.). D. $5 \frac{3}{4}$ in. $(14.5 \mathrm{~cm}$.).

29.390 H. $2 \frac{3}{8}$ in. $\left(6 \mathrm{~cm}\right.$.). D. $8 \frac{1}{4}$ in $(21 \mathrm{~cm}$.).

29.389 H. $4 \frac{1}{2}$ in. $\left(11.5 \mathrm{~cm}\right.$.). D. $8 \frac{7}{8}$ in. $(22.5 \mathrm{~cm}$. $)$.

Late sixteenth century.

See pages 138, 139. 


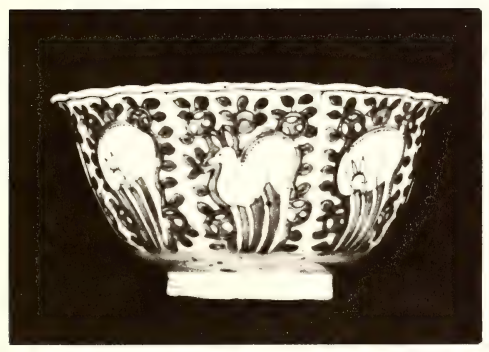

29.388

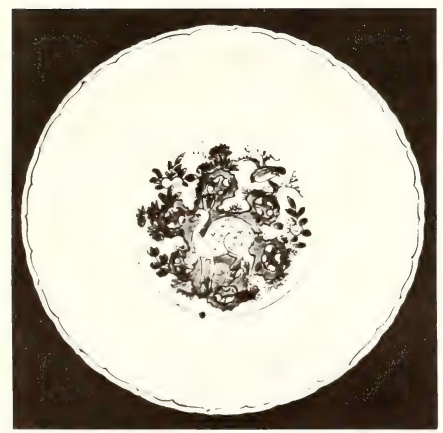

29.389

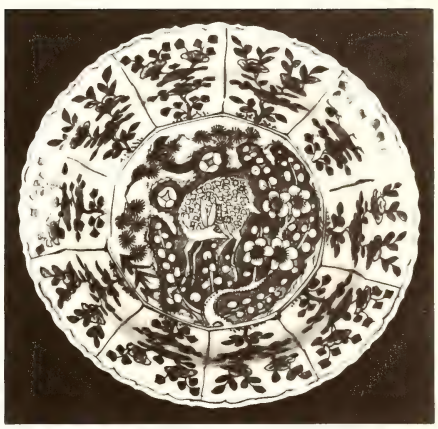

29.390

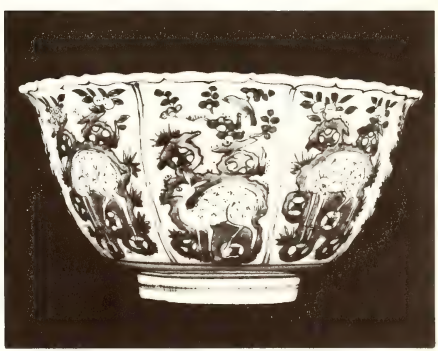

29.389 


\section{PLATE 108}

Small saucers with flaring foliate rims. The decoration consists of underglaze designs in slip both inside and out, and in the centers are medallions in underglaze blue framing flowering plants, auspicious objects, etc.

Four of these small dishes carry the abbreviated mark of Shāh 'Abbās.

$29.280-285$ (6 pieces) H. 1 in. $\left(2.5 \mathrm{~cm}\right.$.). D. $5 \frac{1}{2}$ in. $(14 \mathrm{~cm}$.).

Covered cup with molded sides; one of three decorated inside with medallions framing various flowers and objects around central medallions in each of which is a bird on a rock; outside are panels separated by beaded ornaments and framing landscapes, figures, insects, etc. The covers are similarly decorated, and the edges are flanged and unglazed to fit the cup rims. Inside the "feet" of two covers are hare marks, and the third has the character $f u$ in a square.

29.381-386 ( 3 cups and 3 covers) H. $6 \frac{1}{2}$ in. $\left(15.5 \mathrm{~cm}\right.$.). D. $5 \frac{1}{2}$ in. $(14 \mathrm{~cm}$.).

Ewer of octagonal shape; the panels are decorated with floral sprays and on each side a sage in a landscape; under the base is the mark $f u$-shou- $k^{2}$ ang-ning in a double square.

29.444 H. $5 \frac{3}{4}$ in. $\left(14.5 \mathrm{~cm}\right.$.). D. $4 \frac{3}{8}$ in. $(11 \mathrm{~cm}$.).

Late sixteenth century.

See pages $138,139$. 


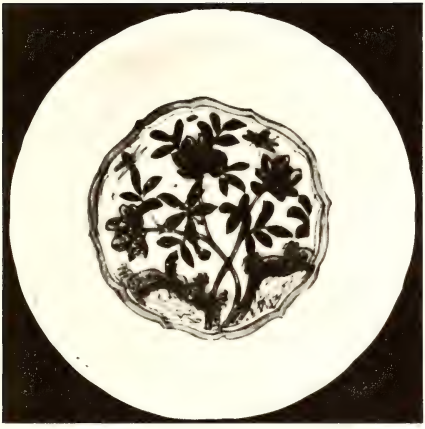

29.284

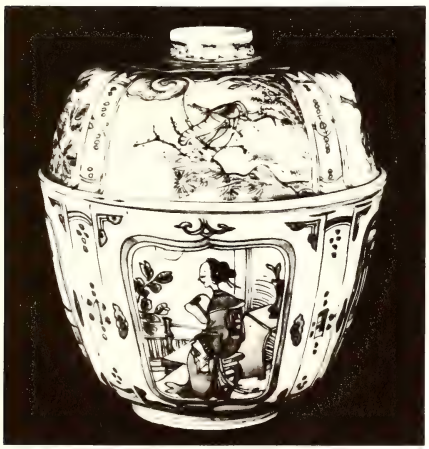

$29.382,29.386$

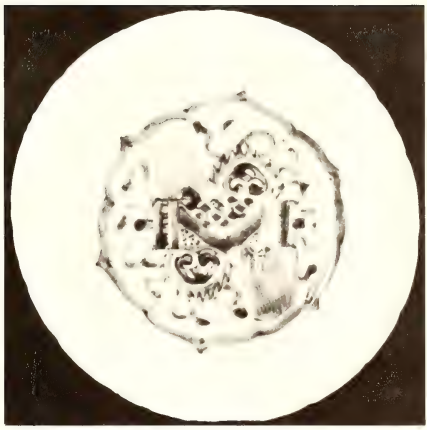

29.283

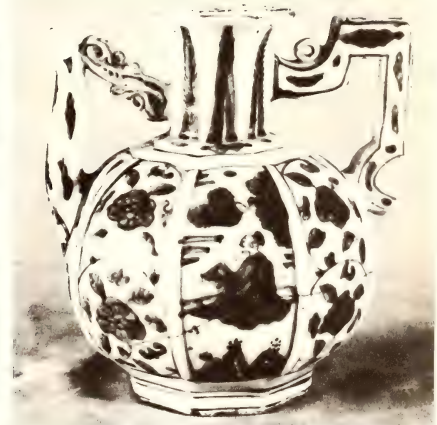

29.444 


\section{PLATE 109}

Bottle of hexagonal form; the tall thin neck is decorated with stiff leaves, a band of thunder pattern, and a broad zone of flowering shrubs and rocks; the body of the vessel has a flower spray and one of the "hundred antiques" on each side with scroll patterns on the shoulder above and on the foot below. The high flaring base is glazed inside and carries the mark of the hare underneath.

29.468 H. $12 \frac{1}{4}$ in. $(31 \mathrm{~cm}$. $)$. D. $5 \frac{1}{2}$ in. $(14 \mathrm{~cm}$. $)$.

Ewer (chih-hu) of hexagonal form decorated with stiff leaves, a diaper band and flower sprays on the neck; a trefoil band lies on the shoulder, and the six panels on the sides frame flowers, foliate scrolls and symbols reserved in white on a blue ground. Flying horses above waves appear on the high flaring foot. The base is glazed underneath.

29.467 H. $11 \frac{1}{2}$ in. $(29 \mathrm{~cm}$. $)$.

Ewer with high foot and handle in the form of a rat; the decoration includes birds on branches, floral sprays, and on each side two phoenixes worked into medallion form. Under the base is the mark Ta-ming-nien-tsao.

29.473 H. $6 \frac{3}{4}$ in. $(17 \mathrm{~cm}$.$) . D. 4 \frac{1}{2}$ in. $(11.5 \mathrm{~cm}$. $)$.

Deep cup on a low flaring foot. Inside the rim is a diaper border and in the bottom is a cloud scroll in the form of a swastika. The outside of the cup itself is decorated in white reserved on a blue ground. A diaper border lies above six rows of blossoms, and a row of lotus panels surrounds the bottom; round dots appear on the swelling area above the flaring foot decorated with pendent stiff leaves. The base is glazed underneath.

29.484 H. $5 \frac{3}{4}$ in. $\left(14.5 \mathrm{~cm}\right.$.). D. $4 \frac{3}{4}$ in. $(12 \mathrm{~cm}$.).

Late sixteenth century.

See page 140 . 


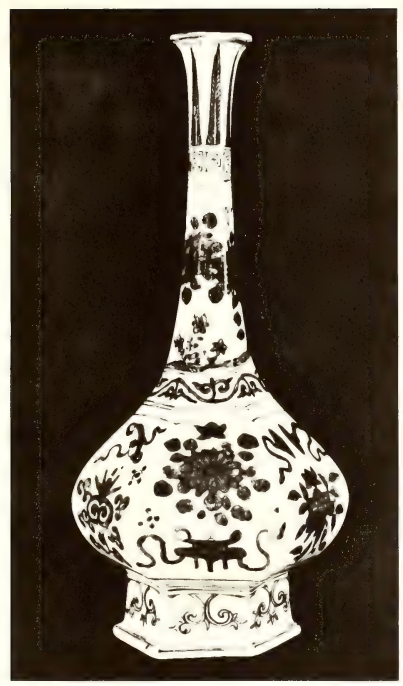

29.468

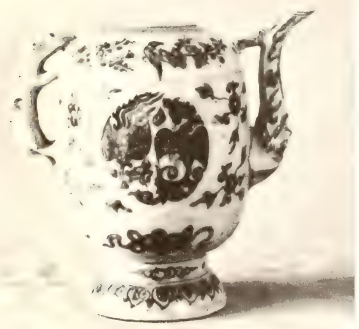

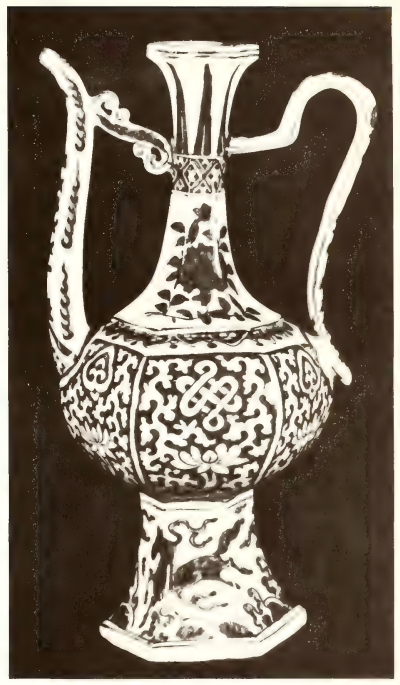

29.467

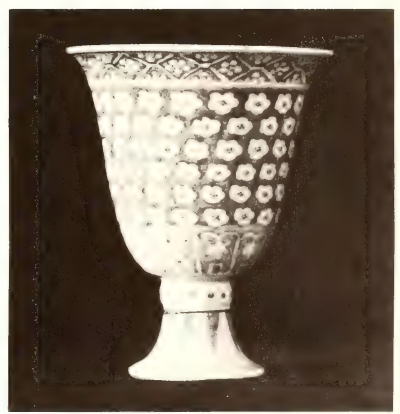

29.484 


\section{PLATE 110}

Dish with plain rim. Inside are a scroll border, floral scrolls in the cavetto, and a central design of a bouquet tied with a fillet; all are executed in fine incised lines. A scroll border above floral scrolls appears again on the outside, and a band of thunder pattern surrounds the foot. The base is unglazed and shows tinges of iron red.

This is the plain white version of such standard blue-and-white designs as 29.1-29.20 (pls. 30-31). $29.687,692$ ( 2 pieces) H. $2 \frac{3}{4}$ in. $\left(7 \mathrm{~cm}\right.$.). D. $15 \frac{3}{4}$ in. $(40 \mathrm{~cm}$.).

Dish with plain rim. Inside the cavetto is a floral scroll while a 5-clawed dragon decorates the center; the outside is plain, the base is unglazed, and the surface of the paste shows tinges of iron red.

The dish illustrated is not one of the two in the Ardebil Collection but a piece with identical decoration in the writer's possession photographed at the Freer Gallery of Art by infrared light to bring out the hidden design more clearly. It has a gold lacquer repair on the rim.

$29.678,682$ (2 pieces) H. $2 \frac{3}{8}$ in. $\left(6 \mathrm{~cm}\right.$.). D. $13 \frac{3}{8}$ in. $(34 \mathrm{~cm}$.).

Early fifteenth century.

See page 144 . 


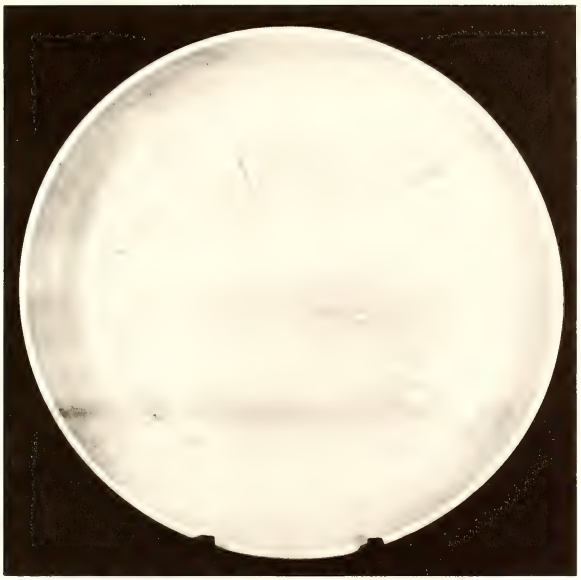

29.687

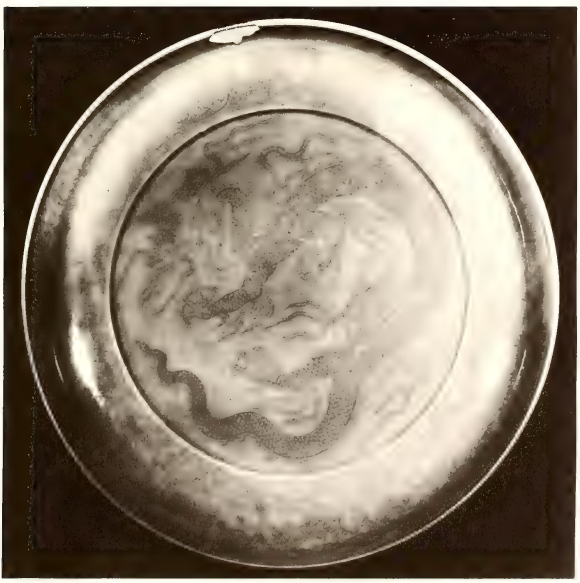

Type of 29.678 


\section{PLATE 111}

Dish with flattened rim slightly raised at the edge; there are remains of overglaze decoration in gold.

The scrolls on the rim and the chrysanthemum design on the outside of the cavetto are clearest; the rest is rather obscure. The base is unglazed.

29.691 and 29.694 have the mark of Qarachaghāy drilled in their bases.

29.691 D. $13 \frac{3}{8}$ in. $(34 \mathrm{~cm}$. $)$.

29.694 D. $14 \frac{3}{8}$ in. $(36.5 \mathrm{~cm}$. $)$.

29.695 D. $15 \frac{3}{4}$ in. $(40 \mathrm{~cm}$. $)$.

Fifteenth century.

See page 144 . 

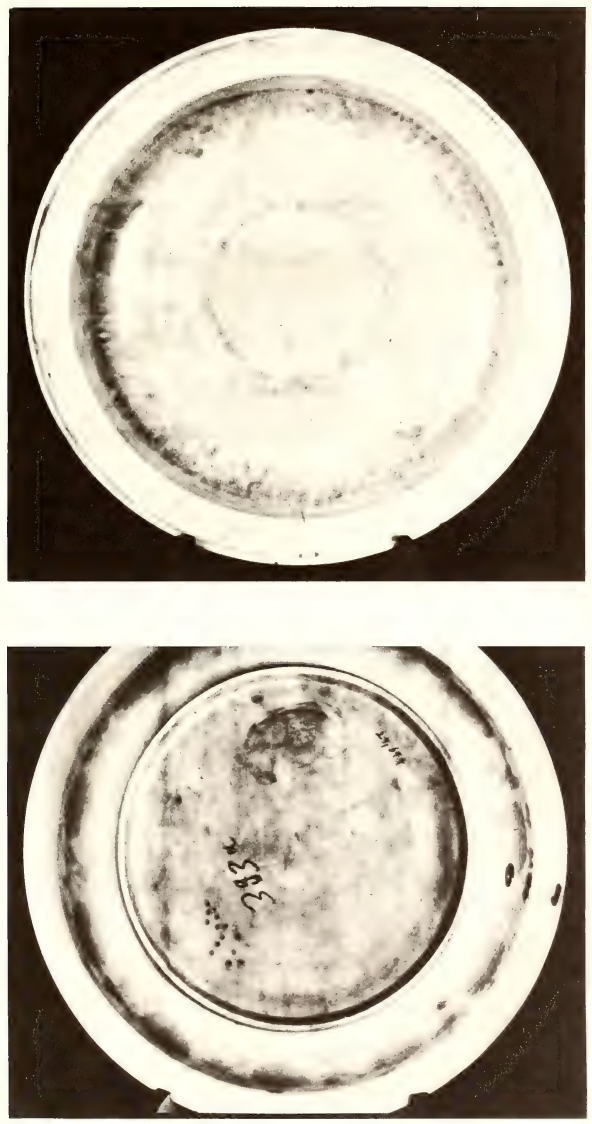


\section{PLATE 112}

Dish with flattened rim slightly raised at the edge. On the rim are fungus scrolls, floral scrolls decorate the cavetto, and in the center are floral sprays and scrolls, all incised in the paste. The base is unglazed.

On the base is some writing in ink in what appears to be Uighur script.

29.697 D. $15 \frac{5}{8}$ in. $(39.5 \mathrm{~cm}$. $)$.

Dish with flattened foliate rim and molded cavetto. There is no decoration, and the base is unglazed. 29.679 D. 16 in. $(40.5 \mathrm{~cm}$.).

Early fifteenth century.

See page 144 . 


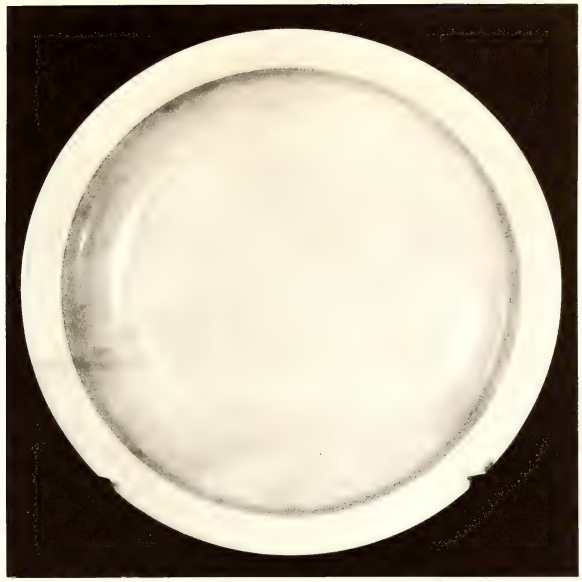

29.697

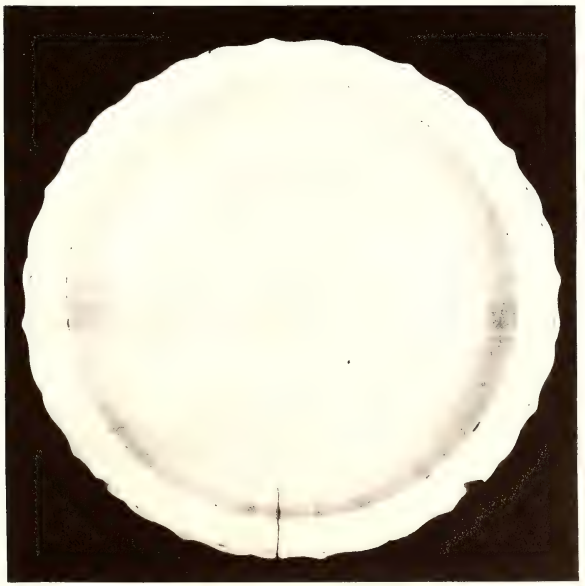

29.679 


\section{PLATE 113}

Bowls of lien-tzŭ shape. Inside are incised borders of thunder pattern above floral scrolls; outside are scroll borders above two rows of petals. The bases are glazed.

The petal design is emphasized by the thickening of the pale bluish glaze in the incised outlines. Occasional bubbles in this area have burst, and dirt in the resulting pits accounts for the dotted effect seen in the reproduction. No. 29.718 has a plain gold band about three-quarters of an inch wide applied around the outside of the rim.

29.717-718 (2 pieces) H. 4 in. $\left(10 \mathrm{~cm}\right.$.). D. $8 \frac{1}{8}$ in. $(20.5 \mathrm{~cm}$.$) .$

Early fifteenth century.

Bowl with plain flaring rim. There is no decoration, and the base is unglazed.

29.702 H. $4 \frac{1}{6}$ in. $\left(10.5 \mathrm{~cm}\right.$.). D. $10 \frac{1}{4}$ in. $(26 \mathrm{~cm}$. $)$.

Fifteenth century.

Bowl with steep sides and plain rim. Incised in the paste inside is a single chrysanthemum spray, and outside are four fruit sprays over a row of lotus petals. In every respect this is the plain white counterpart of blue-and-white bowl No. 29.340 (pl. 49).

$29.716 \mathrm{H}$. about $3 \frac{1}{2}$ in. $(9 \mathrm{~cm}$. $)$. D. $6 \frac{7}{8}$ in. $(17.5 \mathrm{~cm}$. $)$.

Fifteenth century.

See pages 50, 144, 145 . 


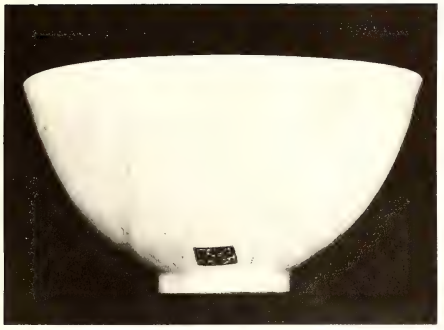

29.717

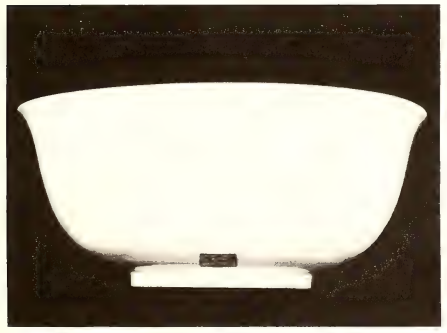

29.702

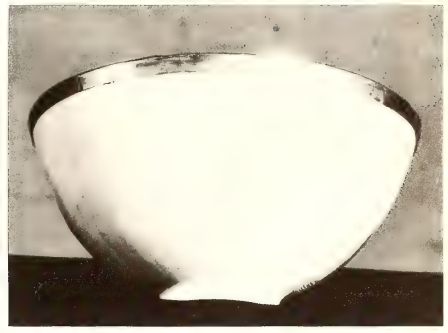

29.718

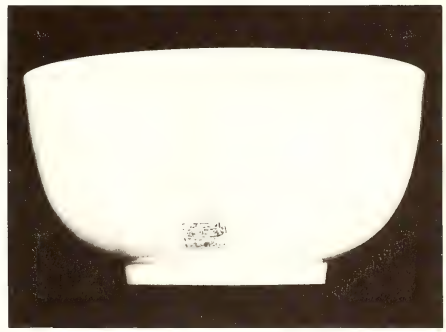

29.716 


\section{PLATE 114}

Bowl with plain rim. Outside are flying horses with cloud scrolls and waves incised in the paste. The glazed base carries the mark $f u-k u e i-c h i a-c h i$ in underglaze blue; the foot is deep and undercut. 29.772 H. $6 \frac{3}{8}$ in. $(16 \mathrm{~cm}$.$) . D. 13 \frac{7}{8}$ in. $(34 \mathrm{~cm}$. $)$.

Sixteenth century.

Bowl with slightly flaring rim. There is no decoration; and the base carries the 6-character mark of the Hung-chih period in underglaze blue.

A bowl of this same type in the Isfahan group bears the incised mark of Jahāngīr as well as the Shāh 'Abbăs mark and the owner's sign often seen on wares of this period.

$29.711,712,714$ (3 pieces) H. $3 \frac{5}{8}$ in. $(9 \mathrm{~cm}$.$) . D. 7 \frac{7}{8}$ in. $(20 \mathrm{~cm}$.$) .$

Hung-chih period.

Bowl with steep sides. Inside and out are floral patterns incised in the paste. The base is unglazed and the foot rim is squarely cut.

$27.703,774$ (2 pieces) H. $5 \frac{1}{2}$ in. $(14 \mathrm{~cm}$.$) . D. 13 \frac{3}{8}$ in. $(34 \mathrm{~cm}$.$) .$

Fifteenth century.

See pages 56, 57, 145, 146, 147. 


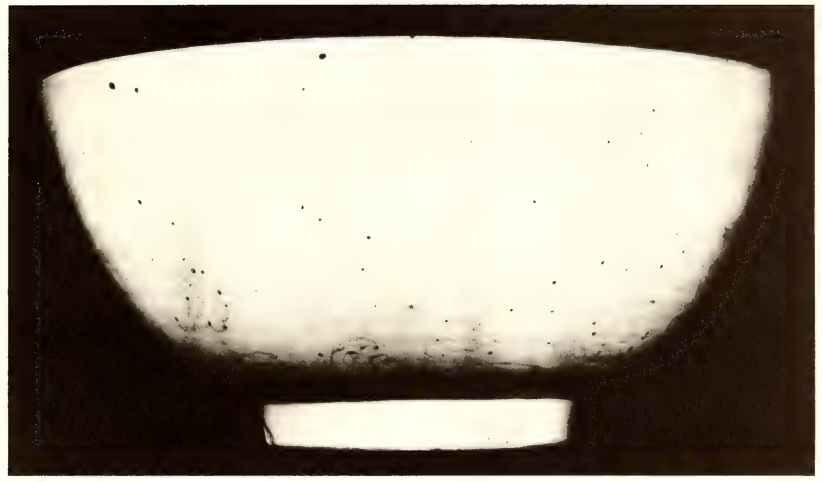

29.772

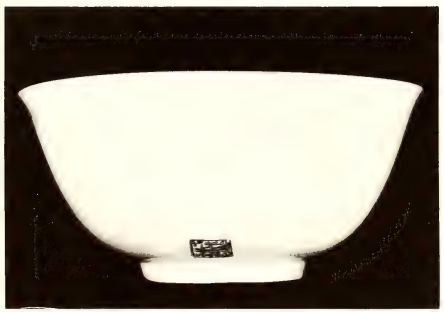

29.714

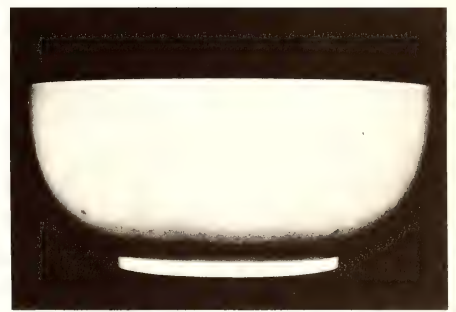

29.774 


\section{PLATE 115}

Dish with slightly flaring rim. No decoration. The convex base is finely glazed and carries the 6character mark of the Ch'eng-hua period in underglaze blue. At one side is incised the undeciphered owner's mark.

Five similar dishes $8 \frac{1}{2}$ in. $(21.5 \mathrm{~cm}$.) in diameter have the 6-character Hung-chih mark (29.658$662)$, two of them have the same owner's mark; and number $29.656,7 \mathrm{in}$. (18 cm.) in diameter, has the 6-character Cheng-te mark and the owner's mark as well. On all seven of these pieces the mark of Shāh 'Abbās is incised with unusual beauty and precision.

29.657 D. $7 \frac{7}{8}$ in. $(20 \mathrm{~cm}$. $)$.

Ch'eng-hua, Hung-chih, and Cheng-te periods.

Vase of mei-p ing shape with incised fruit sprays on the shoulder, floral scrolls around the body, and flower sprays below. The unglazed base has a low flat foot rim.

These mei-ping are the plain white counterparts of such blue-and-white pieces as 29.409 (pl. 51); another one, 29.723 , is exactly the same as 29.413 , with pendent lotus panels above and stiff leaves below. All are very thin and lightly potted.

$29.719-722$ (4 pieces) H. $9 \frac{5}{8}-10 \frac{7}{8}$ in. $\left(24.5-27.5 \mathrm{~cm}\right.$.). D. $5 \frac{7}{8}-7 \frac{1}{8}$ in. $(15-18 \mathrm{~cm}$.).

Early fifteenth century.

Vase of kuan shape with no decoration. The unglazed base has a low rounded rim.

29.773 H. $11 \frac{7}{8}$ in. $\left(30 \mathrm{~cm}\right.$.). D. $12 \frac{1}{4}$ in. $(31 \mathrm{~cm}$.).

Sixteenth century.

See pages $146,147$. 


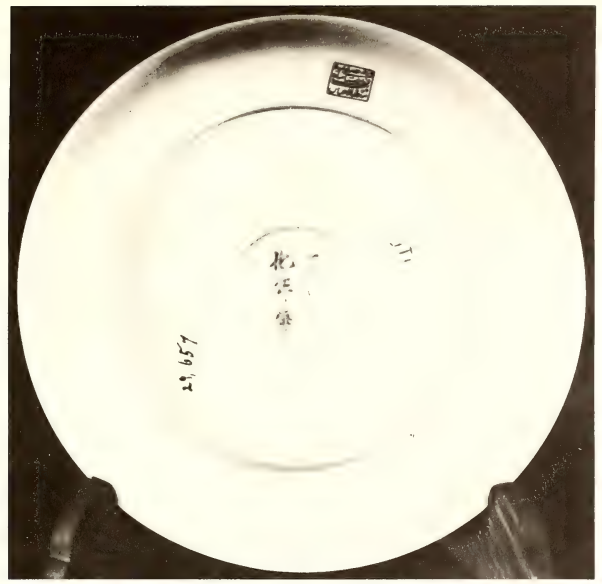

29.657

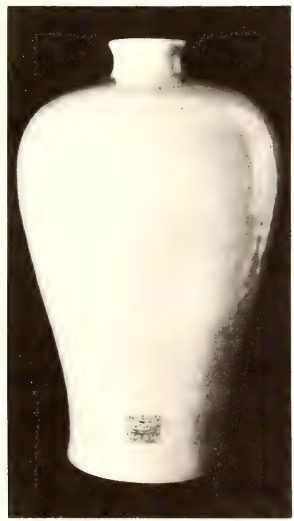

29.722

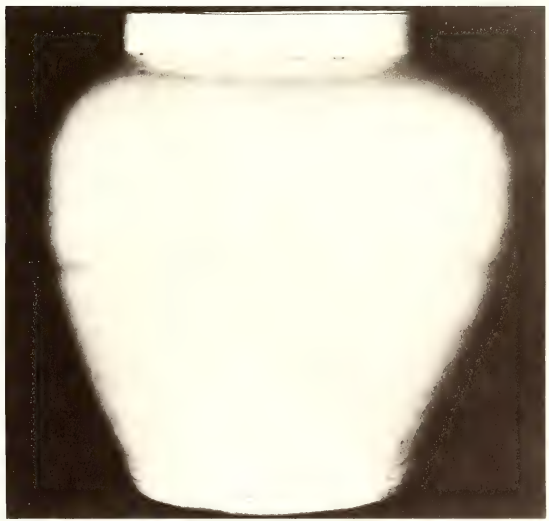

29.773 


\section{PLATE 116}

Dish with slightly flaring rim. The inside is plain; outside are fishes and aquatic plants painted in dark cobalt blue under an even turquoise glaze. On the base is the 4-character mark of the Cheng-te period in underglaze blue.

29.769 D. $8 \frac{1}{4}$ in. $(21 \mathrm{~cm}$.).

Cheng-te period.

Dish with plain rim. Inside are two lions amid streamers, and a central roundel; outside are birds on branches, flying birds, and dragonflies all in colored enamels. On the base is the 6-character mark of the Hung-chih period. The dish is broken on one side.

$29.761-762$ ( 2 pieces) D. $8 \frac{1}{2}$ in. $(21.5 \mathrm{~cm}$.).

Hung-chih period.

See page 149 . 


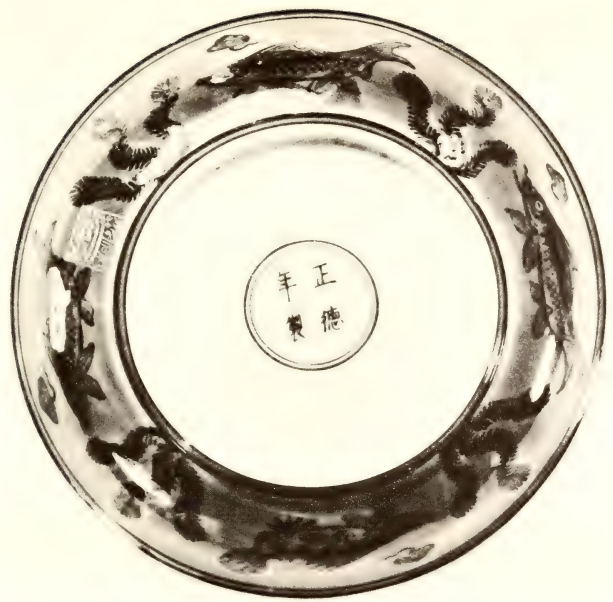

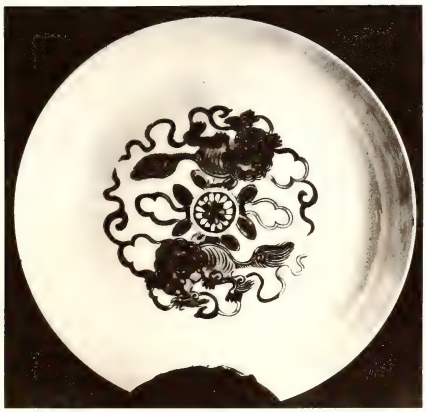

29.761

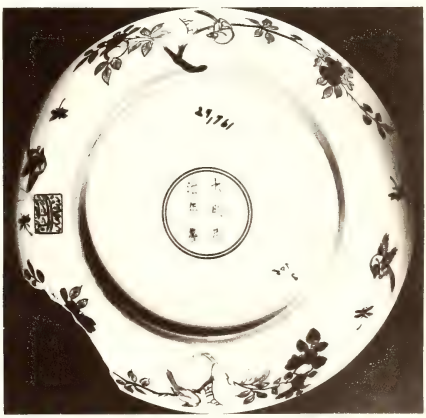

29.761 


\section{PLATE 117}

Dish with slightly flaring rim. Inside bamboos, a stylized rock, a peach tree, and butterflies in red, yellow, and green enamels; outside is the same design repeated all around.

29.763 D. 8 in. $(20 \mathrm{~cm}$.).

Late fifteenth century.

Bowl with slightly flaring rim. Inside is a $\operatorname{ch}^{i} i$-lin with flames and auspicious objects. Outside are four animals: a lion, a pai-ts'e, a ch'i-lin and an elephant each with a disk on its back inscribed with the character $f u$ in gold. All decoration is in enamel colors. On the base is the 6-character mark of the Cheng-te period in underglaze blue, and beside it the undeciphered owner's mark is cut in the glaze.

29.764 H. $3 \frac{1}{8}$ in $(8 \mathrm{~cm}$.). D. 7 in. $(18 \mathrm{~cm}$. $)$.

Cheng-te period.

See page 149 . 


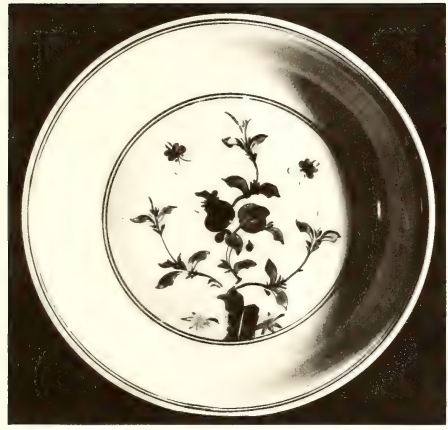

29.763

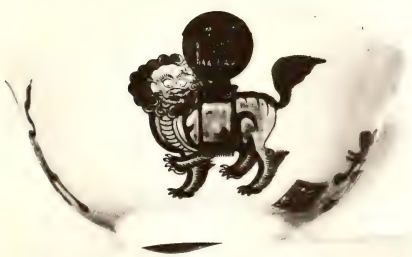

29.764

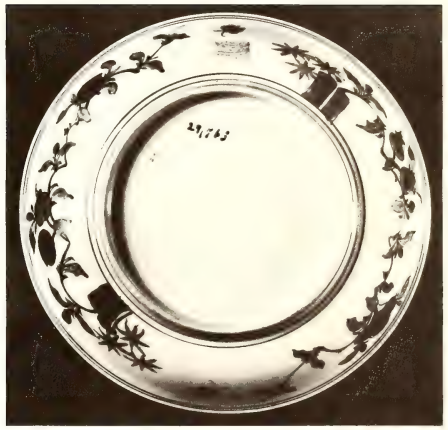

29.763

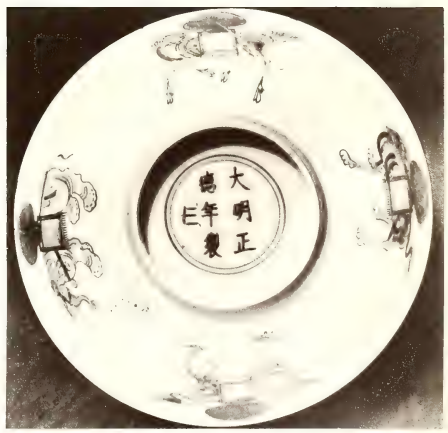

29.764 


\section{PLATE 118}

Dish with plain rim. Inside is a wave border over a white cavetto; surrounded by a row of standing trefoils is the central decoration of landscape and figures, all executed in red, green, and yellow enamels. On the convex base the 6-character Chia-ching mark is incised in the paste, and the mark Hsüan-te-nien-tsao is written on top of this in overglaze iron red.

The mark is like that illustrated in TOCS 25 (1949-1950), plate 3a.

29.759 H. $2 \frac{3}{8}$ in. $(6 \mathrm{~cm}$.$) . D. 15$ in. $(38 \mathrm{~cm}$.).

Chia-ching period.

Bowl with flaring rim. Inside is a fish in underglaze red surrounded by underglaze blue waves in which the white areas have been colored with overglaze red; around this central medallion are aquatic plants in overglaze enamels. Outside are four underglaze red fish on white areas reserved in a wave ground of underglaze blue and overglaze iron red. Under the base is the 6character mark of the Hsüan-te period in underglaze blue.

29.758 H. $3 \frac{3}{8}$ in. $\left(8.5 \mathrm{~cm}\right.$.). D. $7 \frac{1}{4}$ in. $(18.5 \mathrm{~cm}$.).

Late sixteenth century.

See page 150 . 


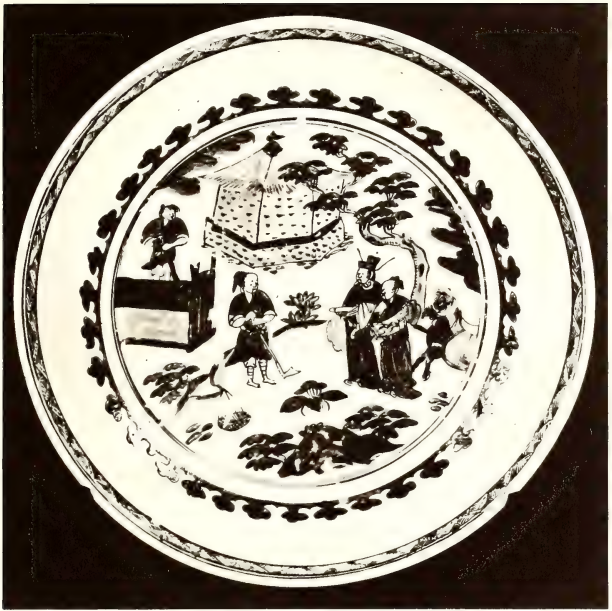

29.759
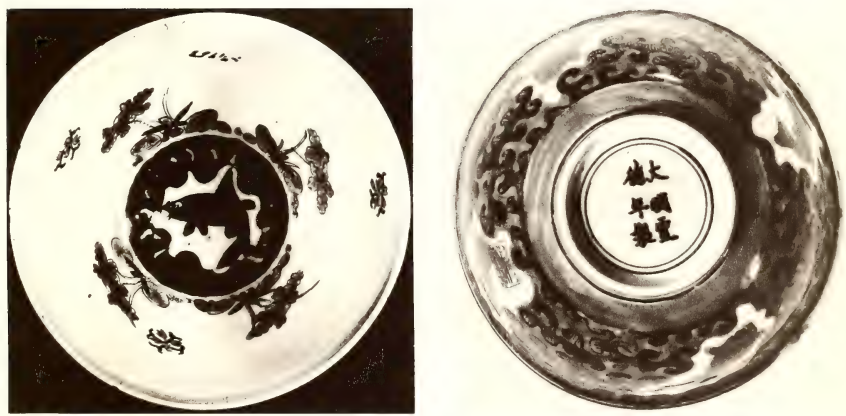

29.758

29.758 


\section{PLATE 119}

Dish with flaring foliate rim. Inside is a single 3-clawed dragon executed in white slip and incised in detail against a ground of dark blue glaze. The base is unglazed and is joined by the foot rim in a curve.

29.747 D. 18 in. $(46 \mathrm{~cm}$.).

Fourteenth century.

See page 151 . 

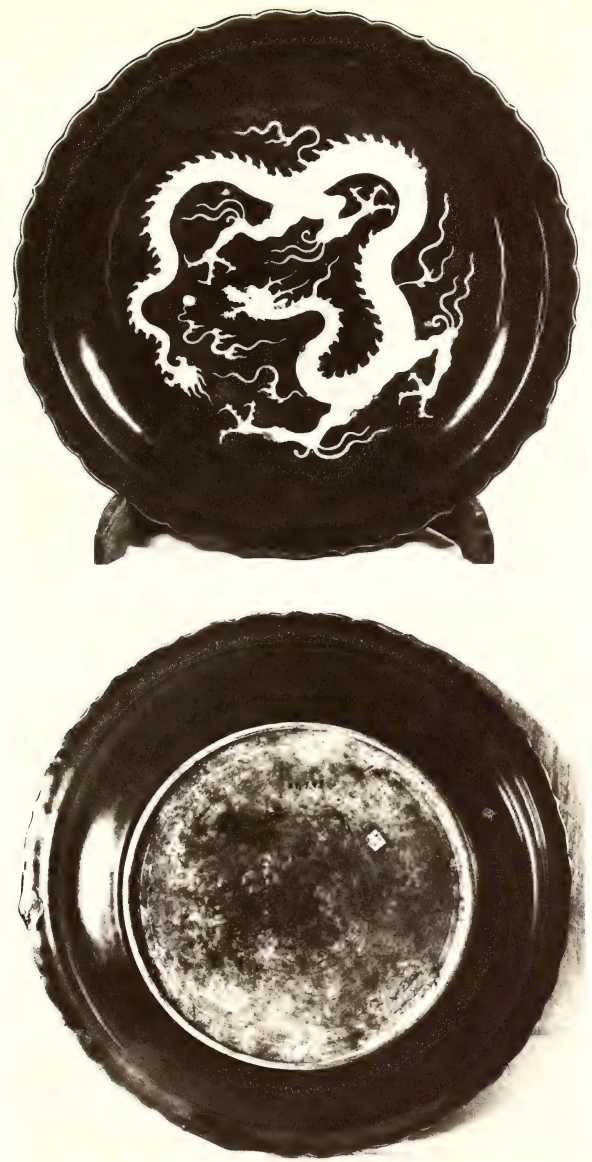
PLATE 120

Vessel in the shape of a recumbent cat; a tall pipe with flanged rim and base rises from the back, and a tube is seen through the hollow eyes and ends in the mouth supported between the tip of the tongue and the upper teeth. Glazed in a mottled watermelon shade of green, which runs over the edges of the flat base.

No number. H. 8 in. $(20 \mathrm{~cm}$.).

Date uncertain but before 1611 .

See pages 151,152 . 

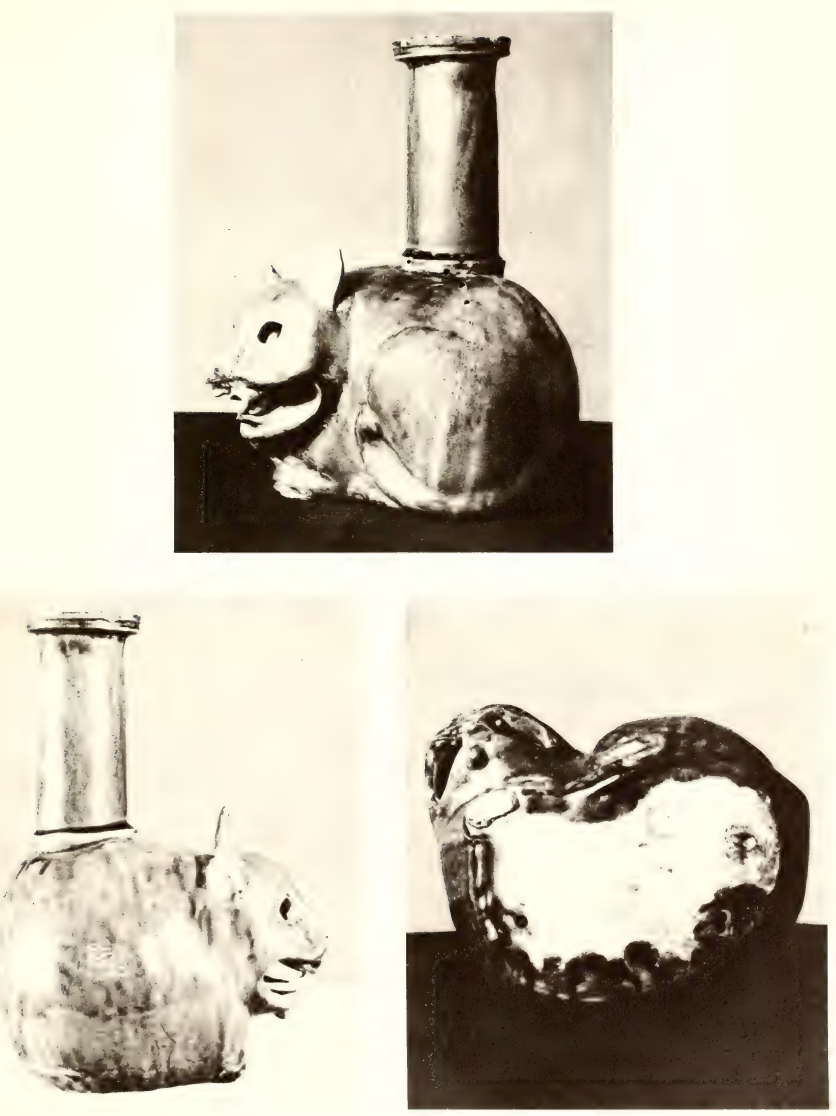


\section{PLATE 121}

Celadon dish with flattened foliate rim with raised edge. The cavetto is fluted radially, and in the center is a single freely incised lotus blossom. The outside is plain, the foot rim is rounded and glazed over, and an unglazed ring of reddish biscuit is seen on the base.

29.617 H. 3 in. ( $7.5 \mathrm{~cm}$.), D. 17 in. $(43 \mathrm{~cm}$.).

Celadon dish with flattened rim decorated inside with incised scrolls; in the cavetto are lotus blossoms with foliage, and in the center is a single lotus plant. The outside is plain, the foot rim is thick, rounded, and glazed over, and there is an unglazed ring of reddish biscuit on the base.

29.619 H. $2 \frac{3}{4}$ in. $\left(7 \mathrm{~cm}\right.$.). D. $18 \frac{1}{2}$ in. $(47 \mathrm{~cm}$.).

Fifteenth century.

See page 155 . 


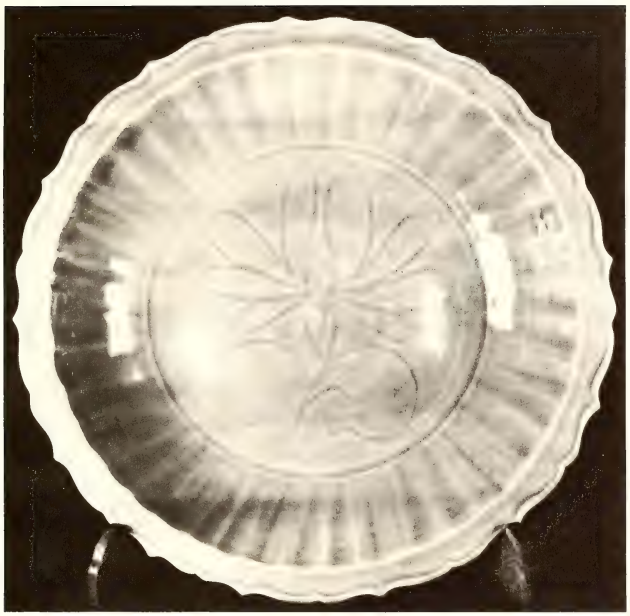

29.617
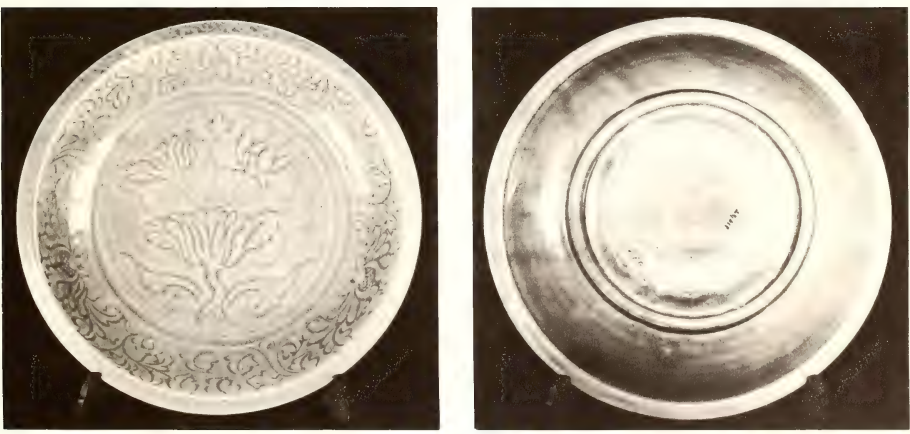


\section{PLATE 122}

Celadon dish with plain flattened rim. Incised scrolls appear on the rim; the cavetto is plain and incised in the center is a single large tree peony. The outside is plain. The rounded foot rim is glazed over, and just inside this is an even ring of unglazed biscuit.

The quality of this celadon is unsurpassed among wares of the period. The color is a rich even seagreen; the potting is beautifully done, and the paste is fine-grained and very light gray, almost white.

29.621 H. $3 \frac{1}{8}$ in. $\left(8 \mathrm{~cm}\right.$.). D. $17 \frac{1}{2}$ in. $(44 \mathrm{~cm}$.).

Fifteenth century.

See page 155 . 

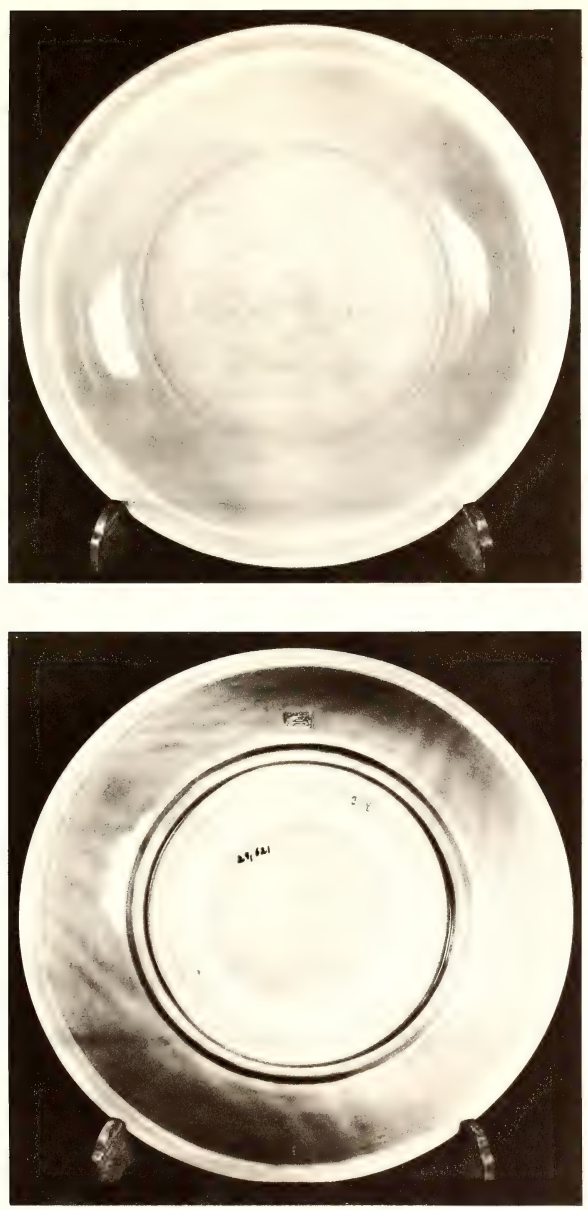


\section{PLATE 123}

Celadon dish with plain rim. The cavetto is decorated with peony scrolls reserved in relief by virtue of the fact that the background around them has been cut away. In the center is an allover diaper pattern of interlocking circles giving the effect of the cash motif. The outside is plain; the foot rim is rounded on the outside, cut vertical on the inside and glazed over. On the base is a broad uneven ring of reddish unglazed biscuit.

The glaze is even, glossy, dark olive-green; the dish is thinly potted, and the execution of the design is of excellent quality.

29.626 H. $2 \frac{3}{4}$ in. $\left(7 \mathrm{~cm}\right.$.). D. $21 \frac{5}{8}$ in. $(55 \mathrm{~cm}$.).

Celadon dish with plain rim. In the cavetto is a boldly incised lotus scroll, and in the center a diaper pattern based on diagonals. The foot rim is glazed over, and there is a ring of unglazed reddish biscuit on the base.

29.630 H. $2 \frac{3}{4}$ in. $\left(7 \mathrm{~cm}\right.$.). D. $19 \frac{1}{4}$ in. $(49 \mathrm{~cm}$.).

Celadon dish with plain rim. In the cavetto is a freely incised wave pattern, and the bottom has a diaper pattern on a square plan. The foot rim is glazed over, and there is a ring of unglazed reddish biscuit on the base.

29.631 H. $2 \frac{3}{4}$ in. $(7 \mathrm{~cm}$.$) . D. 17 \frac{3}{8}$ in. $(44 \mathrm{~cm}$.$) .$

Fourteenth or fifteenth century.

See page 155 . 


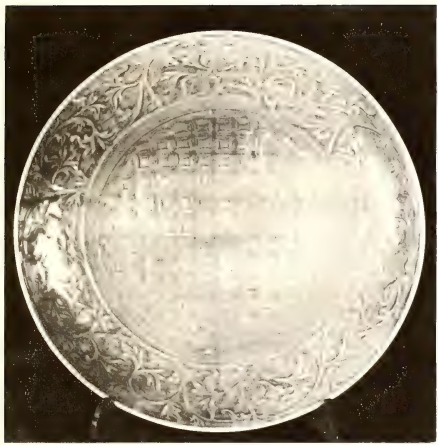

29.626

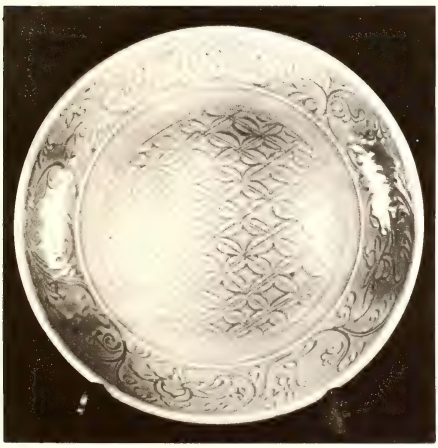

29.630

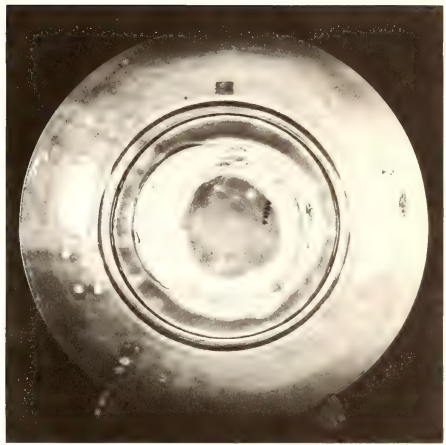

29.626

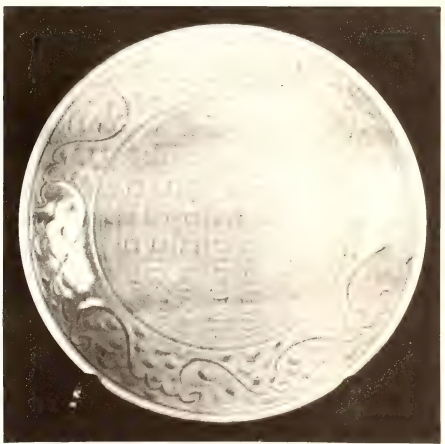

29.631 


\section{PLATE 124}

Celadon dish with flattened rim and raised edge. The cavetto is fluted radially, and in the center is a lotus spray impressed in the clay with a mold. The foot is small in diameter but very thick, sloping outside and vertical inside; the base is completely glazed and the broad rim is bare.

All seven dishes with feet of this type in the collection lack the Shāh 'Abbās mark; both stamped and incised designs decorate the centers; all are of excellent quality.

29.609-10, 29.612-13, 29.622-24 (7 pieces) H. $3 \frac{1}{8}$ in. ( $8 \mathrm{~cm}$.). D. $13 \frac{3}{8}$ in. $(34 \mathrm{~cm}$.$) .$

Fourteenth or fifteenth century.

See page 155 , n. 316. 

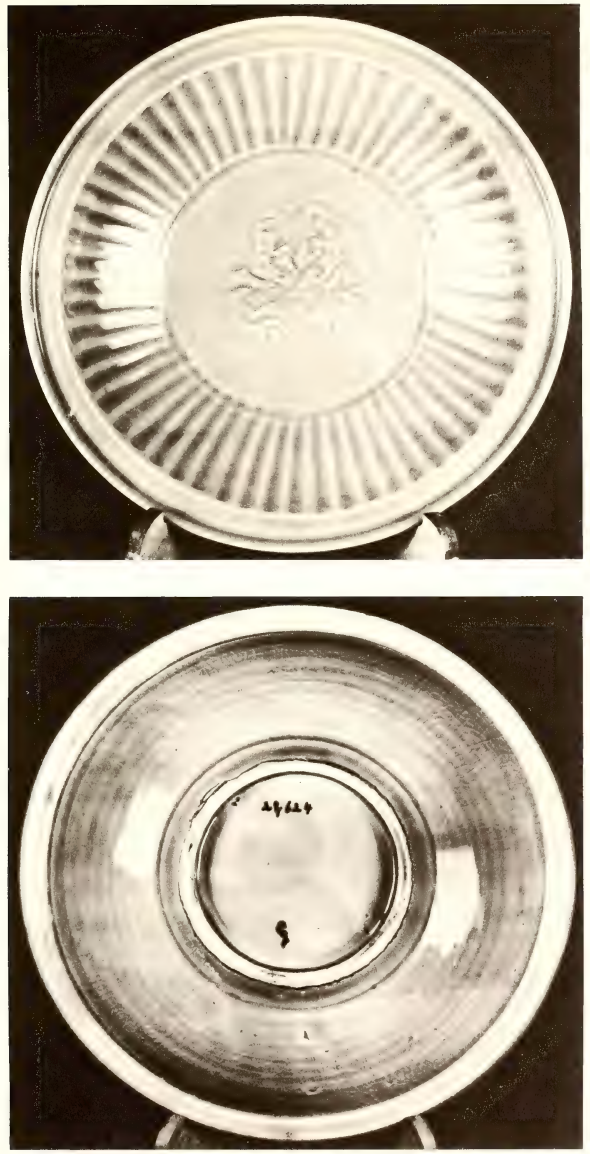
PLATE 125

Celadon bowl with plain flaring rim. A floral spray incised inside is the only decoration. The bowl is very thickly potted; the foot rim is glazed over and there is a ring of unglazed reddish biscuit on the base.

29.646 H. $3 \frac{3}{8}$ in. $(8.5 \mathrm{~cm}$.$) . D. 6 \frac{7}{8}$ in. $(17.5 \mathrm{~cm}$.$) .$

Fourteenth or fifteenth century.

Celadon tripod of lien shape; cylindrical body decorated with floral scrolls applied in relief; one foot missing; double bottom, the inner part of which rises to a rounded protuberance inside the vessel (pl. 142).

29.655 H. $6 \frac{1}{4}$ in. $(16 \mathrm{~cm}$.$) . D. 7 \frac{1}{2}$ in. $(19 \mathrm{~cm}$. $)$.

Fourteenth or fifteenth century?

See page 156 . 


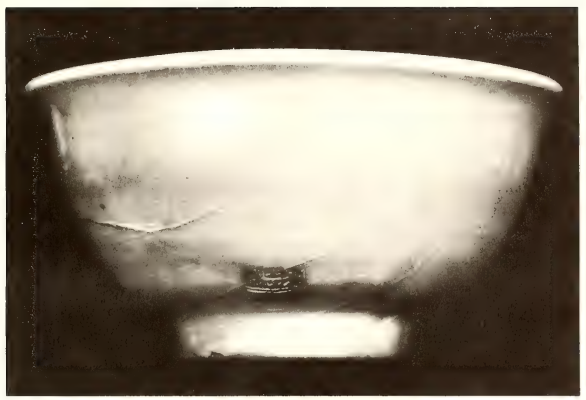

29.646

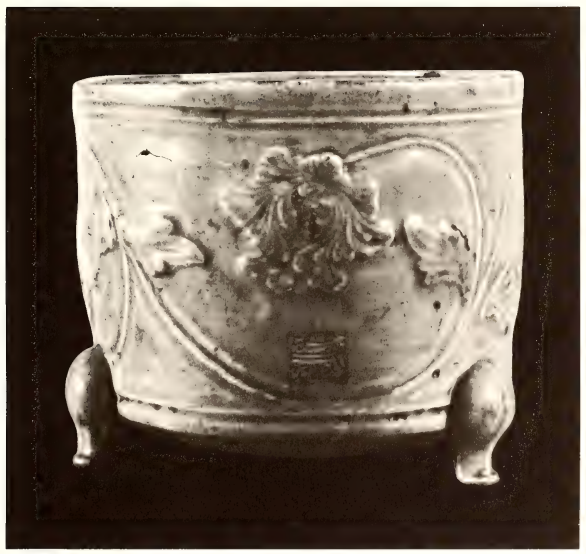

29.655 
PLATE 126

Celadon bowl with contracted mouth and slightly flaring lip. The inside is plain; outside is a band of thunder pattern above a row of lotus panels, both incised in the clay. The small base has been broken and ground off flat showing a light gray biscuit with black specks.

It is possible that the original base may have been high and flaring like a stem. If that was the case, the vessel must have resembled the blue-and-white stem bowl at Oxford.

29.647 H. $3 \frac{3}{4}$ in. $\left(9.5 \mathrm{~cm}\right.$.). D. (at lip) $9 \frac{7}{8}$ in. $\left(25 \mathrm{~cm}\right.$.). D. (max.) $10 \frac{1}{4}$ in. $(26 \mathrm{~cm}$.).

Fourteenth century.

See page 156 . 

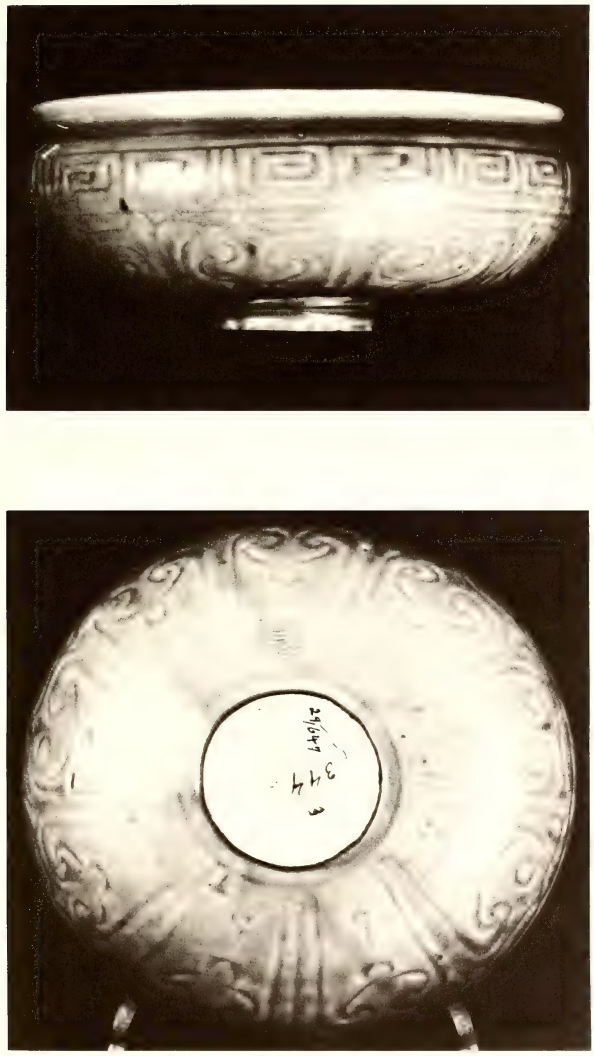

29.647 


\section{PLATE 127}

Celadon bowl with plain rim. Inside is an incised formal wave pattern surrounding a central floral spray in low relief which appears to have been executed by means of a stamp. Outside is an incised cloud border above scrolling lotus plants. The base is glazed except in a circular recessed hole in the center and on the inner side of the foot rim.

This bowl lacks the mark of Shāh 'Abbās.

29.649 H. $5 \frac{1}{8}$ in. $\left(13 \mathrm{~cm}\right.$.). D. $12 \frac{1}{4}$ in. $(31 \mathrm{~cm}$.).

Fifteenth century?

See page 156. 

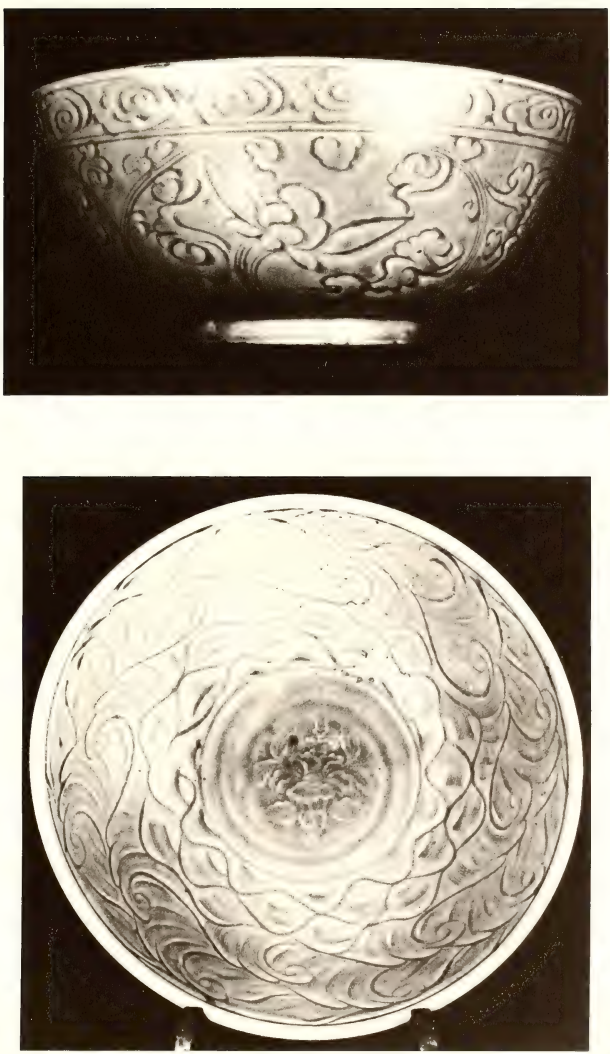
PLATE 128

Celadon bowl with foliate rim. The sides are radially fluted inside and out; and in the center is a lotus blossom medallion stamped in relief. The base has a recessed circular hole in the center and is entirely glazed over inside the foot rim which reveals an iron-red surface.

29.651 H. $4 \frac{1}{8}$ in. $(10.5 \mathrm{~cm}$.$) . D. 13$ in. $(35 \mathrm{~cm}$.$) .$

Fourteenth or fifteenth century.

See page 157 . 

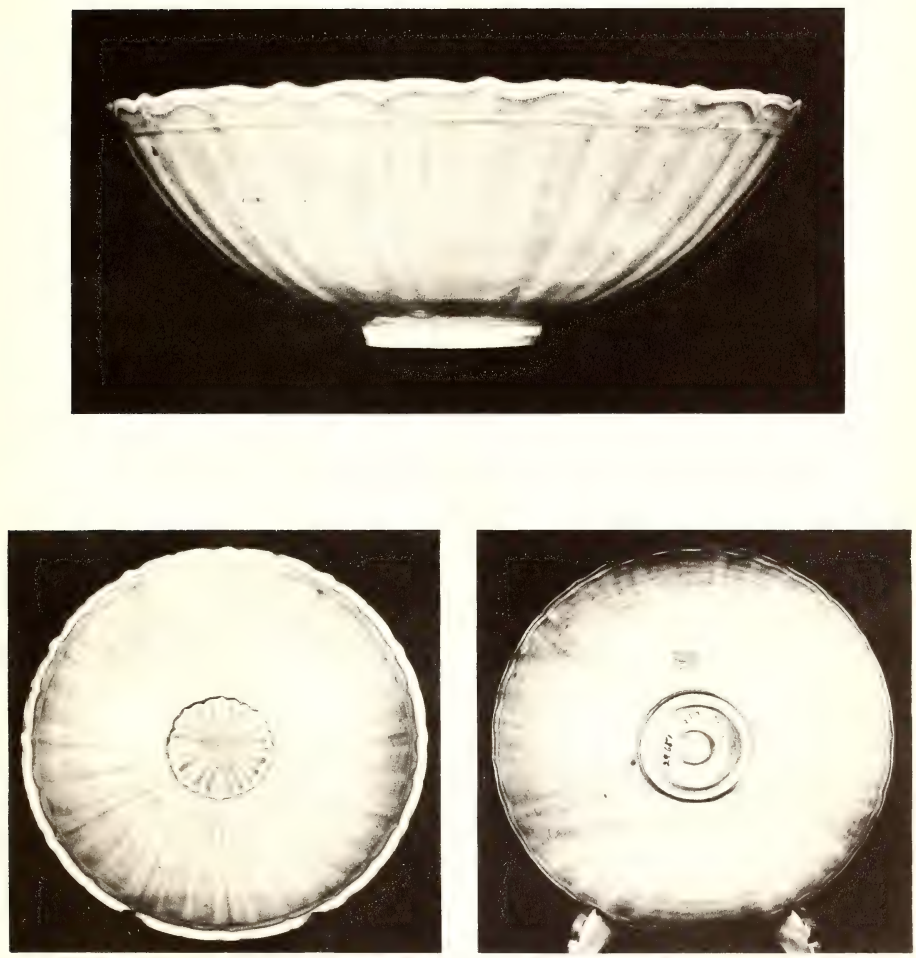

29.651 (three views) 


\section{PLATE 129}

Celadon vase with a baluster body, tall neck, and flaring mouth. The neck is fluted horizontally, and the body is decorated with lotus scrolls incised in the paste; around the bottom is a row of tall slender petals carved in low relief. The double base is glazed, and the biscuit foot rim is iron red.

29.648 H. $16 \frac{1}{8}$ in. $(41 \mathrm{~cm}$.$) . D. 7 \frac{7}{8}$ in. $(20 \mathrm{~cm}$.$) .$

Celadon vase of bottle shape with flaring lip and decoration carved in relief. Around the neck are stiff leaves and a band of diaper pattern, and a row of trefoils on the shoulder tops the main decoration of floral scrolls on the body. Below is a row of lotus panels. The glazed base has some gravelly adhesions, and the biscuit at the foot rim has an iron-red surface.

$29.652 \mathrm{H} .17$ in. $\left(43 \mathrm{~cm}\right.$.). D. $10 \frac{\mathrm{s}}{\mathrm{B}}$ in. $(27 \mathrm{~cm}$. $)$.

Fourteenth or fifteenth century.

See pages 156, 157. 


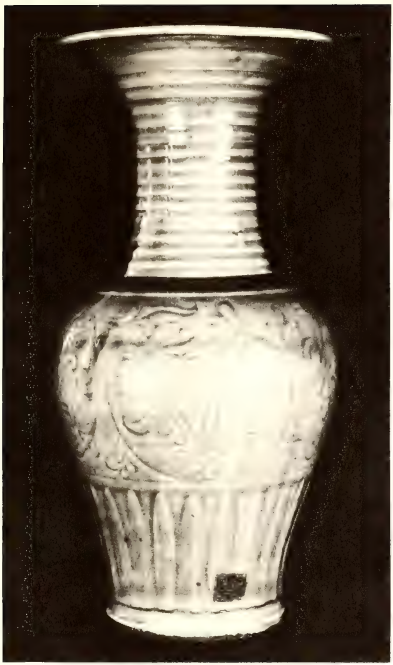

29.648

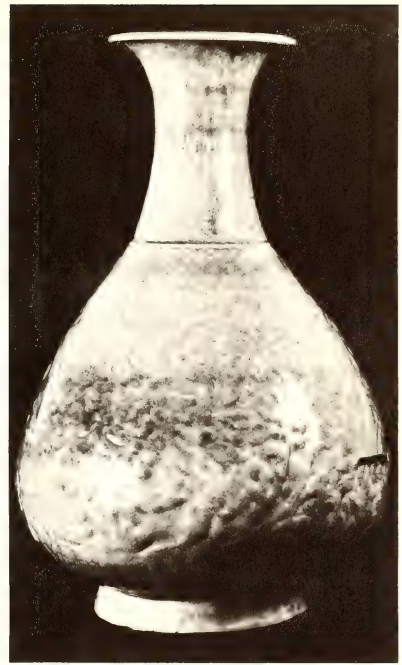

29.652

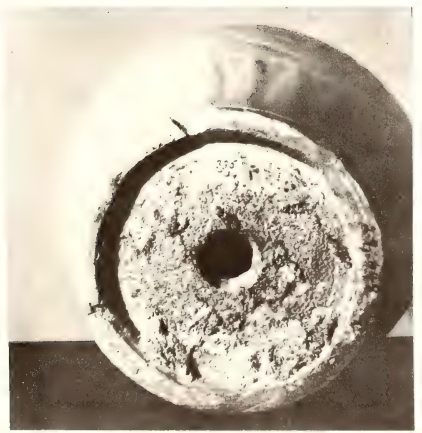


PLATE 130

Celadon vase of kuan shape. The only decoration consists of closely spaced deep vertical grooves all around the vessel. The base is glazed over, and the lip rim and foot rim are unglazed and show iron-red.

It would appear that when this vessel was made the bottom was first left open; and before firing the potter placed inside it a shallow dish slightly larger in diameter than the aperture; this was then covered with glaze which effectively cemented it in place at the time of firing.

29.650 H. $9 \frac{5}{8}$ in. $(24.5 \mathrm{~cm}$. $)$. D. $13 \frac{3}{8}$ in. $(34 \mathrm{~cm}$. $)$.

Celadon vase of kuan shape. Bold floral scrolls are carved in relief all over the body above a row of stiff leaves. The glazed base is of the same type as above; and the unglazed rim shows an ironred surface.

29.654 H. $9 \frac{1}{8}$ in. $\left(23 \mathrm{~cm}\right.$.). D. $13 \frac{3}{8}$ in. $(34 \mathrm{~cm}$.$) .$

Fourteenth century.

See page 157. 


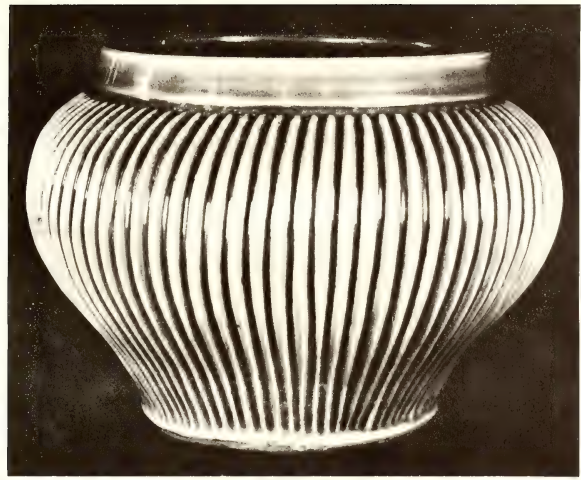

29.650

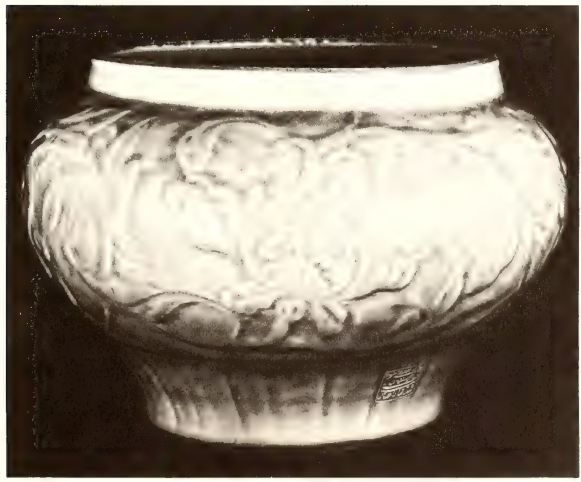

29.654 


\section{PLATE 131}

A-B. Fragments of two fourteenth-century Chinese bowls recovered from Fostāt, Egypt, showing one type of foot commonly used in this period.

Freer Gallery of Art (Study Collection).

See page 60 .

C-D. Two views of a Near Eastern blue-and-white pottery dish excavated at Hamã, Syria, showing designs borrowed from the fourteenth-century Chinese repertory.

Before A.D. 1400 .

Courtesy of Direction Générale des Antiquités, Musée de Damas.

See pages 70,71 . 


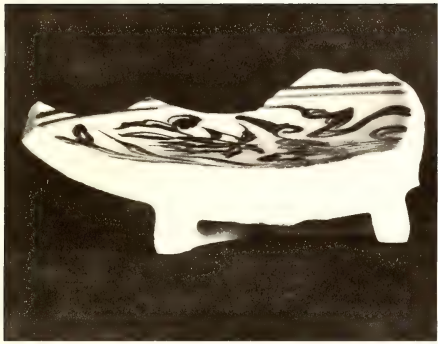

A

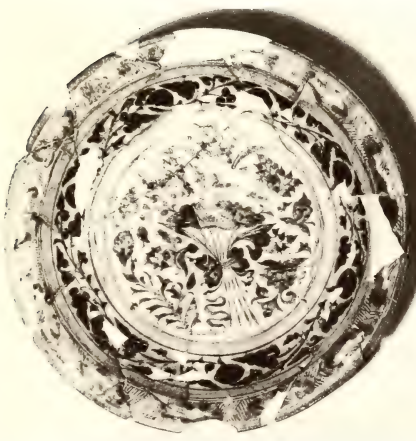

C

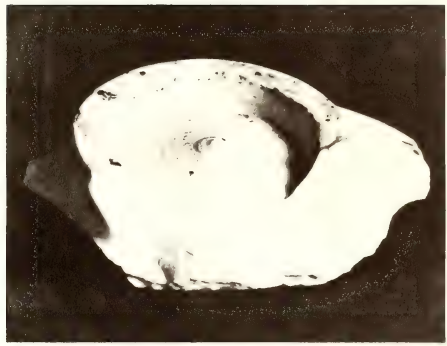

B

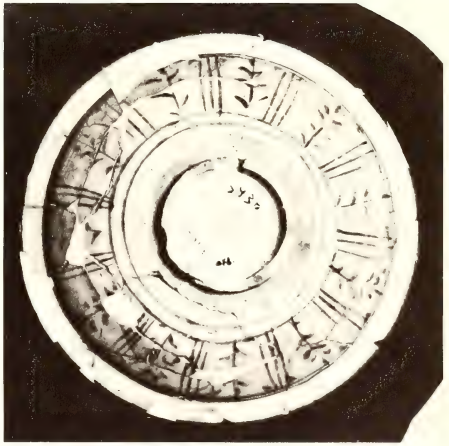

D 


\section{PLATE 132}

Three examples of Near Eastern blue-and-white pottery excavated at Hamā, Syria, showing designs borrowed from the fourteenth-century Chinese repertory.

Before A.D. 1400 .

Courtesy of Nationalmuseet, København.

See pages 70,71 . 

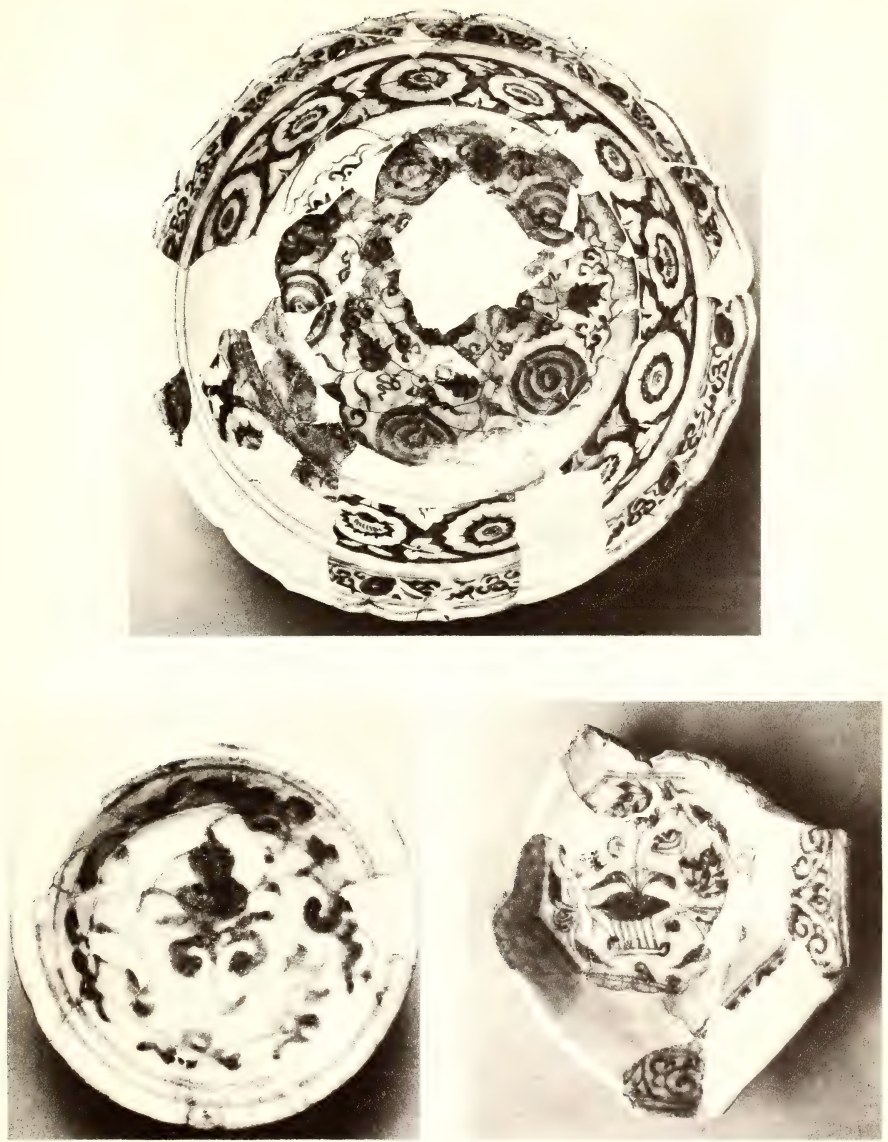


\section{PLATE 133}

Twenty-six fragments of Chinese blue-and-white excavated at Kharakhoto, Mongolia.

Fourteenth century.

Photographs by Folke Bergman reproduced by kind permission of Dr. Sven Hedin.

See page 75 for detailed descriptions. 

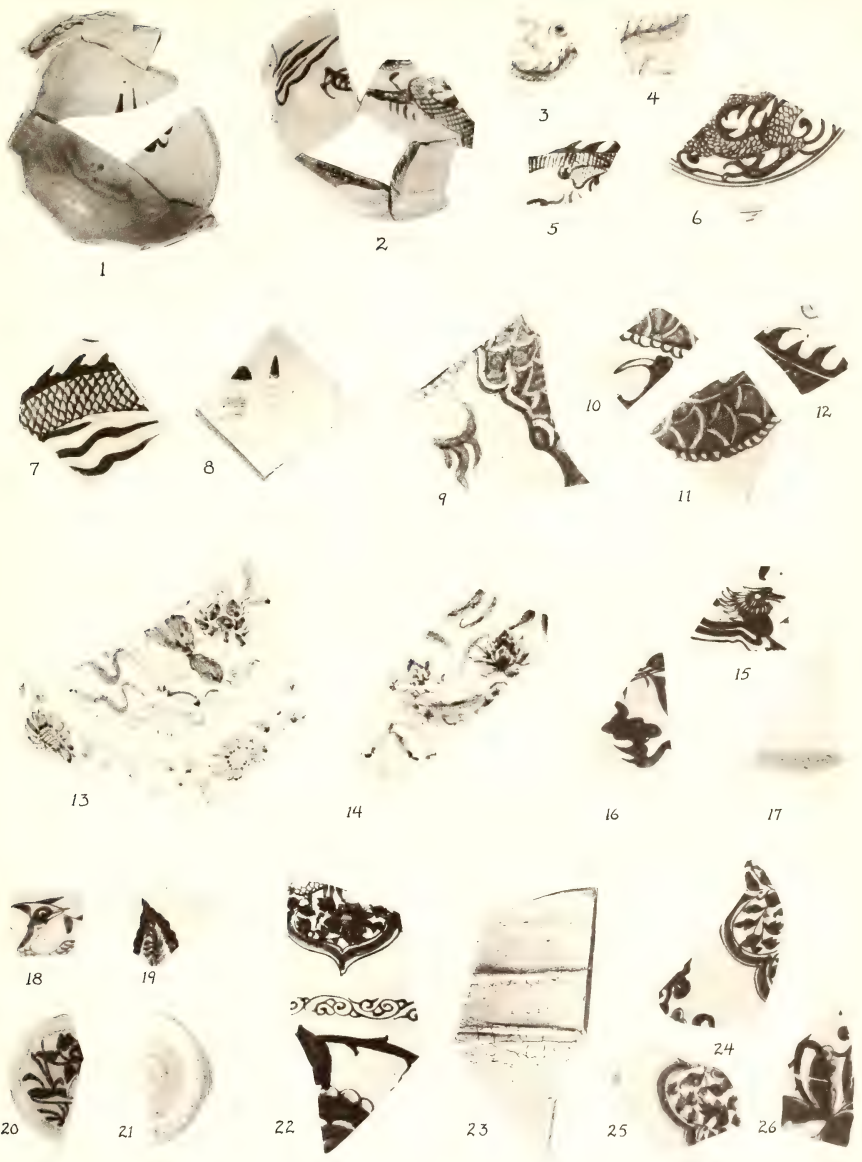


\section{PLATE 134}

Thirty-four fragments of Chinese blue-and-white excavated at Kharakhoto, Mongolia.

Fourteenth century.

Photographs by Folke Bergman reproduced by kind permission of Dr. Sven Hedin.

See pages 76,77 for detailed descriptions. 

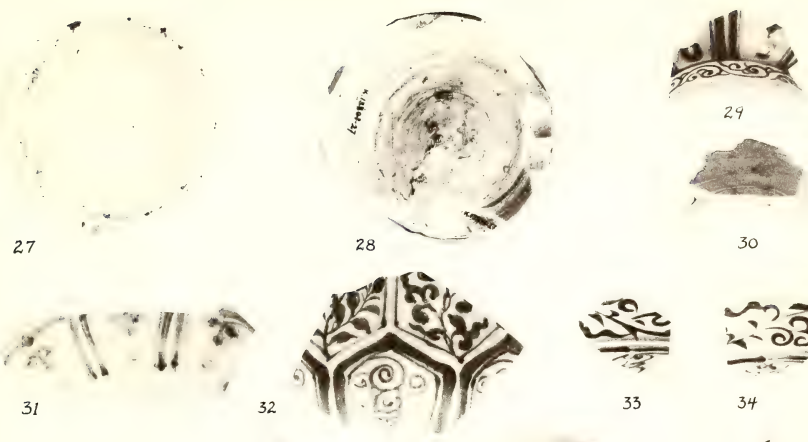

$$
31
$$

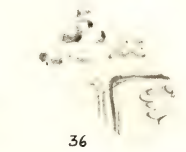

35

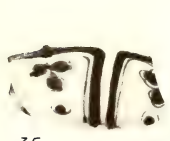

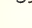

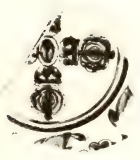

39
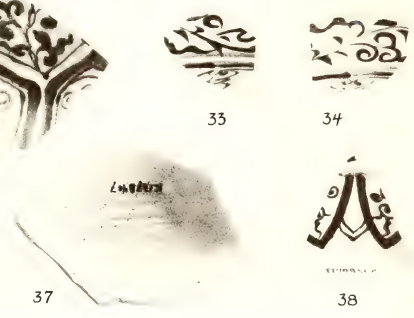

33

34

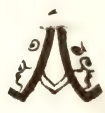

38
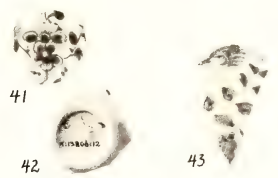

40

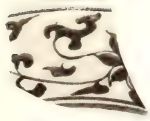

45

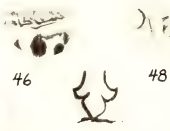

47

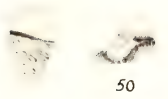

49

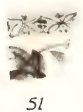

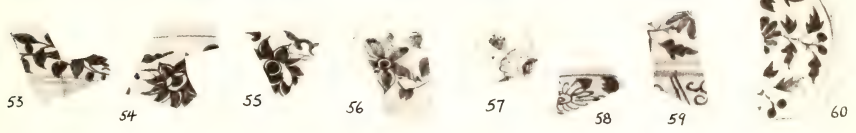


PLATE 135

A. Enameled glass flask. Damascus, c. A.D. 1300.

H. 10 in. $(25.5 \mathrm{~cm}$.).

Courtesy of the Toledo Museum of Art, gift of Edward Drummond Libby.

See page 87 .

B. Enameled glass basin. Syria, fourteenth century.

D. $11 \frac{1}{2}$ in. $(29.2 \mathrm{~cm}$. $)$.

Courtesy of the Metropolitan Museum of Art.

See page 89 . 


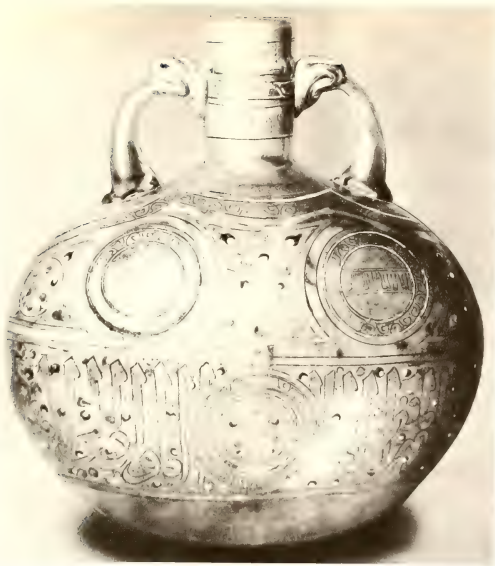

A

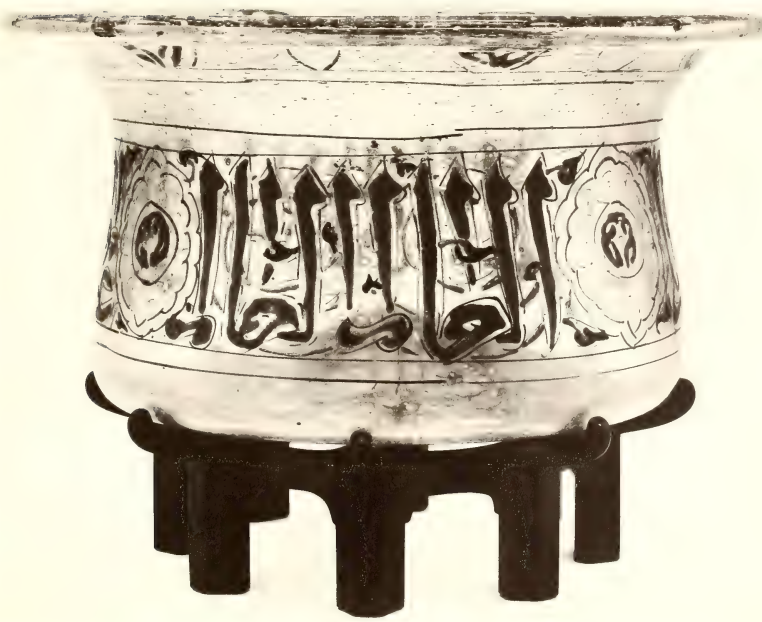




\section{PLATE 136}

A. Brass ewer inlaid with silver. Iran, not later than A.D. 1377. Benaki Museum, Athens.

H. 11 in. $(28 \mathrm{~cm}$.).

Photograph courtesy of D. S. Rice.

See page 87, n. 183 .

B. Tinned copper ewer with engraved designs. Iran, eighteenth century. Victoria and Albert Museum. H. $1911 / 16$ in. $(50 \mathrm{~cm}$.).

Courtesy of the Victoria and Albert Museum. Crown copyright.

See page 88 .

C. Vase of kuan shape. Chinese, late fifteenth century.

H. $7 \frac{1}{2}$ in. $(19 \mathrm{~cm}$. $)$.

Courtesy of the Victoria and Albert Museum.

See page 115 .

D. Flask. Top broken and ground down. Chinese, late fifteenth century.

H. 11 in. $(28 \mathrm{~cm}$.).

Courtesy of the Victoria and Albert Museum.

See page 116 . 


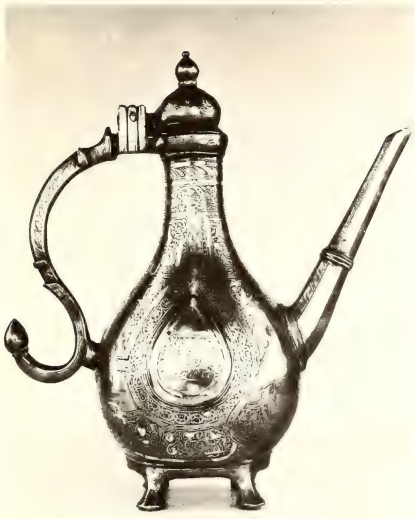

A

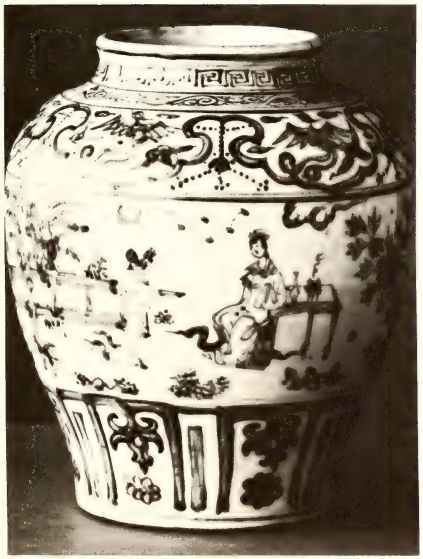

C

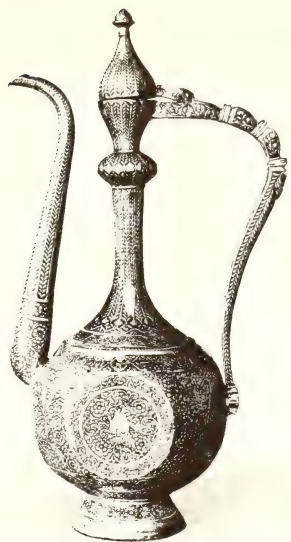

B

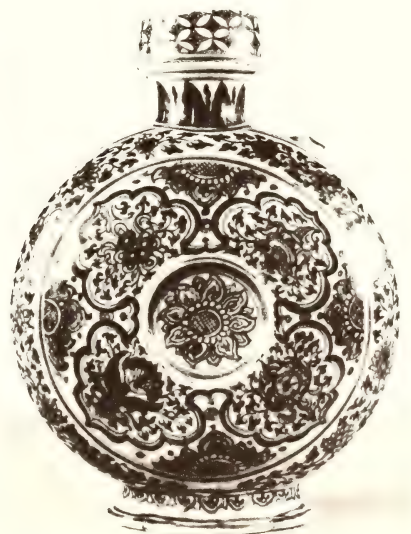

D 


\section{PLATE 137}

A. Upper part of a bronze vase with body in the form of a faceted cube. Iran, Seljük period, A.D. twelfth century.

H. $3 \frac{7}{8}$ in. $(5 \mathrm{~cm}$. $)$.

Collection of Richard Ettinghausen.

See page 88 .

B. Drinking vessel of kĕndi shape. Buff pottery with emerald-green glaze; 3-clawed dragons in relief on shoulder. Chinese, $\mathrm{T}^{\text {'ang }}$ or later.

H. 6 in. $(15.3 \mathrm{~cm}$. $)$.

Courtesy of Dr. Leonard B. Cox, Melbourne.

See page 117 .

C. Small dish with ch'i-lin design and brown rim; buff stoneware. South China (?), fifteenth or early sixteenth century.

D. $4 \frac{5}{8}$ in. $(11.8 \mathrm{~cm}$. $)$.

Author's collection.

See page 119 .

D. Fragment of a blue-and-white bowl with overlapping petal band and mark similar to that on 29.345 (pl. 63). Chinese, late fifteenth century.

Longest dimension 3 in. $(7.7 \mathrm{~cm}$.).

Author's collection.

See page 112 . 


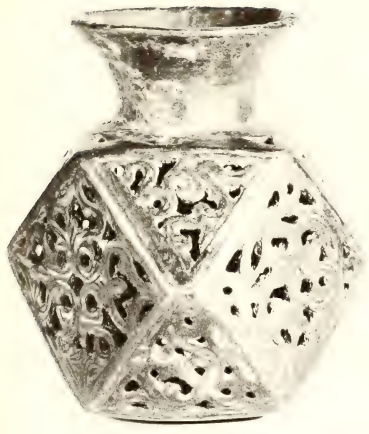

A

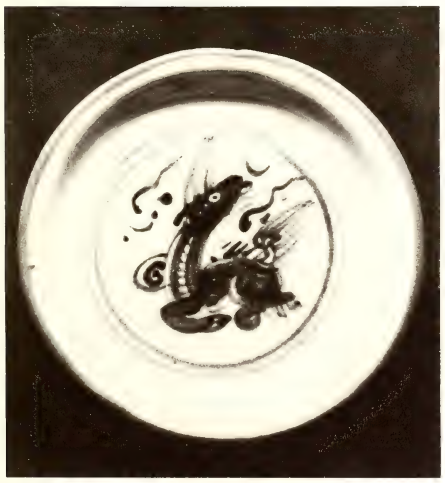

C

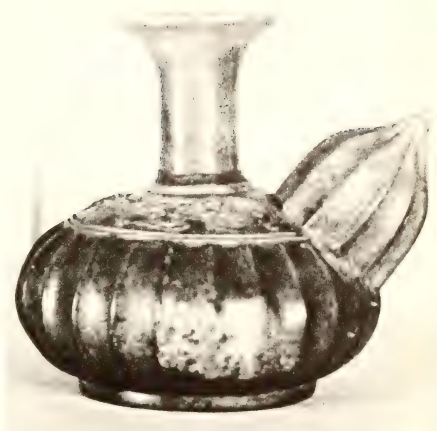

B

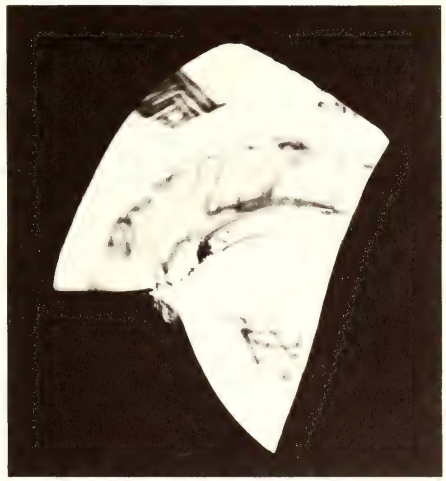

D 


\section{PLATE 138}

A. Blue-and-white vase of albarello shape. Chinese, early fifteenth century. H. $8 \frac{3}{8}$ in. $(21.2 \mathrm{~cm}$.).

Freer Gallery of Art (54.117).

See page 89.

B. Vase of mei-p'ing shape; solid dark-blue glaze decorated with 3-clawed dragon in white slip. Chinese, fourteenth century. (Cf. 29.747, pl. 119.)

H. $13 \frac{3}{4}$ in. $(35 \mathrm{~cm}$. $)$.

Courtesy of the Musée Guimet, Collection Grandidier.

See page 151 .

C-D. Blue-and-white dish decorated with Arabic inscriptions and cloud scrolls; outside are incised concentric waves; 6-character mark of the Hung-chih period.

D. $12 \frac{1}{2}$ in. $(31.7 \mathrm{~cm}$. $)$.

Courtesy of Sir David Home.

See pages 123,124 . 


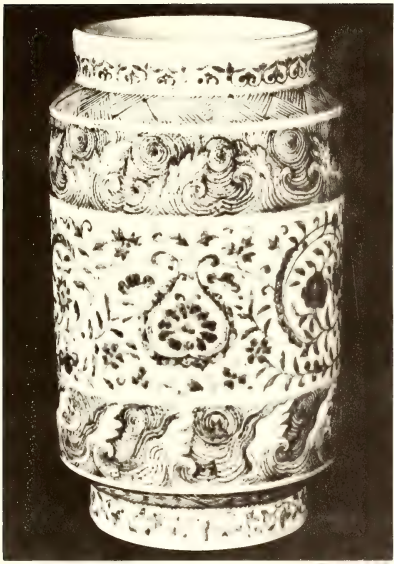

A

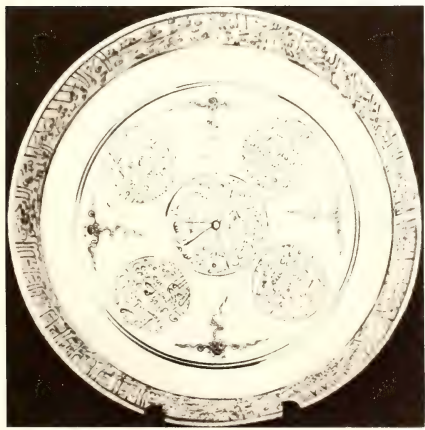

C

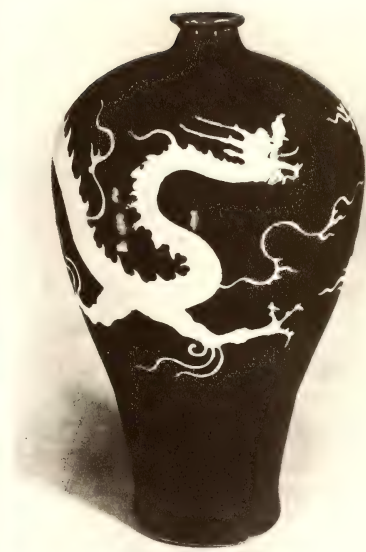

B

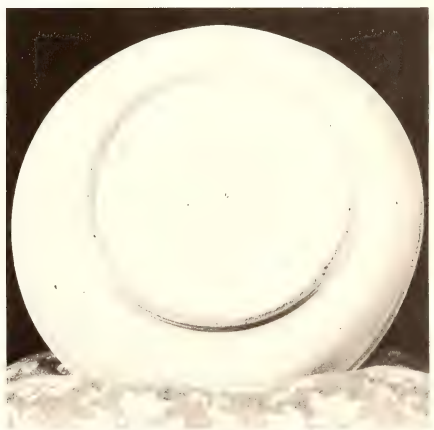

D 


\section{PLATE 139}

Sketches of foot profiles showing some of the variations found among the fourteenth-century dishes in the collection reproduced on plates $7-22$.

See page 60. 


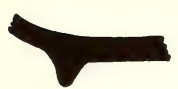

29.38

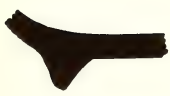

29.45

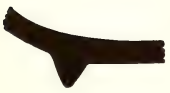

29.120

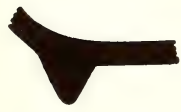

29.121

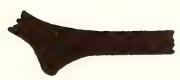

29.123

$$
29.127
$$
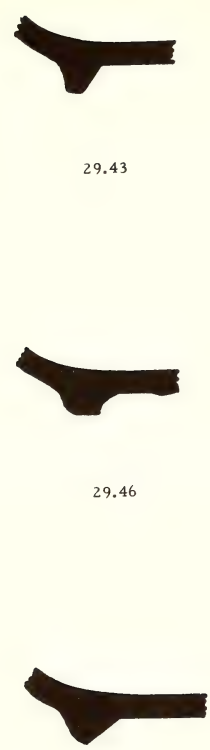

29.43

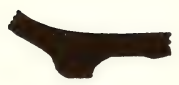

29.46

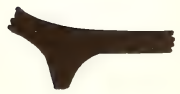

29.122 


\section{PLATE 140}

Sketches of foot profiles showing some of the variations found among the early-fifteenth-century dishes in the collection. It is of particular interest that the first 11 profiles on this plate are all from dishes of the "bouquet pattern" group, of which five examples are illustrated on plates 3031. No. 29.63 is the great dish with litchi nuts on plate 41 . 


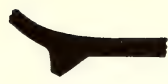

29. 1-7

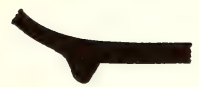

$29.8-11$

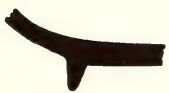

29.14

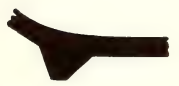

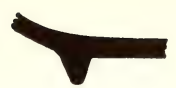

29.1-7

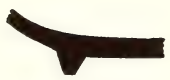

29. 8-11

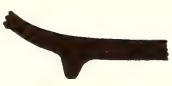

29.15

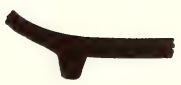

29.1-7

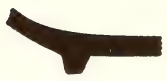

29.12

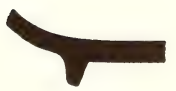

29.13

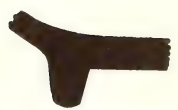


PLATE 141

Sketches of profiles

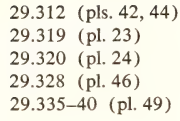




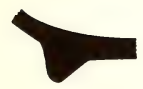

29.312

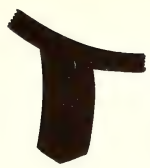

29.319
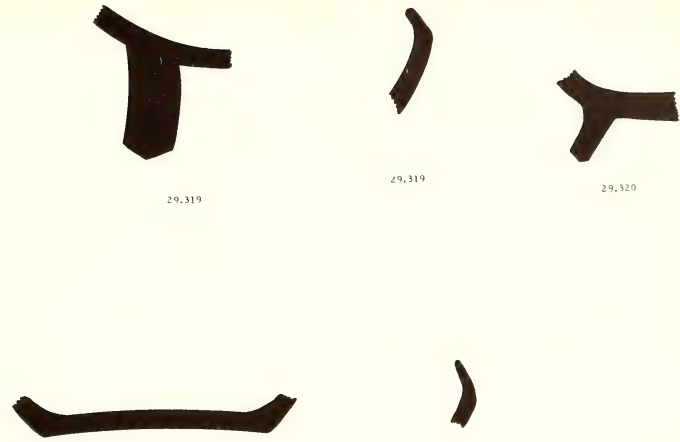

29.319

29.320

29.328

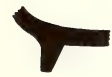

29.335

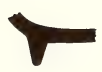

29.336

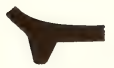

29. 338

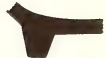

29. 340

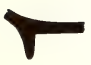

29.344

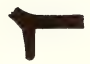

29.345

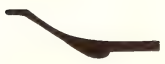

29.142

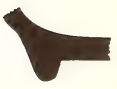

29,143 
PLATE 142

Sketches of profiles

29.313 (pls. 75-76)

29.131 (pl. 78)

29.164 (pl. 103)

29.154 (pl. 102)

29.172 (pl. 100)

29.203 (pl. 101)

29.205 (pl. 93)

29.208 (pl. 94)

29.231 (pl. 92)

29.136 (pl. 72)

29.747 (pl. 119)

29.423 (pl. 99)

29.655 (pl. 125) 


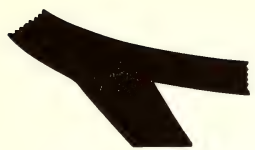

29.313

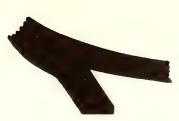

29.131

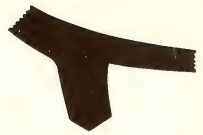

29.164

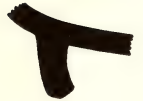

29.154

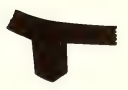

29.172

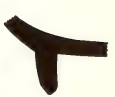

29.203

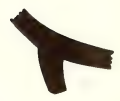

29.205

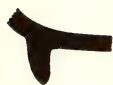

29.208

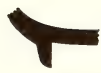

29.231

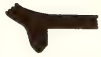

29.136

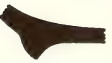

27.747

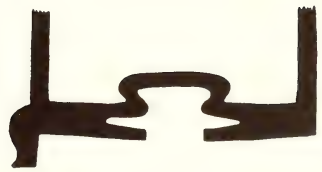

29655 



\section{INDEX}

(Plate numbers refer only to subjects mentioned in plate descriptions)

'Abbās I, Shāh ("The Great"), x, xi, 5-10, 19, $25,49,50,51-57,121,142$.

books of, 8, 13-16.

dedicatory inscription (vaqfnameh), 9, 17, $49,51,56,57,113,133,146,152,154$, 160 ; pls. $6,115$.

philanthropic program, 6-8.

porcelains listed by Jalāl ad-Dīn, 10, 11, 49. porcelains remaining today, $x, 49,50,159$, 160.

Abd el-Haqq, Selim, 70.

Abderrazak Samarqandi, 21n.

Abstract scrolls. See under Decoration: Scrolls.

Abū Bakr, 5.

Abū Sa‘īd, 53.

Abū Tālib, 54, 160; pls. 6, 53.

Àftābeh (ewer), 10, 11.

Aga-Oglu, Kamer, 104n., 124, 126.

Agate, 14, 15, 54n.

Akbar Shāh, 56, 146.

'Ālamgìr (Aurangzeb), 57.

Alamūt, Castle of, 5.

Albarello, 89; pl. 138A.

Albino dragon, 67, 80.

Aleppo, 69.

Alexander, Sir James, 15.

'Alī, 3, 9, 10, 14, 51, 54.

'Alī Shan Qarachaghāy Khān, 52n.

Altar sets, 60 .

Amalik, 21.

Amiot, Father, 22, 23.

Amsterdam, 136.

Amu Darya, 22.

Animals. See under Decoration; Shapes.

Annals of Fou-liang, 41.

Annamese ware, 103, 104, 118n., 119; pls. 56, 57.

Aq-qoyūnlu, 4.

Aquatic plants and scenes. See under Decoration.

Arab shipping, 24.

Arabia, 5, 24.
Arabic script, 34, 55, 121-124; pls. 75-77, 138

C-D.

Arberry, A. J., xii.

Archaeological finds, references to:

Ch'ing-ho Hsien, 39, 40.

Chü-lu Hsien, 40.

Fostāt, 60; pl. 131A-B.

Hamā, 69-72; pls. 131C-D, 132.

Kharakhoto, 69, 72-77, 100; pls. 133, 134.

Philippine Islands, 40, 120n., 126.

Ardebil:

History and location, $3 ;$ pl. 1.

Shrine:

Chïnī-khaneh, 6, 7, 12-17; pls. 2-4.

Dedication of the porcelains, 8-10.

History and description, 6-17.

Library, 8, 13-16.

Ashmolean Museum, 61n.

Ashpara, 21.

Astarābād, 6, 53.

Aster, 95, 96; pls. 43, 44.

Astrakhan, 3.

Aubin, J., xii, 8n.

Auspicious characters and objects. See under Decoration.

Ayers, John, xii, 60n.

Azalea, 95; pls. 42, 101.

Azerbaijan, 3, 52.

Badakshan, 23n.

Bädiyeh (wine cups), 10, 11.

Baghdad, 4.

Bahrami, Mehdi, xii, 8n., 10n., 53n., 54n., 113, $146 n$.

Balkh, 21.

Baluster vase, 157 ; pl. 129.

Bamboo. See under Decoration.

Banana, 66, 109, 127; pls. 12-14, 22, 26, 73, 83.

Bands. See under Decoration. 
Baptistère de St. Louis, 89.

Bardlis, Mount, 8.

Barnham, Denis, 61n.

Barreto, Padre Belchior Nunes, 135n.

Barrett, D. E., 122n.

Barsin, Miss, xii.

Barthold, W., 154n.

Basin, 88, 112n., 119; pls. 70, 135B.

Bat, 130; pl. 92.

Battuta. See Ibn Battuta.

Beaded strings or pendants. See under Decoration.

Beal, S., 117n.

Beasts, 137.

Bee, 68, 137; pl. 26.

Beh-bood Khan, 53n.

Behbūd, 53, 54; pls. 6, 49, 53.

Behbut-Beg (variant of Behbūd), 53.

Bellan, L-L., 8.

Benaki Museum, 87n.; pl. 136A.

Bergman, Folke, 72n., 74; pls. 133, 134.

Beveridge, A. S., 54n.

Bỉbī Fātima, 3.

Birds. See under Decoration.

Bird-shaped vessel, 133.

Bīrūnī, 19.

Blackberry lily. See under Decoration.

Black enamel, 113; pl. 61.

Bloxam Collection, 128.

Blue-and-white:

Annamese, 103, 104, 118n., 119; pl. 56, 57.

Beginnings in China, 38-45.

Evidence for fourteenth-century date, 69-77.

Japanese, 34n.

Physical characteristics, 59, 60, 84, 108, 123.

Quality of the blue, 65, 84, 108.

Shapes, 60-65, 85-89, 116-118. See also

Shapes of porcelains.

Shards, 39, 40, 60, 70, 74-77.

Style of decoration:

Early fifteenth century, 89-100, 141, 142.

Fourteenth century, 65-69, 141.

Hung-wu, 77-81.

Kraakporselein, 136-140.

Late fifteenth century, 107-120, 142.

Mid-fifteenth century (Interregnum), 101-105.
Blue-and-white-continued

Style of decoration-continued

Sixteenth century, 121-142.

Summary of development, 141-142.

Transition wares, 34n., 132n., 141.

White on blue, $65,67,68,96$; pls. $16-$ 23.

Blue wares, 151.

Bluett, Edgar E., 40, 144n.

Bodleian Library, 8.

Böckler, George Andreas, 135n.

Books in decoration, 139.

Books of Shāh 'Abbās, 8, 13-16.

Bottle-shaped vases. See under Shapes.

Boucher (or Bouchier), Guillaume, 135n.

Bouquet patterns. See under Decoration.

Bowls. See under Shapes.

Boxer, C. R., 57, 135n.

Box-shaped vessels, 121.

Brankston, A. D., 83n., 85n., 109, 111n., 146n.

Brass mounting, pl. 53.

Bretschneider, E., 22n., 23.

British Museum, 8, 61n., 63, 119, 127n., 128n., 140n., 151n.

Bronze, Chinese, 87, 90.

Brown dressing on base, pl. 57.

Brown wares, 151, 159, 160.

Browne, Edward G., 3n.

Brush rests, 121.

Bruyn, Cornelis de, ix.

Bucket shape, 131; pl. 96.

Buddhist symbols, 110, 111; pls. 23, 72 .

Bulbul, 97, 111.

Burlington House Exhibition, Chinese art, 95n., $151 \mathrm{n}$.

Persian art, 17, 54n.

Burrell Collection, 80.

Bushell, Stephen W., 27, 28, 30, 31, 36, 42, 43.

Butterfly, 118, 128, 130, 137, 149; pls. 71, 90, 117.

Caliphs of the Sunnīs, 5 .

Calystegia hederacea, pls. 43, 44.

Cambaluc (Peking), 21.

Camellia. See under Decoration.

Cammann, Schuyler, 36n. 
Candlestick, 121, 122n.

Canton, 24.

Carnation, 93; pl. 43.

Carp, 131, 132; pl. 11.

Carved decoration, 155, 157; pls. 90, 129, 130.

Cash pattern, 76, 137, 155; pls. 55, 123.

Caspian Sea, ix, 3, 142.

Cat. See under Shapes.

Cavetto, molded, $85,143,144,156$; pls. $33,35-$ $37,41,112$.

Celadon, 42, 49, 61, 62, 70, 76, 153-158; pls. 121-130.

northern, 154.

Ceramic interregnum, 101-105; pls. 47, 49, 51, $56,57$.

Cervidae, 138.

Chaghatay, 22.

Chaldirān, 5.

Chang Hsien-i, 39n.

Ch'ang-ming-fu-kuei, 161.

Chang T'ien-tse, 25n.

Chang Wen-chin, 59.

Chau Ju-kua, 23, 24, 43n.

Chays Khan, 20n.

Chehel Sotūn, 56, 57, 159.

Chekiang Province, 30, 153, 157.

Cheng Ho, 24.

Ch'eng-hua, 23, 84, 94, 101, 105, 107-112, 114$118,132,133,140,142,146,149,160,161$; pls. $115,137 \mathrm{D}$.

Ch'eng-hua marks, 34, 107, 109, 112n., 146, 149, 150 ; pls. 60,115 .

(apocryphal), 132; pl. 96.

Cheng $\mathrm{P}^{\mathrm{u}} \mathrm{u}, 39 \mathrm{n}$.

Cheng-te, 23, 34, 35, 88n., 99, 114, 115, 121$124,141,146,149,151$; pls. 75, 76, 115-117.

Cheng T'ing-kuei, 27n., 30.

Ch'eng-tsu, 24.

Cheng-t'ung, 23, 102.

Cherry, pls. 42, 47, 56.

Chia-ching, 23, 31, 34, 35, 98, 113-115, 121, $125-128,132,140,141,147,150,151,160$, 161 ; pls. 79-82, 87, 91, 118.

Chia-ching marks, 35, 125, 126, 127n., 128n., 129, 135n., 136n., 150, 151, 160; pls. 79-82, 91, 118.

Chiang Ch'i, 41-43.
Chiang-hsi-ta-chih, 31.

Chien (trigram), 138.

Ch'ien-lung, 30, 92.

Chih-cheng, 59.

Chih-hu. See under Shapes.

Chihli Province, 30.

Chih-yüan, 74.

Children, 113; pl. 68.

Chi-lin. See under Decoration.

Chi-yu (cyclical year), 41.

Chi Yüan-sou, 43n.

Chin Tatars, 102.

Chinese influence on Near Eastern forms, 45, 87, 88.

Chinese water deer, 138; pl. 100.

Ching-chih (mark), 161.

Ch'ing Dynasty, 28, 30-33, 41, 66, 92, 130, 140, 141, 153.

Ch'ing-ho Hsien, 39, 40.

Ch'ing-hua, 43, 44; pl. 30.

Ch'ing-pai, 42, 43, 62, 86, 143, 158.

Ch'ing-pi-tsang, 32n.

Ching-t'ai, 23, 102.

Ching-te Chen, 30, 38, 39, 43, 89, 103n.

Ching-te-chen-t'ao-lu, 27-30, 36, 41, 42.

Chīni-khaneh, 6, 7, 12-17; pls. 2-4.

Chīnī-serai, 13.

Chinoiserie, 87.

Ch'iu Yüeh-hsiu, 27n.

Chou Li-ching, 39n.

Chronological data, xv.

Chrysanthemum. See under Decoration.

Chu-fan-chih, 23, 43n.

Chï-lu Hsien, 40.

Ch'un (spring), 80n., pl. 9.

Chün ware, 61, 62, 134.

Chung-t'ung, 74.

Chu Wen-tsao, 27n., 30.

Chu Yen, 27, 28, 30-32, 38, 39, 84n., 101.

Chu Yü, 24.

Chu Yüan-chang, 27.

Clark, Mrs. Alfred, xii, 80, 151n.

Classic scroll. See under Decoration: Scrolls.

Clavijo, Ruy Gonzalez de, 20, 21, 25.

Cleaves, Francis W., xiii, 73n.

Cloud collar. See under Decoration.

Cloud scroll. See under Decoration: Scrolls. 
Clouds. See under Decoration.

Cobalt, 44, 65, 66, 84, 96, 102, 107, 108; pl. 21. Coffee-brown glaze, 151.

Coins, Iranian, 53, 54.

Colasanti, Arduino, 135n.

Collections of Chinese porcelain:

Ardebil, passim.

Ashmolean Museum, 61n.

Bloxam, 128.

British Museum, 8, 61n., 63, 119, 127n., 128n., 140n., 151n.

Burrell, Sir William, 80.

Clark, Mrs. Alfred, xii, 80, 151n.

Cox, Leonard B., 117; pl. 137B.

Cunliffe, Lord, 94n.

David, Sir Percival and Lady, 79n.

See also Percival David Foundation of Chinese Art, below.

Eumorfopoulos, G., 62n., 63n., 145n.

Fitzwilliam Museum, 110n.

Freer Gallery of Art, 65n., 94n., 96n., 98n., 105n., 109, 110n., 115, 125n.; pl. 138A.

Glasgow Art Gallery, 80.

Grandidier, 151; pl. 138B.

Home, Sir David, 123; pl. 138C-D.

Jakarta Museum, 118.

Lo Chen-yü, pl. 60.

Mallett, Francis, 61n.

Metropolitan Museum of Art, 34, 97n.; pl. 135B.

Musée du Cinquantenaire, $104 \mathrm{n}$.

Musée Guimet, pl. 138B.

Museum of Eastern Art, pl. 126.

Nelson. See William Rockhill Nelson Gallery of Art, below.

Nezu Museum, 95n.

Palace Museum, 127n., 145.

Percival David Foundation of Chinese Art, 34n., 59, 69, 80n., 109, 115, 151n., 154.

Pope, John A., 94n., 112, 119; pls. 110, 137C-D.

Princessehof Museum, 99n., 111n., 126, 133n.

Riesco, R. F. A., 40.

Sedgwick, Mrs. Walter, xii, 57.

Seligmann, Mrs. C. G., xii.

Topkapu Sarayı Müzesi, 59, 60, 75, 79, 86, 89n., 94n., 95n., 103, 109n., 118, 126,
Collections of Chinese porcelain-continued 133, 135n., 136n., 153, 156. See also Istanbul.

Victoria and Albert Museum, 56, 57, 68n., $76,115,116,132 n ., 151$ n.; pls. 6,136 B-C-D.

Walters Art Gallery, 52n., 57, 139n.; pl. 6.

William Rockhill Nelson Gallery of Art, 34, 62n., 64n., 97n.

Wu Lai-hsi, 80n.

Commelina communis, pls. 43, 44 .

Concentric bands, 79 .

Concentric pattern, 67.

Concentric waves, 66, 116; pls. 7, 15, 23, 138D.

Conch, 116; pl. 69.

Confucius, $94 \mathrm{n}$.

Conical bowls, 86, 98, 105; pls. 47, 48.

Constantinople, 17.

Constellations, 119.

Coomaraswamy, A. K., 117.

Copenhagen, 70, 139.

Coturnix coturnix, 138.

Counterweight for a mosque lamp, 100.

Cox, Leonard B., 117; pl. 137B.

Coxcomb, 34n., 95, 96; pl. 42.

Crabapple. See under Decoration.

Crane. See under Decoration.

Crapemyrtle. See under Decoration.

Crescent moon, 108, 119, 128; pls. 59, 73, 88.

Cross in a double circle, 162.

"Cuffick character," 14.

Cunliffe, Lord, 94n.

Cup, 139, 140; pls. 108, 109.

Cup stand, 79; pl. 29.

Cyclical date, 41 .

Damascus, 19, 69.

Dandelion, 95; pls. 42-44.

Danish archaeologists, 69.

David, Abbé Armand (his deer), 131, 132, 138; pls. 91, 96.

David, Lady, xii, 79n.

David, Sir Percival, xii, 28, 31n., 32n., 39n., 41n., 43n., 84n., 133, 134n., 135n.

David Foundation. See under Collections: Percival David Foundation of Chinese Art. 
Day lily, pls. 42, 44.

Decoration:

Albino dragon, 67.

Animals, recumbent, 119, 139, 151; pls. 73, $106,120$.

Animal's head, 116.

Aquatic plants, 57, 66, 92, 113, 124, 137, $139,149,150,161$; pls. $7-9,36,42,64$, $66,106,116$.

Aquatic scenes, 66-68, 71, 74, 75, 112.

Arabic script, 34, 55, 121-124; pls. 75-77, 138C-D.

Aster, 95, 96; pls. 43, 44.

Auspicious characters, 126, 128, 129; pls. 80, 86, 89, 90.

Auspicious objects, 68, 119, 138-140, 149; pls. $19,21,26,50,73,86,100,106,108$, 117.

Azalea, 95; pls. 42, 101.

Balustrade, 110n., 129; pl. 89.

Bamboo, 66, 93, 108, 126, 127, 129, 142, 149; pls. $12-14,22,24,26,40,44,47$, 59, 60, 80, 83, 89, 91, 107, 117.

Banana, 66, 109, 127; pls. 12-14, 22, 26, $73,83$.

Bands, 68, 79, 112, 116; pls. 34, 105, 106.

Bat, 130; pl. 92.

Beaded strings or pendants, 114, 137, 139; pls. $69,74,102,103,106,108$.

Beasts, 137.

Bee, 68, 137; pl. 26.

Birds, 75, 97, 111, 115, 126, 128, 129, 137, $139,140,149$; pls. $63,81,87,89-92$, 100-103, 105, 108, 109, 116.

Biscuit, modeled or molded, 133, 151; pl. 97.

Blackberry lily, 77, 90, 100; pls. 14, 22-24, 54.

Blade forms, 76, 77.

Blossoms. See various flowers by name.

Books, 139.

Bouquet, 71, 75, 92, 93, 144; pls. 30, 31, 110.

Brocaded ball, 57, 108, 149; pls. 26, 58, 82.

Bud, 68, 93; pls. 26, 27, 32, 33, 54.

Buddhist symbols, 110, 111; pls. 23, 72.

Bulbul, 97, 111.
Decoration-continued

Butterfly, 118, 128, 130, 137, 149; pls. 71, 90, 117.

Calystegia hederacea, pls. 43, 44.

Camellia, 90, 91, 93, 112, 124; pls. 17, 21, $33-36,42,44,61,78$.

Carnation, 93; pl. 43.

Carp, 131, 132; pl. 11.

Carved, 155, 157; pl. 90, 129, 130.

Cash pattern, 76, 137, 155; pls. 55, 123.

Cervidae, 138.

Cherry, pls. 42, 56.

Chevron band, pl. 55 .

Children, 113; pl. 68.

Chi-lin, 67, 119, 129, 134, 136; pls. 26, 71, $73,89,99,117,137 \mathrm{C}$.

Chinese water deer, 138; pl. 100.

Chrysanthemum, 67, 68, 75, 77, 90, 91, 93, 99,100 ; pls. $14,17,19,21-23,26,33$, $34,36,40,42,111$.

Circles, 68, 122, 123, 138; pls. 27, 47, 48, $55,64,76,77,86,100,106,123$.

Classic scroll. See under Scroll, below.

Clematis, pl. 23.

Cloud collar, 67-69, 75, 115, 116, 139; pls. $16-19,21,23,25,26,28,52,54,56,69$, $85,86,106$.

Cloud scroll. See under Scroll, below.

Clouds, 35, 91, 99, 109, 110, 115, 119, 128-130, 137, 138, 144n., 147; pls. 15, $48,60,68,79,81,86,88,89$.

Commelina communis, pls. 43, 44 .

Concentric bands, 79 .

Concentric pattern, 67.

Concentric waves, 66, 116; pls. 7, 15, 23, 138D.

Conch, 116; pl. 69.

Constellations, 119.

Convolvulus, pl. 33.

Coturnix coturnix, 138.

Coxcomb, 34n., 95, 96; pl. 42.

Crabapple, 67, 95, 96, 111; pls. 22, 23, 43, $44,63,101$.

Crane, 126, 128, 130, 131, 138; pls. 81, 86, $88,93,95,100$.

Crapemyrtle, 66, 77, 90, 100; pls. 14, 22, 24, 54. 
Decoration-continued

Crescent moon, 108, 119, 128; pls. 59, 73, 88.

Dandelion, 95; pls. 42-44.

David's deer, 131, 132, 138; pls. 91, 96.

Day lily, pls. 42, 44.

Deer, 118, 126, 129-132, 138, 139; pls. 71, $81,91,92,96,100-103,107$.

Diamond, 66, 76, 127, 137, 140, 155, 157; pls. $8,9,13,15,26,86,87$.

Diaper pattern, 66, 76, 89, 127, 128, 137, 140,157 ; pls. $25,26,55,64,85,87,89$, 102, 103, 105, 109, 123, 129.

Doe, pl. 71.

Dove, 130; pl. 92.

Dragons, 33-38, 67-69, 75, 80, 91, 96-99, $130,136,142$; pls. $28,71,92$.

5-clawed, 33-38, 80, 125, 144; pls. 50, $79,110$.

4-clawed, 36, 75, 126; pl. 79.

3-clawed, 34, 75, 80, 96, 151; pls. 15, 45, 48, 53, 119, 137A, 138B.

winged, 110,$119 ;$ pl. 70.

with foliate tail, 110, 116; pl. 62 .

Dragonfly, 128, 149; pls. 88, 116.

Duck, 57, 66, 74-76, 112, 120, 139; pls. 7, $65,74,106$.

Duckweed, pls. 9, 11.

Eagle, 161n.

Eelgrass, 66; pls. 9, 11.

Egret, 67; pl. 18.

Elaphurus davidianus, 132.

Elephant, 129, 149; pls. 91, 117.

Fan, 139; pl. 66.

Fern, 95, 105; pls. 43, 51, 56, 69.

Fighting cock, $34 \mathrm{n}$.

Figures (human), 68, 109, 110, 127, 128, 139,150 ; pls. $86,106,108$.

Fish, 66-68, 112, 113, 124, 149; pls. 9, 11, $64,65,67,68,96,116$.

underglaze red, 149, 150; pl. 118.

Flame scroll, 113, 119, 139; pls. 69, 70, 106.

Flames, 119, 136, 149; pls. 50, 73, 82, 89, 117.

Flaming jewel (or pearl), 75, 151; pls. 48, 60.

Flaming wheel, 111; pls. 66, 105.
Decoration-continued

Floral motifs and flowers in general, 79, 89$100,109,111,114,115,119,124,126$, 130, 136-140, 145-150, 151n., 155, 156. See also various flowers by name.

Foliage and foliate patterns, 70, 75-77, 122, 139 ; pls. 28,72 .

Foliate tail. See Dragon.

Fountain, 134-136; pl. 99.

Fruit, 91, 92, 94, 96-98, 140, 145, 149; pls. $32,40,42,46,47,49,51,52,56,76,83$, $87,92,105,113,115$.

$F u$ (happiness), 126, 130, 149; pl. 117.

Fungus, 90, 91, 92, 108, 112, 116, 118, 130, $137,139,144$; pls. $29,33-35,37,40,41$, $54,55,59,65,69,71,72,82,83,92,100$, $106,112$.

Garden scenes, 113, 128, 130; pls. 60, 68 .

Gardenia, 67; pls. 22, 42.

Gilt, 143, 144.

Gold, 144, 149; pls. 111, 113, 117.

Gold mounting, 145; pl. 113.

Golden pheasant, 130; pl. 92.

Goose, 76, 130, 151n.; pl. 92.

Gourd, 139.

Grape, $66,68,70,94,126$; pls. 13, 16, 22, 24, 26, 29, 37-39, 56, 81, 94.

Grass, pls. 9, 89.

Hare, 132, 133; pl. 96.

Hawk, 132; pl. 96.

Heron, pl. 94.

Hexagram, 138; pl. 100.

Hibiscus, 91, 93; pls. 34, 37, 55.

Hindu symbols, 111.

Horse, 128, 139, 147; pls. 71, 82, 87, 105, 106, 109, 114.

Hsi (joy), 126.

Hundred antiques, pl. 109.

Hydropotes inermis, 138.

Impressed, 157; pl. 124.

Incised, 96, 112, 143-147, 151, 155-157; pls. $45,50,53,89,110,112-115,121-$ 127, 138D.

Insects, 137; pl. 87, 91, 94, 99, 100, 102, 108.

Jeweled strings, pl. 79 .

Kinrande, 144n.

Knotweed, 95, 96, 112; pls. 42, 43, 64. 
Decoration-continued

Landscape, 91, 94-96, 108-110, 118, 126$132,138,139,150$; pls. $42,43,59,63$, $71,81,83,86,89,91-96,99-103,105$, 106, 108.

inverted, 129, 130.

Leaves, 40, 41, 57, 70, 71, 75, 77, 90, 92$94,100,110,114-116,118,140,144$; pls. $7,12,27,32-34,36,37,39-41,46$, $47,50-52,54,56,57,69$. spiky, 66, 68, 70, 71; pls. 7-22, 24, 26. stiff, 136,157 ; pls. $54,69,74,99,109$, $115,129,130$.

Lily, 95 ; pls. $42-44$.

Ling-chih, 90.

Lion, $57,108,126,129,149,150$; pls. 26 , $58,82,89,99,116,117$.

Litchi, 94, 95, 156; pls. 41, 56, 140.

Lotus, $35,66,77,110,120,131,142,155$; pls. $64,65,95,101$.

Lotus blossom, 61, 71, 76, 90, 92, 93, 110, 128 ; pls. $32-34,36,39,46,47,56,66$, $69,71,72,74,89,121,128$.

Lotus bouquet, $71,75,92,93,144$; pls. 30 , $31,110$.

Lotus bud, 68; pls. 26, 27, 32, 46.

Lotus leaves, $71,90,92,110$; pls. $34,36,46$, 54.

Lotus panel, 66-68, 71, 75, 76, 79, 92, 97, $98,123,139,140,156,157$; pls. $7,8,12$, $19,21,23-27,47,50,51,54,55,57,61$, $64,69,77,83,85,87,100,106,109,115$, 126, 129.

Lotus petal, 99, 145; pls. 20, 29, 46, 48, 55, $79,113$.

Lotus plant, pls. 94, 100, 101, 121, 127.

Lotus pond, 66, 74; pls. 7, 8, 22.

Lotus scroll. See under Scroll, below.

Lotus spray. See under Spray, below.

Lotus wreath, 66, 71, 90; pls. 7-22, 24.

Lozenge, 140,155 ; pl. 86.

Magpie, 137, 138; pl. 100.

Man in a boat, 130 .

Mandarin duck, 130; pl. 92.

Meander, pl. 52.

Medallion, 79, 111, 126, 128, 133, 138-140, 150,157 ; pls. $17,54,86,89,97,103$, 105, 106, 108, 109, 128.
Decoration-continued

Melon, 67, 70, 85n., 92, 94; pls. 12, 13, 16, $22,26,40,91$.

Monster, pls. 71, 96.

Moon, $108,119,128$; pls. $59,73,88$.

Morning-glory, 67; pls. 13, 17, 22, 24, 26, $35,36$.

Moss-grown wall, 94; pl. 39.

Mountain, 95, 129, 131, 139.

Narcissus, 95; pls. 42-44.

Nightshade, 95; pls. 42-44.

Outline and wash, 85, 98, 100, 102-104, 108-115; pl. 56.

Overglaze enamel, 113, 130, 149, 150; pls. $61,93,104,116-118$.

Overlapping petal band, 112, 116; pls. 69, 105, 106, 137D.

Pagoda, 130.

Pai-ts'e, 68, 129, 149; pls. 25, 26, 28, 91, 117.

Palace, 109, 110; pls. 60, 86 .

Palm, 95; pls. 42, 66 .

Panel. See Lotus panel, above.

Parakeets, 95, 97.

Park, fenced, pl. 96.

Pavilion, 128, 130; pl. 92.

Peach, 94, 95, 98, 112, 128, 129, 149; pls. 40, 42, 46, 54, 65, 90, 94, 117.

Peafowl, 68, 119, 133; pls. 23, 27, 28, 72, 78, 98.

Pennisetum japonicum, 95; pls. 43, 44.

Peony, 68, 69, 75, 79, 91, 93, 98, 99, 103, 119,133 ; pls. $21,23,28,32-35,37,42$, $54,56,57,98,101$.

Peony blossom, pls. 33, 34, 36.

Peony buds, pl. 32 .

Peony leaves, 77 ; pl. 57.

Peony scroll. See under Scroll, below.

Peony spray. See under Spray, below.

Peony tree, 124, 155; pls. 72, 78, 122.

Peony wreath, 67, 90; pls. 17, 19, 22.

Persian inscription, 55, 121; pls. 20, 51.

Persimmon, pl. 56.

Petal, 119, 157; pls. 57, 69, 113. See also Lotus petal, above.

Petal band, 112, 116, 119; pls. 69, 105, 106, 137D. 
Decoration-continued

Phoenix, 35, 37, 67, 68, 116, 118, 140, 142, 144 n.; pls. $17,19,21,22,25,28,69,71$, 98, 109.

Pica pica, 138.

Pine, 93, 95, 118, 126, 128-130, 139, 142; pls. $40,42,44,47,60,71,80,86,91$, 107.

Pine needle, pls. 44, 74.

Pinks, pl. 55.

Plantain, 95, 105, 119; pls. 43, 44, 51, 56, 69.

Plants, 66, 90; pls. 43, 44, 73, 74, 92, 100, 101, 108. See also Aquatic plants, above. terrestrial, 66.

Pomegranate, 90, 128; pls. 33, 42, 87.

Poppy, pls. 21, 27.

Praying mantis, 68; pl. 26.

Primrose, 95; pl. 42.

Prunus, 93, 108, 109, 126, 128, 129, 142; pls. $40,44,47,59,60,80,88-90,92$, 107.

Quail, 138.

Radial segments, 137.

Rectangles, pl. 88.

Relief, 67, pls. $123,125,127-130$.

Rocks, 34n., 66, 93, 95, 96, 108, 109, 119, 124, 129-131, 133, 137, 139, 149; pls. $12,13,22,28,59,72,78,79,89,92,96$, 98, 101, 108, 109, 117.

Roses, 91; pls. 33, 41, 43, 71, 100, 101.

Rosette, pl. 55.

Roundel, 122, 126, 129; pls. 75, 81.

Sage in a landscape, 139.

Sagittaria, 92; pls. 30, 31, 36.

Sanskrit characters, 64n., 112.

Scalloped band, pls. 34, 105.

Scholars, 109; pl. 60.

Scrolls, abstract, 68, 115, 116.

camellia, 112, 124; pls. 21, 61 .

chrysanthemum, $75,100,144$; pls. 21 , $22,29,55$.

classic, $66,68,75,76,89,97,114$, 119,124 ; pls. $11,12,23,25,26,30$, $32,36,45-48,54,55,70-74,78$.
Decoration-continued

Scrolls-continued

cloud, $100,119,123,128$; pls. 17, 18, $21,45,55,66,70,71,73,79,87$, $89,93,105,109,138 \mathrm{C}$.

crapemyrtle, 66 .

flame, 113, 119, 139; pls. 69, 70, 106.

floral. See Floral motifs. . . .

foliage or foliate, $70,76,77$; pls. 40 , $55,56,72,75,76,79,93,109$.

fungus, $90,112,139,144$; pls. 29, 33$35,40,41,65,69,72,82,83,92$, 112.

hibiscus, pl. 55.

leafy. See foliage or foliate, above.

lotus, 68, 76, 77, 90, 97-99, 109, 116, $118,126,127,134,139,156,157$; pls. $7,9,11,13,23,25,26,28,34$, $51-57,64,69,71-74,79,85,127$, 129.

peony, 68, 76, 90, 98, 124, 156; pls. $17,19,21-23,25-27,32,55,56$, $78,123$.

poppy, pl. 27.

tight, 57.

undefined, 57, 98, 99, 115, 116, 155; pls. $21,51,52,54,55,57,69,71$, $82,87,90,91,94,101,105,106$, $109-111,113,121$.

vine, pls. 26, 30, 32-36, 39, 40, 45-47. waterchestnut, pl. 55.

Scrollwork, 71.

Seahorse, 129; pl. 89.

Sea perch, pl. 9.

Seascape, pl. 89.

Sedge, pl. 43.

Seed pod, 92.

Serpentine waves. See under Waves, below. Shell, 116.

Shou (longevity), 80n., 126, 128, 129; pls. $80,86,89,90$.

Shrubs, pls. 101, 102, 109.

Sika, 138; pl. 107.

Slip, 62, 67, 75, 80, 98, 138, 139, 143, 144, 151 ; pls. 22, 48, 106, 108, 119, 138B.

Spiky leaves. See under Leaves, above. 


\section{Decoration-continued}

Sprays, camellia, pls. 32, 37, 42.

cherry, pls. 42, 47, 56.

chrysanthemum, $68,91,93,145$; pls. $14,17,23,28,32,33,35,37,42$, $54,113$.

day lily, pl. 42.

floral. See Floral motifs. . . .

fruit, $91,92,97,145$; pls. $32,40,42$, $46,47,51,52,56,83,92,105,113$, 115 .

fungus, 91, 92, 137; pls. 29, 33, 37, 41, 54, 55, 71, 100.

gardenia, pl. 42.

grape, pls. 29, 56, 94.

hibiscus, pl. 37.

leaf. See Leaves.

litchi, pl. 56.

lotus, 69, 136; pls. 12, 19, 23, 28, 33,

$35,50,51,54,62,124$.

morning-glory, pl. 35 .

narcissus, pl. 42.

peach, 98,112 ; pls. $42,46,54,65,94$. peony, 79,91 ; pls. $21,23,33,35,37$, $42,54,56,101$.

persimmon, pl. 56.

pomegranate, pls. 32,42 .

poppy, pls. 21.

prunus, pl. 90.

rose, pls. $33,41,71,100,101$.

vine, pls. 33,72 .

Squares, 155.

Squirrels, 126; pls. 81, 91.

Stamped, 157; pls. 124, 127, 128.

Starlike flower, 112.

Sui-han-san-yu, 93.

Sun, 113; pl. 68.

Swastika, 127, 140; pls. 85, 109.

Symbols, pls. 66, 109.

Taoist paradise, 110n.

Teal, 132; pl. 97.

Tendrils, 70, 94; pls. 37, 39.

Terrace, 110n., 129; pl. 89.

Three friends (of winter), 93, 98, 109, 128, 129; pls. 40, 44, 47, 60, 86, 89, 107.

Thunder pattern, 76, 89, 90, 97, 116; pls. $30,36,40,45-47,54-56,69,99,109$, 110.
Decoration-continued

Tibetan script, 111; pl. 66.

Tiger lily, pl. 44.

Tortoise, 129; pl. 91.

Trees, 137; pls. 86, 92.

Trefoil, 110,157 ; pls. $34,46,54,56,61,62$, $65,69,109,129$.

Trigrams, 138.

Vajra, 76, 110; pls. 23, 62 .

Vines, 67, 85n., 90, 94; pls. 26, 30, 32-40, 45-47, 72 .

Waffle pattern, 155.

Wash, graded, 96, 108, 131.

Wash with outline. See Outline and wash.

Waterchestnut, pls. 9, 11, 55.

Waterfall, 129, 130; pl. 91.

Water fern, pls. 9, 11.

Waterfowl, 132; pl. 97.

Watermelon. See Melon.

Water plants (or waterweeds). See Aquatic plants.

Waves, 79, 89, 96, 98, 129; pls. 30, 34, 37, $40,41,46,47,50,53,54,72,79,89$, 105, 109, 114, 117, 127.

concentric, $66,67,116$; pls. $7,15,23$, $69,138 \mathrm{D}$.

incised, 112, 156; pls. 65, 127.

serpentine, 67, 79, 90; pls. 16-19, 21, 26, 27.

Willow, 76, 130.

Winged dragons, 110, 119; pl. 70.

Wreaths, lotus, 66, 71, 90; pls. 7-22, 24. peony, 67, 90; pls. 17, 19, 22. Yin-Y ang, pl. 55.

Dedication of the porcelains, $8-10$.

Deer, 118, 126, 129-132, 138, 139; pls. 71, 81, 91, 92, 96, 100-103, 107.

Chinese water, 138.

Père David's, 131, 132, 138; pls. 91, 96.

Sika, 138; pl. 107.

Deignan, Herbert G., xiii.

Detroit Institute of Arts, Exhibition of 1952, 120n., 128n.

Diaper pattern. See under Decoration.

Dishes. See under Shapes. 
Disney, Walt, 118.

"Dog of the threshold of "Ali,", 9.

Double-gourd vase. See under Shapes.

Dragonfly, 128, 149; pls. 88, 116.

Dragons. See under Decoration.

Drinking vessels, 117, 132, 133; pls. 69, 97.

Dubosc, Jean-Pierre, xiii.

Duck. See under Decoration.

Duck-shaped vessel, 133n.

Duckweed, pls. 9, 11.

Du Sartel, Octave, 27, 133.

Dutch, 136, 137n.

Dutch painting, 133n., 139.

Duyvendak, J. J. L., $24 n$.

Dyār Bakr, 4.

Edges. See Rims.

Edwards, E. D., xii.

Eelgrass, 66; pls. 9, 11.

Egret, 67; pl. 18.

Egypt, 5, 24.

Ekber, 'Alī, 21, 122n.

Elaphurus davidianus, 132.

Elephant. See under Decoration.

Elephant-shaped vessel, 132, 133; pl. 97.

Enamel over the glaze, 113, 130, 149, 150; pls. $61,93,104,116-118$.

Ethnografiska Museet, 75n.

Etsin-gol, 72.

Ettinghausen, Elizabeth, vii, xiii.

Ettinghausen, Richard, vii, 52n.; pl. 137A.

Etzina, 72, 73.

Eumorfopoulos, George, xii.

Eumorfopoulos Collection, 62n., 63n., 145n.

European influence, 140.

Evans, I. H. N., 117.

Ewers. See under Shapes.

Export porcelain, 49, 50, 136.

Fa-hsien, 117.

Falsafī, Nasrollah, 52n.

Famille noire, 113.

Fan, 139; pl. 66.

Farīdūn Khān, 10.

Ferghana, 55.
Fern, 95, 105; pls. 43, 51, 56, 69.

Figures (human). See under Decoration.

Finjān (cup), 10.

Fīrūz, 3.

Fischel, Walter J., 70n.

Fish. See under Decoration.

Fitzwilliam Museum, 110n.

Flames, etc. See under Decoration.

Flask. See under Shapes.

Flattened rims. See under Rims.

Floral motifs. See under Decoration.

Foliage, etc. See under Decoration.

Foliate rims. See Rims, foliate.

Foot rims, $60,84,108,123,154,155$; pls. 139142.

Fostāt, 60; pl. 131A-B.

Fou-liang-hsien-chih, 41n.

Fountain ewer, 134.

Fragments. See Shards.

Franks, Sir Augustus, 27, 134.

Fraser, James B., 14.

Freer Gallery of Art, xiii, 144. See also under Collections.

Friedmann, Herbert, xiii.

Frog shape, 132, 133; pl. 97.

Fruit. See under Decoration.

Frye, Richard N., vii, xii.

$F u$ (happiness), 126, 130, 139, 149, 161; pls. 105, 108, 117.

Fu-ch'eng, 30 .

Fu-ch'eng-chih Hsien, 30.

Fukien, 113, 119.

Fu-kuei-chia-ch i i, 128, 147, 150, 161; pls. 87, 89, 114.

Fu mark, 139; pls. 105, 108.

Fungus. See under Decoration.

Funnel shape, 99; pl. 55.

Fu-p'ing-chih Hsien, 30.

Fu-shou-k'ang-ning, 140, 161; pl. 108.

Garden scenes, 113, 128, 130; pls. 60, 68 .

Gardenia, 67; pls. 22, 42.

Garner, Sir Harry, xii, 75, 85n., 86n., 89n., 103n., $121 n ., 122 n ., 128 n$., 132n., 149n., 156n.; pl. 28.

Gāvdūsh (or Kāvdūsh), 10, 11. 
Ghulämän, 8.

Gilt, 143, 144.

Glasgow Art Gallery, 80.

Glass, Islamic, 86, 88n., 89; pls. 135A-B.

Glaze:

Blue, 65n., 151; pls. 119, 138B.

Bluish, 43, 105, 143; pls. 49, 112.

Celadon, 42, 49, 61, 62, 76, 153-158; pls. 121-130.

Coffee brown, 151.

Kinuta type, 154.

Thin, pl. 49.

Turquoise, 149; pl. 116.

Watermelon green, 152; pl. 120.

Yellow, 151.

Godard, André, xii.

Gold, 144, 149; pls. 111, 113, 117.

Gold mounting, 145; pl. 113.

Gold vessels, 8, 20, 37 .

Golden pheasant, 130; pl. 92 .

Goose, 76, 130, 151n.; pl. 92.

Gordon, Antoinette K., 111.

Gorgelet, $117 \mathrm{n}$.

Gosu (or Goshu) ware, 34n.

Gourd, 139.

Gourd shape, 63 n., pls. 55, 86.

Grandidier Collection, 151; pl. 138B.

Grape. See under Decoration.

Gray, Basil, xiii, 64, 70n., 71, 86n., 87n., 88n.

Gujerat, 24.

Gyllensvärd, Bo, xiii.

Ha-dong, $104 \mathrm{n}$.

Hai-tzu, 131.

Hai Yen, 30.

Hajii Baba of Ispahan, 14.

Halīma, 4.

Hamā, 69-72; pls. 131C-D, 132.

Hamadān, 6.

Hambis, L., 73n.

Hami, 21, 22.

Han Dynasty, 61, 83, 130, 153.

Hangchou, 102.

Han-hai, 32n., 43n.

Hanoi, 104n.

Hannover, E., 134, 139n.
Han Wai-toon, 117.

Han Wei-chün, 41n.

Hare, 132, 133; pl. 96.

Hare mark, 136, 139, 140; pls. 99, 108, 109.

Harīm, 55.

Harrisson, Tom, 124n.

Hatstand, 99, 121, 128.

Hawk, 136; pl. 96.

Hedin, Sven, 72n., 73, 75; pls. 133, 134.

Heidar, Sheikh, 4, 14.

Herāt, 4, 21, 23n., 53, 54.

Heron, pl. 94.

Herrmann, A., 21n., 42n.

Hetherington, A. L., $117 \mathrm{n}$.

Hibiscus, 91, 93; pls. 34, 37, 55.

Hideyoshi, 125.

Hindu, Prince, 73.

Hindu symbols, 111.

Hinduism, 111.

Hippisley, A. E., 36.

Hirth, F., 24n., 43n.

History and description of the Shrine, 6-17; pl. 2.

Hobson, R. L., xii, 17, 28, 36, 61n., 62n., 63, 69n., 74, 88, 101, 115n., 116n., 117n., 119n., 125n., 128, 131n., 154n.

Holmes, W. R., 15.

Holy Roman Empire, 5.

Home, Sir David, 123; pl. 138C-D.

Honan, 113.

Honey, W. B., 98n.

Horses. See under Decoration.

Ho San-wei, 39n.

Hosein Baïqara, 53, 54n.

Hosein be-juft, 55.

Hosein haqq, 55.

Hsi (joy), 126.

Hsi-an-fu, 21.

Hsiang Yüan-pien's album, 28n.

Hsiao-tsung, 121.

Hsieh Chao-huang, 27n.

Hsien-tsung, 101.

Hsin-chou, 59.

Hsin Yüan Shih, 73n.

Hsü P'u, 37n.

Hsüian-te, 23, 24, 78, 84, 94, 98, 101, 102, 105 , 107, 110, 111n., 112n., 114. 
Hsüan-te marks. See under Marks: Nien-hao. apocryphal. See under Marks: Nien-hao.

Hsüan-tsang, 21.

Hsüan-tsung, 101.

Huang Cheng-wei, 39n.

Huang Hsi-fan, 27n.

Huang Hung-hsien, 39n.

$H u-l u, 63$ n.; pl. 86.

Humãyūn, 56.

Hummel, Arthur W., xiii.

Hundred antiques, pl. 109.

Hung-chih, 23, 107, 111, 114, 115, 118, 124, 133, 149, 151; pls. 115, 116.

Hung-chih marks. See under Marks: Nien-hao.

Hung-hsi, 24.

Hung-wu, 23, 33n., 39n., 44, 77-81, 83.

Huo, 87.

Huqqeh, 10, 11. See also Kĕndi.

Hydropotes inermis, 138.

Ibn Battuta, 19.

Ibn Khaldūn, 70n.

I-chi-nai, 73.

I-men-kuang-tu, 39n., 44n.

"Imperial" wares, 33-38.

Incense burner, 59, 61 .

Incised decoration. See under Decoration.

India, 24, 117, 145.

Indra, 111.

Infrared photography, pl. 110.

Ingholt, Harald, 69n., 70n., 71.

Inscriptions on the porcelains:

Arabic script, 34, 55; pls. 55, 75.

Chinese (in ink), pl. 30.

Dedicatory, 9, 17, 49, 51, 56; pl. 6.

Mughal, 56, 57, 146; pl. 6.

Naskhi, 123.

Persian, 55; pls. 20, 51.

Portuguese, 57, 58, 114; pl. 6.

Thulth, 122.

Tibetan, 111.

Uighur (in ink), pls. 30, 112.

See also Marks.

Insects. See under Decoration.

Intaglio stamp, 157.

Interregnum, 32, 101-105, 142; pls. 47, 49, 51, 56.
Ioannes, Kalo, 4.

Isfahan, 6, 7.

porcelains in, 56, 57, 68, 120, 146, 159;

pls. 26, 54, 114.

Ishāq Safĩ ed-Dīn, Sheikh, 3.

Isina, 73.

Islamic copies of Chinese blue-and-white, 70, 71; pls. 131C-D, 132.

Islamic glass, $86,88 \mathrm{n} ., 89$; pl. $135 \mathrm{~A}-\mathrm{B}$.

Islamic influence, $44,61,63,64,86-89,121-$ 124.

Islamic metalwork, 64, 87-89, 99; pls. 136A, $137 \mathrm{~A}$.

Islamic pottery, 44, 70, 87-89, 99.

Ismael (variant of Ismā'īl), 14.

Ismā'îl, Shāh, 4-6, 9, 14, 15, 55n.

Ismā'îl II, Shāh, 5, 9 .

Istanbul, 5, 111, 112, 115, 116, 124, 145. See also under Collections: Topkapu Sarayı Müzesi.

Ivanov, A., 73, 74n.

Ivory, 66.

Ivory-colored paste, 108.

Jacquemart, A., 36.

Jade, 14, 16, 66.

Jahān, Shāh, 56n.

Jahāngīr, Shāh, 56, 146; pls. 6, 114.

Jaihun River (Amu Darya or Oxus), 22.

Jakarta Museum, 118.

Jalāl ed-Dīn Mohammad Munajjim Yazdī, 8, 14, $49,51$.

Jannat-Makani, Shāh, 10.

Janse, Olov R. T., 104n., 120n.

Jao-chou, 30, 38.

Japan, 34n., 125.

Japanese blue-and-white, $34 \mathrm{n}$.

Jars, 75, 76, 129. See also Kuan.

Jaubert, Pierre Amedée, 14.

Java, 117.

Javadvipa, 117.

Jaxartes River, 55.

Jenkinson, Anthony, 12.

Jenyns, Soame, xiii, 40, 61n., 68n., 76, 95n., 103n., 110n., 114-117, 120n., 128n., 132n., 139n., 151n.

Jesuits, 135n.

Jewels, 145. 
Jigha, 56.

Ju-chou, 154n.

Ju ware, 28, 154n.

Julien, Stanislas, 27, 42, 43.

Jumahir fi-Ma'rifat al-Jawahir, 19.

Juneid, Sheikh, 4.

Kabul, 55.

Kafcheh (spoon), 10, 11.

Kahle, Paul, 19n., 22n., 122n.

Kalgi-i-ablaq, 56.

Kan-chou, 21, 72.

K'ang-hsi, 30, 41, 96, 103, 112n., 113, 119, 129, 131, 141, 142; pl. 93.

Karakhodja, 21.

Karakorum, 72, 135n.

Kāshān, 6.

Kashgar, 21.

Kashkül (beggar's bowl), 10.

Kashmir, 22.

Kâvdūsh (milk container), 10, 11.

Këndi (drinking vessel), 11, 117, 132, 152; pls. 69, 97, 137B.

Kershaw, F. S., 117.

Kessler, Melvin, 74n.

Khanbalik (Peking), 21.

Kharakhoto, 69, 72-77, 100; pls. 133, 134.

Khatai, paper of, 14.

Khātalan, 55.

Khāylan, 55.

Khitai, 22.

Khitai Nameh, 22n., 122n.

Khorasan, 5, 23n., 52, 53.

Khotan, 21, 22.

Khwāja 'Alī, 3, 4.

Kiangsi Province, 30, 38, 40, 56, 59, 104, 153.

Kiln sites, 104n.

King, William, 57.

King of Saintliness, 51.

Kinnier, Col. Macdonald, K. L. S., 15.

Kinrande, 144n.

Kinuta, 154.

Knop in stems, 64.

Knotweed, 95, 96, 112; pls. 42, 43, 64.

Ko-ku-yao-lun, 32n., 38, 43.

Kotvich, V., 73n.

Kozlov, Col. P. K., 72n., 73.
Kraakporselein, 136-140, 151.

Krenkow, F., 19n.

$\mathrm{Ku} \mathrm{T}^{\prime} \mathrm{ai}, 32 \mathrm{n}$.

Kuan. See under Shapes.

Kuang-hsü, 94n.

Kucha, 22.

Kuei, 120n.

Küklan tribe, 10.

Ku-kung, 127n.

Ku-kung-shu-hua-chi, 145n.

K'un (trigram), 138.

Kundi (Kĕndī), 117.

Kundika, 117.

Kuo Tzu-ch'ang, 31.

Kushi Takushin, 94n., 112n., 128n., 129.

Ku-tung-chih, 32n.

Küzeh (earthenware jugs), 10.

Lacque, 15.

Lacquer, 11, 66.

Lam Dien, $104 \mathrm{n}$.

Lamm, C. J., 86n., 88n.

Lan P'u, 27n., 30, 41.

Land routes, China to Iran, 20-23.

Landscape. See under Decoration.

Lane, Arthur, xiii.

Langari (large tub, etc.), 10, 11.

Laufer, B., $122 \mathrm{n}$.

Leaves. See under Decoration.

Le Blant, Edmond, 36.

Lee, Jean Gordon, 80n.

Leth, André, xiii.

Levy, R., xii.

Li Hui-lin, xiii.

Li T'iao-yüian, 32n., 43n.

Liao Dynasty, 40.

Library of Congress, xiii, 39n.

Library of the Shrine, 6, 8, 13-16.

Lien-tzu (lotus seed bowls), 86, 97, 144, 145;

pls. $46,47,113$.

Lily, 95; pls. 42-44.

Ling-chih, 90.

Lion. See under Decoration.

Lion-Goldschmidt, Daisy, xiii.

Litchi, 94, 95, 156; pls. 41, 56, 140.

Liu Feng, 39n.

Liu Ping, 27n., 30. 


\section{CHINESE PORCELAINS FROM THE ARDEBIL SHRINE}

Lo Chen-yü, 22n.; pl. 60.

Loewenthal, Rudolf, $74 \mathrm{n}$.

London, xii, 8n., 59, 123n.

Lotus. See under Decoration.

Louvre, Musée du, 89.

Lozenge decoration, 140, 155; pl. 86.

Lozenge marks, 111, 162; pls. 63, 137D.

$L u$ (prosperity), 130.

Lung-ch'ing, 31, 121, 125, 150.

Lung-ch'üan, 61, 63, 86, 87.

Lu-p'ing, 35n.

Maani, Madam, 13.

Macao, 135n.

Maggi, Giovanni, 135n.

Magic Fountain, 135n.

Magpie, 137, 138; pl. 100.

Malacca, Straits of, 136.

Malaya, 117.

Mallet, Francis, 61n.

Man in a boat, 130.

Mangu Khān, 135n.

Mann, William M., xiii.

Manüchehr Khān, 52.

Marhamdāni, 10.

Marhüm, 55.

Maritime routes, China to Iran, 23-25.

Markāb, 10.

Marks:

'Abbās, 9, 17, 49, 51, 56, 57, 113, 133, 146, $152,154,160$; pls. 6,15 .

abbreviated form, 51, 160; pls. 6, 49, 53, 90, 108.

Abū Tālib, 54, 160; pls. 6, 53.

'Älamgīr, 57.

Behbūd, 53, 54, 160; pls. 6, 49, 53.

Ch'ang-ming-fu-kuei, 161.

Ching-chih, 161.

Cross in a double circle, 162.

Double circle, $112 n$.

Fruit spray, 151.

Fu, 139, 161; pls. 105, 108.

Fu-kuei-chia-ch'i, 128, 147, 150, 161; pls. 87, 89, 114.

Fu-shou-k'ang-ning, 140, 161; pl. 108.

Hare, 136, 139, 140, 162; pls. 99, 108, 109.

\section{Marks-continued}

Jahāngīr, 56; pls. 6, 114.

Lozenge, 111, 162; pls. 63, 137D.

Närinjī (or nāranjū ), 55, 160; pl. 31 .

Nien-hao:

Apocryphal or spurious, 125, 128, 129, 136n.

Ch'eng-hua, 34, 109, 122n., 146, 149, 160,161 ; pl. 115.

apocryphal, 132, 150, 161; pl. 96.

Cheng-te, 34, 35, 122, 123, 146, 149n., 160,161 ; pls. $75,115-117$.

Cheng-t'ung, 102.

Chia-ching, 34, 35, 125, 126, 127n., 128n., 129, 135n., 136, 150, 160, 161 ; pls. 79-82, 118.

Ching-t'ai, 102.

Hsüan-te, 64n., 65n., 78, 79, 88, 95n., 97, 98, 102, 111n., 119n., 145n.; pl. 55 .

apocryphal, $117 \mathrm{n} ., 123,127 \mathrm{n}$., $128,129,133,136,140$ n., 150 , 151,161 ; pls. $77,86,87,89$, 98, 99, 118.

Hung-chih, 34, 55, 56, 107, 122n., 123, 124, 128n., 146, 149, 160, 161; pls. 114-116, 138D.

Hung-wu, 33n., 34n.

T'ien-shun, 102.

Wan-li, 34, 35, 125, 127, 128n., 147, $150,160,161$; pls. $79,83-86$.

Yüan-yu, 154.

Non-Chinese, 51-58; pl. 6.

Owners', 58, 146; pls. 62, 64, 114, 115, 117. Qāī, 55.

$\rightarrow$ Qarachaghāy, 51-53, 160; pls. 6, 25, 30-36, $38,42,53,71,111$.

Qulī (or Qütì), 55, 160; pls. 30, 31, 33, 40, 41.

Swastika, 129, 162; pl. 90.

Ta-ch'ing-chi-yu-nien-chih, 41.

T'ai-ko-chia-ch'i, 131.

T'ai-p'ing-nien-chih, 40.

Ta-ming-nien-tsao, 57, 114, 125, 140, 161; pls. 74, 109.

Ta-sung-nien-tsao, 154.

Te-jen-ch'ang-ch'un, 161. 
Marks-continued

Wan-fu-yu-t'ung, 57, 161.

Yüan-yu-nien-tsao, 154.

See also Inscriptions.

Martabān, 10, 11.

Mashhad, 6, 8, 15, 52n.

Masjid, 12.

Master patterns, 93.

Maulānā. See Mohammad Hosein Hakkāk e-Khorasānī.

Mayuyama, J., 112n.

Mazar, 13.

Mecca, 3, 9, 22, 23n.

Medallion. See under Decoration.

Mei-p'ing. See under Shapes.

Melons. See under Decoration.

Menges, K. H., xii.

Merry, Harriet Harrison, xii.

Mesar, 13.

Meskit, 12.

Metalwork, Chinese, 66.

Islamic, 64, 87-89; pls. 136A-B, 137A.

Metropolitan Museum of Art, 34, 97n.; pl. 135B.

Michigan, University of, 40.

Miles, George C., xii, 54n.

Milk containers, 10, 11.

Min (Russian transcription of Ming), 73.

Ming Dynasty, 66, 73, 77, 80.

Ming history, 39n., 73, 77.

Ming money, 73, 74.

Ming Shih, 39n., 73n.

Ming statutes, 36, 37 .

Ming texts, 31-33, 37, 38.

Minorsky, V., xii.

Mogholistan, 22.

Moghul, Emperor of India, 17. See also Mughal.

Mohammad (inscription), 55.

Mohammad Beg Shams ed-Dīn, 8.

Mohammad Hosein Hakkāk e-Khorasānī, 9, 51, 57.

Mohammad Khodā-bandeh, Shāh, 5.

Molla Jalāl, 8. See also Jalāl ed-Dīn. . . .

Mongols, 3, 20, 102, 125, 135n.

Monochromes, 151, 152.

Monster, pls. 71, 96.

Monteith, Col., 15.

Montell, Gösta, 75.
Moon, 108, 119, 128; pls. 59, 73, 88.

Moon flask, 86.

Morier, James, 14.

Morning-glory. See under Decoration.

Mosque at Ardebil, 6, 12; pl. 2.

Mostafavi, K. M., xii.

Motifs. See Decoration.

Moule, A. C., 72n.

Mountain, 95, 129, 131, 139.

Mounting, brass, pl. 53. gold, 145 ; pl. 113. silver, 139.

Mughal inscriptions, 56, 57, 146; pl. 6.

Münsterberg, Oskar, 134.

Mūsā Kãzim, 3.

Musée des Beaux Arts, 133n.

Musée du Cinquantenaire, 104n.

Musée Guimet, pl. 138B.

Museum of Eastern Art, pl. 126.

Na'lbaki (saucers), 10.

Namakdan (salt cellars), 10.

Narcissus, 95; pls. 42-44.

Narin, 55.

Nārinj̄̄ (or näranj̄̄ ), 55, 160; pl. 31.

"Narghili," 117.

Naskh (or naskhi), 56, 123.

Nasta'liq, 56.

Nau Dỉhī in Tālish, 10.

Near Eastern. . . . See Islamic.

Nelson, William Rockhill, Gallery of Art, 34, $62 n ., 64 n ., 97 n$.

Nezu Museum, 95n.

Nien, unusual form of, 149n.

Nien-hao, 33-35, 84, 101, 112n., 113, 114, 122, $124,125,127,128,146,149$ n., 150, 154, 160, 161. See also under Marks.

Nightshade, 95; pls. 42, 43.

$N i-k u-l u, 32 \mathrm{n}$.

Ningsia Province, 72.

Nisbah, 55.

Norton, H. R. N., 109.

Okuda Seiichi, 104n., 118.

Olearius, Adam, 13, 14, 52, 53n.; pl. 2. 
Olschki, Leonardo, 135n.

Ordowill (variant of Ardebil), 12.

Oriental Ceramic Society, Exhibition of, 19531954, 33n., 35, 60n., 64n., 67n., 69n., 75, 76, 85n., 86n., 89n., 94n., 98n., 109n., 110n., 120n., 123n., 131n., 132n., 156n.; pl. 28.

Ormuz, 24, 25.

Orontes River, 69.

Orsoy de Flines, E. W. van, 104n., 118.

Ottema, Nanne, 86n., 99n.

Ottoman Turks, 5.

Outline and wash. See under Decoration.

Overlapping petal band, 112, 116; pls. 69, 105, 106, 137D.

Owners' marks, 58, 146; pls. $62,64,114,115$, 117.

Ox shape, 133.

Oxus River, 22.

Pagoda, 130.

Pai-ts'e. See under Decoration.

"Palace" bowls, 109-112, 146.

Palace Museum, 127n., 145.

Palm, 95; pls. 42, 66.

Palmgren, Nils, 39, 40n.

Pao T'ing-po, 27n., 30.

Parakeets, 95, 97.

Paskiewitch, 16.

Patterns, master, 93.

Peach. See under Decoration.

Peafowl. See under Decoration.

Peking, 20n., 21, 31, 33, 109, 112, 131, 145.

Pelliot, P., 20n., 27n., 28n., 39n., 72n., 122n.

Pen box, 88.

Pen rest, 122.

Pennisetum japonicum, 95; pls. 43, 44.

Peony. See under Decoration.

Percival David Foundation of Chinese Art. See under Collections.

Persian imitations of celadons, 159.

Persian inscriptions, 55, 121; pls. 20, 51.

Persian spoken in China, 55, 124.

Persimmon, pl. 56.

Philadelphia Museum of Art, Exhibition of 1949, 33n., 34, 35n., 60n., 62n., 64n., 68n., 69n., 75, 76, 78n., 79n., 86n., 87n., 91, 94n., 97n., 98n., 103n., 105n., 115n., 116n., 145n., 156n., 157n.; pl. 29.
Philippine Islands, 40, 120n., 126.

Phoenix. See under Decoration; Shapes.

Phu-Tinh-Gia, 104n.

Pickens, C. L., 122n.

Pien-hu (flask), 99; pls. 55, 69.

Pine. See under Decoration.

P'ing, pl. 74.

P'ing-chou-k'o-t'an, 24.

Pipes. See Kĕndi; also under Shapes.

Pitchers, 16.

Piyāleh (small bowls), 10, 11.

Plain rims. See under Rims.

Plantain. See under Decoration.

Plants. See under Decoration.

Plates. See Dishes under Shapes.

Plumer, James M., 119.

Pole-star of the gnostics (epithet of Sheikh

Safī), 9.

Polo, Marco, 72, 73.

Polychrome wares, 149, 150.

Pomegranate, 90, 128; pls. 33, 42, 87.

Pontanus, 136.

Pope, Arthur Upham, 87n.-89n., 122n.

Pope, John A., vii, 5n., 11n., 35n., 59n., 61n., 65n., 66n., 67n., 69n., 75, 80n., 96n., 110n., 125n., 126n., 145n.; pls. 27, 110, 137.

Poppy, pls. 21, 27.

"Porcelane," 13.

Portuguese inscription, 57, 58; pl. 6.

Portuguese trade, 25, 136.

Poulsen, Vagn, 70, 71.

Po-wu-yao-Pan, 32n.

Praying mantis, 68; pl. 26.

Primrose, 95; pl. 42.

Princessehof Museum, 99n., 111n., 126, 133n.

Prunus. See under Decoration.

Qadah (wine bowls), 10.

Qäi, 55.

Qajārs, 15.

Qandahar, 56.

Qarābeh (double-handled pitchers), 10.

Qarachaghāy, 51-53, 160; pls. 6, 25, 30-36, 38, $42,53,71,111$.

Qārūn, 8.

Qazvīn, 6, 20, 53.

Qizilbash, 4, 55.

Quail, 138. 
Quatremère, M., 21n.

Quli (or Qülì), 55, 160; pls. 30, 31, 33, 40, 41. Qulī Beg Afshāh, 55.

Qul-lar Aga-si, 52.

Qum, 15.

Qu'ranic texts, 122.

Qūrchī, 8.

Rabino di Borgomale, 54n.

Raku ware, $34 \mathrm{n}$.

Rat-shaped handle, 140; pl. 109.

Ray, 19.

Rebus, 118, 130.

Rectangles, pl. 88 .

Rectangular vessels, 60, 62, 68; pl. 28.

Red, underglaze, 78, 150; pls. 29, 118.

Red ring base, 155n., 156; pls. 121, 123, 125.

Redheads. See Qizilbash.

Reidemeister, L., 34n.

Reign names. See Nien-hao.

Reitlinger, Gerald, 104n.

Rezā, Imām, 6.

Ricci, Father Matteo, 136n.

Rice, D. S., xii, 87n., 89n., 123n.; pl. 136A.

Riesco, R. F. A., 40.

Rieu, Charles, 8n.

Rims, contracted or inturning, $61,79,86,97$, 156; pls. 23, 46, 126.

flaring, 61, 64; pls. 24, 47, 48, 60, 62-66, $77,80,84,87,88,90,95,96,105,106$, 108, 113-119, 125, 126.

flattened, $66,85,119,137,143,144$; pls. $7-22,29,32-37,40,41,56,70,72,73$, $75,81,82,89,92,100,111,112,121$, $122,124$.

foliate, $67,70,76,85,91,129,137,138$, $143,144,151,157$; pls. 16-22, 29, 33, $35-37,41,55,72,82,89,92,100-103$, 105, 106, 108, 112, 119, 121, 128.

inturning. See contracted, above.

plain, $85,138,143$; pls. $30-34,36,39,40$, $42,43,45,47,58,59,61,65,67,68,71$, $72,74,78,83,87,89,91-95,101-103$, $106,110,113,114,116,118,122,125$, 126.

Rivière, H., 89n.

Robinson, B. W., 52n.

Rockhill, W. W., 24n., 43n., 135n.
Rocks. See under Decoration.

Rokh, Shāh, 20, 56.

Roses. See under Decoration.

Ross, E. Denison, 12.

Rostam Mīrzā, 9.

Routes, China to Iran, 19-25.

Rubruck, William of, 135n.

Ruby, gift to Jahāngīr, 56.

Rukh. See Rokh.

Rūm (Turkey), 23n.

Rumyancov Museum, 27n.

Russians sack Ardebil, 15.

Sabi ${ }^{\prime}, 10$.

Sabū (tall jar with single handle), 10.

Sadr ed-Dīn, 3, 6.

Safavid Dynasty, x, 3-10, 12-14, 51, 54.

Safī, Shāh (another title of Sheikh Safī), 9, 51.

Safî, Sheikh, 3, 6.

Safĩ ed-Dīn, Sheikh, 3.

Sagittaria, 92; pls. 30, 31, 36 .

Sahn (large tray or plate), 10, 11 .

St. Petersburg, 16.

Sairam, 21.

Sa-ma-erh-han (Samarqand), 23.

Samarqand, 20, 21, 23.

Sancheh, 10.

Sangir Islands, 99n.

San-i-chih-yu, 94n.

Sanskrit characters, 64n, 112.

Santa Catarina, 136.

San-ts'ai, 61, 62.

Sarāhi (long-necked jars), 10.

Sarre, F., 6, 11, 16, 17, 134.

Sasanian emperor, 3 .

Saucers, 50, 119; pl. 108.

Savory, Roger M., xii, 8n.

Sawankalok ware, 118.

Sayer, G. R., 27n., 42, 43.

Sayyid, 10.

Schich-Sefi, 13.

Scrolls. See under Decoration.

Seahorse, 129; pl. 89.

Sea perch, pl. 9.

Sea routes, 23-25.

Seascape, pl. 89.

Sedgwick, Mrs. Walter, xii, 57.

Sefī (variant of Safī), 16. 
Seligmann, Mrs. C. G., xii.

Selim, Sultan, 5, 22n.

Seljuk period, pl. 137A.

Seng-mao-hu (ewer), 146.

Sepulchre. See Tomb. . . .

Serpentine waves. See under Decoration.

Sha-chu-ting, 22, 23.

Shāh kāseh (large bowls), 10, 11.

Shahnameh in Windsor Castle, 52n.

Shāh Rokh, 20, 21.

Shāh-rukh (variant of Shāh Rokh), 56.

Shāh Safī (another title of Sheikh Safī), 9, 51.

Shaikh Suffee (variant of Sheikh Safī), 15.

Shang Dynasty, 66, 90, 108.

Shansi Province, 35.

Shan-si-ting, 22.

Shapes of porcelains:

$\bar{A}$ ftäbeh (ewer), 10, 11.

Albarello, 89; pl. 138A.

Animal, 133, 151, 152; pls. 97, 120.

Bädiyeh (wine cups), 10, 11.

Baluster vase, 157; pl. 129.

Basin, 88, 112n., 119; pls. 70, 135B.

Bird, 133.

Bottle, 60, 75, 86, 96, 99, 109n., 114, 140, 151n., 157; pls. 53, 74, 109, 129.

Bowls:

Blue-and-white:

Fifteenth century, 86, 105, 109 113 ; pls. 46-49, 60-68.

Fourteenth century, 60, 68, 75, 76 ; pls. 23, 24.

Sixteenth century, $123,127,132$, 138 ; pls. $77,80,83-85,87-89$, 95, 96, 105-107.

Celadon, 156, 157; pls. 125-128.

Conical, 86, 98, 105; pls. 47, 48.

Deep-sided, 86, 105, 145; pls. 49, 114.

Kraakporselein, 138, 139; pls. 105107.

Lien-tzu (lotus seed bowl), 86, 97, 144, 145 ; pls. 46, 47, 113.

Monochrome, 151.

"Palace," 109, 110, 112, 146.

Polychrome, 149, 150; pls. 117, 118.

White, 144-147; pls. 113-114.

With inturning rims, $61,79,86$; pls. 23, 46.
Shapes of porcelains-continued

Boxes, 121.

Brush rest, 121.

Bucket, champagne, 131; pl. 96.

Cat, 151, 152; pl. 120.

Chih-hu (ewer), pls. 54, 55, 69, 70, 99, 109.

Cup, 139, 140; pls. 108, 109.

Cup stand, 79; pl. 29.

Dishes:

Blue-and-white:

Fifteenth century, 85, 86, 89-97, 103, 108, 109, 118-120; pls. 29-45, 57-59, 71-74.

Fourteenth century, 60, 61, 6668 ; pls. 7-22, 29.

Sixteenth century, 122-124, 129$131,137,138$; pls. $75,76,78$, 81, 82, 90-94, 100-104.

Celadon, 154-156; pls. 121-124.

Monochrome, 151; pl. 119.

Polychrome, 149, 150; pls. 116-118.

White, 143, 144, 146; pls. 110-112, 115.

Double-gourd, $60,63,69,87,116,128$; pls. 27, 86.

Drinking vessel, 117, 132, 133; pls. 69, 97. Duck, 133n.

Elephant, 132, 133; pl. 97.

Ewers, 10, 11, 76, 87, 88, 99, 114, 115, $133-136,139,140,145$; pls. $54,55,69$, 70, 98, 99, 108, 109.

Finjān (cup), 10, 11.

Flask, 62, 86, 87, 99; pls. 55, 69.

Frog, 132, 133; pl. 97.

Funnel, 99; pl. 55.

Gāvdūsh (or Kāvdüsh, milk container), 10, 11.

Gorgelet, $117 \mathrm{n}$.

Gourd, 63n.; pls. 55, 86.

Hatstand, 99, 121, 128.

Hookah. See Huqqeh.

$H u-l u, 63$ n., pl. 86.

Huqqeh, 10, 11. See also Këndi.

Incense burner, 59, 61 .

Jar, 75, 76, 129.

Kafcheh (spoon), 10, 11.

Kashkül (beggar's bowl), 10.

Kā $v$ düsh (milk container), 10, 11. 
Shapes of porcelains-continued

Këndi, 11, 117, 132, 152; pls. 69, 97, 137B.

Kuan:

Blue-and-white:

Fifteenth century, 34, 97n., 98, 103-105, 110n., 115, 120; pls. $52,56$.

Fourteenth century, 60, 62, 68; pls. $26,27$.

Sixteenth century, 13n., 125, 126, 134 ; pl. 79.

Celadon, 157; pl. 130.

White, 147; pl. 115.

Kuei, 120n.

Küzeh (earthenware jugs), 10.

Langarī (large tubs), 10, 11.

Lien, 156; pl. 125.

Lien-tzu. See under Bowls, above.

Mei-p'ing:

Blue-and-white:

Fifteenth century, 34, 50, 80, 86, 96, 98, 103-105, 115, 120n.; pls. $50,51,56$.

Fourteenth century, 60, 62, 68, 76,80 ; pls. $25,26,138 \mathrm{~B}$.

Sixteenth century, 127; pl. 86.

Comparison of shapes, 62,63 .

White, 146; pl. 115.

Moon flask, 86.

Na'lbakī (saucers), 10.

Namakdan (saltcellar), 10.

"Narghili," 117.

Ox, 133.

"Palace" bowls, 109-112, 146.

Pen box, 88 .

Pen rest, 122.

Phoenix, 133.

Pien-hu, 99; pls. 55, 69.

P'ing, pl. 74.

Pipe, 100, 117.

Pitchers, 16.

Piyāleh (small bowls), 10, 11.

Plates. See Dishes, above.

Qadah (wine bowls), 10.

Qaräbeh (double-handled pitchers), 10.

Rat-shaped handle, 140; pl. 109.

Rectangular, 60, 62, 68; pl. 28.

Sabū (tall jar with single handle), 10.
Shapes of porcelains-continued

Sahn (large tray or plate), 10, 11.

Sancheh, 10.

Sarāhi (long-necked jars), 10.

Saucer, 50, 119; pl. 108.

Seng-mao-hu (ewer), 146.

Shāh kāseh (large bowl), 10, 11.

Sphere, 99; pl. 55.

Spherical object, 128; pl. 86.

Stem bowl, 60, 156; pl. 126.

Stem cup, 60, 63-65, 140, 143.

Stove jar, 35 .

Tabak (tray), 10.

Table screen, 121.

Tankard, 88.

Tripod, 61n., 156; pl. 125.

Vases. See Albarello, Baluster, Bottle, Double-gourd, Gourd, Kuan, Mei-p'ing, Rectangular, etc.

Vases, David, 59, 69, 75, 78.

Wine bowl, 10 .

Wine cup, 10, 11.

Yüeh p'ing (moon flask), 86.

Sharbat-khaneh, 9.

Shards:

Ch'eng-hua, 112; pl. 137D.

Ch'ing-ho Hsien, 39, 40.

Chü-lu Hsien, 40.

Fostāt, 60; pl. 131A-B.

Hamā, 69-72; pls. 131C-D, 132.

Kharakhoto, 74-77, 100; pls. 133, 134.

Philippine Islands, 40.

Te-hua ware, 70.

Sheikh Ishāq Safĩ ed-Dīn, 3.

Sheikh Shāh Beg, 10.

Shên-tsung, 19.

Sherley brothers, 13.

Shī‘a (or Shīīte) , 4, 5, 8, 15, 51, 56.

Shich-Sefi (variant of Sheikh Safī), 13.

Shih-wu-kan-chu, 32n.

Shiraz, 14, 23n.

Shou. See under Decoration.

Shrine at Ardebil:

Chīnī-khaneh, 6, 7, 12-17; pls. 2-4.

Dedication of the porcelains, 8-10.

History and description, 6-17; pl. 2.

Library, 6, 8, 13-16.

Shrubs. See under Decoration. 
Shu Min, 39n.

Shun-chih, 141-142.

Sika, 138; pl. 107.

Silpasālar, 52.

Silver mounting, 139.

Silver vessels, $8,20,37$.

Singhala, 117.

Sinological Institute, Leiden, 27n.

Sino-Mongolian inscription, 73.

Sino-Swedish Expedition, 72n., 75.

Slave of the King of Saintliness, 51.

Slip. See under Decoration.

Smirnov, Y. I., 64n.

Smith, Myron Bement, xii.

Sommerström, Dr., 75n.

Sophie, 12.

Soreau, Jan, 139n.

Soukhtaline, Count, 15.

Southern Sung, 102.

Spiky leaves. See under Decoration.

Sprays. See under Decoration.

Squirrels, 126; pls. 81, 91.

Ssu-i-kuan-k'ao, 22n.

Stein, Sir Aurel, 72n., 73, 74.

Stem bowl, 60, 156; pl. 126.

Stem cup, 60, 63-65, 140, 143.

Stern, Harold P., xiii.

Storey, Charles A., 8n.

Stove jar, 35.

Su Tung-p`o, 93n.

Su-chou, 21.

Süfï, 3, 4, 9, 12n.

Sui-han-san-yu, 93.

Süleymān the Magnificent, 5, 22n.

Sultān Hasan Khān, 10.

Sultānīyeh, 8, 25.

Sung Dynasty, 24, 38-40, 43, 61, 62, 74, 76, 83, $87,101,102,113,143,153,154,158$.

Sunnī, 4, 5.

Su-ni-po blue, 84.

Swastika mark, 129, 162; pl. 90.

Swastika pattern, 127, 140; pls. 85, 109.

Swatow wares, 124, 131; pl. 93.

Swedish archaeologists, 72n., 74, 75.

Symbolism, 36, 111, 118, 126.

Symbols, 68, 111; pls. 66, 109.

Syr Darya, 55.
Syria, 5, 69.

Syrian glass, 89 .

Sz'yi kuan, 22n.

Tabak, 10.

Tabak-e sorkh, 10, 11.

Table screen, 121.

Tabriz, 3-6, 17, 20.

Ta-ch'ing-chi-yu-nien-chih, 41.

Tahmāsp, Shāh, 5, 6, 8, 12.

T'ai-ko-chia-ch'i, 131.

T'ai-p'ing-nien-chih, 40.

Tajik people, 8 .

Taklamakan Desert, 21.

Tâlish, 10.

Ta-ming-hui-tien, 37, 38.

Ta-ming-nien-tsao, 57, 114, 125, 140, 160; pls. 74, 109.

T'ang Dynasty, 61, 62, 83, 87, 117, 153.

T'ang mirror, 67.

Tankard, 88.

T'ao-chi-fu, 41n.

T'ao-chi-lïeh, 41.

Tao-kuang, 42n., 94n.

T'ao-lu. See Ching-te-chen-t'ao-lu.

T'ao-shuo, 27-31, 38, 84n.

$T^{\prime} a o-y a, 43 \mathrm{n}$.

T'arikh-e-'Abbāsī, 8-10; pl. 5.

Tashkent, 21.

Ta-sung-nien-tsao, 154.

Tatars, 52, 102.

Tavernier, Jean Baptist, 14.

Tea ceremony, $34 \mathrm{n}$.

Teal, 132; pl. 97.

Tehran, vii, 49, 159.

Te-hua ware shards, 70 .

Te-jen-ch'ang-ch'un, 161.

Tendrils, 70, 94; pls. 37, 39.

Terrestrial plants, 66 .

Textiles, 66.

Than-hoa, 104n.

Thielmann, Max von, 16.

Three friends (of winter). See under Decoration.

Thulth script, 122.

Thunder pattern. See under Decoration.

Tibetan script, 111; pl. 66. 


\section{INDEX}

T'ien-ch'i, 32n.

T'ien-fang, 22.

T'ien-shun, 23, 39n., 102.

Tiger lily, pl. 44.

Tīmūr, 3, 20, 56, 70.

Timurid Dynasty, 53, 54.

Ting ware, 38, 61-63, 86, 87, 119, 143, 158.

Tobacco, 117, 118.

Toledo Museum of Art, 87; pl. 135A.

Tomãns, 7, 9, 10.

Tomb of Sheikh Safī, 3, 6, 12-15.

Tonkin, 104n.

Topkapu Sarayı Müzesi. See under Collections.

Tortoise, 129; pl. 91.

T'o-t'o, Prince, 73n.

Trade by sea, 23-25.

Trade via Central Asia, 20-23.

Transition wares, 34n., 132n., 141.

Transoxiana, 5.

Trays, 10, 11.

Trees, 137; pls. 86, 92.

Trefoil. See under Decoration.

Trigrams, 138.

Trubner, Henry, 62n.

Tsao (in nien-hao), 114, 126, 127; pls. 82,86 , $98,118$.

Ts'ao Chao, 38, 39n.

Ts'ao-shu, 126n.

Tsung-kuan (official), 73.

Tsun-sheng-pa-chien, 84n.

Tubs, 10, 11.

Tu-lu-fan, 22.

T'ung-ya, 32n.

Turāb Khān, 10.

Turfan, 21, 22.

Turkish pottery, 88 .

Turkomans, 4 .

Turquoise, pl. 53.

Turquoise glaze; pl. 116.

Tūzuk-i-Jahāngīrī, 56n.

Tzenetsera, 13.

Tz'u-chou ware, 40, 62, 63, 87, 158.

Tz'u-yuan, 93n.

Uighur script, pls. 30, 112 .

Ulugh Beg, 56.
Umaiyad period, 3.

'Umar, 5.

University of London, xii, 8n., 59, 123n.

'Uthmān, 5 .

Utrecht, Adrian van, 133.

Uzbeks, 5 .

Uzgand, 55.

Üzūn Hasan, 4.

Vajra, 76, 110; pls. 23, 62.

Vala, 111.

Va-la-gla-ma-ja-na, 111.

Valī Sheikh Beg, 10.

Valle, Pietro della, 13.

Vaqf, 7, 8, 49, 51, 53, 121, 145.

Vaqfnameh. See Dedicatory inscription under 'Abbās I.

Vases, David, 59, 69, 75, 78. See also under Shapes: Albarello, Baluster, Bottle, Doublegourd, Gourd, Kuan, Mei-p'ing, Rectangular, etc.

Vermilion, 37.

Vessels used in court ceremonies, 37 .

Victoria and Albert Museum:

Carpet, 12.

Copper ewer, pl. 136B.

Porcelains. See under Collections.

Vines. See under Decoration.

Volker T., 11n., 25n., 136n.

Waley, Arthur, 84n.

Wallis, Henry, 89n.

Walters Art Gallery, 52n., 57, 139n.; pl. 6.

Walters Collection, Catalogue of, $27 \mathrm{n}$.

Wan-fu-yu-t'ung, 57, 161.

Wang Tso, 39n.

Wang Tsung-mu, 31.

Wan-li, 17, 23, 32, 87, 103, 113, 121, 125, 128, 132n., 135n., 136, 141, 142, 150, 151; pls. 79, 83-87.

Wan-li marks. See under Marks.

Warner, Langdon, 119.

Wash, graded, 96, 108, 131.

Wash with outline, 85, 98, 102-104, 108-115; pl. 56. 
Waterchestnut, pls. 9, 11, 55.

Waterfall, 129, 130; pl. 91.

Water fern, pls. 9, 11.

Waterfowl, 132; pl. 97.

Watermelon. See Melon under Decoration.

Water pipe, 100. See also Kĕndi.

Water plants. See Aquatic plants under Decoration.

Water routes. See Maritime routes.

Waves. See under Decoration.

Wei Ching-yü, 28n.

Wells, Mr. and Mrs. Charlemagne Edward, xii.

Wenley, Archibald G., xiii, 126n.

West Asian metalwork, 64. See also Islamic metalwork.

White-on-blue style, 65, 67, 68, 70.

White Sheep Dynasty, 4.

White wares, 49, 143-147; pls. 110-115.

Wiet, Gaston, 54n.

Wiles, Bertha Harris, 135n.

Willow, 76, 130.

Windsor Castle, 52n.

Wine vessels, 10, 11 . gold, lacquer, pewter, porcelain, silver, wood, 37.

Winged dragons, 110, 119; pl. 70.

Winkworth, W. W., xiii.

Wreaths. See under Decoration.

Wu Lai-hsi, 80n., 114n.
Xavier, Father Francis, 135n.

Yamani carnelian, 10.

Yang-chou, 19.

Yashb, 10.

Yellow wares, 151.

Yellowish paste, 105; pls. 49, 58-60, 62.

Ying-ch'ing, 43. See also Ch'ing-pai.

Yin-Yang, pl. 55.

Yüan Dynasty, 39, 41-44, 61, 63, 66, 72-77, 136n., 153, 154, 158.

Yüan history, 73, 77.

Yüan money, 73, 74, 77.

Yüan Shih, 73n.

Yüan-yu-nien-tsao, 154.

Yüeh ware, 61, 153, 158.

Yüeh p'ing, 86.

Yule, Sir Henry, 72n.

Yung-cheng, 92.

Yung-lo, 23, 24, 34n., 78, 84, 97, 105.

Yung-lo-ta-tien, $43 \mathrm{n}$.

Zahīd of Gilan, Sheikh, 3.

Zanzibar, 24.

"Zerfkhanah," 14.

Zimmerman, Ernst, 80n., 94n., 145n., 153, 156n., $157 \mathrm{n}$.

Zinjān, 8.

Zurūf, 10. 





